UN IVERS I A DE DE S Ã O PAULO

Faculdade de Filosofia, Letras e Ciências Humanas

Departamento de Geografia

RODOLFO FINATTI

AgLOMERAÇÕES INDUSTRIAIS NO BRASIL:

USO DO TERRITÓRIO E TRANSFORMAÇÕES RECENTES

Versão Corrigida

SÃo PAULO

2017 


\section{RODOLFO FINATTI}

\section{AgLOMERAÇÕES INDUSTRIAIS NO BRASIL:}

USO DO TERRITÓRIO E TRANSFORMAÇÕES RECENTES

Tese apresentada ao Departamento de Geografia da Faculdade de Filosofia Letras e Ciências Humanas da Universidade de São Paulo para obtenção do título de doutor em Geografia

Área de Concentração: Geografia Humana

Orientadora: Prof ${ }^{\mathrm{a}}$. Dra ${ }^{\mathrm{a}}$. Mónica Arroyo

\section{SÃO PAULO}


Autorizo a reprodução e divulgação total ou parcial deste trabalho, por qualquer meio convencional ou eletrônico, para fins de estudo e pesquisa, desde que citada a fonte.

Catalogação na Publicação

Serviço de Biblioteca e Documentação

Faculdade de Filosofia, Letras e Ciências Humanas da Universidade de São Paulo

F491a

Finatti, Rodolfo

Aglomerações industriais no Brasil: uso do

território e transformações recentes / Rodolfo Finatti

; orientadora María Mónica Arroyo. - São Paulo, 2017. $300 \mathrm{f}$.

Tese (Doutorado)- Faculdade de Filosofia, Letras e Ciências Humanas da Universidade de São Paulo. Departamento de Geografia. Área de concentração: Geografia Humana.

1. Território. 2. Industrialização. 3. Aglomeração industrial. 4. Localização. 5. Seletividade espacial. I. Arroyo, María Mónica, orient. II. Título. 
Tese apresentada ao Departamento de Geografia da Faculdade de Filosofia Letras e Ciências Humanas da Universidade de São Paulo para obtenção do título de doutor em Geografia

Aprovado em: 16 de dezembro de 2016. 


\section{AGRADECIMENTOS}

A finalização desta pesquisa, que neste momento posso considerar uma realidade, foi mais difícil do que eu poderia imaginar em 2012 quando a ideia de um doutorado começou a ser construída. 0 que eu sabia é que eu precisaria de muita ajuda para atingir este objetivo, o que realmente aconteceu. Estas linhas não serão suficientes para expressar os meus agradecimentos.

Em primeiro lugar meu obrigado à Professora Mónica Arroyo pelo apoio, inspiração, lições e paciência. Com ela, aprendemos diariamente. Não somente sobre os conceitos necessários para escrever uma tese, mas sobre escolhas, sobre conduta e também sobre a vida. Obrigado por me ensinar tantas coisas em tão pouco tempo e pela paciência nos momentos, que não foram poucos, nos quais eu desanimava.

Agradeço igualmente aos meus pais, Sérgio e Célia, pelo exemplo de dedicação em tudo o que fazem e pela sustentação que me dão, diariamente, permitindo que eu possa tentar o melhor de mim. Não deve ser fácil aguentar um doutorando mal humorado... Eu não poderia fazer isso sem este apoio e carinho. Por isso, obrigado!

Fazemos amigos em qualquer trajetória, ainda mais quando passamos por muitos lugares. Agradeço pela ajuda, próximos ou distantes! Mais uma vez aos meus sempre professores Carminha, Eliseu Sposito e Sandra Lencioni, que sempre me auxiliam carinhosamente. Aos meus irmãos unespianos Cássio, Flávio, Rê, Lulu! Ao pessoal do Nordeste, em Natal ou Fortaleza, Aldo, Vitor, Edmara, Edilson e Denise, e Rafael. Aos meus amigos veteranos de Laboplan Aline, Igor, Paul, Aninha e ao pessoal da Unicamp: Prof. Vicente, Cíntia, Rafael Sá e Lucas Baldoni. Vocês moram no coração!

Agradeço também a todos que cederam um pouco do seu tempo para me receber, concedendo entrevistas e informações preciosas. Minha gratidão por concederem um pedacinho dos seus dias durante estes últimos quatro anos, e dividir um pouco do que sabem, sobretudo pelo prazer em ajudar, como muitas vezes ficou nítido. É gratificante saber que continuamos trocando materiais, percepções e novas ideias. Que possamos seguir trabalhando juntos e construir esse conhecimento.

Obrigado a Deus, por sempre cuidar de mim de um jeito tão especial. 
As aglomerações industriais podem ser analisadas como formas geográficas que expressam a preparação do território para a atividade produtiva, inclusive a intencionalidade e as ações realizadas para a sua implantação, que ressaltam diferenças qualitativas e topológicas - e eventualmente também combinações - entre Estado e mercado. Foram identificados onze diferentes tipos de aglomerações industriais no Brasil, por meio de revisão bibliográfica e trabalho de campo realizado em dez unidades da federação, durante os quais foram entrevistados os principais agentes articulados à gestão destas áreas. Neste escopo, a análise geográfica das formas de aglomeração industrial permite apresentar feições do meio técnico-científico-informacional e do uso corporativo do território no período contemporâneo, bem como os processos pelos quais se reafirma a seletividade espacial no território brasileiro, evidenciando-se áreas com diferentes níveis de especialização.

Palavras-chave:

Território, industrialização, aglomeração industrial, localização, seletividade espacial 
Industrial agglomerations can be analysed as geographic forms that express the preparation of the territory for productive activity, including the intentionality and actions taken towards its implantation, which highlight qualitative and topological differences, and occasionally, combinations between the State and the market. Eleven different types of industrial agglomerations have been identified in Brazil, through bibliographic review and field research done in ten states of the Brazilian Federation, where the main agents linked to the management of these areas were interviewed. Within this scope, the geographic analysis of the forms of industrial agglomeration allows us to present features of the technical-scientific-informational environment and the contemporary corporative use of the territory, as well as the processes through which the spatial selectivity in the Brazilian territory is reaffirmed and makes clear areas with different levels of specialization.

Keywords:

Territory, industrialization, industrial agglomeration, location, spatial selectivity 


\section{LISTA DE QUADROS}

QUADRO 1 Dados das atividades de campo realizadas no período de julho de 2014 a 15

QUADRO 2 Características para análise das aglomerações industriais 79

QUADRO 3 Principais planos de desenvolvimento nacionais e posição da indústria $\quad 88$

QUADRO 4 Distritos Industriais - Características de sua distribuição geográfica 165

QUADRO 5 Arranjos produtivos locais - Características de sua distribuição geográfica 173

QUADRO 6 Condomínios empresariais - Características de sua distribuição geográfica 182

\section{LISTA DE MAPAS}

MAPA 1 BRASIL - Aglomerações industriais visitadas em trabalho de campo 16

MAPA 2 BRASIL - Indústria de transformação e sua tendência à concentração $\quad 142$

MAPA 3 BRASIL - Aglomerações industriais e sua distribuição no território $\quad 151$

MAPA 4 SÃO PAULO - Distribuição das aglomerações industriais, por tipo 155

MAPA 5 RIO DE JANEIRO - Distribuição das aglomerações industriais, por tipo 156

MAPA 6 MINAS GERAIS - Distribuição das aglomerações industriais, por tipo 157

$\begin{array}{lll}\text { MAPA } 7 & \text { BAHIA - Distribuição das aglomerações industriais, por tipo } & 158\end{array}$

MAPA 8 AMAZONAS - Distribuição das aglomerações industriais, por tipo 159

MAPA 9 BRASIL - Distribuição dos condomínios empresariais (2016) 187

MAPA 10 BRASIL - Total de parques tecnológicos, por unidade da federação (2013) 189

\section{LISTA DE FIGURAS}

FIGURA 1 Anúncio do Centro Industrial Jaguaré (1939) 71

$\begin{array}{lll}\text { FIGURA } 2 & \text { Os Quatro Brasis } & 131\end{array}$

FIGURA 3 Planta da Cidade Industrial de Contagem 201

\section{LISTA DE TABELAS}

TABELA 1 BRASIL - Indústria de transformação, total de estabelecimentos e empregos (1985-2013)

BRASIL - Produto Interno Bruto setorial: taxas médias de crescimento (\%)

SÃO PAULO - Distribuição de aglomerações industriais, número total e

TABELA 3 número nas áreas metropolitanas (\%)

TABELA 4 BRASIL - Estabelecimentos e empregos industriais, por unidade da federação (2010) 


\section{LISTA DE GRÁFICOS}

GRÁFICO 1 BRASIL - Condomínios empresariais, por tipo (2016) 176

GRÁFICO 2 BRASIL - Total de condomínios empresariais por unidade estadual 177

GRÁFICO 3 TECHNO PARK CAMPINAS - Serviços compartilhados 259

\section{LISTA DE FOTOS}

FOTO 1 Avenida central localizada na Cidade Industrial de Contagem 205

$\begin{array}{lll}\text { FOTO } 2 \text { Fachada da empresa Arcelormittal } 205 & 205\end{array}$

FOTO 3 Praça central da Cidade Industrial de Contagem 206

FOTO 4 Avenida de acesso à Rodovia Fernão Dias 206

FOTO 5 Centro do Distrito Industrial de Fortaleza 212

FOTO 6 Fábrica da empresa Esmaltec no Distrito Industrial de Fortaleza 212

FOT0 7 Centro de exposições FeiraCenter no Distrito Industrial de Fortaleza 213

FOTO 8 Residências localizadas no Distrito Industrial de Fortaleza 213

FOTO 9 Via de acesso principal ao Centro Industrial Subaé 218

FOTO 10 Etapa construtiva de galpão, em área do Centro Industrial Subaé 218

FOTO 11 Parte de avenida central do Distrito Industrial de Queimados 221

FOTO 12 Avenida central do Distrito Industrial de Queimados 221

FOTO 13 Painel das empresas instaladas do Distrito Industrial de Queimados 222

FOTO 14 Anúncio (outdoor) de galpões disponíveis para aluguel 222

FOTO 15 Avenida central do Polo Industrial de Manaus 225

FOTO 16 Entrada do Polo Industrial de Manaus 225

FOTO 17 Terminal de operações da empresa Adukargo 226

FOTO 18 Fábrica da empresa LG 226

FOTO 19 Via de acesso a edifícios de área residencial no Polo Industrial de Manaus 227

FOTO 20 Terminal portuário do Polo Industrial de Manaus 227

$\begin{array}{lll}\text { FOTO } 21 \text { Polo Industrial de Camaçari } & 244\end{array}$

FOTO 22 Polo Industrial de Camaçari e condomínio industrial da Ford 244

$\begin{array}{lll}\text { FOTO } 23 & \text { Polo Industrial de Triunfo } & 248\end{array}$

FOTO 24 Usina da Braskem no Polo Industrial de Triunfo 248

FOTO 25 Polo Industrial de Triunfo, entrada para a refinaria 249

FOTO 26 Via interna no Polo Petroquímico de Triunfo 249

FOTO 27 Techno Park Campinas, via de circulação interna 260

FOTO 28 Centro de convenções do Techno Park Campinas 260

FOTO 29 Fachada da Intertech Worldwide no Techno Park Campinas 261

FOTO 30 Hotel Dan Inn no Techno Park Campinas 261

FOTO 31 Parque Tecnológico de São José dos Campos 266

FOT0 32 Via interna do Parque Tecnológico de São José dos Campos 266 


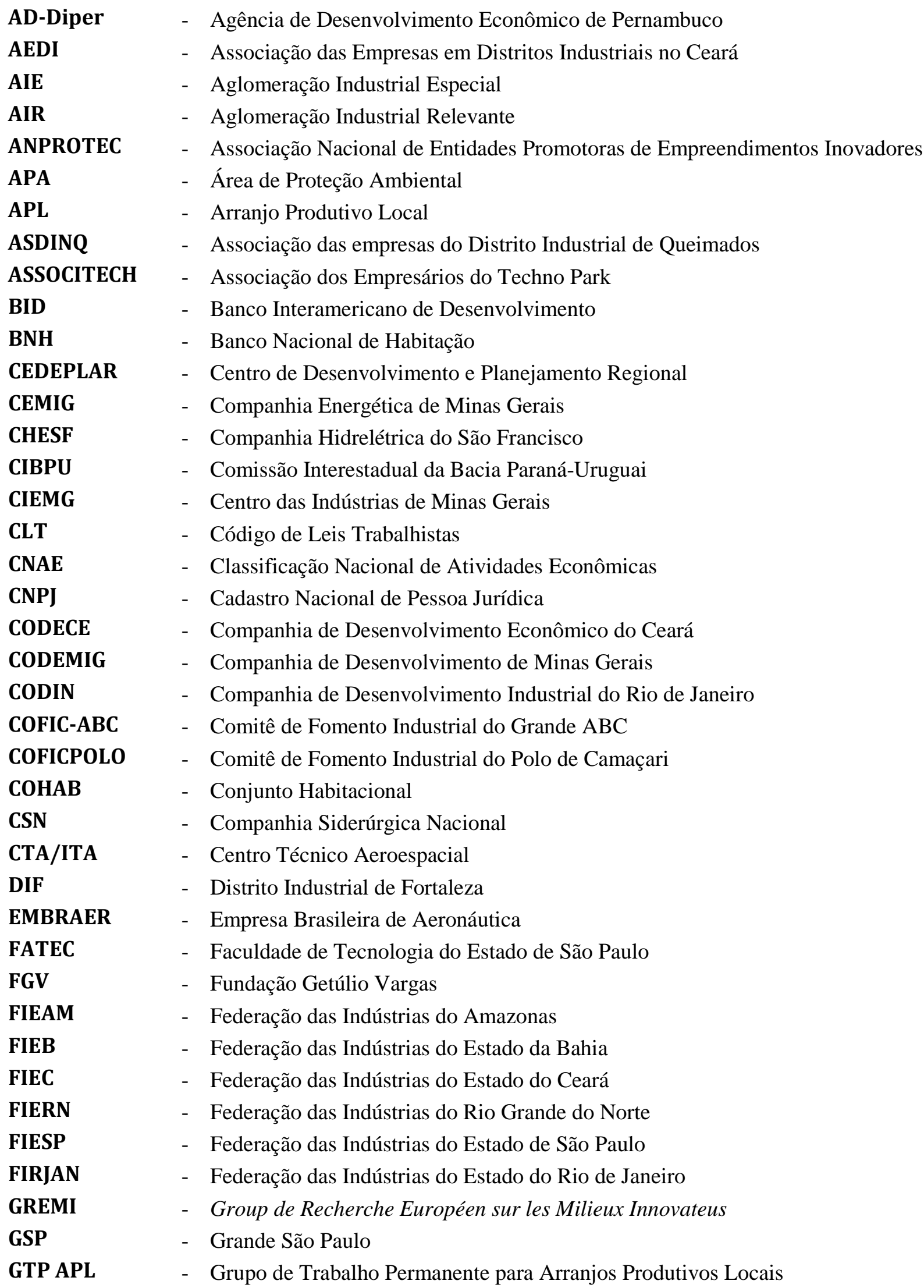




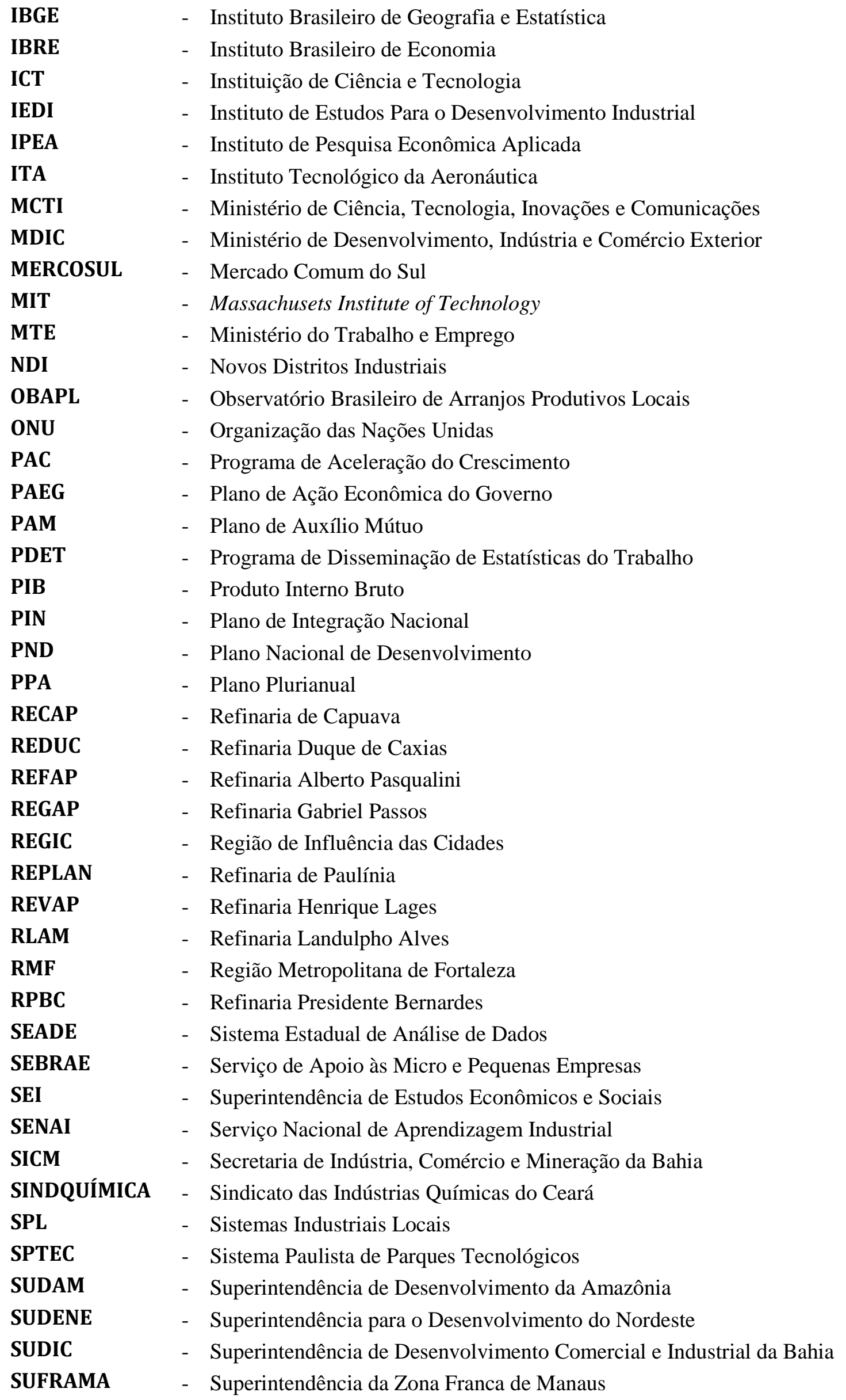


UNB

UFRJ

UNESP

UNICAMP

UNILESTE

USP

VTI
- Universidade Nacional de Brasília

- Universidade Estadual do Rio de Janeiro

- Universidade Estadual Paulista

- Universidade Estadual de Campinas

- Loteamento Industrial Unidade Leste de Piracicaba

- Universidade de São Paulo

- Valor de Transformação Industrial 
INTRODUÇÃO.

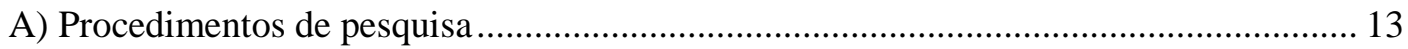

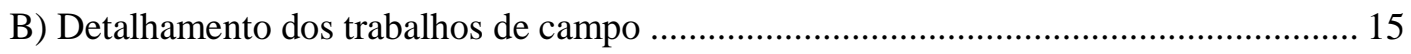

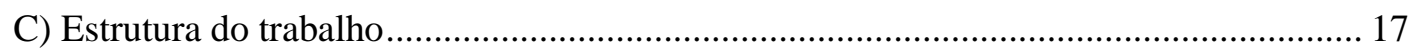

\section{CAPÍTULO 1}

AGLOMERAÇÕES INDUSTRIAIS NO BRASIL ............................................. 19

1.1. Uma visão geral das aglomerações industriais: a importância da proximidade.................... 23

1.2. As formas predominantes no território nacional ................................................................. 30

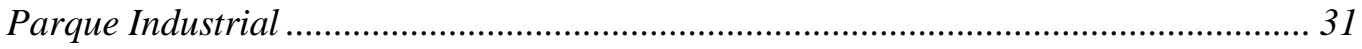

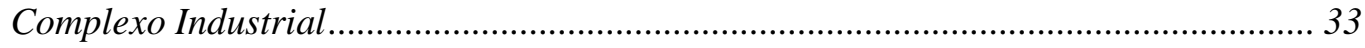

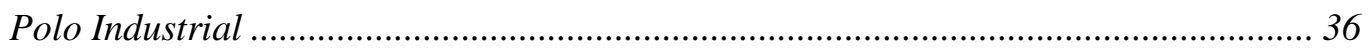

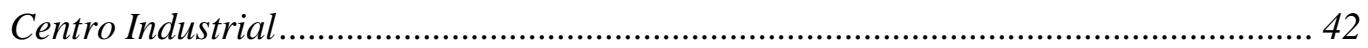

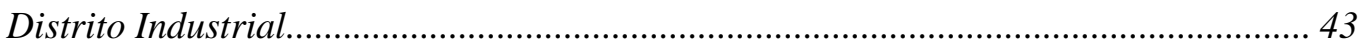

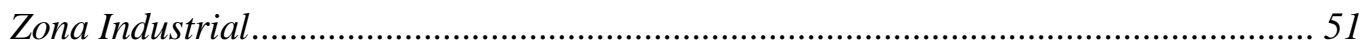

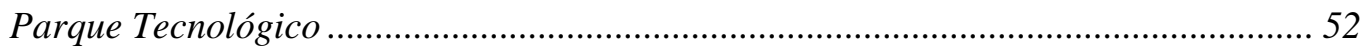

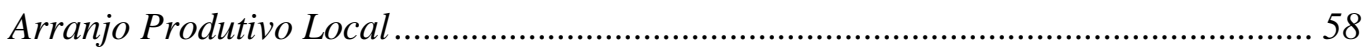

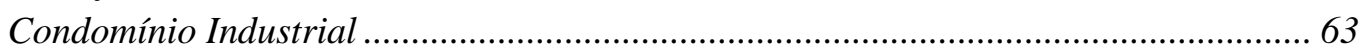

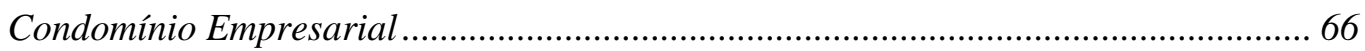

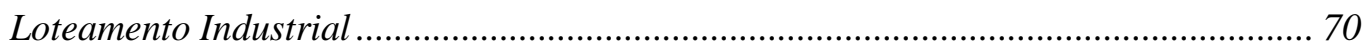

1.3. Noções para interpretação das aglomerações industriais (Quadro síntese).......................... 73

\section{CAPÍTULO 2}

AS AÇÕES DO ESTADO E DO MERCADO NO BRASIL QUE SE INDUSTRIALIZA: AGENTES E PROCESSOS NA CONFIGURAÇÃO DAS AGLOMERAÇÕES

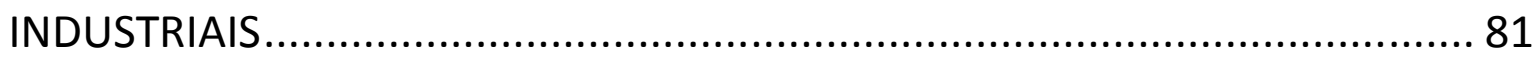

2.1. Formação espacial, Estado desenvolvimentista e ideologia da industrialização no Brasil .. 85

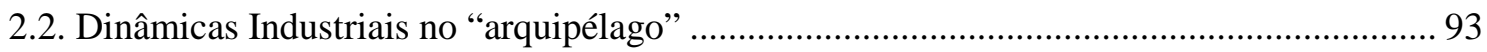

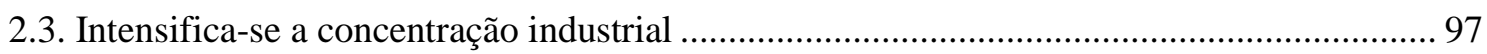

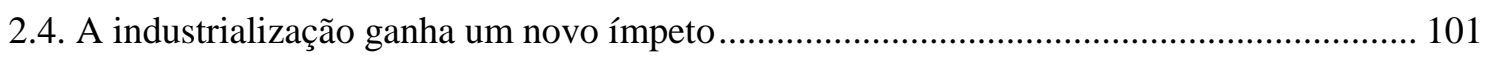

2.5. Os planos de desenvolvimento durante o governo militar .................................................. 106

2.6. Desconcentração-concentrada no Estado de São Paulo ........................................................ 111

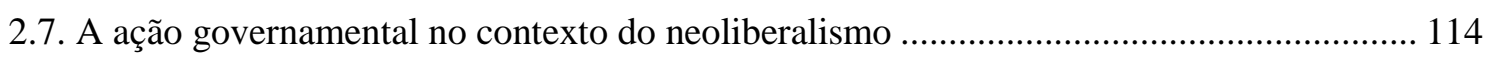

2.8. Indicadores dos últimos vinte anos: uma leitura sobre a desindustrialização ...................... 120 


\section{CAPÍTULO 3}

SELETIVIDADE E PRODUTIVIDADE ESPACIAL: UMA ANÁLISE ATUAL A PARTIR DAS AGLOMERAÇÕES INDUSTRIAIS

3.1. A estrutura do território nacional e as formas de aglomeração industrial

3.2. Distribuição da indústria e de suas aglomerações no território nacional: o que os números mostram?

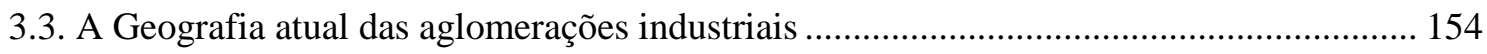

3.4. Aglomerações industriais e a divisão territorial do trabalho.............................................. 183

Condomínios empresariais como movimento recente do capital imobiliário............... 186

Parques tecnológicos como espaços de pesquisa e desenvolvimento .......................... 188

3.5. O Estado e o mercado face à rentabilidade e seletividade espaciais: alguns apontamentos

\section{CAPÍTULO 4}

SOBRE ALGUMAS FORMAS NO TERRITÓRIO BRASILEIRO: SUA DINÂMICA E TRANSFORMAÇÃO

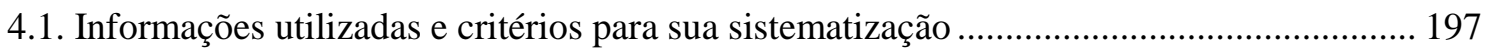

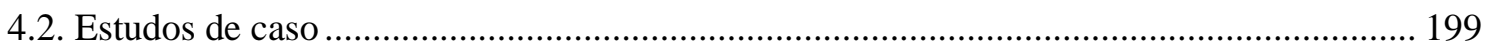

4.2.1. Transformações no uso do solo e busca por renovação: distritos industriais........... 199

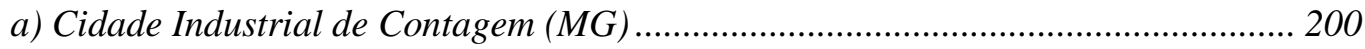

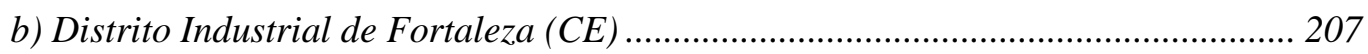

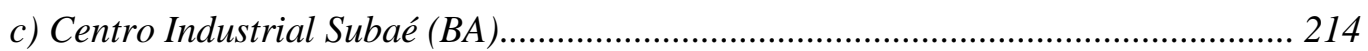

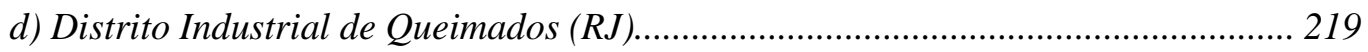

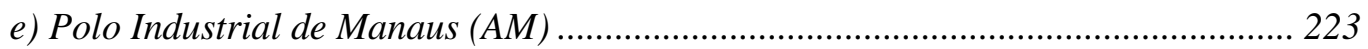

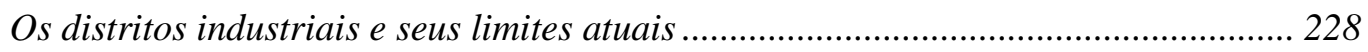

Propostas de renovação dos distritos industriais .................................................... 232

4.3.2. Influência e perenidade da indústria-motriz: polos industriais ............................... 237

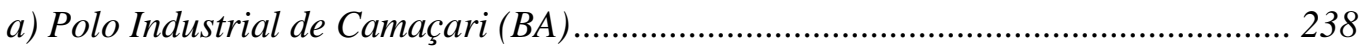

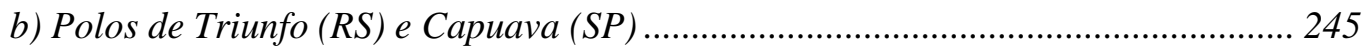

4.3.3. Organização territorial das pequenas indústrias: arranjos produtivos locais .......... 250

4.3.4. Quando o imobiliário define a localização: condomínios empresariais.................. 253

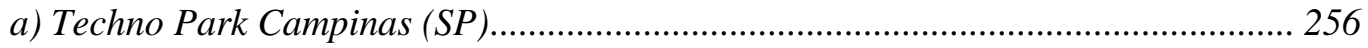

4.3.5. O território especializado: Parque Tecnológico de São José dos Campos............... 262

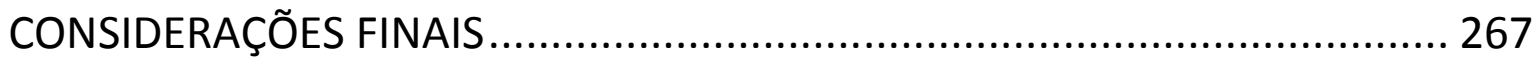

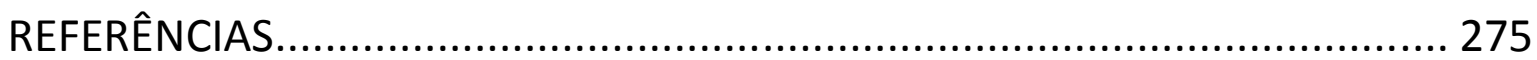

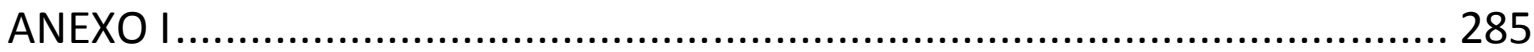




\section{INTRODUÇÃO}

No Brasil, desde a década de 1940, existem esforços para organizar, estimular e atrair unidades industriais para áreas propriamente localizadas e planejadas para o uso produtivo, resultando em aglomerações. Estas aglomerações acompanharam a industrialização do país e podem ser consideradas uma importante expressão territorial deste processo, historicamente e também no período contemporâneo.

De 1941, quando foi implantado o primeiro distrito industrial, até o ano de 2016, podemos dizer que o país passou a ter uma segmentação econômica diversificada, da qual a indústria tem participação importante. Neste processo, as aglomerações foram, algumas vezes, atreladas à necessidade de agrupar uma indústria eventualmente dispersa pelos centros urbanos, permitindo concentrar os seus impactos negativos (tráfego pesado, poluição, ruídos, etc.). Em outras ocasiões, as aglomerações industriais foram consideradas uma "ferramenta" administrativa e política, efetivamente um ponto de partida para estimular o crescimento econômico de uma região ou município.

Estas situações, embora expostas simplificadamente, permitem mostrar a importância do estudo das aglomerações industriais e produtivas. Trata-se de uma nuance do planejamento do território - realizado pelo poder público e pela iniciativa privada - e que expressa o seu uso corporativo. Na escala nacional, as aglomerações refletem também as características da formação espacial brasileira e da divisão territorial do trabalho. Se analisadas pela sua distribuição geográfica, mostram a desigualdade regional do Brasil, e se analisadas por meio de suas características e configurações internas, mostram as especializações de algumas parcelas do território.

Existe, atualmente, uma grande variedade de aglomerações industriais no território brasileiro, podendo-se encontrar variações de acordo com o planejamento de cada um dos governos estaduais e de acordo com as políticas de industrialização, nacionais ou estaduais. A atuação da iniciativa privada, principalmente de incorporadores imobiliários, cuja atuação tem aumentado e se diversificado, é também responsável pela produção de aglomerações industriais. 
Embora seja um tema clássico na Geografia Econômica ${ }^{1}$, podemos afirmar que o entendimento das aglomerações industriais precisa ser aperfeiçoado. Os estudos realizados no Brasil, em sua maioria, fixaram a atenção em uma determinada região e/ou preocuparam-se exclusivamente com estudos de caso, contexto que não permitiu ainda uma análise abrangente e sistemática das formas de aglomeração existentes no território nacional.

É preciso considerar também que a indústria se transformou desde a década de 1970. Processos produtivos mudaram, a superfície necessária para produzir e as características da demanda por produtos industrializados também tiveram mudanças. A ciência e a tecnologia, bem como processos de inovação que influenciam decisivamente nestas mudanças desempenham um papel cada vez mais relevante. Tentaremos evidenciar como o território é produzido a partir destas necessidades e estratégias produtivas, por meio das diferentes formas de aglomeração.

Além das transformações próprias da atividade industrial, outra situação que complexifica a interpretação das aglomerações industriais é a diversidade de agentes envolvidos. Na dimensão da administração pública, os níveis estaduais e municipais são mais atuantes, porém o nível de decisão federal, com atuação expressiva para alavancar o processo de industrialização no Brasil é que explica as aglomerações, historicamente. Some-se a estes agentes um leque diversificado de atuação dos promotores imobiliários que está aumentando nas últimas décadas. Os investimentos privados acompanham mais rapidamente as transformações na estrutura produtiva e, evidentemente, são influentes junto ao poder público. Por isso, o modelo oriundo do investimento imobiliário tem influenciado crescentemente as características das aglomerações industriais. Neste cenário, o que verificamos é a diversidade de tipos de projetos, suas respectivas configurações e uma escolha locacional atrelada ao interesse particular dos investidores imobiliários.

A correlação público e privado perpassa a análise presente nesta tese, pois assim se encontram hoje as aglomerações industriais; não apenas resultado do poder público e não unicamente uma novidade da esfera da iniciativa privada (como poderiam ser apontadas na década de 1990). Existem novas iniciativas que têm logrado sucesso quanto à atração de empresas e sobre as quais podemos oferecer nossa análise.

\footnotetext{
${ }^{1} \mathrm{Na}$ Geografia como campo disciplinar, as aglomerações industriais foram preocupação de subáreas como Geografia Econômica, Geografia Urbana e Geografia das Indústrias. Outros campos do conhecimento também se preocuparam com o tema, sobretudo a Economia Regional, Arquitetura e Urbanismo e Engenharia de Produção.
} 
Há uma expressiva dispersão das aglomerações industriais que poderíamos denominar de "clássicas" pelo território nacional e uma pluralidade de formatos se considerarmos as novas iniciativas. Mesmo se falássemos apenas das formas de aglomeração clássicas (que muitos julgam obsoletas devido à falta de estudos sobre as suas transformações atuais), elencaríamos novas ações em curso e projetos com o objetivo de modernizar e renovar estas áreas.

Para fazer a interpretação das aglomerações industriais de acordo com o contexto e os elementos expostos, nosso ponto de partida é a própria Geografia e suas categorias de análise. Nessa perspectiva decidimos considerar, como centrais para estruturar a pesquisa, a formação espacial, a divisão territorial do trabalho e as características atuais do meio geográfico - ao mesmo tempo técnico, científico e informacional - bem como as implicações oriundas destas características, quando concentradas ou ausentes.

Consideramos, como objetivo principal de nossa pesquisa: atualizar e sistematizar as informações sobre as aglomerações industriais no Brasil, por meio de uma leitura geográfica destas áreas que possa subsidiar posteriores análises do território brasileiro.

Nosso objetivo específico é determinar quais são os tipos de aglomerações industriais existentes no território nacional, qualificar a proposta relacionada à implantação destas áreas de acordo com os agentes e com o momento histórico em que foram idealizadas e, finalmente, apresentar e analisar sua distribuição geográfica e configuração territorial resultante. Nesse caminho proposto, tentaremos oferecer uma interpretação da industrialização brasileira a partir de uma visão territorial do processo, por meio das formas geográficas que melhor o expressam, quais sejam, as aglomerações industriais.

Nossa hipótese diz respeito ao entendimento de que as aglomerações industriais são formas geográficas que expressam a dimensão espacial da industrialização brasileira e mostram a importância da proximidade para o processo produtivo. Estas formas resultam da divisão territorial do trabalho e da dinâmica da formação espacial brasileira, apontando a permanente seletividade espacial dos investimentos.

Para isso, consideramos inicialmente a existência de onze tipos de aglomeração industrial no território brasileiro, que foram identificadas por meio de levantamento bibliográfico e revisão dos principais autores sobre o tema e sobre cada um dos tipos de aglomeração, especificamente. Deste universo, selecionamos quatro formas de aglomeração, devido à sua importância (número e distribuição no território): distritos 
industriais, polos industriais, arranjos produtivos locais e condomínios empresariais. Estas quatro tipos de aglomeração escolhidas também permitem que a pesquisa tenha uma abrangência temporal ampla: os distritos industriais são formas de aglomeração pioneiras no Brasil ao passo que os condomínios empresariais representam iniciativas contemporâneas. Por fim, vale ressaltar uma breve abordagem sobre parques tecnológicos para, comparativamente, ressaltar aspectos da divisão territorial do trabalho e as iniciativas e parcelas do território que tendem a se especializar.

\section{A) Procedimentos de pesquisa}

Como procedimentos de pesquisa empenhados para a realização desta tese, cumprimos as seguintes atividades:

(1) Revisão bibliográfica feita em livros e artigos. Foram contempladas questões relacionadas à natureza do espaço geográfico, à localização industrial e à formação e organização das aglomerações industriais. A compreensão histórica da industrialização no país, outro tema bastante relevante para a pesquisa, foi realizada principalmente por meio de estudos de Economia que interpretaram este processo, ao qual tentamos concatenar a produção territorial das aglomerações industriais, sua intencionalidade e localização. Além disso, foi feito um estudo teórico mais detalhado sobre alguns tipos de aglomeração específicos, principalmente distritos industriais, polos industriais, arranjos produtivos locais, condomínios empresariais e parques tecnológicos. Ainda em relação à formação conceitual necessária à pesquisa, abordamos os conceitos de divisão territorial do trabalho e formação espacial para auxiliar na leitura mais geral destas formas em relação ao território.

(2) A partir do desenvolvimento conceitual de cada uma das aglomerações, foram selecionadas aquelas que são mais representativas industrialmente (em número e densidade), no país. Dessa forma, pudemos direcionar o estudo conceitual para o estudo das formas, bem como orientar melhor os trabalhos de campo que sucederam.

(3) $\mathrm{Na}$ condição de referência para a leitura das aglomerações industriais no período atual, foram realizados trabalhos de campo em dez estados brasileiros, nos quais entrevistamos alguns dos principais agentes envolvidos com o planejamento das áreas industriais, a partir de agendamento prévio realizado por telefone. Procuramos seguir sempre os mesmos critérios para a realização de entrevistas em cada estado, para isso buscando a principal instituição relacionada a cada uma das áreas industriais: Secretarias estaduais de desenvolvimento econômico, de indústria e comércio / prefeituras municipais / Coordenadorias regionais do Serviço Brasileiro de Apoio às Micro e Pequenas 
Empresas (SEBRAE) / federações industriais / associações de empresas existentes em alguns distritos industriais. Ao todos foram realizadas 61 entrevistas, detalhadas no item seguinte.

(4) Visita às áreas industriais, in situ: atrelado aos trabalhos de campo em cada um dos estados, foram coordenadas algumas visitas técnicas às principais áreas industriais e realização de seu registro fotográfico, sobretudo distritos industriais e polos industriais. Ao todo foram realizadas 24 visitas, detalhadas no item seguinte. Destaque-se a visita aos Polos Petroquímicos de Camaçari (BA), Triunfo (RS) e Mauá (SP).

(5) Desenvolvimento de um banco de dados georreferenciado para armazenamento das localizações e características básicas das aglomerações industriais, a partir de dados secundários. Os dados foram coletados a partir de diversas fontes, para distritos industriais e arranjos produtivos locais. Os polos industriais, devido ao seu pequeno número, foram georreferenciados a partir de levantamento direto. Foram registrados, neste banco de dados, 650 fixos geográficos a partir das seguintes fontes:

- Companhia de Desenvolvimento de Minas Gerais (CODEMIG);

- Companhia de Desenvolvimento Industrial do Rio de Janeiro (CODIN);

- Superintendência de Desenvolvimento Comercial e Industrial da Bahia (SUDIC);

- Fundação Sistema Estadual de Análise de Dados (SEADE);

- Observatório Brasileiro de Arranjos Produtivos Locais (OBAPL);

- Instituto Brasileiro de Geografia e Estatística (IBGE).

(6) Desenvolvimento de um banco de dados georreferenciados exclusivo para o mapeamento e armazenamento de informações mais detalhadas sobre os condomínios empresariais. Aproveitou-se o banco de dados já desenvolvido (FINATTI, 2011) para o Estado de São Paulo e, por meio de pesquisas e levantamentos on-line pudemos incorporar informações sobre os condomínios empresariais localizados nos demais estados da federação. As informações foram coletadas a partir de diversas fontes: sites institucionais e corporativos, matérias de jornais e revistas, publicações do mercado imobiliário e outras pesquisas acadêmicas que se debruçaram sobre este objeto. Ao banco de dados foram também incorporadas informações importantes para a melhor interpretação do fenômeno, como a área do empreendimento, o ano de inauguração (quando possível), os promotores imobiliários envolvidos (separados por função: incorporadores, projetistas, construtores e corretores) e o conjunto de funcionalidades existentes nos empreendimentos, separadas por categorias pré-determinadas. Foram registrados, neste banco de dados, 319 fixos geográficos.

(7) Enquetes realizadas por telefone, junto a importantes incorporadores imobiliários, construtoras e também administradoras com negócios no nicho de condomínios de galpões modulares, a fim de levantar informações sobre ocupação e segmentos que procuram instalar-se nos empreendimentos. 
(8) Levantamento de informações estatísticas sobre estabelecimentos e empregos industriais, visando a caracterização do tema de estudo, utilizando o sistema de recuperação de dados do Programa de Disseminação de Estatísticas do Trabalho (PDET) do Ministério do Trabalho e Emprego (MTE). Foram selecionados: número de estabelecimentos e número de empregos da Indústria de Transformação (1985, 1995, 2005 e 2013).

\section{B) Detalhamento dos trabalhos de campo}

Para realização dos trabalhos de campo foram visitadas as capitais de dez unidades estaduais, com histórico representativo de industrialização, para entrevistar os agentes que estão diretamente envolvidos com a implantação das aglomerações industriais e, quando possível, visitar estas áreas.

Fizemos o registro dos áudios durante as entrevistas, mediante a autorização de nossos interlocutores, e realizamos registros fotográficos de algumas áreas, quando possível (a solicitação para registro fotográfico pode ser negada ou o registro pode ser inviabilizado pelas condições do tempo). Os dados levantados em campo foram utilizados nos Capítulos 3 e 4 da tese. Apresentaremos um detalhamento das entrevistas realizadas em cada etapa, bem como as áreas visitadas, por meio do Anexo I.

Para sintetizar os números dos trabalhos de campo, um possível indicador da abrangência das atividades realizadas nas dez unidades estaduais, elaboramos o quadro a seguir (Quadro 1).

\section{QUADRO 1}

Dados das atividades de campo realizadas no período de julho de 2014 a setembro de 2016

\begin{tabular}{c|c|c|c|c|c}
\hline $\begin{array}{c}\text { Unidade } \\
\text { estadual }\end{array}$ & $\begin{array}{c}\mathbf{n}^{\mathbf{0}} \text { de agentes } \\
\text { entrevistados }\end{array}$ & $\begin{array}{c}\mathbf{n}^{\mathbf{0}} \text { de áreas } \\
\text { visitadas }\end{array}$ & $\begin{array}{c}\text { áudio gravado } \\
\text { (horas) }\end{array}$ & $\begin{array}{c}\mathbf{n}^{\mathbf{0}} \text { de dias } \\
\text { empenhados }\end{array}$ & $\begin{array}{c}\text { participação } \\
\text { em eventos* }\end{array}$ \\
\hline$R N$ & 7 & 3 & $06 \mathrm{~h} 59$ & 7 & - \\
$C E$ & 6 & 3 & $05 \mathrm{~h} 09$ & 4 & 1 \\
$B A$ & 10 & 2 & $09 \mathrm{~h} 22$ & 6 & - \\
$P E$ & 5 & 5 & $05 \mathrm{~h} 33$ & 6 & - \\
$R J$ & 3 & 1 & $03 \mathrm{~h} 55$ & 5 & 1 \\
$M G$ & 3 & 1 & $04 \mathrm{~h} 22$ & 5 & - \\
$R S$ & 4 & 2 & $04 \mathrm{~h} 45$ & 4 & 1 \\
$A M$ & 5 & 1 & $04 \mathrm{~h} 52$ & 4 & 1 \\
$S P$ & 15 & 5 & $09 \mathrm{~h} 51$ & 10 & - \\
$P R$ & 3 & 1 & $02 \mathrm{~h} 26$ & 3 & $\mathbf{5}$ \\
\hline Total & $\mathbf{6 1}$ & $\mathbf{2 4}$ & $\mathbf{5 8 h 1 3}$ & $\mathbf{5 4}$ & \\
\hline
\end{tabular}

*) Refere-se à participação em eventos públicos ou corporativos diretamente relacionados ao tema de pesquisa, que estavam acontecendo durante as nossas atividades no respectivo estado. 
Para oferecer uma ideia da abrangência geográfica do trabalho de campo, o Mapa 1 mostra as principais as aglomerações industriais visitadas (não estão contempladas no Mapa 1 as localizações de instituições onde realizamos entrevistas ou das áreas cujas observações foram insuficientes para análise posterior).

\section{MAPA 1}

BRASIL - Aglomerações industriais visitadas em trabalho de campo
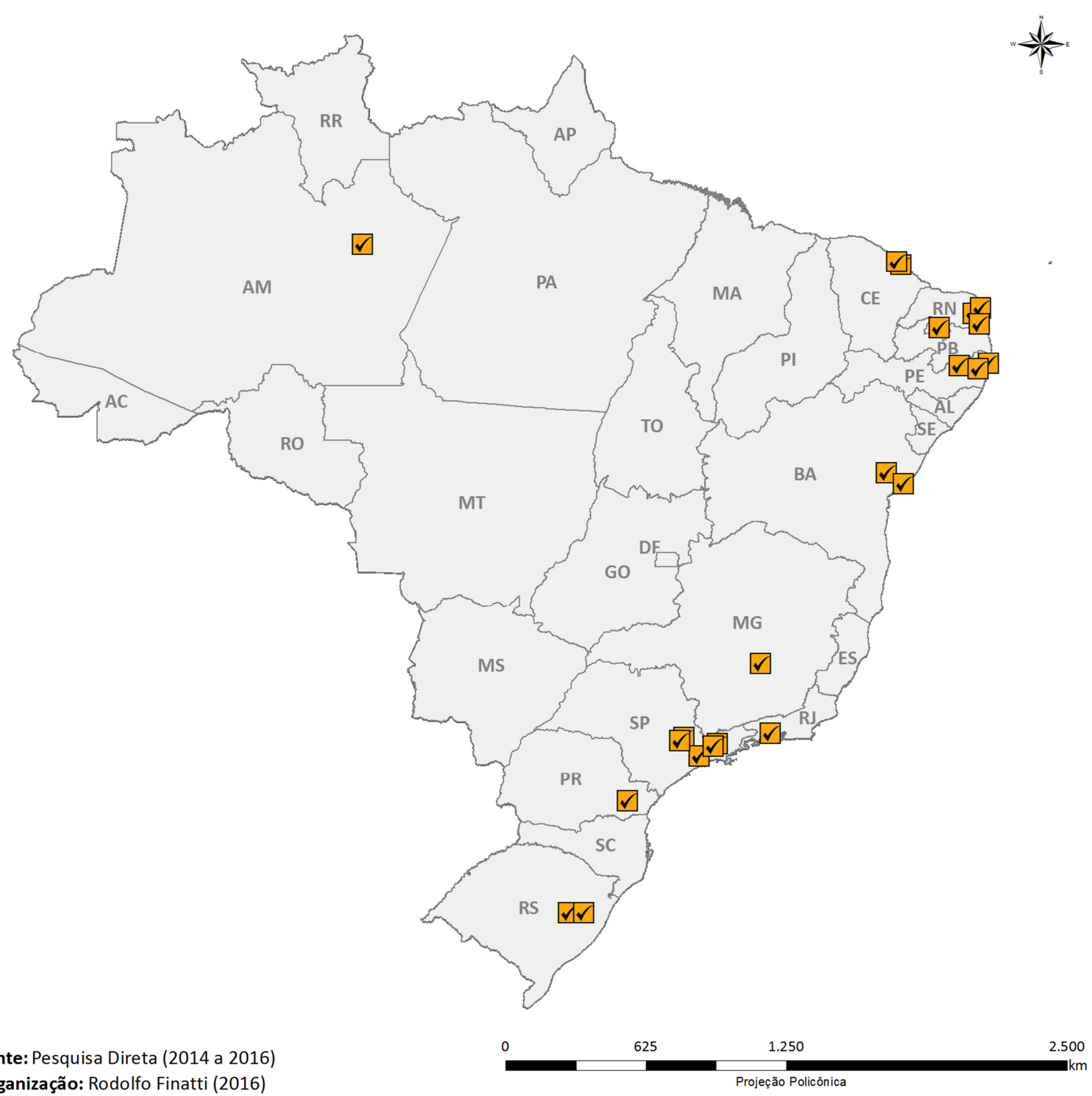

É importante destacar a organização dos trabalhos de campo para a realização desta pesquisa, uma vez que significaram uma fonte de informação atualizada dos processos em curso. Imprescindivelmente, as análises traduzem a visão de gestores públicos, analistas e técnicos envolvidos com implantação e posterior administração das aglomerações industriais, bem como de outros pesquisadores entrevistados, os quais 
tiveram, em algum momento, preocupação similar em suas áreas de estudo. A visão dos investidores, com os quais também tivemos aproximação, se traduz pela interpretação de sua intencionalidade, estratégia de comercialização e escolhas de localização.

\section{C) Estrutura do trabalho}

A tese está estruturada em quatro capítulos. No primeiro deles, chamado “Aglomerações industriais no Brasil”, mostramos um extenso levantamento bibliográfico com o objetivo de contemplar a diversidade das diferentes formas de aglomeração detectadas no território nacional, bem como conhecê-las em seu quadro teórico. Este capítulo, portanto, remete à sistematização do conhecimento produzido sobre as formas de aglomeração, o que nos permitiu reagrupá-las e escolher os tipos que deveríamos estudar com maior atenção e detalhe. Elaboramos um quadro com as principais variáveis relevantes para a leitura das aglomerações industriais, a partir de um ponto de vista territorial. Do conjunto estudado, foram escolhidos para posterior análise os seguintes tipos de aglomeração:

- Distritos industriais

- Polos industriais

- Arranjos produtivos locais

- Condomínios empresariais

O segundo capítulo, nomeado "As ações do Estado e do mercado no Brasil que se industrializa: agentes e processos na configuração das aglomerações industriais", tem o objetivo de apresentar os eventos mais importantes do processo de industrialização no Brasil, tomando como objeto de atenção as ações que engendraram algumas das aglomerações mais importantes (ou o ideal de alguns tipos de aglomerações) e, sobretudo em que contexto histórico das políticas públicas e dinâmicas territoriais estas áreas foram fomentadas.

O terceiro capítulo, intitulado "Seletividade e produtividade espacial: uma análise atual a partir das aglomerações industriais", tem como objetivo apresentar uma análise das aglomerações industriais na atualidade face à formação espacial e divisão territorial do trabalho, uma vez que o conjunto das informações e interpretações realizadas nos permitiu, neste ponto, sistematizar uma leitura do território nacional em relação à 
temática proposta. Neste capítulo, os parques tecnológicos, embora não tenha sido um tipo de aglomeração selecionado para o detalhamento, mostram uma possibilidade extra de explicarmos com maior riqueza a divisão territorial do trabalho e a especialização de algumas parcelas do território brasileiro.

Finalmente, o quarto e último capítulo, "Sobre algumas formas no território brasileiro: sua dinâmica e transformação", contempla os resultados dos trabalhos de campo nas dez unidades estaduais visitadas, permitindo melhor analisar a situação atual das aglomerações industriais, afinar os conceitos estudados com relação à realidade brasileira, bem como estabelecer críticas e questões-chave para a leitura destas áreas. Foram centrais para a elaboração deste capítulo as entrevistas realizadas com os agentes públicos e privados que estão envolvidos diretamente com o planejamento das áreas industriais, e por isso nossa interpretação reflete processos e iniciativas atuais.

O desenvolvimento de nossa pesquisa, realização dos trabalhos de campo, compra de materiais e participação em importantes eventos de Geografia realizou-se com o apoio financeiro da Fundação de Amparo à Pesquisa do Estado de São Paulo (FAPESP), por meio de uma bolsa de doutorado. 


\section{CAPÍTULO 1}

\section{AGLOMERAÇÕES INDUSTRIAIS NO BRASIL}

Podemos definir as aglomerações industriais como áreas destinadas à produção industrial cuja localização, infraestrutura urbana, subsídios e possíveis relações interfirmas ou organizacionais tendem a estimular e rentabilizar a instalação de unidades produtivas. Elas possuem delimitações físicas e delimitações normativas, sendo ora mais bem definidas e identificáveis fisicamente e ora mais bem definidas normativamente (quando a aglomeração é menos densa ou não apresenta limites físicos evidentes).

Como uma inspiração inicial para interpretá-las, é P. George quem afirma: “indústria atrai indústria”. Em outras palavras: "A proliferação e a diversificação das atividades produtivas em uma região industrial são, portanto, fatos lógicos e geralmente observados" (GEORGE, 1967 [1958], p.80). Não obstante, o território atrai indústria, quer seja pelos recursos existentes, pela configuração dos fixos e fluxos ${ }^{2}$ geográficos ou ainda pelo planejamento diretamente objetivando a organização industrial/produtiva.

É válido mostrar que tais noções não são importantes unicamente no meio acadêmico, mas também usadas pelo planejamento territorial feito pela gestão pública. A Coordenadoria de Ação Regional do Estado de São Paulo ressalta, em manual publicado no ano de 1981:

Como preconiza a teoria econômica e conforme foi constatado em recente pesquisa desenvolvida por esta coordenadoria - Fatores Locacionais da Indústria e o Desenvolvimento Regional no Estado de São Paulo - dentre os fatores que atuam de forma decisiva para acentuar os níveis de concentração espacial das atividades produtivas, mormente das indústrias, destacam-se as economias de aglomeração que realimentam o processo cumulativamente (GOVERNO DO ESTADO DE SÃO PAULO, 1981, p.2).

\footnotetext{
${ }^{2}$ Os fixos e fluxos geográficos devem ser entendidos conjuntamente: "O espaço e, também e sempre, formado de fixos e de fluxos" (SANTOS, 1988, p.77). Complementarmente, devemos considerar que "[...] os fixos nos dão o processo imediato do trabalho. Os fixos são os próprios instrumentos de trabalho e as forças produtivas em geral. Os fluxos são o movimento, a circulação e assim eles nos dão, também, a explicação dos fenômenos da distribuição e do consumo" (idem).
} 
Nosso objeto de estudo pode se expressar predominantemente em diferentes aspectos, e por isso é necessário aprender a identificá-los. Em um aspecto visual, as aglomerações industriais podem apresentar uma materialidade densa e bastante evidente na paisagem. Todavia, em aspectos menos visíveis elas são definidas por normas que, juridicamente, as legitimam. Embora as aglomerações industriais possuam uma evidente fixidez, não podem ser compreendidas exclusivamente pela densidade material e pela sua localização, pois há aglomerações menos densas ou até descontínuas cuja principal referência será a normativa.

Com base na proposta de M. Santos (2004 [1996]), precisamos considerar que é indispensável interpretar, junto ao conjunto de objetos existentes no território (fixos geográficos), o conjunto de ações que esses espaços compreendem e ativam em outros pontos do mundo (fluxos materiais e imateriais), bem como a maneira pela qual, na condição de aglomerações industriais, integram o meio técnico-científico-informacional ${ }^{3}$ como característica do período atual (SANTOS, 2002).

Poderíamos ainda afirmar as aglomerações como o espaço industrial propriamente dito. De fato, os modelos teóricos estão classicamente ligados às análises de localização e concentração geográfica, e essa economia de aglomeração resultante explica suas vantagens comparativas. Contudo, uma importante noção a ser ressaltada é que não podemos resumir estes espaços à arena de produção, exclusivamente. Tampouco podemos resumi-los à teoria da localização de indústrias.

$\mathrm{Na}$ abordagem de C. Manzagol (1985) afirma-se que "explicar o espaço industrial é tornar inteligíveis suas estruturas e sua dinâmica, em diferentes escalas". Em outras palavras, é oferecer uma análise do papel das aglomerações no âmbito da totalidade do espaço. As aglomerações industriais seriam, por assim dizer, as principais densidades no âmbito do espaço industrial organizado, justificando a análise focada no seu processo de produção territorial. Isso requer estudar a formação destes espaços e as funções que desempenham no processo de produção e acumulação.

Para organizar nossa apresentação, consideraremos que o conjunto do espaço social pode ser dividido conforme as instâncias: o "espaço da produção propriamente dita", o "espaço da circulação e da distribuição" e o "espaço do consumo" de acordo com a terminologia proposta por M. Santos (1985).

\footnotetext{
${ }^{3} \mathrm{O}$ período atual, ao qual corresponde também um meio geográfico, pode ser identificado como técnicocientífico-informacional. Neste meio, se aprofunda a relação entre técnica, ciência e informação: "[...] a ciência e a tecnologia, junto com a informação, estão na própria base da produção, da utilização e do funcionamento do espaço e tendem a constituir o seu substrato" (SANTOS, 2004 [1996], p.238).
} 
O espaço da produção propriamente dita corresponde diretamente à produção industrial e é tributário de uma fração determinada do território, uma vez que socialmente organizado:

Na produção de bens materiais ou imateriais, segundo as condições dadas de tecnologia, capital e tempo, o território tem que ser adequado ao uso procurado e a produtividade do processo produtivo depende, em grande parte, dessa adequação (SANTOS, 1985, p.61).

Nesse sentido, podemos dizer que a produção de valor começa antes mesmo que a mercadoria produzida na fábrica ou no escritório esteja concluída. $\mathrm{O}$ valor do espaço pode ser auferido pela sua prestabilidade junto ao processo produtivo, e este valor cada vez mais aumenta devido ao conteúdo técnico e científico atribuído às formas urbanas. Assim, há um “[...] significado todo especial à produção do espaço como condição da produção de valor pelos que devem utilizá-lo como suporte" (SANTOS, 1985, p.62).

Neste mesmo contexto, como abordaremos no decorrer da tese, cada forma produzida é capaz de atribuir determinada rentabilidade ao processo produtivo. A combinação entre as densidades e dinâmicas do território, pré-existentes a uma aglomeração industrial ou por ela estimuladas, e a rentabilidade oferecida pela aglomeração industrial propriamente dita (de acordo com suas características), explicam a seletividade espacial dos investimentos. As decisões locacionais explicadas por meio das aglomerações industriais (ou a atratividade de empresas que as aglomerações são capazes de exercer) seguem a mesma lógica.

Esta instância (espaço da produção propriamente dito) precisa estar combinada às demais para a realização da acumulação do capital, ou seja, precisa estar combinada às etapas de circulação, distribuição e consumo. Para M. Santos:

Uma vez que a área de mercado tem tendência a ampliar-se e estender-se a todo o território da nação, ou, mesmo, para além dele, é indispensável transformar as massas produzidas em fluxos [...] Quem o fizer mais rapidamente, terá condições para tornar-se o mais forte (1985, p.63).

Embora estas demais fases tendam a ser consideradas, sobretudo em uma visão locacional, como um conjunto de demais fixos (meios de transporte, rodovias, mercados e espaços de consumo) que estão distantes da arena produtiva, sua importância é central. Essa é uma noção importante para ressaltarmos que as aglomerações industriais são espaços heterogêneos, fato que habitualmente não é abordado pelos modelos teóricos. 
Além das indústrias historicamente localizadas nas diferentes formas de aglomeração, existem outros processos e empresas não necessariamente industriais coexistindo. São, principalmente, empresas prestadoras de serviços industriais ${ }^{4}$, operadores logísticos e também centros de armazenagem e distribuição. Evidentemente, isso está atrelado ao tipo de aglomeração, mas podemos também encontrar conjuntos de escritórios, unidades de pesquisa, shopping centers, centros de convenções, escolas, universidades, hospitais, hotéis, igrejas, bairros residenciais de diferentes padrões sociais e inclusive condomínios residenciais fechados. Há uma multiplicidade de outros fixos que podem ou não estar associados às empresas industriais existentes nas aglomerações.

Práticas contemporâneas como o just in time e a necessidade de, a todo o momento, ampliar a competitividade, estimulam a especialização dos segmentos produtivos e permitem antever uma aproximação entre eles cada vez maior. Por essa razão, os gestores de um grande número de aglomerações industriais permitem e estimulam a instalação de qualquer segmento econômico (sem excluir comércio ou serviços).

Por fim, escrever sobre aglomerações industriais se torna ainda mais complexo devido à grande extensão do território brasileiro, às diferentes políticas federais já elaboradas e também às diferentes políticas estaduais vigentes. Com base nas especificidades históricas, intencionalidade dos agentes envolvidos e configuração territorial, pudemos identificar onze diferentes tipos de aglomeração industrial.

$\mathrm{Na}$ sequência, estudaremos alguns modelos teóricos destas aglomerações, buscando primeiro uma visão geral para, na sequência, abordar cada uma das formas especificamente. O objetivo deste capítulo é apresentar nosso objeto de estudo (as aglomerações industriais) e também um caminho para sua leitura geográfica, por meio da investigação das características em comum e noções-chave capazes de identifica-las e caracterizá-las.

Este caminho deverá mostrar que existe um planejamento governamental (mas também da iniciativa privada) que resulta na preparação do território para albergar as empresas. As aglomerações industriais/produtivas são a principal expressão geográfica

\footnotetext{
${ }^{4}$ Os serviços industriais se desenvolvem a partir das relações entre empresas produtoras de bens de produção e de capital. Podem ser considerados como atividades de apoio e de serviço de caráter industrial: controle de qualidade, projetos industriais, limpeza de fornos, tratamento de resíduos, serviços de seleção, limpeza e embalagem. Podem também possuir maior valor agregado, sobretudo quando envolvem pessoal especializado em projetos industriais ou focam no desenvolvimento de média e alta tecnologia para inserir no processo produtivo (por exemplo: o desenvolvimento de produtos químicos orgânicos ou inorgânicos). $C f$. Mergulhão-Barros (2011 e 2015).
} 
deste processo e a proximidade geográfica, por consequência, um elemento fundamental capaz de rentabilizar tais localizações.

1.1. Uma visão geral das aglomerações industriais: a importância da proximidade

Antes de apresentarmos alguns modelos teóricos relacionados a cada tipo de aglomeração industrial, tentaremos sistematizar algumas ideias mais gerais sobre a própria noção de aglomeração industrial. Se comparadas aos estudos de caso ou estudos regionais focados em um tipo específico de aglomeração, o empenho em analisar genericamente a aglomeração industrial é sensivelmente menor.

Em primeiro lugar, podemos constatar que existe um esforço contínuo em analisar as formas de aglomeração industrial. Cada momento histórico tem, predominantemente, um tipo de aglomeração que é objeto de implantação e políticas públicas, e os estudos acompanham essas tendências. Assim como há uma difusão dos estudos, há também uma difusão das formas de aglomeração, em seu número e em diferentes tipos. Isso não quer dizer que são substituídas, mas coexistem e mudam com o passar do tempo. As aglomerações também podem se mesclar, eventualmente. Por essa razão, acreditamos que os estudos sobre aglomeração industrial devem levar em conta análises pormenorizados de cada um de seus tipos.

Outra informação sobre as aglomerações industriais é a diversidade dos agentes envolvidos em sua formulação e implantação, cada qual com uma determinada proposta e intencionalidade. Partimos, evidentemente, das políticas federais e estaduais como as principais responsáveis pelas aglomerações no Brasil, sobretudo as pioneiras. No entanto, a administração pública na escala municipal também participa da formulação, bem como outras instituições na esfera pública tais como as universidades e secretarias de planejamento, comércio e indústria. Os investidores privados, mais recentemente, são também responsáveis pela implantação de formas de aglomeração próprias, aspecto esse que diversifica a nossa análise.

Entre os autores clássicos estão presentes as definições de algumas das terminologias que remetem diretamente às aglomerações em seu sentido pioneiro. Desde o trabalho precursor do economista A. Marshall (1890), é importante ressaltar que a ideia de aglomeração/concentração é espacialmente expressa por meio do termo "distrito". Para Marshall o distrito refere-se não apenas à indústria, mas genericamente a qualquer tipo de 
aglomeração; distritos populacionais, comerciais ou agrícolas são mencionados. Assim, o distrito é um termo usado para descrever a compartimentação dos usos do solo.

Quando remonta às condições que influenciaram as primeiras concentrações de pequenas indústrias, Marshall destaca que foram estimuladas pelo mecenato: procuravam produtos de qualidade muito elevada fazendo com que trabalhadores competentes se mantivessem reunidos para aproveitar essa demanda. Por vezes estes trabalhadores assumiam riscos financeiros das viagens e da abertura de seus negócios, outras vezes o governo convidava artesãos de outras localidades e os mantinham agrupados.

Para o autor, estas primeiras aglomerações foram gradualmente responsáveis pela divisão entre o trabalho mecânico e o trabalho administrativo:

[...] This elementary localization of industry gradually prepared the way for many of the modern developments of division of labour in the mechanical arts and in the task of business management (MARSHALL, 1890, p.605).

Dessa forma, as aglomerações eram compostas por pequenas empresas localmente estabelecidas, bem como suas próprias decisões de produção e investimentos. Relações comerciais de insumo e produto eram substanciais no interior do distrito, tanto que os relacionamentos com empresas fora do distrito poderiam ser consideradas mínimas. Contudo, o que fazia o distrito marshalliano especial seriam a natureza e qualidade de sua força de trabalho; operários e empresários, os quais viviam numa mesma comunidade e tinham, por isso, um senso de comprometimento que não se dava com uma empresa em particular, mas com o distrito (comunidade) como um todo. Essa comunidade, então estável, permitia o desenvolvimento de uma forte identidade local e o fértil compartilhamento de experiências e ideias:

The mysteries of the trade become no mysteries; but are as it were in the air, and children learn many of them unconsciously. Good work is rightly appreciated, inventions and improvements in machinery, in processes and the general organization of the business have their merits promptly discussed: if one man starts a new idea, it is taken up by others and combined with suggestions of their own; and thus it becomes the source of further new ideas. And presently subsidiary trades grow up in the neighbourhood, supplying it with implements and materials, organizing its traffic, and in many ways conducing to the economy of its material (MARSHALL, 1890, p.609). 
Esta importante caracterização pioneira da aglomeração industrial está assentada nos traços de uma cultura local forte, compromissada e inovativa. Algumas destas características podem, inclusive, ser consideradas para a análise dos diferentes tipos de aglomeração industrial detalhadas neste capítulo.

Uma das abordagens mais atuais e utilizadas sobre as aglomerações, considerando seu sentido mais amplo, vem do trabalho de M. Porter (1999), responsável pelo emprego e generalização do termo cluster para denominar as aglomerações produtivas atuais. Na esfera da administração de empresas, o objetivo de Porter foi apresentar os fatores que aumentariam a competitividade dos aglomerados de empresas (não necessariamente empresas industriais).

$\mathrm{Na}$ perspectiva dos clusters o contexto geográfico é muito importante, especialmente quando é capaz de estimular ou ser estimulado por relações sociais e econômicas, muitas das quais estão localmente estabelecidas. Para este autor:

Um aglomerado é um agrupamento geograficamente concentrado de empresas inter-relacionadas e instituições correlatas numa determinada área, vinculadas por elementos comuns e complementares. O escopo geográfico varia de uma única cidade ou estado para um país ou mesmo uma rede de países vizinhos (PORTER, 1999, p.211).

Porter argumenta que o ambiente de negócios - condição e expressão de sua própria localidade, do contexto em que se inserem - é um fator fundamental para as empresas, daí a importância geográfica na definição de cluster em um contexto de mundialização da economia. $\mathrm{O}$ autor afirma isso em contraposição à noção de que os custos mínimos de produção, transporte, qualidade da mão de obra, isenção de impostos, níveis salariais, etc. seriam os principais definidores das vantagens competitivas de uma aglomeração produtiva.

Porter destaca também que os aglomerados variam em tamanho, amplitude e estágio de desenvolvimento. Para ele, as teorias que antecederam os clusters eram ideias muito específicas dos aglomerados tradicionais ou se restringiam unicamente a certos tipos de aglomerados. É importante ressaltar que a perspectiva dos clusters é mais ampla e, evidentemente, não se restringe à dimensão das indústrias.

Talvez a principal contribuição de Porter para nossa análise seja sua argumentação sobre a competitividade, quando afirma que "[...] a sofisticação e a produtividade com que as empresas competem em determinada localidade é muito influenciada pela qualidade do ambiente de negócios" (1999, p.222). Em outras palavras, o 
autor está considerando justamente as características do território na competitividade das empresas.

Um dos aspectos que frisa é que a competitividade é diferente - ou algo além do que simplesmente a eficiência operacional, e esta pode ser obtida em um espaço que não necessariamente estimule a competitividade. Esta outra afirmação reforça a relevância do espaço como fator essencial para tratar uma questão cara em sua teoria, qual seja: a forma pela qual se pode estimular a competitividade em uma aglomeração.

Nos clusters, é importante destacar, a realização das condições é apenas potencial. Estes espaços tem seu surgimento atrelado às características locais, um condicionamento histórico prévio. A simples proximidade não garante que tais relacionamentos ocorram, por isso é preciso fomentar e manter a coesão do aglomerado, promovendo um livre fluxo de informações para descoberta de intercâmbios. Isso se daria por meio de uma política de fomento do governo local.

Enfim, o receituário do autor é o seguinte ${ }^{5}$ técnicas logísticas avançadas possíveis em um espaço com infraestrutura de transportes de alta qualidade, a existência de serviços sofisticados fortemente vinculados ao nível educacional das pessoas neste ambiente e, por fim, operar com mais eficiência por meio de um fardo burocrático menor (PORTER, 1999). Ele argumenta que as mais importantes economias de aglomeração no mundo atual giram em torno da inovação, de sorte que é preciso estudar melhor este processo.

O autor, embora siga uma metodologia diferente de nosso estudo, ressalta a importância da proximidade: a geografia proporciona relacionamentos pessoais, comunicação face-a-face e interação entre as redes de indivíduos e as instituições, fatores essenciais para fomentar ações inovativas (PORTER, 1999).

As aglomerações industriais são também objeto de estudo de outros autores. É pontuado por V. M. dos Santos (2003), a respeito do desenvolvimento deste tema no Brasil, que "[...] a experiência recente tem evidenciado, tanto no debate acadêmico quanto na formulação de políticas públicas e de iniciativas empresariais, uma grande difusão de estudos e proposições baseados na abordagem dos chamados clusters produtivos" (p.1), na linha da Economia Regional.

\footnotetext{
${ }^{5}$ O próprio autor questiona a validade de sua teoria para os "países em desenvolvimento". Nestes países, a formação dos clusters estaria inibida por fatores como: baixo nível de educação, baixo desenvolvimento tecnológico, falta de acesso ao capital, subdesenvolvimento das instituições e a própria ação do Estado contrária à formação dos aglomerados devido às restrições quando à localização industrial, restrições quanto a subsídios e em detrimento dos currículos das universidades e escolas técnicas destes países não se adaptarem às necessidades dos clusters (PORTER, 1999).
} 
Paralelamente, os autores Betim et al. (2009), no campo da administração da organização industrial, salientam que está ocorrendo um interesse crescente pela investigação dos sistemas de aglomerações de empresas. Há vários autores, mesmo com enfoques distintos, que apresentam abordagens capazes de se complementar, nesta linha.

Por sua vez, Roxo et al. (2011), também salientam um número cada vez maior de obras encontradas a respeito das aglomerações industriais. Entre as considerações mais importantes destes autores, destacamos a seguinte:

A discussão sobre aglomerados produtivos está evoluindo. No entanto ainda há lacunas para serem preenchidas com relação a abordagens mais funcionais e precisas acerca do tema. A falta de pragmatismo dificulta a conexão entre teoria e prática (ROXO et al., 2011, p.17).

É inegável que as aglomerações industriais são áreas que contemplam os fatores de localização industrial (precisam ser áreas atrativas, inclusive de acordo com as fatores locacionais microeconômicos ${ }^{6}$ ), porém o que gostaríamos de destacar é justamente o seu aspecto diferencial, geograficamente. Um aspecto diferencial das aglomerações industriais é justamente a proximidade geográfica entre os agentes econômicos. Esta proximidade permite articulações e interações que competem junto ao desenvolvimento do sistema, no interior da aglomeração e no circuito produtivo ${ }^{7}$.

Uma análise das aglomerações deverá, portanto, partir dos desdobramentos da proximidade geográfica e o que ela representa em diferentes conjunturas. É importante ressaltar que modelos diferentes são aplicados para situações diferentes, pois a proximidade pode estar fundada em interesses diversos.

Os distritos marshallianos estariam assentados em uma concepção social, em uma conjuntura sobre a qual se pode dizer que "respira o ar" daquele tipo de indústria, na qual as crianças crescem aprendendo os mesmos valores de seus pais e existe um

\footnotetext{
${ }^{6} \mathrm{O}$ tema dos fatores de localização industrial apresenta um grande número de autores e abordagens, bem como obras de síntese destes fatores. O pioneiro neste campo é o alemão Alfred Weber, que primeiro determinou os fatores básicos e "luminosamente óbvios" capazes de determinar a localização de qualquer estabelecimento industrial, em 1909. Como obras de síntese sobre a teoria da localização industrial, consultar A. Fischer (1978), C. Manzagol (1985) ou A. Méndez (1997). Críticas a estas premissas podem ser encontrados em A. Lipietz (1977) e M. C. Andrade (1986).

${ }^{7}$ Os circuitos espaciais de produção seriam "[...] as diversas etapas pelas quais passariam um produto, desde o começo do processo de produção até chegar ao consumo final" (SANTOS, 1988, p.49). Eles abarcam as diferentes fases do processo produtivo (produção, distribuição, circulação e consumo) e, assim, são formados por empresas de diversos tamanhos e que atingem de forma articulada diferentes frações do território. Além disso, M. Arroyo destaca que essa articulação se expressa pelo movimento dos fluxos de produtos, ideias, ordens, informação e dinheiro, em sua circulação. Cada fração do território pode ser alcançada por diferentes fases de diferentes circuitos de produção, o que permite explicar sua inserção na divisão territorial do trabalho. $C f$. M. Arroyo (2008).
} 
indissociável compromisso social com a comunidade. Por outro lado, os clusters são descritos como ambientes nos quais cooperação e concorrência coexistem num sistema de empresas de diferentes segmentos que precisam constantemente buscar sua competitividade em um mercado mundial e sem as mesmas reservas de mercado que estimularam os distritos industriais.

Para uma terceira via de interpretação, as empresas podem se aglomerar com objetivo de usufruir de uma boa localização e da organização do território para a finalidade produtiva. Este grupo de empresas suposto representaria segmentos distintos e não necessariamente estabeleceria parcerias comerciais ou disputas de mercados. Aproveitando o caso dos condomínios empresariais (FINATTI, 2011) é possível observar áreas que oferecem uma completa infraestrutura urbana em um ambiente que permite $o$ compartilhamento de serviços (no qual todos os gastos são divididos e, portanto, tornam-se mais baratos).

Existe um arcabouço social/institucional que sustenta essas diferentes organizações. Pode ser uma forte identidade social historicamente estabelecida em uma região, o papel do governo local em fomentar ambientes competitivos de cultura associativa ou ainda o papel do investidor privado que organiza e administra um condomínio. Mesmo o contexto social e institucional que existe nestas três diferentes possibilidades depende da proximidade geográfica.

V. M. dos Santos (2003) salienta justamente a análise das aglomerações baseada em níveis de similaridade e interdependência. $\mathrm{O}$ enfoque baseado no conceito de interdependência atribui importância particular às relações entre as empresas, internamente à aglomeração: "Este enfoque concebe as relações entre setores ou atividades como mola propulsora da dinâmica interna dos clusters industriais" (p.3). A abordagem predominantemente pautada na noção de similaridade pressupõe "[...] diferentes atividades econômicas que se estruturam em clusters porque necessitam de uma infra-estrutura semelhante para operarem de forma eficiente" (SANTOS, 2003, p.3).

Podemos, nesse sentido, pensar em relações horizontais ou verticais que, geograficamente, estimulam o desenvolvimento de uma dada aglomeração. No primeiro caso há um enfoque horizontal entre as empresas que se apoiam na institucionalidade que deve ser mantida na aglomeração. No caso da predominância da interdependência, a aglomeração será sustentada pela rede de relações comerciais estabelecidas entre as empresas (cliente-fornecedor) e com o próprio mercado localmente ou regionalmente estabelecido a partir da aglomeração. 
Muito embora se possa afirmar, para alguns fenômenos, que a proximidade perde sua importância face à propagação das telecomunicações e aos ganhos de eficiência logística, as aglomerações industriais reafirmam o papel da proximidade.

Assim como, no Século XIX, a cooperação simples, o reagrupamento de artesão sob o teto da mesma oficina foi a primeira etapa da hierarquia capitalista, assim também a aglomeração, com seu cortejo de oportunidades potenciais, atualizáveis a baixo custo, foi e continua sendo a primeira condição do mercado capitalista (BENKO, 1996, p.59).

Alguns tipos de aglomeração especialmente assentadas na interação e relação interpessoal para avanço nos campos de pesquisa e inovação (por exemplo, os parques tecnológicos) permitem argumentar a este favor. A proximidade entre as instituições de pesquisa e, destas com as universidades (em sua maioria também localmente estabelecidas) por meio de rede de contatos, intercâmbios e promoção de eventos científicos é elemento que, em um primeiro momento, permite o estabelecimento das relações interpessoais que, muitas vezes, fundam novas pesquisas e atividades que geram conhecimento e inovação. $\mathrm{O}$ "burburinho" 8 ", como também é conhecido, existe devido à proximidade e relacionamento entre os contatos.

Resta fazer uma advertência acerca da pluralidade de termos empregados e a própria polissemia de alguns deles. $\mathrm{O}$ mesmo pode-se dizer das escolas e linhas de análise das formas de aglomeração, quer sejam aglomerações industriais na literatura portuguesa ou espanhola, os distritos industriais na literatura italiana ou os clusters na literatura em língua inglesa. Estes três termos (aglomerações, distritos e clusters) referem-se a processos basicamente equivalentes, nos quais se verifica a tendência ao agrupamento/concentração de empresas em uma localização que satisfaça as características básicas destas empresas e, para as quais, mesmo que por razões diferentes, a proximidade é um elemento central, evidenciando a importância das aglomerações, um pouco de seu "funcionamento interno" e também o papel do território.

\footnotetext{
${ }^{8}$ Dizer "burburinho" é uma maneira coloquial de descrever o comportamento de contatos profissionais próximos, cujos diálogos resultam em novas ideias e potenciais pesquisas e inovações científicas. A este respeito pode-se consultar G. Benko (1996) e, no Brasil, os trabalhos de J. L. Solleiro (1993) e R. N. Mello (2014).
} 


\subsection{As formas predominantes no território nacional}

Para destacar os tipos de aglomeração industrial predominantes no território nacional, realizamos uma investigação na literatura científica existente, sobretudo relacionada a casos e regiões brasileiras. Esse esforço permitiu elencar os onze tipos de aglomeração que abordaremos na sequência, caso a caso. Ao final deste capítulo, mostraremos a proposta de um quadro geral para sua interpretação. Agrupamos as obras consultadas de acordo com a ênfase que elas oferecem, podendo ser de caráter descritivo, de análise crítica, ou estudos de caso. São elas:

- Obras de caracterização: preocupação em descrever um tipo de aglomeração e sua origem histórica, com maior ênfase nos contextos que tiveram influência no desenvolvimento do conceito. Estes trabalhos apresentam certa quantidade de informação empírica e, por isso, a análise das aglomerações também permite uma abordagem de seus conteúdos, eficiência produtiva, sinergias e, em alguns poucos casos, também uma avaliação de seus desdobramentos socioeconômicos. Alguns raros trabalhos deste grupo preocupam-se com o planejamento territorial atrelado à forma de aglomeração e, em alguns casos, por fim arriscam avaliar quais podem ser seus desdobramentos futuros.

- Obras de análise crítica: preocupação em desconstruir o discurso hegemônico reproduzido nos trabalhos de referência e repercussão sobre um determinado tipo de aglomeração, sobretudo no que tange aos seus possíveis desdobramentos socioeconômicos, os quais nem sempre são verificáveis na prática. Outra linha de pensamento presente na análise crítica das formas de aglomeração trata da desconstrução da ideia de sinergia empresarial potencialmente fomentada a partir da aglomeração ou ainda da possibilidade de inovação produtiva e/ou tecnológica que pode ser fomentada nestas áreas.

- Estudos de caso: estudos que focam exclusivamente em um tipo de aglomeração, normalmente com estudo empírico mais detalhado. A análise é de um tipo de aglomeração específico, já implantado e em funcionamento. Não existe maior preocupação com a origem do conceito e as avaliações normalmente dizem respeito à organização empresarial e iniciativas internas consubstanciadas à aglomeração. Um grande número de trabalhos sobre estudos de caso pode ser encontrado, principalmente acerca de arranjos produtivos locais e, em número relativamente menor, sobre distritos industriais e condomínios empresariais.

De acordo com as literaturas consultadas, onze tipos de aglomeração industrial se destacam no território brasileiro. Iniciaremos sua apresentação com algumas noções 
menos detalhadas como o parque industrial e o complexo industrial, para então abordar conceitos utilizados com mais frequência e maior profundidade, como é o caso distrito industrial, do arranjo produtivo local e mesmo do condomínio empresarial, muito embora seja esse mais recente. Além disso, optamos por apresentar inicialmente as formas de aglomeração com maior influência do poder público e, ao final, aquelas originadas de iniciativas imobiliárias.

\section{Parque Industrial}

O parque industrial é a noção de maior abrangência entre as onze formas de aglomeração consideradas, pois não se limita a um circuito produtivo específico e tampouco a um recorte territorial. O parque industrial pode ser sinônimo do conjunto de indústrias de um território nacional ou região, sem fazer alusão direta ao tipo de distribuição geográfica existente, seja ela concentrada ou dispersa.

Precisamos considerar esta noção por duas razões. A primeira delas é que pode indicar algum grau de aglomeração. A outra razão é a popularidade deste conceito, que aparece em literatura acadêmica, no planejamento governamental e também em materiais didáticos. Entretanto, não conseguimos identificar uma definição precisa para o parque industrial. Uma das poucas encontradas é da arquiteta G. C. Bruna, segundo a qual o parque industrial "[...] é o conjunto de indústrias estabelecidas numa região, cujo processo de desenvolvimento industrial não necessariamente se fez de um modo planejado" (1974, p.2).

$\mathrm{O}$ uso do termo parque industrial pode se apresentar com as mesmas características destacadas por autores que abordam a noção de "região industrial". Entre eles, no trabalho dos geógrafos R. Estall e O. Buchanan (1976) há inclusive uma noção evolutiva (bairro industrial < centro industrial < região industrial). A região industrial, segundo os autores, representa a tendência cumulativa dos processos de industrialização que fazem com que as empresas sejam atraídas para uma mesma localização, cujos fatores seriam: suprimentos energéticos, matéria-prima, uma situação nodal (transportes e comunicações) e a existência de outras indústrias.

Entretanto, o estabelecimento da região industrial depende da atratividade de serviços (não exclusivamente industriais). Enquanto no centro industrial a aglomeração ganharia instalações bancárias, estabelecimentos comerciais e serviços de reparo e 
manutenção de máquinas, na condição de região industrial a aglomeração necessariamente precisa dispor de serviços de transporte em escala regional, garantia da oferta de mão de obra e articulação com organizações de pesquisa.

No trabalho de Estall e Buchanan (1976) destaca-se a noção de associação geográfica, que no caso da região industrial seria uma associação entre indústrias e demais segmentos econômicos que, em sinergia, amplificariam a atratividade locacional e a densidade da aglomeração.

Por outro lado, para Bruna (1974, p1.), a noção de região industrial permaneceu associada à simples ideia da delimitação: “[...] área geográfica definida e reservada ao uso industrial, sem que necessariamente tenha uma estrutura natural de recursos que propicie o desenvolvimento industrial", equivalente nesse sentido a uma "zona industrial".

Em relação ao seu processo de formação, o parque industrial pode ser espontâneo ou induzido. No caso de espontâneo, os agentes são as empresas e seus critérios e decisões locacionais (o que vincula sua configuração às decisões microeconômicas de localização). No caso de induzido, trata-se da ação do poder público, por meio de políticas federais ou estaduais (fomento à industrialização, à desconcentração industrial, tentativa de correção de disparidades regionais, etc.).

O uso é voltado para a produção industrial, evidentemente, mas como observamos no trabalho de Estall e Buchanan (1976), outros tipos de serviços (sejam industriais ou não) podem estar associados, se considerarmos válida sua equivalência com a noção de "região industrial".

Nesse sentido, uma hipótese é que o parque industrial de um país ou região se manifestaria em uma área já economicamente densa, uma vez que as indústrias tendem à atração. A possível mescla de indústria com outros serviços validaria o uso do termo região industrial, devido à importância de existir uma delimitação geográfica para o fenômeno.

O parque industrial, portanto, é uma noção generalista para identificar a mera existência de indústrias (mesmo em diferentes níveis e escalas: regional ou nacional) do que um conceito propriamente dito. Sua concentração geográfica, por isso, pode ser de fraca (baixa densidade de indústria) à forte (alta densidade de indústrias). Nesse sentido é um pouco mais difícil definir seus fatores de análise, como a densidade de aglomeração, sua extensão, se há ou não especialização produtiva, etc. 


\section{Complexo Industrial}

O conceito de complexo industrial teve origem na obra do geógrafo J. Chardonnet. O principal elemento, ou seu "traço original”, é a relação entre as indústrias: “[...] relações de dependência caracterizam as principais indústrias-chave, uma em relação às outras, ou umas e outras em relação a seus fatores comuns" (CHARDONNET, 1965, p.218).

Entre os aspectos de interesse no tocante ao complexo industrial, mencione-se a discussão sobre a atração de uma indústria por outra. São três tipos de "dependências" que caracterizam essa atração: dependência técnica, dependência econômica e dependência em relação a um fator comum. De acordo com o autor:

- Dependência técnica: ocorre a partir da solidariedade técnica entre indústrias complementares. Chardonnet menciona a atração que uma indústria siderúrgica exerce em indústrias mecânicas e químicas.

- Dependência econômica: concentração industrial suscitada das relações econômicas a partir de uma indústria principal, em que os insumos são extraídos das indústrias que suscitaram a concentração.

- Dependência em relação a um fator comum: concentração de indústria resultante da existência de um fator comum prévio, tais como energia elétrica, extração carbonífera ou fator humano (mão de obra ou mercado de consumo).

Estes fatores de concentração, embora simples, são transversais a debates existentes em outras obras clássicas e deles podem se desdobrar uma perspectiva de síntese dos fatores de dependência (ou concentração propriamente dita). Este debate pode ser encontrado também em obras como as de A. Weber (1909) em que são apresentados os fatores de localização comuns às indústrias, P. George (1958) em seu livro Geografia Econômica, no qual é feita uma análise das tendências de concentração entre as indústrias e as principais áreas de concentração no mundo, ou ainda A. Fischer (2008) com a discussão sobre os "efeitos à montante" e os "efeitos à jusante" que se desdobram da aglomeração industrial em uma área determinada.

O complexo industrial está fortemente associado, no início de sua formação, às indústrias de base. O autor pondera a possibilidade dos laços de dependência não serem facilmente identificáveis, e para esse caso propõe a existência de uma "osmose econômica" que nada mais é do que a existência de uma economia de aglomeração, ou seja, uma 
maneira de reforçar que o complexo industrial é, ao mesmo tempo, uma economia de aglomeração:

O complexo coloca à disposição uma infraestrutura de transportes, certo número de organismos de crédito e de bancos, organização comercial para compra e venda de matérias-primas e para exportação mais mercado e mão-de-obra com as especialidades técnicas já desenvolvidas (CHARDONNET, 1965, p.220).

Finalmente, Chardonnet discute também sobre a concentração relativa das indústrias no complexo industrial, similar ao que estamos chamando de "densidade da aglomeração" em nossa pesquisa. O complexo industrial é "muito concentrado" quando a concentração é uma necessária em decorrência da dependência técnica ou para reduzir as despesas de transporte. Por outro lado, o complexo pode ser "frouxo" nas ocasiões em que a concentração não é expressiva, comumente quando as indústrias se "esticam" pelos eixos de circulação, nas palavras do autor.

Nesse ponto existe uma diferença entre o complexo industrial e a região industrial, argumentando que na formação de uma região industrial o espalhamento da indústria ocorre por uma superfície mais vasta em relação ao complexo. Dessa forma, no complexo a concentração espacial é sempre maior. Além disso, a ausência de diversidade ou de qualquer traço de dependência entre as empresas em uma área é um fator para qualifica-la como uma região industrial.

Outro comparativo pode ser feito com a noção de Combinado Soviético. Chardonnet descreve esta outra forma de aglomeração como a ocorrência de concentrações industriais, porém afastadas (estas concentrações são chamadas de "zonas industriais") e, entre as quais, fundamentalmente, se desenvolvem relacionamentos ("interconexões econômicas") apesar de afastadas.

Nesse sentido, no complexo industrial ocorre a aglomeração propriamente dita e se fundam relações econômicas entre as indústrias, sem as quais o fenômeno não poderia ser chamado de complexo industrial. Ou seja, é no complexo industrial que ocorre o relacionamento entre as empresas, por meio dos diferentes tipos de dependência já mencionados (técnica, econômica, em relação a um fator comum ou "por osmose").

O autor ainda comenta que, historicamente, as reservas de carvão foram o fator de criação dos mais poderosos complexos industriais nos mundos, e que tantos outros se formaram a partir da existência de mão-de-obra e mercado consumidor, cuja combinação acarretou, posteriormente, nas áreas em que hoje existem metrópoles de grande porte. Não 
se pode esquecer, por fim, dos portos e eixos de circulação como elemento dinamizador de centros industriais ${ }^{9}$, muitas vezes fazendo com que se formem complexos.

Outra discussão que deve ser feita é que a formação do complexo industrial não é induzida pelo poder público ou por uma empresa particular, mas se forma devido às circunstâncias de determinados fatores, ou seja, apresenta uma formação espontânea. Não há indicação direta no texto de Chardonnet sobre o agente principal destas aglomerações, pois elas são resultado de dependências e atrações entre as indústrias e, num momento posterior, entre indústria, serviços e comércio.

Na visão de S. Selingardi-Sampaio (2009), analisando o Estado de São Paulo, argumenta-se que existe não apenas um, mas vários complexos territoriais industriais que formam um multicomplexo territorial industrial. Estes complexos podem se materializar de duas maneiras: (1) como cadeias produtivas setoriais completas e aglomeradas em um único município, processo este que seria exemplificado pelo que ocorre no município de Americana $^{10}$ (SP) ou (2) como segmentos territorializados de modo aglomerado, conformando cadeias produtivas setoriais e intersetoriais; nestes territórios que podem ser aparentemente delimitados, o espaço econômico se completa, de fato, podendo abarcar as escalas regional, nacional e internacional (SELINGARDI-SAMPAIO, 2009).

A noção central abordada por Selingardi-Sampaio (2009) ao tratar de complexos é a integração produtiva. Dessa forma, os complexos se formariam a partir de empresas produtivamente vinculadas (encadeamentos para frente e para trás) e com certa aglomeração espacial (sugerindo as seguintes escalas: local, metropolitana, microrregional e regional). Via de regra, o complexo se organiza ao redor de um "núcleo integrador" que pode ser um setor, ramo ou produto, tais como os complexos petroquímicos, têxteis ou de montagem automotiva.

Na definição desta autora:

Os aludidos complexos podem, ainda, apresentar arranjos multivariados quanto à estrutura produtiva, à organização industrial, à densidade e à forma de relações de interdependência, de cooperação e outras solidariedades que ocorrem em seu interior (SELINGARDI-SAMPAIO, 2009, p.19).

\footnotetext{
${ }^{9}$ Para Chardonnet (1965), o centro industrial é apenas o complemento industrial de um centro urbano, no qual as indústrias não tem poder, diversidade ou caráter de indústrias de base.

${ }^{10}$ No município de Americana (SP) existe uma aglomeração industrial denominada "Polo Têxtil de Americana", referente aos segmentos têxtil e confecções, regionalizado nos município de Sumaré, Santa Bárbara D’Oeste, Nova Odessa, Hortolândia e Americana. Esta aglomeração pode ser também considerada um arranjo produtivo local.
} 
Na obra de Selingardi-Sampaio (2009), a forma final da densa aglomeração industrial no Estado de São Paulo seria a de Multicomplexo Territorial Industrial (Metropolitano/Urbano) Paulista.

Um ponto muito importante deste conceito é a densidade das relações entre as empresas e seus efeitos, "para frente e para trás". Com isso podemos, de fato, qualificar o complexo industrial, já que a ideia central mesmo em diferentes obras é a do encadeamento produtivo. Este é um importante fator para explicar, entre outras características de aglomerações, a configuração do polo industrial.

\section{Polo Industrial}

Para falar de polo industrial será necessário contextualizar a ideia de Polo de Desenvolvimento como um conceito e também como um princípio de aplicação em políticas territoriais. Esta foi uma ideia largamente difundida e aplicada pelos governos centrais em todo o mundo, inclusive no Brasil, de maneira que não há como falar em polos de desenvolvimento ou, simplificadamente, de polos industriais, sem mencionar seu contexto desenvolvimentista como parte da organização do território.

Esse contexto é importante para situar algumas estratégias do governo federal na tentativa de equilibrar as desigualdades regionais existentes no território. Todavia, como esta tese tem como objeto de estudo as aglomerações industriais (não desprezando os seus efeitos e implicações) optamos por simplificar a análise do polo de desenvolvimento à sua realidade industrial. Assim, optamos também por empregar o termo polo industrial, sem desprezar por inteiro os princípios ligados ao que seria um conceito mais amplo (polo de desenvolvimento).

O polo de desenvolvimento tem origem no trabalho do economista francês $F$. Perroux, durante a década de 1960. O argumento central da teoria de Perroux para o desenvolvimento regional está na interpretação de que o crescimento econômico não se realiza homogeneamente por todo o território de um país ou cobrindo homogeneamente todas as partes de uma determinada região. De acordo com as palavras do próprio Perroux: "[...] o crescimento não surge em toda parte ao mesmo tempo; manifesta-se com intensidades variáveis, em pontos ou polos de crescimento; propaga-se, segundo vias diferentes e com efeitos finais variáveis" (PERROUX, 1975 [1970], p.100). 
Esse processo se daria em certos pontos privilegiados (estimulados para tanto) e com dinâmicas diferentes e variáveis sobre o conjunto da economia. É uma proposta de inspiração keynesiana, pois caberia ao Estado fomentar a infraestrutura necessária ao estímulo da industrialização (elementos de infraestrutura pré-industrialização) e, por vezes, inclusive cumprindo o papel de empresário da indústria-motriz, como se verificou no Brasil.

Estes pontos privilegiados seriam os polos de crescimento. Para Perroux, se forem planejados adequadamente, viriam a ser o centro econômico dinâmico de uma região (ou mesmo de um país ou continente), acarretando importantes efeitos econômicos à montante e à jusante. Para melhor apresentar esses efeitos, fazemos uso das palavras de $\mathrm{H}$. M. Tavares: “[...] aumentam as necessidades coletivas em matéria de habitação, de transportes, de serviços, eleva-se a renda, surgem empreendedores, trabalhadores qualificados, formam-se quadros de alto nível, etc" (2011, p.54).

É importante mencionar a distinção entre polos de crescimento e polos de desenvolvimento, pois a implantação do polo suscita desequilíbrios econômicos e sociais, inclusive o autor menciona que o crescimento ou desenvolvimento podem ser, ao contrário, retardados (PERROUX, 1975 [1970]). O geógrafo M. C. de Andrade, um dos estudiosos da obra de F. Perroux no Brasil, também adverte a respeito desta relação crescimento/desenvolvimento:

Pode ainda ocorrer o fato de um pólo surgido em uma determinada região - muito frequentemente subdesenvolvida - se desenvolver à custa da região sem lhe devolver em recursos as riquezas que dela tira (ANDRADE, 1970 [1967], p.62).

$\mathrm{Na}$ teoria, as relações do polo com a região deveriam ser canalizadas por "caminhos" que responderiam pela ligação entre o polo e sua região de influência. Nós de tráfego e eixos de circulação, assim, possuem forte relação com a ideia dos polos de crescimento/desenvolvimento na medida em que aparecerão associados aos importantes centros urbanos que centralizam os fluxos. Quando fala em "canais", Perroux quer dizer ferrovias e rodovias, que também são chamados de eixos de desenvolvimento em relação ao polo (ANDRADE, 1975 [1970]).

A proposta de Perroux ganhou grande repercussão em todo o mundo, marcando fortemente as propostas de desenvolvimento regional e urbano em um ambiente de 
planejamento macroeconômico, uma vez que uniu as dimensões econômica e espacial. J.R. Boudeville (1973) faz a seguinte observação:

A teoria econômica contemporânea dos eixos e dos pólos de desenvolvimento tem a grande vantagem de salientar a importância dos instrumentos urbanos e municipais de qualquer política de organização do território (BOUDEVILLE, 1973, p.75).

De acordo com Tavares: “Ao longo dos decênios 1950 e 1960, praticamente todos os países europeus adotaram políticas de ordenamento de seus respectivos territórios" (2011, p.56). A operacionalização destas teorias era tarefa do Estado. Isso deu força às políticas públicas de desenvolvimento regional no Brasil, as quais foram concebidas também na década de 1960 e que se concatenavam com o princípio de desenvolvimento via industrialização (IANNI, 1991), em que o "desenvolvimento" do conjunto de países considerados subdesenvolvidos se daria justamente por intermédio do estímulo à industrialização. Esses princípios ficaram bastante evidentes no I e II Plano Nacional de Desenvolvimento durante o governo militar.

Com referência direta ao planejamento, já que este foi um dos poucos modelos que "saiu do papel", é necessário questionar como os polos de crescimento/desenvolvimento foram efetivamente implantados no território brasileiro. Os próximos capítulos tratam especificidades deste processo, apresentando principalmente a análise da forma de aglomeração propriamente dita (polo industrial), mas também uma breve interpretação destas formas na condição de polos de desenvolvimento.

Para isso, precisamos primeiramente atentar para as críticas feitas à concepção dos polos de desenvolvimento. Uma primeira constatação, feita pelo próprio Perroux é que a teoria da polarização só tem valor quando é instrumentalizada pela política, a partir de uma análise rigorosa (TAVARES, 2011). Outra importante crítica oriunda da própria teoria é a possibilidade de não ocorrer o crescimento, mas ao contrário, que o polo resulte na ampliação da desigualdade da região. Em outras palavras, o polo "drena" a região, como afirmado por H. Rattner (1988), R. S. Wiltgen (1991) e H. M. Tavares (2011).

Para Wiltgen, o dinamismo do polo é efêmero: “[...] percebe-se que a polarização é um fenômeno inerente ao crescimento, no entanto, efêmero, dado que o crescimento das regiões periféricas se dá por indução do próprio dinamismo do polo" (1991, p.533). O autor afirma ainda que os mecanismos de difusão do crescimento formam um aspecto importante que não fora contemplado por Perroux e que possíveis efeitos 
desfavoráveis à região podem ocorrer: (1) ao invés de absorver o desemprego da região atrasada, seus talentos profissionais são retirados em favor do polo, bem como os empresários mais dinâmicos, (2) atividades industriais pré-existentes da região podem sofrer depressão quando expostas à concorrência devido à menor eficiência e menor proteção (WILTGEN, 1991).

A. Lipietz (1988), em sua crítica marxista, considera que a teoria da polarização possui uma ambiguidade considerável ao tentar forçar a solução da contradição social/privado quando atribui a certos espaços privados os mesmos atributos da dimensão social. Para Lipietz, a indústria motriz é a materialização de uma ou várias empresas privadas (em seu sentido econômico, fruto da decisão de um agente autônomo) que deve cumprir o papel de motor para o desenvolvimento de uma região. Os efeitos desse polo demandam integração, porém o que parece ocorrer é uma simples matriz de trocas interindustriais "diagonais" ou "diagonais em bloco" (os quais seriam o bloco da economia artesanal, o bloco dos serviços tradicionais, o bloco do crescimento potencial). Em outras palavras, são processos economicamente integrativos ${ }^{11}$.

[...] os teóricos do desenvolvimento, discípulos de F. Perroux, insistiram amplamente na noção de "integração" como necessariamente ligada à de desenvolvimento. Se a integração técnica não se produzir, a estrutura econômica permanecerá fraca (LIPIETZ, 1988, p.134).

E assim Lipietz (1988) afirma serem os polos de desenvolvimento, na verdade, “catedrais no deserto" ou "polos de desenvolvimento do subdesenvolvimento".

Analisando o caso do Brasil e dos países do Terceiro Mundo, M. Santos (2003 [1979]) afirma que este conceito teria se tornado um slogan e apropriado pela administração pública. Os planos efetivados estavam imbuídos de uma preocupação demasiadamente voltada para a forma em detrimento de seu conteúdo. Além disso, sua crítica assevera que foram disseminados princípios teóricos indistintos das realidades dos países desenvolvidos ou subdesenvolvidos.

Como o espaço dos países subdesenvolvidos tem uma estrutura menos rígida quanto às transformações e quanto aos investimentos (oferece menor resistência

\footnotetext{
${ }^{11}$ Essa crítica também foi explorada por Wiltgen (1991) que destaca a descrição superficial, na teoria de Perroux, que explicaria os mecanismos de transferência do crescimento econômico para a região. Na formulação original, os mecanismos de difusão do crescimento são inerentes ao próprio mercado. A. Hirschmann (1961 apud WILTGEN [1991]) avança na proposição deste mecanismo por meio da concomitância entre efeitos de polarização e efeitos de fluência, cujos possíveis desequilíbrios dependem da correção do investimento público.
} 
econômica, cultural, bem como a inércia de formas-conteúdo pretéritas) esse espaço está sujeito ao planejamento em muitos níveis de tomadas de decisão, sendo assim um espaço multipolarizado. Nas palavras do autor:

Descontínuo e instável, o espaço do Terceiro Mundo também é multipolarizado, ou seja, está sujeito a (e dividido entre) uma multidão de influências e polarizações provenientes de muitos níveis de tomada de decisão (SANTOS, 2003 [1979], p.171).

Os estudos sobre os polos de crescimento econômico contemplariam apenas o circuito produtivo superior, aquele diretamente ligado à modernização tecnológica e comandado por poucos, cujo quadro de referência extrapola a escala das cidades e tem no quadro nacional e internacional a sua escala de atuação principal. O circuito inferior, cuja escala de ação é restrita, compõe-se muitas vezes pela população pobre e na condição de estratégia de sobrevivência. Este circuito encontrar-se-ia bem situado na cidade e conseguindo estabelecer relações privilegiadas com sua região. Questiona como apenas o circuito superior (fazendo referência específica ao discurso dos polos) foi o alvo de análises sistemáticas e também a maneira como cidade e região são, ambas, abreviadas em função deste circuito, cuja aplicabilidade à realidade dos países subdesenvolvidos é questionável (SANTOS, 2003 [1979]).

Finalmente, no que tange ao aspecto da forma polo industrial propriamente dita, é importante salientar: a configuração desta forma está, operacionalmente e territorialmente, ligada a uma indústria motriz (assim como previsto em todo o escopo da teoria dos polos de desenvolvimento). Na explicação de Wiltgen (1991):

\footnotetext{
A indústria motriz é aquela que se desenvolve prematuramente como grande indústria moderna, como separação dos fatores de produção, concentração de capitais, decomposição técnica de tarefas e mecanização. Uma indústria com tais características absorve progresso técnico, experimentando crescimento de seu produto acima da média (p.533).
}

Ao conceito de indústria motriz, combina-se o conceito de complexo industrial. Similar ao que já abordamos, o complexo é estimulado pelos efeitos encadeados à montante e à jusante no circuito de produção, fazendo com que ao redor da indústria motriz tendam a se instalar indústrias complementares que podem ser servidoras ou beneficiadoras dos insumos gerados pela indústria motriz (considerada o "coração" do polo industrial). 
A definição que melhor explica este sistema é "indústria industrializante", denominado por Destanne de Bernis em 1967, que seriam as indústrias de energia (petróleo, eletricidade, energia termonuclear) e indústrias de metais essenciais à siderurgia e à metalurgia de um modo geral (TAVARES, 2011, p.54).

A configuração deste aglomerado de indústrias tende a se apresentar de maneira compacta, com unidades próximas umas das outras e uma organização interna de vias e dutovias para transferência dos insumos. Da mesma forma, prestadoras de serviços industriais e outros serviços complementares (operadores logísticos, manutenção, limpeza, alimentação) também se instalam nas proximidades e mesmo dentro do polígono definido do polo industrial. Apesar da proximidade e da densidade alta, o polo ocupa uma grande e contígua extensão territorial.

Dada a abrangência de sua proposta, é também uma das formas que mais demanda incentivo e ação do Estado, entre as demais estudadas. O polo de desenvolvimento econômico - em nossa pesquisa apenas polo industrial - abriu possibilidades de ação para o planejamento econômico.

Esses grandes projetos de políticas territoriais chamam um reflexão: de que espaço se fala nestes projetos? Qual a importância da formação espacial ${ }^{12}$ em suas formulações? A. Lipietz questiona que o "espaço abstrato" da teoria de Perroux equivale ao "espaço como conteúdo de um plano", ou seja, aquele da decisão locacional microeconômica ou das regiões-programa do Estado. O espaço como conteúdo de um plano é o espaço do cálculo.

A diferença é importante: não se trata mais da teorização do real, mas de uma representação (ideal) de um objeto, ele mesmo, ideal. Além do mais, este objeto-ideia (o "plano") é, ele próprio, referido a um sujeito pensante fundador (a firma, o Estado); é, de alguma maneira, o "espaço privado" deste sujeito (LIPIETZ, 1988, p.133 - grifo nosso).

Embora esta reflexão escape ao estudo da forma de aglomeração propriamente dita "polo industrial", entendemos que não podemos desviar especificamente essa discussão sobre o que ela representou e representa da dimensão do planejamento governamental. O polo industrial encontra sua explicação na interface entre a abordagem

\footnotetext{
12 A categoria de formação socioespacial, desenvolvida por M. Santos (2012 [1979]), tem como base a formação econômica e social de Marx, por meio do qual o autor argumenta que os modos de produção se definem sobre uma base territorial historicamente determinada e que se mantém em movimento contínuo. A base da explicação para a transformação do espaço é o trabalho do homem. Retomaremos este conceito, com detalhes, no Capítulo 2.
} 
da produção propriamente dita, circulação e consumo, bem como da política e do planejamento.

\section{Centro Industrial}

Entre as formas de aglomeração abordadas, o centro industrial é também uma das noções de difícil definição, pois não foi trabalhado teoricamente com mais vigor ou atenção. $\mathrm{O}$ apontamento da arquiteta G. C. Bruna refere-se ao centro industrial com as seguintes palavras:

[...] é um instrumento de planejamento e sua resultante efetuação consubstanciada pela ocupação racional de uma área bem definida, à qual se associa um conjunto de motivações e providências indutoras de um processo de desenvolvimento industrial, harmonizado ao processo geral de desenvolvimento econômico da região (BRUNA, 1974, p.5).

Para J. Chardonnet (1965), como já mencionado na abordagem sobre o complexo industrial, o centro industrial é meramente "um complemento industrial de um centro urbano", certa área com indústrias de menor expressão se comparada à indústria de base ou de grande porte.

Na visão de Estall e Buchanan, o centro industrial parece ser uma etapa de transição entre um bairro industrial e a região industrial. Nele ocorreria o desenvolvimento e a ampliação do bairro industrial, quando passa a ser capaz de atrair agências bancárias e de seguros, estabelecimentos comerciais e serviços de reparo e manutenção de máquinas.

Frente a estas três definições, divergentes, precisamos atentar para a diferença da realidade vivenciada pelos autores. Para G. Bruna, que desenvolveu seu trabalho na arquitetura, o centro industrial é um instrumento do planejamento urbano/regional. Parecenos ser uma forma de aglomeração associada a um agente indutor, enquanto os demais autores fazem apontamentos segundo os quais os centros industriais seriam formas de aglomeração oriundas de um processo espontâneo. Como nossa atenção é, primeiramente, com os agentes promotores das aglomerações, poderíamos considerar o centro industrial como equivalente à zona industrial, porém ele nos parece mais abrangente na medida em que Bruna destaca a preocupação da articulação entre o centro industrial e as tendências econômicas regionais. 
L. Fuini (2013) também menciona o centro industrial em seu trabalho, da seguinte maneira:

São grandes e diversificadas aglomerações industriais onde as grandes empresas costumam ter importante papel, não havendo fortes sinergias e relações entre elas. Exemplos: região do $\mathrm{ABC}$ paulista e regiões metropolitanas de Belo Horizonte e de Porto Alegre (FUINI, 2013, p.63).

Outrossim, apesar da divergência com os demais autores, um geógrafo francês e dois geógrafos ingleses, consideraremos que o contexto de implantação de um centro industrial está associado às políticas econômicas dos municípios, e que por ser resultado do planejamento territorial, "em uma área bem definida", sua densidade de aglomeração será forte.

Muito embora existam loteamentos industriais (bairros industriais) e outras formas de aglomeração que podem ganhar o nome de centro industrial (Por exemplo, o bairro industrial denominado Centro Industrial Jaguaré, de 1935, ou o distrito industrial chamado Centro Industrial Subaé, de 1968) optamos, por definição, a restringir o termo centro industrial para as iniciativas municipais. Ou seja, quando a prefeitura ocupa-se de equipar a zona industrial, desde infraestrutura básica até equipamentos urbanos.

\section{Distrito Industrial}

A primeira referência a esta forma vem do economista A. Marhsall (1919), a qual ganhou uma variante de análise muito expressiva na Itália, sobretudo com G. Becatini na década de 1980, e também a revisão de outros autores em seus países, cada qual com suas particularidades, como A. Markusen (1995) e C. Courvet e B. Pecqueur (1994).

$\mathrm{Na}$ primeira formulação científica sobre distritos industriais, A. Marshall analisou uma região cuja economia estava baseada em pequenas firmas e cujas decisões sobre investimentos e características da produção seriam totalmente de base local, formando uma densa rede de ligações no interior do distrito, pautada na confiança. Por essa razão, estas formas, originalmente, se configuram a partir da cultura empreendedora local. Além disso, um ponto importante, destacado na interpretação de A. Markusen (1995) é que “[...] os encadeamentos (linkages) ou a cooperação com firmas de fora do distrito são 
praticamente inexistentes" (p.18). Segundo a autora, este aspecto difere os distritos Marshallianos em relação à sua variante italiana.

$\mathrm{Na}$ formulação de G. Becatini (1994) o distrito industrial é “[...] uma entidade socioterritorial caracterizada pela presença activa de uma comunidade de pessoas e de uma população de empresas num determinado espaço geográfico e histórico" (p.20). Para Becatini, tende-se a criar uma "osmose perfeita" entre a comunidade local e as empresas, sendo a característica mais marcante dos distritos industriais à italiana, seu sistema de valores e de pensamentos que é relativamente homogêneo.

Tais valores culturais condicionam os principais aspectos da vida no distrito (BECATINI, 1994), muito embora o autor saliente que não se trata de um sistema fechado; ele muda com o passar do tempo. Nesse sentido, os valores não podem constituir um entrave ao espírito empresarial ou à introdução de inovações tecnológicas. Por essa razão, não é possível caracterizar esse tipo de espaço sem levar em conta a visão histórica.

Embora esta visão acadêmica esteja bastante consolidada, talvez a primeira formulação de maior abrangência em termos de investigação empírica seja uma publicação da Organização das Nações Unidas da década de 1960 sobre as iniciativas, tratadas no relatório como distritos industriais e analisados mundialmente, para o seguinte propósito: “[...] cada país deverá elaborar um programa de distritos industriais de acordo com suas próprias condições" (ONU, 1966 [1962], p.73).

Este relatório oferece um panorama amplo dos distritos industriais pioneiros no mundo. Para citar os quatro primeiros:

- Trafford Park (Inglaterra - Manchester, 1896)

- Clearing Industrial District (Estados Unidos - Chicago, 1899)

- Zona Industrial de Nápoles (Itália - Nápoles, 1904)

- Distrito industrial central (URSS - Don e Dnieper, 1922)

Em linhas gerais, os objetivos da formulação destes distritos industriais são ligados, em sua origem, à preocupação com a desconcentração da indústria e à possibilidade de influenciar sua relocalização. Ao distrito também se associa a ideia de recuperação de áreas defasadas (diminuição das disparidades regionais) e também a empregabilidade ou recolocação profissional em certas regiões (onde há mais pobreza).

Um levantamento similar foi realizado no Brasil pela Comissão Interestadual da Bacia Paraná-Uruguai (CIBPU, 1966), baseado no mesmo estudo pioneiro da ONU para o mundo. A CIBPU ressalta informações que devemos ponderar, pois muitas delas 
divergem em relação ao modelo canonizado de distritos industriais e, ao mesmo tempo, apresentam diferenças em relação ao modelo habitualmente verificado no Brasil. Destacam-se algumas características dos distritos industriais no mundo:

- Existem diferenças entre os modelos de distritos industriais implantados em diferentes países;

- No modelo inglês, os distritos industriais estavam ligados ao poder público, que os incorporava ou construía os prédios e galpões para, posteriormente, serem permutados com os empresários industriais. Estes deveriam devolvê-los ao término de um contrato;

- Nos EUA, até 1957, 70\% dos distritos industriais estavam ligados a capitalistas privados (investidores imobiliários) e $24 \%$ a organizações comunais que buscavam lucro, restando apenas $6 \%$ destes espaços relacionados à administração pública;

- Como característica padrão nos países citados, foram organizados como lotes ou prédios industriais;

- Tem incorporadas diversas funcionalidades no chamado "setor central", como: administração, refeitório, salas de conferência e cursos, corpo de bombeiros, repartição de polícia preventiva, estação telefônica e agência de correios.

Segundo este mesmo relatório (CIBPU, 1966), a experiência do governo brasileiro no planejamento de áreas industriais começou com as secretarias estaduais e, na sequência, administrações municipais. Em relação ao conjunto das primeiras iniciativas de distritos brasileiros é mencionado: “A organização dos distritos industriais se deve aos governos estaduais. Recebem ainda a denominação de zonas, núcleos e mesmo cidades industriais, sem se fazer muita distinção entre êstes termos" (CIBPU, 1966, p.17).

$\mathrm{O}$ distrito industrial pioneiro no Brasil foi instalado em Contagem (MG) no ano de 1941. Ficou nomeado de "Cidade Industrial de Contagem ${ }^{13}$ ". O grande objetivo do governo mineiro era incentivar a industrialização por meio de condições vantajosas para obtenção de terreno, aproveitando sua característica de fornecimento de matérias primas de origem mineral e em grande mão de obra disponível. O relatório CIBPU qualifica a iniciativa como de pleno êxito, pois conseguiu atrair 106 empresas até o ano de 1966.

O Rio Grande do Sul foi o segundo estado a inaugurar uma política estadual de desenvolvimento industrial, e após algumas iniciativas que não lograram sucesso, como o

\footnotetext{
${ }^{13}$ Foi também chamado de Distrito Industrial Coronel Juventino Dias.
} 
caso da "Cidade Industrial do Delta", o projeto Distrito Industrial de Porto Alegre foi, finalmente, efetivado já na década de 1960. É considerado pelo relatório CIBPU como o melhor projeto efetivado no Brasil. Algumas características desse projeto são as seguintes: a área total tem zonas residenciais, industriais e de equipamentos (escola técnica e feira industrial), sendo que as quadras industriais foram projetadas para ter duas frentes: uma delas é voltada para a rodovia e a outra voltada para a ferrovia. Além disso, apenas $40 \%$ do terreno estavam destinados à indústria, a maior parte seria para as residências dos operários.

Outra iniciativa que vale a menção é a do Distrito Industrial de Fortaleza, com participação da Superintendência para o Desenvolvimento do Nordeste (SUDENE) e da Companhia de Desenvolvimento Econômico do Ceará (CODECE). O distrito, ainda em funcionamento, previa desde o seu projeto inicial além da zona industrial, a zona para habitação operária e também estabelecimentos comerciais. Também era previsto um setor de armazenagem, estação ferroviária e um parque com áreas verdes e reservas naturais (CIBPU, 1966).

Muito embora estejamos falando de iniciativas pontuais, é importante fazer duas observações: tais iniciativas descritas pouco tem relação com as formulações de A. Marshall ou G. Becatini, em virtude da ausência da combinação de elementos que estes autores apontam em suas definições. Por outro lado, algumas outras iniciativas, se analisadas as características de sua implantação nos Estados Unidos e Inglaterra, também não são equivalentes ao que se propõe, conceitualmente, como distrito industrial. Analisaremos as ponderações de outros autores importantes, na sequência, antes de retornar ao caso brasileiro.

A geógrafa A. Markusen (1995), em uma revisão dos distritos industriais nos países Estados Unidos, Japão, Coréia do Sul e Brasil, chega a uma tipologia própria (Novos Distritos Industriais - NDI) com quatro tipos de distrito industrial, os seguintes: NDI Marshalliano com vertente italiana, NDI Centro-Radial (ou hub and spoke), NDI Plataforma Industrial Satélite e NDI suportado pelo Estado (state-centered). Para os propósitos deste projeto, não é necessário apresentar o distrito do tipo Plataforma Industrial Satélite, pois ela consiste basicamente em sucursais ou subdivisões de corporações multinacionais em sua estratégia de instalação em outros países. Entretanto, discutiremos as outras três perspectivas.

O distrito industrial com vertente italiana é basicamente o mesmo sistematizado por Marshall, porém Markusen aponta a importante diferença que, no distrito 
à italiana não se verifica a certa passividade das firmas presentes, conforme apontado por Marshall. Por outro lado, se funda um "[...] alto nível de intercâmbio entre consumidores intermediários e fornecedores, assim como cooperação entre competidores visando a estabilização de seus mercados e o compartilhamento de riscos e de inovações" (1995, p.19). Em outras palavras, no modelo original de Marshall, não há necessariamente a cooperação consciente entre cada um dos agentes no distrito, enquanto na variante italiana, o nível de intercâmbio entre as empresas é uma condição indispensável.

No caso do NDI Centro-Radial, sua ocorrência é estimulada pela ação de unidades industriais mais importantes, cumprindo o papel de "firmas-chave" que congregam em torno de si fornecedores e outras atividades correlatas. Markusen cita como exemplos a aglomeração na cidade de Toyota (Japão) e, no Brasil, São José dos Campos, com a Embraer. É importante destacar que as ligações no distrito centro-radial podem ter diferentes intensidades; em uma forma mais clássica, as empresas apresentam uma firme teia de relações entre si, em uma situação na qual as empresas menores são altamente dependentes da demanda ou da oferta das empresas mais importantes. Mas podem ocorrer também com caráter mais nuclear, no qual um conjunto de firmas menores usufrui das economias de aglomeração estimuladas pelas firmas-chave do distrito, mas sem necessariamente tê-las como compradoras ou fornecedoras.

Em relação ao agente que estimula esse tipo de aglomeração, a autora destaca que são as empresas mais expressivas do núcleo que tratam com o governo local e com o seu estado a fim de tratar de uma agenda restrita aos pontos de suas próprias jurisdições.

A autora destaca também, para um último tipo de distrito industrial, chamado de "Distrito Ancorado pelo Estado", que é organizado "[...] em torno de alguma entidade pública ou não-lucrativa, seja uma base militar, uma universidade, um centro de pesquisa ou laboratório ligado ao setor bélico, um complexo prisional ou uma grande concentração de órgãos públicos" (MARKUSEN, 1995, p.28). Nesse caso, forma-se uma área de atração que é dominada pela presença deste tipo de instituição, como o caso de economias de escala que foram estimuladas pela indústria bélica em cidades dos EUA: Santa Fé, Albuquerque, San Diego e Colorado Springs (MARKUSEN, 1995).

Evidentemente, nesta categoria de aglomeração da indústria, as empresas locais desempenham papel menos relevante nas economias locais em relação aos Distritos Marshallianos ou Centro-Radiais, mas também o papel do governo na regulação e na promoção de atividades distritais é mínimo. Dada a dimensão das empresas ou instituições 
públicas que estimulam essas aglomerações, devido aos seus altos gastos, o potencial de crescimento para um conjunto de fornecedores é grande.

A perspectiva francesa de Sistemas Industriais Locais (SPL) também é similar à concepção dos Distritos Industriais, marshallianos ou em sua variação italiana. Os autores C. Courvet e B. Pecqueur (1994) relatam as características do que chamam de "modelo canônico francês", cujas primeiras experiências - aliadas ao desenvolvimento local em suas localizações - aconteceram em: Choletais, Vale do Arve, Thiers e Oyonnax, relacionados à produção de calçados e confecções, cutelaria e plásticos.

A proximidade entre os Sistemas Industriais Locais e os Distritos Industriais é nítida na explicação dos autores, que descrevem um sistema de pequenas empresas especializadas em diferentes funções da produção resultante da divisão do trabalho. Eles também sinalizam o seguinte:

Esta aglomeração específica de numerosas pequenas empresas com características similares favorece a transmissão dos conhecimentos técnicos específicos e a livre troca das ideias novas necessárias ao desenvolvimento da flexibilidade e da inovação (COURVET e PECQUEUR, 1994, p.50).

Estes distritos industriais franceses têm as seguintes características: divisão do trabalho entre pequenas e médias empresas especializadas, difusão da industrialização pelo território francês, flexibilidade produtiva e a formação de economias de aglomeração. Além disso, é importante mencionar que há reciprocidade, ou "[...] relação entre os agentes, dotada de vida própria, e que excede o âmbito das relações puramente comerciais" (COURVET e PECQUEUR, 1994, p.55). Para os autores, isso remete à fidelidade, gratidão e identidade entre os agentes. Essa identidade tenta ser mantida a partir de um conjunto mais complexo de agentes e também à perspectiva do crescimento destes sistemas industriais locais.

As iniciativas destas formas de aglomerações, no modelo francês, estão ligadas à ação do poder público. Para fomentá-los, buscaram-se áreas agrícolas que conservaram uma população ativa jovem e nos seus espaços existia certa tradição artesanal, bem como a capacidade de mantê-la e fazê-la evoluir com o passar do tempo.

Muito mais próxima ao planejamento governamental, e talvez uma proposta intermediária, é a do economista W. Bredo (1965). Para ele, o distrito industrial é uma prática que torna viável a expansão industrial, de maneira ordenada. Em suas palavras, o 
distrito é uma "tecnologia social para o desenvolvimento econômico" e deve ser pensado da seguinte forma:

É o approach planejado para a instalação de um conjunto viável de empresas industriais. A área utilizada deverá ser provida com os elementos básicos de infra-estrutura física interna, incluindo-se estradas e ruas, suprimento d'água, energia e esgotos, assim como transportes (BREDO, 1965, p.81).

O economista também sinaliza como pioneiras as iniciativas nos Estados Unidos (que teria mais de mil distritos industriais em funcionamento no ano de 1965), Reino Unido (com o primeiro programa de larga escada na década de 1930, com objetivo de levar indústrias para as áreas de depressão) e também a Índia (que seguiu o modelo britânico, e contava com mais de 100 distritos industriais em 1965). No ano em que escreveu seu livro, Porto Rico estava alavancando um programa de estímulo à industrialização por meio de distritos industriais, onde os empresários interessados "tinham que se mudar apenas com máquinas e pessoal para prédios já prontos e assim começavam imediatamente a operar" (BREDO, 1965, p.83).

Embora a participação governamental seja fundamental para este autor, para que ficasse demonstrada a validade da prática em outros lugares do mundo, ele considerava ainda que o interesse da iniciativa privada deveria ocorrer o quanto antes, “[...] pois possibilitará a descentralização das decisões, assim como a mobilização de investimentos privados" (1965, p.83).

No caso da experiência brasileira, mais uma vez, é clara a iniciativa do poder público, porém em dois momentos distintos: em um primeiro momento como resultado das ações das secretarias e agências de desenvolvimento das unidades estaduais, embora já tenhamos verificado que as superintendências (federais) também tenham atuado nesta linha na década de 1960. Posteriormente, estas iniciativas tornaram-se exclusividade da administração pública municipal, ora como tentativa de atração de indústrias, ora como bandeira de atuação político-partidária.

Novamente, o relatório da CIBPU nos dá um apontamento importante:

Muitos municípios paulistas, independentemente da realização de seus planos diretores e da iniciativa estadual, estão chamando a si, a responsabilidade de promover a instalação de indústrias, através da promoção de loteamentos industriais, mediante o que doam os lotes ou concedem facilidades às indústrias para a aquisição dos terrenos (CIBPU, 1966, p. 90). 
É justamente nesta perspectiva que chegamos a outro grupo de autores que, no Brasil, estiveram preocupados com os distritos industriais do ponto de vista do planejamento territorial. Primeiramente a definição central da arquiteta G. C. Bruna:

O conceito de Distrito Industrial está correlacionado com diretrizes de planejamento que providenciem-lhe uma área apropriada ao funcionamento das indústrias, provendo uma infra-estrutura adequada, arruamentos e circulações necessárias, bem como os demais equipamentos sociais, administrativos, residenciais e comerciais para o pessoal operário nêle empregado (BRUNA, 1974, p.1).

Podemos observar que a preocupação central é a configuração do espaço, e que este espaço está diretamente relacionado à ação do poder público, o único que pode ser responsabilizado pela infraestrutura demandada. Assim, a autora defende que a industrialização, em seu sentido mais amplo, necessita de um programa de planejamento.

O agente promotor, para Bruna, pode ser tanto um governo central quanto os governos locais, por meio de agências especializadas. Contudo, a autora também prevê a possibilidade de que sejam feitas iniciativas e consórcios com a iniciativa privada associada ao poder local, bem como, exclusivamente, pela iniciativa privada. Exatamente por essa razão, ela destaca que cada país, ao fomentar a implantação de distritos industriais, deve procurar enquadrá-los nas diretrizes básicas de seu sistema de planejamento territorial ${ }^{14}$.

Já B. Nogueira (1991), com o objetivo de conceituar o que chamou de "área industrial", admite que qualquer área industrial possa ter duas origens: espontânea ou planejada. O distrito industrial, na condição de uma área industrial planejada, “[...] constitui-se no tema por excelência do planejamento territorial de áreas industriais" (NOGUEIRA, 1991, p.31).

Este autor faz uma distinção importante ao contrapor loteamento industrial e distrito industrial. Em primeiro lugar, qualquer área planejada seria uma "zona industrial”, claramente fazendo alusão aos princípios do zoneamento urbano. Estas zonas industriais poderiam dividir-se em dois tipos: loteamentos industriais (cujo objetivo é a comercialização dos lotes industriais, cuja organização é feita pelo empreendedor segundo

\footnotetext{
${ }^{14}$ É lei na Inglaterra que todo empresário necessita de um certificado de desenvolvimento industrial para poder implantar a sua indústria, porém tal certificado só é emitido se estiver de acordo com uma das zonas planejadas para o desenvolvimento industrial (BRUNA, 1974, p.38).
} 
as diretrizes de ocupação já fixadas pelo zoneamento) e os distritos industriais (quando efetivamente são áreas planejadas segundo normas e critérios mais avançados).

No caso do distrito, a configuração da área deverá estar atrelada às políticas de desenvolvimento industrial do município ou região, bem como o seu planejamento deve obedecer à organização geral da cidade. Em sua generalidade, resultam do envolvimento do poder público (adquirir a área, promover a sua ocupação segunda o política industrial), mas pode ocorrer o envolvimento de outros agentes na sua formulação.

A complicação para análise do distrito industrial brasileiro está relacionada ao uso puramente instrumental da noção, sobretudo quando o poder público municipal delimita uma zona industrial. Com a denominação de distrito industrial, faz-se referência a situações diversas que nem sempre se relacionam aos conceitos clássicos. Por isso, apontamos que o que se chama de distrito industrial, no Brasil, é diferente principalmente das abordagens de que se desdobraram de A. Marshall.

Por fim, existam essas variações e possíveis inconsistências relacionadas ao conceito, a maneira mais simples e objetiva de caracterizá-lo, no Brasil, é pela ótica do uso do solo urbano, ou seja, pela reserva de uma área para uso industrial, conforme aponta $\mathrm{O}$. Firkowski: “[...] um distrito industrial na ótica do uso do solo urbano, ou seja, uma área reservada para uso industrial" (2001, p.179). Neste sentido, o distrito industrial brasileiro está mais relacionado à zona industrial, assim definida, delimitada e equipada pelo poder público dos estados ou, posteriormente, dos municípios.

\section{Zona Industrial}

A zona industrial é um termo amplamente utilizado no planejamento urbano, como uma noção teórica desenvolvida para uso instrumental. A zona industrial deriva da técnica do zoneamento, cujo princípio é essencialmente a divisão da área urbana a fim de estabelecer regulamentação adequada às determinadas áreas e propriedades existentes em cada uma delas, de acordo com o arquiteto H. D. Villares (1948).

A essência do zoneamento é a regulamentação das características e dimensões do bloco edificado em relação à área e categoria do terreno. Tal regulamentação baseia-se na natureza, densidade e limitação de altura das construções (VILLARES, 1948, p.68). 
A zona industrial é uma das que fazem parte do planejamento urbano, ao lado das zonas residenciais, comerciais ou mistas, bem como às zonas de espaços livres e atividades desportivas. A regulamentação é garantida por força jurídica, por intermédio de leis de zoneamento e uso do solo urbano, efetivadas pela administração pública municipal, às quais pode se combinar um código de obras do respectivo município.

É justamente este sentido, da organização e da restrição, que menciona G. Bruna (1974): “A zona industrial é uma área bem definida, dentro de uma área urbana, onde institucionalmente podem se localizar indústrias que atendam a pré-requisitos urbanísticos bem determinados" (p.2). Os pré-requisitos indicam, por exemplo, se a destinação da área será orientada para indústrias leves ou indústrias pesadas, ou ainda restrita a certos ramos industriais de acordo com os interesses municipais (como incentivar a instalação de indústrias de alta tecnologia, indústrias não poluentes, direcionas a um certo padrão produtivo regional, etc.).

A rigor, a definição de uma zona industrial deve ocorrer antes da efetiva instalação industrial, assim permitindo que a administração municipal direcione sua localização para as áreas mais adequadas. Idealmente, visando maior eficiência para a produção e que representem menos impactos negativos para o conjunto da vida social (VILLARES, 1948). Entretanto, a implantação da zona industrial pode ocorrer mesmo após a instalação de várias unidades industriais; nesse caso, poderá impor adequações e inclusive restringir a instalação de novas unidades na área.

Uma das implicações evidentes da técnica e política do zoneamento urbano é a formação de aglomerações industriais e, em alguns casos, economias de aglomeração. Por isso podemos fazer o seguinte questionamento: não seriam os distritos industriais brasileiros, promovidos pelas prefeituras municipais, equivalentes às zonas industriais? Sobretudo no tocante ao ponto de partida, os primeiros esforços para a implantação do distrito industrial dizem respeito à implantação de uma zona industrial no município.

\section{Parque Tecnológico}

Assim como verificado nas abordagens das demais aglomerações industriais, também existe uma variedade de termos que se referem aos parques tecnológicos, muito embora, nesse caso, sejam processos similares. L. C. Lima (1994), em seu estudo sobre 
tecnopolos, aponta como termos equivalentes: distrito industrial de alta tecnologia, science park, centro de inovação ou mesmo tecnópole.

Em estudos recentes como os de R. N. Melo e L. Baldoni comparecem ainda outras nomenclaturas que ajudam a explicar os parques tecnológicos. Melo (2014) se apoia nos conceitos de technopôle (tecnopolo ou polo tecnológico), technopole (tecnópole, no mesmo sentido da pólis - cidade) e science park. Para Baldoni (2015), os conceitos centrais seriam: parque científico (science park), parque tecnológico (technology park), parque de pesquisa (research park), centro de inovação e parques empresariais ou comerciais. Para estes dois autores, os mais importantes seriam o parque tecnológico e o parque científico, os quais refletem o modelo que tem se tentado implantar no Brasil.

A literatura sobre este tema, não apenas acadêmica, é também vasta e atual. Contudo, a identificação dos parques tecnológicos é relativamente mais simples. O número de parques tecnológicos implantados é menor e, em linhas gerais, a organização tende a ser formalizada e mais eficiente. O caso embrionário - e exemplo clássico - deste tipo de organização é a iniciativa das empresas inovadoras que se localizavam ao redor da Universidade de Stanford (Palo Alto, Estados Unidos), inicialmente com uma configuração de distrito, impulsionando a iniciativa da consolidação de um "parque" que permitiria fomentar e intensificar o relacionamento empresa-universidade (LALKALE E BISHOP, 1995), configurando a área que é hoje conhecida como Sillicon Valley.

As iniciativas mais importantes foram elencadas por Lima (1994), que considera pioneiras no mundo:

- Palo Alto (EUA, 1950): Iniciativas da Hewlett Packard, Texas Instruments e Shockley Semiconductor.

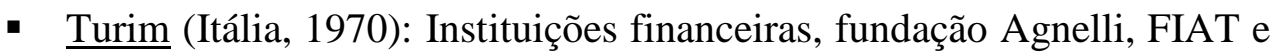
Olivetti se unem para configurar a Tecnocity.

- Meylan-Grenoble (França, 1972): Cerca de 130 empresas que intensificaram sua rede de relações, conjugando "saber produzir e saber inventar".

- Milão (Itália, 1987): Tendo o grupo Pirelli como patrono, criou-se uma gestão técnico-administrativa "para por a cidade de Milão na vanguarda do ponto de vista econômico, científico e urbanístico". 
Além de outros programas de incentivo expressivos que foram detectados em países como Japão, França, Inglaterra, Itália e Canadá, conforme o estudo realizado por Lima (1994).

Como ponto de partida, G. Benko (1996) considera como polos tecnológicos os espaços que seriam um local cuja estratégia de desenvolvimento econômico se apoie na valorização do potencial universitário e de pesquisa, e que seja indutor de empresas de alta tecnologia, as quais podem ser criadas pelo contexto local ou para lá atraídas (BENKO, 1996). Na visão do autor é imprescindível que sejam implantados em regiões com potencial já instalado de pesquisa e desenvolvimento - espaços metropolitanos - os quais “[...] oferecem economias de aglomeração, forte concentração de setores de técnica elevada e transição possível entre antigas e novas tecnologias” (1996, p.160).

Para Melo, da mesma forma, os tecnopolos (technopôles) estão associados aos projetos de desenvolvimento econômico das cidades, cujo objetivo é "[...] valorizar seu potencial universitário e de pesquisa para gerar uma nova industrialização a partir de empresas de alta tecnologia" (2014, p.78), considerando sempre a articulação entre a gestão pública, a universidade e as empresas.

A análise de J. L. Solleiro (1993) discute as vantagens do parque tecnológico do ponto de vista das empresas e das universidades. O autor situa que, para as empresas, trata-se de desfrutar de uma área física delimitada e urbanizada convenientemente a fim às atividades das empresas intensivas em tecnologia, bem como se valer da proximidade universitária com o objetivo de aproveitarem a capacidade técnica e científica de pesquisadores e laboratórios. Para as universidades, por sua vez, a articulação junto ao parque tecnológico representa o canal aberto para a obtenção de linhas de financiamento e melhorias, bem como obter feedback das empresas e cultivar um campo de atuação para seus pesquisadores.

É também J. Mitra (1997) que realiza uma abordagem sobre os parques tecnológicos focado no relacionamento universidade-empresa, porém do ponto de vista normativo. $\mathrm{O}$ autor afirma que, para o sucesso do parque, é preciso estimular uma ligação formal com a universidade ou centro de pesquisa, bem como implantar uma estrutura de gestão que delimite as ações necessárias para, de maneira eficiente, garantir a transferência de tecnologia e habilidades científicas e empresariais. Diferentemente da maior parte das outras aglomerações industriais estudadas, é o parque tecnológico que demanda este tipo de organização formalizada e eficiente. 
Para sair do desenvolvimento meramente acadêmico do termo, podemos complementar nosso rol de ideias a partir da proposição da Associação Nacional de Entidades Promotoras de Empreendimentos Inovadores (ANPROTEC) que define o parque tecnológico como:

[...] um complexo produtivo industrial e de serviços de base científicotecnológica, planejado, de caráter formal, concentrado e cooperativo, que agrega empresas cuja produção se baseia em pesquisa tecnológica desenvolvida nos centros de $\mathrm{P} \& \mathrm{D}$ vinculados ao Parque. Trata-se de um empreendimento urbanístico promotor da cultura da inovação, da competitividade, do aumento da capacitação empresarial, fundamentado na transferência de conhecimento e tecnologia (ANPROTEC, 2016).

Finalmente, é importante distinguirmos entre o parque tecnológico e o parque científico. Baseado no estudo de L. Baldoni (2015), os parques tecnológicos são áreas (públicas ou privadas), cujo zoneamento é definido como tal no plano diretor, que permitem a instalação física de laboratórios para a produção científica, conteúdo tecnológico e inclusive o desenvolvimento de produtos e processos inovadores.

Por sua vez, o parque científico (science park) é uma área que pertence a uma ou a determinadas instituições de ciência e tecnologia (ICT). A área é gerida pelas ICT envolvidas, "[...] com ocupação temporária via projetos em parceria ou incubação de empresas" (BALDONI, 2015, p.26). Além disso, podemos considerar que as instalações tem um caráter temporário, uso compartilhado e as pesquisas ocorrem em sua fase exploratória. O caráter temporário do modelo de parque científico implica obstáculos que atingem diretamente a atração de empresas. Existem duas visões opostas: para o empresário, o projeto dever ser extremamente vantajoso para tal investimento em um local que será temporário. Em contrapartida, a instalação de uma unidade empresarial no espaço da academia (campus universitário) interfere na "missão" da universidade.

No contexto dos parques científicos se desenvolve o conceito de incubadoras, estruturas que visam atender às expectativas de empresas nascentes (start-ups) cujo apoio ocorre, sobretudo, no tocante às instalações físicas necessárias para alavancar seu processo produtivo:

[...] Prédios destinados a amparar o estágio inicial de empresas nascentes que se enquadram em determinadas áreas de negócios. Presença de ambiente empreendedor no qual são oferecidas facilidades para o crescimento de novas empresas além de assessoria na gestão técnica e empresarial e a possibilidade de serviços compartilhados. São mantidas 
por entidades governamentais, privadas, ICTs ou grupos comunitários (BALDONI, 2015, p.26).

É também válido mencionar a importância institucional das incubadoras. A partir do relacionamento que é constantemente alimentado entre as ICT e as empresas nascentes no ambiente das incubadoras, vínculos nascem, se reforçam e podem se manter mesmo depois do período de incubação (LALKALA e BISHOP, 1995), quando a empresa graduada precisa deixar a incubadora. Dessa forma, os relacionamentos que nascem no âmbito do parque científico se transferem para o parque tecnológico.

Existem diversos modelos que orientam a gestão de um parque tecnológico, inspirados, sobretudo, na interação universidade-empresas, mas também no tocante às estratégias para atender ao conjunto da sociedade, e à visão estratégica de negócios. Audy et al (2003) elencam o modelo " $n$ ", o coupling model, networking model, ou ainda o modelo de gestão desenvolvido pelo Massachusets Institute of Technology (MIT).

Atualmente em voga, o modelo Triple Helix tem inspirado iniciativas correntes. Na concepção de Etzkowitz e Leydesdorff (2000), o triple helix parte da interação entre universidade - indústria - governo, na qual a universidade possui o objetivo de cultivar a cultura empreendedora, a indústria o objetivo de participar de pesquisas através da partilha de conhecimentos e melhores práticas, e, o governo objetivo de promover o investimento em maior educação e capacitação da pesquisa.

De acordo com o Triple Helix Research Group (2016), a perspectiva da inovação é um processo resultante das relações entre ciência, tecnologia, pesquisa e desenvolvimento nas universidades, empresas e governos "em uma espiral de transições sem fim". Neste propósito, a universidade é vista como a indutora das relações com as empresas, e o governo deve regular e fomentar esta atividade econômica. Espera-se que a produção de novos conhecimentos e a inovação tecnológica leve ao desenvolvimento econômico. De fato, podemos apontar que o relacionamento é o elemento chave que fundamental estas aglomerações produtivas e variável imprescindível para o seu sucesso.

A especificidade dos parques tecnológicos em relação às demais aglomerações industriais está no fato de demandar a participação direta entre empresas, universidades e a administração pública, o que fica claro a partir das definições mostradas e, sobretudo, dos modelos de gestão inspirados nos parque tecnológicos. O triple helix nada mais é do que a formalização de uma lógica já presente nestas aglomerações e que a fundamentam. 
Uma vez que são inspirados na transferência de conhecimento e tecnologia, é necessária a forte participação da universidade e da gestão pública (federal, estadual ou municipal) em sua organização. A esse respeito, Lima (1994) aponta duas dinâmicas que podem originar os parques: em um primeiro caso, são investimentos privados que se dirigem para as pesquisas universitárias, fazendo surgir empresas spin-off com potenciais efeitos multiplicadores. Em outra perspectiva, os parques derivam do planejamento regional público, visando atrair empresas com pouca relação com as instituições acadêmicas e que habitualmente importam suas pesquisas.

Além disso, é imprescindível atentarmos ao conteúdo destas aglomerações, quer sejam parques tecnológicos ou científicos, pois neles estão consubstanciados: a iniciativa da pesquisa científica, o desenvolvimento tecnológico e, por vezes a produção dos protótipos e estratégicas para sua inserção no mercado e produção em escala. Destaque-se o estudo de Medeiros (1997), que elenca as pré-condições para a implantação desses espaços de inovação: a) existência de instituições de ensino e pesquisa que possuam densidade tecnológica em algumas áreas; b) apoio governamental, sendo da União, Estado e/ou Município; c) existência de Empresas que se interessem pelas novas tecnologias; d) parcerias e projetos conjuntos entre academia e empresas; e) estruturas organizacionais convenientemente organizadas.

Dessa forma, é importante dizer que estes são espaços ancorados na geografia: de acordo com Benko (1996) no sentido próprio da localização; um espaço preciso, um ponto singular, que permite articular empresas inovadoras, atividades acadêmicas de pesquisa e desenvolvimento, produção e também comercialização. Muito embora a organização de contatos em rede, entre empresas e entre pesquisadores, seja uma premissa necessária à competitividade do parque tecnológico, a proximidade é considerada fator de base para o seu sucesso.

Portanto, podemos considerar o parque tecnológico como uma forma de aglomeração produtiva, com a necessária presença de instituições de ciência e tecnologia e, neste caso específico, tendo a presença da indústria especializada, capaz de produzir protótipos específicos que darão os contornos ao produto final, e uma indústria que requer uma elevada especificidade em sua localização.

Se considerarmos a noção de ciclo de vida do produto, a produção intelectual e tecnológica (produção não standartizada) requer uma série de fatores locacionais necessários ao seu bom funcionamento. Seriam eles, de acordo com Benko (1996): (1) força de trabalho com um nível de qualificação compatível às atividades de pesquisa e 
desenvolvimento; (2) existência de universidades e institutos de pesquisa, com possibilidades de parcerias em pesquisas buscadas pelas empresas; (3) atrativo paisagístico que inspire modernidade e com infraestrutura cultural e de ensino elevada; (4) infraestrutura de transportes visando fácil acesso (sobretudo aéreo) para as pessoas; (5) serviços e clima político e de negócios fomentado pela presença de consultores, acesso à informação, disponibilidade de capital de risco em um ambiente no qual o poder público é um facilitador.

Por fim, (6) a existência de economias de aglomeração, como fator essencial para as atividades de pesquisa e desenvolvimento e estímulo aos processos de spin-off. Nestas economias são valorizados os processos face-a-face, bem como a formação de redes de contato e informação (BENKO, 1996).

\section{Arranjo Produtivo Local}

$\mathrm{O}$ arranjo produtivo local é reconhecido como um conceito que tem extensa aplicação no território nacional e está presente nas abordagens e políticas territoriais. Isso se deve ao fato de que este tipo de aglomeração se conforma a partir especializações produtivas pré-existentes, oriundas de iniciativas anteriores e vinculadas à história de produção em uma determinada localização. Dizer que tal aglomeração é um arranjo produtivo local é apenas uma forma de reconhecer algumas especializações produtivas já existentes, e institucionalizá-las como parte de um programa de governo.

Por essa razão, é importante destacar que utilizaremos as definições dos principais pesquisadores sobre este tema e também, conjuntamente, de instituições que desenvolvem e utilizam este conceito. São abordagens que se complementam.

A ideia de arranjo produtivo local foi sistematizada inicialmente por um grupo de pesquisadores reunidos na Universidade Federal do Rio de Janeiro, onde se formou o REDESIST (Rede de Pesquisa de Sistemas Locais de Produção e Inovação do Instituto de Economia/UFRJ). Na figura de J. Cassiolato e H. Lastres, principalmente, foi pensada a sua definição, nas seguintes palavras:

[...] arranjos produtivos locais são aglomerações territoriais de agentes econômicos, políticos e sociais - com foco em um conjunto específico de atividades econômicas - que apresentam vínculos mesmo que incipientes. Geralmente envolvem a participação e a interação de empresas - que 
podem ser desde produtoras de bens e serviços finais até fornecedoras de insumos e equipamentos, prestadoras de consultoria e serviços, comercializadoras, clientes, entre outros - e suas variadas formas de representação e associação (CASSIOLATO e LASTRES, 2003, p.27).

Este conceito foi apropriado e também aperfeiçoado por agências de fomento, as quais participam da definição de políticas públicas. Poderíamos citar a definição do BNDES por intermédio dos autores G. dos Santos, E. Diniz e E. Barbosa (2004), os quais assinalam:

[...] pode-se concluir que o conceito de APL - ao ter como paradigma principal os distritos industriais italianos e ser associado a uma política que vise, de alguma forma, adaptar essa experiência a outras localidades - tem, tradicionalmente, como catalisador mais destacado, a importância da cooperação e, como característica fundamental, a presença de pequenas ou médias empresas concentradas espacialmente em alguns dos elos de uma cadeia produtiva (SANTOS et al., 2004, p.158).

Na condição de objeto de intervenção do poder público, os arranjos produtivos locais apareceram como forma de aglomeração nos Planos Plurianuais dos triênios 20042007 e 2009-2011 15 . Os autores asseveram ainda que o sucesso do conceito de arranjo produtivo local se deve a ter sido praticamente o único nicho de ação de política industrial aceito dentro do meio neoliberal (SANTOS et al., 2004), reconhecidamente crítico à intervenção estatal.

Como já evidenciado, devemos assinalar as inspirações e possíveis equivalências deste conceito, já que foi desenvolvido em observação à realidade brasileira e não sem influências de teorias externas. Uma compilação destas influências foi feita por L. Fuini (2013), que afirma os arranjos produtivos locais terem antecedência teórica nos distritos industriais italianos e nos clusters de Michael Porter. Essa afirmação é comum entre os que se propõem a estudar este tipo de aglomeração, o que provavelmente nos indica ser essa forma uma "equivalência brasileira" dos distritos industriais (no sentido original deste conceito em sua abordagem italiana) tendendo à, modernamente, referenciarse em elementos da abordagem dos clusters.

Além destes, foram outros conceitos influentes para a formação do conceito de arranjo produtivo local: centro industrial, polos de crescimento e de desenvolvimento,

\footnotetext{
${ }^{15}$ Em agosto de 2004 foi criado o Grupo de Trabalho Permanente para Arranjos Produtivos Locais (GTP APL), uma Secretaria Técnica exclusiva, instalada no Ministério de Desenvolvimento, Indústria e Comércio Exterior (MDIC), por meio da Portaria Interministerial no 200. L. Fuini (2014) afirma que foram envolvidas 23 instituições, entre as quais: Banco do Brasil, Caixa Econômica Federal, Banco do Nordeste e Finep.
} 
complexos industriais e tecnopolos (FUINI, 2013). A conceituação do arranjo produtivo local ancora-se em muitas outras noções, fazendo-se importante apresentar a conjuntura que originou esta concepção.

Por se tratar de um tipo de aglomeração que se desenvolveu - empiricamente e conceitualmente - no Brasil, é importante ter maior destaque o contexto de seu surgimento. Na década de 1990 o Estado nacional já não tinha o mesmo fôlego de intervenção direta, a economia ainda refletia uma grave crise na qual os esforços e planos desenvolvidos tiveram o intuito de recuperação financeira. A esse contexto econômico nacional some-se a emergência de práticas neoliberais que passam a se tornar realidade no país e, na esfera da organização da produção é preciso levar em conta as alterações induzidas pelas lógicas de produção pós-fordistas. J. Bittencourt (2011, p.110), para sintetizar esse processo, assinala que ocorreu adaptação "[...] dos princípios do distrito industrial marshalliano como um sistema produtivo local de base inovadora adaptada à lógica de produção capitalista (pósfordista)". Dessa forma, adotou-se um modelo de crescimento econômico pautado em pequenas e médias empresas organizadas em rede, espacialmente concentradas e com especialização local.

Para termos uma ideia da relevância deste tema para interpretação do Brasil industrial, a pesquisa de J. Saboia (2000b) identificou a existência de 155 aglomerações industriais no Brasil no ano de 1997. Todas elas tinham mais de cinco mil empregos formais, das quais 45 podem ser consideradas aglomerações especializadas. Ou seja, nas quais pelo menos metade do emprego industrial concentra-se num único circuito (SABOIA, 2000). Há, portanto, um número expressivo destas aglomerações (ressalte-se que foram usados apenas dados relativos à indústria).

Mencionar essa possível equivalência com o distrito industrial à italiana é o mesmo que contextualizar o arranjo produtivo local como representação geográfica de um sistema de desenvolvimento endógeno, ou seja, um conjunto de empresas e empresários com base local, desintegrados e especializados como o paradigma da substituição do modo de regulação fordista. Nas palavras de G. Benko (1996), formando um sistema de desenvolvimento endógeno coordenado pelo mercado e pelos encontros face-a-face em “[...] uma divisão social do trabalho desintegrada entre as firmas menores, especializadas num segmento do processo produtivo" (BENKO, 1996, p.57).

Assim como o distrito industrial à italiana, também o arranjo produtivo local é coordenado pelas próprias firmas (daí a importância da reciprocidade), exigindo um estabelecimento de sistema de governança articulado, diferentemente da indústria fordista; 
quebra-se o paradigma da integração vertical e da centralização em função da especialização flexível (BENKO, 1996).

É importante salientar as características do paradigma produtivo pós-fordista que diretamente influenciaram a concepção destas aglomerações. Podemos citar as seguintes, acompanhando a sistematização de Fuini (2014):

- Flexibilidade no trabalho: na medida em que é comum a existência de formas de contratação / subcontratação de trabalho em domicílio, não formalizado de acordo com o Código de Leis Trabalhistas (CLT) ou o emprego feminino, sobretudo em segmentos da indústria têxtil, de confecções e calçadista.

- Flexibilidade produtivo-organizacional: na medida em que pequenos produtores são capazes de inserir-se em redes mais amplas de produção, comercialização e distribuição. Há mecanismos que permitem subcontratação, terceirização empréstimos e assistência tecnológica.

- Flexibilidade público-estatal: uma vez que há mais possibilidades de articulação socioinstitucional e pactos de cooperação com empresas / poder público para o desenvolvimento local. Essa flexibilidade se expressa na maior capacidade local de oferecer estímulos na medida em que se reconhece uma descentralização político-administrativa.

L. Fuini destaca que os arranjos produtivos locais "[...] já nascerem estruturados como redes de empresas e concentrações de empresas em rede" (2014, p.240). É fato que as aglomerações industriais de pequenas e médias empresas surgiram na década de 1980 e consolidaram-se em 1990; para J. Bittencourt (2011) são três dinâmicas que explicam esse surgimento: o esgotamento do crescimento econômico sob a liderança do Estado ou da multinacional, ao que se acompanha a crise no mercado de trabalho impulsionando investimento em pequenos negócios como alternativas e, concomitantemente, podemos afirmar que cresce a cultura empreendedora no país. É dentro desse contexto que "[...] os APLs se transformaram na ponta de lança do desenvolvimento local no Brasil a partir da década de 2000” (BITTENCOURT, 2011, p.118).

Outro aspecto que diferencia o arranjo produtivo local da maioria dos outros tipos de aglomeração analisados nesta tese, é que atualmente não é uma forma de aglomeração exclusivamente industrial, ou seja, podemos verificar arranjos produtivos locais destinados a demais segmentos da economia. A pesquisa de M. Steda (2015) elenca 
30 municípios ou regiões brasileiras nas quais a autora identificou arranjos produtivos locais de software. Outro segmento bastante comum no quadro de arranjos produtivos locais é o turismo; neste segmento, a pesquisa de H. Costa et al. (2009) identificou 10 arranjos produtivos locais no Brasil, os quais envolvem 99 municípios. Embora foquemos exclusivamente na indústria e na predominância industrial existente nas áreas estudadas, o arranjo produtivo local é mais bem definido como uma aglomeração produtiva ${ }^{16}$.

No âmbito de trabalhos críticos sobre os arranjos produtivos locais, destacamos dois pontos importantes na análise de W. Suzigan et al (2003) e as críticas direcionadas ao “exagerado desenvolvimento local”, expressa no trabalho de C. Brandão (2007).

Para W. Suzigan e autores, o conceito de arranjo produtivo local é inadequado para designar essa forma de aglomeração específica, argumentando que não se tratam de arranjos, mas de um sistema, nos seguintes termos:

Em geral, um sistema local de produção comporta um conjunto de empresas com capacidades relacionadas ou afins, de portes variados, mas em geral com um conjunto expressivo de pequenas e médias empresas não integradas verticalmente. Essas empresas, por sua vez, atraem fornecedores e outras indústrias correlataras e de apoio, cuja presença e importância nos sistemas locais são determinadas exclusivamente por forças de mercado. Por fim, surgem também importantes instituições locais de apoio a empresas (SUZIGAN et al., 2003, p.2).

Como mostrado pelos autores, existe uma carência de critérios metodológicos para definição, delimitação geográfica e caracterização dos sistemas ou arranjos produtivos locais (SUZIGAN et al., 2003).

Em sua visão mais crítica, há que se desconfiar de um contexto, aparentemente forjado, segundo o qual "o local pode tudo". Essa perspectiva retira do debate e do planejamento a escala nacional (BRANDÃO, 2007; BITTENCOURT, 2011), de maneira que "[...] o desenvolvimento econômico local tem como função primordial a inserção do local no global” (BITTENCOURT, 2011, p.110). Para C. Brandão “[...] a concepção de que a escala local teria poder ilimitado invadiu o debate sobre o desenvolvimento territorial, no Brasil e no mundo" (2007, p.38).

\footnotetext{
${ }^{16}$ Conforme destacamos na introdução, todas as aglomerações apresentam, em maior ou menor grau, a presença de outros segmentos e mesmo áreas comerciais e residenciais. A expressão aglomeração produtiva, embora seja mais adequada para os arranjos produtivos locais, também se aplica às demais formas de aglomeração. Apenas para justificativa, o próprio distrito industrial, classicamente, carrega uma definição de comunidade muito mais importante do que a própria definição dos segmentos industriais que lhe fazem parte.
} 
Essa 'endogenia exagerada' das localidades crê piamente na capacidade das vontades e iniciativas dos atores de uma comunidade empreendedora e solidária, que tem controle sobre seu destino e procura promover sua governança virtuosa lugareira (BRANDÃO, 2007, p.38).

Brandão afirma que são casos nos quais o espaço local pode ser tratado com um mero "nó entrelaçado" na rede crendo na perspectiva da sociedade em rede de M. Castells (1999), ou então o espaço é um recorte singular e dotado de vantagens específicas e únicas, que só ali se encontram e que seriam a chave para sua autopropulsão, identidade e autonomia. Em um caso ou em outro "[...] ora há estrutura sem sujeito, ora há sujeito sem estrutura" (BRANDÃO, 2007), ignorando-se totalmente a escala intermediária entre o local e o global, ou seja, a escala nacional:

O Estado pouco teria o que fazer nesse contexto de "aprendizagem coletiva" e "atmosfera sociopolítica", em que os atores se congregam e se aproximam de forma cooperativa. A ação pública deve prover externalidades positivas, desobstruir entraves microeconômicos e institucionais, deve regular e, sobretudo, desregular, a fim de garantir o marco jurídico e o sistema normativo, atuando sobre as falhas de mercado (BRANDÃO, 2007, p.46).

Apesar de nitidamente dividir os intelectuais acerca da validade deste conceito na condição de instrumento viável para políticas públicas, temos que considerar a existência destas formas em grande número na realidade atual do Brasil (o GPT APL indica a existência de 267 arranjos produtivos locais e prioritários para atuação) e como uma aglomeração que, muitas vezes pode ser originada e fomentada numa distante das capitais e áreas metropolitanas, são os arranjos produtivos locais que, geograficamente, explicam muitas das aglomerações industriais fora do eixo urbano-industrial mais pronunciado do Brasil e também no interior das unidades estaduais. Além disso, é também o arranjo produtivo local que explica formas de aglomeração baseadas em médias, pequenas e micro empresas. Nesse sentido, é um conceito importante para nossa pesquisa na medida em que explica o território nacional, com foco nas aglomerações industriais.

\section{Condomínio Industrial}

O conhecimento sobre condomínios industriais está, em sua grande maioria, sintetizado inicialmente em publicações dos estudos de Engenharia de Produção. Contudo, 
uma definição precisa é difícil, pois também neste caso, diversos termos são atribuídos a formas de aglomeração parecidas. O primeiro estudo falando de condomínio industrial que encontramos no Brasil foi de M. Kalife (2002). Trata-se de uma dissertação que fala principalmente do conceito de modularidade entre as empresas e da formação de um condomínio industrial. Seriam duas dinâmicas principais, ambas pautadas na noção de modularidade.

A modularidade trata de processos gerenciais assumidos por empresas, mas que não se restringem unicamente à ocorrência de condomínios industriais. Em linhas gerais, diz respeito à maneira de gerir um sistema complexo, decompondo-o em partes que podem ser fisicamente separadas, mas sem afetar a integridade do todo. A modularidade, além disso, pode ocorrer em três dimensões: projeto, produção e consumo. Dessa noção de modularidade se desdobram duas formas de aglomeração (consórcio modular e condomínio industrial), segundo Kalife (2002):

- O consórcio modular tem uma dimensão física facilmente identificável. Trata-se de um conjunto de fornecedores - denominados modulistas que, ao estabelecer-se em consórcio com um montador principal, instalam-se anexados em um mesmo espaço físico. Foi comprovada esta ocorrência, no Brasil, para o caso da fábrica da Daimler Chrysler em Betim (MG).

- O condomínio industrial seria uma estrutura organizacional e física que mais recentemente vem sendo adotada por algumas montadoras, em um tipo de iniciativa na qual permanece a racionalidade de trazer para perto os fornecedores (ainda chamados de modulistas). Entretanto, neste caso a montadora controla totalmente a área onde serão alocados; negocia benefícios com o governo local, oferece terreno e infraestrutura e ainda projeta um sistema de produção que seja compatível com os módulos de produção do produto final. A este respeito podemos mencionar o Condomínio Industrial da Ford instalado em Camaçari (BA), na área do polo petroquímico.

É importante destacar que, nos exemplos citados, a ação que resulta no condomínio industrial está associada aos próprios dirigentes da indústria em função da promoção de contiguidade física entre os fornecedores e a empresa montadora, em uma área que pode ser da própria montadora, às vezes inclusive em seu espaço físico interno ou, em outra perspectiva, em uma área que ela mesma irá organizar.

O. Firkowski (2001) estudou estas formas de aglomeração na Região Metropolitana de Curitiba. Ela os nomeia como "complexos de produção", com as 
seguintes características: "[...] várias empresas juridicamente independentes, compartilham um mesmo espaço de produção, capitaneadas pelas montadoras, o que muitos atores denominam de "quase integração vertical'” (FIRKOWSKI, 2001, p.143).

Nos dois casos citados, as autoras estudaram montadoras de automóveis, em Minas Gerais e Paraná, respectivamente, e apontam que, nos dias de hoje, a implantação da indústria automobilística se faz em rede, em que cada montadora precisa estar acompanhada dos demais fornecedores que participam diretamente da produção do automóvel. Neste caso, evidentemente, estes fornecedores se materializam localmente, inclusive ocupando um determinado local no terreno em que sua posição agilize o processo produtivo global.

A importância de pesquisar estas áreas é que são expressão de espaços produtivos que se organizam a partir da racionalidade da flexibilização produtiva. A tese de Firkowski (2001) é que no contexto atual, a estrutura produtiva se consolida com alterações no governo e na territorialidade produzida. Dessa forma, a nova lógica territorial corresponde, evidentemente, à nova lógica funcional das empresas. Para a autora, criar-se uma espécie de "distrito industrial fechado", mas em outras passagens ela menciona também que seriam "novos distritos industriais" e, finalmente, em termos conclusivos, “complexos de produção flexíveis".

Dois pontos importantes a se destacar é que, segundo Firkowski (2001), estes complexos "recusam o passado industrial", no sentido de que irão buscar novas áreas para se instalar, preferencialmente distante das áreas industriais que se consolidaram no passado; para isso, o foco recai no entorno metropolitano e em determinada localização que os ligue também aos fornecedores fora do complexo. Novamente, a fluidez potencial do território é condição indispensável para se escolher uma localização. A autora ressalta ainda:

\footnotetext{
Apesar de, genericamente, permitir uma flexibilidade maior de localização, as novas infraestruturas são, no nível do lugar, concentradoras, uma vez que não se distribuem uniformemente pelo espaço, pelo contrário, privilegiam certos lugares em detrimento de outros (FIRKOWSKI, 2001, p.187).
}

Tais características de localização vêm ao encontro de uma constatação que já vimos discutindo, qual seja: os critérios locacionais e aglomerações territoriais da indústria de empresas ligadas ao paradigma flexível de produção, embora relacionadas a ele, ou seja, com processos flexíveis, encontram certa rigidez nas opções de localização, pois seus 
critérios passam a ser bem mais específicos. Esse apontamento já fora feito por autores como G. Benko (1996) e M. Castells (1999).

Muito embora optemos, inicialmente, por trata-los como condomínio industrial há o questionamento da validade dos termos empregados. Em primeiro lugar, para se efetivar um condomínio é preciso que ocorra a copropriedade do terreno, o que não é se verifica por meio dos casos estudados; neles, o terreno e sua organização cabe à montadora. Além disso, o "condomínio industrial" pode gerar equivalência com alguns condomínios empresariais que se autodenominam condomínio industrial. Parece-nos que seria mais adequado utilizar o termo "consórcio modular", como uma ocorrência de aglomeração industrial associada às empresas montadoras de automóveis.

\section{Condomínio Empresarial}

Entre as formas de aglomeração industrial estudadas nesta pesquisa, o condomínio empresarial é a mais recente. Embora existam indicações de condomínios empresariais iniciados nos EUA na década de 1980 (MACHADO et al., 1997 e MENDES, 2007), no Brasil as primeiras iniciativas se deram na metade da década de 1990.

Os condomínios empresariais são a forma de aglomeração de maior diversidade de termos empregados para sua identificação. Além do próprio "condomínio empresarial" - termo que optamos por usar em nossa pesquisa -, podemos mencionar os demais: condomínios industriais, condomínios de galpões, condomínios de escritórios, centros logísticos, parques industriais, business centers e business parks.

Em nossa dissertação de mestrado, chegamos à seguinte definição sobre estas formas de aglomeração: são empreendimentos de natureza imobiliária destinados a albergar atividades econômicas, nos quais os terrenos são vendidos às empresas ou infraestruturas prontas, sobretudo galpões, alugados por um tempo determinado (FINATTI, 2011).

Além destas características, é importante destacar que são espaços fechados em relação ao seu entorno por meio de controle de acesso e sistemas de segurança reforçados, bem como dotados de objetos técnicos facilitadores para a ação das empresas que nele se instalam (relativos à segurança, comunicação e manutenção, bem como serviços de alimentação, comerciais, bancários e de lazer). 
Devido à racionalização de sua localização pelos promotores imobiliários ${ }^{17}$ (normalmente em situação de privilegiada fluidez territorial em termos de eixos de circulação rodoviários e aeroportos), bem como pelo conjunto de funcionalidades que nele se instalam, estes empreendimentos ampliam (territorialmente) e intensificam (operacionalmente) a produtividade das empresas, e desta forma ampliam e intensificam o uso corporativo do território.

Os condomínios empresariais são expressão das estratégias dos promotores imobiliários, que inovam e diversificam sua mercadoria saindo dos nichos apenas residencial ou comercial. Como resultado desta ação, são agentes econômicos que se somam a uma função, no Brasil, tradicionalmente exercida pelo poder público por meio dos distritos industriais. Os condomínios empresariais são também capazes de estimular localizações e induzir aglomerações industriais (não excluindo outros segmentos econômicos como serviços e comércio).

S. Lencioni (2011) analisou estes empreendimentos na condição de negócios imobiliários, apontando aquilo que representariam como novidade no período contemporâneo:

A novidade dos condomínios industriais reside na condição jurídica que assume a propriedade imobiliária que abriga a produção industrial, pois nela está contido (na propriedade condominial) o conceito de quota-parte da propriedade ou de fração ideal da propriedade da terra (LENCIONI, 2011, p.185).

Em função da constituição jurídica do condomínio, na qual reside a ideia de copropriedade, é possível ao empresário poupar gastos que antes eram feitos com a compra do terreno e construção do edifício, elementos que representam gastos em ativos fixos. Nos condomínios empresariais existe uma garantia de boa localização, segurança, licença ambiental e infraestrutura urbana de qualidade, agilizando e desonerando a implantação ou relocalização de empresas.

Temos a destacar ainda que a segurança por operar em um espaço controlado e vigiado $24 \mathrm{~h}$ por dia, que podemos considerar um importante fator de atração do condomínio empresarial, foi apontada por uma parcela significativa de empresas questionadas quanto à sua decisão locacional. No ano de 2008, foram entrevistados

17 São os agentes responsáveis pelos condomínios empresariais e pelos loteamentos empresariais. Os promotores imobiliários atuam em várias frentes, mesmo que possam segmentar sua atuação. De acordo com M. Fix (2007) existem quatro tipos principais, de acordo com a função que desempenham: incorporadores, projetistas, construtores e corretores. 
representantes de 24 empresas instaladas em um condomínio empresarial e, entre eles, o fator de escolha "segurança" atingiu 74 pontos $^{18}$ ante "acesso rodoviário" (44 pontos) em segundo lugar e outros dez fatores de localização (FINATTI e SPOSITO, 2010).

Além da securitização da área, outro aspecto diferencial que diz respeito aos condomínios empresariais é a produção de uma psicoesfera ${ }^{19}$ corporativa com a finalidade de divulgar o empreendimento e atrair as empresas (potenciais clientes dos promotores imobiliários). Os incorporadores se empenham em definir slogans e criar propagandas em outdoors, jornais e revistas com a finalidade de atração.

Outro aspecto pelo qual se manifesta essa psicoesfera é justamente o status que um empresário pode acreditar possuir quando sua empresa está sediada nestes empreendimentos. O status por operar em um condomínio empresarial foi também um dos fatores de atração declarado pelos empresários (FINATTI, 2011).

As propagandas abordam a inserção dos empreendimentos em um território que facilita a comunicação e um mundo cada vez mais rápido e dinâmico. Essa iniciativa diz respeito à inserção dos condomínios empresariais em uma perspectiva de mundialização, cujo objetivo é a competitividade, a rapidez e os fluxos (materiais e imateriais) de longo alcance. Estes são os elementos abordados nas propagandas dos condomínios empresariais.

Para operacionalizar a pesquisa sobre os condomínios empresariais, chegamos à classificação de três tipos, a partir de uma análise dos empreendimentos existentes no Estado de São Paulo: condomínios empresariais mistos, condomínios de galpões modulares e condomínios horizontais de escritórios, que possuem as seguintes características:

- Condomínio empresarial misto: Permitem abrigar unidades de indústria, comércio ou serviço a partir da venda de seus lotes. São áreas de maior extensão, organizadas e loteadas para a venda. Possuem número mais elevado de unidades industriais entre os três tipos de condomínios empresariais. Localizam-se predominantemente fora dos limites da Região Metropolitana de São Paulo.

\footnotetext{
${ }^{18}$ Nesta pesquisa foi assumido um critério de pontuação para um conjunto objetivo de fatores de localização declarados. Se o fator declarado foi considerado o mais importante entre quatro opções recebeu a pontuação máxima (4). Se o fator declarado figurou em quarto lugar entre os mais importantes recebeu a pontuação mínima (1). Cf. Finatti e Sposito (2010).

${ }^{19}$ A psicoesfera, na definição de M. Santos (2004 [1996]) é um os pilares com o qual o meio técnicocientífico-informacional introduz a racionalidade no próprio conteúdo do território, definindo o seu funcionamento. Nesse sentido, tecnoesfera e psicoesfera condicionam os comportamentos humanos. Abordaremos a relação entre psicoefera e a ação dos promotores imobiliários, com mais detalhes, no Capítulo 3.
} 
- Condomínio de galpões modulares: Permitem unidades de prestação de serviços, principalmente operadores logísticos, e indústrias. São áreas de média extensão, nas quais predominam empresas prestadoras de serviços (destacam-se as operações logísticas). Apresentam unidades industriais instaladas, mas em menor número em relação aos condomínios empresariais mistos. Existe uma rotatividade maior dos clientes, que apenas alugam os galpões por tempo determinado. Sua localização é a mais fortemente articulada aos eixos de circulação.

- Condomínio horizontal de escritórios: Áreas pouco extensas e marcadas por conjuntos de edificações de escritórios com predominância horizontal. Há também grande rotatividade das empresas instaladas, pois se objetiva a renda do aluguel. Localizam-se mais próximos ao centro urbano da Região Metropolitana de São Paulo e também em eixos de circulação importantes na escala intraurbana.

Focaremos apenas nos dois primeiros tipos, os condomínios empresariais mistos e os condomínios de galpões modulares, pois são os tipos que permitem a instalação de unidades industriais, enquanto os condomínios horizontais de escritórios estão voltados exclusivamente para os serviços.

A intensificação deste fenômeno, associado à dispersão de suas unidades pelo Brasil, diz respeito justamente à ampliação do uso corporativo do território a partir da ação dos promotores imobiliários. Isso está diretamente relacionado à ocorrência da implantação privada da arena produtiva, o que equivale a dizer que existe também uma intencionalidade particular consubstanciada a estas formas de aglomeração.

Os condomínios empresariais estão relacionados à obtenção da renda fundiária decorrente do custo da terra, quando esta é incorporada ao mercado urbano. Nesse sentido, diferentemente das demais aglomerações industriais, a essência do empreendimento imobiliário é o seu valor de troca, a renda obtida pelos promotores imobiliários. Por isso, estes empreendimentos apresentam uma dinâmica de implantação associada diretamente ao capital particular, e o contexto é justamente da incorporação imobiliária ligada à mercantilização do espaço, por meio da venda ou do aluguel ${ }^{20}$.

O perfil dos incorporadores é variado, desde aqueles tradicionais como: Cyrela, Hines, Colliers, Bratke Collet, Rossi ou Carmargo Corrêa, até empresas cuja visibilidade não diz respeito diretamente ao ramo de incorporação, mas que cumpriram essa função produzindo condomínios empresariais. Entre elas, podemos destacar IBM, DPaschoal,

\footnotetext{
${ }^{20}$ R. L. Corrêa (1995) assinala que a incorporação "[...] é a operação chave da promoção imobiliária; o incorporador realiza a gestão do capital-dinheiro na fase de sua transformação em mercadoria, em imóvel" $(1995$, p.20).
} 
Tintas Coral e Kodak (FINATTI, 2011). Portanto, mesmo entre os incorporadores imobiliários, há um conjunto de diferentes agentes privados (como os trataremos genericamente à diante) que podem atuar neste ramo.

Finalmente, resta destacar que existe um planejamento associado ao condomínio empresarial, que antecede sua localização, preços, psicoesfera e funcionalidades que serão incorporadas ao empreendimento. Inclusive, sua localização e infraestrutura tendem a ser extremamente racionalizadas. Contudo, em nada tem a ver com o planejamento governamental, pois se trata de uma preocupação setorial e direcionada.

\section{Loteamento Industrial}

Poucas referências bibliográficas foram encontradas sobre os loteamentos industriais. Trata-se muito mais de uma noção do que um conceito desenvolvido, propriamente. Contudo, é provável que esta seja a forma de aglomeração mais antiga no Brasil. Na literatura consultada, a aglomeração de registro mais antigo é do bairro Jaguaré, no município de São Paulo, que foi justamente resultado de um loteamento originado de um investidor particular.

Em 1935, o arquiteto Henrique Dumont Villares teria projetado este bairro com finalidade residencial, que contava também com um loteamento industrial, o qual ganhou o homônimo de Centro Industrial Jaguaré. Nele, eram oferecidos terrenos para fábricas e depósitos, bem como desvios das Ferrovias Sorocaba, São Paulo Railway e Central do Brasil, como mostra um anúncio da época (Figura 1).

Para o arquiteto B. C. Nogueira (1991) o loteamento industrial é uma área de formação planejada, com objetivo de comercialização de lotes industriais, por parte de um empreendedor privado. Sua organização é feita pelo próprio empreendedor, segundo diretrizes pré-estabelecidas de normas de ocupação fixadas pelo zoneamento urbano. Para este autor, a classificação dos loteamentos industriais é difícil e pode variar de "convencionais" a "de elevado padrão urbanístico". 


\section{FIGURA 1}

Anúncio do Centro Industrial Jaguaré (1939)

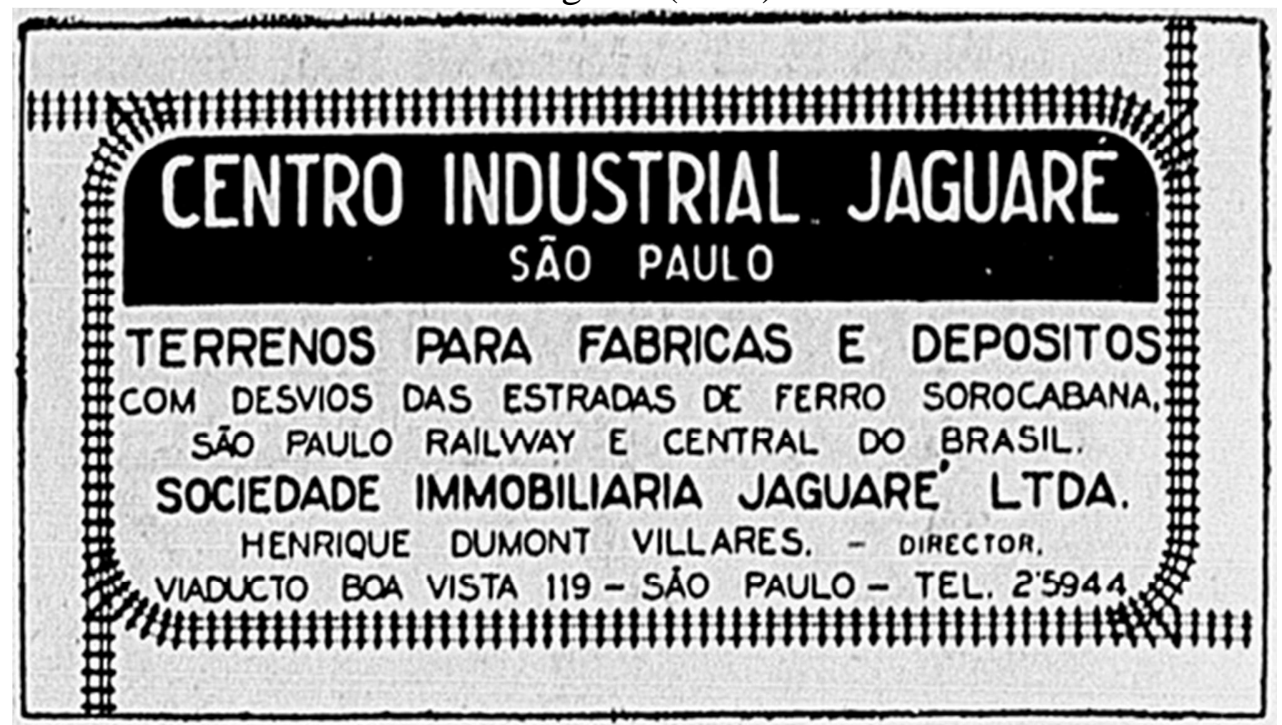

Fonte: 〈http://www.saopauloantiga.com.br>. Acesso: outubro de 2016.

(*) publicado no Jornal Correio Paulistano, em 26/02/1939.

Em sua concepção mais tradicional, o loteamento industrial talvez estivesse mais próximo ao que se entendia por Bairro Industrial. H. D Villares (1946) indica que o bairro industrial seria objeto de planejamento (loteamento e normas), no qual deveria existir preocupação com a fluidez (entroncamentos rodoviários e ferroviários), bem como facilidade de acesso ao centro urbano, já que o bairro industrial deve situar-se fora da cidade, bem como água, esgoto e iluminação adaptados às necessidades das indústrias. Além disso, seria indispensável, ter em anexo um distrito residencial (ou o que passou a se chamar de bairro operário). Na concepção de Villares "[...] é como que uma cidade nova e completa que surge" (1946, p.37).

O. F. Camillo (1974), em seu estudo sobre o distrito industrial do município de Piracicaba (SP), menciona a comercialização de um loteamento no próprio distrito, o Loteamento Industrial Unidade Leste de Piracicaba (UNILESTE), criado para a atração da empresa Caterpillar ${ }^{21}$ para o Brasil, que teria sido ao mesmo tempo uma polarizadora de indústrias complementares no mesmo loteamento. Segundo Takami (2013) em estudo posterior sobre a mesma área, de 240 alqueires reservados para o loteamento, 180 alqueires foram concedidos para a empresa, mostrando que o loteamento não foi fruto de uma política industrial do município, mas foi, sobretudo, um fator atrativo para a empresa.

\footnotetext{
${ }^{21}$ É uma empresa norte-americana fabricante de máquinas, motores e veículos pesados, bem como outros equipamentos de construção civil.
} 
Além disso, Camillo (1974) aponta que o loteamento Unileste tinha previsão para atender as seguintes funções: industriais, de armazenagem, centro comercial e de prestação de serviços, áreas verdes e habitacionais (onde existiriam comércio e equipamentos sociais). Todavia, estas funcionalidades não foram atendidas pela prefeitura, que apenas disponibilizou os terrenos por um preço mais acessível. Em outras palavras, não podemos dizer que chegou a constituir-se como um distrito industrial, muito embora use esta nomenclatura. Para Takami:

Cabe ressaltar que o Distrito Industrial UNILESTE e UNINOROESTE, em Piracicaba, são privados, pois os empresários não receberam nenhum tipo de incentivo fiscal ou infraestrutura pelo Governo, apenas compraram o terreno da Prefeitura por um preço mais acessível (2007, p.55).

Com o aumento da ação dos promotores imobiliários voltada ao nicho industrial, os loteamentos industriais são também objeto de investimento recente, muito embora sejam diferentes dos casos descritos, já que atualmente tendem a ser unicamente industriais (embora próximos às reservas de mão de obra e eixos de circulação, indispensavelmente).

Já detectamos, em trabalhos de campos prévios (FINATTI, 2011) a existência de loteamentos industriais em Indaiatuba (SP) e Jundiaí (SP). O município de Jundiaí, caso expressivo devido à extensão que ocupa (um milhão de $\mathrm{m}^{2}$ ), com empresas de renome do segmento alimentício, evidencia a importância deste tipo de aglomeração.

O loteamento industrial pode se confundir com uma zona industrial ou com um condomínio empresarial. No caso da zona industrial, ela é promovida pelo poder público municipal. Esse fato a diferencia do loteamento industrial, que depende de um incorporador imobiliário, por definição (muito embora este incorporador imobiliário dependa de um zoneamento urbano adequado).

No caso da possível confusão com um condomínio empresarial, que também é objeto do promotor imobiliário, há uma grande diferença devido ao controle de acesso e à copropriedade da área. O loteamento urbano permanece integrado à circulação urbana irrestritamente, e cada empresa responsabiliza-se pela sua segurança. Em outras palavras, não copropriedade ou princípio de divisão de gastos entre as empresas, embora estas possam se organizar para usufruir de funcionalidades comuns, devido à sua proximidade.

Portanto, consideraremos este termo restritivamente a produtos imobiliários, ou seja, promovido por um agente imobiliário. 
1.3. Noções para interpretação das aglomerações industriais (Quadro síntese)

Elaboramos uma proposta de quadro síntese (Quadro 2) com a expectativa de apresentar quais seriam as principais características para interpretar as aglomerações industriais, a partir de uma leitura geográfica. Como mostramos no decorrer deste capítulo, existem onze tipos de aglomerações que predominam no território brasileiro ${ }^{22}$.

A partir do estudo destas onze formas, sintetizamos as características importantes para descrever os principais fatores de análise referentes às aglomerações. Antes de apresentar o quadro, destacaremos as principais ideias necessárias para subsidiar os fatores utilizados no quadro.

A primeira característica a ser considerada diz respeito ao agente formulador da respectiva aglomeração industrial. Tratam-se de agentes econômicos/sociais que investem, fomentam ou diretamente as organizam. Sua importância é tal que, conhecer o agente pode significar o primeiro passo para compreender quais são as intencionalidades que prevalecem em cada tipo de aglomeração. Os agentes envolvidos podem ser:

- Poder público: instituições de natureza político-administrativa nas esferas federal, estadual ou municipal. Historicamente um investidor direto em aglomerações industriais e/ou outros fatores de atração de atração industrial.

- Promotores imobiliários: agentes privados de natureza econômica (em função do mercado imobiliário) principalmente empresas incorporadoras e construtoras que, a partir dos anos 1990 no Brasil, transformam aglomerações industriais em um de seus nichos de negócios.

- Empresas: agentes privados de natureza econômica que podem ser empresas industriais (em sua maioria), prestadoras de serviço (industriais ou não), operadores logísticos ou unidades comerciais cujo conjunto de decisões microeconômicas é capaz de resultar em aglomerações industriais. Exceto promotores imobiliários.

- Instituição de Ensino e Pesquisa: universidades públicas e outros centros de pesquisa (públicos ou privados) que centralizam iniciativas relacionadas às aglomerações industriais visando o fomento à pesquisa e ao desenvolvimento tecnológico.

\footnotetext{
${ }^{22}$ A esse respeito, é importante mencionar que são onze tipos desde que ignoremos as equivalências existentes entre os tipos ou mesmo características peculiares de alguns casos que justificariam uma abordagem diferenciada para os mesmos. Para considerar este número é ainda importante frisar que alguns tipos "híbridos" (que misturam características de um ou outro tipo de aglomeração) também foram descartados.
} 
Em segundo lugar, consideramos que o processo histórico de configuração de uma determinada aglomeração (doravante apenas processo), combinado ao conhecimento dos agentes responsáveis, permite explicar a intencionalidade atrelada aos tipos de aglomeração por meio, justamente, dos agentes envolvidos cada caso (que tipo de ação ele realiza e porque a realiza).

Acreditamos que a intencionalidade seja um aspecto chave para explicação do processo que resulta nas aglomerações industriais ou qualquer outro tipo de concentração de fixos geográficos. De acordo com M. Santos, analisar a intencionalidade nos permite interpretar a "trama das coisas":

[...] o produto já está contido no ato produtivo e, assim, a faculdade da consciência que torna possíveis as suas ações produtivas consiste em estar sempre fora dela mesma. Desse modo e como consequência da intencionalidade, encontramo-nos desde o indício implicados na 'trama das coisas' (2004 [1996], p.91).

Por essa razão tentamos, para cada tipo de aglomeração industrial, compor uma descrição do processo, mesmo que pequena e sintética - sempre atrelada aos agentes envolvidos - que mostre a ação central (econômica ou política) que resulta na respectiva aglomeração.

Para complementar a perspectiva do processo, podemos ainda mencionar certos contextos de surgimento que são reflexo das ações que dão origem às aglomerações industriais. Estes contextos se resumem à capacidade de cada agente e sua posição na implantação de cada aglomeração. Nesse escopo, os contextos podem ser três: espontâneo, induzido ou planejado, cada qual com as seguintes características:

- Espontâneo: a aglomeração resulta da proximidade entre unidades produtivas, motivada por decisões microeconômicas independentes. As decisões estão associadas às condições territoriais ou normativas prévias, porém não estão atreladas à ação de um agente específico com objetivo de induzir ou planejar uma aglomeração industrial.

- Induzido: a aglomeração é induzida por vantagens comparativas regionais ou locais oferecidas pelo poder público. Não há o planejamento governamental específico da aglomeração industrial, apenas diretrizes que devem ser seguidas para obtenção de recursos financeiros. Assim, a aglomeração é fomentada pelas políticas públicas por meio de infraestruturas, incentivos/isenções fiscais e recursos financeiros diretos. $\mathrm{O}$ planejamento territorial e organizacional ficará a cargo de uma associação ou entidade representativa dos empresários, em decisão conjunta dos mesmos. 
- Planejado: a aglomeração resulta da ação direta de um agente planejador, sendo ele do poder público ou privado. Pode articular-se com o contexto histórico de uma formação espontânea ou das linhas de fomento oferecidas pelo poder público. Diferentemente das demais, há uma concepção definida de tipo de aglomeração a ser seguido, que pode ser identificada pelo planejamento de sua localização, zoneamento e infraestruturas implantadas ou diretamente associadas à mesma, bem como aos agentes que dela participam e suas ações.

Para consolidar um primeiro grupo de fatores que visam permitir a explicação histórica dos diferentes tipos de aglomeração, podemos ainda mencionar quais seriam os seus fatores de atração ou as variáveis presentes em cada tipo de aglomeração que respondem pela capacidade de atração das empresas. Evidentemente, isso se refere a um grupo de teorias comumente conhecido como as teorias de localização industrial ${ }^{23}$ que perpassa, mesmo que indiretamente, toda esta tese.

Considerando a ideia básica de que indústria atrai indústria apresenta por $\mathrm{P}$. George (1967 [1958]), procuramos observar cada uma das formas de aglomeração e compreender quais seriam os fatores atrativos que explicariam a lógica de uma decisão microeconômica associada à respectiva aglomeração.

C. Manzagol (1985) mostra perfeitamente como forças de aglomeração podem estar ligadas à proximidade com o mercado e com a concentração de mão de obra qualificada ou ainda, em outras palavras, tende a ser equivalente à concentração populacional e densidade urbana. Há várias tentativas de explicação para as vantagens comparativas da aglomeração, entre elas o papel das economias externas, que podem ser definidas como "[...] benefícios coletivos que as empresas auferem em função de sua localização relativa, independentemente de qualquer operação comercial" (MANZAGOL, 1985, p.81) justamente o ponto ao qual chamamos de importância da proximidade.

Por outro lado, devemos também atentar que podem ocorrer deseconomias externas, ou uma inversão da economia (diminuição de custos) outrora causada pela aglomeração. Entre possíveis fatores: aumento da demanda de espaço e elevação do preço dos terrenos, tempo perdido em congestionamentos ou problemas ambientais como a

\footnotetext{
${ }^{23}$ Para citar aquele que seria o precursor destes estudos, o economista alemão A. Weber definiu, em 1909, os fatores de atração que mais influenciavam as decisões locacionais da indústria: as fontes de matéria prima e os mercados consumidores em primeiro lugar, podendo existir alguma variação em função da presença de uma concentração regional de mão de obra. Com essa base elaborou um "triângulo locacional" que permite definir espacialmente uma área na qual as indústrias se implantariam. A relação das distâncias entre estes pontos (matéria-prima, mercado consumidor e mão de obra) deveria ser considerada de acordo com o tipo de indústria e os deslocamentos predominantes que este tipo requer, contabilizando os custos deste processo em função do peso do material transportado pela distância percorrida.
} 
poluição, constituindo-se como forças de dispersão. Por isso C. Manzagol (1985) alerta que existe um nível ótimo de concentração.

O que tentamos responder com os fatores de atração (Quadro 2) são as condições específicas de cada uma das formas de aglomeração, a partir da literatura especializada sobre cada uma delas, que permita entender porque seria mais vantajoso uma unidade industrial aglomerada em relação à uma unidade industrial dispersa.

Para justificar a análise das aglomerações industriais utilizando estes fatores de atração (inclusive sendo esta uma abordagem que pouco verificamos na literatura especializada), é importante considerar a configuração do território brasileiro: muito extenso e com uma distribuição profundamente desigual dos fatores de produção e de desenvolvimento. Embora a explicação das vantagens locacionais das aglomerações possa ser polêmica, a importância da proximidade é que adquire um significado especial face às características da configuração territorial do Brasil. Dessa forma, elaboramos um agrupamento dos fatores de atração de acordo com as características específicas de cada forma de aglomeração.

Quanto ao uso do território, foi empregado para reforçar a natureza das atividades que efetivamente se instalam nas áreas. Entendemos que todo território tem ações que coexistem juntos aos objetos e, portanto, qualquer território implica em seu uso. Entendemos que as aglomerações industriais tem uso econômico, muito embora outros usos não econômicos possam ocorrer e desenvolver-se nelas.

Na concepção de M. Santos (2012 [1993]): “O território são formas, mas o território usado são objetos e ações, sinônimo de espaço humano, espaço habitado". Para o autor, o conjunto de objetos, considerado apenas em sua materialidade, significa a possibilidade da ação, uma ação virtual que pode se transformar na ação efetivada, tornada real. Nesse sentido sugere que se tome como categoria de análise o território usado. Ou seja, a análise do território em que objetos e ações são entendidos em seu conjunto. Por essa razão, apesar de todas essas formas evidenciarem o uso econômico, tentaremos identificar e detalhar cada um destes usos específicos, os quais podem ser a produção industrial propriamente dita, mas também relativos à pesquisa e desenvolvimento e, por vezes, até mesmo coexistirem a prestação de serviços, operadores logísticos ou unidades comerciais de diferentes portes.

Talvez referir-se ao uso econômico pareça suficiente em um primeiro momento, porém acreditamos que o maior detalhamento do uso do território auxilia a qualificar a aglomeração estudada. 
Em relação ao fator denominado densidade da aglomeração, não há como assumir uma medida (métrica, como a taxa de ocupação) para melhor defini-la, no escopo desta tese. Entretanto, trata-se de um fator importante para melhor descrever as aglomerações industriais, uma vez que há grandes diferenças entre elas, neste quesito. Para definir a densidade da aglomeração foi preciso nos apoiar, sobretudo, na percepção adquirida por meio das atividades de campo, embora correndo o risco de ser uma mera indução. Para minimizar a possibilidade de erros, empregaremos três categorias simples para definir este fator: forte, média ou fraca, as quais também podem aparecer combinadas (densidade fraca à média, por exemplo).

A sinergia é uma noção muito comum empregada pela escola regulacionista ${ }^{24}$ que ganhou bastante destaque, como expressão, na linguagem empresarial. Em linhas gerais, a potencial sinergia entre as empresas pode ser mensurada pelas possibilidades de relacionamento entre elas. Seria o mesmo que o desenvolvimento de interdependência entre as empresas, quer sejam do mesmo segmento ou de segmentos diferentes do circuito produtivo. A sinergia pode resultar em diminuição de gastos ou em sofisticados mecanismos de repartir e fomentar conhecimento, dependendo da natureza e interesses das empresas envolvidas.

Portanto, estamos empregando o termo sinergia tendo em vista a possibilidade de existência de relacionamento e interdependência entre as empresas que participam de uma determinada aglomeração. É evidente que, devido à proximidade, qualquer tipo de relacionamento pode ocorrer entre as empresas da aglomeração. Pela dificuldade de mapear precisamente as relações entre as empresas e qualificar uma possível sinergia existente que seja facilitada pela forma de aglomeração, optaremos por tratar a resposta de maneira binária: sim ou não.

A especialização será analisada como a tendência a que uma aglomeração permita ou mesmo estimule poucos e específicos segmentos industriais, podendo refletir uma decorrência do tipo de aglomeração ou até da orientação que os agentes envolvidos optaram por incentivar. Se não existir nenhuma distinção quanto às possibilidades de instalação de diferentes segmentos industriais na aglomeração, por outro lado, ela não será indicada como especializada. Assim como optamos por conduzir a interpretação da

\footnotetext{
${ }^{24}$ Que interpreta a reestruturação produtiva como uma quebra no pacto de bem estar social fordista implicando uma nova regulação social flexível, tanto na esfera das relações de produção quanto na arena produtiva propriamente dita. Uma explicação sobre isso pode ser encontrada em G. Benko (1996).
} 
sinergia, a tendência à especialização também terá a mesma interpretação binária: sim ou não.

Apresentaremos ainda os principais autores que trabalharam as aglomerações, quando existirem, e tentaremos elencar os principais casos de cada uma das aglomerações, no Brasil. É importante destacar que, por vezes, não é acadêmica a fundamentação de um determinado termo, como já esboçamos neste capítulo (em muitas situações o que acontece é uso instrumental do termo).

Por fim, tentaremos indicar algumas possíveis equivalências entre os termos, ou seja, outros conceitos/nomes que, embora diferentes ou que apresentem apenas alguma diferença empírica (às vezes devido ao enfoque de cada obra) remetam à mesma forma de aglomeração, serão indicados.

Esta proposta (Quadro 2) tem o objetivo de sistematizar nossos avanços conceituais e servir como referencial para o desenvolvimento das análises seguintes. É importante lembrar que as formas elencadas e as características escolhidas para interpretálas consideram os traços da formação espacial brasileira, o que equivale a dizer que o quadro certamente refletiria outras escolhas e outros resultados, caso tivéssemos como base qualquer outro contexto histórico e geográfico. 
QUADRO 2

Características para análise das aglomerações industriais

\begin{tabular}{|c|c|c|c|c|c|c|c|c|c|c|c|c|}
\hline & Tipo & Agentes & Processo & Contexto & $\begin{array}{c}\text { Fatores de } \\
\text { atração* }\end{array}$ & $\begin{array}{c}\text { Uso do } \\
\text { território }\end{array}$ & $\begin{array}{c}\text { Densi- } \\
\text { dade }\end{array}$ & Sinergia & $\begin{array}{l}\text { Especia- } \\
\text { lização }\end{array}$ & $\begin{array}{c}\begin{array}{c}\text { Principais } \\
\text { autores }\end{array} \\
\end{array}$ & Exemplos & $\begin{array}{c}\begin{array}{c}\text { Possíveis } \\
\text { equivalências }\end{array} \\
\end{array}$ \\
\hline 1 & $\begin{array}{l}\text { Parque } \\
\text { Industrial }\end{array}$ & $\begin{array}{l}\text { Poder } \\
\text { público e/ou } \\
\text { empresas }\end{array}$ & $\begin{array}{c}\text { Relativo a decisões microeconômicas ou } \\
\text { fomentado por políticas estaduais / } \\
\text { nacionais }\end{array}$ & $\begin{array}{l}\text { Espontâneo } \\
\text { ou Induzido }\end{array}$ & $\begin{array}{l}\text { Proximidade com } \\
\text { outras indústrias ou } \\
\text { incentivos fiscais }\end{array}$ & Produção industrial & $\begin{array}{l}\text { De fraca } \\
\text { à forte }\end{array}$ & Não & Não & (5) & $\begin{array}{l}\text { "Parque industrial } \\
\text { paulista" }\end{array}$ & Região industrial \\
\hline 2 & $\begin{array}{l}\text { Centro } \\
\text { Industrial }\end{array}$ & Empresas & $\begin{array}{l}\text { Fomentado por uma política econômica } \\
\text { municipal }\end{array}$ & Espontâneo & $\begin{array}{l}\text { Infraestrutura urbana e } \\
\text { incentivos fiscais }\end{array}$ & $\begin{array}{c}\text { Produção } \\
\text { Industrial, serviços, } \\
\text { logística, comercial } \\
\text { e residencial }\end{array}$ & $\begin{array}{l}\text { De fraca } \\
\text { à forte }\end{array}$ & Não & Não & $\begin{array}{l}\text { G.C.Bruna } \\
\text { (1974) }\end{array}$ & $\begin{array}{l}\text { Indústria } \\
\text { automotiva no } A B C\end{array}$ & - \\
\hline 3 & $\begin{array}{l}\text { Zona } \\
\text { Industrial }\end{array}$ & $\begin{array}{l}\text { Poder } \\
\text { público }\end{array}$ & $\begin{array}{l}\text { Definido por Lei de Zoneamento do Solo } \\
\text { Urbano e Plano Diretor municipal }\end{array}$ & Planejado & $\begin{array}{l}\text { Infraestrutura urbana e } \\
\text { incentivos fiscais }\end{array}$ & $\begin{array}{c}\text { Produção } \\
\text { Industrial, serviços, } \\
\text { logística, comercial } \\
\text { e residencial }\end{array}$ & $\begin{array}{l}\text { De fraca } \\
\text { à forte }\end{array}$ & Não & Não & $\begin{array}{l}\text { W. Bredo } \\
\text { (1960) }\end{array}$ & $\begin{array}{l}\text { Zona Franca de } \\
\text { Manaus }\end{array}$ & - \\
\hline 4 & $\begin{array}{l}\text { Distrito } \\
\text { Industrial }\end{array}$ & $\begin{array}{l}\text { Poder } \\
\text { público }\end{array}$ & $\begin{array}{l}\text { Definido por Lei de Zoneamento do Solo } \\
\text { Urbano e investimento em } \\
\text { infraestrutura urbana }\end{array}$ & Planejado & $\begin{array}{l}\text { Infraestrutura urbana e } \\
\text { incentivos fiscais }\end{array}$ & $\begin{array}{c}\text { Produção } \\
\text { Industrial, serviços, } \\
\text { logística, comercial } \\
\text { e residencial }\end{array}$ & $\begin{array}{l}\text { De fraca } \\
\text { à forte }\end{array}$ & Não & Não & - & $\begin{array}{l}\text { Cidade Industrial de } \\
\text { Contagem I } \\
\text { Distrito Industrial } \\
\text { de Fortaleza }\end{array}$ & Cidade Industrial \\
\hline 5 & $\begin{array}{l}\text { Complexo } \\
\text { Industrial }\end{array}$ & Empresas & $\begin{array}{c}\text { Relativo a decisões microeconômicas, } \\
\text { considerando importante proximidade } \\
\text { ao conjunto de fornecedores }\end{array}$ & Espontâneo & $\begin{array}{c}\text { Vantagens } \\
\text { comparativas regionais }\end{array}$ & Produção industrial & $\begin{array}{l}\text { De média } \\
\text { à forte }\end{array}$ & Não & Não & $\begin{array}{l}\text { J. Chardonnet } \\
\text { (1965) }\end{array}$ & 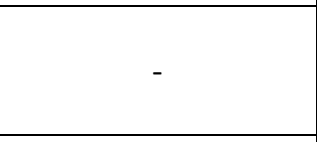 & Combinado Industrial \\
\hline 6 & $\begin{array}{c}\text { Polo } \\
\text { Industrial }\end{array}$ & $\begin{array}{l}\text { Poder } \\
\text { público }\end{array}$ & $\begin{array}{l}\text { Fomentado por políticas de } \\
\text { industrialização estaduais e federais }\end{array}$ & Planejado & $\begin{array}{l}\text { Infraestrutura urbana e } \\
\text { regional, existência de } \\
\text { indústria-motriz }\end{array}$ & $\begin{array}{c}\text { Produção } \\
\text { industrial, serviços } \\
\text { e logística }\end{array}$ & $\begin{array}{l}\text { De média } \\
\text { à forte }\end{array}$ & Sim & Sim & $\begin{array}{l}\text { F. Perroux } \\
\text { (1967) }\end{array}$ & $\begin{array}{l}\text { Polo Petroquímico } \\
\text { de Camaçari }\end{array}$ & $\begin{array}{c}\text { Cidade-fábrica } \\
\text { (Company-town) }\end{array}$ \\
\hline 7 & $\begin{array}{l}\text { Parque } \\
\text { Tecnológico }\end{array}$ & $\begin{array}{l}\text { Poder } \\
\text { público e } \\
\text { Instituição } \\
\text { de Ensino- } \\
\text { Pesquisa }\end{array}$ & $\begin{array}{l}\text { Fomentado por políticas estaduais / } \\
\text { federais (políticas industriais, de } \\
\text { pesquisa e desenvolvimento } \\
\text { tecnológico) em parceria com } \\
\text { universidades e centros de pesquisa, e } \\
\text { iniciativa privada }\end{array}$ & Planejado & $\begin{array}{l}\text { Proximidade com } \\
\text { universidades e } \\
\text { centros de pesquisa, } \\
\text { políticas de incentivo à } \\
\text { incubação de novas } \\
\text { empresas }\end{array}$ & $\begin{array}{l}\text { Pesquisa e } \\
\text { Desenvolvimento, } \\
\text { produção } \\
\text { especializada } \\
\text { (protótipos) }\end{array}$ & $\begin{array}{l}\text { De fraca } \\
\text { à forte }\end{array}$ & Sim & Sim & $\begin{array}{l}\text { ANPROTEC } \\
\text { (2016) }\end{array}$ & $\begin{array}{l}\text { Parque Tecnológico } \\
\text { de São José dos } \\
\text { Campos I Parque } \\
\text { Científico e } \\
\text { Tecnológico da } \\
\text { UNICAMP }\end{array}$ & $\begin{array}{l}\text { Polo Tecnológico, } \\
\text { Science Park, Tecnopólo, } \\
\text { Espaço de Inovação }\end{array}$ \\
\hline 8 & $\begin{array}{l}\text { Arranjo } \\
\text { Produtivo } \\
\text { Local }\end{array}$ & $\begin{array}{l}\text { Poder } \\
\text { público e } \\
\text { empresas }\end{array}$ & $\begin{array}{l}\text { Resulta de especialização produtiva } \\
\text { local, reconhecida pelo poder público } \\
\text { com incentivos às empresas associadas }\end{array}$ & $\begin{array}{l}\text { Espontâneo } \\
\text { e Induzido }\end{array}$ & $\begin{array}{l}\text { Integração produtiva, } \\
\text { existência/manutenção } \\
\text { de cultura } \\
\text { empreendedora local }\end{array}$ & Produção industrial & $\begin{array}{l}\text { De média } \\
\text { à forte }\end{array}$ & Sim & Sim & $\begin{array}{l}\text { Grupo } \\
\text { REDESIST- } \\
\text { UFRJ (Década } \\
\text { de 1990) }\end{array}$ & $\begin{array}{c}\text { APL Têxtil de } \\
\text { Americana I } \\
\text { APL Calçadista de } \\
\text { Franca }\end{array}$ & $\begin{array}{l}\text { Distrito Industrial } \\
\text { (à italiana), Sistema } \\
\text { Produtivo Local }\end{array}$ \\
\hline 9 & $\begin{array}{l}\text { Condomínio } \\
\text { Industrial }\end{array}$ & $\begin{array}{l}\text { Empresas } \\
\text { montadoras } \\
\text { de } \\
\text { automóveis }\end{array}$ & $\begin{array}{l}\text { Iniciativa de uma grande empresa que } \\
\quad \text { demanda proximidade e } \\
\text { integração sistêmica com fornecedores }\end{array}$ & Planejado & $\begin{array}{l}\text { Ligação com grande } \\
\text { empresa, insumos e } \\
\text { serviços à jusante da } \\
\text { montagem industrial }\end{array}$ & $\begin{array}{l}\text { Produção industrial } \\
\text { (montadoras) }\end{array}$ & Forte & Sim & Sim & - & $\begin{array}{l}\text { Condomínio } \\
\text { Industrial de } \\
\text { Araucária }\end{array}$ & $\begin{array}{c}\text { Consórcio Modular, } \\
\text { Novo Distrito Industrial, } \\
\text { Complexo de Produção } \\
\text { Flexível } \\
\end{array}$ \\
\hline 10 & $\begin{array}{l}\text { Condomínio } \\
\text { Empresarial }\end{array}$ & $\begin{array}{l}\text { Promotores } \\
\text { imobiliários }\end{array}$ & $\begin{array}{l}\text { Ação de promotores imobiliários } \\
\text { orientados pela } \\
\text { obtenção da renda do solo urbano }\end{array}$ & Planejado & $\begin{array}{l}\text { Compartilhamento de } \\
\text { gastos, infraestrutura } \\
\text { urbana, segurança }\end{array}$ & $\begin{array}{c}\text { Produção } \\
\text { industrial, serviços, } \\
\text { logística e comércio } \\
\text { atacado }\end{array}$ & Forte & Não & Não & $\begin{array}{l}\text { S. Lencioni } \\
\text { (2011) } \\
\text { R. Finatti } \\
\text { (2011) }\end{array}$ & $\begin{array}{c}\text { Techno Park } \\
\text { Campinas | Parque } \\
\text { Empresarial e } \\
\text { Industrial San José } \\
\end{array}$ & $\begin{array}{c}\text { Condomínio Logístico, } \\
\text { Business Park, } \\
\text { Loteamento Empresarial } \\
\text { Fechado } \\
\end{array}$ \\
\hline 11 & $\begin{array}{l}\text { Loteamento } \\
\text { Industrial }\end{array}$ & $\begin{array}{l}\text { Promotores } \\
\text { imobiliários }\end{array}$ & $\begin{array}{l}\text { Ação de promotores imobiliários } \\
\text { orientados pela } \\
\text { obtenção da renda do solo urbano }\end{array}$ & Planejado & $\begin{array}{l}\text { Infraestrutura urbana e } \\
\text { funcionalidades } \\
\text { produtivas }\end{array}$ & $\begin{array}{c}\text { Produção } \\
\text { industrial, serviços, } \\
\text { logística, comercial } \\
\text { e residencial } \\
\end{array}$ & Forte & Não & Não & $\begin{array}{l}\text { H. D. Villares } \\
\text { (1946) }\end{array}$ & $\begin{array}{l}\text { Centro Industrial } \\
\text { Jaguaré | FazGran }\end{array}$ & Bairro Industrial \\
\hline
\end{tabular}

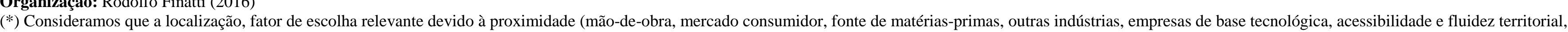
entre tantos outros possíveis) é um fator de atração para qualquer uma das aglomerações industriais apresentadas. 
Portanto, chegamos a um levantamento de onze formas de aglomeração industrial existentes no Brasil. Um dos principais problemas quanto à abordagem das aglomerações industriais é o da equivalência dos nomes; muitas vezes a literatura de um determinado fenômeno pode ter recebido outro nome no Brasil, é o caso dos distritos industriais em sua vertente à italiana: o que mais se aproxima deste conceito são os chamados arranjos produtivos locais, o que imediatamente leva a outra pergunta: o que é, então, o distrito industrial existente no Brasil?

Outro ponto que requer lembrança é que nenhuma aglomeração industrial será exatamente como a sua descrição. Em nosso estudo de campo não encontramos uma forma "pura", mas mesclas de características, bem como características que se encontram em uma área e não em outra. Por isso a dificuldade em delinear os aspectos gerais que possam ter a validade mais ampla possível. 
CAPÍTULO 2

\section{AS AÇÕES DO ESTADO E DO MERCADO NO BRASIL QUE SE INDUSTRIALIZA: AGENTES E PROCESSOS NA CONFIGURAÇÃO DAS AGLOMERAÇÕES INDUSTRIAIS}

Neste capítulo mostraremos como as aglomerações industriais participaram, historicamente, do processo de industrialização do território nacional. O enfoque maior, como declarado no próprio título, diz respeito aos agentes responsáveis e ao processo de produção do território.

Tentaremos, sobretudo, caracterizar a conjuntura histórica na qual foram implantadas as formas de aglomeração do território nacional. Apesar de seus onze tipos e, para alguns destes tipos, um grande número e dispersão por todo o território, escolheremos aqueles que, de alguma maneira, foram marcos deste processo.

Em cada momento histórico, participando de sua determinada conjuntura e a partir de uma determinada topologia a ser seguida, uma forma de aglomeração foi utilizada como ferramenta considerada mais adequada para equipar o território em função do processo produtivo. Lembramos que foram escolhidas, para estudo mais detalhado (mesmo que em diferentes níveis de detalhamento) as seguintes aglomerações: (1) distrito industrial, (2) polo industrial, (3) arranjo produtivo local e (4) condomínio empresarial.

Além disso, as aglomerações industriais também acompanharam e expressaram (expressam) as diferenças regionais características do território brasileiro, economicamente. Por isso, acreditamos que o seu estudo também fornece um olhar sobre essa importante questão.

Diante deste enredo, o principal conceito a ser destacado é o do uso do território. M. Santos e M. L. Silveira (2001), que se debruçaram sobre o estudo do território de um país, em toda sua abrangência e complexidade, assinalam que "[...] o território, visto como unidade e diversidade, é uma questão central da história humana e de cada país e constitui o pano de fundo do estudo das suas diversas etapas e do momento atual" (p.20). 
O território poderia ser analisado, classicamente, na condição de "nome político" para o espaço de um país, analisado em sua totalidade. Pode também ser analisado a partir dos diferentes usos cujo mosaico compõe esse mesmo espaço e totalidade do espaço de um país. Essa segunda possibilidade requer a compreensão dos diferentes usos do território, recompondo este mosaico em diferentes períodos, já que os usos podem ser diferentes nos diversos momentos históricos. Trata-se de pensar diversas manifestações particulares que evoluem juntas, pois estão interligadas em princípios gerais que podem ser encontrados em uma totalidade (SANTOS e SILVEIRA, 2001):

O uso do território pode ser definido pela implantação de infra-estruturas mas também pelo dinamismo da economia e da sociedade. São os movimentos da população, a distribuição da agricultura, da indústria e dos serviços, o arcabouço normativo, incluídas a legislação civil, fiscal e financeira (SANTOS e SILVEIRA, 2001, p.21).

Ainda para Santos e Silveira (2001), política e mercado estão lado a lado como as forças de decisão mais importantes que regulam a evolução dos contextos territoriais em cada período. Em suas palavras, a evolução das bases materiais geográficas e também a evolução da própria regulação "[...] não se faz sem uma regulação política do território e sem uma regulação do território pelo mercado" (SANTOS e SILVEIRA, 2001, p.22).

Por isso pontuamos como objetivos a serem alcançados neste capítulo: em primeiro lugar, analisar como o Estado e o mercado, a cada momento histórico relacionado ao processo de industrialização, participaram da promoção das aglomerações industriais. Em segundo lugar, posicionar as aglomerações industriais, na condição de fixos geográficos que expressam um determinado uso do território, no contexto da industrialização do território nacional.

É importante lembrar que consideramos as aglomerações industriais não apenas como um resultado. Assim como quaisquer outras formas geográficas, são expressão de uma intencionalidade (preparar o território para o produtivo), cuja localização resulta de critérios (os quais devem considerar uma configuração territorial prévia ou configuração territorial de base) e que, por sua vez, cumprindo seu papel, são capazes de definir e redefinir localizações de outros fixos e estimulam fluxos de pessoas, produtos e informações. Ou seja, passam a integrar e potencialmente ser pontos ativos de circuitos produtivos em diversas escalas.

Consideramos ainda que a aglomeração industrial é a principal expressão geográfica da industrialização, devido à concentração (no sentido expressivamente 
geográfico) e à capacidade desta concentração em orientar processos econômicos e sociais, tanto na direção de um possível crescimento econômico, quanto na direção de ampliar desigualdades ou outros déficits sociais e ambientais.

Ao menos em relação à história da industrialização no Brasil, como tentaremos mostrar, as aglomerações industriais tiveram participação relevante; tanto as formas planejadas (principais casos de tentativa de alavancar desenvolvimento econômico regional), quanto as formas de aglomeração induzidas ou espontâneas. Outro aspecto importante, complementar, é a densidade de algumas destas aglomerações; o princípio da "cidade industrial" (company-town), os grandes polos petroquímicos e sua influência regional ou a conjuntura associada aos grandes parques industriais constituem casos que serão lembrados no decorrer deste capítulo.

Podemos pensar, a partir de um processo histórico, respeitando a estruturação do território brasileiro a cada momento, quais foram e podem ser as funções desempenhadas por cada uma das formas de aglomeração analisadas. Tentaremos encontrar formas e funções em seu processo histórico de acordo com a estruturação do território brasileiro $^{25}$.

Ao remontar às origens da história da industrialização no país, usaremos como ponto de partida a acumulação de capital resultante do ciclo econômico do café no Estado de São Paulo ${ }^{26}$. As condições deste momento histórico explicariam a passagem de uma economia agrário-exportadora para uma industrialização incipiente no território paulista, motivada principalmente pelas taxas de lucro decrescentes a partir da crise de 1929 e a política de substituição de produtos importados. A década de 1930, seguindo a periodização proposta por W. Cano (1998 [1985]) seria o segundo ponto de inflexão importante, pois nela começaria um processo de concentração regional da indústria. Segundo Cano, até 1933 o motor da economia nacional era o capital mercantil, então só se poderia falar efetivamente de processo de industrialização a partir desta data.

Uma análise dos planos de desenvolvimento nacionais começará, a partir de 1955, com o Programa de Metas do Presidente Juscelino Kubitscheck e se estenderá até o

\footnotetext{
${ }^{25}$ Forma, função, estrutura e processo são os pilares para cumprir o método de análise geográfico, conforme proposto por M. Santos (1985).

${ }^{26}$ Esta tese pode ser contestada. A. Mamigoniam (1969) assinala que existiram outras iniciativas paralelas de industrialização, tais como pequenos capitalistas europeus imigrados para o Brasil (com ou sem experiência industrial prévia) e iniciativas estatais. Muitos comerciantes e fazendeiros teriam se interessado pela atividade industrial apenas quando esta se tornou um investimento seguro. Além disso, R. Moreira (2012) defende que existia uma economia industrial "colada" nas diferentes regiões agrícolas do país, atendendo aos seus mercado locais, antes da centralização do capital industrial no Estado de São Paulo.
} 
final do II Plano Nacional de Desenvolvimento. É importante destacar que os planos de desenvolvimento começaram a ser editados durante o Estado Novo, na década de 1930, marcando a posição objetivamente intervencionista do Estado que se prolonga até a crise fiscal na década de 1980. Segundo W. M. da Costa, "Com eles, a era do planejamento econômico é inaugurada no país" (2011 [1988], p.47), e destes projetos surgem as aglomerações industriais, efetivamente, como aplicação para tentar alavancar o desenvolvimento econômico e social nas regiões.

Para A. Kon (1999), inclusive, é apenas na década de 1960 que se verifica a difusão e cristalização do desenvolvimento industrial, na condição de resultado do planejamento governamental, cujos resultados mais expressivos ocorrerão, finalmente, na década de 1970. O período entre 1950 e 1970, para R. Moreira (2012), é marcado pela maturação do arranjo capitalista no Brasil, na condição de efetivamente uma fase da formação espacial brasileira com a centralidade econômica na atividade industrial e o Estado cumprindo ativamente o papel de regulador do desenvolvimento.

Neste momento histórico, a despeito de mecanismos de mercado, os quais de fato impulsionaram as primeiras iniciativas de produção industrial no país, tentaremos privilegiar a análise do papel do Estado na definição das aglomerações. Isso se expressa nos planos econômicos que escolhemos para pontuar as ações do Estado. Neles, identificase um Estado diretamente interventor, capaz de atuar como o próprio empresário em muitas das vezes (e não apenas como apoiador ou investidor em grandes projetos industriais, como se verifica posteriormente ${ }^{27}$ ).

Intervenções tais como a construção da Companhia Siderúrgica Nacional em Volta Redonda (RJ), o Polo Petroquímico de Camaçari (BA) ou a implantação da Zona Franca de Manaus (AM) dão o tom de iniciativas que, embora pontuais, foram capazes de influenciar alterações nas dinâmicas regionais.

Em linhas mais gerais, o processo de industrialização brasileiro teve momentos sucessivos de concentração e desconcentração geográfica, ora intensificando a principal "mancha" industrial do país existente no Estado de São Paulo, ora desconcentrando-se. Todavia, uma desconcentração-concentrada, como revela o estudo de S. Lencioni (1994), na medida em que se reforça a centralização do comando do capital na metrópole paulista. Algumas empresas outrora localizadas nesta mancha também se transferiram a partir de

\footnotetext{
${ }^{27}$ Políticas de incentivo ao desenvolvimento local e coordenado pelos agentes localmente estabelecidos, com grande vigor na década de 1990, no qual o Estado cumpre papel de financiador, mostram isso muito bem.
} 
conjuntos de ações regionalizadas capitaneadas pelo Estado nacional ou pelos governos estaduais, sem alterar, todavia, a estruturação do território brasileiro.

A mais contínua "mancha" industrial brasileira, que poderíamos chamar de parque industrial paulista, também teve uma importante dinâmica de centralização do capital, o que diz respeito à definição da localização das gerências de grandes grupos industriais no centro econômico da mancha e do país, a metrópole São Paulo. A importância desta porção do território - tanto um espaço da produção quanto do comando industrial - é evidente. S. Selingardi-Sampaio (2009) o define como Multicomplexo Territorial Industrial Paulista: “[...] o território primaz da organização socioespacial paulista e nacional" (p.399).

É justamente essa densidade (populacional, econômica, de redes de infraestruturas e também de mercado) existente no Estado de São Paulo e demais unidades estaduais do Sudeste brasileiro que incentivou, em um primeiro momento, os primeiros investimentos da iniciativa privada em formas aglomerativas empresariais, por meio de loteamentos industriais e condomínios empresariais, já na metade da década de 1990, o que tende a reforçar o uso corporativo do território.

Como pudemos destacar, mesmo que brevemente, cada momento histórico teve no processo de industrialização, certa forma de aglomeração que foi considerada como utilitária para a tentativa de atrair empresas e promover a industrialização e, em tese, também o desenvolvimento econômico por meio da produção do território.

2.1. Formação espacial, Estado desenvolvimentista e ideologia da industrialização no Brasil

Derivada diretamente do conceito de formação econômica e social, a formação espacial tem como princípio que “[...] a base da explicação é a produção, isto é, o trabalho do homem para transformar, segundo leis historicamente determinadas, o espaço com o qual o grupo se confronta" (SANTOS, 2012 [1979], p.22). Exatamente por isso, os modos de produção se definem sobre uma base territorial historicamente determinada, representados em cada um de seus momentos, pelos objetos técnicos em sua perenidade e cujo desenvolvimento é contínuo:

O espaço reproduz a totalidade social na medida em que essas transformações são determinadas por necessidades sociais [...] Mas o 
espaço influencia também a evolução de outras estruturas e, por isso, torna-se um componente fundamental da totalidade social e de seus movimentos. Os objetos geográficos aparecem nas localizações correspondentes aos objetivos da produção num dado momento e, em seguida, pelo fato de sua própria presença, influenciam-lhes os momentos subsequentes da produção (SANTOS, 2012 [1979], p.33).

A própria concentração industrial hoje predominante no Estado de São Paulo, onde inclusive coabita o seu centro de comando, é resultado das desigualdades existentes no conjunto do território nacional, cujas diferenças populacionais, econômicas e técnicas são responsáveis pela orientação de grande parte dos investimentos. Essa é uma característica fundamental da atual estrutura espacial brasileira, como um traço permanente de sua formação espacial, atuante e que tende a reforçar as mesmas diferenças regionais históricas.

Para R. Moreira (2012), a formação espacial é também o balizamento das formas de relação sociedade-espaço no Brasil, no tempo. Seriam seis fases $^{28}$ da formação espacial brasileira até o momento atual. $\mathrm{Na}$ visão do autor, é a partir justamente da implantação (ou maturação) do arranjo capitalista, no início do Século XX, que a formação espacial brasileira está consolidada, territorialmente e cartograficamente (MOREIRA, 2012). Neste momento específico, o Estado nacional esgota e ultrapassa a fase dos ciclos rumo à industrialização,

[...] cujo começo de reestruturação numa formatação regional sistemática terá fundamental importância para o desenvolvimento da indústria, dado o caráter de uma divisão territorial de trabalho que já está implícita nessa divisão regional, que o Estado vai intensamente utilizar com o fim de daí extrair as divisas de exportação necessária ao desenvolvimento industrial (MOREIRA, 2012, p. 9).

O marco da maturação do arranjo capitalista seria a década de 1950, na qual inclusive se iniciaram os planos de desenvolvimento mais abrangentes cobrindo o nível federal. O regime de acumulação industrial "rege o modelo histórico brasileiro" de acordo com Moreira (2012), que acrescenta: “[...] peça importante desse modelo é a intervenção do Estado, instalando infraestrutura, regulando os preços de mercado, implementando os setores da indústria de sentido estratégico" (MOREIRA, 2012, p.297). Sobretudo entre as

\footnotetext{
${ }^{28}$ De acordo com o autor, seis fases podem ser historicamente apontadas para mostrar as transições da formação espacial brasileira: vetores fundacionais, ciclos de assentamento, maturação do arranjo capitalista, redesconcentração e privatização da gestão do espaço, articulação das sociabilidades e tendências de uma formação espacial complexa.
} 
décadas de 1950 e 1970, quando se iniciaria a fase de privatização da gestão do espaço, as políticas públicas são a espinha dorsal do modelo de industrialização (MOREIRA, 2012).

Para tentar captar o teor destas políticas públicas, o papel do Estado interventor (ao menos no seu discurso, pois nem todas as propostas foram efetivamente implantadas) analisamos os mais importantes planos de desenvolvimento desde a década de 1950 .

Traçaremos um panorama (Quadro 3) que mostra os principais planos governamentais de desenvolvimento e suas características centrais. Ao total foram consultados dezoito (de 1939 a 2008); entre eles os mais importantes para nossa pesquisa são aqueles em que a indústria é inserida como a engrenagem principal no motor do desenvolvimento. Por isso, buscamos elencar a posição da indústria em relação ao que é planejado (a indústria pode ter uma posição de protagonista, coadjuvante ou então seu papel é inexpressivo) e a "visão geográfica" do plano, em relação ao modo de implantação da proposta. 
QUADRO 3

Principais planos de desenvolvimento nacionais e posição da indústria

\begin{tabular}{c|c|c|c|c|c|c}
\hline Plano & Ano & $\begin{array}{c}\text { Presi- } \\
\text { dente }\end{array}$ & $\begin{array}{c}\text { Preocupações } \\
\text { centrais }\end{array}$ & $\begin{array}{c}\text { Posição } \\
\text { da indústria }\end{array}$ & $\begin{array}{c}\text { Abordagem } \\
\text { geográfica }\end{array}$ & Marcos \\
\hline $\begin{array}{c}\text { Plano Especial } \\
\text { de Obras } \\
\begin{array}{c}\text { Públicas e } \\
\text { Aparelhamento } \\
\text { da Defesa } \\
\text { Nacional }\end{array}\end{array}$ & 1939 & $\begin{array}{c}\text { Getúlio } \\
\text { Vargas }\end{array}$ & $\begin{array}{c}\text { Industrialização } \\
\text { de base, obras } \\
\text { públicas } \\
\text { principalmente } \\
\text { ferrovias) e } \\
\text { defesa nacional. }\end{array}$ & Protagonista & - & $\begin{array}{c}\text { Primeiro } \\
\text { planejamento } \\
\text { quinquenal } \\
\text { brasileiro. }\end{array}$ \\
\hline $\begin{array}{c}\text { Plano de Obras } \\
\text { e }\end{array}$ & 1943 & $\begin{array}{c}\text { Getúlio } \\
\text { Equipamentos }\end{array}$ & $\begin{array}{c}\text { Investimentos } \\
\text { concentrados no } \\
\text { setor de } \\
\text { transportes. }\end{array}$ & Coadjuvante & $\begin{array}{c}\text { Integração } \\
\text { nacional }\end{array}$ & - \\
\hline
\end{tabular}

Conjuntura: Os planos de Getúlio Vargas podem representar a ruptura com o antigo Estado oligárquico rural. A burguesia industrial adquire hegemonia. Assume-se a fragilidade da economia nacional, estímulo a infraestruturas visando a integração do mercado interno (1943). Buscava-se superar a dependência importações para a operação indústria básica.

\begin{tabular}{|c|c|c|c|c|c|c|}
\hline $\begin{array}{l}\text { Plano } \\
\text { SALTE }\end{array}$ & 1950 & $\begin{array}{c}\text { Eurico } \\
\text { Gaspar } \\
\text { Dutra }\end{array}$ & $\begin{array}{l}\text { Controle da } \\
\text { inflação e } \\
\text { Investimento } \\
\text { em setores } \\
\text { declinantes } \\
\text { (Saúde, } \\
\text { Alimentação, } \\
\text { Transporte e } \\
\text { Energia). }\end{array}$ & $\begin{array}{c}\text { Inexpressiva } \\
\text { (exceto pelo } \\
\text { grande } \\
\text { investimento } \\
\text { na atividade } \\
\text { de extração de } \\
\text { petróleo) }\end{array}$ & - & $\begin{array}{l}\text { O Plano SALTE } \\
\text { foi criado para } \\
\text { direcionar } \\
\text { dinheiro para } \\
\text { segmentos } \\
\text { emergenciais } \\
\text { que } \\
\text { apresentaram } \\
\text { crescimento } \\
\text { desordenado. }\end{array}$ \\
\hline
\end{tabular}

Conjuntura: O Brasil passava por um crescimento urbano desordenado, decorrente do anterior investimento maciço na indústria, o que também acarretou um período inflacionário. Aumento expressivo do custo de vida da população. O plano não conseguiu controlar a inflação e foi abandonado após o seu primeiro ano.

\begin{tabular}{|c|c|c|c|c|c|c|}
\hline $\begin{array}{c}\text { Plano Nacional } \\
\text { de } \\
\text { Reaparelhame } \\
\text { nto Econômico } \\
\text { (Plano Lafer) }\end{array}$ & 1951 & $\begin{array}{l}\text { Getúlio } \\
\text { Vargas }\end{array}$ & $\begin{array}{c}\text { Fortalecimento } \\
\text { da indústria de } \\
\text { base, exploração } \\
\text { de novas fontes } \\
\text { energéticas e da } \\
\text { agricultura } \\
\text { voltada à } \\
\text { exportação. }\end{array}$ & Protagonista & - & - \\
\hline \multicolumn{7}{|c|}{$\begin{array}{l}\text { Conjuntura: Inaugurada a administração política dos problemas cambiais, priorização de importações "essenciais", } \\
\text { continuidade da substituição de importações. O investimento na indústria segue: na visão de Vargas a industrialização } \\
\text { estava pronta para avançar para a fase de produção de bens de capital. }\end{array}$} \\
\hline $\begin{array}{c}\text { Diretrizes } \\
\text { Gerais do Plano } \\
\text { Nacional de } \\
\text { Desenvolvi- } \\
\text { mento / } \\
\text { Programa de } \\
\text { Metas }\end{array}$ & 1956 & $\begin{array}{l}\text { Juscelino } \\
\text { Kubtschek }\end{array}$ & $\begin{array}{c}\text { Expandir a } \\
\text { indústria de } \\
\text { base (todos os } \\
\text { ramos), } \\
\text { investimento em } \\
\text { infraestrutura e } \\
\text { modernização } \\
\text { geral do setor } \\
\text { produtivo. }\end{array}$ & $\begin{array}{l}\text { Protagonista } \\
\text { (12 segmentos } \\
\text { prioritários) }\end{array}$ & $\begin{array}{l}\text { Combinados } \\
\text { Industriais } \\
\text { Integração } \\
\text { nacional }\end{array}$ & $\begin{array}{c}\text { É considerada a } \\
\text { mais ampla ação } \\
\text { orientada pelo } \\
\text { Estado para a } \\
\text { implantação de } \\
\text { uma estrutura } \\
\text { industrial, de } \\
\text { maneira } \\
\text { integrada. }\end{array}$ \\
\hline \multicolumn{7}{|c|}{$\begin{array}{l}\text { Conjuntura: Aderência às tendências preconizadas pelos EUA (Doutrina Truman), reformulando as condições de } \\
\text { interdependência com o capitalismo mundial (estímulo à livre iniciativa, criando um clima de estabilidade e } \\
\text { otimismo). }\end{array}$} \\
\hline
\end{tabular}




\begin{tabular}{|c|c|c|c|c|c|c|}
\hline Plano & Ano & $\begin{array}{l}\text { Presi- } \\
\text { dente }\end{array}$ & $\begin{array}{c}\text { Preocupações } \\
\text { centrais }\end{array}$ & $\begin{array}{c}\text { Posição } \\
\text { da indústria }\end{array}$ & $\begin{array}{c}\text { Abordagem } \\
\text { geográfica }\end{array}$ & Marcos \\
\hline $\begin{array}{c}\text { Plano Trienal } \\
\text { de Desenvolvi- } \\
\text { mento } \\
\text { Econômico e } \\
\text { Social }\end{array}$ & 1963 & $\begin{array}{c}\text { João } \\
\text { Goulart }\end{array}$ & $\begin{array}{l}\text { Controle do } \\
\text { déficit público e } \\
\text { do crescimento } \\
\text { da inflação, } \\
\text { redistribuição } \\
\text { de renda e } \\
\text { combate à } \\
\text { dívida externa. }\end{array}$ & Inexpressiva & - & - \\
\hline $\begin{array}{l}\text { Programa de } \\
\text { Ação } \\
\text { Econômica do } \\
\text { Governo }\end{array}$ & 1964 & $\begin{array}{l}\text { Castelo } \\
\text { Branco }\end{array}$ & $\begin{array}{c}\text { Estabilidade dos } \\
\text { preços, } \\
\text { aumentar os } \\
\text { investimentos } \\
\text { diretos, } \\
\text { equilibrar o } \\
\text { déficit público. }\end{array}$ & Inexpressiva & - & $\begin{array}{l}\text { O PAEG teve } \\
\text { sucesso na } \\
\text { redução da } \\
\text { inflação, } \\
\text { preparando o } \\
\text { campo para os } \\
\text { investimentos } \\
\text { expressivos dos } \\
\text { PND. }\end{array}$ \\
\hline \multicolumn{7}{|c|}{$\begin{array}{l}\text { Conjuntura: Dívida externa contraída por JK, rápida desaceleração do PIB e recessão econômica (inflação mostrando } \\
\text { tendência ao aumento). }\end{array}$} \\
\hline $\begin{array}{l}\text { Programa } \\
\text { Estratégico de } \\
\text { Desenvolvi- } \\
\text { mento }\end{array}$ & 1968 & $\begin{array}{l}\text { Costa e } \\
\text { Silva }\end{array}$ & $\begin{array}{l}\text { Estabilização } \\
\text { dos preços, } \\
\text { consolidação da } \\
\text { infraestrutura, } \\
\text { expandir o } \\
\text { emprego, } \\
\text { ampliar o } \\
\text { mercado interno } \\
\text { e dar impulso à } \\
\text { iniciativa } \\
\text { privada. }\end{array}$ & Coadjuvante & - & $\begin{array}{l}\text { Os principais } \\
\text { instrumentos do } \\
\text { PED dizem } \\
\text { respeito ao } \\
\text { controle } \\
\text { inflacionário e } \\
\text { política fiscal } \\
\text { atrativa } \\
80 \% \text { dos } \\
\text { investimentos } \\
\text { foram para } \\
\text { infraestrutura }\end{array}$ \\
\hline \multicolumn{7}{|c|}{$\begin{array}{l}\text { Conjuntura: Segundo o diagnóstico do programa, o país estava perdendo a capacidade de substituição de importações. } \\
\text { Dado o esgotamento do modelo de substituição de importaçôes, o programa optou por "diversificar as fontes de } \\
\text { dinamismo". }\end{array}$} \\
\hline $\begin{array}{c}\text { Metas e Bases } \\
\text { para a Ação do } \\
\text { Governo / } \\
\text { I Plano } \\
\text { Nacional de } \\
\text { Desenvolvi- } \\
\text { mento }\end{array}$ & $\begin{array}{l}1970 \\
1972\end{array}$ & $\begin{array}{l}\text { Emílio G. } \\
\text { Médici }\end{array}$ & $\begin{array}{c}\text { Ampliar o PIB, } \\
\text { criar a "grande } \\
\text { empresa } \\
\text { nacional", } \\
\text { integração } \\
\text { nacional (criar } \\
\text { mercado } \\
\text { interno), sistema } \\
\text { financeiro } \\
\text { nacional, } \\
\text { política } \\
\text { tecnológica. }\end{array}$ & Protagonista & $\begin{array}{c}\text { Polo de } \\
\text { desenvolvimento } \\
\text { Desenvolvimento } \\
\text { regional }\end{array}$ & $\begin{array}{l}\text { Elaborada uma } \\
\text { estratégia } \\
\text { industrial } \\
\text { própria, com } \\
\text { importância } \\
\text { atribuída ao } \\
\text { setor de bens de } \\
\text { capital. } \\
\text { Embora a visão } \\
\text { geográfica seja } \\
\text { expressiva, não } \\
\text { são } \\
\text { mencionados } \\
\text { critérios de } \\
\text { escolha da } \\
\text { localização. }\end{array}$ \\
\hline
\end{tabular}

Conjuntura: Influência crescente do governo no sistema econômico, ampliando seus investimentos e sua capacidade de regulamentar. 


\begin{tabular}{|c|c|c|c|c|c|c|}
\hline Plano & Ano & $\begin{array}{l}\text { Presi- } \\
\text { dente }\end{array}$ & $\begin{array}{l}\text { Preocupações } \\
\text { centrais }\end{array}$ & $\begin{array}{c}\text { Posição } \\
\text { da indústria }\end{array}$ & $\begin{array}{l}\text { Abordagem } \\
\text { geográfica }\end{array}$ & Marcos \\
\hline $\begin{array}{c}\text { II Plano } \\
\text { Nacional de } \\
\text { Desenvolvi- } \\
\text { mento }\end{array}$ & 1975 & $\begin{array}{c}\text { Ernesto } \\
\text { Geisel }\end{array}$ & $\begin{array}{l}\text { Ênfase nas } \\
\text { indústrias } \\
\text { básicas } \\
\text { (sobretudo bens } \\
\text { de capital e } \\
\text { eletrônica } \\
\text { pesada), } \\
\text { consolidação da } \\
\text { sociedade } \\
\text { industrial, } \\
\text { energia, } \\
\text { integração } \\
\text { nacional (com } \\
\text { ocupação } \\
\text { produtiva da } \\
\text { Amazônia e } \\
\text { Centro Oeste). }\end{array}$ & Protagonista & $\begin{array}{c}\text { Polos de } \\
\text { desenvolvimento } \\
\text { Corredores de } \\
\text { exportação } \\
\text { Desconcentração } \\
\text { industrial }\end{array}$ & $\begin{array}{l}\text { Como sentido } \\
\text { da tarefa } \\
\text { nacional, } \\
\text { menciona-se } \\
\text { "integração com } \\
\text { o mundo } \\
\text { industrializado". } \\
\text { Pela primeira } \\
\text { vez está } \\
\text { expressa a } \\
\text { postura de um } \\
\text { planejamento } \\
\text { cumulativo } \\
\text { (atitude flexível } \\
\text { e de } \\
\text { ajustamentos). } \\
\text { O polo é a } \\
\text { forma } \\
\text { geográfica } \\
\text { correlata aos } \\
\text { investimentos e } \\
\text { também redução } \\
\text { das disparidades } \\
\text { regionais no } \\
\text { Brasil. }\end{array}$ \\
\hline \multicolumn{7}{|c|}{$\begin{array}{l}\text { Conjuntura: Período de maior crescimento e diversificação da indústria, à custa de um endividamento também } \\
\text { expressivo. O Brasil teve o maior PIB de sua história, que chegou a } 12 \% \text { de crescimento. }\end{array}$} \\
\hline $\begin{array}{l}\text { III Plano } \\
\text { Nacional de } \\
\text { Desenvolvi- } \\
\text { mento }\end{array}$ & 1980 & $\begin{array}{c}\text { João } \\
\text { Baptista de } \\
\text { Oliveira } \\
\text { Figueiredo }\end{array}$ & $\begin{array}{l}\text { Crescimento } \\
\text { do emprego e } \\
\text { renda, melhor } \\
\text { distribuição, } \\
\text { redução das } \\
\text { disparidades } \\
\text { regionais, } \\
\text { contenção da } \\
\text { inflação, } \\
\text { energia. }\end{array}$ & $\begin{array}{l}\text { Coadjuvante } \\
\text { (os setores } \\
\text { prioritários } \\
\text { são: } \\
\text { agricultura, } \\
\text { abastecimento } \\
\text { energético e } \\
\text { social). }\end{array}$ & & $\begin{array}{l}\text { Maior atenção } \\
\text { para a política } \\
\text { anti- } \\
\text { inflacionária, } \\
\text { financeira, de } \\
\text { comércio } \\
\text { exterior. } \\
\text { O planejamento, } \\
\text { como técnica, } \\
\text { ganha contornos } \\
\text { mais } \\
\text { científicos/admi } \\
\text { nistrativos. }\end{array}$ \\
\hline
\end{tabular}

\section{0-1995}

Ocorre um período de relativa "omissão" do Estado com o planejamento nos moldes até então realizados. As preocupações voltaram-se totalmente ao controle inflacionário e os planos refletem essa conjuntura. 


\begin{tabular}{|c|c|c|c|c|c|c|}
\hline Plano & Ano & $\begin{array}{l}\text { Presi- } \\
\text { dente }\end{array}$ & $\begin{array}{c}\text { Preocupações } \\
\text { centrais }\end{array}$ & $\begin{array}{c}\text { Posição } \\
\text { da indústria }\end{array}$ & $\begin{array}{l}\text { Abordagem } \\
\text { geográfica }\end{array}$ & Marcos \\
\hline $\begin{array}{l}\text { PPA Brasil } \\
\text { em Ação }\end{array}$ & 1996 & $\begin{array}{c}\text { Fernando } \\
\text { Henrique } \\
\text { Cardoso }\end{array}$ & $\begin{array}{l}\text { Coadjuvante } \\
\text { (Estado instala } \\
\text { fixos para atrair } \\
\text { investimentos }\end{array}$ & $\begin{array}{c}\text { Eixos } \\
\text { Nacionais de } \\
\text { Integração e } \\
\text { Desenvolvime } \\
\text { nto } \\
\text { Políticas } \\
\text { regionais de } \\
\text { redução de }\end{array}$ & $\begin{array}{l}\text { O Estado deixa } \\
\text { totalmente a } \\
\text { função de } \\
\text { empresário, para } \\
\text { concentrar-se } \\
\text { como árbitro do } \\
\text { processo de } \\
\text { desenvolvi-mento. } \\
\text { A questão } \\
\text { regional é } \\
\text { retomada (porém, }\end{array}$ & $\begin{array}{c}\text { Eixos Nacionais } \\
\text { de Integração e } \\
\text { Desenvolvi- } \\
\text { mento } \\
\text { Políticas } \\
\text { regionais de } \\
\text { redução de }\end{array}$ \\
\hline $\begin{array}{c}\text { PPA Avança } \\
\text { Brasil }\end{array}$ & 2000 & & produtivos) & $\begin{array}{l}\text { desigualdades } \\
\text { Complementa } \\
\text { ridade } \\
\text { regional }\end{array}$ & $\begin{array}{l}\text { o instrumento é a } \\
\text { implantação de } \\
\text { infraestrutura para } \\
\text { atrair os } \\
\text { investimentos, } \\
\text { não } \\
\text { necessariamente } \\
\text { industriais). }\end{array}$ & $\begin{array}{l}\text { Complemen- } \\
\text { taridade } \\
\text { regional }\end{array}$ \\
\hline
\end{tabular}

Conjuntura: Em um ambiente de inflação controlada, espera-se retomar investimentos (esperado o maior dos últimos 11 anos), em que há uma "Nova Política Industrial” diferente daquela de substituição de importações (exauriu/caráter protecionista que inibiu o desenvolvimento). O contexto é de estabilidade econômica e de abertura comercial.

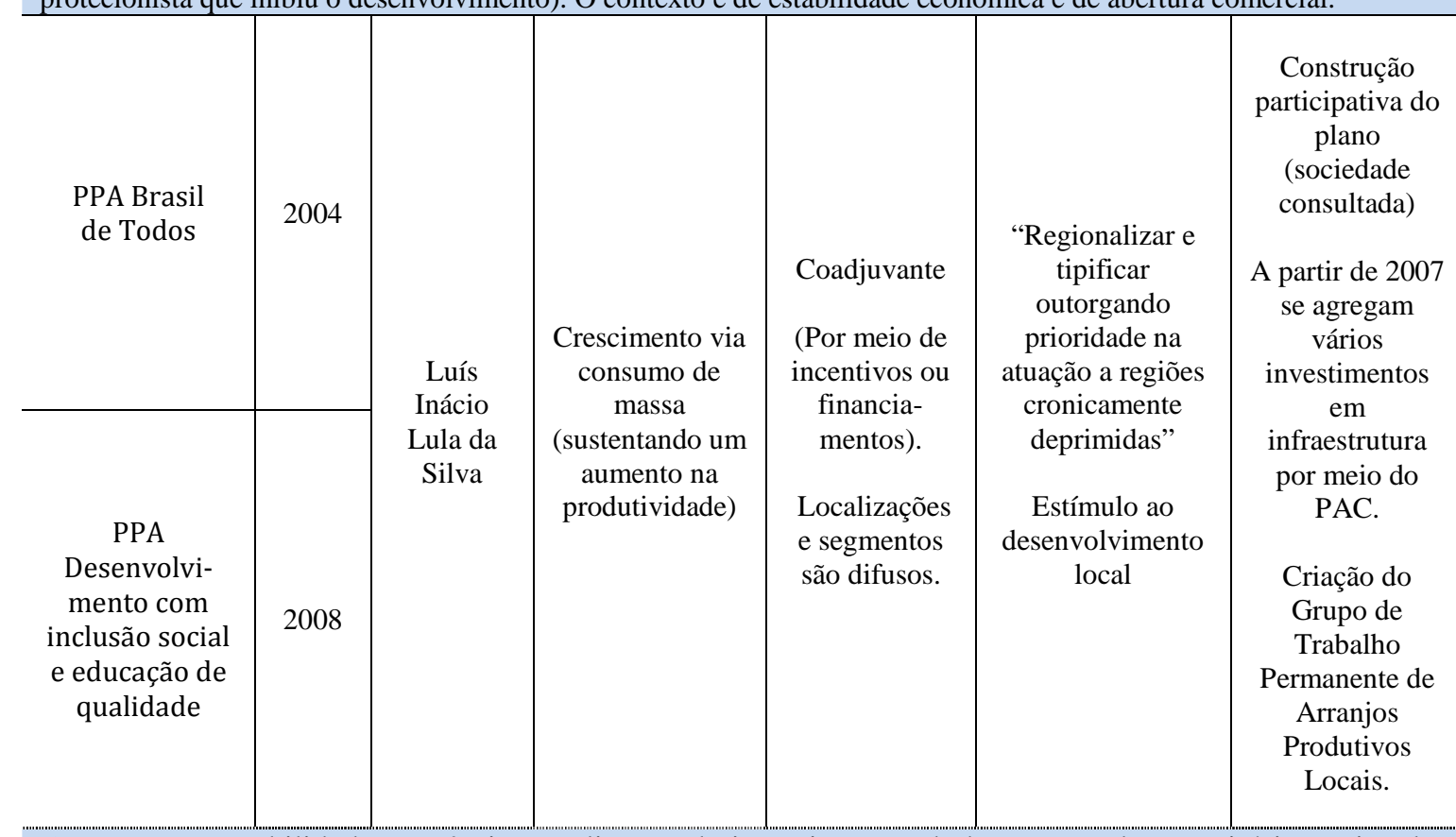

Conjuntura: Estabilidade econômica, realização de investimentos de base em todo o território nacional e valorização de uma matriz econômica apoiada no mercado consumidor.

Fonte: Elaboração do autor com base no levantamento e análise dos Planos governamentais de 1939 a 2008.

Em termos gerais, verifica-se que a indústria era considerada o "carro-chefe" do desenvolvimento em alguns momentos (indústria como protagonista). Considerada a principal engrenagem, os planos econômicos expressavam essa ideologia. Já no Programa de Metas a tônica era a substituição de importações, por meio da instalação de uma indústria de base capaz de suprir a demanda interna. 
Destaque deve ser dado à mentalidade que ganha força neste período. Segundo O. Ianni: “[...] A indústria, como categoria econômica, política e cultural passara a dominar o pensamento e a atividade dos governantes, e das classes sociais dos centros urbanos grandes e médios" (1991, p. 177).

Em alguns casos, a preocupação com a indústria aparece acompanhada da tentativa de resolução das desigualdades regionais em escala nacional e, conjuntamente, da integração do espaço nacional. Foram pensados instrumentos para se chegar a isso - os mais expressivos se apoiaram na ideia de polo de desenvolvimento - com objetivo de fortalecer conceitualmente as iniciativas, que de fato podem ser responsabilizadas pela existência de expressivas aglomerações industriais nas regiões Nordeste e Norte do país.

Neste momento ganha mais força o discurso da "ideologia industrializante" ou a perspectiva da industrialização como um "caminho para o desenvolvimento", que foram identificados e explicados por O. Ianni (1991) ou R. Piquet (2007). Estes discursos elitistas e governamentais tratavam a industrialização como o único caminho possível (inclusive que já teria sido traçado pelos países desenvolvidos) para se chegar a um estágio de desenvolvimento. Apresentaremos também, no decorrer do capítulo, como se apresentou esse discurso de "industrialização tropical" em documentos como os Planos Nacionais de Desenvolvimento.

Posteriormente, sobretudo após o período de combate à inflação, que marcamos entre 1980 a 1995, a indústria está presente sempre na condição de coadjuvante, dirimida entre vários outros setores considerados então prioritários. Perde-se o caráter de instrumento primordial para o desenvolvimento até então atribuído à indústria, que passa a ser assumido por outras variáveis trabalhadas, como o comércio exterior ou a evolução do padrão de consumo do mercado interno, em outros planos de governo posteriores.

A proposta de planejamento no Brasil pode ser interpretada, segundo O. Ianni (1991) como o momento em que o poder público passou a funcionar mais adequadamente de acordo com as exigências do sistema capitalista. Para este autor, o planejamento como uma técnica e instrumento de política estatal começou a ser incorporada no Brasil durante a II Guerra Mundial.

[...] foi nessa época que a planificação passou a fazer parte do pensamento e da prática dos governantes, como técnica "mais racional" de organização das informações, análise dos problemas, tomada de decisões e controle da execução de políticas econômico-financeiras (IANNI, 1991, p.54). 
É importante destacar essa congruência de interesses entre Estado e mercado. Isso é evidente não apenas não formas de aglomerações espontâneas, mas também naquelas que são efetivamente planejadas. Atualmente, mesclam-se iniciativas e princípios advindos destas diferentes esferas.

Analisamos esses momentos que fazem parte da história da industrialização do Brasil, entremeados a alguns eventos que explicam os papéis complementares do Estado e do mercado, como os principais agentes; daremos destaque para a maneira como, a cada momento, uma forma de aglomeração participa de uma determinada conjuntura econômica como instrumento de apoio às tentativas de desenvolvimento.

Iniciaremos nossa análise a partir de um momento no qual o mercado nacional não estava ainda integrado, fazendo com que alguns autores o interpretem como um "arquipélago", e continuaremos até a implantação efetiva de um Estado neoliberal, característica do período contemporâneo.

\subsection{Dinâmicas Industriais no "arquipélago"}

A tese mais amplamente aceita para explicar o primeiro impulso de concentração industrial no Brasil, notadamente no Estado de São Paulo, tem origem no trabalho de C. Furtado (1958), cuja interpretação do processo de industrialização está diretamente associada ao de substituição de artigos importados que abasteciam o mercado nacional. Um primeiro momento é o da crise de 1929, que ocasionou aumento nos preços dos artigos importados (desvalorização no poder aquisitivo externo da moeda), fazendo com que um coeficiente da renda ficasse represado dentro do país. Complementarmente, a procura interna mantinha-se com mais firmeza que a externa, despertando o interesse maior do que a economia de exportação, criando uma situação nova da economia brasileira, no qual o processo de formação de capital volta-se para o mercado interno. Nas palavras de Furtado: "[...] o fator dinâmico principal, nos anos que se seguem à crise, passa a ser, sem nenhuma dúvida, o mercado interno" (2003 [1958], p.198).

Em um primeiro momento, aproveitou-se com maior intensidade a capacidade produtiva já instalada no país, pelo que se pode explicar o aumento substancial da indústria têxtil nos anos que se seguiram à crise (FURTADO, 2003 [1958]). Um segundo momento requeria a subsequente expansão da indústria, já com os fundos acumulados de sua primeira expansão. A indústria nacional importa equipamentos provenientes de fábricas, 
em países centrais atingidos pela crise, que fecharam suas portas. Assim, uma situação que poderia ser conjuntural transforma a estrutura econômica, trazendo consigo outros desequilíbrios; entre eles o estabelecimento de um novo nível de preços relativos para os artigos de produção interna e os artigos importados e "[...] com base nesse novo nível de preços relativos, desenvolveram-se as indústrias destinadas a substituir importações" (FURTADO, 2003 [1958], p.202).

É dessa forma que Furtado sugere um deslocamento do centro dinâmico da economia, o qual pode ser explicado a partir da crise de 1929 e do processo de substituição de importações no seio da economia nacional. É exatamente esse o ponto de partida de W. Cano, para quem a nova formação industrial em vigor necessitava de maior autonomia para sua reprodução ampliada, e não apenas para contornar a crise. Também por isso, segundo o autor, "Só a partir de 1933, quando a economia nacional se recupera da crise e o movimento de acumulação industrial é o motor determinante da economia, é que se pode falar de industrialização" (CANO, 1998 [1985], p.48).

Uma vez explicado esse momento histórico, embora feito apenas a partir de uma leitura que é predominante, precisaria ser complementado com outras interpretações e com um esforço de compreender a configuração territorial resultante deste momento.

Na periodização de W. Cano, de 1850 a 1929 existia no Brasil uma indústria totalmente descentralizada, integrada com a economia que era própria à cada região. As regiões do país não estavam integradas e, por isso, afirma também que não poderia existir um mercado nacional genuíno. Por essa razão, trata a economia da época como um "complexo econômico nacional" (CANO, 1998 [1985]), por vezes comparando-o a um arquipélago; e que cada ilha se desenvolve isoladamente. Em linhas gerais, a região Norte vivia o ciclo da borracha desde 1970, o Nordeste tinha suas bases assentadas no beneficiamento do açúcar e do algodão e as regiões Sul e Sudeste, com maior diversificação, possuíam uma forte indústria têxtil no Estado do Rio de Janeiro, café em São Paulo e Minas Gerais e também mate e charque do Paraná ao Rio Grande do Sul.

Contudo, enquanto a análise econômica fica demasiadamente centrada no aspecto econômico e, sobretudo, na economia cafeeira, podemos perder nuances relevantes deste processo. A. Mamigonian (1969 e 2000) interpreta as raízes da industrialização brasileira analisando primordialmente o aspecto social, comparando a mentalidade e a conduta do latifundiário e do imigrante, que formou uma classe média com relativa capacidade de acumular e investir em pequenas indústrias. 
Das possibilidades abertas com essa leitura, embora contrastante com a interpretação de que a indústria teria sido diretamente financiada pelo capital dos cafeicultores, o autor distingue quatro grandes tipos de iniciativas industriais no Brasil (MAMIGONIAN, 1969): 1) de "capitalistas de capitais", modestos imigrantes europeus com ou sem experiência industrial anterior, 2) comerciantes de importação-exportação e fazendeiros que se interessaram seriamente pelo negócio industrial apenas quando ele se tornou seguro, 3) as iniciativas estatais e 4) iniciativas estrangeiras que vieram tirar proveito da industrialização em andamento.

A relevância dos imigrantes no processo de industrialização, constituindo principalmente o primeiro tipo das iniciativas industriais, é tal que, de um estudo ${ }^{29}$ que abordou 204 empresários de São Paulo em 1962, 84,3\% eram de origem imigrante, sobretudo Itália, Portugal e Alemanha. A expansão da agricultura em São Paulo fora aproveitada pelos imigrantes que traziam experiência de trabalho variada e possuíam nível de vida mais elevado que o dos escravos, ao que se pode somar seus hábitos econômicos equilibrados (trabalho persistente e consumo sóbrio) e vontade de independência, condições que impulsionaram a modernização da agricultura nos locais onde ocuparam e também as primeiras iniciativas industriais (MAMIGONIAN, 1969).

Segundo o próprio Mamigonian, esta interpretação entra em choque com a leitura da transferência direta de capitais da cafeicultura à indústria pois, com medo de resvalarem na ideologia do self made man, negaram-se a considerar o papel da imigração no processo (MAMIGONIAN, 2000).

Encarando as especificidades desse momento histórico como as raízes do processo de industrialização no Brasil, podemos reconstruir um cenário no qual a produção industrial, concentrada em alguns pontos específicos, “[...] não apresentava suficiente dinâmica de crescimento que lhe obrigasse a romper o 'arquipélago' nacional e cativar para si o mercado nacional" (CANO, 1998 [1985], p.150).

O Rio de Janeiro e a Guanabara representavam juntos $38 \%$ da produção industrial enquanto o Estado de São Paulo apenas 16\%. (CANO, 1998 [1985]). Paralelamente, outras iniciativas estavam espalhadas pelas regiões Sudeste e Sul, sobretudo Santa Catarina e Rio Grande do Sul, e Pernambuco no Nordeste (MAMIGONIAN, 1969). O que se verifica é a ausência de uma concentração industrial expressiva; apenas os Estado do Rio de Janeiro e a Guanabara, principalmente por meio de sua indústria têxtil,

\footnotetext{
${ }^{29}$ Estudo realizado por L. C. Bresser Pereira, citado por Mamigonian (1969).
} 
conseguia atingir mercados regionais vizinhos a eles. Porém, até 1929 essa tendência de concentração seria invertida em favor de São Paulo.

Para W. Cano (1998 [1985]), como já abordado, o bloqueio do café "libertou" em São Paulo o seu excedente para diversificar a acumulação industrial. Quer seja por meio do investimento direto de cafeicultores em atividades potencialmente mais lucrativas como forma de substituir importações que se encontravam em situação delicada, quer seja por meio da iniciativa individual e empreendedora dos imigrantes no país que formavam uma classe média com capacidade para poupar e certo conhecimento que traziam da Europa, ao menos no quesito espacial, foi certa situação geográfica existente do Estado de São Paulo (privilegiadamente o maior estado produtor de café) que fez com que nele se desencadeasse esse processo que pode ser considerado primordial para a densa concentração industrial que, em pouco tempo, se processaria.

Já durante a I Guerra Mundial encontrava-se dificuldade de importar produtos, então entre 1914-1919 o Estado de São Paulo é foco de uma forte inversão que faz com que a representatividade do Estado de São Paulo no total da indústria nacional salte de 15\% (1907) para 40\% em 1929 (CANO 1998 [1985]). Em termos das exportações de São Paulo para as demais áreas do Brasil, entre 1900-1910, essa exportação representava 15\% dos destinos das mercadorias produzidas em São Paulo; entre 1910-1920 esse indicador eleva-se para $20 \%$ até que, no final da década de 1930, o destino da produção industrial paulista era 50\% para o mercado externo e 50\% para as demais áreas do Brasil.

Neste contexto se mesclaram fatores de mercado, ora interno e regional com algumas iniciativas pontuais de industrialização, ora voltado ao mercado externo (sobretudo a partir da I Guerra Mundial e, pouco tempo depois, com a Crise de 1929 que minou as possibilidades de comercialização do café). Estes eventos influenciaram significativamente os rumos da economia brasileira e as estratégias encontradas pelos agentes econômicos para superar/tirar proveito destes momentos de crise, inclusive apresentando as primeiras iniciativas que lograram a concentração industrial no território brasileiro. Essa concentração incipiente é estimulada/acompanhada pelas primeiras etapas da formação de um mercado nacional (CANO, 1998 [1985]), que se encontrava então em fase de integração.

Nesse sentido, as escolhas locacionais que são pioneiras no parque industrial paulista encontram suas razões em decisões microeconômicas já que os agentes individuais, mesmo que influenciados por um contexto mundial (e igualmente submetidos à uma situação geográfica específica que se encontrava no Estado de São Paulo), 
propiciaram não apenas uma concentração dos antigos cafeicultores, mas também da maior parcela de imigrantes que vieram para o país. Essa concentração geográfica expressa o "capital represado", em busca de melhores alternativas de investimento.

\subsection{Intensifica-se a concentração industrial}

A partir de 1930, tendo como possível marco o ano de 1933, intensifica-se a concentração industrial iniciada com a dificuldade de importações, abrindo caminho para investimentos que visavam abastecer a demanda interna. Neste contexto de expansão podemos conferir, paralelamente ao processo de industrialização, o início da integração de um efetivo mercado nacional. Estas duas dinâmicas caminhariam paralelamente ao ritmo da urbanização do país, o que também forçava a produção de cimento, madeira, vidro e cerâmica (CANO, 1998 [1985]), como produtos demandados pela construção civil e de obras públicas.

Como parte de uma periodização, necessário para essa etapa da pesquisa, nos parece consistente considerar o intervalo situado entre a crise de 1929 e o ano de 1955, em que a indústria no Estado de São Paulo passa a ter participação em mais da produção nacional. Esse intervalo é proposto no estudo de Cano (1998 [1985]) e usado na abordagem de C. Brandão (2007), já que em 1955 inicia-se o Programa de Metas do Presidente Juscelino Kubitschek, um marco que também é posto como divisor de águas nas demais considerações de A. Kon (1999) e R. Piquet (2007). Além disso, o cenário político da Revolução de 30 é de fundamental importância para entender o significado da modernização estatal e suas ações centralizadoras, como abordado em Costa (2011 [1988]).

A indústria paulista durante este período cresce 20 pontos percentuais ${ }^{30} \mathrm{em}$ termos de participação relativa no total da indústria nacional, demonstrando que efetivamente ocorre uma expressiva concentração nesta parcela do território. Em contrapartida, a região Nordeste perde participação relativa, em que prevalece o capital mercantil (CANO, 1998 [1985]) e a Amazônica ainda sofria pela crise na exportação da borracha que afetara severamente a sua condição econômica.

\footnotetext{
${ }^{30}$ Como mostrado em Cano (1998 [1985]), em 1919, SP representava 32\% da indústria nacional. Em 1939 essa participação cresce para 41\%, em 1949 para 49\%, atingindo 52\%, mais da metade do total nacional, no ano de 1952.
} 
O mais importante a destacar deste período é a integração do mercado, podendo então ser chamado de mercado nacional (CANO, 1998 [1985]) ou como destaca C. Brandão (2007), da "imposição de coerência ao mercado interno nacional” que partia do centro dinâmico, cuja implicação é o impedimento de qualquer outra região do país alavancar projetos para replicar a trajetória da economia paulista, pois acionadas por esse centro passaram a incorporar seus produtos, tornam-se reflexas dele (BRANDÃO, 2007).

A Revolução de 30 pode ser considerada como pré-condição para a centralização capitalista em São Paulo, pois o caráter político "bipolar" que alternava governos de São Paulo e Minas Gerais (muito embora existisse, formalmente, um republicanismo), cuja dominância foi alvo de grande descontentamento após a Crise de 29 (COSTA, 2011 [1988]), facilitando a tomada do poder por Getúlio Vargas em 1930 após sua derrota nas eleições.

O novo governo tem um caráter centralizador e instala órgãos e empresas estatais que configura uma estratégia de reaparelhamento do Estado. Nos moldes das tendências dominantes que determinavam a relação entre o Estado e a economia nos países desenvolvidos à época, o então chamado Estado Novo centralizou "[...] as políticas e o planejamento econômico, tais como o controle do investimento, da poupança e dos salários a nível nacional” (COSTA, 2011 [1988], p.47). É nesse contexto que o governo passa a editar planos de desenvolvimento para o país, sendo talvez o principal deles, durante o Estado Novo, o Plano Especial de Obras Públicas e Aparelhamento da Defesa Nacional. Faz-se importante mencionar a leitura de Costa sobre essas mudanças:

Pela primeira vez, instaura-se um regime político que é fruto e sustentáculo das classes dominantes, mas que muda as regras do jogo, de modo a garantir, pela proeminência de um Estado forte, "acima das regiões, das classes, dos partidos, etc.", a continuidade acelerada da modernização capitalista do país e a articulação, "pelo alto" de sua unidade nacional (COSTA, 2011 [1998], p.46).

É neste mesmo sentido que é afirmado por Cano (1998 [1985]): para conseguir a integração do mercado nacional, o Estado não poderia mais permitir a supremacia de interesses regionais sobre os nacionais. A partir das consultas realizadas, entre os diferentes autores, talvez seja possível dividir a atuação do Estado em quatro frentes principais:

(1) A modernização do aparelho estatal para assessorar assuntos técnicos permanentes, que resultou na criação de órgãos centralizados para tratar a política 
econômica para temas específicos como: café, sal, açúcar, álcool e até siderurgia (CANO, 1998 [1985]). Podemos mencionar também a criação dos Ministérios do Trabalho, Indústria e Comércio, Educação e Saúde, bem como o Departamento de Imprensa e Propaganda e o próprio Instituto Brasileiro de Geografia e Estatística, que podem ser interpretados como faces do centralismo e do intervencionismo (COSTA, 2011 [1988]).

(2) A implantação de infraestrutura de circulação, implicando principalmente na construção de rodovias. Bastaria lembrar que até 1929 as principais modais de circulação eram a ferrovia, com 32 mil quilômetros no Brasil e a navegação de cabotagem, como pontua J. Barat (1978). Na década de 1930 foram pavimentadas ligações rodoviárias entre Santos-São Paulo-Campinas e São Paulo-Rio de Janeiro. A partir de 1950 ligando as capitais das regiões Sudeste e Sul, além da Bahia (São Paulo-Curitiba, Rio de Janeiro-Belo Horizonte, Rio de Janeiro-Salvador e Curitiba-Porto Alegre).

(3) Importante mencionar o imposto interestadual, que se processava nas trocas comerciais entre as unidades da federação, os quais foram gradativamente sendo reduzidos de 1938 até 1943, até sua extinção (CANO, 1998 [1985]).

(4) Finalmente, de decisões macropolíticas de alocação espacial de determinados investimentos de grande vulto (CANO, 1998 [1985]). Entre os mais importantes poderíamos elencar:

- Fábrica Nacional de Motores (Duque de Caxias -RJ, 1939) ${ }^{31}$

- Companhia Siderúrgica Nacional (Volta Redonda -RJ, 1941) ${ }^{32}$

- Companhia Nacional Vale do Rio Doce (Itabira -MG, 1942) ${ }^{33}$

- Companhia Nacional de Álcalis (Cabo Frio -RJ, 1943) ${ }^{34}$

- Usina Hidrelétrica de Paulo Afonso (Paulo Afonso -BA, 1948) ${ }^{35}$

Ocorre, em todos os aspectos, a dinamização da produção nacional. A maior taxa de crescimento é a do Estado de São Paulo, muito embora tenha ocorrido crescimento industrial na indústria brasileira como um todo, a despeito de se pensar que só o Estado de São Paulo se industrializava:

O produto real da indústria brasileira mais que triplicara entre 1919 e 1939, mais que duplicando entre 1939/49. A indústria periférica nacional,

\footnotetext{
${ }^{31}$ Foi vendida à FIAT em 1977, que encerrou a produção em 1979.

${ }^{32}$ Foi privatizada em 1993 e segue em operação.

${ }^{33}$ Foi privatizada em 1997 e segue em operação.

${ }^{34}$ Foi privatizada de 1992 e teve sua produção interrompida em 2006.

${ }^{35}$ Faz parte do atual Complexo Hidrelétrico de Paulo Afonso, administrado pela Companhia Hidrelétrica do São Francisco (CHESF). Começou a operar apenas em 1954.
} 
que quase triplicara entre aqueles dois anos, em 1949 era 1,8 vez maior do que em 1939. SP quadruplicou seu parque industrial no primeiro período, tendo em 1949 uma indústria duas vezes e meia maior do que em 1939 (CANO, 1998 [1985], p.75).

Podemos notar que começaram a se configurar algumas linhas de integração entre algumas regiões do país, embora este fosse ainda, na visão de Cano (1998 [1985]), uma "soma" de regiões econômicas distintas. Era, evidentemente, o Estado de São Paulo que apresentava as melhores condições de receber os novos investimentos industriais, na medida em que apresentava relações capitalistas já mais avançadas em relação às demais regiões. (BRANDÃO, 2007). Embora crescimento da industrialização tenha sido emblemático, esse crescimento também foi resultado de uma série de políticas industriais sugeridas ao governo por uma elite industrial ${ }^{36}$, sobretudo paulista, que ganha força política ao mesmo tempo em que passa a representar o poder econômico.

Talvez pudéssemos pontuar não apenas o início da formação da consolidação do parque industrial paulista, objeto que nos interessa diretamente nesta pesquisa, mas este foi também o momento, como destacado por M. Santos e M. L. Silveira (2001), dos primeiros movimentos que irão definir a Região Concentrada do país. Embora o discurso vigente na época fosse o da integração nacional, existia um conjunto de infraestruturas de transportes e comunicações, bem como a existência de todos os segmentos produtivos, que autoriza a afirmar que já estavam integradas as regiões Sudeste e Sul (SANTOS e SILVEIRA, 2001).

As intervenções diretas do Estado nacional, como se pode verificar pelas datas de instalação e localização, embora tenhamos listado apenas as de grande vulto, vieram a reforçar a densidade industrial locada nos estados de São Paulo, Rio de Janeiro e Minas Gerais, formando o arcabouço para o advento da industrialização pesada no território nacional.

O contexto de um planejamento econômico incipiente, característico deste momento histórico, reflete as iniciativas em crescentes teorizações e estratégias de conduzir a economia pela esfera governamental. Estas preocupações foram originadas na década de 1920, em países capitalistas avançados, diante da necessidade de atingir objetivos econômicos e sociais definidos, uma vez que se assumiu "[...] que o simples jogo

\footnotetext{
${ }^{36}$ Como símbolo do crescimento da poder econômico do empresariado industrial paulista, podemos mencionar a criação da Federação das Indústrias do Estado de São Paulo (FIESP), por meio de um decreto de 1930, o qual permite a representação dos sindicatos em uma entidade única. Para C. Barbosa (2008), é um contexto que expressa a ação do crescente empresariado industrial frente ao Estado: "[...] a partir de 1940, a FIESP tornava-se cada vez mais um órgão técnico e consultivo frente ao governo federal” (p.109).
} 
das forças de mercado, com pequena intervenção do Estado, era incapaz de levar aos resultados desejados pela sociedade", como aponta C. Lafer (1970, p.12).

Parece-nos claro, todavia, a acenar com base na dinâmica deste momento histórico do país, que estas duas forças, Estado e mercado, atuaram concomitantemente e com objetivos equivalentes. Organiza-se o parque industrial paulista, o qual viria a se consolidar como complexo industrial, ou um multicomplexo industrial (SELINGARDISAMPAIO, 2009).

Em um primeiro momento, com base nas decisões microeconômicas pautadas em certa situação geográfica específica e privilegiada no território nacional, tais decisões foram ratificadas pela atuação do Estado Novo, reforçando a consolidação deste complexo por meio de infraestruturas de circulação, eliminação de barreiras fiscais e, enfim, a instalação de um arranjo industrial - como um camada que se sobrepõe e se encaixa à primeira camada de indústrias - que sustentará a vinda de indústrias pesadas, consolidando o parque.

2.4. A industrialização ganha um novo ímpeto

A partir de 1955, com os incentivos provenientes do Programa de Metas, a industrialização entraria no período da "indústria pesada" (CANO, 1998 [1985]), quando se instalam no Brasil empresas produtoras de bens de consumo durável e de produção, em investimentos de alto risco do capital estrangeiro e também estatal, os únicos com condições para investir nessa dimensão.

Entre 1956 e 1961 é possível identificar a fase áurea das inversões decorrentes do Programa de Metas, sobretudo nos ramos de automóveis e autopeças, mecânica pesada e material elétrico. O parque industrial brasileiro conhece outra duplicação entre 1959 e 1970 (CANO, 1998 [1985]) e, embora tenha ocorrido reforço do processo de concentração industrial, o Brasil além do Sudeste-Sul também apresentou crescimento positivo da indústria ${ }^{37}$.

A respeito do processo de concentração no Estado de São Paulo é preciso destacar:

${ }^{37} \mathrm{O}$ crescimento da indústria paulista durante a industrialização restringida foi de $7,9 \%$ e durante a industrialização pesada 9,2\%. O crescimento da indústria brasileira (exclusive São Paulo) foi de 5,4\% durante a industrialização restringida e 7,2\% durante a industrialização pesada (CANO, 1998 [1985]). O diferencial de crescimento entre São Paulo e o resto do país diminuiu entre esses dois períodos. 
Esse período reforçaria o processo de concentração industrial, na medida em que se instalam as chamadas indústrias "pesadas", principalmente em SP, onde, graças à sua maior diversificação industrial previamente existente (veja-se o caso da indústria de autopeças, em relação à automobilística, recém-implantada), seus "efeitos de encadeamento" foram muito maiores (CANO, 1998 [1995], p.100).

Ainda na visão do economista, será entre 1962 e 1967 que o processo de integração pode ser identificado em sua forma mais avançada, pois ocorre dominação do processo de acumulação de capital à escala nacional. Em outras palavras, o processo de integração é tal que podemos falar em consolidação do mercado nacional, cuja implicação é o seu domínio pelo capital industrial sediado no polo (CANO, 1998 [1985]). Dois processos concomitantes explicariam essa alteração na base de acumulação das demais regiões do país: o primeiro efeito é o de bloqueio, segundo o qual as demais regiões não podem repetir o processo histórico do desenvolvimento em São Paulo (segundo Cano, elas podem ser parcialmente contornadas via decisões macropolíticas de inversão tomadas pelo governo federal). $\mathrm{O}$ segundo efeito é o estímulo, quando ocorre justamente a complementariedade (agrícola ou industrial) inter-regional.

Ao analisar a mudança na estrutura industrial de São Paulo em relação ao resto do país podemos assinalar uma transformação que expressa bem essa complementaridade. De acordo com Cano (1998 [1985]), a representatividade de indústrias produtoras de bens de capital, analisadas em relação às indústrias produtoras de bens de consumo não durável, aumenta 26 pontos percentuais até a década de 1970, sendo suficiente para caracterizar uma forte mudança na estrutura produtiva ${ }^{38}$.

Este período específico, conforme considerado por W. Cano (1998 [1985]) como o de "industrialização pesada", pode ser visto também como o mais ativo do ponto de vista do planejamento e intervenção direta do governo federal em relação à dinamização da economia via industrialização. Este assunto merece uma abordagem um pouco mais direcionada, dada sua importância para nossa pesquisa, sobretudo no que tange às ações do Estado.

Durante o governo de Juscelino Kubitschek ocorreu o mais amplo conjunto de ações voltadas à implantação de uma estrutura industrial no país, em um contexto específico no qual o poder público já havia incorporado e assimilado os elementos

\footnotetext{
${ }^{38}$ De acordo com Cano (1998 [1985]), se considerarmos a agrupamento de indústria produtoras de bens de consumo não durável (GI) e o agrupamento de indústrias produtoras de bens de capital (GIII): A concentração do GI em São Paulo era 74\% em 1919 e diminuiu para 37\% em 1970. A concentração do GIII em São Paulo era de apenas 3\% em 1919 e sobre para 29,3\% em 1970.
} 
essenciais da técnica do planejamento. Neste período, segundo O. Ianni (1991, p.58) “[...] a ideia, a técnica e a prática do planejamento haviam sido incorporados ao debate sobre a política econômica governamental" e se argumentava em favor da neutralidade do planejamento e da possibilidade de sua aplicação em qualquer sistema econômico.

Devido a esse contexto é possível mais claramente enxergar uma ideologia industrializante nos planos de governo, bem como o próprio discurso de um "desenvolvimento via industrialização", explícito como proposta econômica e social. Além disso, é importante perceber como a visão da transformação de um lugar também estava atrelada à presença de indústrias. Uma discussão perene no Brasil, que data deste período, é justamente a redução das disparidades regionais. Sobre isso, podemos afirmar que a indústria era vista como ferramenta de intervenção supostamente capaz de induzir ao desenvolvimento econômico de uma região.

Em 1956 foi lançado o Programa de Metas, que teria duração até 1961 e no qual se daria atenção especial a quatro áreas: energia, transporte, alimentação e indústrias de base. Neste plano, o Estado deveria investir na infraestrutura necessária para abolir os pontos de estrangulamento da indústria, bem como expandi-la por meio de estímulo aos investimentos nacionais e estrangeiros (IANNI, 1991).

Embora tenham ocorrido, de fato, muitos investimentos estatais - o Estado assumia a posição de empresário - é diretriz do Programa de Metas a criação de condições para o "florescimento da livre iniciativa" (BRASIL, 1958). Lafer (1970) mostra a expressividade dos investimentos na indústria: apenas em energia $(43,4 \%)$ e indústrias de base $(20,4 \%)$ estavam concentrados mais que $60 \%$ dos investimentos previstos pelo programa. A taxa média de crescimento do PIB no período 1957-1962 foi de 7\% ante os $5,2 \%$ do quinquênio anterior e, ao final do programa, o ritmo de crescimento da produção industrial aumentou mais de $96 \%$ (entre 1952 e 1955 foi de 42\%).

Esses números evidenciam que a indústria ocupou uma posição central como instrumento da política econômica no Programa de Metas. Isso pode ser expresso também pelos investimentos e seus respectivos resultados e, de forma indireta, pela mentalidade que apostava na indústria como uma base produtiva para o país no futuro. A opinião de Kubitschek era de que o Brasil não era, “[...] um país de produtos agrícolas por vocação hereditária e, consequentemente, uma vigorosa industrialização, com vistas para o futuro, se fazia necessária” (LAFER, 1970, p.33). Algumas importantes obras do governo federal no período são as seguintes: 
- Companhia Siderúrgica Paulista (Cubatão -SP, 1953) ${ }^{39}$

- Usina Siderúrgica de Minas Gerais (Ipatinga -MG, 1956) ${ }^{40}$

- Usina Hidrelétrica de Furnas (Furnas -MG, 1958) ${ }^{41}$

Pela primeira vez é mencionada, em um plano de governo, uma específica forma de aglomeração industrial. Nas Diretrizes Gerais do Plano Nacional de Desenvolvimento (1956) há uma breve proposta de se fomentar "combinados industriais". A noção é abordada indiretamente, um mero termo instrumental, mas estava atrelada, sobretudo, ao fomento de maior relacionamento entre os ramos industriais, aproveitando principalmente um recurso territorial claro. Em outras palavras, seu princípio era estimular a instalação de indústrias ao redor de áreas como a Usina Hidrelétrica de Paulo Afonso ou próximas às reservas de carvão mineral no Estado de Santa Catarina.

A proposta dos combinados industriais, assim como a própria natureza das instalações capitaneadas diretamente pelo Estado, dão o tom da busca por prover as bases necessárias para a consolidação de uma industrialização pesada, ou produtora de bens de capital e bens de consumo durável, marcando efetivamente uma nova fase do processo de industrialização no país.

Em continuidade aos governos anteriores, as ações voltadas à integração nacional seguem e são intensificadas. Podemos dar um destaque especial à própria construção de Brasília, no centro geográfico do território brasileiro, cujo pretexto foi justamente deslocar a capital do país para um "ponto de equilíbrio" entre as suas regiões mas também, subjetivamente, afirmar o poder central do Estado sobre o conjunto do território (SANTOS e SILVEIRA, 2001). Na interpretação de W. M. da Costa:

Brasília representou a implantação de um poderoso "posto de vanguarda" para o norte e o oeste do país, regiões que o Estado vinha tentando "capturar" há algumas décadas. Como verdadeiro pólo, ou nó de articulação inter-regional, deslocou para a imensa "hinterlândia" parte das atenções governamentais, dos segmentos privados da economia e da opinião pública nacional" (2011 [1988], p.54).

Inegavelmente, Brasília demandaria um conjunto de vias de ligação, estimulando a construção das chamadas "rodovias de penetração" a partir de 1956, tais como: São Paulo - Brasília, Belo Horizonte - Brasília, Brasília - Belém, Cuiabá - Porto

\footnotetext{
${ }^{39}$ Foi inaugurada em 1963, privatizada em 1993 e segue em operação.

${ }^{40}$ Foi inaugurada em 1966, privatizada em 1991 e segue em operação.

${ }^{41}$ Começou a ser construída em 1958 e entrou em operação em 1963.
} 
Velho (CANO, 1998 [1985]), não apenas para ligá-la aos demais centros urbanos, mas também para a expansão do consumo.

$\mathrm{O}$ traçado dessas estradas obedecia às novas exigências da indústria e do comércio, e assim acabou por reforçar a posição de São Paulo como centro produtor e, ao mesmo tempo, de distribuição primária. A criação de uma indústria automobilística e a construção de Brasília confluíram também para favorecer São Paulo e aumentar o desequilíbrio econômico. Constitui-se nessa cidade um parque de numerosas indústrias de base, cujo enorme mercado é dado pelo esforço de equipamento de todo o território e mesmo pelo abastecimento normal da população brasileira (SANTOS e SILVEIRA, 2001, p.45).

Neste novo ímpeto do processo de industrialização nacional, as regiões Norte e Nordeste também conhecem efetivos programas alçados pelo Estado visando sua industrialização. Embora essas agências não tenham sido objetivo do plano que analisamos, elas se inserem claramente no contexto da industrialização pesada, com integração nacional e complementaridade entre as regiões do país. A Superintendência de Desenvolvimento do Nordeste - SUDENE (Recife -PE, 1959) foi formada durante o governo de Juscelino Kubitschek e inspirada no sucesso da Superintendência para a Valorização Econômica da Amazônia, de 1953, durante o Governo Vargas. A Superintendência de Desenvolvimento da Amazônia - SUDAM (Belém -PA, 1966), com objetivos similares aos da SUDENE, foi alicerçada já durante o governo militar, com o Presidente Castelo Branco.

A região Nordeste era vista como a "região-problema" do Brasil, e sua criação tinha o objetivo de fazer frente à pressão demográfica e à deficiência estrutural de sua base econômica (IANNI, 1991). A primeira ação de iniciativa da SUDENE foi investir em obras de combate à seca, pois se acreditava que a seca era a raiz dos problemas do Nordeste. Contudo, a partir de 1958 procurou-se implantar um conjunto de medidas que garantisse, de fato, o desenvolvimento econômico da região, entre eles o desenvolvimento de frentes de colonização e o fomento à atividade industrial. Esta última, especificamente, era encarada como "[...] a única forma de absorver grandes quantidades de mão de obra, com elevada produtividade, dada a escassez de recursos naturais (terra)", conforme destaca J. B. Barros (1970, p.122), que analisa especificamente o papel deste órgão.

Para o estímulo à industrialização do Nordeste, o governo se encarregaria dos fatores básicos e infraestruturas, tais como energia e transporte, acreditando que levariam à instalação de empresas industriais. Contudo, essa meta só se realizaria, ainda que 
parcialmente, por meio de uma intervenção direta e ainda maior do Estado. Isso se deu a partir dos chamados polos de desenvolvimento econômico inspirados nas ideias de F. Perroux, durante o governo militar.

Avaliando os importantes governos de Vargas e Kubitschek, Ianni (1991) aponta que, em ambos, a noção de desenvolvimento econômico (progresso econômicosocial) estava contida no conceito de industrialização. Os dois estadistas, ambos de ideologia nacionalista, diferem apenas quanto à orientação da política econômica, pois Vargas almejava uma emancipação econômica nacional, enquanto Kubitschek promoveu uma política econômica internacional, o que inclusive resultou na "[...] reprodução da dependência estrutural que sempre caracterizou a economia brasileira" (IANNI, 1991, p.183). Paralelamente, A. Kon aponta que os resultados do Programa de Metas “[...] podem ser visualizados não só através dos investimentos maciços no setor industrial de ponta, como também pela transferência do excedente gerado nesse setor para outras atividades" (1999, p.18).

É preciso destacar, por fim, que se em um momento anterior as localizações industriais estavam prioritariamente sendo induzidas quase que espontaneamente, a partir de 1955, após a mudança na estrutura produtiva do país, podemos dizer que existe maior seletividade geográfica da produção industrial, mediante uma polarização mais clara e mais forte (SANTOS e SILVEIRA, 2001).

2.5. Os planos de desenvolvimento durante o governo militar

Os governos militares tiveram duas propostas de planejamento com bastante ênfase na atividade industrial. Essas propostas seriam alçadas durante o I e II Planos Nacionais de Desenvolvimento (PND) no transcorrer da década de 1970. Segundo A. Kon (1999), embora na década de 1960 tenham ocorrido difusão e cristalização do desenvolvimento industrial, os resultados mais expressivos do planejamento governamental, em termos de sua política industrial e regional, ocorreram justamente na década de 1970, o que direcionou nossa escolha em analisar estes dois planos.

O I PND teve vigência de 1972 a 1974, durante o governo de Emílio Garrastazu Médici. Seus objetivos globais eram: manter o alto nível global do PIB, combater a inflação, equilibrar a balança de pagamentos e chegar à melhor distribuição de renda (BRASIL, 1971). Há no plano uma explícita visão de integração nacional, 
consubstanciada no Plano de Integração Nacional ${ }^{42}$ (PIN), conjuntamente. Esse padrão de desenvolvimento integralista, também inspirado em Perroux, se daria: "[...] com a disseminação dos resultados do progresso econômico a partir de centros de crescimento regional e de seus efeitos multiplicadores, buscando-se nas vantagens comparativas do país”, conforme propõe A. Kon (1999, p.22).

No II PND (1975-1979), os objetivos foram similares aos do primeiro plano: continuidade da política anti-inflacionista, equilíbrio na balança de pagamentos e políticas de melhoria da distribuição pessoal e regional da renda (KON, 1999). Este último objetivo permite constatar que se aprofundou a preocupação com a questão regional. Como já comentamos, o tratamento da questão regional tem inspiração direta na teoria dos polos de crescimento econômico, de F. Perroux.

Segundo M. C. de Andrade (1970), Perroux tinha como base que o crescimento econômico não se realiza homogeneamente por todo o território de um país, mas em certos pontos privilegiados e com dinâmicas diferentes em relação ao conjunto da economia. Nesta proposta de inspiração keynesiana, caberia ao Estado desencadear a infraestrutura territorial necessária à industrialização, como a instalação de fontes de energia elétrica e os eixos de circulação que permitissem à atividade industrial instalar-se no local. A partir daí, o crescimento econômico ocorreria de forma inicialmente concentrada e paulatinamente se espalharia pela "região de influência", irrigando-a (ANDRADE, 1970).

Em linhas gerais, com base em nossas indagações, podemos apontar que o I PND teve como princípio a integração e ocupação de todo o território nacional e, no II PND, os incentivos e investimentos à industrialização das regiões foram efetivados. A criação de programas de desenvolvimento regionais demonstra a maior atenção e intervenção direta nas regiões.

Outro aspecto bastante evidente, concordando com Gremaud e Pires (1999), é que ambos planos mostram a influência crescente do governo na gestão do sistema econômico. As políticas industriais seguiam, evidentemente, muito expressivas e se atrelavam agora a um discurso de "Brasil Potência", condição que só poderia ser alcançada por meio da redução do hiato tecnológico em relação aos países industriais mais avançados e a combinação do desenvolvimento territorial da seguinte forma: ocupação das áreas vazias e o progresso das áreas novas sem o comprometimento do ritmo de crescimento do núcleo mais desenvolvido (BRASIL, 1971; 1974).

\footnotetext{
${ }^{42}$ Legitimado pelo decreto-lei $\mathrm{n}^{\mathrm{o}}$ 1106, de 16/07/1970.
} 
Em termos reais de resultados, devemos mencionar que I PND registrou investimentos vultosos na indústria básica, principalmente siderurgia, petroquímica, construção naval, energia elétrica, comunicações, mineração e transporte. Em 1973 foram registradas as maiores taxas de crescimento do PIB na história nacional: o PIB industrial teve crescimento de $12,7 \%$ e o PIB total crescimento de $11,7 \%$ (GREMAUD e PIRES, 1999). Este crescimento representativo foi discurso de legitimação do regime militar no país. Inclusive, o período de 1968 a 1973 ficou conhecido como o "milagre econômico", muito embora à custa da contração de empréstimos vultosos, aumentando a dívida externa a tal nível que travaria o crescimento econômico posteriormente.

O II PND ocorre em um período de reafirmação do desenvolvimentismo para legitimar a atuação ainda maior do Estado. A estratégia implícita é novamente a da substituição de importações (agora como enfrentamento do choque do petróleo sobre a produção industrial mundial). Para isso, foram criadas empresas estatais com o importante papel de atuar onde o setor privado não estava presente; almejava-se, sobretudo, completar a matriz industrial brasileira. Está claro, no II PND, que a indústria de base deveria ser autossuficiente, abertos novos ramos para exportação de manufaturados e dado maior impulso à agroindustrialização (BRASIL, 1974).

Uma das características mais marcantes dos I e II Planos Nacionais de Desenvolvimento é a capacidade de intervenção do Estado nacional. A Sudene e a Sudam, já estruturadas, canalizavam os estudos e decisões relativas às implantações em suas respectivas regiões, e ao mesmo tempo já se contava com uma malha rodoviário muito maior e pavimentada. Brandão reforça que "[...] a complementação dos sistemas nacionais de infra-estrutura serão marcas da ação estatal da década de 1970 e início da de 1980" (2007, p. 138). Em 1966 o Brasil contava com 36.000 quilômetros em sua rede rodoviária, dos quais apenas 1/3 era pavimentado. Em 1987 o Brasil passa a ter 88.000 quilômetros de rodovias, dos quais 47.000 estavam pavimentados. A ideia de integração, contudo, não era apenas do ponto de vista da possibilidade de circulação potencial, mas a proposta evolui para a integração do sistema produtivo como um todo, considerando sua complementaridade, e também, como uma proposta presente desde a década de 1930, a integração do mercado nacional. Ainda a esse respeito, C. Brandão destaca o seguinte:

Nesse processo, a periferia logra melhorar sua inserção no mercado nacional, ampliando seus laços de complexidade com a economia central (densifica-se a matriz insumo-produto do país); a periferia também 
avança em algumas frentes do mercado internacional de commodities e de produtos semimanufaturados (2007, p.137).

Abaixo, elencamos algumas iniciativas que foram levadas a cabo durante o período de governo militar. A maioria delas, como se observa, está relacionada à ideia de polo de desenvolvimento, inclusive leva este termo em seu título. As que elencamos abaixo estão diretamente associadas ao processo de industrialização, muito embora se tenha tentando a implantação de outros polos - como os polos agrícolas e de exploração mineral - sobretudo nas regiões Norte e Centro-oeste.

Para administrar essas implantações, além da atuação técnica da SUDAM e SUDENE, que realizavam estudos técnicos e definiam os incentivos e financiamentos concedidos a cada projeto, foram também criados programas especiais como o Polamazônia e o Polocentro, instrumentos desenvolvidos com o objetivo de estabelecer “[...] medidas agressivas relacionadas à expansão da fronteira econômica e ao tipo de ocupação econômica das chamadas 'áreas vazias' do território” (COSTA, 2011 [1988], p.64). Do ponto de vista do uso industrial do território, algumas das mais importantes iniciativas, ainda em operação, são as seguintes:

- Zona Franca de Manaus (Manaus -AM, 1967) ${ }^{43}$

- Polo Petroquímico de Camaçari (Camaçari -BA, 1972) ${ }^{44}$

- Usina de Itaipu (Foz do Iguaçu -PR, 1973) ${ }^{45}$

- Polo Cloro-Químico de Maceió (Maceió - AL, 1975) ${ }^{46}$

- Polo Petroquímico do Sul (Triunfo-RS, 1975) ${ }^{47}$

Além da cristalização de áreas bem definidas a partir destes projetos, outras iniciativas também definiram localizações e concentrações industriais e urbanas no período. Poderíamos mencionar a extração de ferro em Carajás (PA), conhecida como Programa Grande Carajás e o Programa Nacional do Álcool.

Essa desconcentração, mesmo que em caráter relativo, reconfigura o território brasileiro, consolidando uma nova divisão territorial do trabalho. A. de Oliveira (2006) afirma que a desconcentração incentivou os segmentos considerados estratégicos,

\footnotetext{
${ }^{43}$ Área criada pelo Decreto-Lei 288, de 1967.

${ }^{44} \mathrm{O}$ complexo de Camaçari está associado à criação da Companhia Petroquímica do Nordeste - COPENE, em 1972. Em 1976 começaram a operar as primeiras unidades, até a inauguração do complexo em 1978, com dez unidades industriais.

${ }^{45}$ O acordo para implantação da usina foi assinado em 1973, entre Brasil e Paraguai. Sua construção foi iniciada em 1975 e começou a operar em 1984.

${ }^{46}$ A idealização desse polo começou em 1975, entrando em operação em 1977.

${ }^{47}$ A idealização do polo começou em 1975 e as obras começaram em 1977. Sua inauguração é de 1983.
} 
sobretudo os de bens intermediários, a localização de fontes de matérias-primas e a implantação de projetos regionais de grande envergadura. Estes projetos foram realizados de acordo com o "perfill" ou "vocação" esperada para alguns centros urbanos, por meio do estímulo a aglomerações industriais que respeitassem essa chamada vocação.

Em uma nova etapa do esforço de integração nacional, uma vez ligada à redução dos desequilíbrios regionais, pôde ser usada como uma estratégia para valorização e popularização do plano (GREMAUD e PIRES, 1999). O II PND não tinha a aceitação necessária da população. Dessa forma, o governo almejava articular uma base de apoio com as forças políticas locais, independentemente do capital industrial representado por São Paulo.

Ainda durante o governo militar foi lançado o III Plano Nacional de Desenvolvimento. Iniciado já na década de 1980, teve seus objetivos muito alterados em relação aos PND anteriores. O foco estava totalmente voltado para o reequilíbrio do câmbio e controle das taxas de inflação, "[...] porém suas medidas efetivas não foram colocadas em prática" (KON, 1999, p.27). Ainda entre 1985 e 1987, o governo procurou formular estratégias para o desenvolvimento industrial, porém a avaliação de Kon é que “[...] não foram devidamente implementadas" (p.30). No ano de 1986 a inflação, que havia se estabilizado no patamar de $220 \%$ no ano anterior, ameaçava tornar-se incontrolável, exigindo do governo sucessivas medidas de contenção ${ }^{48}$.

Resumidamente, a década de 1980 pode ser considerada "vazia" em termos de planejamento territorial da indústria, pois a preocupação recai no combate à inflação e às tentativas de correção monetária que se fizeram necessárias devido à inflação, financiamentos e endividamentos externos feitos até então.

Assumindo que tenha ocorrido desconcentração da atividade industrial em São Paulo e crescimento relativo em outras regiões, o incentivo governamental não pode ser considerado o único responsável. Segundo C. Diniz (2000) acompanham-se os fatores: deseconomias de aglomeração na área metropolitana de São Paulo e criação de economias de aglomeração em outros centros urbanos e regiões, ação do Estado em termos de investimento direto, incentivos fiscais e construção de infraestruturas, busca de recursos naturais (movimento das fronteiras agrícola e mineral com reflexo na localização industrial e, por fim, unificação do mercado).

\footnotetext{
${ }^{48}$ Tais como: Plano Cruzado (fevereiro de 1986), Plano Cruzado 2 (Novembro de 1986), Plano Bresser (junho de 1987), Plano Maílson (janeiro de 1988), Plano Verão (janeiro de 1989), Plano Collor I (março de 1990), Plano Collor II (janeiro de 1991) e, na, gestão presidencial seguinte os Planos FHC1 e FHC2, que finalmente viriam a conseguir estabilidade monetária.
} 
Para finalizar as considerações sobre este momento histórico, podemos afirmar que, embora o I e II Planos Nacionais de Desenvolvimento tenham sido os planos com maior ênfase na preocupação geográfica, ainda assim podemos mencionar que o planejamento territorial passa longe das estratégias explicitadas neles. Embora seja evidente a influência da indústria na medida em que se promulgava uma "sociedade industrial nos trópicos" dentro de uma espécie de "modelo brasileiro de capitalismo industrial", as estratégias para a realização/implantação destes objetivos não são evidentes. Nesse contexto, a única forma explicitada é a de polo de desenvolvimento e, ainda assim, em nenhum momento define-se o seu significado ou a escala na qual o polo poderia ser configurado - o polo poderia ser configurado em um município, região ou país - e, além disso, não necessariamente o polo era sempre de natureza industrial; outros polos com características agrícolas foram propostos nas regiões Nordeste e Norte. Por isso ressaltamos que a visão geográfica é fracamente existente e/ou fundamentada nos Planos Nacionais de Desenvolvimento e, mesmo que o polo de crescimento econômico tenha sido empregado em diversas ocasiões e regiões, não há uma definição clara sobre o que é o polo no plano propriamente dito, tampouco como este será implantando e motivado.

\subsection{Desconcentração-concentrada no Estado de São Paulo}

Entre os autores estudados com objetivo de traçar uma visão geral da evolução da indústria no país, há consenso em afirmar que, aproximadamente entre 1970 e 1985, ocorreram processos de desconcentração da indústria partindo da Região Metropolitana ao interior do estado.

Para W. Cano (1998 [1985]) esse processo se iniciaria em 1970, tendo seu auge em 1985, porém cujos efeitos podiam ser sentidos até o ano de 1995. Para esse economista, o processo de desconcentração teve dois vetores: o primeiro deles seria a "ampliação do uso da base periférica nacional de recursos naturais e de outros projetos decorrentes do II PND, como por exemplo, em minerais não-metálicos, metalúrgica, papel, borracha e matérias plásticas" (p.325). Em segundo lugar, o chamado "vetor interno", que é denotado pela diminuição na participação industrial da Grande São Paulo (GSP, para Cano): em 1970, a participação da GSP era de 43,5\% e do interior do estado 14,7\%; em 1985 a participação da GSP caíra para 29,4\% e a do interior tinha se acelerado para 22,5\%. 
Vejamos os fatores que seriam os responsáveis, segundo W. Cano (1998 [1985]), pelo chamado "vetor interno": (1) políticas de descentralização do governo do Estado de São Paulo, embasadas por um conjunto de obras de infraestrutura rodoviária e de pesquisa, como a UNICAMP, CPqD e CTI. (2) política de atração municipal instaurados por municípios do interior, “[...] com subsídios fiscais, dotação de infra-estrutura local, distritos industriais" (p.326). (3) investimentos federais implantados no interior que teriam desempenhado papel crucial: refinarias da Petrobrás e os centros de pesquisa (telecomunicações, informática, pesquisa agrícola), que geraram efeitos multiplicadores e atraíram empresas, bem como fomentaram a criação de novas (4) políticas de incentivo às exportações e o Programa Próalcool que potencializaram a agricultura já avançada existente no Estado de São Paulo. Por fim, um aspecto que pode ser melhor abordado (5) os custos de concentração na GSP, diretamente relacionados ao tempo de deslocamento espacial na metrópole, o combate à poluição industrial, aumento da insegurança pessoal e um novo e moderno sindicalismo surgido e organizado no ABCD paulista.

Conforme também foi apresentado por S. Lencioni (1994) verificou-se um movimento de afastamento da indústria em relação ao centro da metrópole que pode ser qualificado como desconcentração concentrada, pois ao mesmo tempo em que se esvazia de conteúdo industrial, no sentido da produção propriamente dita, ocorre centralização das funções de gestão e comando destas atividades industriais, por isso o uso conjunto dos termos desconcentração e concentração.

A desconcentração esteve associada principalmente aos fatores "internos" à metrópole, tais como o alto preço do solo urbano, o congestionamento e a deterioração das condições de vida, como um tudo, devido à densa concentração industrial. Entretanto, o movimento da desconcentração esteve também associado ao da centralização da metrópole enquanto centro financeiro e de gestão, de forma que “[...] A metrópole de São Paulo se desconcentra como negação dos mecanismos de concentração e afirma a sua centralidade" (LENCIONI, 1994, p.59).

Se visto a partir da configuração territorial resultante, em um processo mais amplo, poderia ser resumido a partir da dispersão industrial pelo Estado de São Paulo, num raio de aproximadamente $150 \mathrm{~km}$ a partir da capital e que "[...] indo além desta distância, ao longo dos principais eixos rodoviários" (LENCIONI, 1994, p.56). Vale a pena ressaltar a importância das rodovias para a configuração territorial resultante da indústria paulista, o que pode valer também para outras unidades da federação. Na perspectiva estudada por E. 
Sposito (2011), estes eixos seriam mais do que simplesmente fixos para circulação, mas também impulsionadores de importante dinâmica econômica.

Na visão de C. Diniz (1993), que também parte de um processo de desconcentração industrial a partir da metrópole paulistana, teria ocorrido uma "reconcentração poligonal". Este polígono poderia ser delimitado da seguinte forma: o próprio Estado de São Paulo e mais as áreas de influência dos municípios de Belo Horizonte, Uberlândia, Londrina, Maringá, Porto Alegre, Florianópolis e São José dos Campos (DINIZ, 1993).

Diniz também admite uma reversão da polarização de São Paulo, o que equivale a dizer que ocorre desconcentração da atividade produtiva motivada pelo investimento do Estado na "periferia" do sistema produtivo, porém que se associam a deseconomias de urbanização no interior da Região Metropolitana de São Paulo. Contudo, assevera que a este processo se combina, posteriormente, uma dinâmica de reafirmação da concentração industrial, porém respeitando os limites do polígono delimitado. Segundo o próprio Diniz (1993, p.57): “[...] tal região ampliou sua participação na produção industrial do país de 33 para 51\%, entre 1970 e 1990”, excluindo-se a aglomeração metropolitana de São Paulo.

Cano (1998 [1985]) e Diniz (1993) concordam que a grave crise financeira da década de 1980 e a imposição de uma dinâmica neoliberal a partir dos anos 1990 afetaram drasticamente o projeto de desconcentração iniciado no planejamento econômico da década de 1960. Para Cano:

Em que pese o esforço de industrialização periférica realizado, as frustrações daqueles que imaginavam que essa desconcentração diminuiria sensivelmente os padrões de divergência econômica e social em termos da média nacional aumentaram ainda mais nos anos 90 , diante dos nefastos efeitos que as políticas neoliberais estão causando ao país e suas regiões (CANO, 1998 [1985], p.305).

Complementarmente, na visão de C. Diniz (1993) “[...] a crise geral da economia brasileira levou à simultânea redução dos investimentos estatais diretos, dos incentivos e da construção de infra-estrutura, o que seguramente prejudicará o processo de desconcentração industrial” (p.58).

O que se pode afirmar, com segurança, é a tendência a relocalização de indústrias que saíram da aglomeração paulistana mais densa para área com mais amenidades no interior do Estado de São Paulo. Ao menos esse processo parece ser ponto 
pacífico entre os autores, que diferente no tocante aos limites / ao raio que essa desconcentração teria atingido em linhas mais gerais.

Importa afirmar, além disso, que ocorreu e ocorre uma disjunção funcional entre o chão de fábrica, que pode funcionar distante da sede administrativa da empresa. Esta tende a permanecer na metrópole.

$\mathrm{Na}$ obra de A. Fischer (2008) se explica como alguns circuitos produtivos, anteriormente verticalizados na própria fábrica da indústria fordista, se reestruturam de maneira a promover especialização em cada etapa do circuito. A especialização é permitida pela disjunção funcional entre as unidades que comporiam uma cadeia, mas é acompanhada de integração espacial garantida principalmente por fluxos imateriais que propiciam comunicação instantânea.

.Dessa forma, conforme apontado por Lencioni (1994) ocorreu um movimento expressivo de afastamento da indústria em relação ao centro da metrópole que pode ser qualificado como desconcentração concentrada, pois ao mesmo tempo em que se esvazia de conteúdo industrial, no sentido da produção propriamente dita, ocorre centralização das funções de gestão e comando destas atividades industriais. A mesmo autora, identificando a ocorrência propõe sua interpretação nos termos de uma cisão territorial da indústria (LENCIONI, 2003), pois apesar da separação física entre sede e chão de fábrica, é importante considerar onde estão alocadas as atividades de comando que irão definir o que ocorre nos demais pontos do território.

2.7. A ação governamental no contexto do neoliberalismo

Na chamada "década perdida" de 1980 as atenções estiveram voltadas para o controle da inflação e os ajustes fiscais necessários para equilibrar as contas nacionais. Apenas a partir da metade da década de 1990 ocorreu uma retomada dos planos nacionais, abordando aspectos territoriais, inclusive com uma nova interpretação da configuração territorial do desenvolvimento. Como marco desta retomada é lançado em 1996 (pela primeira vez com em seu formato atual de Plano Plurianual) o PPA Programa Brasil em Ação (1996-1999).

Sob o governo de Fernando Henrique Cardoso, este plano tem como objetivo principal: reforma do aparelho de estado e enfoque em projetos de infraestrutura 
(CARDOSO, 1995), cuja pretensão seria justamente redefinir regionalmente a distribuição dos investimentos e do desenvolvimento.

Algumas alterações são marcantes na presidência de Fernando Henrique Cardoso. Em primeiro lugar, consolida-se o Estado neoliberal proposta na década de 1990, o que ocasiona impacto relevante no investimento industrial direto, pois o Estado não exerceria mais a função de capitanear o investimento, como ocorreu em décadas anteriores (seu papel passa a ser tão somente o equipamento do território por meio de infraestruturas físicas e o estímulo de investimentos por meio de incentivos financeiros). Como mencionado no próprio plano, o Estado tem o papel da arbitragem dos investimentos.

Outro ponto de mudança importante para nossa analise é a retomada do desenvolvimento em bases espaciais, como destacado por A. Galvão e C. Brandão (2003) com a proposta de Eixos Nacionais de Integração e Desenvolvimento em substituição à concepção de polos de desenvolvimento, que eram prevalentes durante a base de planejamento militar. Em linhas gerais podemos apontar a mudança da política do Estado que deixou o investimento direto na base produtiva e sua condição de "empresário industrial", bem como as políticas regionais de desenvolvimento, antes ancoradas em pontos (polos) e, neste momento, tentando alavancar-se por meio da concepção de Eixos Nacionais de Integração e Desenvolvimento.

A ideia dos Eixos Nacionais de Integração e Desenvolvimento permitiu distinguir a abordagem geográfica presente no plano. Suas diretrizes são:

- Complementaridade regional: integração nacional por meio dos investimentos básicos;

- Desconcentração: estímulos para viabilizar novos espaços econômicos;

- Participação privada: privilegia/financia a participação privada;

- Desenvolvimento local integrado: adotar/privilegiar iniciativas integradas que permitam alavancar o desenvolvimento local.

A Nova Política Industrial, preconizada no governo de F. H. Cardoso (1998) divulga diretrizes distintas das que vigoraram durante as décadas de "substituição de importações”. Conforme se avalia no Plano Plurianual de 1996, as políticas de substituição de importações estariam ultrapassadas e seriam as responsáveis pela falta de competitividade da indústria nacional, na medida em que subsídios teriam mantido este 
setor numa "zona de conforto" que impedia a preocupação em incorporar novas tecnologias e desenvolver produtos competitivos no cenário mundial. Portanto, a Nova Política Industrial previa uma reestruturação industrial voltada à maior produtividade e abertura econômica (que influenciaria o fator competitivo dentro das empresas, fazendo-as sair da "zona de conforto", termo usado no próprio plano).

Todavia, também podemos interpretar que o processo de industrialização se desenvolvia com a segurança de ter uma reserva de mercado disponível. Entendia-se que esta segurança atrapalharia a competitividade industrial e impedia alavancar o produto nacional ao patamar de exportação ou mesmo deixava de estimular a inovação nos produtos e processos produtivos. Esta nova conjuntura resulta da perspectiva de

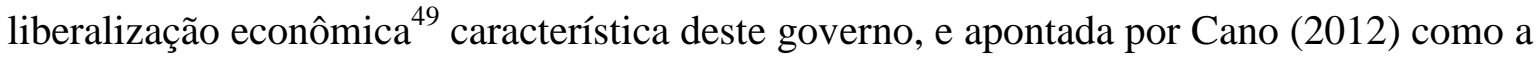
primeira causa que levaria ao processo de desindustrialização.

Além disso, no PPA de 1996, não é mais a indústria o carro-chefe do modelo de desenvolvimento (ou redução das desigualdades inter-regionais do país). Embora as políticas regionais tenham uma nova roupagem, são diferentes daquelas dos Planos Nacionais de Desenvolvimento e expressam territorialmente o investimento em fixos geográficos para ativar estimular e ativar o escoamento da produção para fora do país: o cerne das políticas regionais deste plano é o investimento em infraestrutura econômica visando, ao mesmo tempo, permitir a "integração do território" e ser chamariz de novos investimentos de capitais privados, sejam eles industriais ou não.

Também se observa presente o discurso próprio do desenvolvimento local, atribuído justamente ao contexto neoliberal onde o Estado deve ser visto como mínimo, não interventor, e as possibilidades de desenvolvimento foram "entregues ao local". Como destaca C. Brandão (2007), "o local pode tudo" nessa corrente de pensamento e atuação política, tendo como uma das principais implicações a inércia da escala intermediária entre o local e o global, justamente a escala nacional.

A autora S. Sassen (2007), que refletiu sobre o planejamento em um contexto regional (ou mega-regiões, em suas palavras), aponta que o estímulo à competitividade está profundamente centrado em infraestruturas convencionais, como "[...] transporte de todo tipo, producción y distribuición de agua y eletricidad, aeropuertos, y así sucesivamente" (p. 15). Contudo, a autora está também preocupada com o conteúdo destas mega-regiões no que tange à transferência do crescimento econômico gerado. Por isso, aponta que “[...]

\footnotetext{
${ }^{49}$ Uma "abertura desregrada" (CANO, 2012) que se inicia em 1989 (Governo Sarney), amplia-se no Governo Collor (1990) e prossegue a partir de 1994 (Governo de FHC).
} 
una ciudad o región necesita ser construida sobre las especificidades de su historia económica em ordem a alcanzar una diferenciación especializada" (2007, p.33), que é o que, de certa forma, teria sido buscado, ao menos em teoria, por este plano, no sentido clássico de "aproveitamento das vocações locais/regionais".

Diga-se, de passagem, que a ideia de integração do território nestes planos, nada mais é do que uma integração entre corredores de escoamento da produção em direção aos pontos de saída do território, como os portos e as ligações com os países do Mercosul. O Plano Brasil em Ação é um conjunto de ações para a exportação, visando sua base espacial (que também é considerada a base para a definição do portfólio de investimento) expressa tão somente esta preocupação com logística e exportação. Segundo análise desenvolvida pelos autores Galvão e Brandão (2003), “[...] os eixos passariam a ser regiões, que continham a via de transporte - mediante suas respectivas 'unidades espaciais' - e também o subespaço complementar com 'outras unidades espaciais adjacentes à via de transporte" (pp.197-198).

Precisamos destacar que, nesta perspectiva, não é considerada a totalidade do espaço, mas apenas as parcelas que mais interessavam às atividades produtivas, sobretudo voltadas à exportação. Muitos conteúdos ficaram de fora e não participaram do planejamento, sendo apenas áreas adjacentes aos eixos que não receberam atenção:

A espacialidade da logística específica dos grandes projetos infraestruturais prevaleceu sobre a pesada dimensão espacial, efetivamente regional, da pobreza e de outros campos de preocupação das ações governamentais (GALVÃO e BRANDÃO, 2003, p.198).

Do ponto de vista da atenção à escala local, que se traduz num estímulo ao empreendedorismo local e às "vocações regionais", ganham fôlego linhas de fomento voltadas aos arranjos produtivos locais que, por definição, contemplam a história e o conhecimento acerca de um ramo produtivo na figura de empresários locais em um município ou região, que potencialmente apresentam características para alavancar processos produtivos empreendedores.

Os arranjos produtivos locais foram e tem sido estimulados pelo governo federal e analisados/trabalhados em conjunto, via de regra, pelas unidades estaduais do Serviço de Apoio às Micro e Pequenas Empresas (SEBRAE), as federações industriais e também secretarias estaduais. Sua raiz local e a possibilidade de fomento ao empreendedorismo atrelado à filosofia do APL vêm ao encontro das perspectivas do 
planejamento econômico do período, que ao mesmo tempo passou a invalidar o papel do Estado como investidor direto, conforme ocorria nos períodos anteriores.

Ao mesmo tempo, os distritos industriais (na condição de formas, até então, mais importantes para a organização territorial da indústria) passaram a ser competência dos municípios interessados, tanto no que tange à administração dos distritos já existentes, quanto na abertura de novos distritos. Essa transferência de responsabilidade, que acontece paulatinamente, também demonstra a transição do Estado na condição de primordialmente interventor ou mesmo empresário para primordialmente apoiador.

Nas próximas duas gestões presidenciais, na figura de Luís Inácio Lula da Silva, também dois Planos Plurianuais foram apresentados, ambos com concepções similares, o que nos permite também uma análise conjunta. O primeiro deles foi Plano Brasil de Todos (2004-2007) que expressa, senão as mesmas concepções para a indústria, contexto muito parecido com o período de Cardoso: o investimento industrial é difuso no território, contempla iniciativas pontuais e, em geral, é orientado por incentivos ou financiamento.

Em relação à matriz espacial, por outro lado, os eixos de desenvolvimento sujeitos a críticas - são deixados de lado e não é apresentada nenhuma forma que possa ser definida como a "visão espacial" do plano, mas menciona-se como metodologia "regionalizar e tipificar outorgando prioridade na atuação a regiões cronicamente deprimidas”. Independentemente de uma regionalização proposta ou evidente, a questão regional existe e ganha aspectos sociais e culturais mais pronunciados como novidade em relação aos planos e programas anteriores. No Megaobjetivo II, meta 20, é mencionado: "Reduzir as desigualdades regionais e intra-regionais, valorizando identidades e diversidades culturais, estimulando a participação da sociedade no desenvolvimento local" (BRASIL, 2004, p.3).

A redução das desigualdades regionais comparece com bastante ênfase durante todo o texto e, inclusive, está na própria concepção do planejamento, conforme se menciona: "A atividade de planejamento é entendida como coordenação e articulação dos interesses públicos e privados no sentido de minorar a pobreza da população, minimizar as desigualdades sociais e regionais" (BRASIL, 2004, p.7).

Uma evidência de que a indústria deixara de estar no centro das propostas econômicas para enfrentamento das desigualdades regionais, também durante a gestão de Lula, se mostra por meio de uma das diretrizes deste plano: o estímulo às organizações econômicas associativas e solidárias como estratégia para o desenvolvimento local 
sustentável. O enfoque localista é ainda mais enfático nesse período em relação aos PPA de Fernando Henrique Cardoso, muito embora não se apresente no plano nenhuma definição clara do que venha a ser o "desenvolvimento local sustentável", termo adotado nos planos. Uma importante iniciativa para isso foi a criação do Grupo de Trabalho Permanente para Arranjos Produtivos Locais (GPT APL) instituído em agosto de 2004 e envolvendo 23 instituições governamentais e não-governamentais ${ }^{50}$, reforçando a concepção e planos de trabalho envolvendo os APL, já mencionados.

Neste período, o crescimento dos arranjos produtivos locais é notável como importante forma de aglomeração. Isso permite analisar a organização e a configuração territorial da indústria no "Brasil não industrial", ou seja, no Brasil do interior dos estados, eventualmente fora das capitais e regiões metropolitanas ${ }^{51}$.

Finalmente, precisamos avaliar que, em linhas gerais, a estratégia deste plano parece enfocar outra dimensão da sociedade; espera-se um "crescimento via consumo de massa", que seria sustentado por ganhos de produtividade. Em outras palavras, o foco estaria nas políticas sociais geradoras de renda para a população mais pobre que, por consequência, reduziria a pressão na oferta de mão de obra sobre o mercado de trabalho e favoreceria, a seu tempo, a transmissão dos aumentos de produtividade aos salários. Essa estratégia aumentaria o poder de consumo da população como um todo, aproveitando o vasto mercado consumidor brasileiro que, em tese, influenciaria um aumento da produção em geral.

A atividade produtiva estaria amparada pelo Estado por meio de investimentos voltados à modernização de cadeias produtivas exportadoras e competidoras, mostrando também a ênfase exportadora do plano para as políticas industriais.

No PPA seguinte (2008-2011) denominado "Desenvolvimento com Inclusão Social e Educação de Qualidade", a ênfase nos investimentos em infraestrutura ganha mais força com o lançamento do Programa de Aceleração do Crescimento (PAC), que se materializa em um grande portfólio de obras públicas. Por fim, um ponto que se destaca

\footnotetext{
50 Atualmente, o GTP APL tem sua atuação focada em 267 arranjos considerados prioritários e indicados pelos núcleos de apoio estaduais. O critério de prioridade tem relação com a promoção da diversidade setorial e o desenvolvimento regional.

${ }^{51}$ Embora se tenha criado o Grupo de Trabalho, uma das dificuldades dos PPA durante o Governo Lula, especificamente sobre os Arranjos Produtivos Locais é distinguir as ocasiões nas quais se fomentam APL industriais ou não. Além de ser uma aglomeração industrial, o APL é também uma aglomeração produtiva e pode constituir-se por empresas de serviços ou turismo, por exemplo. A concepção do PPA é abrangente, assim como dos arranjos produtivos locais. No que tange aos APL, são encontrados nas capitais e no interior dos estados, e podem envolver micro e pequenas empresas (mais comumente), mas também oferecer apoio às empresas de grande porte aglomeradas por região ou segmento produtivo.
} 
neste PPA, confirmando ainda a importância com que segue o discurso da questão regional, é a recriação de agências regionais de desenvolvimento, casos da SUDENE e SUDAM, com objetivo declarado de desburocratizar os investimentos, sobretudo atuando na questão ambiental e acelerando investimentos nas regiões Nordeste e Norte do Brasil.

2.8. Indicadores dos últimos vinte anos: uma leitura sobre a desindustrialização

Para melhor interpretar o processo de desindustrialização, que o país atravessa desde a década de 1980, com maior ênfase a partir dos anos 1990, vale abordar sua conceituação principal. Há um domínio dos economistas na construção destas análises, por meio dos modelos estatísticos. Em linhas gerais, a maioria deles aponta a desindustrialização como a redução relativa da participação da indústria na economia, quer seja em termos do número de empregos industriais ou do valor adicionado (abordagem tradicional), como ressaltam J. A. Silva e A. Lourenço (2014) ou, conforme análise de W. Cano (2012) considerando a estrutura de exportações e o PIB (total x setorial).

Considerando a análise do Instituto Brasileiro de Economia (IBRE/FGV), em um traço histórico, a parcela da produção da indústria no PIB brasileiro saiu de $20 \%$ (em 1947) para o pico de 36\% (1985) para então chegar aos 16\% (em 2008). Podemos mencionar que "[...] há ainda a abertura comercial de 1990 a 1992, praticada em um contexto de recessão doméstica, que também parece ter provocado um impacto significativo no mesmo sentido" (IBRE, 2010, p.9), na visão da instituição. Na busca pelas raízes deste processo, Cano assevera que se trata tão somente da “[...] continuidade de uma crise muito longa, que vem desde o fim da década de 1970” (2012, p.17).

Portanto, tentaremos nesta seção, seguindo o padrão de apresentação de cada momento histórico já abordado, analisar conjuntamente as ações do governo federal considerando as implicações da abertura econômica e comercial - bem como os indícios de desindustrialização que se manifestam com maior expressão neste período. Neste ínterim, destacaremos como se desenvolvem as formas aglomerativas a fim de responder à dada conjuntura. 
Uma aproximação da distribuição industrial no Brasil, para o respectivo período, pode ser definida por meio de dados secundários relacionados à indústria, utilizando como indicadores o número de estabelecimentos e de empregos ${ }^{52}$.

A Tabela 1 mostra, para os quatro anos consultados, um balanço simples dos números absolutos de estabelecimento e também de emprego em cada década, iniciando em 1985 (em que pela primeira vez foram divulgados publicamente os resultados do levantamento cadastro do Ministério do Trabalho e Emprego), até o ano de 2013.

TABELA 1

BRASIL - Indústria de transformação, total de estabelecimentos e empregos (1985-2013)

\begin{tabular}{c|c|c|c}
\hline Ano & $\begin{array}{c}\mathbf{N}^{\mathbf{0}} \text { de estabelecimentos / } \\
\text { (\% crescimento) }\end{array}$ & $\begin{array}{c}\mathbf{N}^{\mathbf{0}} \text { de empregos / } \\
\text { (\% crescimento) }\end{array}$ & $\begin{array}{c}\text { Razão empregos / } \\
\text { estabelecimentos }\end{array}$ \\
\hline 1985 & 141.548 & 5.213 .804 & 36,8 \\
1995 & $208.745 /(47,5)$ & $4.906 .412 /(-5,9)$ & 23,5 \\
2005 & $280.618 /(34,4)$ & $6.133 .461 /(25,0)$ & 21,8 \\
2013 & $377.292 /(34,5)$ & $8.292 .739 /(35,2)$ & 21,9 \\
\hline
\end{tabular}

Fonte: Elaboração do autor com base na Relação Anual de Informações Sociais (RAIS) - Ministério do Trabalho e Emprego (MTE, 2013).

Em primeiro lugar, existem mais unidades industriais no país. Desde 1995, considerando as duas décadas seguintes, o número total de estabelecimentos da indústria de transformação aumentou em média 34,5\%. Em 1985 o Brasil tinha 141 mil unidades, número aumenta 47,5\% na década seguinte, segue crescendo até 377 mil unidades industriais no ano de 2013 (com crescimento de 34,5\% em relação a 2005). Dessa forma podemos afirmar que o número de indústrias aumentou nos últimos 20 anos, apesar do ritmo de crescimento desse número ter diminuído, se comparado com o período 1985 1995.

Do ponto de vista do estudo de aglomerações industriais, esta é uma informação importante, visto que, a partir deste contexto cresce potencialmente o número de estabelecimentos industriais que demandam espaços organizados ou se configuram em clientes de um mercado imobiliário de loteamentos e galpões que também cresceu no mesmo período.

\footnotetext{
${ }^{52} \mathrm{O}$ número de estabelecimentos, embora seja um variável relativamente simples, é importante para nossa pesquisa pois é a que, mais diretamente, pode mostrar o número real de unidades industriais efetivamente instaladas e ativas em um dado território. Assumimos que quanto maior o número de indústrias, mais a possibilidade de existirem aglomerações industriais, já que não encontramos nenhum estado que se destaque em termos de políticas públicas estritamente voltadas para aglomerações industriais que o fariam diferenciarse dos demais. Todavia, o número de empregos formais da indústria pode ser considerado um indicador clássico do peso industrial de um determinado território, embora seja essa uma escolha não isenta de críticas.
} 
Em relação à dinâmica apresentada pelo número absoluto de empregos na indústria e sua evolução, muitos outros fatores influentes exigem maior esforço para interpretação dos números da Tabela 1 . O que se verifica é também um crescimento em números absolutos, acompanhando o crescimento das unidades industriais: o número de empregos na indústria era de 5 milhões em 1985, passando para 8 milhões em 2013. Se considerarmos os dados mais próximos à última década (1995-2013) o crescimento no número total de empregos chega a 35,2\%.

Ante o aumento dos números absolutos devemos considerar a razão de empregabilidade da indústria. Este indicador, por sua vez, mostra crescente diminuição da capacidade da indústria de transformação em absorver mão de obra. Uma forma de verificar essa ocorrência é observar a razão entre o número de estabelecimentos e o número de empregos registrados. No caso dos últimos 30 anos uma razão bem menor seria esperada, como de fato se deu: em 1985 cada estabelecimento industrial empregava 36,8 pessoas em média, valor que se reduziu para 21,8 e 21,9 em 2005 e 2013, respectivamente.

Comparativamente, em 1985 a razão empregos/estabelecimentos era de 36,8 ao passo que, nas últimas duas décadas, mantiveram-se na média de 21,8.

Seria de se esperar que o emprego industrial sempre acompanhasse positivamente o número de unidades industriais, mas as novas tecnologias de produção, visando maior eficiência e competitividade (o que muitas vezes significa eliminação do estoque de vagas de trabalho direto) impactam negativamente no emprego industrial. Essa dinâmica foi especialmente influente a partir da chamada reestruturação produtiva, como se pode verificar em G. Benko (1996), entre outros autores.

Conforme indicado pelo IBRE, em análise que parte dos dados das Pesquisas Industriais Anuais, “[...] o emprego industrial reportado pelas empresas aumentou de 7,44\% da população total ocupada, em 1996, para 8,35\%, em 2008" (IBRE, 2010, p.9). Outro importante indicador diz respeito ao investimento industrial. Do ponto de vista dos investimentos internos, corroborando essa aparente tendência de ampliação industrial, o IBRE indica que aconteceu aumento de 4,1 pontos percentuais, quando saiu do patamar de 14,4\% em 1996 para 18,5\% em 2008. Todavia, e mais importante como causa explicativa, o investimento estrangeiro apresenta forte queda nas últimas décadas.

De acordo com análise de Cano (2012), a participação da indústria de transformação no montante dos investimentos externos girava em torno de $75 \%$ na década de 1980; essa participação cai para 60\% nos anos 90 e cai para 30\%-40\% a partir de 2001. Em termos numéricos, a média anual de investimento externo na indústria era de US\$ 17 
bilhões na década de 1980, sobe para US\$ 25 bilhões na década de 1990 e, bruscamente, cai para US\$ 8,5 bilhões entre 1996 e 2010. O autor assevera que:

Quanto ao investimento interno também se observa fatos semelhantes, predominando a alocação dos serviços, especialmente no setor financeiro, construção, negócios imobiliários, agropecuária e mineração, sendo hoje mais reduzia a participação na indústria de transformação (CANO, 2012, p.5).

Além da já mencionada "reforma liberalizante", apontada como principal causa de desindustrialização ${ }^{53}$, estes números expressam a guinada do investimento externo que se direcionou para a China em busca de trabalho barato, câmbio desvalorizado e alta competitividade (CANO, 2012).

Outro importante dado referencial do processo de desindustrialização é a perda relativa da indústria no Produto Interno Bruto. A Tabela 2 mostra a participação da industrial de transformação brasileira face aos demais setores econômicos, em três períodos selecionados (1989-2001 / 2001-2006 / 2006-2010).

\section{TABELA 2}

BRASIL - Produto Interno Bruto setorial: taxas médias de crescimento (\%)

\begin{tabular}{c|c|c|c}
\hline Ano & $\mathbf{1 9 8 9 - 2 0 0 1}$ & $\mathbf{2 0 0 1 - 2 0 0 6}$ & $\mathbf{2 0 0 6 - 2 0 1 0}$ \\
\hline PIB Agrícola & 3,8 & 3,9 & 3,5 \\
PIB Industrial $(*)$ & 1,4 & 2,8 & 2,3 \\
PIB Serviços & 2,4 & 3,2 & 4,6 \\
PIB Total & 2,2 & 3,0 & 4,6 \\
\hline
\end{tabular}

Fonte: Adaptação do autor com base em Cano (2012), utilizando dados IPEA-Data.

(*) Foram considerados somente os dados relativos à Indústria de Transformação.

Com base nos números comparativos entre os respectivos segmentos da economia, podemos avaliar como decresce relativamente o PIB Industrial em relação aos demais. O PIB Industrial apresenta-se sempre abaixo do PIB Total (-0,8 entre 1989-2001 / -0,8 entre 2001-2006 e, finalmente, -2,3 de diferença no último período de 2006-2010). O PIB de Serviços descreve um caminho positivo e equilibrado: +0,2 entre 1989-2001 / +0,2 entre 2001-2006 e localizado no mesmo patamar de crescimento do PIB brasileiro entre 2006 e 2010.

\footnotetext{
${ }^{53}$ Associa-se a política cambial instaurada a partir do Plano Real, cuja política de estabilização e o câmbio excessivamente valorizado ancorou os preços de forma que o produto nacional perdeu competitividade internacional perante outros países.
} 
A Carta 499 do Instituto de Estudos Para o Desenvolvimento Industrial (IEDI), de 23 de dezembro de $2011^{54}$, reafirma que em 2011 ocorreu um agravamento da crise industrial, deflagrando menor ritmo de crescimento com as causas então conhecidas e reafirmadas: (1) elevação da taxa de juros, (2) contenção do crédito, (3) corte de despesas públicas e (4) expectativas negativas decorrente do agravamento da crise nos países centrais. Dessa forma, a análise do respectivo instituto aponta como consequência o seguinte contexto:

Esses fatores esmoreceram a evolução do consumo e do investimento privado, afetando em primeira mão a indústria que, paralelamente, sofria os efeitos intensos de uma aguda carência de competitividade, graças a um câmbio que desde 2006 vem minando sua competitividade e a uma acumulação de custos sistêmicos que transformou o Brasil em uma das economias mais caras para se produzir em todo o planeta (IEDI, 2011).

Uma publicação recente da Organização das Nações Unidas (Trade and Development Report, 2016) analisa as tendências de desindustrialização no mundo. Segundo a avaliação da ONU, os países da América do Sul que tiveram processos de industrialização expressivos (Brasil e Argentina) teriam iniciado uma tendência ao arrefecimento e diminuição já na década de 1970, intensificando-se nos anos 1990, devido ao abandono das políticas desenvolvimentistas e à abertura comercial.

The abandonment of long-standing industrialization strategies, beginning in the Southern Cone in the late 1970s, followed by aggressive structural adjustment were clearly factors contributing to such an outcome. The declining trends were generalized throughout the region following the debt crisis in the 1980s and the policy conditionalities imposed by the International Monetary Fund and the World Bank (ONU, 2016).

Mesmo assim, a organização assevera que o Brasil passaria por uma desindustrialização precoce ${ }^{55}$ e seria o mais expressivo caso na América do Sul devido à relevância de sua economia.

Os dados utilizados para esta análise revelam a queda na participação da indústria no valor adicionado e emprego industrial no Brasil. Em 1970 a indústria tinha uma participação de 27,4\% no valor adicionado, chegando a $31 \%$ da década de 1980 .

\footnotetext{
54 Disponível em: 〈http://iedi.org.br/cartas/carta_iedi_n_499_industria_e_economia_brasileira_na_atualidade.html > Acesso: junho de 2016.

55 A desindustrialização é considerada precoce quando uma economia industrial não atinge toda a sua potencialidade, quando se espera que ela evolua para o setor terciário (indústria de serviços com alto valor agregado) e invista em formação profissional e ciência e tecnologia. Opostamente, a desindustrialização precoce faria a economia "regredir" para a atividade agrícola ou tornar-se informal (ONU, 2016).
} 
Contudo, em 2014 observa-se uma queda de 20 pontos percentuais, quando a participação da indústria regride para o patamar de 10,9\%. Em termos de emprego industrial a participação era de 13,3\% em 1970, chegando a 14,7\% em 1990 e regredindo para 11,5\% em 2011 (queda de 3,2\% pontos percentuais).

Nesse escopo, diferente do crescimento exuberante verificado no período 19501970, pautado na consolidação do parque industrial nacional, a partir da "década perdida" e, com maior ênfase a partir dos anos 2000, o quadro que se verifica no Brasil é de perda da participação relativa da indústria. Muito embora, como verificamos inicialmente a partir do número de estabelecimentos e empregos, não ocorre diminuição do número de indústrias, mas sim sua produtividade e competitividade. Evidentemente, não se pode afirmar que exista unanimidade sobre o processo de desindustrialização. Além disso, diversas formas de interpretá-lo estão em uso. A perspectiva ponderada do IBRE indica que, mesmo sob a ótica dos que advogam sobre a desindustrialização, "[...] há o reconhecimento de que não existe nenhum processo avassalador em curso" (2010, p.8).

Para Brandão (2007), a década de 1990 pode ser caracterizada como um "ambiente de baixo crescimento", justamente com características desfavoráveis ao crescimento industrial, e é no âmbito deste quadro que, atualmente, precisamos considerar a interpretação das formas de aglomeração industrial. Ainda sobre a desindustrialização, L. P. Lamoso (2014) analisa que a maior dificuldade não é quantidade de variáveis ou indicadores que podemos considerar para chegar a uma conclusão definitiva sobre o processo, mas quanto à diversidade de formações espaciais dos diferentes países, de forma que:

Um mesmo fenômeno de desindustrialização pode representar resultados diferentes quando ocorre em territórios diferentes, pois cada país tem uma capacidade de resposta aos desafios que lhe são postos pelo curso do desenvolvimento econômico (LAMOSO, 2014, p. 426).

Neste contexto, vale a pergunta: o que as aglomerações mostram sobre a estruturação do território, atualmente? O que verificamos no período é que um contexto completamente diferenciado dos anteriores deu margem à reorientação das formas de aglomeração industrial para perspectivas diferentes e contraditórias:

- Iniciativas de base empreendedora/localista por meio de fomentos federais ao passo que a responsabilidade pela organização dos distritos industriais é "rifada" entre administrações municipais, associações dos 
empresários (em raras ocasiões em que se consegue articular uma associação) ou, quando muito, secretarias estaduais.

- Privatização das grandes empresas estatais, como evidente nos casos dos polos de Camaçari, Triunfo e Capuava que passaram ao controle prioritário da Braskem-Odebrecht na década de 1990 ao passo que, aproveitando-se das então antigas e, em sua maioria, "ultrapassadas" áreas industriais, os investidores imobiliários entram no mercado com um novo produto, a partir de uma racionalidade condominial e objetos técnicos concernentes às tecnologias e rapidez do período atual, que tem se mostrado capaz de atender e atrair médias e pequenas indústrias.

Brandão interpreta a década de 1990 como um período em que os setores produtivos foram expostos - alta e abruptamente - à competição internacional, resultando na dominação da "especialização regressiva”, ou seja: “[...] concentrando ainda mais nossa estrutura industrial na produção de bens pouco elaborados, com pequeno valor agregado e com poucas perspectivas dinâmicas nos mercados internacionais" (BRANDÃO, 2007, p.160). Como decorrência, os segmentos produtores de bens de capital foram penalizados com perda de sua capacidade competitiva quando se somou a crise da década de 1980 com a falta de uma política de coordenação produtiva. Como tentamos mostrar citando alguns planos e o contexto da década de 1980, o foco das atenções recai na política cambial e tentativa de controle da inflação.

Inclusive, Brandão pondera que as plantas de maior conteúdo tecnológico e complexidade $^{56}$ tiveram sua decisão locacional implicada no polo de maior dinamismo, devido à rede de relações existentes e necessidades como mão-de-obra qualificada, ambiente científico, difusão rápida das tecnologias de base eletrônica, etc. A mesma dinâmica é evidenciada por Diniz e Crocco (1996): embora se tenha identificado certa desconcentração na década de 1970, a qual poderíamos chamar de desconcentraçãoconcentrada (ou centralizada), de acordo com Lencioni (1994), essa desconcentração tem um limite determinado pela "Região Centro-Sul” (DINIZ e CROCCO, 1996).

[...] o processo de reestruturação relacionado com as mudanças tecnológicas e organizacionais e a consequente emergência de novos setores industriais tende a restringir o processo de desconcentração macro-espacial, retendo o crescimento em cidades de porte médio, próximas às grandes capitais do Centro-Sul ou mesmo em áreas metropolitanas de menor dimensão dentro dessa região (DINIZ e CROCCO, 1996, p.87).

\footnotetext{
${ }^{56} \mathrm{O}$ autor refere-se a ramos como os de máquinas-ferramenta, automação industrial, telecomunicações, informática, eletrônica, fármacos e biotecnologia. $C f$. Brandão, 2007.
} 
Principalmente se a empresa estiver dentro de um contexto de reestruturação produtiva pós-fordista, voltada para o desenvolvimento tecnológico, sua limitação locacional é ainda maior, estando restrita ao polígono onde estaria a maior base universitária de pesquisa, infraestrutura de transportes e telecomunicações, bem como a maior rede urbana do país, "[...] pré-requisito para a implantação da indústria de alta tecnologia", conforme lembram os autores (DINIZ e CROCCO, 1996).

Em uma visão geral, os limites da desconcentração estariam contidos em dois grandes eixos: o primeiro deles seria em direção aos estados da Região Sudeste e Sul - ou Região Concentrada (SP, RJ, MG, ES, PR, SC e RS) -, os quais teriam se beneficiado muito dos efeitos do crescimento industrial das últimas décadas. Na visão dos autores: crescimento agrícola, aumento da renda e melhoria dos serviços urbanos (DINIZ e CROCCO, 1996), e também das possibilidades (potenciais) alavancadas pela proximidade com outros países que formam o MERCOSUL. O outro eixo seria no sentido da região central do Estado de Minas Gerais onde se conforma importante encadeamento com indústria metalúrgica por parte da indústria automobilística e demais componentes (DINIZ e CROCCO, 1996). Esses eixos constituiriam parte importante onde se manifesta a "mancha" industrial do Brasil, sua mais extensa e densa aglomeração.

Por outro lado, demais manifestações pontuais coexistem e não podemos sequer afirmar que perderam dinamismo, apesar do contexto de aparente estagnação. $\mathrm{O}$ próprio autor ressalta que foram orientados por presença de recursos naturais ou por políticas governamentais que estavam maturando ainda na década de 1990 (BRANDÃO, 2007). Para Diniz e Crocco (1996) as áreas industriais dispersas no restante do território nacional fazem parte de uma antiga área industrial vinculada a uma grande concentração populacional ou se originam dos sistemas de incentivos fiscais regionais.

Elas não demonstram força para uma alteração macro-espacial da localização industrial no Brasil embora o crescimento da fronteira agrícola continue acelerado e o sistema de incentivos fiscais tenha sido mantido e até ampliado (DINIZ e CROCCO, 1996, p.87).

Dessa forma, fica bastante claro, também como já vimos desenvolvendo durante a análise dos planos de desenvolvimento econômico, que os pontos luminosos ${ }^{57}$

\footnotetext{
${ }^{57}$ Os pontos luminosos ou, por definição, os espaços luminosos são aqueles que mais acumulam densidades técnicas e informacionais e, assim ficam "[...] mais aptos a atrair atividades com maior conteúdo em capital, tecnologia e organização" (SANTOS e SILVEIRA, 2011, p.264). Em oposição, os espaços onde estas características estão ausentes poderiam ser chamados de espaços opacos.
} 
fora dessa mancha industrial (sobretudo na Região Nordeste do país) apresentam sua origem vinculada principalmente à ação direta do Estado desenvolvimentista, quer seja com ofertas de subsídios fiscais, que seja na figura própria do empresário, essas formas de aglomeração industrial - mais evidentes, mais facilmente identificáveis - tem a origem na ação direcionada do poder público.

Como evidenciaremos nas análises seguintes, o Estado de São Paulo além da maior concentração de fábricas, é também a unidade estadual que apresenta maior número e diversidade de aglomerações industriais. Praticamente todos os tipos de formas aglomerativas podem ser encontrados no Estado de São Paulo e também distribuídos nos eixos de ligação rodoviários que o conecta ao Rio de Janeiro, Minas Gerais e Paraná. Além disso, também mostraremos que os estados mais expressivos da Região Concentrada são aqueles que apresentam as iniciativas mais recentes, inovadoras, bem como os planos de recuperação / modernização das áreas quando necessário ${ }^{58}$.

Também como processo relevante, mostraremos como a expressão industrial encontrada em estados nordestinos como Ceará e Bahia, está também atrelada - em sua base material - às aglomerações industriais. O Distrito Industrial de Fortaleza alberga as mais importantes indústrias cearenses, ao passo que a Bahia tem sua maior relevância industrial concentrada no Polo Petroquímico de Camaçari e Centro Industrial do Subaé, ambas as áreas abordadas diretamente no decorrer do trabalho. A mesma situação se pode apontar para o Estado do Amazonas, que industrialmente é sustentando pelas políticas oriundas da Zona Franca de Manaus, que fisicamente se organiza como um distrito industrial em seu formato mais tradicional possível, aos moldes brasileiros.

\footnotetext{
${ }^{58} \mathrm{O}$ Estado de Minas Gerais, que foi também pioneiro na implantação de distritos industriais, iniciou em 2015 o Programa de Revitalização e Modernização dos Distritos Industriais de Minas Gerais.
} 


\section{CAPÍTULO 3}

\section{SELETIVIDADE E PRODUTIVIDADE ESPACIAL: UMA ANÁLISE ATUAL A PARTIR DAS AGLOMERAÇÕES INDUSTRIAIS}

Uma vez construída a base interpretativa necessária para a compreensão das aglomerações industriais existentes no território nacional, sua importância e direta associação com os processos - históricos e geográficos - da industrialização no Brasil, apresentaremos uma análise que integre a perspectiva da localização industrial e sua seletividade espacial.

O ponto de partida para a interpretação que realizaremos neste capítulo é a própria distribuição geográfica da indústria e as características do território nacional. Não podemos fazer a leitura da seletividade espacial associada aos investimentos industriais por meio das aglomerações, exclusivamente. Tampouco isso deve ser feito unicamente observando a configuração territorial (fixos, fluxos, normas). Uma visão mais completa das formas de aglomeração deve considerar a configuração territorial e os investimentos como influências complementares nas decisões microeconômicas.

Estas condições, selecionadas para interpretar a localização da indústria por meio de uma leitura geográfica, mostra que os investimentos não são "cada vez mais independentes" ou se tornariam "livres" das condições territoriais. Pelo contrário, para investir com um grau de assertividade elevado se busca condições territoriais específicas (diretamente relacionado à especificidade do segmento produtivo). Ou seja, estamos considerando que quanto mais específica é a atividade, mais específica tende a ser sua localização ${ }^{59}$. Este é um dos pontos de partida para interpretarmos as decisões de localização ${ }^{60}$ no período atual e, proporcionalmente, à difusão do meio técnico-científicoinformacional.

\footnotetext{
${ }^{59}$ Esse pressuposto foi identificado por autores como G. Benko (1996) e M. Castells (1999).

${ }^{60}$ Para a elaboração deste capítulo consideraremos as tendências identificadas quanto à implantação das aglomerações industriais, identificadas por meio das leituras e dos trabalhos de campo realizados durante a pesquisa.
} 
Mais uma vez, considerando o pressuposto básico de que o território precisa ser preparado para a localização das atividades econômicas, entre outros processos, isso induz à diferença entre parcelas do território, concomitantemente valorizando e desvalorizando, fazendo com que algumas tenham maior produtividade espacial.

É evidente que, independentemente da escala de análise - nacional, estadual ou regional -, não existem condições homogêneas. A diferenciação é uma característica do território, tanto em suas condições naturais quanto em suas características sociais historicamente determinadas. Assim, algumas de suas parcelas reúnem certas características que podem fazer com que sejam mais "produtivas" para uma ou para outra atividade. A premissa de que cada parcela do território não é capaz de rentabilizar igualmente uma mesma produção é fundamental. Foi sintetizada por M. Santos da seguinte maneira: “[...] cada combinação tem sua própria lógica e autoriza formas de ação específicas a agentes econômicos e sociais específicos" (2004 [1996], p.247).

Mais detalhadamente, são condições técnicas locais (equipamentos, infraestrutura e acessibilidade) e condições normativas locais (leis, impostos, relações trabalhistas, tradição laboral) que, somando-se, resultam em maior ou menor produtividade espacial. A busca por rentabilidade de qualquer investimento econômico talvez seja sintetizado em sua localização: “[...] assim como se fala de produtividade de uma máquina, de uma plantação, de uma empresa, podemos, também, falar de produtividade espacial ou produtividade geográfica" (SANTOS, 2004 [1996], p.248).

Os investimentos privados precisam garantir uma taxa de retorno, sua intencionalidade é autocentrada e a ligação com o conjunto do território, mesmo quando se manifesta localmente, tende a ser restrita. Por vezes, há maior ligação com localizações distantes do que, propriamente, com a cidade na qual funciona uma fábrica. O Estado pode tentar equalizar condições de infraestrutura e estímulo aos investimentos, e isso ocorre (ou deveria ocorrer) de maneira proporcional às diferentes densidades e às diferentes necessidades existentes em cada região. Todavia, também a iniciativa do Estado responde a interesses de grupos econômicos e/ou se choca com políticas de atração específicas de cada unidade estadual ou cada município. Nesse modelo, a totalidade do território nacional fica negligenciada e se mantêm ativas as diferenças regionais.

Para auxiliar nossa interpretação a partir das diferentes densidades e dinâmicas que caracterizam algumas parcelas específicas no Brasil, bem como para podermos explorar as diferentes expressões do meio técnico-científico-informacional no Brasil, consultamos a proposta de M. Santos e M. L. Silveira, que sintetizam uma divisão regional 
básica do território nacional em Quatro Brasis (SANTOS e SILVEIRA, 2001). A figura abaixo (Figura 2) mostra esta elaboração. As regiões brasileiras são abordadas de acordo com períodos explicativos (meio natural / meio técnico / meio técnico-científicoinformacional ${ }^{61}$ ).

FIGURA 2

Os Quatro Brasis (Segundo proposta de Milton Santos e Maria Laura Silveira)

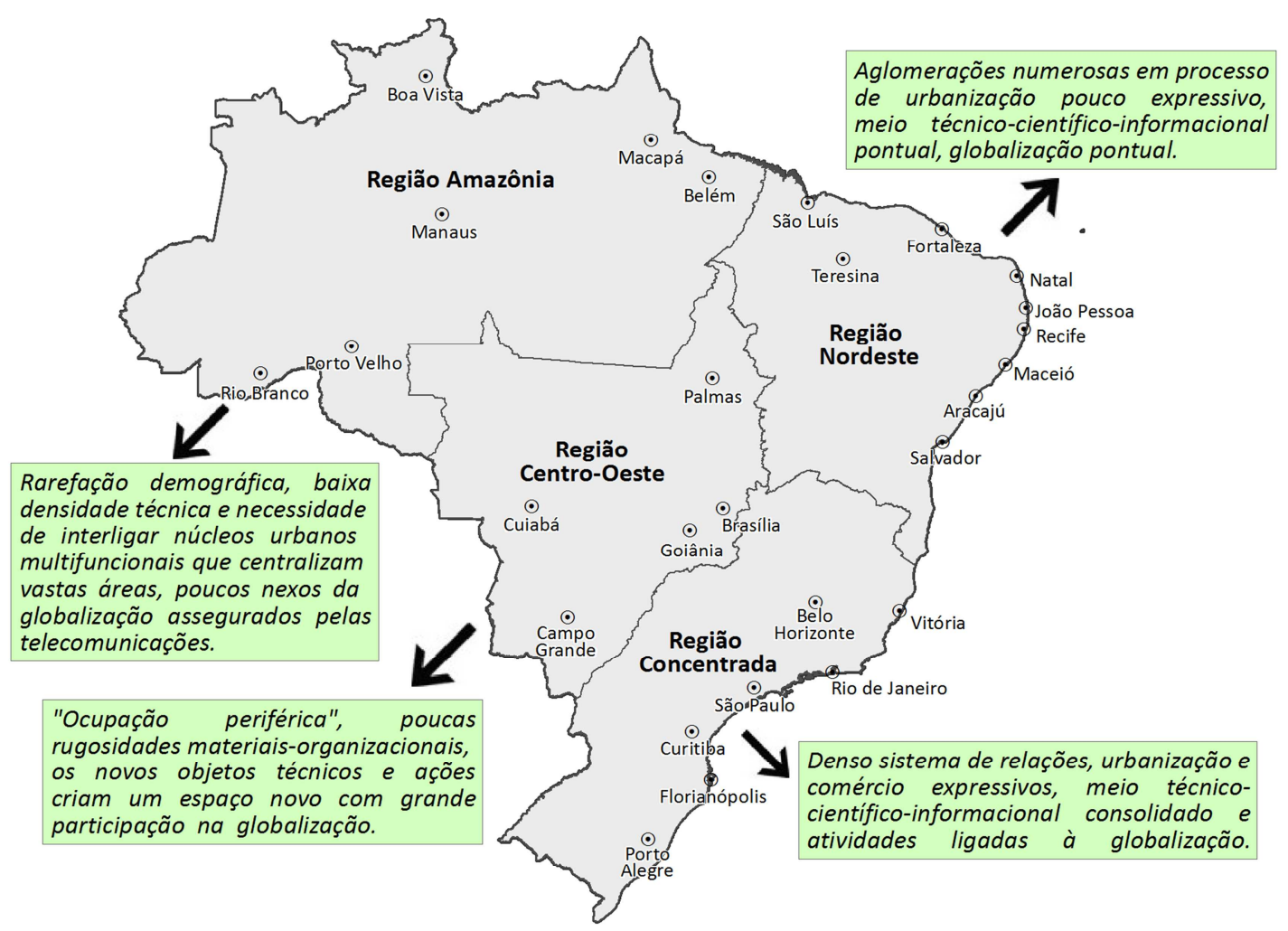

Fonte: Santos e Silveira (2001) | Organização: Rodolfo Finatti (2015)

Uma vez que se pode compreender a formação destas regiões em suas condições históricas e geográficas principais, relacionadas à formação espacial brasileira, podemos associá-las com as características próprias que as aglomerações industriais assumem, em cada período, em cada região.

A Região Concentrada é onde se verifica maior densidade e dinamismo econômico, bem como é mais bem consolidado o meio técnico-científico-informacional no Brasil. É nesta região onde se localiza o mais antigo e diversificado parque industrial e também onde ocorreram, na década de 1940, as primeiras iniciativas de constituição de

${ }^{61} \mathrm{O}$ meio técnico-científico-informacional, expressão do meio geográfico no período contemporâneo e também da globalização em curso no planeta, denota a relação cada vez maior entre a técnica (relação do homem com o meio) e a ciência, ao passo que a informação passa a ser incorporada de maneira decisiva como uma das variáveis definidoras das características contemporâneas. Reforçando a definição do que seria o meio e período técnico-científico-informacional, considera-se que "[...] a ciência e a tecnologia, junto com a informação, estão na própria base da produção, da utilização e do funcionamento do espaço e tendem a constituir o seu substrato" (SANTOS, 2004 [1996], p.238). 
distritos industriais (planejados), já denotando uma tendência à concentração e áreas industrialmente mais densas. Os sistemas de circulação e comunicação, primordiais para a indústria, também são mais presentes, juntamente com a atividade econômica como um todo.

Na história do Brasil, a passagem de uma economia agroexportadora para uma economia pautada na industrialização se deu, de forma pioneira, no Estado de São Paulo onde já se concentrava a riqueza agrária. W. Cano (1985 [1998]) salienta a reinversão do capital cafeeiro em indústrias como uma verdadeira mudança no centro dinâmico da economia nacional. Esse impulso à industrialização fora estimulado pela ausência de mercados consumidores para o café após a Crise de 29, e marcou profundamente a economia e a paisagem do Sudeste. Essa reinversão de capital impulsionou sobremaneira a Região Concentrada, que já se encontrava em processo de formação como centro econômico dinâmico da economia nacional.

Com relação à Região Nordeste, pode-se mencionar uma porção do território nacional relativamente mais populoso, espaço de inúmeras aglomerações, porém a maior delas de pequeno porte e com urbanização menos expressiva. Com exceção das capitais estaduais, onde se manifesta de maneira mais proeminente o processo de urbanização, bem como o meio técnico-científico-informacional e o processo de globalização, o espaço pode ser considerado comparativamente "opaco", ou seja, com urbanização e dinamismo econômico menos expressivo se comparado às capitais (que seriam os espaços luminosos na Região Nordeste).

Por isso, a densidade do meio técnico-científico-informacional existe seletivamente nesta região, o que pode ser restritivo para novos investimentos. O Nordeste foi o palco das principais atuações do governo federal no sentido de promover o desenvolvimento regional, no momento das décadas de 1960 e 1970 em que se acreditava no já mencionado "industrialismo", resultando em áreas de aglomeração que hoje são muito importantes em nível nacional, tal como o Distrito Industrial de Fortaleza (CE) e o Polo Industrial de Camaçari (BA). As formas de aglomeração industrial existentes no Nordeste resultam do período de planejamento e intervenção do Estado nacional, que tinha como política tentar direcionar indústrias para áreas menos desenvolvidas. Essas ações aconteceram por meio da implantação de infraestruturas fixas e eixos de ligação com o restante do país, integrando seu território e mercado.

Em relação ao Centro-oeste, hoje foco de novos investimentos, porém sem algumas rugosidades existentes em quadros espaciais mais antigos como o Sudeste. Seu 
território é considerado por Santos e Silveira (2001), como "menos engessado" em relação à implantação das novidades. Se esta região é tradicionalmente reconhecida como área de expansão do agronegócio no país, fato inquestionável, atualmente pode ser atrelado também à expansão industrial em alguns pontos. Isso ocorre por "extravasamento" da Região Concentrada, devido à proximidade (sobretudo entre São Paulo e Mato Grosso do Sul e Minas Gerais e Goiás), como mostraremos por meio de dados básicos de estabelecimentos e empregos industriais ${ }^{62}$ ou pela criação de novas e modernas áreas industriais, como foi identificado pelo estudo de Pacheco (1999). Em resumo, essa área de ocupação periférica é a que mais rapidamente se adapta à globalização e nela o meio técnico-científico-informacional avança sem resistência material ou organizacional.

Por fim, a Região Amazônica possuiria um “oásis” industrial representado pelo Polo Industrial de Manaus. Esse "polo", vinculado à Zona Franca de Manaus é historicamente objeto de implantação federal e necessitou grande incentivo e políticas de isenção fiscal para conseguir romper a inércia da região, cujas dificuldades para a produção industrial seriam a distância e o acesso. Estes estímulos, que garantem a rentabilidade da localização, precisam manter-se vigentes em Manaus, na condição de ponto focal onde se manifesta o meio técnico-científico-informacional e onde existe ligação direta com processos globais a partir da Amazônia, onde também se dá a principal arrecadação que sustenta financeiramente todo um estado.

As técnicas do período estão carregadas de ciência e de informação e seu ritmo de evolução é rápido, tendendo à aceleração (SANTOS, 2002). Além disso, as técnicas precisam ser globais, por imposição do próprio mercado. As ações do Estado implantam infraestruturas e normas em função dos agentes hegemônicos. O espaço se transforma para atender ao sistema técnico atual e aos agentes que necessitam deste sistema, atualizado e globalizado.

3.1. A estrutura do território nacional e as formas de aglomeração industrial

A estrutura diz respeito à " [...] inter-relação de todas as partes de um todo; o modo de organização ou construção (SANTOS, 1985, p.50)", como uma das categorias: forma, função, estrutura e processo. Foi proposto por M. Santos (1985) que podemos

\footnotetext{
${ }^{62}$ O Estado de Goiás, principalmente, apresenta crescimento de estabelecimentos e empregos industriais em relação à última década ( $c f$. Item 3.1).
} 
dividir a estrutura em instâncias a fim de facilitar nossa análise: instância política, instância econômica, cultural-ideológica e, finalmente, espacial.

Utilizando estes conceitos, podemos compreender o "modo de organização" do espaço, ou seja, entender como estas instâncias se apresentam individualmente e, ao mesmo tempo, se inter-relacionam. Precisamos olhar para o território brasileiro considerando os aspectos históricos e geográficos que conformam sua estrutura espacial (ao mesmo tempo causa e efeito em relação às demais estruturas). Em cada localização, as demais instâncias se combinam à espacial de maneira diferente:

[...] A estrutura espacial seria exatamente isso: a combinação localizada de uma estrutura demográfica específica, de uma estrutura de classes específica, de uma estrutura de receita específica, de uma estrutura de consumo específica etc.; e de uma organização também específica das técnicas que estão na base das relações entre as estruturas específicas e os recursos. A realidade social é o resultado da interação de todas essas estruturas. As transformações na organização do espaço são simplesmente modificações do valor relativo de cada conjunto local de variáveis (SANTOS, 2012 [1979], p.44 - grifo nosso).

Dessa forma, resultando uma especificidade territorial, geográfica e histórica, à qual podemos chamar de formação espacial. Cada um dos objetos técnicos (ou formas geográficas) representam os momentos da formação espacial por meio de sua perenidade, em um desenvolvimento contínuo.

As formas geográficas surgem em um determinado momento, de acordo com os objetivos da produção e reprodução da sociedade, influenciando na sequência a produção, inclusive a própria produção do território. Nesse processo se definem também sucessivas divisões territoriais do trabalho, já que a distribuição das técnicas não é uniforme. Segundo R. Moreira, as divisões territoriais do trabalho que engendraram a formação espacial brasileira podem ser interpretadas da seguinte maneira:

[...] costuraram uma relação sociedade-espaço cujos efeitos sociais (distribuição das oportunidades de emprego e renda), econômicas (custo de produção e escoamento) e socioambientais (desarrumação dos arranjos do espaço) são evidentes, ensejando hoje pressões generalizadas por reconfigurações e mudanças (MOREIRA, 2012, p.245).

É assim que podemos interpretar, mais uma vez, a história da própria concentração de capital localizada no Estado de São Paulo e oriunda da acumulação do 
capital cafeeiro, como a emergência das bases econômicas e territoriais que hoje definem a concentração industrial na mesma porção do território nacional.

No que tange à estrutura da produção propriamente dita, essa é a raiz da desagregação geográfica entre o comando da atividade produtiva (que muitas vezes é também internacional) e o chão de fábrica. Como já abordado no capítulo anterior, configurou-se a centralização do comando na metrópole de São Paulo, também um aspecto central da divisão territorial do trabalho.

R. L. Corrêa (1997), analisando a divisão internacional do trabalho (resultante da competição capitalista crescente e ampliação das taxas de lucro), aponta cinco características principais das corporações, que são chaves para entendermos as possibilidades mais táteis do uso corporativo do território neste contexto. São elas:

- Escala de operações: a escala de operações é ampla, tanto com relação à produção quanto à sua distribuição geográfica;

- Multifuncionalidade: pode ser considerada horizontal (possui fornecedoras, subsidiárias e filiais) ou vertical (produção integrada tecnicamente desde a extração de matérias-primas, bens intermediários e produtos finais);

- Segmentação: refere-se à diferenciação técnica no que diz respeito ao desenvolvimento tecnológico e divisão social do trabalho em relação às empresas componentes (líderes, intermediárias, atrasadas e de suporte);

- Múltiplas localizações: diferenciais de força de trabalho, especialização funcional, mercado consumidor e mesmo administração induzem a localizações específicas para cada divisão técnica da empresa (há uma divisão territorial do trabalho específica a cada corporação).

- Poder de pressão econômica e política: a empresa traduz-se na gestão do território, influenciando a organização espacial visando a reprodução ampliada do capital personificado na própria corporação.

Tais razões mostram que as corporações desempenham papel expressivo na organização do espaço: podem induzir a ação do Estado (que assume o papel de implantar infraestruturas) e, em sua segmentação produtiva, amplia a divisão territorial (e internacional) do trabalho.

Como já abordamos nos Capítulos 1 e 2, tanto o Estado (estrutura política) quanto o mercado (estrutura econômica) desenvolvem ações cujo resultado é a produção das aglomerações industriais, algumas delas orientadas e outras efetivamente planejadas, em iniciativas de vários momentos históricos do país que, atualmente, se mesclam. Algumas vezes o Estado foi mais atuante, efetivamente um investidor e ora apenas o 
fomentador, ao passo que o mercado está, cada vez mais, realizando diretamente o papel de promover suas próprias aglomerações.

Assim, podemos afirmar outra característica essencial da formação espacial brasileira: há uma crescente desagregação geográfica entre as instâncias e o nível de comando de cada uma delas pode ser diferente (SANTOS, 1985): o nível de decisão política federal é centralizado em Brasília, ao passo que os diferentes governos estaduais também desenvolvem, continuamente, ações relacionadas às aglomerações industriais.

A estrutura econômica tem como seu principal centro de gestão, no território nacional, a metrópole de São Paulo, a qual é o centro também de uma importante mancha da estrutura produtiva (cuja localização corresponde à maior parcela do mercado consumidor). Na Região Concentrada ou fora dela, outras manchas menores são expressivas e representam centros de controle regionais, que não necessariamente estão subordinados à metrópole, mas que, em muitos casos tem na metrópole o escritório da empresa, seu centro de desenvolvimento tecnológico ou representante no Brasil.

Assim como ocorre com a estrutura política, nos casos de subcentros da estrutura produtiva, estes se acercam das maiores densidades populacionais e econômicas, bem como de melhor infraestrutura e fluidez territorial que, fora da Região Concentrada, limitam-se aos pontos luminosos das capitais estaduais, como veremos por meio de algumas representações cartográficas.

O modo de organização do território brasileiro conhece, via de regra, a Região Concentrada e, nela, a metrópole paulistana e seu entorno como core area, de efetiva concentração da estrutura econômica. Essa desigualdade, de forte assimetria, pode ser considerada, então, um ponto de partida - uma característica crucial da estrutura espacial do território brasileiro.

Como, então, se relacionam as instâncias política e econômica (inclusive produção efetivamente) com a estruturação do território nacional? A separação entre a gestão do Estado (Brasília) e o poder econômico (São Paulo), a densidade do mercado consumidor e do desenvolvimento econômico centralizado em uma pequena porção do território contrasta com as demais áreas. Especificamente sobre a estrutura produtiva, o mesmo se pode dizer a partir das evidências de como se espalha, diferencialmente, o meio técnico-científico-informacional no país.

M. Santos pontua que a difusão das novas variáveis no território é seletiva e a evolução da organização do espaço torna-se imprevisível e incontrolável, pois orientada para fora e comandada de fora: "A dialética do espaço no Terceiro Mundo se dá então 
entre o Estado-Nação e as atividades modernas, principalmente as empresas multinacionais e os monopólios" (2012 [1979], p.46).

A estrutura espacial é reflexo e também condição para o exercício da economia. Dessa forma,

É as vezes difícil dizer o que é causa e o que é efeito, mas à expansão geográfica do chamado meio técnico-científico corresponde uma concentração da economia nacional que, por sua vez, supõe ou exige um poder maior do governo central (SANTOS, 1985, p.44).

Com a expansão do meio técnico-científico-informacional, todos os espaços são, potencialmente, o teatro de uma multiplicidade de ações, nos diversos níveis de comando. Os lugares recebem investimentos alheios, comandados de fora e cujas relações são tênues. O mercado induz esta condição e o Estado tende a ser um facilitador, via de regra privilegiando os agentes econômicos que encontram respaldo territorial, normativo e financeiro para que escolham as melhores localizações (para cada etapa de sua produção) e, com isso, também ampliem a divisão territorial do trabalho. Importante mencionar, com M. Santos, as consequências para a sociedade local, que sofre os impactos dessa teia de interesses nem sempre convergentes:

Na medida em que tudo isso está subordinado a um jogo de relações onde as variáveis são, sobretudo, oriundas de centros de decisão cujos objetivos não são coincidentes e que estão situados em pontos diversos do país e mesmo fora, a sociedade local se torna sujeita a tensões muito mais numerosas e frequentes (SANTOS, 1985, p.48).

Dessa forma podemos nos aproximar da interpretação do objeto principal de nossa análise, as aglomerações industriais ou, em outras palavras, formas geográficas que reúnem coleções de objetos voltados à produção.

Segundo M. Santos “[...] o espaço constitui uma realidade objetiva, um produto social em permanente processo de transformação" (1985, p.49). O resultado deste processo é a cristalização das ações da sociedade em sua relação com o meio. Os objetos geográficos dão durabilidade à história e se traduzem em formas. Por forma, o autor entende “[...] o aspecto visível de uma coisa. Refere-se, ademais, ao arranjo ordenado de objetos, a um padrão" (p.50).

A todo processo, além disso, corresponde uma intencionalidade. As características das formas e das funções a que estão desempenhadas em um dado momento, se explicam pela intencionalidade consubstanciada aos agentes que competem em sua 
produção (e que, ao mesmo tempo, produzem o espaço). Este conceito permite identificar, imbricados, o agente e a natureza da ação que o mesmo realizou. A esse respeito, podemos ressaltar:

[...] o produto já está contido no ato produtivo e, assim, a faculdade da consciência que torna possíveis as suas ações produtivas consiste em estar sempre fora dela mesma. Desse modo e como consequência da intencionalidade, encontramo-nos desde o indício implicados na "trama das coisas' (SANTOS, 2004 [1996], p.91).

Para Santos, a interpretação da intencionalidade permite uma releitura crítica das relações entre os objetos e as ações, sendo esta "[...] eficaz na contemplação do processo de produção e de produção das coisas, considerados como um resultado da relação entre o homem e o mundo, entre o homem e o seu entorno" (2004 [1996], p.90). Esta relação demonstra também o caráter geográfico que se encontra associado a este exercício de interpretação.

Portanto, nesse aspecto, o estudo das aglomerações industriais tem como agentes principais o Estado e o mercado (principalmente promotores imobiliários se os analisarmos como agentes diretos). Embora os discursos possam ser variados: industrialização do país, redução de desigualdades regionais, rentabilização do capital imobiliário, o fato último é a produção do território cujo resultado é a permissividade do seu uso corporativo. O uso corporativo do território pode ser analisado pelas condições das estruturas e, também, das formas que fisicamente, lhe dão fixidez.

É importante relembrar que existem diferentes combinações de formas e de técnicas correspondentes em cada momento. Isso "[...] constitui o atributo produtivo de um espaço, sua virtualidade e sua limitação" (SANTOS, 2012 [1979], p.31). Um conjunto diferente de técnicas pode se sobrepor ao que existe em uma parcela do território, correspondendo às necessidades da produção ou às iniciativas do Estado em redirecionar/redistribuir a estrutura da produção. Como vimos, historicamente, as formas de aglomeração foram uma das ferramentas principais utilizadas para este fim.

Por fim, para abordar as tendências de configuração do espaço brasileiro, R. Moreira aborda dois períodos, com características importantes, aos quais ele chama de implantação do arranjo capitalista e privatização da gestão do espaço (MOREIRA, 2012).

O período de implantação do arranjo capitalista (industrialização) pode ser caracterizado pela concentração econômica e subordinação das atividades regionais à performance econômica da indústria paulista, bem como a transferência de recursos entre 
regiões e desigualdade no desenvolvimento entre cidade e campo "[...] todos conflitos referidos à forma da regulação espacial industrial e que não raro têm nas políticas territoriais do Estado seus termos iniciais de equacionamento" (MOREIRA, 2012, p.18).

Quanto ao período de desconcentração e privatização da gestão do espaço, Moreira afirma a instituição de uma nova norma de gestão do espaço iniciada nas décadas de 1980 e 1990, com as políticas de privatização que (aliadas à cultura da soja, pecuária e reflorestamento) entregam para o setor privado o mando sobre os seu recortes. Assim, “[...] a escala da privatização da gestão do espaço se torna um fato de abrangência tão ampla, que praticamente torna o poder privado o poder do território nacional" (MOREIRA, 2012, p.21). Por consequência, a administração do território nacional passa a ser, cada vez mais, realizada à luz da lógica do mercado.

Se observarmos exclusivamente as formas de aglomeração da indústria, também elas refletem essa dinâmica, a partir do número e variedade cada vez maior de espaços privados que coexistem aos distritos industriais, por exemplo. As características destas formas são reveladoras do contemporâneo e das técnicas que tendem a predominar, bem como da formação espacial atual.

3.2. Distribuição da indústria e de suas aglomerações no território nacional: o que os números mostram?

A complexidade do território brasileiro também pode ser retratada nos dados estatísticos sobre a indústria. Contudo, não podem ser observados unicamente, mas sempre associados às características da formação espacial do país, que os explica. O que os números mostram é, bastante simples, o território segmentado: há uma densidade e uma centralidade que são muito evidentes, em contraposição às manifestações pontuais de indústrias em parcelas nas quais não há industrialização predominante.

Para mostrar essa contraposição utilizaremos dois mapas. O primeiro deles foi elaborado a partir do número de estabelecimentos industriais. O segundo deles é resultado de uma seleção de autores os quais se debruçaram sobre a métrica da aglomeração industrial e propuseram isso para o conjunto do território nacional. Representamos cartograficamente estes estudos, cada um em uma camada do mapa, permitindo sua visualização e comparação. 
Dessa forma, em nossa primeira aproximação, a distribuição da atividade industrial é mostrada a partir da quantidade de estabelecimentos industriais existentes no Brasil (Mapa 2), por meio da Relação Anual de Informações Sociais ${ }^{63}$. Este é um registro muito importante para o objetivo desta pesquisa, por duas razões: em primeiro lugar porque tem uma origem cadastral, ou seja, o levantamento acontece por meio do Ministério do Trabalho ao nível da unidade, do estabelecimento propriamente dito. Em segundo lugar, pois se trata da unidade industrial propriamente dita, que é o nosso objeto de estudo quando aglomerada.

Embora esteja sujeita a críticas devido à sua simplicidade, ou mesmo porque outras variáveis possam expressar melhor a atividade industrial ${ }^{64}$, nossa opção para retratar a distribuição básica da indústria, devido ao nosso objeto de estudo, é ainda pelo número de estabelecimentos.

Outra ressalva metodológica deve ser feita, em decorrência da nossa opção em excluir os estabelecimentos industriais cujo número de funcionários era igual a zero no ano de 2014. Este filtro foi adotado pois é possível que uma empresa registrada não esteja de fato operando. Há empresas ativas com número de funcionários igual a zero, porém são mais comuns nos segmentos de serviços e comércio. No caso de indústrias essa situação é mais difícil, pela própria demanda de mão-de-obra ser maior na indústria e também pelo fato de terceirizações serem mais difíceis neste segmento devidos às leis trabalhistas e fiscalizações mais rígidas.

Em outra hipótese, para justificar a subtração dos estabelecimentos com zero funcionário, constatamos que uma empresa pode ter mais de um Cadastro ${ }^{65}$ ativo, ou seja, ter dois ou três CNPJ registrados, com finalidade administrativa ou fiscal. Para melhor justificar essa opção, mencione-se o Programa de Revitalização e Modernização dos Distritos Industriais, no qual foram elencadas 105 empresas industriais no Distrito Industrial de Contagem (MG) por meio de atividade de campo. Entretanto, o número

\footnotetext{
${ }^{63}$ A Relação Anual de Informações Sociais (RAIS) é um dos produtos estatísticos do Ministério do Trabalho e Emprego (MTE), que organiza anualmente no escopo do Programa de Disseminação de Estatísticas do Trabalho (PDET). Decreto $\mathrm{n}^{\mathrm{a}} 76.900 / 75$.

${ }^{64}$ Podemos mencionar, por exemplo, o emprego industrial ou a empregabilidade industrial (colocando o número de estabelecimento como denominador) ainda no escopo do Ministério do Trabalho e Emprego. Como trabalho do Instituto Brasileiro de Geografia e Estatística, teríamos opções como o PIB; Produto Interno Bruto (valor adicionado industrial) ou ainda o VTI; Valor de Transformação Industrial, ambos utilizados com mais frequência para retratar a distribuição geográfica da indústria. Existe uma discussão sobre estas variáveis no trabalho de Selingardi-Sampaio (2009).

${ }^{65}$ O Cadastro Nacional de Pessoa Jurídica (CNPJ) é um registro ao nível de estabelecimento, que identifica uma pessoa jurídica ou outros tipos de arranjos sem personalidade jurídica (como um condomínio ou órgãos públicos) junto à Receita Federal Brasileira.
} 
oficial de indústrias neste distrito industrial, por meio dos CNPJ registrados junto à Companhia de Desenvolvimento de Minas Gerais (CODEMIG), chegava a 1.000.

Em ambos os possíveis casos considerados, vemos que o critério de excluir as empresas com 0 funcionários tende a aproximar o resultado real. Assim, em 2014 o número de estabelecimentos industriais no Brasil era de 351.056, distribuídos entre 4.837 municípios brasileiros (cerca de $88 \%$ dos municípios brasileiros), os quais tem ao menos um estabelecimento industrial. Entre estes municípios, entretanto, apenas 24 possuem acima de 1.500 estabelecimentos industriais. Entre estes 24 municípios, estão na Região Concentrada o total de dezoito.

As informações apenas reforçam essa característica fundamental da estrutura espacial brasileira, a concentração geográfica. O Mapa 2, a seguir, foi elaborado a partir dos dados de estabelecimento industriais para gerar uma superfície de tendência (método kernel). Utilizamos uma relação numérica de vizinhança para o algoritmo de três vizinhos (municípios) mais próximos. Para tentar ainda melhor explorar um critério de divisão versus homogeneidade, extraímos da representação cartográfica os municípios que tinham apenas uma indústria em 2014. Podemos visualizar com maior propriedade as manchas desta concentração industrial, que se expressam nitidamente pelo desenho formado pela superfície de tendência. Por fim, como camada acima da superfície de tendência, pontuamos os 24 municípios que apresentam acima de 1.500 estabelecimentos industriais.

O Mapa 2 mostra, precisamente, as duas principais manchas industriais: na Região Concentrada, com maior intensidade na Região Metropolitana de São Paulo e arredores, estendendo-se pelos estados de Rio de Janeiro, Minas Gerais, Espírito Santo, Paraná, Santa Catarina, Rio Grande do Sul e, inclusive Goiás e Distrito Federal. No Nordeste, a maior expressividade ocorre nas três principais capitais: Fortaleza (CE), Recife (PE) e Salvador (BA).

$\mathrm{O}$ efeito de quebra nas manchas industriais (tonalidade cinza), usado para a melhor definição de suas fronteiras, se deu a partir da exclusão dos munícipios que teriam apenas um ou zero estabelecimento industrial no ano de 2014. Juntos, estes municípios são 1.233 e possuem 507 estabelecimentos industriais, o que pode ser considerado inexpressivo. Embora possa ser criticado, a exclusão destes municípios do cálculo de vizinhança para produzir a superfície de tendência permitiu resultar nesta divisão bastante evidente e importante. 


\section{MAPA 2}

BRASIL - Indústria de transformação e sua tendência à concentração geográfica (2014)

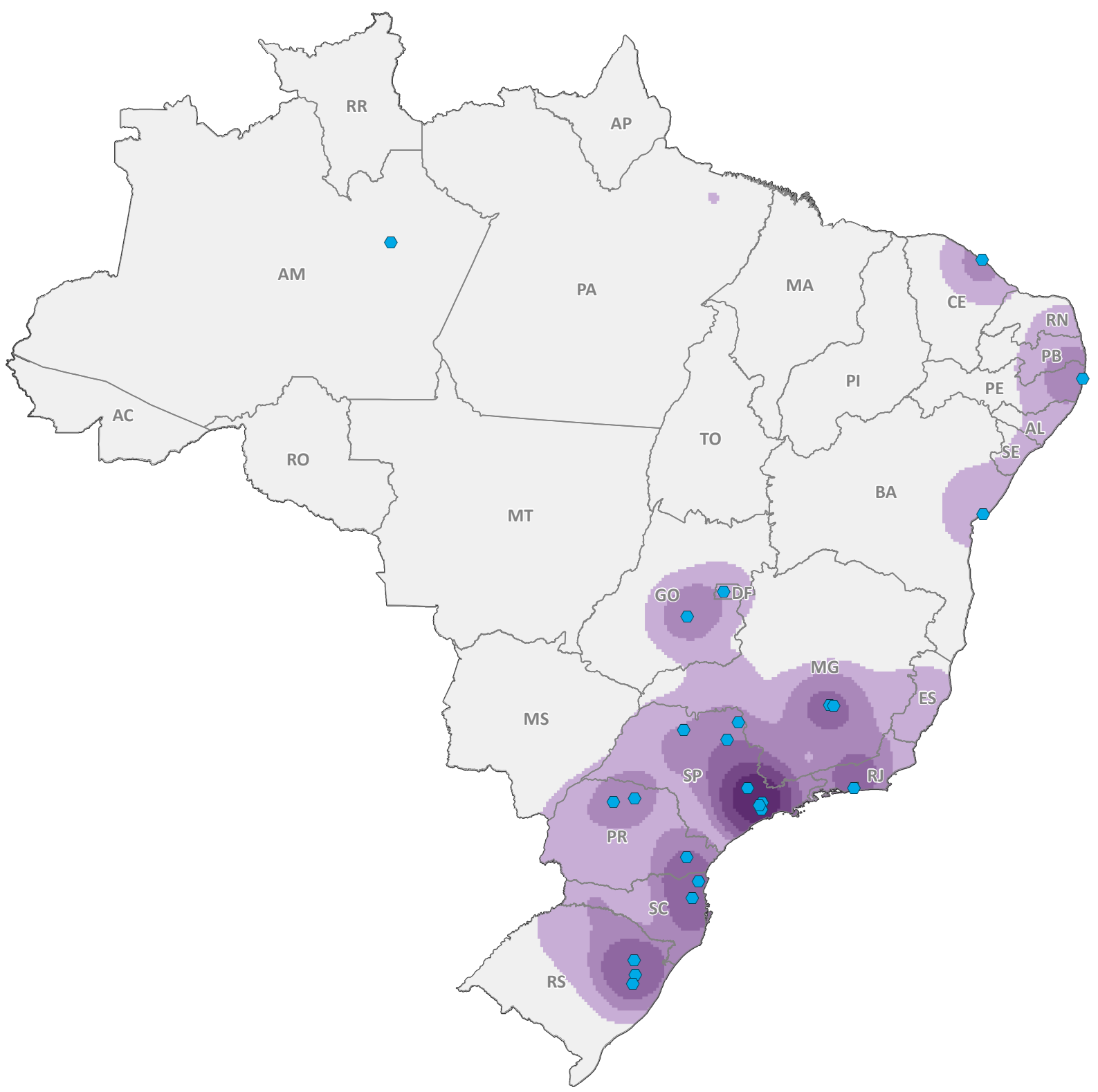

- Municípios com 1.500 ou mais estabelecimentos industriais

1

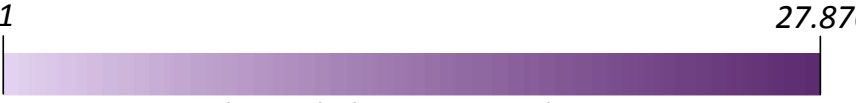

$n$ o de estabelecimentos industriais superficie de tendência

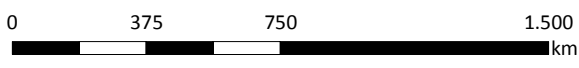

Fonte: Ministério do Trabalho e Emprego (MTE, 2014)

Base cartográfica: Instituto Brasileiro de Geografia e Estatística (IBGE)

Organização: Rodolfo Finatti 
Complementarmente, elaboramos um mapeamento similar para as aglomerações industriais, com base em estudos de economistas que utilizaram fontes de dados quantitativos. É importante ressaltar que, nestes estudos, não são as aglomerações industriais formalizadas (distritos industriais, polos industriais, etc.) unicamente, mas qualquer tendência à aglomeração (por proximidade / concentração espacial em alguns casos e ainda concentração setorial em outros) que está sendo considerada ${ }^{66}$.

Em primeiro lugar, as fontes de estatísticas oficiais, independentemente do tratamento estatístico atribuído aos dados, não permitem a identificação de formas aglomerativas industriais no nível de detalhe de nosso trabalho. A razão para isso é que tratamos de fixos intraurbanos na maioria dos casos, e os dados disponíveis publicamente permitem chegar ao nível municipal mais detalhado em termos geográficos e à segmentação máxima de cinco dígitos pela Classificação Nacional de Atividades Econômicas (CNAE). Outra limitação encontrada para responder aos nossos questionamentos diz respeito ao baixo número de pesquisas dedicadas à interpretação do território nacional, e assim a maioria destes estudos encontra-se principalmente na escala estadual.

Mesmo com estes problemas, algumas abordagens permitem uma aproximação aos "grandes aglomerados" ou "áreas com tendências à aglomeração industrial” em relação às quais podemos analisar mais detalhadamente. Iniciaremos apresentando os estudos selecionados para, então, apresentar o mapa síntese resultante.

Os primeiros autores considerados, Diniz e Crocco (1996), movidos pela insatisfação com as análises do desenvolvimento regional da indústria, em sua totalidade realizadas apenas no nível estadual ou comparativo das cinco regiões brasileiras, utilizam as microrregiões definidas pelo IBGE, com mais de 10.000 pessoas empregadas na indústria, para chegar às Aglomerações Industriais Relevantes (AIRs). Os autores empregam os dados dos censos industriais de 1970 a 1985, bem como o censo demográfico de 1991 e os dados do Ministério do Trabalho e Emprego (Relação Anual de Informações Sociais), tendo como medidas o valor da transformação industrial (VTI) e o nível de emprego percentual.

\footnotetext{
${ }^{66}$ Foi necessário consultar uma série de trabalhos de autores que, reconhecidamente, se debruçaram sobre este tema e esta metodologia, para selecionar os mais importantes e que permitiam representação cartográfica. Alguns destes trabalhos estão, inclusive, em linhas de pesquisa relativamente recentes e cujo aperfeiçoamento, sobretudo no tocante ao tratamento estatístico dado, está em aberto e evoluindo. São eles: Diniz (1996), Diniz e Crocco (1996), Lemos (2005) e Góis Sobrinho (2014).
} 
Diniz e Crocco (1996) chegaram a 91 aglomerações industriais relevantes, sua maioria nos estados de São Paulo e Minas Gerais, porém com extensão para os três estados da região sul, incluindo o Rio de Janeiro, o que os permite desenhar o seu "polígono industrial" brasileiro. Os autores agrupam as AIR em três tipos: (1) de baixo dinamismo ou estagnadas, cujo crescimento do pessoal ocupado se deu abaixo da média brasileira (22 AIR), (2) dinâmicas, cuja participação em relação ao valor da transformação industrial, relativa à brasileira, foi aumentada (68 AIR dinâmicas) e (3) especiais, que resultam da concentração de mais de 50.000 empregos na indústria, com crescimento acima da média brasileira, para as quais foi dado mais um filtro, relativo à sua participação no valor da transformação industrial brasileira significativamente aumentado, o que resultou na existência onze áreas (11 AIR). Uma espacialização destes resultados podem ser vistos no mapa 5, apresentado ao final deste item.

C. A. Pacheco (1999) se apoia nos dados do censo industrial de 1970 a 1985, Valor da Transformação Industrial e Relação Anual de Informações Sociais do Ministério do Trabalho e Emprego para analisar se existem novos padrões de localização industrial no Brasil, partindo da premissa de desconcentração econômica recente no Brasil (1986 a 1996). O autor chega a conclusões relevantes em relação ao período.

Em primeiro lugar, identificou uma tendência de manter, nas antigas áreas industriais (sobretudo a Grande São Paulo) as linhas de maior conteúdo tecnológico ou que demandem, por algum razão, força de trabalho com maior qualificação. Pacheco (1999) identificou também o acirramento da tendência de novas atividades industriais localizaremse fora das regiões metropolitanas, fugindo das deseconomias de aglomeração próprias destas áreas. A Região Metropolitana de São Paulo e o Estado do Rio de Janeiro foram as áreas que mais perderam peso na indústria e, paralelamente a isso, surgiram "ilhas de produtividade" em todas as regiões do país.

Pacheco aponta que os investimentos da década de 1970, principalmente os que foram idealizados durante a vigência do II Plano Nacional de Desenvolvimento ainda repercutiram, durante a década de 1980, sobre as bases regionais da indústria brasileira. Por fim, especificamente sobre o cenário atual e a influência das ações do Estado no tocante à localização da indústria, assevera:

[...] é importante observar que, à medida que os programas de investimento patrocinados pelo Estado vão maturando e não são substituídos por políticas ativas e, ao contrário, a privatização e a crise fiscal reduzem o grau de intervenção pública, a desconcentração 
industrial perde fôlego e abrangência. Isso é particularmente visível para a economia nordestina, que passa a ser cada vez menos beneficiária da desconcentração, que tem efeitos maiores no Sul, no próprio Sudeste (Minas Gerais e Espírito Santo) e no Centro-Oeste (PACHECO, 1999, p.36).

Outro trabalho relacionado é o de J. Saboia (2000a e 2000b), cujo enfoque foi a identificação de aglomerações industriais no Brasil (2000a) e, posteriormente, uma análise para chegar à distribuição de aglomerações industriais especializadas (nas quais ao menos metade do emprego industrial se concentra em um único segmento), de acordo com trabalho de 2000b. O autor se apoia em dados da Relação Anual de Informações Sociais do Ministério do Trabalho e Emprego (MTE) e analisa as taxas de variação de emprego, número de estabelecimento e também o seu tamanho médio. Em um momento posterior, considera os cinco ramos mais representativos em cada microrregião identificada.

Assim como já destacamos, apontado por demais autores, J. Saboia (2000a) assinala certa desconcentração industrial entre as unidades da federação. Um dos aspectos centrais deste trabalho é que identifica uma taxa de crescimento industrial expressiva na região Centro-Oeste, para um período recente: Enquanto o Sudeste teve uma variação negativa da taxa de emprego, para o período analisado, em todos os estados (Rio de Janeiro foi o estado com maior decréscimo, 43,1\%), o Centro-Oeste apresentou variação positiva em todos os estados que o compõem: os maiores crescimentos foram de Mato Grosso e Goiás, respectivamente, $84,3 \%$ e 42,7\%. Na região Norte, Roraima e Rondônia tiveram o maior crescimento (respectivamente $78,1 \%$ e 59,7\%) enquanto o Estado de Amazonas decresce $37,3 \%$ do período. Na região Nordeste, Piauí $(22,9 \%)$ e Ceará $(9,1)$ foram as unidades da federação de maior crescimento no período e no sul do país apenas o Paraná teve crescimento positivo $(9,3 \%)$.

Além da desconcentração regional, o autor afirma outro processo concomitante, qual seja o do deslocamento da indústria das capitais para o interior dos estados. Saboia afirma que houve essa queda em quase todos os estados. No conjunto do Brasil de 1989, o emprego industrial se concentrava 52,8\% nas capitais. Esse total cai para $45,7 \%$ em 1997.

Saboia também parte de um agrupamento das aglomerações industriais elencadas num total de 155 . Os quatro grupos são os seguintes:

- Macroaglomerações, com 100 mil ou mais empregos (6);

- Grandes aglomerações, com de 50 mil a 100 mil empregos (10); 
- Médias aglomerações, de 10 mil a 50 mil empregos (75);

- Pequenas aglomerações, de 5 mil a 10 mil empregos (64).

Entre os anos de 1989 e 1997 todas as dimensões de aglomeração tiveram queda em seu número absoluto, exceto as pequenas aglomerações que em 1989 eram 46 e 1997 eram 18 mais. Destaque deve ser dado para a maior aglomeração com crescimento do emprego: "[...] é Goiânia, com 41.606 empregosem1997 e crescimento de 53,5\% em relação a 1989. Esse dado é ilustrativo do crescimento do emprego na região Centro-Oeste, já assinalado" (SABOIA, 2000a, p.85).

Se avaliarmos quais são macro aglomerações de Saboia (São Paulo, Rio de Janeiro, Porto Alegre, Belo Horizonte, Campinas e Curitiba), sua distribuição geográfica corrobora com aqueles que seriam os principais núcleos do polígono industrial de Diniz (1996).

Além dessas informações, há um total de 45 aglomerações especializadas, ou seja, com mais da metade do emprego em um único setor e podendo ser encontradas nas mais diferentes regiões do país. Para o autor: "[...] confirma-se que a especialização industrial não está restrita às menores aglomerações, nem localizada obrigatoriamente nas regiões menos desenvolvidas" (SABOIA, 2000a, p.111).

Uma das principais conclusões é o downsizing do emprego industrial, ou seja, sua tendência de migração das capitais para cidades de menor porte no interior dos estados. Além disso, ao lado da redução do tamanho das aglomerações industriais (um resultado esperado) ocorreu o aumento no número de pequenas aglomerações industriais (um resultado menos esperado que o primeiro). Por fim, consideramos notável a associação entre menores níveis salariais e crescimento do emprego. Para Saboia, isso sugere que "[...] a indústria estaria utilizando os diferenciais salariais do país como um dos itens para as decisões de (re) localização espacial, procurando regiões com menores níveis salariais" (SABOIA, 2000a, p.115). O autor também encontrou evidência de evolução salarial favorável nessas regiões, beneficiadas pelo aumento da demanda pela mão de obra.

Finalmente, outros dois trabalhos também mostram resultados igualmente importantes. Analisaremos as contribuições de Lemos et al (2005) e Góis Sobrinho (2014). Essas duas pesquisas, diferentemente das que já apresentamos nesta seção, empregaram o Índice de Moran como medida para autocorrelação espacial, tendo como menor nível de desagregação o município e, para construção da base de dados, empregando o valor de transformação industrial (VTI). 
O Índice de Moran é uma medida de autocorrelação espacial de dados, podendo ser usada para identificar transbordamentos entre vizinhos e qual é o grau da autocorrelação entre eles (positiva ou negativa, em mesmo sentido ou sentido oposto); um índice de Moran positivo pode identificar a existência de agrupamentos entre os dados; no caso entre os municípios brasileiros. Os resultados se expressam em quatro agrupamentos, qualitativamente:

- cluster tipo high-high (HH) quando o valor da localidade em análise e a média dos vizinhos são semelhantes e altos;

- cluster tipo low-low (LL) quando o valor da localidade em análise e a média dos vizinhos são semelhantes e baixos;

- cluster tipo high-low (HL) quando se trata de uma ocorrência atípica, ou outlier, na qual o valor da localidade em análise é alto mas a média dos vizinhos é baixa;

- cluster tipo low-high (LH) quando o valor da localidade em análise é baixo, porém a média dos vizinhos é alta.

O principal resultado desta metodologia, empregando o Índice de Moran (a um intervalo de confiança de $90 \%{ }^{67}$ ), é poder captar o efeito da contiguidade espacial da indústria no território brasileiro, e permite não somente observar a abrangência da "mancha" industrial irradiada pela Região Metropolitana de São Paulo, como também identificar os demais centros dinâmicos baseados na atividade industrial. Do ponto de vista da aglomeração industrial, o tipo $\mathrm{HH}$ é o mais relevante na medida em que expressa correlação espacial de ao menos dois municípios com alto VTI. O tipo HL revela uma concentração industrial localizada, uma espécie de "ilha industrial" ou um "enclave urbano-industrial”, de acordo com a expressão empregada pelos próprios autores.

Uma vez explicadas as medidas adotadas por estes trabalhos, podemos comentar seus mais importantes resultados.

A busca de Lemos et al. (2005) é pelas Aglomerações Industriais Espaciais (AIE), utilizando dados de 2000. A distribuição geográfica, de acordo com as regiões apresenta o seguinte número de ocorrências de aglomerações, para um restrito número de municípios que representam $75 \%$ do produto industrial: sudeste: 5 , sul: 5 , nordeste: 4 , norte: 0 e centro-oeste: 0 .

\footnotetext{
${ }^{67}$ Seguindo proposta de M. R. Lemos, S. Moro, E. P. Domingues e R. M. Ruiz (2005).
} 
O desenho destas AIE, que tentaremos transpor para o Mapa 5, mostra uma forte concentração no território nacional, sendo as áreas mais com maior nitidez: o “corredor industrial” ao longo de RJ-MG-SP-PR-SC-RS e as áreas diretamente restritas às regiões metropolitanas de capitais estaduais na região Nordeste, principalmente Salvador (BA), Recife (PE), Natal (RN) e Fortaleza (CE). Em relação às demais áreas, os autores destacam:

[...] não foram identificadas AIEs na região norte, apesar da participação relevante da Zona Franca de Manaus no produto industrial do país. A ausência de AIEs no Centro-Oeste revela, por sua vez, que seu intenso processo de agroindustrialização nos últimos 20 anos ainda não foi suficiente para criar densidade industrial para o surgimento de transbordamentos e encadeamentos industriais no espaço (LEMOS et al., 2005, p.345).

As manchas formadas pelas contiguidades $\mathrm{HH}$ de cada macrorregião do país, de acordo com as respectivas unidades estaduais, teriam seu município mais dinâmico (seguido por número de vizinhanças com valores semelhantes e altos):

Macrorregião Sul

- RS: Porto Alegre (28), Caxias do Sul (9);

- SC: Joinville (14);

- PR: Curitiba (10), Londrina (5).

Macrorregião Sudeste

- SP: São Paulo ${ }^{68}(120)$;

- RJ: Rio de Janeiro (7), Volta Redonda (8);

- MG: Belo Horizonte (17); Ipatinga (5);

- ES: Vitória (6).

Macrorregião Nordeste

- BA: Salvador (6);

- PE: Recife (9);

- CE: Fortaleza (7);

- RN: Natal (3).

Como considerações finais, os autores acreditam que existem poucas AIEs no Brasil e sua distribuição geográfica é restrita a algumas áreas metropolitanas e pólos industriais especializados. É válido apontar que as Aglomerações Industriais Espaciais concentram $75 \%$ do produto industrial das firmas no país e a quase totalidade do produto das firmas inovadoras (LEMOS et al., 2005). Como notória implicação desse cenário de

\footnotetext{
${ }^{68}$ Denominada pelos autores de Aglomeração Industrial Primaz de São Paulo (LEMOS et al., 2005).
} 
fragmentação espacial da produção industrial, “[...] a ausência de coordenação entre políticas industriais e de desenvolvimento regional pode criar conflitos políticos e econômicos, ambas podem ter sua eficiência reduzida" (LEMOS et al., 2005, p.361).

O trabalho de E. Góis Sobrinho (2014) segue metodologia similar e inclusive inspirada na pesquisa apresentada por Lemos et al. (2005), no entanto, algumas pequenas diferenças o levaram a resultados um pouco mais específicos. Além de empregar o Valor Adicionado Bruto (VAB) - pois o autor acredita levar a resultados mais claros -, utilizouse de uma matriz de vizinhança binária tipo rainha $\left(\right.$ Queen $\left.^{69}\right)$. Foi selecionado um conjunto de municípios, empregando também um critério de relevância, que é a participação mínima de $0,5 \%$ do VAB industrial nacional, para assim definir o que chama de Aglomerações Industriais Relevantes. Outro fator que pode ter implicado em resultados diferentes é o ano da pesquisa, o que permitiu uso dos dados mais recentes de 2010.

$\mathrm{O}$ autor chega ao resultado de dezessete aglomerações industriais relevantes em sua pesquisa, sendo que oito delas se distribuem na área denominada como "polígono industrial" por C. Diniz (1996). Levando em consideração as áreas HH em cada região, Góis Sobrinho (2014) aponta a existência das seguintes aglomerações industriais:

Macrorregião Norte

- PA: Parauapebas e Belém

Macrorregião Nordeste

- BA: Salvador

- PE: Recife

- CE: Fortaleza

Macrorregião Centro-Oeste

- GO: Goiânia

Macrorregião Sudeste

- SP: São Paulo

- RJ: Rio de Janeiro e Campos dos Goytacazes

- MG: Belo Horizonte e Uberlândia

- ES: Vitória

Macrorregião Sul

- RS: Porto Alegre e Caxias do Sul

- SC: Joinville

- PR: Curitiba e Londrina

\footnotetext{
${ }^{69}$ Segundo esse tipo de vizinhança binária (Queen), os municípios que compartilham limites e, portanto, são considerados vizinhos, recebem um peso espacial $=1$, enquanto todos os demais municípios recebem um peso espacial $=0$.
} 
No que tange ao nosso estudo, excluiríamos uma investigação mais detalhada de Parauapebas (PA) e Campos dos Goytacazes (RJ), pois ao nível de análise dos dígitos da CNAE estas aglomerações são predominantemente voltadas para a indústria extrativa. Em Parauapebas a extração mineral corresponde a 37,44\% do seu emprego industrial, enquanto no município carioca a extração de petróleo e gás natural, junto às atividades de apoio totalizam $28 \%$ do emprego na indústria.

Embora também reconheça que o processo de desconcentração industrial tenha arrefecido na última década, o autor sugere a continuidade da tendência de uma desconcentração, muito embora tímida. Góis Sobrinho assinala, como considerações finais de seu artigo: “[...] os resultados desse trabalho mostram mais evidências de que as regiões economicamente mais desenvolvidas e com maior nível de renda no Brasil também apresentam as mais importantes aglomerações" (2014, p.44). Ademais, ainda sugere que possíveis medidas para reduzir as desigualdades regionais no Brasil seria a adoção de políticas para desenvolver as aglomerações e criar novas, fora do eixo Belo Horizonte-São Paulo-Porto Alegre.

Por fim, ao observar este quadro geral de análises, parece ter restado um questionamento. Qual é o peso da Zona Franca em Manaus (AM)? Talvez relativamente deixada de lado nas análises dos autores por não gerar nenhum transbordamento para os municípios vizinhos e consequentemente impedir um arquitetura $\mathrm{HH}$ nos mapas gerados. Entretanto, o município de Manaus figura no trabalho de Lemos et al. (2005) como uma ocorrência outlier à qual dão o título de "aglomeração industrial localizada" (AIL), que seria similar a um tipo de enclave industrial.

No conjunto das AIL apresentadas por Lemos et al. (2005), a de maior destaque é a de Manaus, com o maior VTI entre as 23 cidades que possuem características similares, inclusive mais elevado que todo o conjunto de AIL do Sudeste-Sul do país, rivalizando com o conjunto formado por Centro-Oeste, Sudeste e Sul ${ }^{70}$. Portanto, podemos afirmar que o Polo Industrial de Manaus configura-se como uma forma aglomerativa industrial relevante no quadro nacional.

Para uma visão conjunta destes trabalhos, propomos uma síntese (Mapa 3). Foram considerados, para tanto, os trabalhos de Diniz e Crocco (1996), Lemos et al. (2005), Góis Sobrinho (2014) e Diniz (1996).

\footnotetext{
${ }^{70}$ Apenas para estabelecer uma comparação simples, o conjunto das AIL existentes nas regiões Centro-Oeste, Sudeste e Sul somaram um VTI de R 9.235 (em milhões), enquanto apenas Manaus chega a R \$ 7.691 (em milhões), uma informação representativa face à média das 23 AIL, que chegaria apenas a $R \$ 0.929$ (em milhões).
} 


\section{MAPA 3}

BRASIL - Aglomerações industriais e sua distribuição no território brasileiro

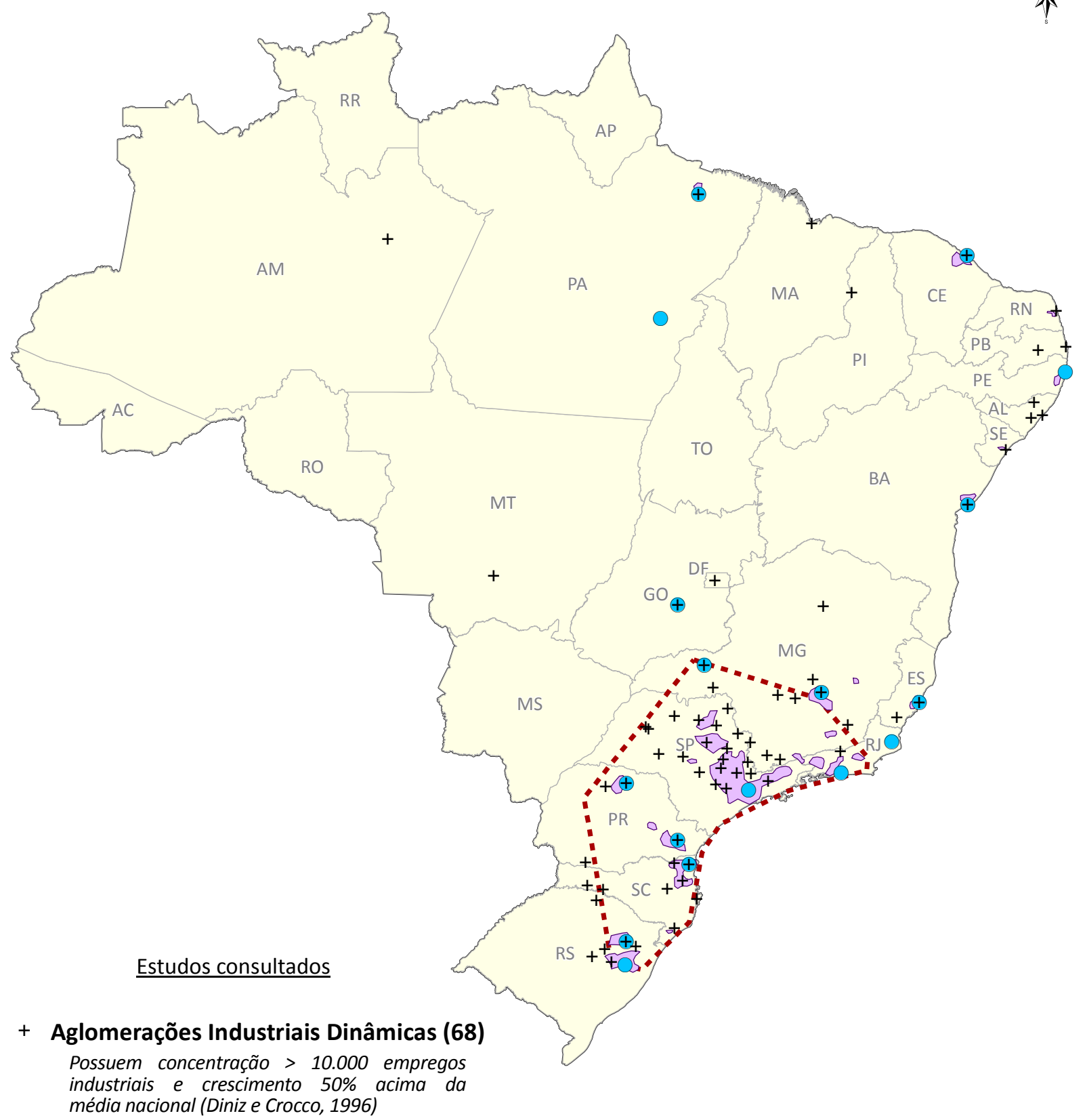

- Aglomerações Industriais Relevantes (17)

Localizações municipais estabelecidas por Góis Sobrinho (2014)

\section{Aglomerações Industriais Espaciais}

Cluster de tipo High-High: autocorrelação espacial positiva e elevada (Lemos, 2005)

\section{Polígono Industrial}

Delimitação estabelecida por Diniz (1996)

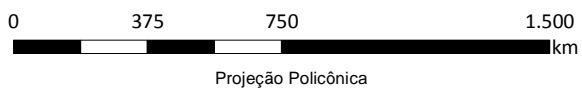

Fonte: Consulta aos autores Diniz e Crocco (1996), Lemos et.al (2005), Góis Sobrinho (2014) e Diniz (1996)

Base cartográfica: Instituto Brasileiro de Geografia e Estatística (IBGE)

Organização: Rodolfo Finatti 
Existe uma evidente associação entre a distribuição da indústria (aquela que está localmente concentrada, conforme objetivos dos autores) e as próprias características da formação espacial. As aglomerações industriais dinâmicas (DINIZ e CROCCO, 1996) se apresentam concentradas, sobretudo, entre São Paulo e Minas Gerais, alguns pontos na Região Nordeste e outros espalhados pelo Brasil.

O mesmo se pode apontar a respeito das aglomerações industriais relevantes de Góis Sobrinho (2014). Este autor, utilizando dados mais atuais, mostra que o maior número delas está nas regiões Sudeste e Sul (Região Concentrada), com algum espalhamento pelas demais regiões (três aglomerações na região Nordeste, duas na Amazônia e uma aglomeração na Centro-Oeste).

Já a metodologia empregada por Lemos (2005) permite verificar as manchas formadas pela contiguidade industrial, e seu resultado é também expressivo do ponto de vista em que se confirma a maior existência na Região Concentrada, bem como mostrando algumas manchas espalhadas pela Região Nordeste. A interpretação de Diniz (1996), apesar de qualitativa, permite os mesmos apontamentos por meio do desenho de um "polígono industrial", cujos vértices perpassam pelas capitais estaduais, as quais são, nos estados do Sudeste e Sul, também os principais centros industriais.

Além disso, ao contrastar essa "extensão industrial" com as tendências de localização das aglomerações, perceberemos quais são as que tiveram/tem força para gerar uma concentração ao nível de expressividade nacional. Os polos industriais clássicos como os existentes em São Paulo (Mauá), Rio Grande do Sul (Triunfo) e Bahia (Camaçari) se fazem notar no mapa.

Distritos industriais mais antigos e consolidados como a Cidade Industrial de Contagem (MG), Distrito Industrial de Queimados (RJ), Distrito Industrial de Fortaleza (CE) ou Abreu e Lima (PE) se manifestaram como manchas capazes de gerar extensão notável ao nível nacional ou, em alguns casos, aglomerações industriais relevantes.

Por fim, na condição de core área da Região Concentrada, a grande extensão formada pelas regiões metropolitanas de São Paulo e Campinas, com ampliação para São José dos Campos, São Carlos e Ribeirão Preto praticamente sem qualquer fragmentação é emblemática da área que também contem o maior número de distritos industriais, arranjos produtivos locais e condomínios empresariais, relativamente; além de três grandes refinarias que conformam também importantes polos nos municípios de Mauá, Paulínia e Cubatão. 
Não podemos, evidentemente, apontar que há correlação entre a distribuição geral da indústria (localmente concentrada) e as áreas em que existem mais aglomerações industriais propriamente ditas. Todavia, há evidente associação entre os dados apresentados no Mapa 3 e a localização das mais importantes aglomerações industriais, inclusive aquelas que serão apresentadas com maior detalhe, na condição de estudos de caso, no capítulo seguinte. Nesse sentido, podemos previamente confirmar as aglomerações estudadas detalhadamente como inseridas nas áreas de maior relevância e tendência à concentração geográfica.

Os dois mapas permitem, além disso, distinguir as unidades estaduais de maior predominância na indústria: os estados do Sudeste e Sul (SP, RJ, MG, ES, PR, SC e RS) e, no Nordeste (CE, PE e BA). No Centro-oeste, é GO o estado de maior destaque e ocorrência de novos investimentos, confirmado pelos Mapas 2 e $3^{71}$.

Para dar sequência à análise, é importante não apenas apontar as localizações, mas entender porque estão onde estão e, sobretudo, o que isso informa sobre o território nacional e sobre as dinâmicas e tendências em cada região. Para isso nos apoiaremos nos conceitos já trabalhados, de formação espacial e divisão territorial do trabalho e analisaremos o caso de cinco unidades estaduais, por meio da distribuição detalhada (e georreferenciada) de suas aglomerações industriais.

\footnotetext{
${ }^{71}$ Entre esses onze estados, realizamos trabalho de campo em oito, além de Rio Grande do Norte e Amazonas. Realizamos também um total de 61 entrevistas, detalhadas no Anexo I.
} 


\subsection{A Geografia atual das aglomerações industriais}

Pode-se apontar que, no interior das unidades estaduais, existe uma concentração evidente ao redor de sua capital ou nos limites das regiões metropolitanas. Essa é a topologia na qual se encontra a maior parte da estrutura produtiva e mercado consumidor (devido à densidade populacional) nos interior dos estados.

Outra característica evidente é como cada estado, entre os que aqui estudaremos (São Paulo, Rio de Janeiro, Minas Gerais, Bahia e Amazonas), mesmo que observado unicamente por suas aglomerações industriais, se relaciona com as características da formação espacial e dos quatro brasis, em uma das leituras possíveis.

As escolhas de cada estado estão pautadas em características particulares: São Paulo, Minas Gerais e Rio de Janeiro são as unidades de maior industrialização na Região Concentrada e no Brasil; o próprio polígono formado pelas capitais São Paulo-Rio de Janeiro-Belo Horizonte poderia ser considerado como a área central (core) do polígono industrial, dada sua importância.

Por sua vez, o Estado da Bahia é a unidade estadual mais bem organizada no que tange ao planejamento de suas áreas industriais, realizada por uma superintendência estadual, e onde há também um dos mais expressivos polos industriais no Brasil (Complexo Petroquímico de Camaçari).

O Estado de Amazonas apresenta um "oásis" industrial, que pode ser considerado o distrito industrial, no Brasil, de maior número de empresas ${ }^{72}$, diversidade de segmentos (entre indústrias, comércios, serviços, bairros residenciais e outros equipamentos urbanos) na condição de uma área na qual é gerada parcela representativa da riqueza deste estado. A capital Manaus (AM) é onde meio técnico-científico-informacional se manifesta de maneira pontual e mais enfática em toda a região Norte, com grande participação do distrito industrial (Zona Franca de Manaus) para esta constatação.

Cada um destes estados foi representado cartograficamente, usando seus limites municipais e rodovias estruturantes (elementos de fundo de carta) sobre os quais foram localizados: distritos industriais, polos industriais, arranjos produtivos locais e condomínios empresariais. Os mapas a seguir (Mapas 4 a 8) mostram essa distribuição e serão analisados na sequência.

\footnotetext{
${ }^{72}$ Estima-se que atualmente existam 600 empresas na Zona Franca de Manaus, de acordo com informação da SUFRAMA. No trabalho de L. Trevisan (2012) aponta-se a existência de 410 empresas, considerando-se apenas aquelas do segmento industrial.
} 


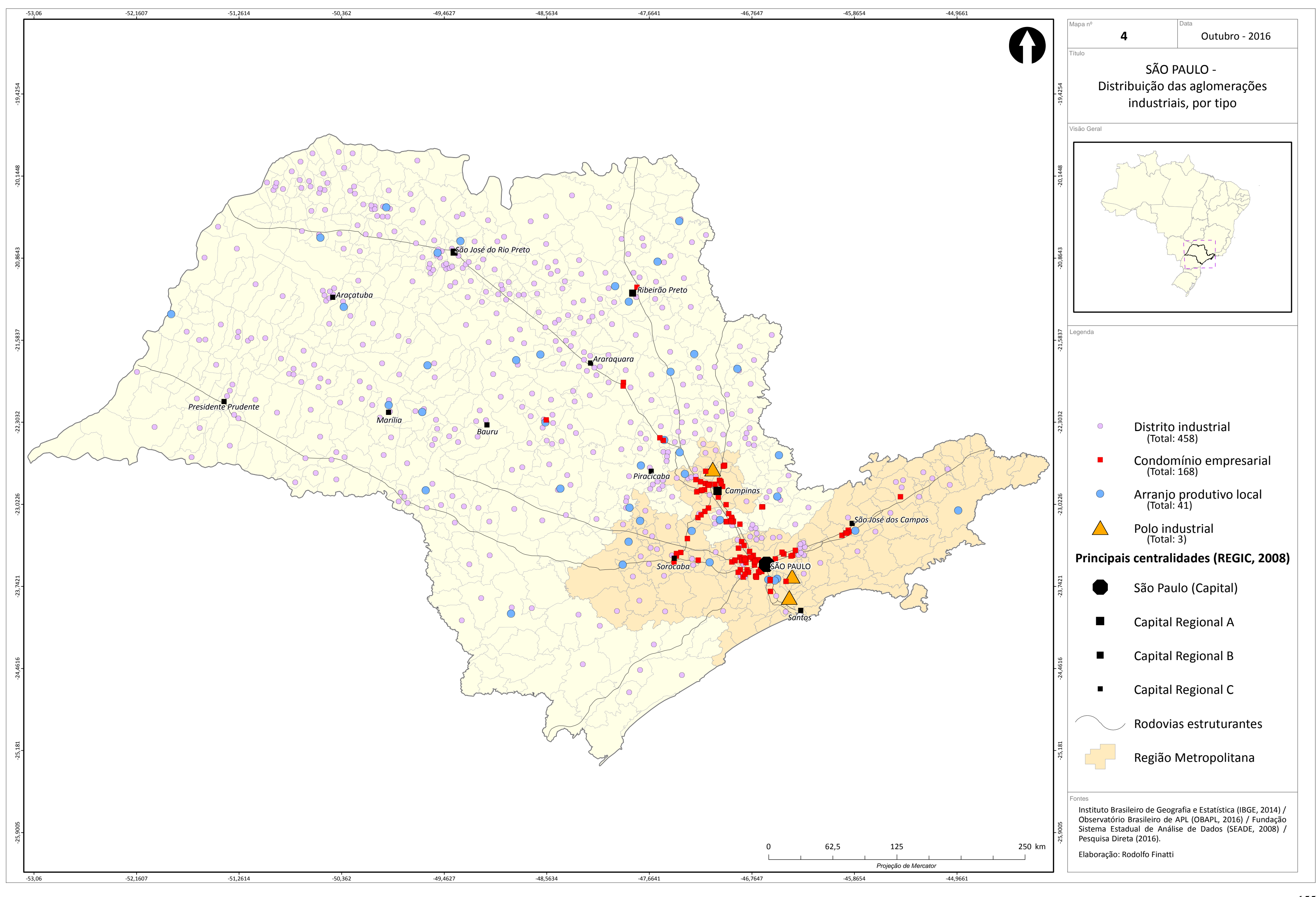




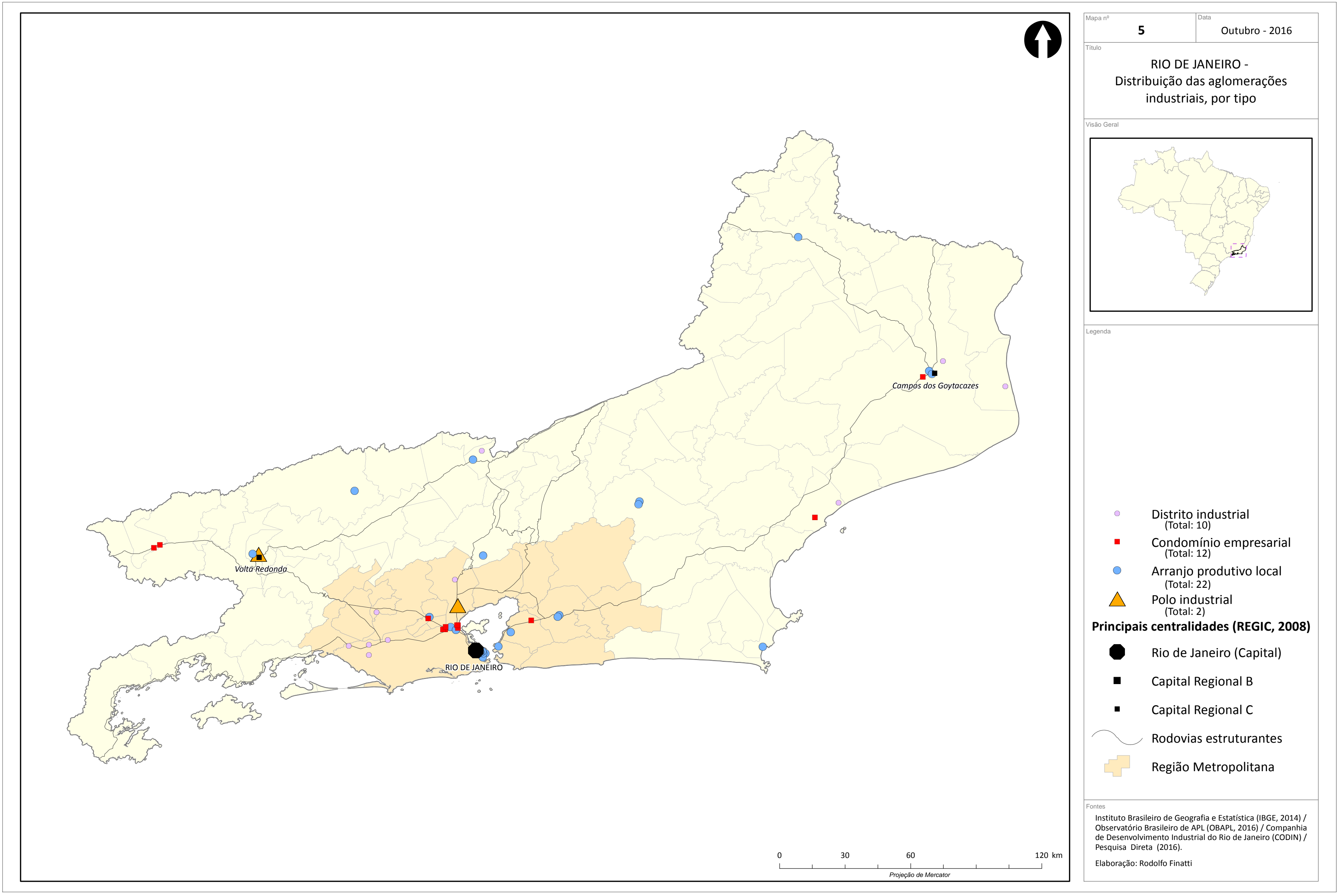




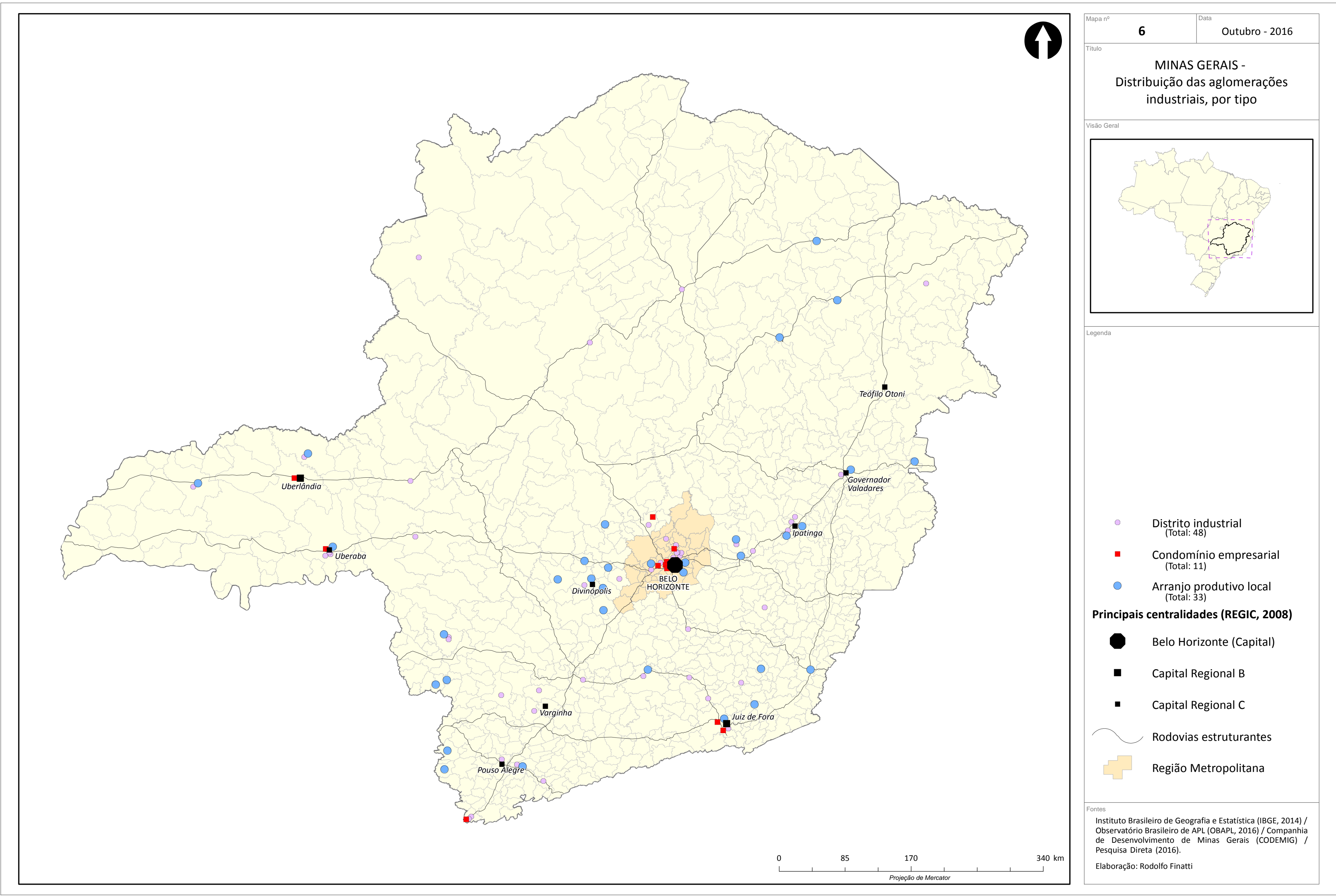




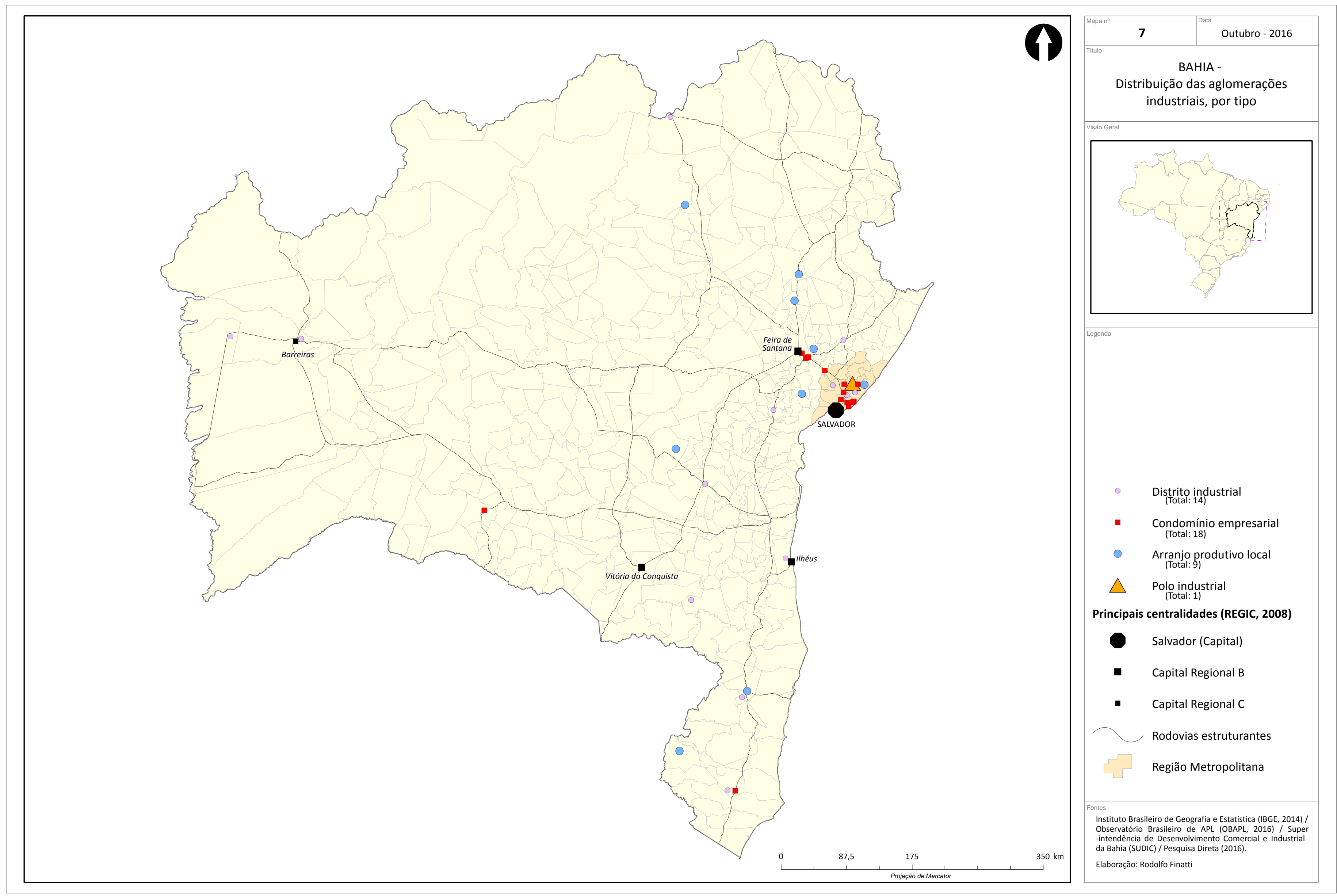




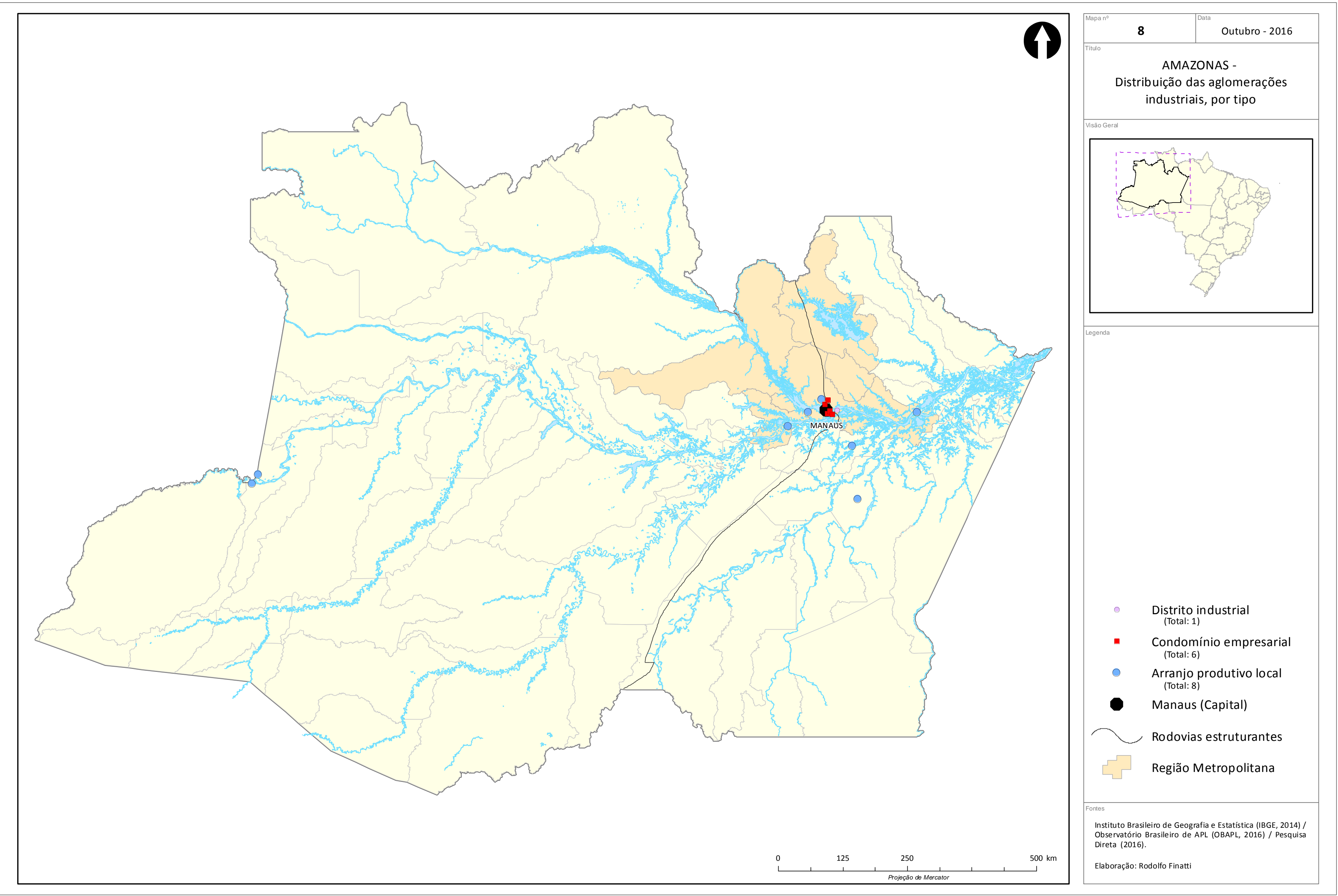


Como apresentam topologias relativamente similares, abordaremos em conjunto as tendências de localização e dispersão das formas de aglomeração apresentadas nos Mapas 4 a 8, bem como outros aspectos estruturantes que ajudem a descrever uma geografia das aglomerações industriais ${ }^{73}$.

É importante frisar que cada unidade estadual apresenta uma política industrial e territorial própria em suas secretarias governamentais, o que dificulta a apresentação integrada dos mesmos ou o levantamento de dados equivalentes e comparativos. Por isso, tentamos evitar interpretações particulares das unidades estaduais, face às suas políticas específicas, até mesmo porque outros trabalhos acadêmicos já o fizeram. O mesmo pode ser dito quanto ao esforço de institutos de pesquisa e análise de dados estaduais que se debruçam sobre a leitura estadual. Abordaremos na sequência do texto, uma análise da distribuição geográfica, respectivamente, de: distritos industriais, polos industriais, arranjos produtivos locais e condomínios empresariais.

Os primeiros distritos industriais, na condição de aglomeração pioneira com algum nível de organização planejada (aglomeração de origem não espontânea), representam o momento histórico no qual a indústria de transformação, sobretudo a industrialização pesada, começava a ser estimulada no país. Isso teve reflexo em suas localizações: os primeiros distritos industriais respeitavam a localização da indústria já existente e concentrada. Foram escolhidas áreas que, à época, eram relativamente próximas das capitais estaduais: quando possível, dentro dos próprios limites municipais ou, quando não, em municípios vizinhos.

Segundo G. C. Bruna (1974), os distritos industriais nascem, no Brasil, junto às diretrizes de planejamento dos governos central e regionais, para resolução de problemas técnicos decorrentes da ocupação desorganizada do solo e de um sistema de circulação viário subdimensionado. Assim, os esforços dos governos estaduais e de secretarias de desenvolvimento estaduais e federais ${ }^{74}$ motivaram a (re)localização das plantas industriais existentes ou, sobretudo, a implantação de novas unidades que se almejava atrair. Podemos identificar uma intencionalidade (pioneira) de organização do território e atração de novas indústrias.

\footnotetext{
73 Além da própria representação cartográfica - importante ponto de partida para nossa leitura -, nos valeremos de algumas observações de campo e também resultados de entrevistas e enquetes que realizamos com os principais agentes promotores, em relação a cada uma das formas abordadas.

${ }^{74}$ Para o detalhamento da história e configuração territorial dos principais distritos industriais mencionados individualmente, consultar os estudos de caso no Capítulo 4.
} 
Em um primeiro momento, os distritos industriais serviram à iniciativa do Estado em promover a industrialização por meio da preparação do território instalando infraestrutura produtiva, bem como se valendo de proximidade com mão de obra e mercado consumidor. A esse primeiro momento corresponde áreas que hoje estão densamente ocupadas e, inclusive, conurbadas com o centro das regiões metropolitanas. Muitas delas ${ }^{75}$, inclusive, já atingiram certa "maturidade" e passam por transformações em seus conteúdos, necessitando de planos de revisão.

Atualmente, os distritos industriais são, em sua maioria, vinculados à administração municipal. Assim como indicado pelo relatório da CIBPU (1966) já no final da década de 1960 alguns municípios paulistas chamavam a responsabilidade pela implantação dos seus distritos industriais. A partir da crise fiscal na década de 1980 e por razões diversas (relocalização das indústrias, atração de indústrias, objetivos políticos) novos distritos seguiram sendo implantados.

A partir do momento em que se verifica, para as regiões metropolitanas, a possibilidade de deseconomias de aglomeração ${ }^{76}$, os municípios próximos às regiões metropolitanas (como ocorreu nos estados de São Paulo e Rio Grande do Sul) recebem essa "interiorização da indústria". Complementarmente, podemos ainda mencionar que em razão das disputas fiscais tipo "guerra dos lugares", as prefeituras se encontraram incentivadas a adaptar o território (física e normativamente).

A partir da década de 1980, com maior ênfase, mesmo os distritos industriais originalmente implantados pelos governos estaduais passam a ter sua administração compartilhada ou assumida pelas prefeituras municipais. Porém, há uma dupla interpretação possível: (1) a administração dos distritos industriais, originalmente estadual, transferiu-se para a prefeitura municipal e (2) os distritos industriais passaram a ser implantados, de fato, por meio de projetos alavancados pelas prefeituras municipais.

De fato, alguns distritos passam por municipalização, porém ela não é geral. Há diversas situações que, combinadamente, explicam a relação do distrito industrial com seus agentes planejadores e sua intencionalidade. Propomos a seguinte classificação:

\footnotetext{
${ }^{75}$ Entre os distritos industriais que visitamos em campo, considerando apenas aqueles de densidade média à forte, mesmo que de diferentes períodos de implantação, podemos mencionar na condição de conurbados com seus municípios: Cidade Industrial de Contagem (MG), Distrito Industrial de São José dos Campos (SP), Cidade Industrial de Curitiba (PR) e Distrito Industrial de Cachoeirinha (RS).

${ }^{76}$ S. Lencioni fez abordagem para a Região Metropolitana de São Paulo (1994), assim como P. R. Soares (2010), por exemplo, fez análise similar para a Região Metropolitana de Porto Alegre.
} 
- Distritos estaduais: resultado da ação dos governos estaduais por meio de suas secretarias de planejamento, desenvolvimento ou indústria. Estes distritos podem estar sob a gestão destes órgãos, sendo a prefeitura municipal responsável pela infraestrutura, equipamentos urbanos, segurança, controle de riscos e paisagismo, bem como áreas residenciais (regularizadas ou irregulares). Neste caso, quem promove a atração das indústrias, direciona e define os incentivos (inclusive doação de terreno) é o próprio governo estadual. São exemplos de agentes, neste caso, a Companhia de Desenvolvimento de Minas Gerais (CODEMIG) e a Secretaria de Indústria, Comércio e Mineração da Bahia (SICM).

- Distritos municipais: podem ser distritos que foram inicialmente implantados por meio de programas estaduais e posteriormente objeto de processos de municipalização, quando se transferiu toda a responsabilidade sobre a manutenção das áreas para as prefeituras municipais ou mesmo podem ser distritos industriais que foram implantados, originalmente, por meio da prefeitura municipal.

- Distritos em parceria público-privada: são distritos industriais alavancados pelas prefeituras municipais, que estimulam a participação conjunta de investidores privados. Por meio de nossa atividade de campo, foi possível detectar dois distritos industriais com estas características, localizados nos municípios de Itupeva (SP) e Goianinha $(\mathrm{RN})$, como talvez as iniciativas pioneiras no Brasil. Por meio da administração destes municípios, articularam-se os esforços públicos e privados para a implantação de distritos industriais com características e funcionalidades modernas.

- Distritos "privatizados": este tipo de ocorrência está ligada à administração dos próprios distritos industriais (que muitas vezes ocorre por meio do estabelecimento de um sistema de governança organizado pelos empresários locais). No nível do discurso destes empresários, o exemplo para a "privatização" do distrito industrial apoia-se na racionalidade dos condomínios empresariais. Nestes casos, um distrito industrial é privatizado e passa à copropriedade dos empresários. Seria um tipo de ocorrência "novíssima", confirmada pela Federação das Indústrias do Estado do Paraná (FIEP) para um dos distritos industriais existentes em Cascavel $(\mathrm{PR})^{77}$. O debate sobre este assunto foi também expressivo durante o $1^{\circ}$ Workshop sobre Distritos Industriais, realizado pela Federação das Indústrias do Estado de Minas Gerais (FIEMG) ${ }^{78}$ e mostrou-se objeto de e interesse dos dirigentes da Federação Indústrias do Estado da Bahia (FIEB) ${ }^{79}$.

\footnotetext{
77 Atualmente existem quatro distritos industriais no município de Cascavel (PR). Nossas tentativas de contato com as associações de empresários destes distritos, bem como com a prefeitura municipal, visando detalhar estas informações, não tiveram sucesso.

${ }_{78}^{78}$ Participamos no respectivo workshop no dia 19 de outubro de 2015.

${ }^{79}$ Constatado em visita à FIEB no dia 27 de junho de 2014, durante o trabalho de campo realizado no mesmo estado.
} 
Além das possibilidades de combinações de agentes que tem planejado e desenvolvido os distritos industriais diferentemente do formato em que foram implantados pioneiramente no Brasil, outro processo ocorre paralelamente e vale mencioná-lo: quando os distritos industriais passam a fazer parte de estratégias eleitorais, sobretudo em municípios nos quais se tenta legitimar o desenvolvimento e a geração de empregos por meio da atração de indústrias. Esse tipo de ocorrência mostra a importância da industrialização e sua ligação direta à geração de empregos ainda presente no discurso popular e político. Nele, o distrito industrial é protagonista da atração de indústrias para o município; uma ferramenta à disposição da administração pública capaz de "trazer desenvolvimento para o município".

Portanto, é importante frisar que um segundo momento da implantação de distritos industriais no Brasil está diretamente ligado à prefeitura municipal como agente central deste processo. Por vezes, um tipo de política eleitoral atrelado à implantação de distritos industriais resultou na existência de áreas delimitadas e assim denominadas em cidades de médio e pequeno porte, porém com pouca ou nenhuma indústria instalada.

Diferentemente do arranjo produtivo local, cuja determinada localização no mapa significa efetivamente a existência de unidades industriais, ou do polo industrial que tem na indústria-motriz e os circuitos produtivos que dela derivam uma condição imprescindível. A existência do distrito industrial, atualmente, não necessariamente se traduz na existência de indústrias ou capacidade para atraí-las.

Dessa forma, visando oferecer maior precisão ao conceito de distrito industrial no Brasil (como já abordado no Capítulo 1, diferente do modelo norte americano, inglês ou italiano), podemos considerar os seguintes aspectos de sua geografia atual: (1) embora não seja exclusivamente municipal, os distritos municipais ou municipalizados são a maioria; (2) vincula-se a um contexto de planejamento urbano que está ligado à lei de zoneamento do solo urbano ${ }^{80}$ (VILLARES, 1946; BRUNA, 1976; NOGUEIRA, 1991).

Com base nestas características, podemos definir o distrito industrial brasileiro como um dos polígonos do zoneamento urbano, via de regra definido como área de uso múltiplo, no qual atualmente se localizam não apenas indústrias, mas também empresas de serviços e comércios, shopping centers, residências (ocupações irregulares, regularizadas

\footnotetext{
${ }^{80}$ Ficaremos com esta definição, apoiada também pelos autores citados, embora seja possível identificar uma contradição: não há uma definição formal para o distrito industrial na lei de zoneamento, sendo (em tese) identificado como área industrial. No entanto, a maioria dos distritos é implantado em áreas de uso múltiplo (residencial, comercial, industrial) de maneira que, mesmo buscando essa definição jurídica, ela teria imprecisões.
} 
ou mesmo condomínios residenciais fechados) e demais equipamentos urbanos (escolas, universidades, postos de saúde, hospitais, igrejas, parques ou mesmo prefeituras municipais) ou ainda outras formas de aglomeração como os condomínios de galpões modulares.

A topologia desta forma de aglomeração pioneira, embora seja a de maior número (sendo difícil um mapeamento completo para todo o território nacional no âmbito de uma pesquisa acadêmica), apresenta-se amplamente dispersa no território: os distritos industriais localizam-se principalmente nas áreas de industrialização mais antiga ou industrialmente densas e consolidadas nas unidades estaduais.

Além destas áreas, cada estado apresenta um tipo de dispersão dos distritos industriais (ligada aos projetos dos governos estaduais). Sendo assim, é importante buscar a explicação da distribuição geográfica associada às características e implantação efetivada por cada unidade estadual. Em Minas Gerais foram escolhidas cidades de porte médio e centros regionais, ao passo que na Bahia foram escolhidas regiões, mesmo que não apresentassem um número expressivo de indústrias, mas para as quais se planejava estimular este desenvolvimento.

Para citar um terceiro caso, apesar de não ter sido um estado representado cartograficamente, o Estado de Pernambuco tem atualmente implantado distritos industriais (e também selecionado e direcionado as empresas) de acordo com cidades-sede em regiões definidas de acordo com a ideia de vocações produtivas ${ }^{81}$. É uma estratégia que vigora neste estado desde 2008, apoiada em regionalização e distritos industriais. Vemos, neste caso, o distrito industrial na condição de instrumento de organização do território, e com aporte do governo estadual.

Relacionamos, no quadro a seguir (Quadro 4), algumas outras características complementares, de acordo com cada unidade estadual, da distribuição geográfica de seus distritos industriais.

\footnotetext{
${ }^{81}$ Estas informações foram obtidas durante nossa entrevista na Agência de Desenvolvimento Econômico de Pernambuco (AD-Diper), no dia 10 de julho de 2014, durante trabalho de campo no respectivo estado.
} 
QUADRO 4

Distritos industriais - Características de sua distribuição geográfica

\begin{tabular}{|c|c|}
\hline São Paulo & $\begin{array}{l}\text { No Estado de São Paulo foram identificados } 458 \text { distritos industriais e } \\
\text { estes se encontram, em maior número, ao redor das áreas } \\
\text { metropolitanas (São Paulo, Campinas, São José dos Campos e Sorocaba). } \\
\text { Espalham-se a partir dos eixos rodoviários estruturantes, aos quais } \\
\text { correspondem às faixas de industrialização e urbanização históricas do } \\
\text { estado, ou seus eixos de desenvolvimento (SPOSITO, } 2011 \text { e 2015). Além } \\
\text { disso, apresentam certo nível de concentração predominante em } \\
\text { municípios de porte médio interior como São Carlos, Araraquara e São } \\
\text { José do Rio Preto. Sua dispersão pelo estado é muito significativa; São } \\
\text { Paulo é o estado com maior número e mais ampla dispersão dos distritos } \\
\text { industriais em seu território. }\end{array}$ \\
\hline Minas Gerais & $\begin{array}{l}\text { No Estado de Minas Gerais o número de distritos é sensivelmente menor } \\
\text { (48), se comparado ao Estado de São Paulo, muito embora seja uma } \\
\text { unidade com maior território e número de municípios. Há uma } \\
\text { concentração ao redor de sua capital Belo Horizonte e também na Região } \\
\text { Metropolitana do Vale do Aço, Triângulo Mineiro e Governador } \\
\text { Valadares, áreas que são complementadas por uma dispersão um pouco } \\
\text { mais pronunciada na porção sul do estado. No Norte, a presença de } \\
\text { distritos industriais é menor. }\end{array}$ \\
\hline Rio de Janeiro & $\begin{array}{l}\text { O Rio de Janeiro apresenta um bom nível de organização e conhecimento } \\
\text { de seus distritos industriais, cuja maioria está concentrada na região } \\
\text { metropolitana. São poucos casos fora da Região Metropolitana do Rio de } \\
\text { Janeiro, destacando-se entre eles o município de Campos dos } \\
\text { Goytacazes. }\end{array}$ \\
\hline Bahia & $\begin{array}{l}\text { Na Bahia se pode apontar situação similar ao Estado de Minas Gerais: o } \\
\text { entorno de Salvador, Camaçari e Feira de Santana apresenta } 4 / 14 \\
\text { distritos industriais do Estado. A dispersão destas áreas para o interior, } \\
\text { contemplando municípios como llhéus, Vitória da Conquista e Teixeira de } \\
\text { Freitas, ocorreu de acordo com um planejamento estadual que visava } \\
\text { identificar aglomerados industriais e potencialidades regionais, fazendo } \\
\text { então com que os municípios fossem escolhidos de maneira um pouco } \\
\text { mais criteriosa, considerando também a possibilidade de seu } \\
\text { desenvolvimento econômico. }\end{array}$ \\
\hline Amazonas & $\begin{array}{l}\text { No Estado de Amazonas, embora tenham ocorrido outras iniciativas } \\
\text { (recentes) de implantação de distritos industriais (distritos de pequeno } \\
\text { porte, voltados a pequenas empresas locais) o Polo Industrial de Manaus } \\
\text { (distrito industrial) permanece como única área industrial de grande } \\
\text { porte planejada e consolidada, no município de mesmo nome. }\end{array}$ \\
\hline
\end{tabular}

Fonte: pesquisa direta (2014 a 2016). 
Os polos industriais tem origem no investimento direto do governo federal ${ }^{82} \mathrm{e}$ são privatizados na década de 1990. As escolhas locacionais que se resolvem no plano político são difíceis de evidenciar, pois a decisão política nem sempre respeita a decisão técnica mais adequada e nem sempre as negociações são revelados. As poucas referências diretas estão nos planos de desenvolvimento do governo, analisadas no Capítulo 2.

Com relação aos critérios de localização, no caso de indústrias motrizes, destaca-se certa proximidade com a matéria prima. Trata-se de uma condição fundamental da operacionalização dos polos petroquímicos ou metalúrgicos, como aqueles localizados em Camaçari (BA), Triunfo (RS) e Mauá (SP). Além disso, se verifica a proximidade com as capitais estaduais e áreas que são, atualmente, regiões metropolitanas. No Estado de São Paulo, os municípios que possuem refinarias (Mauá, Cubatão e Paulínia) não estão distantes além de $100 \mathrm{~km}$ da capital. O mesmo se pode dizer para o Polo de Triunfo localizado a $80 \mathrm{~km}$ da capital Porto Alegre ou para o Polo de Camaçari, que se localiza a $60 \mathrm{~km}$ de Salvador, no Estado da Bahia. No Rio de Janeiro, a Refinaria de Duque de Caxias está a aproximadamente $23 \mathrm{~km}$ da capital.

Ainda no Rio de Janeiro poderíamos mencionar a Companhia Siderúrgica Nacional (CSN) no município de Volta Redonda, cuja distância em relação à capital carioca é $120 \mathrm{~km}$, mesmo que esta fábrica não tenha sido inspirada pela ideia de polos de crescimento industrial em seu original - apesar de ter cumprido propósitos equivalentes. Para R. Moreira (1996) a CSN é erigida segundo o modelo company town (ou cidadefábrica $^{83}$ ) de urbanização monoindustrial, na qual a fábrica era acompanhada pela construção de bairros residenciais e toda a infraestrutura urbana em uma área rural distante.

As cidades-fábrica seriam um tipo especial de aglomeração, às quais se verifica a tendência a polarização. Originam-se ao redor de uma única indústria devido à necessidade de formação das vilas operárias, em um modelo que permitiria a gestão e o disciplinamento da força de trabalho, visando baixa rotatividade e a formação de um mercado consumidor local. De acordo com E. A. Pereira (2007) “[...] a organização territorial característica deste período seriam as vilas operárias, nas quais o industrial

\footnotetext{
${ }^{82}$ Importante ressaltar que, desde o seu início, tentou-se viabilizar um modelo tripartite que articulava o Estado, os empresários industriais nacionais e multinacionais com conhecimento tecnológico no segmento. Todavia, segundo M. A. Suarez (1983), durante toda primeira fase da implantação da indústria petroquímica nacional, entre 1948-1964, nota-se ausência do empresariado nacional e a participação muito tímida das multinacionais, as quais se posicionavam com receio face às estratégias nacionalistas. O modelo tripartite foi efetivado nas fases seguintes.

${ }^{83}$ Existem outros exemplos no Brasil, como em Timóteo (MG), povoado escolhido para implantação da Siderúrgica Acesita, em 1949, nos mesmos moldes aplicados pela Companhia Siderúrgica Nacional. $C f$. Pereira, 2007.
} 
edificava, à parte do mundo exterior, todas as condições que julgava necessário para o funcionamento de sua atividade fabril”' (p.12).

Após duas décadas de sua implantação, a cidade cresceu em densidade e os trabalhadores da usina se estendiam pelas demais cidades da baixada fluminense e Região Metropolitana do Rio de Janeiro, fazendo crescer também um vasto setor de serviços, regionalmente (MOREIRA, 1996). Privatizada no ano de 1993 sob o slogan de que "quem compra a CSN compra uma cidade" junto ao contexto de uma realidade conflitiva de greves e lutas pelos direitos trabalhistas da cidade-indústria que representava o sonho do progresso. Este sonho fora posto, na década de 1990, nas mãos do setor privado como salvação nacional. Parte do diagnóstico realizado permite constatar que:

\begin{abstract}
As habitações urbanas avançam a cidade pela encosta de morros em meia laranja fortemente intemperizados do fundo do vale. A população assim mal alojada recolhe os efeitos da multiplicação dos problemas ambientais que já seriam de esperar num espaço industrial-siderúrgico, mas que avultam num sítio inadequado para o fim de um complexo do tipo CSNVolta Redonda. E a padronização disciplinar conflita com um universo de relações já altamente diferenciadas e que se resolvem numa outra escala (MOREIRA, 1996, p.60)
\end{abstract}

Não temos condições de identificar equivalências com as histórias dos Polos de Camaçari, Mauá ou Trinfo, visto que demandaria um estudo mais aprofundado para conseguir atrelar os conceitos de polo e desenvolvimento/crescimento econômico junto às conjunturas regionais. No discurso dos gestores destas áreas industriais há dois componentes presentes. Como ideia mais presente, a afirmação de que o polo trouxe desenvolvimento porque antes "não existia nada na área". (Todavia, o polo emprega pouca mão de obra local $\left.{ }^{84}\right)$.

Vale também salientar que os municípios vizinhos de Triunfo e Montenegro, aglomerações urbanas que estão mais próximas do Polo Petroquímico, em quase nada se assemelham à Volta Redonda (RJ). São primordialmente municípios agrícolas, muito embora Volta Redonda tenha sido erigida, com muito investimento, na condição de company-town.

\footnotetext{
${ }^{84}$ Esse aspecto é especialmente presente nas imediações do Polo Petroquímico de Triunfo, que está um pouco mais afastado da capital gaúcha (em comparação aos polos dos outros estados). Segundo nossa entrevista com Sidnei dos Anjos (administrador deste polo), no dia 21 de maio de 2015, seria de se esperar um interesse maior do jovem (morador de Triunfo, Montenegro ou outros municípios vizinhos) em especializar-se para trabalhar na "grande indústria local". Porém, esta perspectiva não se verifica na prática. Além disso, nosso entrevistado informou que a absorção de mão-de-obra local é baixa, inclusive sendo necessário contratar ônibus fretados para transportar diariamente os trabalhadores de Porto Alegre (RS).
} 
Embora os objetivos desta tese obriguem a focar mais diretamente nas áreas industriais propriamente ditas, retomar uma parte da história da Companhia Siderúrgica Nacional, mesmo que na condição de uma empresa individual, permite analisar os efeitos decorrentes da polarização, não apenas circunscritas à realidade do polo industrial.

Os polos industriais que, historicamente, foram posicionados mais próximos às concentrações pré-existentes, aumentaram sua intensidade e raio de indústrias (podemos mencionar as cadeias de $1^{\mathrm{a}}, 2^{\mathrm{a}}$ e $3^{\mathrm{a}}$ geração de produtos derivados do petróleo). Atualmente o Polo de Camaçari está consolidando a ampliação de sua área para receber unidades industriais da $4^{\mathrm{a}}$ geração da cadeia de valor a partir do petróleo. Esta configuração prévia não apenas estimulou como também sustentou os investimentos estatais nas indústriasmotrizes, até que a alavancaram o modelo tripartite e, posteriormente sua privatização, depois de consolidadas.

Uma ideia para evidenciar a importância da formação espacial na constituição do polo industrial é que alguns polos planejados para a Região Amazônica (expressos nos Planos Nacionais de Desenvolvimento), atrelados ao segmento agropastoril e de $\operatorname{argila}^{85}$, mesmo que aproveitando potencialidades regionais, não lograram sucesso.

Há certo padrão que garantiu o sucesso destas iniciativas e que, devido à densidade industrial, representatividade econômica e ao nível de organização enquanto formas aglomerativas que estas áreas representam no território nacional, devem elas participar da seleção das aglomerações predominantes no Brasil e também ajudar na explicação da distribuição das aglomerações.

Finalmente, uma última questão importante a este respeito é o nível de organização administrativa necessária para o seu funcionamento. Assim, do ponto de vista de sua organização interna os polos apresentam, entre as formas de aglomeração, o sistema de gestão mais eficiente. Muito deste sistema é impulsionado pela necessidade de análise e monitoramento de riscos envolvidos nas atividades produtivas do circuito petroquímico. Por essa razão os indicamos como casos onde há especialização e sinergia, em uma área cuja densidade é alta.

Os principais polos industriais no Brasil - considerados pela sua capacidade de agrupar e conectar os produtores de primeira, segunda e terceira geração (o que denota a densidade e sinergia dos polos) podem ser considerados os seguintes:

\footnotetext{
${ }^{85}$ É importante mencionar que o conceito de polo de desenvolvimento prevê apenas sua implantação a partir da atividade industrial de transformação. A tentativa de estabelecer polos agropastoris e de argila pode ser considerada uma extensão da ideia.
} 
- Polo Industrial do Grande ABC, formado pela Refinaria de Capuava (RECAP), localizada em Mauá (SP) e participação de várias indústrias dispersas pela região do $\mathrm{ABC}$ Paulista, configurando o polo;

- Polo Industrial de Cubatão, centralizado na Refinaria Presidente Bernardes (RPBC) localizada no município de Cubatão (SP);

- Polo Industrial de Paulínia, centralizado pela Refinaria de Paulínia (REPLAN), localizada no município de Paulínia (SP);

- Polo Petroquímico de Camaçari, centralizado pela Refinaria Landulpho Alves (RLAM), localizada no município de Camaçari (BA);

- Polo Petroquímico do Rio de Janeiro, centralizado pela Refinaria Duque de Caxias (REDUC), também conectada à Refinaria Gabriel Passos (REGAP) localizada em Betim (MG) e à Refinaria Henrique Lages (REVAP) localizada em São José dos Campos (SP). A REDUC está localizada no município de Duque de Caxias (RJ);

- Polo Petroquímico de Triunfo (ou Polo Petroquímico do Sul), centralizado pela Refinaria Trinfo, no município de mesmo nome (Triunfo, RS).

No que tange aos arranjos produtivos locais, precisamos lembrar que são aglomerações relacionadas principalmente às micro e pequenas empresas ${ }^{86}$ que existem nas regiões metropolitanas e também no interior dos estados, onde são proporcionalmente mais evidentes.

Os arranjos produtivos locais resultam (expressão de políticas publicas) de um momento no qual o Estado já não mais realiza o investimento direto em indústrias ou organiza áreas industriais enquanto planejador; a transferência dessa responsabilidade deu impulso, na década de 1980, ao que se pode chamar de empreendedorismo local, por parte de pequenos produtores com conhecimento produtivo e um nível mínimo de gestão para que pudessem consolidar-se como um arranjo e angariar recursos para o seu desenvolvimento econômico.

Diversas instituições participam permanentemente para o estímulo aos arranjos produtivos locais. Este tipo de aglomeração tem, por sinal, o melhor nível de organização interinstitucional no que tange à obtenção de recursos, treinamento técnico ou gerencial,

${ }^{86}$ Como critério de diferenciação entre micros, pequeno e médias empresas considere-se o número de funcionários diretamente empregados pela empresa. De acordo com o critério de porte do SEBRAE, a classificação é a seguinte: (1) Micro = até 19 pessoas ocupadas; (2) Pequena $=20$ a 99 pessoas ocupadas; (3) Média $=100$ a 499 pessoas ocupadas e (4) Grande $=500$ pessoas ocupadas ou mais. $C f$. Martins (2014). 
sensibilização pública e representatividade, bem como levantamento e organização de fontes de dados publicamente disponíveis. Entre os principais níveis institucionais, podemos citar a Universidade Estadual do Rio de Janeiro (UFRJ), por meio da REDESIST e o Observatório Brasileiro de APL (OBAPL) com ofertas de dados e informações. O SEBRAE atua continuamente na oferta de treinamento técnico, gerencial, entre outras áreas como marketing e inovação (este último tema, um dos carros chefes dos recentes projetos do SEBRAE); as federações industriais em cada estado na condição de representatividade política do arranjo produtivo local e/ou incentivadora de projetos e investimentos. Finalmente, um dos principais apoiadores financeiros dos arranjos produtivos locais é o Banco Interamericano de Desenvolvimento (BID), por meio de parcerias capitaneadas e coordenadas pelo SEBRAE junto às secretarias estaduais e às federações industriais.

É importante mencionar, até mesmo visando seu credenciamento junto às instituições que disponibilizam recursos de fomento para este tipo de área, que seja implantado e reconhecido pelas empresas integrantes do arranjo - ou as quais pretendem integrá-lo - um sistema de governança ${ }^{87}$. Algumas vezes, essa governança está atrelada a iniciativas individuais de empresários que detêm maior prestígio entre os seus pares, porém em outras ocasiões as governanças precisam ser estimuladas.

A necessidade de uma governança (ou sistema de gestão) territorial e empresarial é o ponto de concordância entre todos os entrevistados das instituições estimuladoras de arranjos produtivos locais. Para eles, uma governança bem estabelecida pode ser o divisor de águas entre o sucesso e o fracasso de um projeto executado junto a este tipo de aglomeração industrial.

Outro aspecto importante da geografia dos arranjos produtivos locais é o reconhecimento da necessidade de mudança conceitual de uma perspectiva setorial para a cadeia produtiva. Isso foi identificado e afirmado por analistas de alguns SEBRAE regionais (nos seguintes estados: Rio de Janeiro, Minas Gerais, Bahia e Pernambuco) e também pela Federação das Indústrias do Estado de São Paulo, devido ao atual desgaste dos projetos, os quais estariam repetitivos (pouca capacidade de inovar em processos e produtos) e seus resultados cada vez menos satisfatórios. Essa é uma questão geográfica

\footnotetext{
87 Embora seja este um termo já em desuso, e eventualmente inadequado (pois também usado em Geopolítica), é empregado pelo corpo técnico envolvido com os arranjos produtivos locais para discriminar a necessidade de um sistema de gestão reconhecido entre as empresas. Governance, em inglês, refere-se a formas de conduta de uma organização humana, o que pode ser ainda muito mais amplo que gouvernment (no sentido de uma estrutura política territorial). Cf. Benko (1996).
} 
importante, na medida em que passam a valorizar não apenas a especialização produtiva regional ou local, mas também as possibilidades de trabalhar conjuntamente os circuitos produtivos por meio de projetos que integrem diferentes segmentos da economia.

O principal estudo de caso, apresentado no Capítulo 4, será o do arranjo produtivo local de roupas íntimas que está localizado em Nova Friburgo (RJ): como exemplificamos, esta aglomeração se expandiu além da dimensão das empresas de vestuário, atrelando outros segmentos industriais como plástico e metal (para produção de peças) e ainda outros segmentos (transportes, turismo, alimentação e hotelaria) para desenvolver o arranjo. Os demais estados mencionados como os que identificaram essa perspectiva de maior abrangência econômica estavam, no momento das entrevistas, elaborando seus projetos integrados.

A topologia dos arranjos produtivos locais acompanha a existência histórica e localização das especializações produtivas no território brasileiro: estas formas de aglomeração não são planejadas, mas induzidas (potencializadas) nas áreas em que algumas características essenciais já estão presentes. Para seu reconhecimento enquanto um arranjo produtivo local (e possibilidade de absorver recursos) é preciso, ainda, estabelecer um nível mínimo de gestão e representatividade entre as empresas, e destas com o poder público.

Os arranjos apresentam dispersão por cidades médias e pequenas, em sua maioria, mas também nas capitais (predominantemente relacionados aos serviços). Há uma imprescindível ligação com a própria história da comunidade e de como se especializou em um determinado segmento, tendo para isso razões e critérios próprios (existência de matéria prima, fontes de conhecimento local, iniciativas de colonização, etc).

É possível que aglomerados relacionados aos arranjos produtivos locais escapem da nomenclatura usada e não estejam presentes nos mapas apresentados. É também possível que outros tipos de aglomerações (tais como as facções, que existem em grande número na região Nordeste) não sejam reconhecidas nos projetos, mesmo que reúnam as características para isso. $\mathrm{O}$ fato importante é que as aglomerações industriais de pequenas e médias empresas são, de fato, mais numerosas e dispersas do que seria possível representar cartograficamente, devido à falta de informação organizada. No entanto, a necessidade de manter um critério e ter a base de uma fonte oficial e sistematizada é indispensável.

Entre as aglomerações estudadas, talvez seja o arranjo produtivo local que apresente uma distribuição mais dispersa, ao menos no que tange às aglomerações 
industriais, na extensão do território nacional. Uma das características apresentadas por este tipo de aglomeração, até mesmo devido ao fato de aproveitar-se uma especialização historicamente consolidada, é que são poucos casos de existir mais de um arranjo produtivo local no mesmo município (excetuando-se as capitais). Isso o difere da distribuição apresentada pelas outras formas aglomerativas.

Além disso, é importante lembrar que, ao falarmos dos arranjos produtivos, não corremos o risco de falar de áreas que possam estar ociosas. Ou seja, há certamente um conteúdo na localização que os arranjos mostram, seja um conteúdo já desenvolvido ("maduro") ou incipiente, ainda por se desenvolver.

Uma análise, estado a estado, quanto aos arranjos produtivos locais (Quadro 5) pode ser conferido a seguir. 
QUADRO 5

Arranjos produtivos locais - Características de sua distribuição geográfica

\begin{tabular}{|c|c|}
\hline São Paulo & $\begin{array}{l}\text { No Estado de São Paulo existem dez arranjos produtivos locais inseridos } \\
\text { nas áreas metropolitanas, ao passo que } 30 \text { deles se localizam no } \\
\text { interior, e com uma dispersão relativamente equilibrada no conjunto do } \\
\text { território (exceto quanto ao Vale do Ribeira e Pontal do Paranapanema, } \\
\text { que são regiões economicamente menos dinâmicas e carentes de } \\
\text { recursos). Essa proporção difere das demais formas de aglomeração } \\
\text { (concentradas principalmente ao redor da metrópole). }\end{array}$ \\
\hline Minas Gerais & $\begin{array}{l}\text { Em Minas Gerais se verifica apenas três de um total de } 33 \text { arranjos } \\
\text { produtivos locais na influência da Região Metropolitana de Belo } \\
\text { Horizonte, ao passo que os demais ( } 30 \text { arranjos produtivos locais) estão } \\
\text { dispersos pelo estado mineiro. A dispersão destas aglomerações se dá, } \\
\text { sobretudo, associada à porção sul do estado, de maior dinamismo } \\
\text { econômico. O norte de Minas Gerais e mesmo o triângulo mineiro } \\
\text { apresentam poucos arranjos produtivos locais, comparativamente. }\end{array}$ \\
\hline Rio de Janeiro & $\begin{array}{l}\text { O Rio de Janeiro apresenta } 22 \text { arranjos produtivos locais, cuja } \\
\text { distribuição também predomina ao redor e fortemente concentrada na } \\
\text { capital fluminense. Porém quase metade dos arranjos produtivos } \\
(10 / 22) \text { está distribuída pelo estado, principalmente na região serrana. }\end{array}$ \\
\hline Bahia & $\begin{array}{l}\text { Na Bahia, apenas um arranjo produtivo local na área de maior densidade } \\
\text { industrial (Salvador-Camaçari), que corresponde ao maior dinamismo } \\
\text { econômico. Em sua maioria (8) seguindo o eixo da Rodovia BR-116, não } \\
\text { se dispersam homogeneamente pelo conjunto do território. }\end{array}$ \\
\hline Amazonas & $\begin{array}{l}\text { No Amazonas, os arranjos produtivos locais enfrentam dificuldades de } \\
\text { implantação, tanto no que tange à logística quanto à mentalidade } \\
\text { oriunda de uma herança cultural que se choca com a ideia de } \\
\text { empreendedorismo (conforme relatado pelo SEBRAE local). Apesar das } \\
\text { dificuldades existentes na região Norte, os arranjos conseguem ser } \\
\text { transformar em iniciativas econômicas no Amazonas (que apresenta o } \\
\text { mesmo número de unidade que a Bahia). O maior número se localiza em } \\
\text { Manaus e a segunda maior concentração em Tabatinga, já na fronteira } \\
\text { internacional. }\end{array}$ \\
\hline
\end{tabular}

Fonte: pesquisa direta (2014 a 2016). 
Por fim, os condomínios empresariais representam a iniciativa mais recente e cujo planejamento/investimento está diretamente relacionado ao agente privado (promotores imobiliários).

Em pesquisa anterior (FINATTI, 2011) verificamos que, além da promoção das "marcas" de condomínios empresariais, os incorporadores também se empenham em produzir uma psicosfera empresarial com slogans e propaganda em outdoors nas rodovias, em revistas e jornais e, também, em televisão. O mais comum destes meios de divulgação é o uso de outdoors em rodovias, o que pudemos verificar em trabalho de campo, não apenas nas rodovias paulistas, mas também em outros estados como Ceará, Pernambuco e Rio Grande do Sul.

Até a inserção dos condomínios empresariais, o elenco de aglomerações industriais não era tão atuante em relação à psicoesfera, pois não eram áreas definidas pelo mercado imobiliário, o que evidencia um traço diferencial consideravelmente importante. Na visão de M. Santos (2004 [1996]), a psicoesfera é sempre criada paralelamente à tecnoesfera e corresponde à produção de um sentido, de ideias e de crenças.

Tecnoesfera e psicoesfera são redutíveis uma a outra. O meio geográfico atual, graças ao seu conteúdo em técnica e ciência, condiciona os novos comportamentos humanos, e estes, por sua vez, aceleram a necessidade da utilização de recursos técnicos, que constituem a base operacional de novos automatismos sociais. Tecnosfera e psicoesfera são os dois pilares com os quais o meio científico-técnico introduz a racionalidade, a irracionalidade e a contra-racionalidade, no próprio conteúdo do território (SANTOS, 2004 [1996], p.256 - grifo nosso).

O que podemos apontar com esta iniciativa diz respeito à expectativa de inserção dos condomínios empresariais em um mundo globalizado, cujo objetivo é a competitividade, a rapidez, o estabelecimento de fluxos de longo alcance. As propagandas abordam a inserção dos condomínios empresariais em um território que facilita a comunicação e um mundo cada vez mais rápido e dinâmico, ao mesmo tempo em que ressaltam também a oferta de segurança e a possibilidade de trabalhar em um meio considerado aprazível (existência de áreas de conservação ambiental, parques e praças, arborização, áreas de lazer e cuidados paisagísticos).

Outra informação importante e que diz respeito à aceleração do mundo atual, é que os condomínios empresariais, na tentativa de cumprir seu papel de território preparado para o uso corporativo, em um paradigma de produção flexível, tende a ser uma 
aglomeração mista ${ }^{88}$. Evidentemente, isso vem ao encontro do objetivo dos negócios imobiliários, o que significa, na prática, não restringir a negociação com qualquer segmento econômico. Em outras palavras, os condomínios foram planejados para atender a todos os segmentos que possam albergar. Pode-se negociar com estabelecimentos industriais, prestadores de serviços (inclusive operadores logísticos), estabelecimentos comerciais (atacados), bem como outros segmentos imobiliários como galpões para aluguel, salas de escritórios para aluguel e mesmo hotéis.

Dessa forma, podemos entender os condomínios empresariais como aglomerações não apenas industriais, mas aglomerações produtivas. Apesar de outras aglomerações admitirem demais segmentos econômica e, eventualmente até mesmo residenciais ${ }^{89}$, não são formas essencialmente "mistas", ou seja, não foram planejadas para a atividade industrial, exclusivamente. Quanto aos condomínios empresariais, a ocupação primordial por empresas industriais é possível, mas não se verifica em todos os casos. É mais comum ocorrer uma distribuição entre vários segmentos. Por isso, se trata de formas de aglomeração produtivas.

Por meio de pesquisa realizada entre 2014 e 2016, detectamos 319 empreendimentos imobiliários desta natureza no Brasil, considerando apenas os seguintes tipos:

- Condomínios empresariais mistos (40 empreendimentos);

- Loteamentos industriais (17 empreendimentos);

- Condomínios de galpões modulares (262 empreendimentos).

Todos estes tipos, embora não necessariamente sejam predominantemente industriais, sobretudo os condomínios de galpões, permitem a instalação de indústrias (por essa razão, foi deixado de lado o condomínio horizontal de escritórios).

\footnotetext{
${ }^{88}$ Até mesmo em nossa proposta de classificação dos condomínios empresariais no Capítulo 1, ressalte-se a categoria de condomínio empresarial misto. Embora os condomínios de galpões modulares que tratamos em conjunto aos condomínios empresariais mistos também permitirem diferente usos (neste caso, sobretudo industrial e de serviços) o condomínio empresarial misto é uma loteamento empresarial fechado, no qual a abordagem primeira é a negociação de lotes urbanos em seu interior. Essa forma mais flexível (loteamento) permite também um número maior de funções em relação ao condomínio de galpões modulares.

${ }^{89}$ Como já vimos destacando, os distritos industriais, mesmo que planejados exclusivamente para a atividade industrial, são áreas que passam por transformações em seu uso do solo. Quer sejam ocupações residenciais (irregulares) ou bairros residenciais (eventualmente bairros operários) planejados, são ocorrências bastante comuns. Verificamos este tipo de uso do solo no Distrito Industrial de Campinas (SP), Distrito Industrial de São José dos Campos (SP), Cidade Industrial de Contagem (MG), Distrito Industrial de Fortaleza (CE) e no Polo Industrial de Manaus (AM). Em Campinas, existem seis bairros residenciais que se chamam DIC (Sigla para Distrito Industrial de Campinas): DIC I, II, III, IV, V e VI. Estes bairros foram regularizados e desmembrados da área original do distrito. No caso do Distrito Industrial de Fortaleza e Cidade Industrial de Contagem, são bairros que fazem parte do distrito industrial. No caso de Manaus, o distrito industrial apresenta, inclusive, dois bairros residenciais fechados.
} 
O Gráfico 1 permite a comparação entre os tipos de condomínios empresariais registrados.

\section{GRÁFICO 1}

BRASIL - Condomínios empresariais, por tipo (2016)

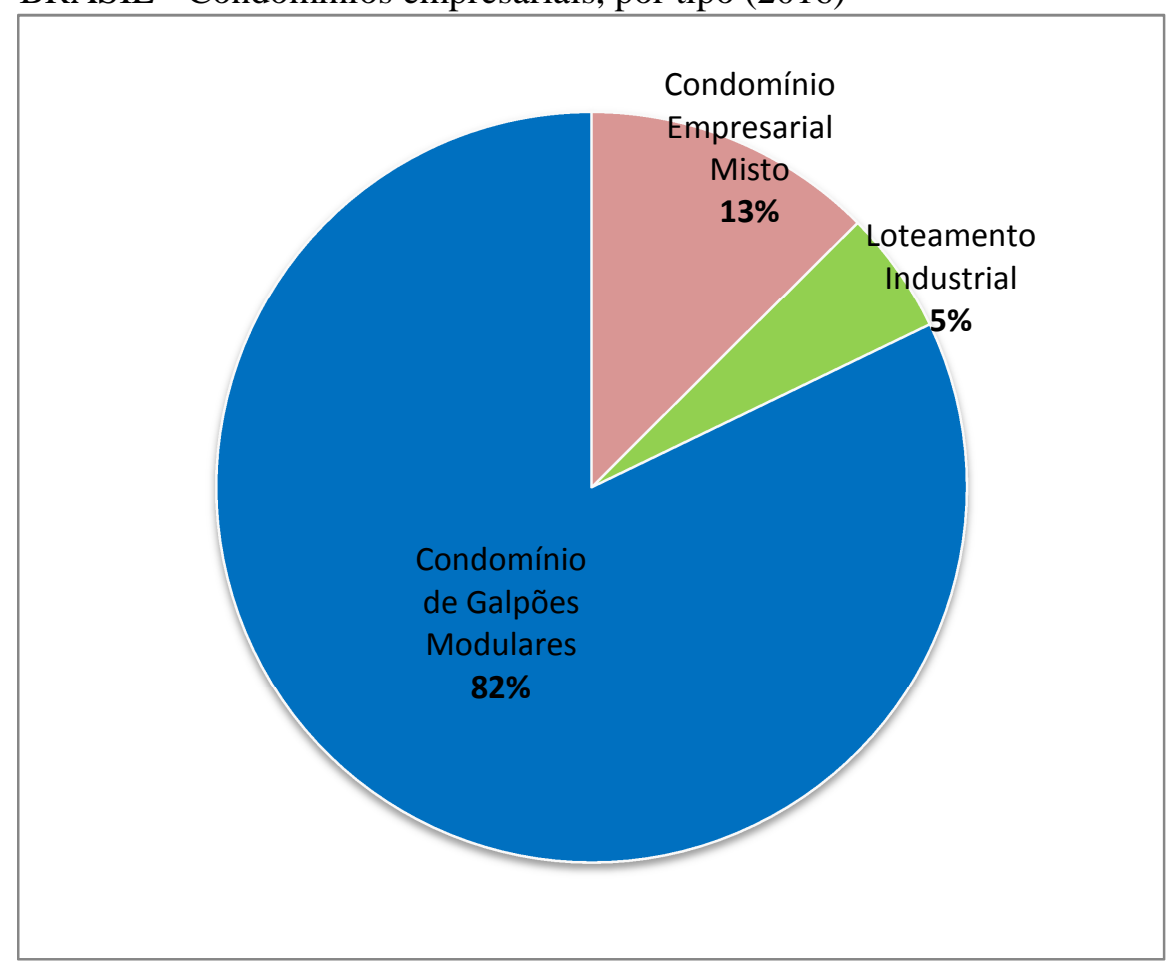

Fonte: Pesquisa direta (2014 a 2016).

Os condomínios empresariais mistos e os loteamentos industriais tem um padrão locacional similar, pois ambos precisam de superfícies de grande extensão. A organização do espaço, mais permissiva, se pauta na venda de lotes, daí a necessidade de maiores espaços. Ao menos no que tange à realidade do Estado de São Paulo, onde sua ocorrência é sensivelmente maior, a necessidade de maiores espaços tende a restringir o número deste tipo de condomínio.

Os condomínios de galpões modulares prezam pela máxima da "localização estratégica”, o que se traduz como a proximidade com os mais importantes eixos de circulação rodoviários $^{90}$. No caso dos condomínios de galpões modulares, por sua menor superfície relativamente aos condomínios mistos, há facilidade para encontrar áreas para investir. Estes empreendimentos estão, inclusive, concentrados nas imediações das capitais

\footnotetext{
${ }^{90}$ Preferencialmente com acesso direto para estes eixos de circulação (rodovia de grande porte) ou, em uma perspectiva considerada conservadora, até $2 \mathrm{~km}$ de distância do eixo, acessível também por rodovia, configurando-se em condomínios que dispõem de "alta fluidez territorial”. C $f$. Finatti, 2011.
} 
e regiões metropolitanas. Unido ao fato de que os condomínios de galpões representam a possibilidade de aluguel por curto período de tempo (poucos são, de fato, adquiridos pelas empresas ocupantes) isso faz deste tipo de empreendimento mais flexível. Estes são os fatores que explicam o número maior de condomínios de galpões modulares.

Comparativamente, o Estado de São Paulo tinha 96 condomínios empresariais $^{91}$ até o final de 2011, número que aumentou para 168 no ano de 2016. O crescimento foi de $43 \%$ em cinco anos. Em relação ao resto do Brasil, a proporção de condomínios empresariais pode ser visualizada no Gráfico 2.

\section{GRÁFICO 2}

BRASIL - Total de condomínios empresariais por unidade estadual

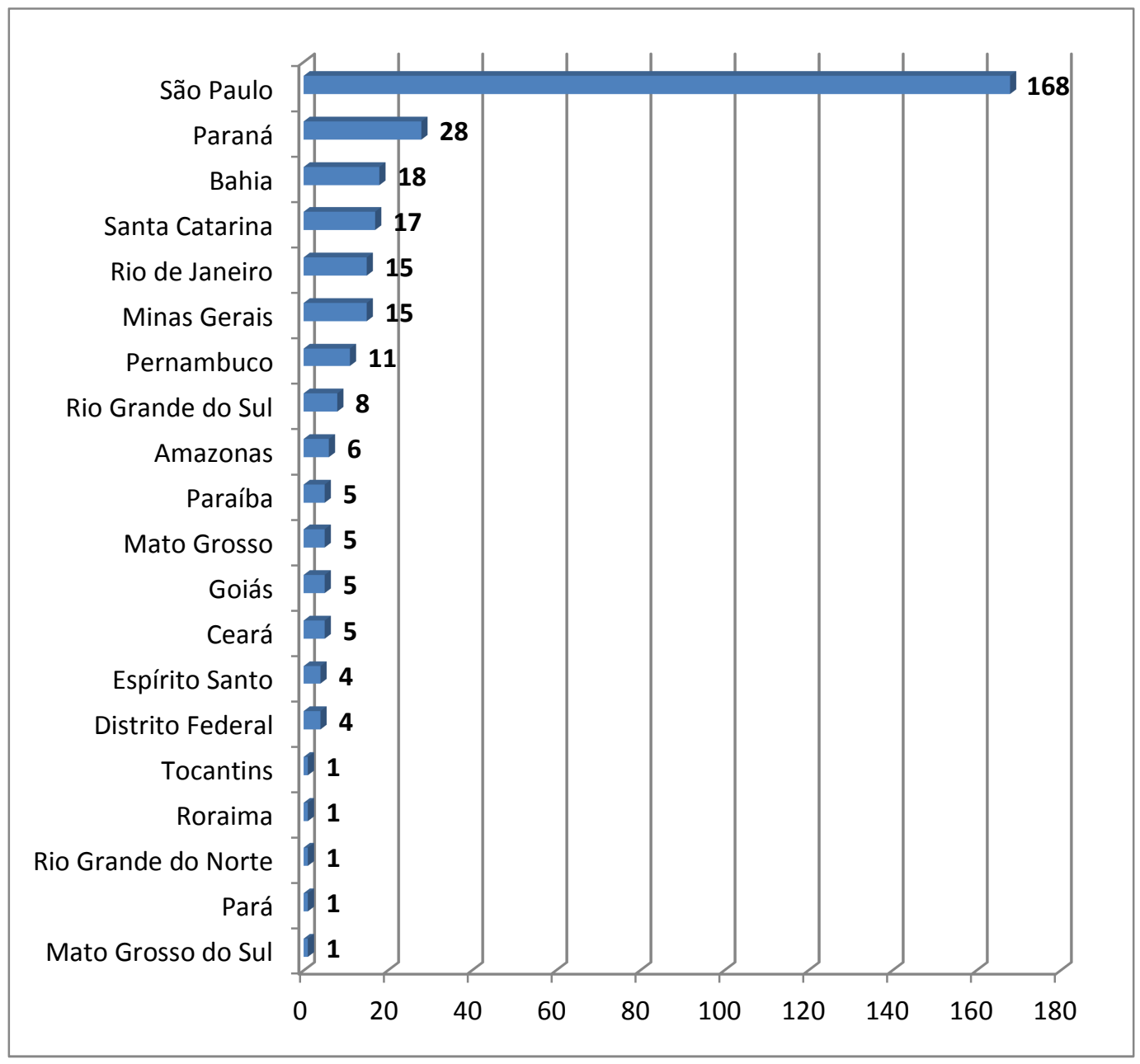

Fonte: Pesquisa direta (2014 a 2016).

\footnotetext{
${ }^{91}$ Considerando condomínios empresariais mistos e condomínios de galpões modulares, que são os tipos compatíveis com unidades industriais (fabris), retiramos desta base os condomínios horizontais de escritórios já que estes empreendimentos não são compatíveis com a instalação de unidades industriais.
} 
Já no cenário nacional, o Estado de São Paulo contém 52,6\% de todos os condomínios empresariais, em parte por ter sido o estado pioneiro, em parte por apresentar as melhores condições de mercado para estes empreendimentos. O Paraná, segundo mais representativo, tem 28 condomínios empresariais (8,7\%). Os demais estados representativos são: Bahia, Santa Catarina, Rio de Janeiro e Minas Gerais, em sua maioria unidades estaduais que fazem parte do que consideramos como a Região Concentrada.

Como são empreendimentos imobiliários, seus objetivos são também particulares. A aglomeração é resultante, nestes casos, dos interesses imobiliários, sendo este o agente intermediário (a escolha da localização tem duas etapas: precisa satisfazer os critérios das indústrias e demais empresas, desde que esteja garantida a satisfação dos critérios imobiliários de mercantilização do solo urbano). Diferem das intencionalidades das outras formas analisadas, quais sejam: organização territorial da indústria e sua atração, desenvolvimento regional e industrial via fornecimento de insumos básicos ou indução ao empreendedorismo local. Os incorporadores imobiliários tem, na obtenção da renda do solo, seu objetivo final.

Para tentar quantificar essa proporção de indústrias ou de prestadores de serviços nos condomínios empresariais, embora seja tarefa difícil ${ }^{92}$, realizamos enquete com importantes promotoras e construtoras imobiliárias, bem como administradoras de condomínios empresariais com objetivo de mapear a proporção dos segmentos e, entre eles quais seriam os principais.

Quanto às empresas envolvidas exclusivamente com condomínios de galpões modulares, a LogCP informou 5\% das empresas ocupantes são indústrias leves, produtoras de embalagens, pacotes e produção de peças simples para automóveis. A Retha Imóveis e Serviços, uma das principais administradoras de condomínios de galpões no Brasil, informa que a proporção de indústrias é de $10 \%$ a $12 \%$ em seus condomínios, sendo principal o segmento de fabricação de peças para celular e componentes eletrônicos. A proporção informada pela Sanca, construtora e administradoras de condomínios de galpões, é muito similar, de 5\% a 10\% de indústrias sendo principalmente indústrias leves: cosméticos e meias elásticas são segmentos existentes em seus empreendimentos. A Fulwood, por sua vez, informa que a proporção de indústrias em seus condomínios de galpões chega a 70\% (os principais segmentos em empreendimentos da Fulwood são: peças automotivas, eletrônicos, equipamentos solares, fraldas, papéis, produtos de higiene

\footnotetext{
${ }^{92}$ Difícil devido à preocupação com a segurança. Uma vez que são empreendimentos fechados e há um grande número de distribuidoras, existe uma opção generaliza por não divulgar informações desta natureza.
} 
pessoal, plásticos e produtos farmacêuticos). Finalmente, a Brazilian Business Parks, incorporadora sediada no município de Atibaia, apresenta uma proporção de indústrias de $67,5 \%$ em relação aos demais segmentos instalados em seus galpões, com um agrupamento representativo de 5 indústrias farmacêuticas e outros segmentos de peças automotivas, equipamentos industriais e cosméticos. Apenas uma empresa entre as contatadas, a DVR Participações, informou que não há indústrias em seus empreendimentos.

No âmbito dos condomínios empresariais mistos, que são em menor número, mas permitem maior diversidade de segmentos econômicos, o Techno Park Campinas apresenta uma proporção de 55\% de empresas industriais entre as que estão localizadas no empreendimento, com um relevante agrupamento de empresas de biotecnologia ${ }^{93}$.

Percebemos, no tocante aos condomínios de galpões modulares, que há possibilidade de grandes variações entre uma presença predominante de indústrias ou, por outro lado, sua ausência. Outros segmentos correlatos dizem respeito aos serviços industriais, que apoiam a infraestrutura industrial (em verdade, outras formas de aglomeração também estimulam a instalação de serviços industriais, casos dos distritos industriais e dos polos industriais). A combinação entre unidades produtivas e empresas de logística, inclusive, pode ser considerada mais uma vantagem de localização existente nos condomínios de galpões modulares.

Finalmente, ao analisar as representações cartográficas observamos que os condomínios estão presentes nos cinco estados apresentados, inclusive sendo um número representativo na Bahia e Amazonas, comparativamente às demais formas de aglomeração. A Bahia é o estado que recebeu mais investimentos deste tipo, depois de São Paulo, assim como outros estados do Nordeste. O importante é notar a tendência à dispersão deste tipo de aglomeração, ao que se acompanha o investimento, sobretudo no Nordeste.

O caso de Manaus (AM) com seis condomínios empresariais está, evidentemente, atrelado à existência da Zona Franca de Manaus, como principal aspecto atrativo para investimentos desta natureza, o que reforça ainda mais a lógica estritamente imobiliária dos condomínios empresariais.

Em linhas gerais, os condomínios empresariais evidenciam com precisão a Região Concentrada e sua core area no Estado de São Paulo, ao passo que os incorporadores paulatinamente investem, sobretudo na região Nordeste, seletivamente, em seus pontos luminosos.

\footnotetext{
${ }^{93}$ De acordo com nossa entrevista com o engenheiro J. L. Guazzelli, diretor do Techno Park Campinas, realizada no dia 28 de julho de 2016.
} 
Por um lado, os condomínios representam áreas mais modernas, parte do meio técnico-científico-informacional e também são capazes de aglomerar e reduzir custos (diretos) de operação, mesmo entre empresas de diferentes segmentos. Do ponto de vista da permissividade da instalação da indústria e de incremento da competitividade, os condomínios atendem às empresas e permitem maior produtividade espacial.

Finalmente, é preciso destacar, como crítica aos condomínios empresariais, que representam também a privatização da gestão do território, tendência apresentada por R. Moreira (2012), como momento atual da formação espacial brasileira: estaríamos passando por este momento no qual as iniciativas privadas assumem um controle cada vez maior do território. Muito embora os condomínios empresariais não sejam áreas privatizadas, expressam a tendência de decisão e controle privativo de uma área, devido à natureza dos agentes imobiliários. Por seu principal agente ser o promotor imobiliário, os condomínios empresariais estão ligados a uma intencionalidade bem definida (obtenção da renda do solo urbano), bem como escolhas locacionais direcionadas e centradas na busca por acumulação de capital.

Estes empreendimentos podem também ser considerados como enclaves fortificados urbanos, no contexto de um aumento do discurso da securitização (CALDEIRA, 2000), que tem como repercussão o processo de urbanização contraditório do privado em detrimento do espaço público. Este processo de urbanização pode ser denominado urbanização difusa, no qual a cidade cresce fragmentada territorialmente e

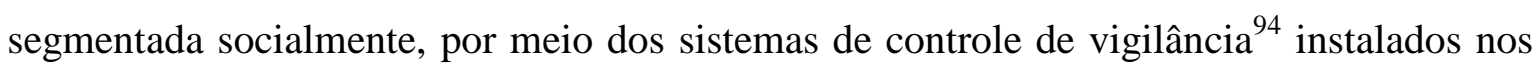
empreendimentos. Uma análise de seu impacto no processo de urbanização, do qual os condomínios empresariais participam, pode levar em conta o seguinte:

Esse contexto enseja, em sociedades com grandes disparidades como a brasileira, a valorização exacerbada dos novos produtos imobiliários que se apresentam no mercado, portadores de sistemas de controle e vigilância e representativos da ideia de que é possível alguma segurança em um mundo de imponderabilidades. A implantação desses empreendimentos é um dos vetores da redefinição completa do par centro-periferia, pois os sistemas de controlam a acessibilidade e a circulação, seja no concernente aos espaços privados, seja no que diz respeito aos espaços públicos, recompõem o tecido espacial para atender e sustentar a recomposição do tecido social (SPOSITO, 2011, p.140 grifo nosso).

\footnotetext{
${ }^{94}$ Os sistemas de controle e vigilância instalados para segmentar espaços em relação ao conjunto da sociedade propagam-se nos espaços residenciais, comerciais e também empresariais, dos quais os condomínios empresariais são exemplos. Uma apresentação mais detalhada desta análise pode ser encontrada em Finatti (2011) e Finatti e Sposito (2010).
} 
A principal implicação envolvida é a intencionalidade própria do agente imobiliário (a mercantilização do solo urbano), que implica na rápida venda ou aluguel das infraestruturas disponíveis. Também por isso os condomínios concorrem entre si por meio da criação de uma psicoesfera corporativa que se apoia nos quesitos: segurança-serviços compartilhados-localização estratégica. Os contratos de aluguel, que são maioria (pois é maioria o número de condomínios de galpões modulares) flexibilizam a ação das empresas, seu tempo de permanência e também a relação com o território, cada vez mais efêmera e "distante".

Embora tenha que respeitar alguns fatores de localização (assim como as demais aglomerações) a decisão da localização do empreendimento é do empreendedor. Em outras palavras, no caso dos condomínios empresariais é o mercado decide a localização das aglomerações produtivas e, como consequência, também a localização das empresas. Se, durante a história da industrialização do Brasil, o Estado desenvolvimentista utilizou distritos e polos industriais como ferramenta para tentar acelerar a economia em uma determinada parcela, a proposta dos condomínios empresariais parece hoje despertar maior interesse.

Finalmente, um fato que chama a atenção em relação a este tipo de aglomeração produtiva é o interesse que vem despertando nas demais instâncias, poder público e associações de empresários. Algumas formas híbridas começam a anunciar sua existência, tais como parcerias entre prefeitura municipal e incorporador imobiliário (distrito-condomínio) e também entre universidades e empresas (condomínio-parque tecnológico).

Por outro lado, temos que também advertir sobre o rápido crescimento destes empreendimentos, o que pode resultar em uma alta taxa de vacância para os próximos anos. De acordo com informações da Revista Buildings, especializada no segmento de condomínios de galpões, "[...] em relação aos investimentos internos, a postura do mercado tem sido de segurar os projetos ou diminuir o ritmo das obras" (BUILDINGS, 2016).

Outra análise complementar aponta que se ultrapassou um estoque de 8,5 milhões de $\mathrm{m}^{2}$ em 2011 para 38,9 milhões de $\mathrm{m}^{2}$ até 2017 (FERNANDES, 2016) devido aos altos investimentos no segmento entre 2010 e 2012. A taxa de vacância no Estado de São Paulo era de $13 \%$ e, no Rio de Janeiro, $17 \%$ no final de 2014, quando não se esperava passar por uma crise econômica tão próxima, quando o aceitável se encontra no nível de $10 \%$ ao ano. Apesar da alta taxa de vacância, existe certo otimismo e as incorporadoras apostam em um equilíbrio do mercado (BUILDINGS, 2016), sobretudo pelos condomínios 
de galpões modulares serem um mercado de curto e médio prazo. Na visão dos especialistas, o cenário econômico desfavorável faz com que mais empresas optem por soluções que resultem em diminuição dos seus gastos, por isso espera-se que com a estabilização dos preços a procura volte a um patamar aceitável.

Por meio do quadro seguinte (Quadro 6) apresentamos uma leitura da distribuição geográfica dos condomínios empresariais.

\section{QUADRO 6}

Condomínios empresariais - Características de sua distribuição geográfica

\begin{tabular}{|c|c|}
\hline São Paulo & $\begin{array}{l}\text { No Estado de São Paulo existem } 168 \text { condomínios empresariais, sendo } \\
138 \text { deles ( } 82 \% \text { ) localizados nas áreas metropolitanas (São Paulo, } \\
\text { Campinas, Baixada Santista, São José dos Campos e Sorocaba) } \\
\text { evidenciando a ação imobiliária desta natureza de empreendimentos } \\
\text { agrupando-se onde existe a maior demanda. Sua tendência de } \\
\text { expansão acontece no sentido dos principais eixos rodoviários, } \\
\text { contudo, a presença de empreendimentos imobiliários no interior do } \\
\text { estado é baixa. }\end{array}$ \\
\hline Minas Gerais & $\begin{array}{l}\text { Em Minas Gerais existem onze condomínios empresariais, sendo cinco } \\
\text { deles localizados na Região Metropolitana de Belo Horizonte. } \\
\text { Diferentemente do padrão apresentado no Estado de São Paulo, os } \\
\text { demais (seis empreendimentos) se localizam distantes da metrópole. } \\
\text { Contudo, articulam-se às cidades de porte médio (como Uberlândia e } \\
\text { Uberaba, no triângulo mineiro). }\end{array}$ \\
\hline Rio de Janeiro & $\begin{array}{l}\text { O caso do Rio de Janeiro, similar ao Estado de Minas Gerais, refere-se a } \\
\text { doze condomínios empresariais, sendo oito deles encontrados na } \\
\text { mancha metropolitana. Os demais se localizam no interior e } \\
\text { relativamente distantes da capital. No RJ é também evidente a forte } \\
\text { correlação com os principais eixos rodoviários (posição não tão } \\
\text { evidente para os arranjos produtivos locais). }\end{array}$ \\
\hline Bahia & $\begin{array}{l}\text { A grande maioria dos condomínios empresariais }(16 / 18) \text { encontra-se na } \\
\text { mancha metropolitana de Salvador ou no eixo Salvador-Feira de } \\
\text { Santana (onde existe um importante entroncamento rodoviário que } \\
\text { conecta as rodovias federais BR-101 e BR-116). }\end{array}$ \\
\hline Amazonas & $\begin{array}{l}\text { Os seis condomínios empresariais se concentram na capital, Manaus, } \\
\text { sobretudo articulados à demanda existente na zona franca. }\end{array}$ \\
\hline
\end{tabular}

Fonte: pesquisa direta (2014 a 2016). 
3.4. Aglomerações industriais e a divisão territorial do trabalho

A partir da apresentação da distribuição geográfica e de outras análises que dela se desdobram, podemos aprofundar a leitura das aglomerações industriais a partir da divisão territorial do trabalho.

A divisão do territorial (e internacional) do trabalho pode ser pensada a partir de um processo interno ao capitalismo. Conforme explica R. L. Corrêa (1997), a diminuição da taxa de lucros (como tendência intrínseca ao capitalismo) e a competição entre capitalistas repercute na internacionalização do capital como solução para ampliar a sua reprodução. Há, assim, uma crescente generalização da atividade industrial nos países e regiões periféricas, de maneira efetivamente integrada no sistema econômico mundial (CORRÊA, 1997, p.279), a partir das interações (espaciais) que se desdobram de um conjunto complexo de pessoas, mercadorias, capital e informação no espaço geográfico.

As interações espaciais podem "[...] apresentar maior ou menor intensidade, variar segundo a frequência de ocorrência e, conforme a distância e direção, caracterizar-se por diversos propósitos e se realizar através de diversos meios e velocidades" (CORRÊA, 1997b).

Podemos classificar como interações espaciais: a circulação de mercadorias entre fábricas, as exportações e importações, o deslocamento dos consumidores, etc. É por meio das interações espaciais que o capital se realiza, que grosso modo seria composto pelas etapas: produção, circulação, distribuição e consumo. A partir da internacionalização crescente do sistema produtivo, ocorrem diversas especializações locais que passam a se conectar: minas, fazendas, fábricas, sedes sociais, centros de pesquisa e desenvolvimento, depósitos, escritórios administrativos, lojas, etc.

É também possível identificar uma divisão do trabalho na dimensão do território nacional, que ao mesmo tempo é reflexo e expressão de suas características. Como analisa R. L. Corrêa:

Interações espaciais a curta e a longa distâncias, entre centros de magnitude semelhante ou distinta, envolvendo uma gama cada vez mais complexa de mercadorias, pessoas, capital e informação, são o resultado das transformações advindas com o capitalismo industrial (1997b, p.283).

Em outras palavras, são fixos e fluxos que interagem, conformando redes e permitindo a realização do sistema produtivo, de circulação e de consumo. A 
industrialização se manifesta com muito mais expressão nos lugares onde o meio técnicocientífico-informacional é mais pronunciado e, acompanhando esta lógica, também as aglomerações industriais (com maior número e variedade), lá estão.

O que evidenciaremos nesta seção é como as aglomerações, na condição de formas-conteúdo (e não apenas a partir de sua localização), expressam em suas características e suas transformações a lógica inerente à divisão territorial do trabalho e como isso pode, ao mesmo tempo, qualificar as parcelas (que podem ser especializadas ou não), do território nacional.

Os distritos industriais pioneiros, extensos e com grandes lotes capazes de abrigar um chão de fábrica também extenso, na sua fase inicial eram capazes de promover novas e importantes centralidades. O mesmo se pode dizer, como já foi mencionado, dos polos industriais enquanto projetos de governo, que por meio da indústria motriz estimularam e ainda estimulam, local e regionalmente, a instalação de circuitos produtivos interdependentes (os polos visitados em trabalho de campo apresentaram projetos consolidados de expansão técnica e geográfica, como mostraremos no Capítulo 4).

Até o final da década de 1970, foi este o padrão de industrialização pesada estimulado e fomentado no país, em termos do planejamento das áreas necessárias para a indústria de grande porte. Assim, o território foi reconfigurado (saindo de um país primordialmente agrário) para receber os fixos desta natureza.

Posteriormente, acompanhando uma tendência de flexibilização produtiva, ao que se soma um arrefecimento das possibilidades de investimento direto do Estado (é preciso interpretar conjuntamente a crise fiscal na década de 1980), as iniciativas locais ganham força até meados da década de 1990, na figura dos arranjos produtivos locais que hoje se encontram também relativamente estabilizados. Concomitantemente, os distritos industriais aparecem com outras características: passam a ser objeto de ação das prefeituras municipais, são configurados como áreas relativamente menores e com reduzida capacidade de influenciar centralidades.

Ao passo que os distritos e os polos eram inicialmente instalados em cidades centrais da rede urbana ou, quando não, produziam centralidades relativas que foram se desenvolvendo com o tempo, os arranjos produtivos locais e os distritos industriais (em cidades de médio e pequeno porte) tem uma distribuição maior pelo território, conforme podemos observar nos mapas 4 a 8 .

A esse respeito, pode ser considerado importante o momento histórico no qual promotores imobiliários começam a investir em seus condomínios empresariais. $\mathrm{O}$ 
planejamento dos promotores imobiliários para os condomínios empresariais é condizente com as condições de uma economia mundializada, que demanda flexibilidade organizacional, produtiva e territorial. É isso o que mostra esta natureza de empreendimento, cujos investidores obtêm as melhores localizações e oferecem uma série de condições mais modernas e flexíveis.

Os condomínios empresariais podem ser divididos em loteamentos (fechados ou não), conjuntos de galpões modulares e conjuntos de escritórios. Essa divisão expressa a disjunção funcional, ou cisão territorial da indústria (LENCIONI, 2003), que pode ser caracterizada como a separação entre chão de fábrica e escritórios de gestão (a transformação localizando-se no interior, e a gestão da produção na capital). Além disso, estes empreendimentos acompanham a tendência de fábricas menores (fornecedores de insumos ou pequenos processos produtivos) capazes de se instalar, por curto espaço de tempo, em galpões modulares que, como vimos, albergam empresas de variados portes. Nesse sentido, é importante ressaltar que a cisão territorial ocorre pelas transformações da indústria fordista e pela fluidez territorial que viabiliza esta separação. Na leitura de E. Sposito:

[...] é inegável a tendência à disjunção produtiva nas duas últimas décadas, isto é, a separação entre o centro de comando e o local da produção final. Isso ocorre em São Paulo, não em decorrência apenas das mudanças por que passou o fordismo, mas pelas facilidades de fluidez no território decorrente da conformação da infraestrutura de transportes e comunicações (SPOSITO, 2015, p.401).

Dessa forma, podemos olhar para as aglomerações industriais em seu conjunto como, propriamente, formas geográficas que correspondem ao processo histórico da divisão territorial trabalho (tanto do ponto de vista da formação espacial brasileira, quanto a partir das mudanças de suas características acompanhando as mudanças da indústria e como áreas que permitem/estimulam essa flexibilidade organizacional e territorial).

Historicamente, representam uma forma de organização do território para o recebimento de unidades industriais em um país que almeja industrialização, bem como o planejamento do território enquanto um instrumental de políticas públicas. As formas de aglomeração mais recentes se articulam ao empreendedorismo local e também contemplam o processo de flexibilização produtiva. A influência atual da iniciativa privada que atua com maior rapidez construtiva e eficiência operacional, resulta também em relações menos duradouras entre as empresas e o território. As formas de aglomeração também mostram a 
disjunção territorial de funções que antes poderiam coexistir em uma mesma localização: gestão, produção, pesquisa/desenvolvimento e armazenagem/distribuição. Cada uma destas etapas possui um tipo de área idealizada de acordo com suas demandas.

Podemos dizer que a somatória das condições resultantes da configuração territorial em determinados pontos, que seria o uso do território produzido (adequado ao uso das empresas, o território corporativo) e as condições de circulação (acessibilidade e fluidez territorial), faz com que se tenha maior ou menor produtividade espacial (SANTOS, 2004 [1996]).

Essa dinâmica acarreta processos de valorização e desvalorização dos lugares, sucessivos, como analisa M. Arroyo: “[...] acarrea la desvalorización de ciertas áreas em favor de aquellas que promuevem el desarollo de nuevas atividades o la modernización de otras ya instaladas" (ARROYO, 2005, p.4). Na medida em que a divisão territorial do trabalho se estende, as formas de aglomeração da indústria tendem a acompanhar e por isso indicam essa dinâmica de valorização e desvalorização, bem como o uso corporativo do território. Podemos analisar dois tipos de aglomeração recentes que elucidam esta questão: os condomínios empresariais e os parques tecnológicos.

\section{Condomínios empresariais como movimento recente do capital imobiliário}

Novas iniciativas que, no Brasil, marcaram a entrada dos promotores imobiliários no planejamento direto e execução de aglomerações industriais do tipo condomínios empresariais, apresentam uma dispersão gradual pelo território. É uma dispersão seletiva e, assim como as demais aglomerações, com maior investimento na Região Concentrada.

Foram mapeados os empreendimentos de origem privada em todas as unidades

estaduais do Brasil (condomínios empresariais mistos, loteamentos industriais e condomínios de galpões modulares). A distribuição geográfica destes condomínios empresariais pode ser verificada no Mapa 9. 


\section{MAPA 9}

BRASIL - Distribuição dos condomínios empresariais (2016)

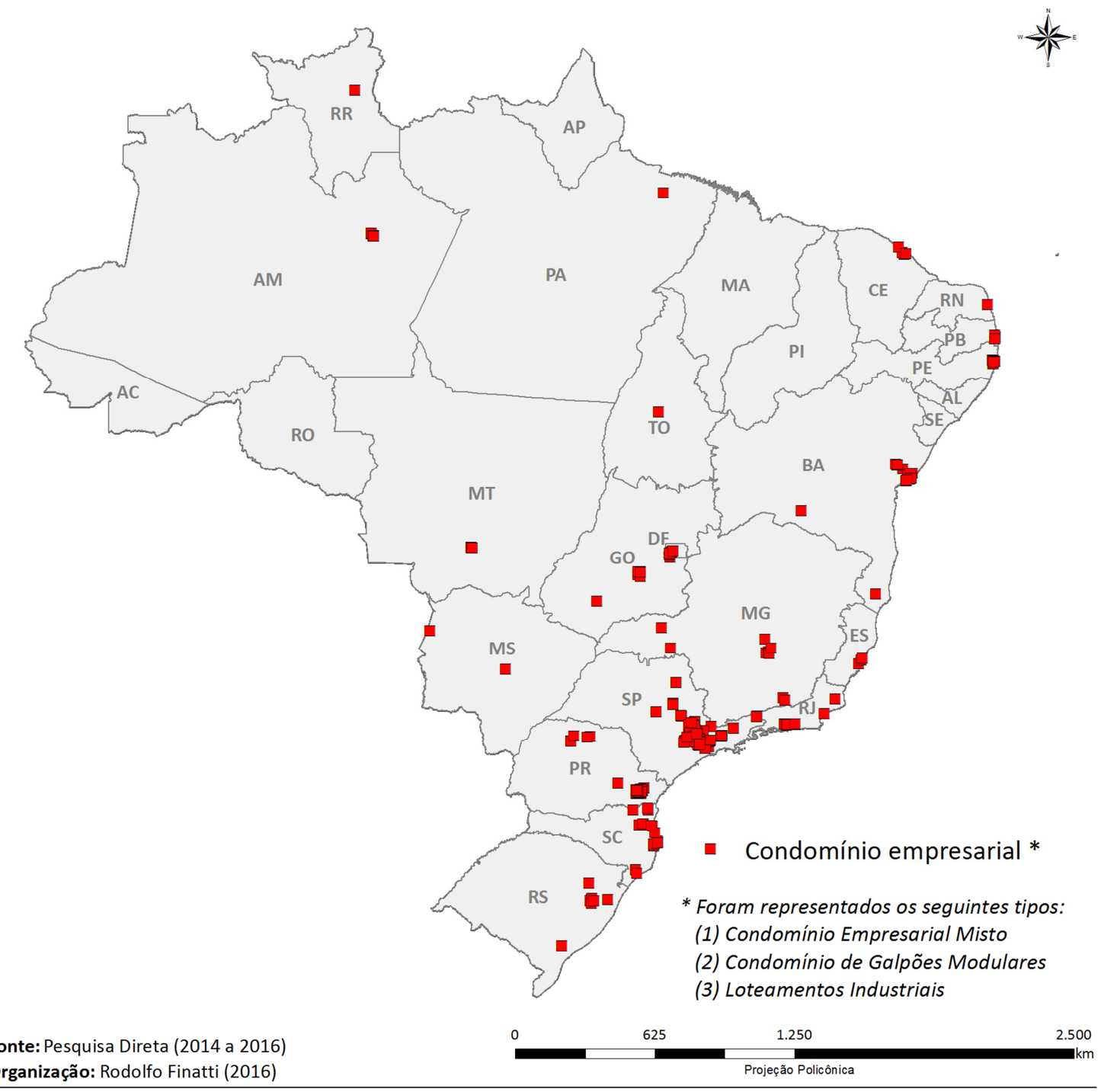

Analisando a partir da noção de divisão do territorial do trabalho, estes empreendimentos expressam a produção do território corporativo e a ação do capital imobiliário. Considerados como fatores de atração, a divisão de gastos (com gestão, segurança, limpeza, paisagismo), e outras funcionalidades ${ }^{95}$ oferecidas pelos administradores (como controle de acesso à área, servidores de internet, etc.) evidenciam um território com serviços especializados.

A própria tipologia dos condomínios empresariais também revela especialização: os condomínios podem ser mistos, aceitando todos os tipos de

\footnotetext{
${ }^{95}$ Uma série de funcionalidades são, habitualmente, incorporadas aos condomínios empresariais. Elas têm a função de operacionalizar e agilizar a atividade produtiva, bem como agregar valor ao conceito de condomínio empresarial (cada incorporador imobiliário busca diferenciar o seu produto perante os demais disponíveis no mercado). Para um maior detalhamento destas funcionalidades, $c f$. Finatti (2011).
} 
investimento, organizados em galpões modulares (que permitem alterações de tamanho e outros redimensionamentos internos para atender as especificações das empresas - o modelo built to suit) ou mesmo os de conjuntos de escritórios voltados exclusivamente os escritórios e seus serviços.

Poderíamos, por fim, mencionar novamente o significado da produção de uma psicoesfera corporativa que visa sensibilizar possíveis clientes quanto às vantagens dos empreendimentos, um tipo de estratégia inexistente nos demais tipos de aglomeração ${ }^{96}$.

Conforme as características da dispersão dos condomínios empresariais, outro fator importante, podemos considerar como um indício de que, mesmo nas diferentes regiões do país, o território corporativo, além de ampliar, também se diversifica e conjuntamente se especializa.

A principal concentração é no Estado de São Paulo, parcela do território que possui 168 empreendimentos, o que representa 52\% de todo o Brasil. Se analisarmos a Região Concentrada são 255 empreendimentos que representam $80 \%$ do total do território brasileiro. Entre os 64 empreendimentos restantes, a grande maioria (40) localiza-se no Nordeste, o que representa $12,5 \%$ da distribuição dos condomínios empresariais no território nacional.

\section{Parques tecnológicos como espaços de pesquisa e desenvolvimento}

Os parques tecnológicos são áreas voltadas ao desenvolvimento da ciência e da tecnologia. Do ponto de vista da divisão territorial do trabalho, representariam as iniciativas voltadas à pesquisa e ao desenvolvimento, cujas tendências locacionais tendem a afirmar proximidade com universidades e centros de pesquisa, condição apontada na revisão bibliográfica como indispensável ao sucesso do parque tecnológico.

A distribuição dos parques tecnológicos no território nacional pode ser visualizada no Mapa 10, que mostra o número total por unidade da federação, em um mapa de círculo proporcionais.

\footnotetext{
${ }^{96}$ Nos outros tipos de aglomeração industrial ocorrem outras estratégias. Nos distritos industriais, por exemplo, as secretarias estaduais podem atuar fazendo "captação direta" de empresas. Já os arranjos produtivos locais possuem uma perspectiva e explicação histórica que define a localização daquele conjunto de empresas.
} 


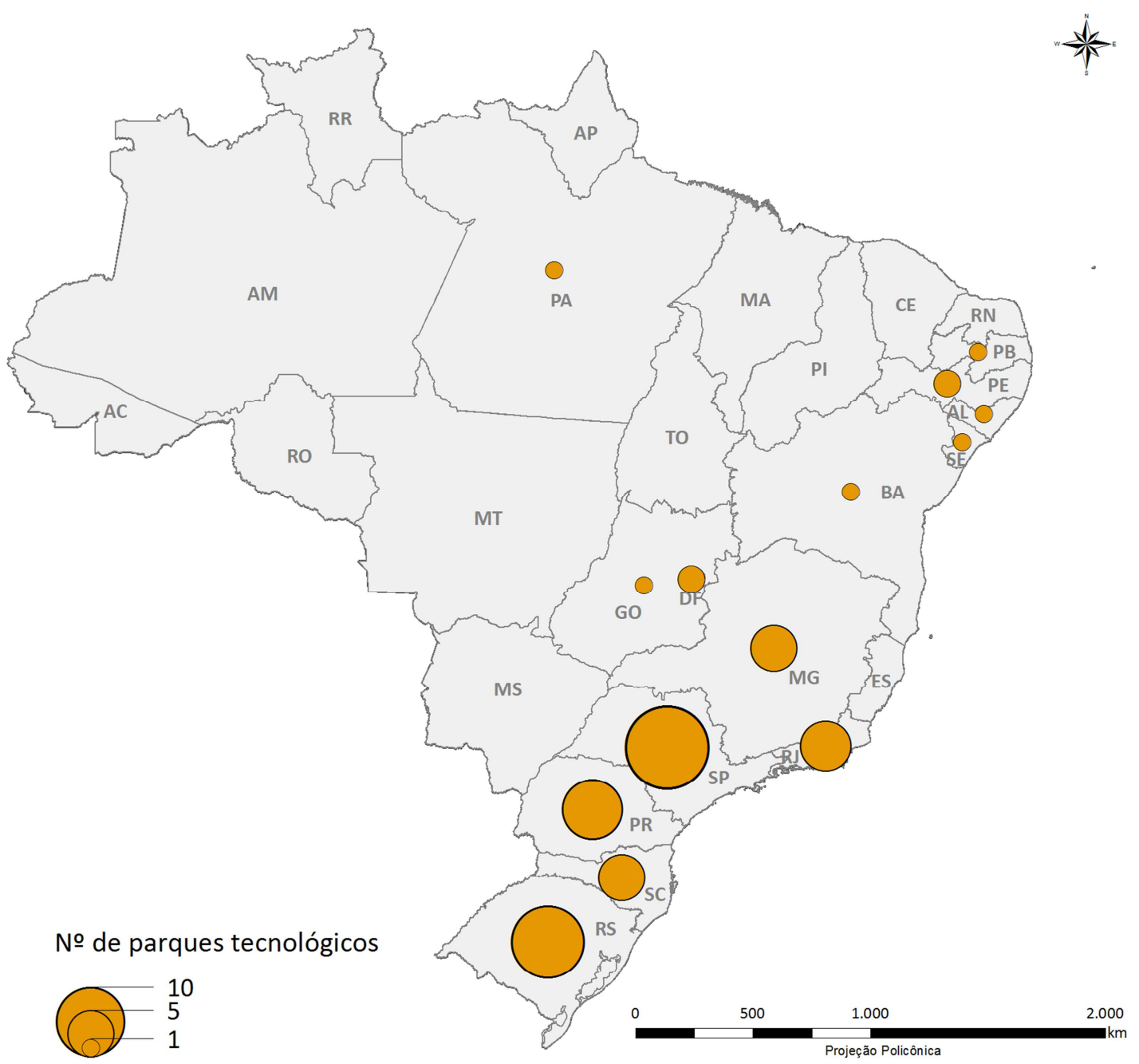

Fonte: Ministério da Ciência, Tecnologia e Informação e Universidade Nacional de Brasília (MCTI/UNB, 2013) Organização: Rodolfo Finatti (2016)

Assim como no caso dos condomínios empresariais, observa-se uma distribuição concentrada no território nacional, que seria condizente com as iniciativas pioneiras acerca destas aglomerações produtivas que, no momento atual, ganham muito destaque, sobretudo no Estado de São Paulo, por meio do Sistema Paulista de Parques Tecnológicos $^{97}$ (SPTEC).

Na Região Concentrada, é inegável o destaque para o Estado de São Paulo, como mostra o Mapa 10. Com base nos dados do Ministério de Ciência, Tecnologia e Informação de 2014, de 59 parques tecnológicos, 14 deles estavam localizados no Estado

\footnotetext{
${ }^{97}$ A ação do SPTEC tem como objetivo fomentar a cultura da inovação, aprofundar o relacionamento entre universidades e empresas e apoiar a formação de novas empresas (start-ups) baseadas na atividade de pesquisa e desenvolvimento. Trata-se de uma iniciativa pioneira no Brasil como apoio a este tipo de aglomeração produtiva, considerando seu novo modelo de credenciamento e monitoramento para a concessão dos incentivos (BALDONI, 2015).
} 
de São Paulo (23\% em relação ao território nacional). O total da Região Concentrada (41 parques tecnológicas) representava $69 \%$ do território nacional. Entre as demais regiões, os principais estados que apoiavam parques tecnológicos eram: Distrito Federal (2 unidades) e Pernambuco (2 unidades).

No final de 2015, o SPTEC acelerou o credenciamento de parques tecnológicos no território paulista, quando sete novas áreas foram consideradas aptas ao credenciamento definitivo $^{98}$ e passaram a usufruir dos benefícios concedidos pelo estado, em sua maioria de natureza fiscal, como a Lei Paulista de Inovação ${ }^{99}$. É importante destacar que usufruem desta lei apenas as empresas que se encontrem instaladas nos parques tecnológicos credenciados pelo SPTEC, portanto privilegiando a formação desta forma de aglomeração que é cada vez mais representativa no Estado de São Paulo.

A distribuição geográfica observada reforça a topologia do parque tecnológico, que necessita de uma posição geográfica favorável para seu adequado funcionamento, contemplando a proximidade com universidades e centros de pesquisa públicos ou privados, bem como empresas privadas com caráter e ações inovativas. A proximidade e os contatos face-a-face são considerados alavancas para os "burburinhos" que resultam na transferência de conhecimento e novas parcerias em projetos. O meio técnico-científicoinformacional, que promove a existência de um ambiente de negócios, será o meio procurado e estimulado para se fundar os parques tecnológicos.

O conceito de meio de inovação, desenvolvido pelo Group de Recherche Européen sur les Milieux Innovateus (GREMI), tinha como hipótese que a inovação está ligada diretamente às características do território. Segundo R. Melo: “[...] os comportamentos inovadores relacionam-se diretamente com as características presentes no lugar e, portanto, o espaço torna-se elemento fundamental na indução das inovações" (2014, p.42).

No que tange à divisão territorial do trabalho, os parques tecnológicos representam a aglomeração de atividades de alto nível intelectual. Por consequência, demandantes de profissionais e professores especializados e uma cultura acadêmica

\footnotetext{
98 Matéria veiculada pela Agência Fapesp em 21 de janeiro 2016. Disponível em: $<$ http://agencia.fapesp.br/governo_de_sao_paulo_concede_credenciamento_definitivo_a_sete_parques tecno $\operatorname{logicos} / 22577 />$. Acesso: março de 2016.

${ }^{99}$ A Lei Paulista de Inovação (Lei Complementar $n^{\circ} 1.049$ de 2008) prevê que as empresas podem recuperar o ICMS pago e monetizá-lo de diferentes formas, desde pagamentos de tributos até investimentos em Pesquisa e Desenvolvimento (preferencialmente).
} 
mínima para o seu funcionamento, bem como uma urbanização adequada para satisfazer as aspirações educacionais e culturais destes profissionais especializados.

Um parque tecnológico instalado fora dessas áreas pode representar também uma "catedral no deserto" utilizando a expressão de Lipietz. Por isso sua maior concentração está circunscrita à Região Concentrada.

3.5. O Estado e o mercado face à rentabilidade e seletividade espaciais: alguns apontamentos

Duas características primordiais devem ser salientadas: (1) resultado de uma condição histórica, observa-se seletividade espacial dos investimentos, reforçando a centralidade e inércia dinâmica da Região Concentrada, sobretudo do Estado de São Paulo e (2) paralelamente, constata-se uma diversificação das caraterísticas dos investimentos, ou seja, todas as regiões possuem aglomerações de todos os tipos, o que é importante sob o aspecto da divisão territorial do trabalho. Essa distribuição qualitativa pode, sim, ser considerada homogênea (no sentido de que todo o país conhece, em maior ou menor grau, esta diversificação).

A seletividade é um processo que acompanha a configuração territorial préexistente, ou seja, a inércia-dinâmica das formas geográficas presentes no território. Contudo, outras informações políticas, sociais e culturais também definem a localização dos investimentos e a valorização entre as diferentes porções do território. São as densidades de fixos e fluxos, a sua fluidez, a espessura do teor de técnica, de ciência e informação. Este fato é claro quando se observa que os investimentos, no Nordeste do país, são direcionados para as capitais e regiões metropolitanas em sua maioria.

Mesmo no que tange apenas ao Estado de São Paulo, podemos identificar diferenças regionais. Os dois tipos de aglomeração tomados como objeto de estudo, na condição de formas mais recentes - condomínios empresariais e parques tecnológicos apresentam uma distribuição muito concentrada ao redor das regiões metropolitanas ${ }^{100}$, ao passo que os distritos e arranjos produtivos locais apresentam o inverso (TABELA 3).

\footnotetext{
${ }^{100}$ No caso dos Parques Tecnológicos, que não pudemos mostrar cartograficamente sua localização precisa, utilizamos levantamento por município realizado por L. Baldoni (2016), que considerou 28 áreas, entre: Parques com Credenciamento Definitivo, Parques com Credenciamento Provisório e Parques em Negociação. Para efeito do número do total de Parques Tecnológicos paulistas considerados nesta pesquisa (20), excluímos aqueles que ainda se encontram em negociação (8).
} 
TABELA 3

SÃO PAULO - Distribuição de aglomerações industriais, número total e número nas áreas metropolitanas (\%)

\begin{tabular}{c|c|c|c}
\hline Aglomeração & $\mathbf{n}^{\mathbf{0}}$ total & $\begin{array}{c}\mathbf{n}^{\mathbf{0}} \text { em áreas } \\
\text { metropolitanas }\end{array}$ & $(\boldsymbol{\%})$ \\
\hline $\begin{array}{c}\text { Distritos } \\
\text { Industriais }\end{array}$ & 458 & 66 & 14,4 \\
\hline $\begin{array}{c}\text { Polos } \\
\text { Industriais }\end{array}$ & 3 & 3 & 100,0 \\
\hline $\begin{array}{c}\text { Arranjos } \\
\text { Produtivos Locais }\end{array}$ & 41 & 12 & 29,2 \\
\hline $\begin{array}{c}\text { Condomínios } \\
\text { Empresariais } \\
\begin{array}{c}\text { Parques } \\
\text { Tecnológicos }\end{array}\end{array}$ & 168 & 138 & 82,1 \\
\hline
\end{tabular}

Fonte: Pesquisa Direta (2014 a 2016).

As regiões sempre apresentam diferenciações internas, independentemente da escala de análise (Tabela 3). Em relação a estas diferenças, se observa comportamentos específicos de cada tipo de aglomeração industrial, reforçando em números o que já vimos discutindo desde as representações cartográficas (Mapas 4 a 8).

No caso dos distritos industriais, que representariam o tipo de aglomeração mais propício às unidades de transformação (chão de fábrica), se nota uma menor participação nas áreas metropolitanas $(14,4 \%)$. O mesmo se pode apontar para os arranjos produtivos locais de indústrias, com 29,2\% de participação das áreas metropolitanas, para o qual era de se esperar uma distribuição maior no interior.

As formas de aglomeração mais recentes - condomínios empresariais e parques tecnológicos - apresentam os percentuais mais elevados nas áreas metropolitanas $(82,1 \% \mathrm{e}$ 60\%, respectivamente) evidenciando como o território, nas áreas metropolitanas, está sendo preparado para atividades produtivas mais sofisticadas.

Os polos industriais estão todos em áreas metropolitanas, cuja localização se explica pela própria história e intencionalidade associada a este tipo de aglomeração, no Brasil. Sua localização representa a porção do território que, nas décadas de 1950 a 1970, detinham também a maior concentração da indústria de transformação.

Estas proporções são corroboradas pela análise da distribuição industrial do Estado de São Paulo realizada por E. Sposito (2015), muito embora não seja uma análise das formas de aglomeração, mas dos estabelecimentos industriais. Segundo Sposito, há uma razão inversa entre a localização de indústrias com alta incorporação tecnológica daquelas relacionadas ao conhecimento tácito. As indústrias de alta tecnologia se restringem às proximidades da metrópole (Grande São Paulo e regiões administrativas 
próximas $^{101}$ ) e as indústrias que se reproduzem pelo conhecimento tácito se distribuem por todo o território paulista, valorizando áreas distantes da capital (SPOSITO, 2015).

Uma proposta do autor diz respeito à disseminação do modo industrial no Estado de São Paulo, o que complementa a explicação da dispersão das formas de aglomeração pelo território paulista.

[...] a industrialização não se realizou em todo o território do estado, mas o modo industrial pode ser verificado nos principais núcleos da rede urbana do estado. Assim o processo de industrialização stricto sensu tem sua manifestação em parte do território paulista, mas em seu lato sensu (como disseminação do modo industrial), ele se manifesta nas cidades de diferentes portes e em ramos de participação significativa do capital variável (SPOSITO, 2015, p.402).

O Mapa 4 mostra justamente a distribuição dos distritos industriais (aglomeração industrial mais tradicional) bem como dos arranjos produtivos locais (empresas de micro e pequeno portes) bem distribuídos no território paulista, seguindo os seus eixos de desenvolvimento e localizados ao redor dos municípios de médio porte. Em nenhuma outra unidade estadual se verifica esta mesma quantidade de formas de aglomeração ou seu nível de dispersão.

Pensando no conjunto do território nacional, entretanto, mesmo as regiões que teriam dinamismo industrial não necessariamente apresentaram um quadro engessado, se comparado ao Estado de São Paulo. Há investimentos novos ou especializados, e a "velocidade" da mudança é, muitas vezes, proporcional às características de suas localizações. Não raro, durante o trabalho de campo, conhecemos iniciativas que tentam, com criatividade, romper a inércia dos investimentos e do desenvolvimento, como em Pernambuco $^{102}$ e Ceará ${ }^{103}$.

\footnotetext{
${ }^{101} \mathrm{O}$ que corresponderia, aproximadamente, ao conjunto das áreas metropolitanas paulistas que destacamos no Mapa 4 (São Paulo - Distribuição das aglomerações industriais, por tipo), formadas por: Região Metropolitana de São Paulo, Região Metropolitana de Campinas, Região Metropolitana da Baixada Santista, Região Metropolitana de Sorocaba (criada em 9 de maior de 2014) e Região Metropolitana do Vale do Paraíba e Litoral Norte (criada em 9 de janeiro de 2012).

${ }^{102}$ Pernambuco desenvolveu, nos últimos 10 anos, uma política industrial baseada em regionalizações, vocações regionais e captação de empresas voltadas a estas regionalizações. Nos distritos industriais recentemente implantados em PE, para evitar que áreas fiquem ociosas, sua delimitação é feita apenas a instalação de um conjunto importante de empresas.

${ }^{103}$ Os mini-distritos industriais são uma iniciativa do Governo do Estado do Ceará. É uma estratégia baseada na aglomeração e proximidade de empresas de um mesmo circuito produtivo, que se instalam por meio de um contrato de outorga em galpões ou outras estruturas pertencentes ao estado (dessa forma reaproveitam-se galpões ociosos que pertencem ao governo estadual).
} 
Em termos de organização e eficiência na administração de áreas industriais, a Bahia apresenta um quadro exemplar, talvez com o melhor nível organizacional, do poder público, mesmo em relação aos estados da Região Concentrada.

O Estado e o mercado, na condição de agentes transformadores do território, se mesclam em ações intrínsecas: a configuração territorial prévia (a infraestrutura física que dá suporte aos investimentos privados) é constantemente demandada pelo mercado, que a ela responde em seus investimentos. Porém, em contrapartida, também o mercado começa a influenciar os padrões das áreas industriais alavancadas pelo Estado.

Essa influência dupla é crescente. Podemos identifica-la nas características das novas áreas, ou na transformação das áreas já consolidadas (as formas de aglomeração privadas parecem ser, atualmente, o modelo a ser seguido e, assim, algumas iniciativas imitam o modelo ou buscam parcerias com os promotores imobiliários).

Embora sejam constatações ainda em pequeno número, podemos apontar que o padrão apresentado pelos condomínios empresariais começa a se manifestar em investimentos do terceiro setor e também em investimentos públicos: verificamos a ocorrência de condomínios empresariais sendo induzido por sindicatos, tais como o Sindicato das Indústrias Químicas do Ceará ${ }^{104}$, que planejou o seu próprio condomínio empresarial, em uma perspectiva cooperativa entre as empresas químicas (área em implantação). Além deste tipo de iniciativa, verificamos o poder público (estadual ou municipal) se inspirando na lógica dos empreendimentos privados para também promover novas áreas de atração, como os principais casos verificados em: Goianinha (RN), Jaboatão (PE) e Itupeva (SP). Nestes municípios existem distritos industriais com controle de acesso, divisão de gastos e outras funcionalidades inspiradas nos condomínios empresariais, conforme declarado pelos gestores públicos que entrevistamos ${ }^{105}$.

Devemos destacar a importação desta racionalidade (dos promotores imobiliários para o poder público), mesmo que em poucos e incipientes casos, porém indicando uma iniciativa que pode se disseminar.

Os próprios parques tecnológicos, embora com características e densidades bastante diferentes no território nacional, também expressam a articulação entre os agentes econômicos, políticos e científicos: o modelo Triple Helix, no momento o mais influente

\footnotetext{
${ }^{104}$ Entrevistamos o presidente do sindicado (SindQuímica), M. F. Soares, no dia 31 de março de 2014.

${ }^{105}$ Em Goianinha (RN), entrevistamos o Secretário de Planejamento Econômico do município, T. Thomaz, em 11 de abril de 2014. Sobre o município de Jaboatão (PE), entrevistamos o Diretor Econômico da agência de desenvolvimento pernambucana, J. G. do Rego, no dia 10 de julho de 2014. Em Itupeva (SP), entrevistamos o Secretário de Indústria e Comércio e Desenvolvimento Econômico do município, L. C. P. de Campos, no dia 15 de janeiro de 2016.
} 
na constituição dos parques tecnológicos, prevê justamente a participação mútua entre administração pública, empresários e universidade.

Ao passo que, em um determinado período, os investimentos públicos foram os responsáveis por certa dispersão da indústria e, até mesmo, influenciando processos de desenvolvimento regional, o Estado poderia ser considerado o principal agente direto na preparação do território corporativo. Hoje pode ser considerado um fomentador das áreas industriais por meio de incentivos e promoção de infraestrutura, mas o mercado (representado pelo capital imobiliário) passa a participar mais diretamente da implantação das aglomerações industriais "aos seus moldes", tanto pelo número e avanço dos empreendimentos imobiliários quanto pela racionalidade imobiliária adotada pelo Estado.

Por outro lado, em seu papel de administrador da totalidade do espaço nacional, podemos afirmar que o Estado investe nas parcelas do território que não interessam às empresas hegemônicas, o que é mostrado pela distribuição dos arranjos produtivos locais instalados no interior das unidades estaduais; alguns casos importantes, destacados em várias de nossas entrevistas, podem ser encontrados nos municípios: Tabatinga (AM), Campo Formoso (BA), Aracás (BA), Valença (RJ), Nova Friburgo (RJ), Ipatinga (MG), Divinópolis (MG), Ituiutaba (MG), Panorama (SP), Itapeva (SP). Há ainda muitos outros arranjos produtivos que não são exclusivamente industriais, os quais podem ser de serviços, agrícolas ou turísticos e que, igualmente, recebem incentivos do governo federal em sua manutenção e apoio às micro e pequenas empresas localmente associadas. Os arranjos produtivos locais podem ser encontrados em todas as unidades da federação ${ }^{106}$, muito embora tenhamos exemplificado em mapas apenas cinco delas.

Grosso modo, a dinâmica sincrônica de seletividade e diversificação indica o avanço do uso corporativo do território, como vimos discutindo desde o início desta tese. A esse respeito, vale lembrar que “[...] à medida que a economia se torna espacialmente seletiva dentro de cada país, e complementar entre países, os instrumentos de trabalho são forçosamente mais numerosos e densos" (SANTOS, 1985, p.39).

A mundialização do capital, o avanço territorial necessário à sua reprodução, e as características com as quais o território é usado pode ser observado por meio da preparação do território, sua expressão e indício. Por isso, é importante e justifica-se a

\footnotetext{
${ }^{106}$ Cf. Observatório Brasileiro de Arranjos Produtivos Locais (OBAPL, 2016), que permite selecionar os tipos de arranjo produtivo local (por segmento) em todos os estados da federação. Disponível em: $<$ http://www.portalapl.ibcti.br>.
} 
análise, atualização e acompanhamento das aglomerações industriais e também, de forma mais ampla, das aglomerações produtivas.

Para R. Moreira, “[...] a integração de regiões com estágios de desenvolvimento tão díspares, fazendo de todo o país uma combinação extremamente desigual, é o hoje o grande problema dessa estrutura" (2012, p.303). As aglomerações industriais expressam também investimentos e uma tentativa de crescimento econômico, mesmo que possa ser isso uma contradição no que tange ao desenvolvimento social. Observando estes investimentos, há grande diferença regional e uma polarização econômica evidente no território brasileiro, que mantém ou reforça esta "combinação extremamente desigual" como descrita por Moreira, e assim também a seletividade espacial. 


\section{SOBRE ALGUMAS FORMAS NO TERRITÓRIO BRASILEIRO: SUA DINÂMICA E TRANSFORMAÇÃO}

Procuramos materializar, a partir de estudos de caso ${ }^{107}$, nossa tese: a primeira é que existe cada vez mais seletividade espacial dos investimentos (requerendo assim territórios corporativos especializados e de acordo com o segmento produtivo) e a segunda diz respeito à importância da proximidade - fator de localização e de aglomeração - que verificamos desde a conformação de áreas tradicionais até as mais contemporâneas. O planejamento das áreas industriais acompanham as tendências internas da organização industrial e precisam assim contemplar demandas atuais, diferentes daquelas que motivaram a implantação de distritos industriais pioneiramente (mas que hoje motivam sua reestruturação).

Atualmente, o promotor imobiliário é que melhor capta essa tendência e consegue materializar, no território, suas características. Isso reforça as aglomerações industriais como um nicho crescente dos negócios imobiliários. Todavia, todos os tipos de aglomeração industrial passam por transformações recentes.

\subsection{Informações utilizadas e critérios para sua sistematização}

Os dados da Relação Anual de Informações Sociais (Tabela 4) mostram a representatividade da indústria em cada unidade estadual, sobretudo no tocante ao número de estabelecimentos, que é uma importante informação para se falar de aglomerações industriais. Em azul, destacamos os estados que foram objeto de trabalho de campo.

\footnotetext{
${ }^{107}$ Em trabalho de campo, vale reforçar, conversamos com os principais agentes que fomentam/motivam as áreas apresentadas. Tentamos, ao estabelecer contato, buscar as melhores posições nas instituições (diretores, gerentes, analistas) para obter informações com qualidade e que permitam descrever os processos pelas quais elas passam atualmente e as ações que lhes tem sido direcionadas pela gestão em diferentes níveis (estadual, municipal ou associativas).
} 
TABELA 4

BRASIL - Estabelecimentos e empregos industriais, por unidade da federação (2010)

\begin{tabular}{|c|c|c|c|c|}
\hline $\mathbf{U F}$ & $\begin{array}{c}\text { Estabelecimentos } \\
\left(\mathrm{n}^{\circ}\right)\end{array}$ & $\begin{array}{c}\text { Estabelecimentos } \\
(\%)\end{array}$ & $\begin{array}{c}\text { Empregos } \\
\left(n^{\circ}\right)\end{array}$ & $\begin{array}{c}\text { Empregos } \\
(\%)\end{array}$ \\
\hline $\mathrm{SP}$ & 98.959 & 28,00 & 2.900 .313 & 34,12 \\
\hline MG & 43.895 & 12,42 & 898.428 & 10,57 \\
\hline $\mathrm{RS}$ & 38.533 & 10,90 & 754.299 & 8,87 \\
\hline PR & 31.852 & 9,01 & 690.919 & 8,13 \\
\hline $\mathrm{SC}$ & 33.021 & 9,34 & 655.295 & 7,71 \\
\hline RJ & 19.008 & 5,38 & 529.316 & 6,23 \\
\hline $\mathrm{CE}$ & 9.991 & 2,83 & 261.198 & 3,07 \\
\hline BA & 10.797 & 3,05 & 255.774 & 3,01 \\
\hline PE & 9.364 & 2,65 & 236.451 & 2,78 \\
\hline $\mathrm{GO}$ & 12.382 & 3,50 & 221.289 & 2,60 \\
\hline $\mathrm{ES}$ & 7.716 & 2,18 & 139.099 & 1,64 \\
\hline $\mathrm{AM}$ & 1.992 & 0,56 & 125.994 & 1,48 \\
\hline PA & 4.046 & 1,14 & 115.307 & 1,36 \\
\hline AL & 1.685 & 0,48 & 110.487 & 1,30 \\
\hline MT & 5.930 & 1,68 & 100.757 & 1,19 \\
\hline RN & 3.594 & 1,02 & 89.663 & 1,05 \\
\hline MS & 3.410 & 0,96 & 86.020 & 1,01 \\
\hline PB & 3.193 & 0,90 & 83.874 & 0,99 \\
\hline $\mathrm{SE}$ & 1.919 & 0,54 & 52.172 & 0,61 \\
\hline MA & 2.162 & 0,61 & 43.996 & 0,52 \\
\hline $\mathrm{DF}$ & 2.965 & 0,84 & 42.443 & 0,50 \\
\hline $\mathrm{RO}$ & 2.395 & 0,68 & 37.057 & 0,44 \\
\hline PI & 2.255 & 0,64 & 32.664 & 0,38 \\
\hline TO & 1.257 & 0,36 & 18.487 & 0,22 \\
\hline $\mathrm{AC}$ & 505 & 0,14 & 7.967 & 0,09 \\
\hline AP & 340 & 0,10 & 5.568 & 0,07 \\
\hline RR & 265 & 0,07 & 4.365 & 0,05 \\
\hline TOTAL & 353.431 & 100,00 & 8.499.202 & 100,00 \\
\hline
\end{tabular}

Fonte: Elaboração do autor com base na Relação Anual de Informações Sociais - RAIS (2010)

Nota: as unidades estaduais em destaque foram objeto de trabalho de campo.

Devido às dimensões do Brasil, suas diferenças regionais, e o planejamento específico de cada uma das unidades estaduais quanto à indústria, nos deparamos com situações distintas ${ }^{108}$ entre elas, principalmente quanto às iniciativas de atração e novos projetos. Todavia, as formas de aglomeração apresentaram-se relativamente similares, independentemente de sua localização.

Com o decorrer da pesquisa e dos trabalhos de campo foi necessário estabelecer um recorte das formas de aglomeração estudadas, diminuindo o quadro geral de onze para o detalhamento de quatro, especificamente. As escolhidas foram: (1) distrito industrial, (2) polo industrial, (3) arranjo produtivo local e (4) condomínio empresarial.

\footnotetext{
${ }^{108}$ Acreditamos ter atingido um balanceamento adequado entre os estados mais densamente industrializados e aqueles que, por razões específicas, foram também investigados. Embora não estejam entre os estados de maior número de indústrias, o Rio Grande do Norte foi utilizado como estado piloto para testarmos nossas perguntas de trabalho de campo e o Amazonas pela existência do Polo Industrial de Manaus. Ademais, podemos mencionar que foram visitados oito entre dez estados mais industrializados do país, pelo qual acreditamos oferecer uma interpretação sobre boa parte do território nacional.
} 
É importante que ao menos algumas questões sobre cada uma destas áreas sejam compreendidas, em nossos estudos de caso: a origem (se pública: em qual escala de atuação se origina, em qual norma se apoia / se privada: a intencionalidade dos agentes envolvidos e como eles se associam para a produção do território), as normas que permitem e legitimam estas áreas, a configuração da área (tanto internamente quanto a configuração territorial que resulta destas áreas organizadas), as políticas públicas que, porventura, possam estar diretamente associadas, principalmente quanto às isenções fiscais que, no Brasil, tem um relevante papel de atração. Devemos ainda avaliar se ocorrem ações ou estudos para diagnosticar ou planejá-las e por fim, apontar algumas tendências que estão sendo captadas em nossas entrevistas de campo relacionadas a novas implantações, novas formas de associação entre poder público x privado e tendências de expansão destas áreas para novas localizações.

Seguindo estes critérios, se pode sistematizar a leitura das formas de aglomeração sem perder de vista a compreensão de suas características fundantes e a dinâmica relacionada à formação espacial. Dessa forma, após a leitura específica de cada forma de aglomeração industrial e, tendo feito uma análise do território nacional, podemos "voltar" a escalas específicas por meio de estudos de caso, cumprindo uma análise que se pode dizer local - global - local.

\subsection{Estudos de caso}

\subsubsection{Transformações no uso do solo e busca por renovação: distritos industriais}

Os distritos industriais brasileiros tem sua origem vinculada diretamente à ação do poder público: a promoção de distritos por influência direta do governo federal é pretérita e não é mais um processo corrente. Por sua vez, a atuação dos governos estaduais e municipais é diversificada. É importante, antes de tudo, mencionar que esta origem diversificada (apesar de sempre atrelada ao poder público) é um traço que dificulta a interpretação dos distritos pois os vincula a diferentes agentes e momentos históricos.

A caracterização dos distritos industriais no Brasil deve passar pela compreensão de que se trata de zoneamento do solo urbano. Lembramos a definição de Bruna (1974) sobre zona industrial: para esta autora, é uma área fisicamente bem definida 
dentro da área urbana, que atenda a pré-requisitos urbanísticos e na qual exista permissividade para a instalação de indústrias.

Ao analisar a configuração destas áreas e a infraestrutura nela existentes, no entanto, encontra-se uma situação atualmente diversa, pois as infraestruturas que definiriam tal área como um distrito industrial podem ser parciais ou totalmente inexistentes, em alguns casos. Em outros casos, como ocorre com certa frequência, pode-se encontrar uma infraestrutura precária, mesmo com um grande número de indústrias em operação na respectiva área.

Estas informações permitem afirmar que o elemento definidor, ou o que consolida o distrito industrial como tal é, mais do que a normatização de uma área - muito embora a normatização seja primeiro passo necessário e que define zona industrial -, o uso que dela se faz, efetivamente. Em outras palavras, o uso do território é a produção industrial e isso deve ser analisado como seu elemento determinante.

O grande número de distritos industriais existentes no país é também responsável por esta dificuldade de interpretação. Tentaremos ajustar essa diversidade a partir da apresentação de alguns estudos de caso e, ao final, uma análise geral que também levará em consideração as iniciativas pioneiras de renovação deste tipo de aglomeração, um elemento que ajudará o traçar o "estado da arte" dos distritos industriais brasileiros.

A seguir, apresentaremos os seguintes estudos de caso sobre distritos industriais: Cidade Industrial de Contagem (MG), Distrito Industrial de Fortaleza (CE), Centro Industrial Subaé (BA), Distrito Industrial de Queimados (RJ) e Zona Franca de Manaus (AM).

a) Cidade Industrial de Contagem (MG)

No Estado de Minas Gerais, o distrito industrial localizado em Contagem pode ser considerado um marco da implantação dessas áreas no Brasil. Foi instituído em 1941 por decreto do Governo Estadual e inaugurado em 1946, com o nome de Cidade Industrial de Contagem Coronel Juventino Dias. É um dos distritos industriais pioneiros no Brasil, com cerca de 100 indústrias atualmente (FIEMG/CODEMIG, 2015), entre as mais importantes: Itambé, Magnesita, Arcelormittal, Magoteaux e Fiat. As empresas Itambé e Arcelormittal estão retratadas nas Fotos 1 e 2, ao final deste estudo de caso. 
A organização desta área, também conhecida como Hexágono de Contagem, mostra a preocupação que existia no planejamento urbano de uma área com lotes grandes e potencial fluidez entre eles. Além disso, é importante mencionar que o distrito foi organizado tendo a Rodovia Fernão Dias - que liga Belo Horizonte (MG) a São Paulo (SP) - atravessando o centro do distrito industrial, permitindo importante acessibilidade rodoviária.

O Hexágono de Contagem (Figura 3) denota uma preocupação clara com o planejamento da área, promovendo lotes grandes, acesso e fluidez territorial ao futuro distrito industrial.

\section{FIGURA 3}

Planta da Cidade Industrial de Contagem

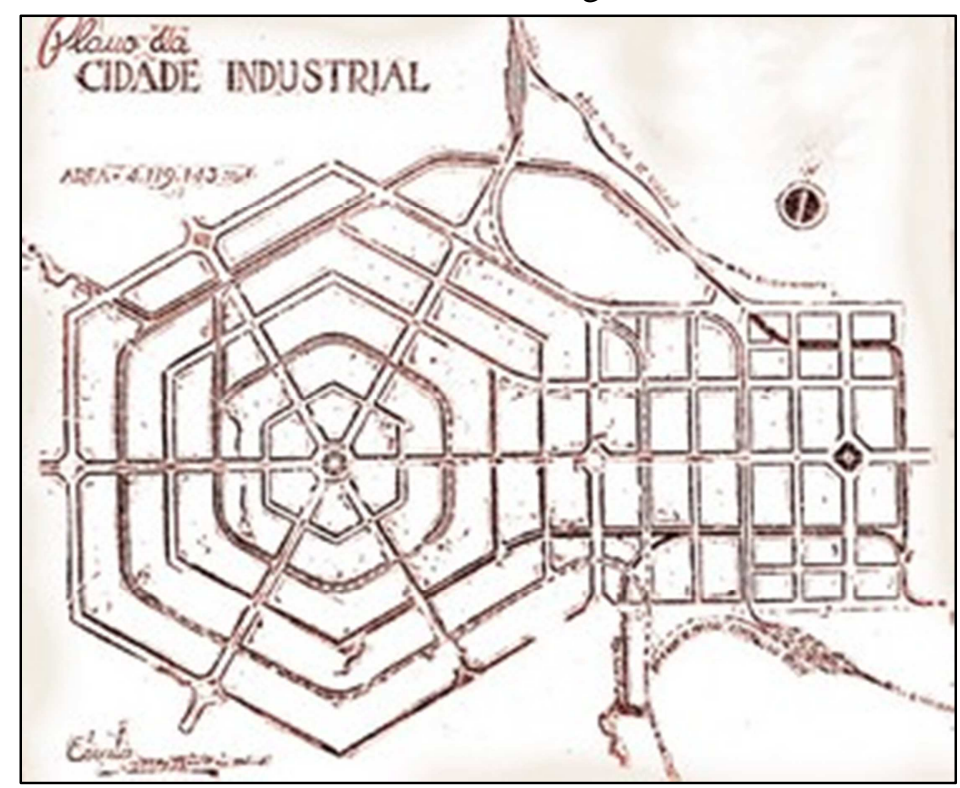

Fonte: 〈www.folhadecontagem.com.br>. Acesso: abril de 2016. (*) Desenho de Israel Pinheiro da Silva, Secretário de Agricultura, Comércio e Trabalho de Minas Gerais entre 1933 e 1942.

Convergente com o ideal da organização de distritos industriais no Brasil do período de sua implantação, a Cidade Industrial de Contagem foi também o primeiro projeto sistemático de industrialização do Estado de Minas Gerais, conforme aponta a literatura econômica mineira:

O lançamento da Cidade Industrial de Contagem, com a respectiva usina hidrelétrica, foi a maior realização do Governo Benedito Valadares (1933-45) no campo econômico, e ao mesmo tempo base para futuras iniciativas estatais [...] Paralelamente, procedeu-se a uma verdadeira política de promoção e atração de indústrias (DINIZ, 1981, p.53). 
$\mathrm{Na}$ constituição deste distrito foi central a implantação da Companhia Energética de Minas Gerais (CEMIG) como fornecedora estatal de energia elétrica, o qual conheceu impulso definitivo a partir da implantação do Centro das Indústrias de Minas Gerais (CIEMG), instituição que centraliza os interesses dos empresários que operam na área, inclusive possuindo sede própria exclusivamente neste distrito industrial (Foto 3).

A área tem, como contexto de surgimento, a normativa de uso do solo industrial efetivado pelo poder público. O território teve que ser equipado com fixos de circulação e geração/fornecimento de energia-elétrica, condição que alavancou a industrialização da área. Como caso do distrito industrial pioneiro no país, a ele sucedeu-se obrigatoriamente a criação de instituições administrativas:

No âmbito da Secretaria da Indústria, Comércio e Trabalho foi constituído o Departamento de Industrialização, encarregado de promover a gestão da Cidade Industrial de Contagem e dos demais distritos industriais que viriam a ser projetados e implantados nos anos seguintes. Isso ocorreu sob a gestão da Companhia de Distritos Industriais de Minas Gerais, sociedade de economia mista constituída em 1971, que incorporou e sucedeu o Departamento de Industrialização (FIEMG/CODEMIG, 2015, p.15).

Foi apenas com uma instituição para promover a gestão da área e a garantia de infraestruturas e fornecimento de energia elétrica que, de fato, o distrito industrial conheceu migração de unidades industriais. Atualmente, há três aspectos marcantes no distrito industrial:

- A combinação de unidades industriais em variadas situações: podem estar em funcionamento, desativadas (observa-se na área muitos anúncios de venda e aluguel) ou ainda refuncionalizadas (uma antiga fábrica foi refuncionalizada como um shopping center).

- A circulação densa que dificulta o deslocamento em algumas partes, sobretudo as mais próximas ao acesso à Rodovia Fernão Dias (BR116), como mostra a Foto 4, e outras vicinais de circulação interna.

- O aspecto de transição no uso do território, que aos poucos está passando de uso totalmente industrial para um misto de usos: industrial, comercial, serviços e residências.

Em alguns pontos é possível observar conjuntos de habitações precárias na área do distrito industrial (essas áreas residenciais, atualmente, passam por processos de regularização para ser incorporadas ao município de Contagem como bairros residenciais). 
Normativamente, esta transição no uso do solo é possível, pois a Cidade Industrial de Contagem é definida como área de uso misto, o que permite que algumas indústrias negociem áreas em localizações hoje muito mais valorizadas do que na década de 1940. Estas áreas estão sendo ocupadas por outros segmentos econômicos, como supermercados, revendas de automóveis, oficinas mecânicas e, também um shopping center.

Com relação ao distrito industrial em Contagem, como o mais importante do Estado de Minas Gerais, é interessante mencionar que se tornou objeto de um dos primeiros projetos de recuperação e planejamento de distritos industriais. Trata-se do Programa de Revitalização e Modernização dos Distritos Industriais (FIEMG/CODEMIG, 2015) ${ }^{109}$, capitaneado pela Federação das Indústrias do Estado de Minas Gerais e Companhia de Desenvolvimento Econômico de Minas Gerais (CODEMIG).

Para poder identificar a natureza destas ações, além de nossa entrevista na FIEMG, estudamos as principais diretrizes deste programa. A Cidade Industrial de Contagem tornou-se foco de estudos e iniciativas em um modelo conjunto (empresários, poder público e universidade) que foi capaz de identificar problemas, tendências e soluções.

Como principal objetivo do programa, "Fomentar o desenvolvimento industrial em Minas Gerais", deduz-se a importância do território produtivo para este fim, uma vez que foram escolhidos os distritos industriais como áreas prioritárias para estudo e desenvolvimento. Por meio do programa, constatamos que este distrito, na maneira como atualmente se organiza, representa uma área que, na visão dos empresários, é atrasada e esquecida (pela gestão pública).

Além disso, devido às transformações no território, em curso, e à densidade forte que alguns distritos atingem, tais como a Cidade Industrial de Contagem, podem representar deseconomias de aglomeração (a este respeito, inclusive, mencionemos que o distrito industrial de Contagem foi conurbado com o município, o que também aconteceu entre os municípios de Contagem e Belo Horizonte).

$\mathrm{Na}$ realização do trabalho de campo, a visitação in situ nos permitiu constatar problemas de trânsito lento e pesado, relativamente nos horários de entrada e saída dos trabalhadores - ao que se soma ao fluxo elevado da Rodovia Fernão Dias. Também pudemos identificar problemas básicos de paisagismo, áreas degradadas (ambientais e

109 O descritivo deste programa encontra-se disponível em: <http://www.codemig.com.br/distritosindustriais> Acesso: março de 2016. 
sociais), nas quais existe risco de alagamento em ocasiões de chuva forte. Também podemos mencionar outros problemas urbanos como elevada emissão de ruídos e poluição.

Algumas fotografias retratam a área estudada. As Fotos 1 e 2 mostram as fachadas das empresas Itambé e Arcelormittal. A Foto 3 mostra a praça central da Cidade Industrial de Contagem, na qual podemos ver a sede do Centro das Indústrias de Minas Gerais (CIEMG) e a Foto 4, por fim, evidencia o trânsito intenso em uma das saídas para a Rodovia Fernão Dias. 


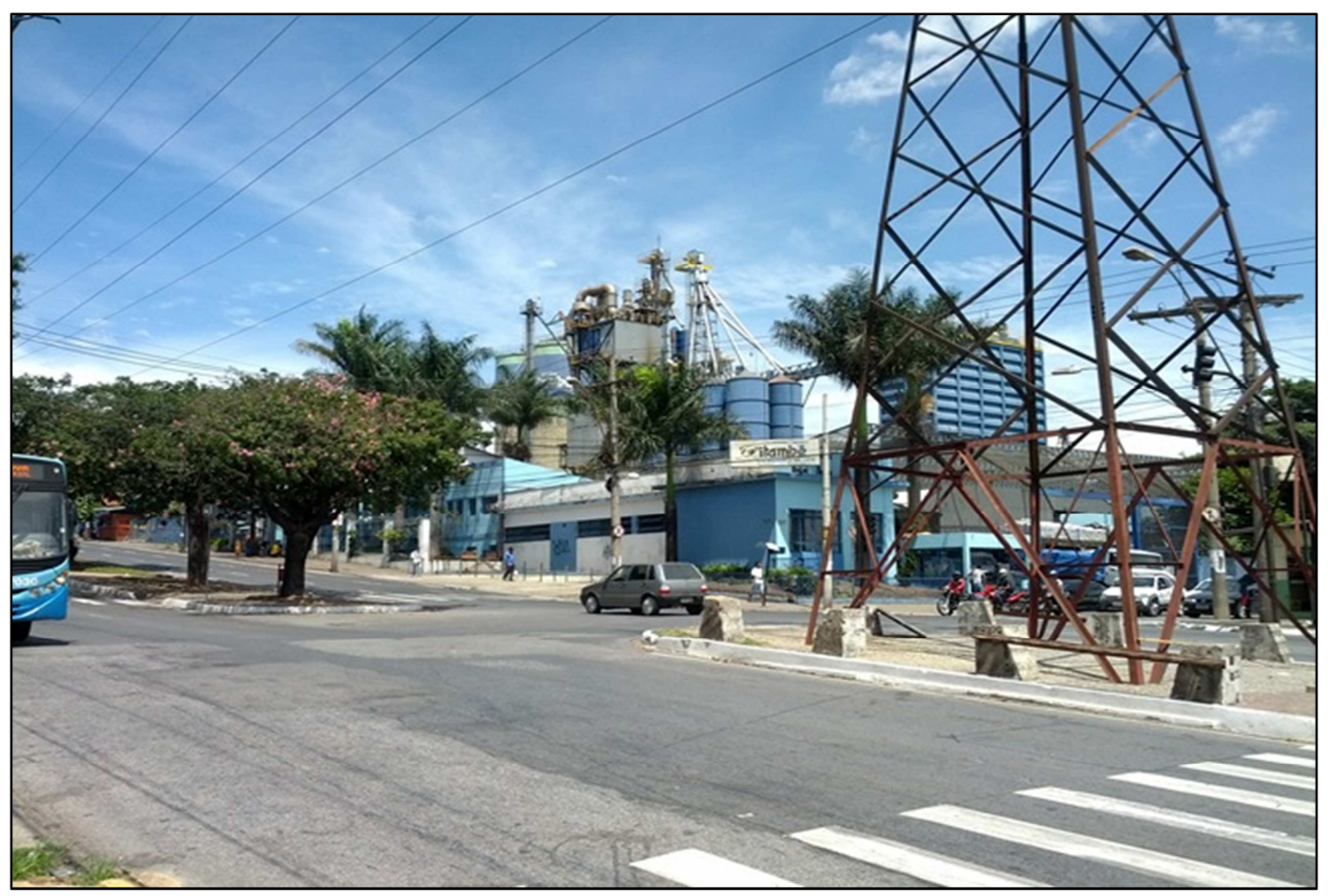

FOTO 1 - Avenida central localizada na Cidade Industrial de Contagem, na qual se verifica, em segundo plano, a fábrica da Itambé (indústria de alimentos). Fonte: Rodolfo Finatti, trabalho de campo, 2015.

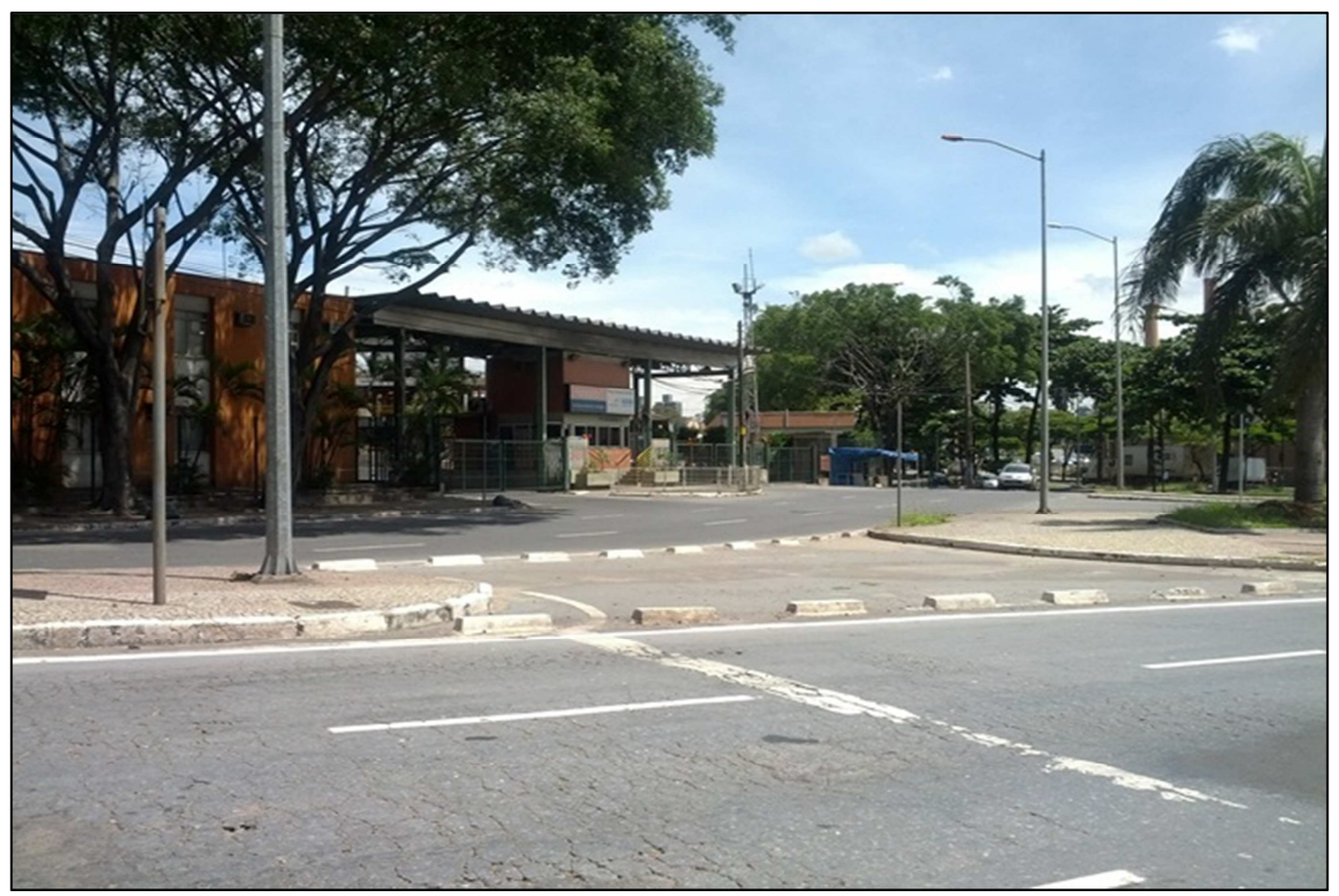

FOTO 2 - Fachada da fábrica da empresa Arcelormittal (siderúrgica), sediada na Cidade Industrial de Contagem. Fonte: Rodolfo Finatti, trabalho de campo, 2015. 


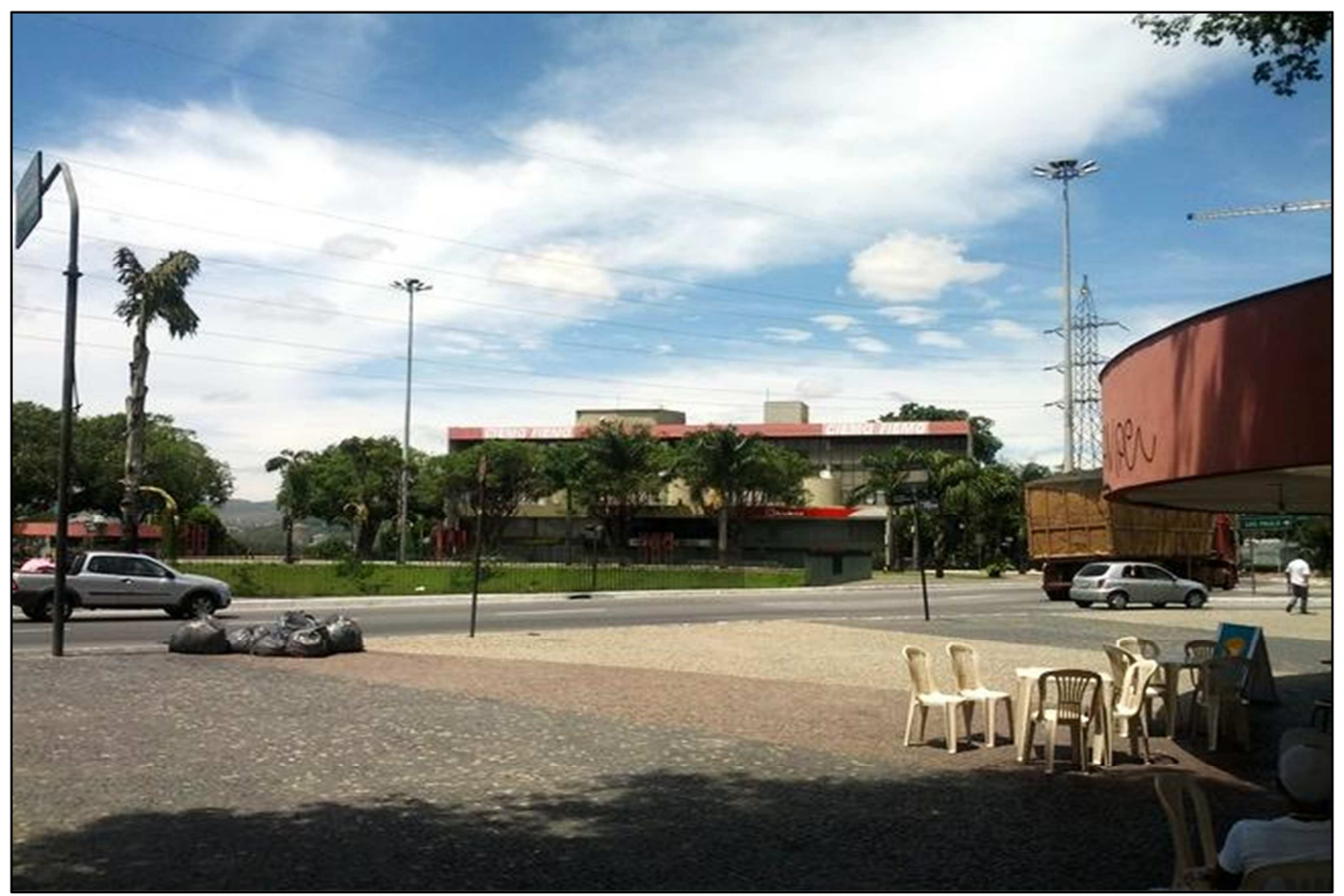

FOTO 3 - Praça central da Cidade Industrial de Contagem, na qual se verifica, em segundo plano, a sede do Centro das Indústrias de Minas Gerais (CIEMG). Fonte: Rodolfo Finatti, trabalho de campo, 2015.

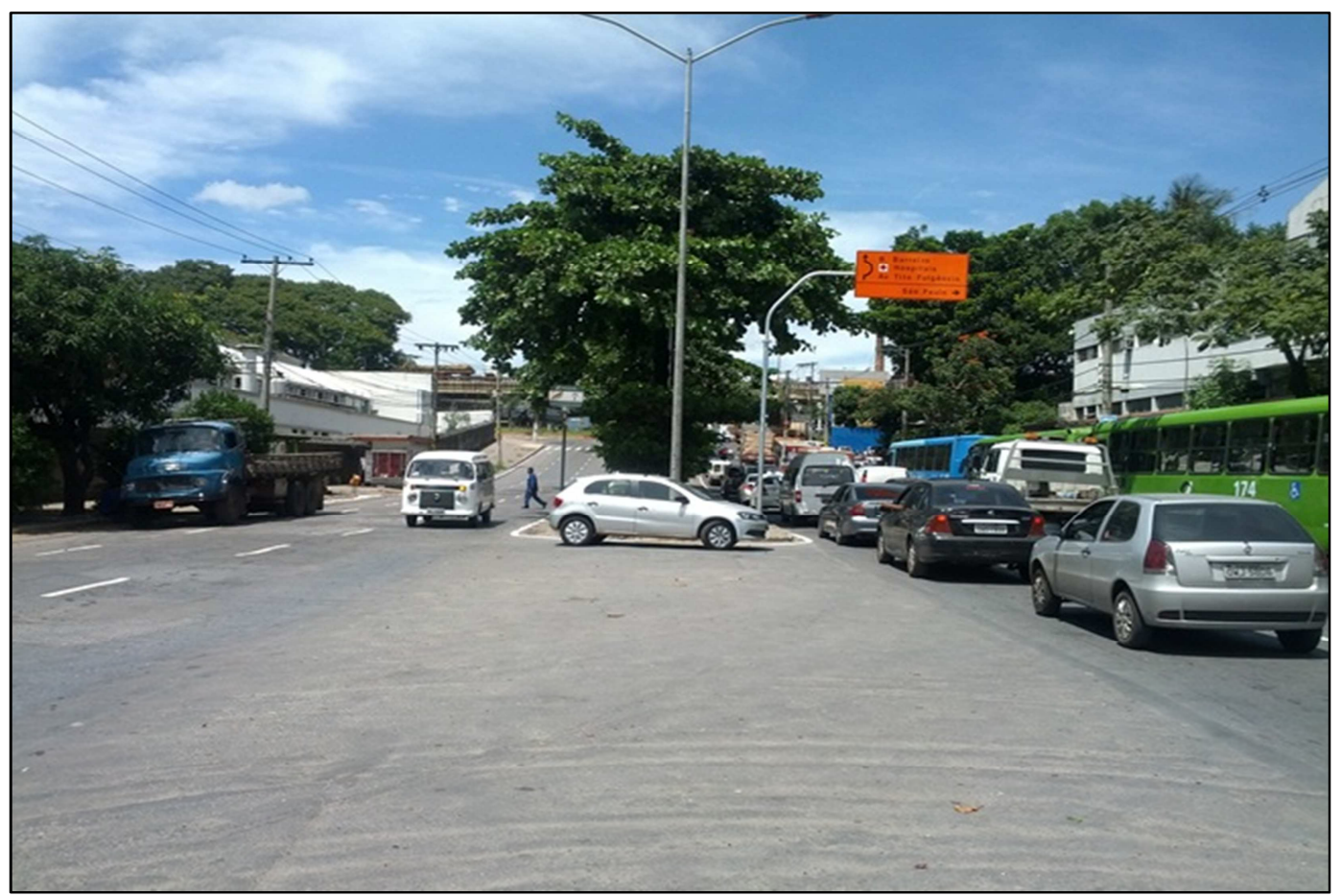

FOTO 4 - Avenida de acesso à Rodovia Fernão Dias, com tráfego intenso de veículos ao final da tarde, que pode ser verificado na parte direita da imagem. Fonte: Rodolfo Finatti, trabalho de campo, 2015. 
O Distrito Industrial de Fortaleza (ou I Distrito Industrial do Ceará) localiza-se no município de Maracanaú (CE), mais precisamente nas imediações do $4^{\circ}$ Anel Viário, que o conecta com a Rodovia Federal BR-116. Localizado na Região Metropolitana de Fortaleza, este é o primeiro distrito industrial do estado cearense, idealizado pelo Governo do Estado do Ceará na década de 1960, por meio da Companhia de Desenvolvimento do Ceará (CODECE) e apoiado pela SUDENE.

O Distrito Industrial de Fortaleza já nasce atrelado ao município de Maracanaú, que era contemplado no planejamento da CODECE e SUDENE como "bairro operário". A área escolhida foi determinada por uma consultoria canadense que indicou o eixo Fortaleza-Maranguape para implantação deste distrito industrial, conforme destaca R. B. Gomes (2015). O Distrito Industrial de Fortaleza foi originado justamente no contexto de planejamento governamental que predominou no Brasil na década de 1960, na qual o ideal do desenvolvimento era posto em prática por meio da industrialização e, nesse escopo inseria-se nos planejamentos estaduais, a criação de áreas para organizar e atrair unidades industriais.

Contudo, o Distrito Industrial de Fortaleza teve uma taxa de ocupação lenta até a década de 1980. Foi apenas a partir da primeira gestão do Governador Tasso Jereissati, em 1985, que o distrito começou a receber um expressivo número de unidades industriais, acompanhando a dinâmica de industrialização que este estado conheceu no mesmo período, por meio dos incentivos fiscais oferecidos. O Distrito Industrial de Fortaleza é um caso no qual se pode reconhecer duas temporalidades que se sobrepõem a um mesmo espaço, como reflexo dos projetos que ocorriam na dimensão política: o insucesso da implantação no período SUDENE, vindo a ficar quase vinte anos como uma área estagnada, quando comparada à afirmação do distrito como a principal aglomeração produtiva do Ceará, somente após forte ação política.

Segundo K. B. Carvalho (2009), autora que apresenta um dos principais estudos de caso específicos sobre esta área industrial, o distrito se consolida justamente por meio da política agressiva de incentivos fiscais do governo cearense. A autora assevera o importante papel do Estado como agente planejador da área e assevera o seguinte:

Pautado no discurso do desenvolvimento econômico como forma de responder as necessidades sociais, o Estado é o principal agente promotor da adequação territorial para a atração, efetivação e atuação da atividade 
produtiva industrial no Nordeste e, sobretudo, no Ceará. Nas últimas décadas, teve papel decisivo na conformação territorial da indústria por intermédio de uma política industrial baseada no peso das externalidades e nos atrativos fiscais para os grandes empreendimentos industriais, alegando serem estes capazes de empregar maior quantidade de mão de obra e com menor qualificação (CARVALHO, 2009, p.117).

Como uma das mais expressivas ações levadas a cabo para a industrialização do território cearense, como bem mostra a história do Distrito Industrial de Fortaleza, não há como negar o papel da subvenção fiscal como parte integrante do projeto governamental de atração de investimentos externos. Para Pereira Junior e Sposito (2013), este projeto teve como condicionantes estratégicos a reestruturação do território e as isenções fiscais. Destaque-se ainda:

[...] as políticas interessadas na atração de investimentos pela via de subsídios fiscais empreenderam relevantes transformações no quadro produtivo industrial cearense, embora seus efeitos no território tenham sido o acirramento dos quadros de desigualdade e o reforço econômico de regiões historicamente já estruturadas (PEREIRA JUNIOR e SPOSITO, 2013, p.16).

Nosso trabalho de campo nesta área industrial ocorreu em abril de 2014. O relevo predominantemente plano do distrito impede que se tenha noção, em campo, de suas dimensões verdadeiras. A área central deste distrito pode ser ilustrada por meio da Foto 5, ao final desta seção, onde se verifica a fábrica da empresa Durametal. Existem 174 empresas, de acordo com Gomes (2015), instaladas no Distrito Industrial de Fortaleza, entre elas, as de maior porte são: Gerdau, Vicunha e Esmaltec (que pode ser visualizada na Foto 6).

Este pode ser considerado um dos distritos industriais mais bem organizados em que realizamos trabalho de campo. A infraestrutura é uma das que menos apresenta deficiências (ainda que constatemos isso apenas por meio da observação e de uma entrevista realizada na associação de empresas). Carvalho (2009) aponta ainda como elementos preponderantes da área: fornecimento de água bruta e tratada, rede de esgoto que conta com cinco lagoas de estabilização, fornecimento de gás natural, energia elétrica e internet por fibra ótica.

Também sobre a organização geral da área, é indispensável mencionar a existência de uma associação de empresas neste distrito: Associação das Empresas em Distritos Industriais no Ceará (AEDI), cujo objetivo é facilitar a administração, interlocução entre os empresários, resolver problemas comuns e ter uma representatividade 
perante o poder público. Nossa entrevistada ${ }^{110}$ nesta associação afirmou a participação de 85 empresas na associação, ou seja, $48 \%$ de participação em relação ao total de indústrias instaladas.

Em 2014, a AEDI completou 35 anos de existência e foi alavancada justamente pela demanda de organização industrial a partir da maior densidade industrial verificada no Estado do Ceará mas, sobretudo no Distrito Industrial de Fortaleza e demais distritos vizinhos (também na Região Metropolitana de Fortaleza).

Conforme destacado pela entrevistada, os principais favorecidos pelas atividades da associação são as médias-gerências que, ao nível operacional, precisam estabelecer articulações com outras empresas e instituições. As articulações são feitas com órgãos públicos e empresas que possam auxiliar na dimensão operacional do distrito (como o descarte de lixo, serviços educacionais e de saúde). É importante mencionar que a escala de atuação da AEDI ocorre em toda a região metropolitana, sobretudo por meio de eventos conjuntos com as prefeituras e os agentes do SEBRAE cujo objetivo é estimular a integração entre possíveis parceiros e fornecedores (pequenas e médias indústrias). A associação também se responsabiliza pela produção de uma revista (Revista Oportuniza) voltada para as médias-gerências, na qual informa sobre atualização de leis, problemas internos do distrito e resoluções, formação de mão-de-obra e outras ações do Serviço Nacional de Aprendizagem Industrial (SENAI).

O tema da gestão dos distritos industriais, que identificamos como um dos principais problemas das aglomerações industriais ou produtivas, destacamos o papel da AEDI como um dos melhores níveis organizacionais. Esta entidade conta com sede física, gestores (empresários eleitos) efetivamente atuantes e com alguma capacidade para desenvolver e executar projetos (nem todas as associações gozam desta possibilidade relativamente autônoma para proposições).

Outro aspecto deste distrito, assim como se pode apontar com relação à Cidade Industrial de Contagem, é a noção de "simbiose" que pode ser estabelecida entre este aglomerado industrial e o município de Maracanaú. Em seu lado sudoeste existe um bairro residencial extenso e denso, visivelmente planejado para implantação articulada ao Distrito Industrial de Fortaleza já na década de 1960, com o princípio de "bairro operário" que vigorava na concepção dos distritos industriais pioneiros no país. Hoje, aqueles que não trabalham nas fábricas são pequenos proprietários e/ou funcionários em um comércio local

${ }^{110}$ Entrevista realizada com a coordenadora F. Noronha, em 02 de abril de 2014. 
bastante representativo, como mostra a dissertação de Gomes (2015), que ressalta a origem desta aglomeração urbana:

[...] nas décadas de 1970 e 1980, atrelados ao crescimento industrial na direção sudoeste da RMF, foram instalados seis conjuntos habitacionais próximos ao DIF I. A expansão dos conjuntos habitacionais (COHAB) resultou das políticas nacionais, com financiamentos do Banco Nacional de Habitação (BNH) (p.201).

A relação entre o distrito e a população local, bem como a necessidade de descolamento para Fortaleza obriga ao oferecimento de serviços de transporte coletivo (ônibus e trem), porém os moradores tendem a circular pela área industrial também para outras finalidades, como acesso a equipamentos de comércio, saúde e educação. Nas duas avenidas centrais que entrecortam a área existe um hospital, um supermercado, escolas técnicas (três unidades do SENAI), restaurante, posto de atendimento ao trabalhador. A coordenadora da AEDI destacou também um projeto de transferir a sede da Prefeitura de Maracanaú para a avenida central do aglomerado industrial, atestando não apenas os graus de conexão da citada "simbiose" entre cidade e indústria, mas também o nível de simbolismo e de importância do distrito industrial para Maracanaú.

O conjunto de fixos não industriais existentes no Distrito Industrial de Fortaleza atesta novas modernizações que estão em curso e comprovam a tendência de diversificação do uso do solo no caso dos distritos industriais: uma parcela do terreno está abrigando estruturas não industriais como um shopping center, um centro de convenções (Foto 7) e um hotel. A empresa Vicunha construiu um conjunto residencial (pequenos edifícios com quatro andares cada) para os seus funcionários, nesta mesma área. A respeito dessa dinâmica, verificamos que uma área do distrito poderia ser considerada transição entre a cidade e sua parcela industrial mais antiga.

Nesta transição nos usos do solo, como também verificamos em relação à Cidade Industrial de Contagem, alguns problemas e desdobramentos são decorrentes, tais como o trânsito pesado nas principais vias de acesso (afetando caminhões e automóveis domésticos), a existência de ocupações residenciais irregulares (Foto 8) em constante risco de desapropriação, edificações em desuso e sem destinação adequada e a falta de terrenos livres para instalação de novas empresas. O estudo de caso de K. B. Carvalho (2009) chegou aos seguintes apontamentos: 
[...] os efeitos das deseconomias de aglomeração convergiram em problemas para instalação de novas empresas industriais. Falta de terreno, engarrafamentos, encarecimento do solo e conflitos com as comunidades residenciais do seu entorno (como os conjuntos habitacionais), a partir da poluição [...] um dos maiores problemas para as empresas industriais se instalar em Maracanaú é a falta de terrenos livres, principalmente no Distrito Industrial I (nome atual do DIF I). Alguns lotes já possuíam proprietários contemplados pelos programas anteriores, mas não consolidaram seus projetos. Portanto, somente no Distrito Industrial I há $240.100 \mathrm{~m}^{2}$ de terrenos ociosos (CARVALHO, 2009, p.232).

Para melhor caracterizar este distrito industrial, as Fotos 5 e 6 evidenciam as unidades fabris da Durametal e Esmaltec, respectivamente. A Foto 7 retrata o galpão destinado a exposições e a Foto 8 mostra um conjunto de residência resultante de invasão à área do distrito. 


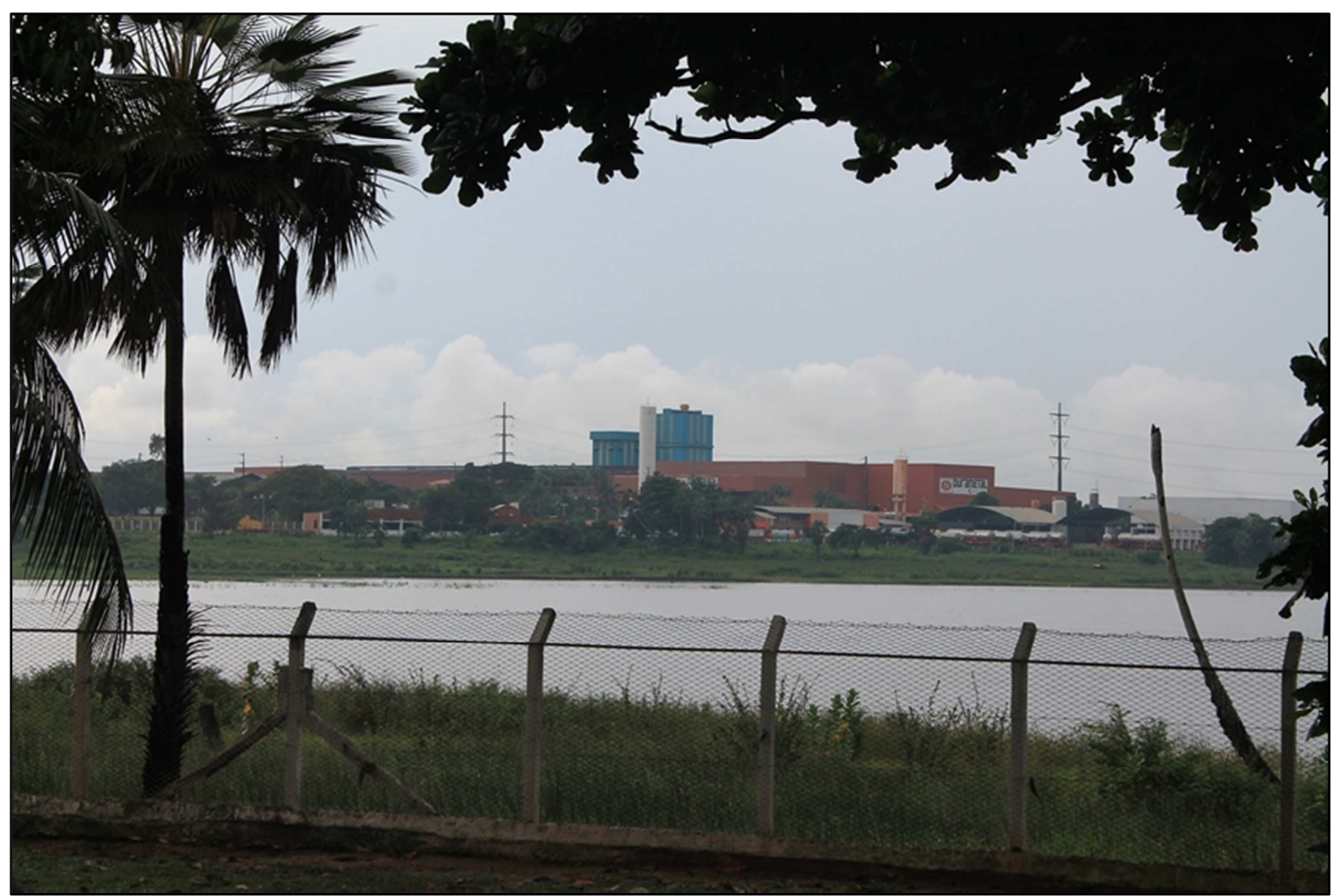

FOTO 5 - Centro do Distrito Industrial de Fortaleza. No segundo plano, se verifica a fábrica da empresa Durametal (peças automotivas) Fonte: Rodolfo Finatti, trabalho de campo, 2014.

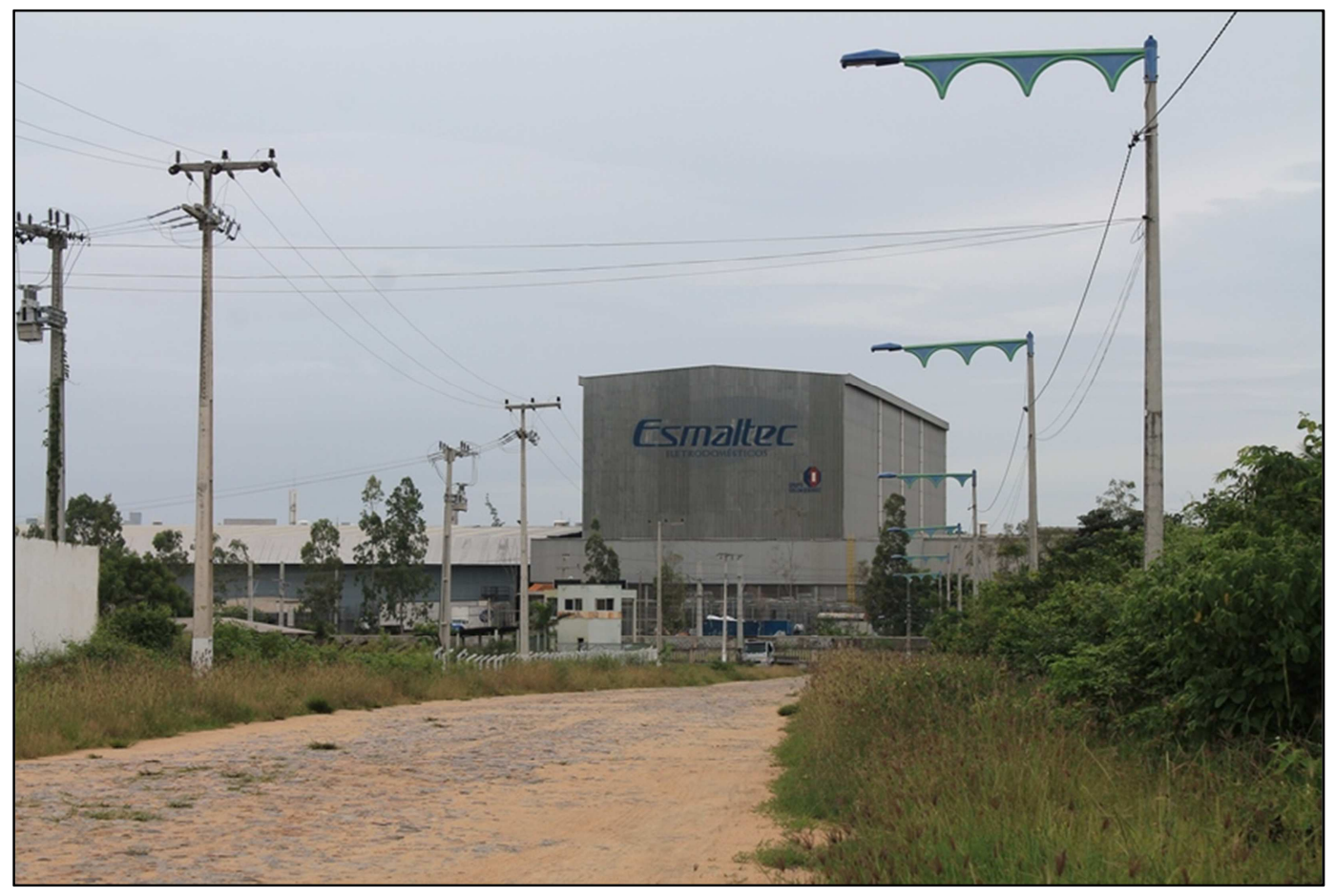

FOTO 6 - Fábrica da empresa Esmaltec (eletrodomésticos) no Distrito Industrial de Fortaleza. No primeiro plano, se verifica via de circulação com ausência de pavimentação asfáltica. Fonte: Rodolfo Finatti, trabalho de campo, 2014. 


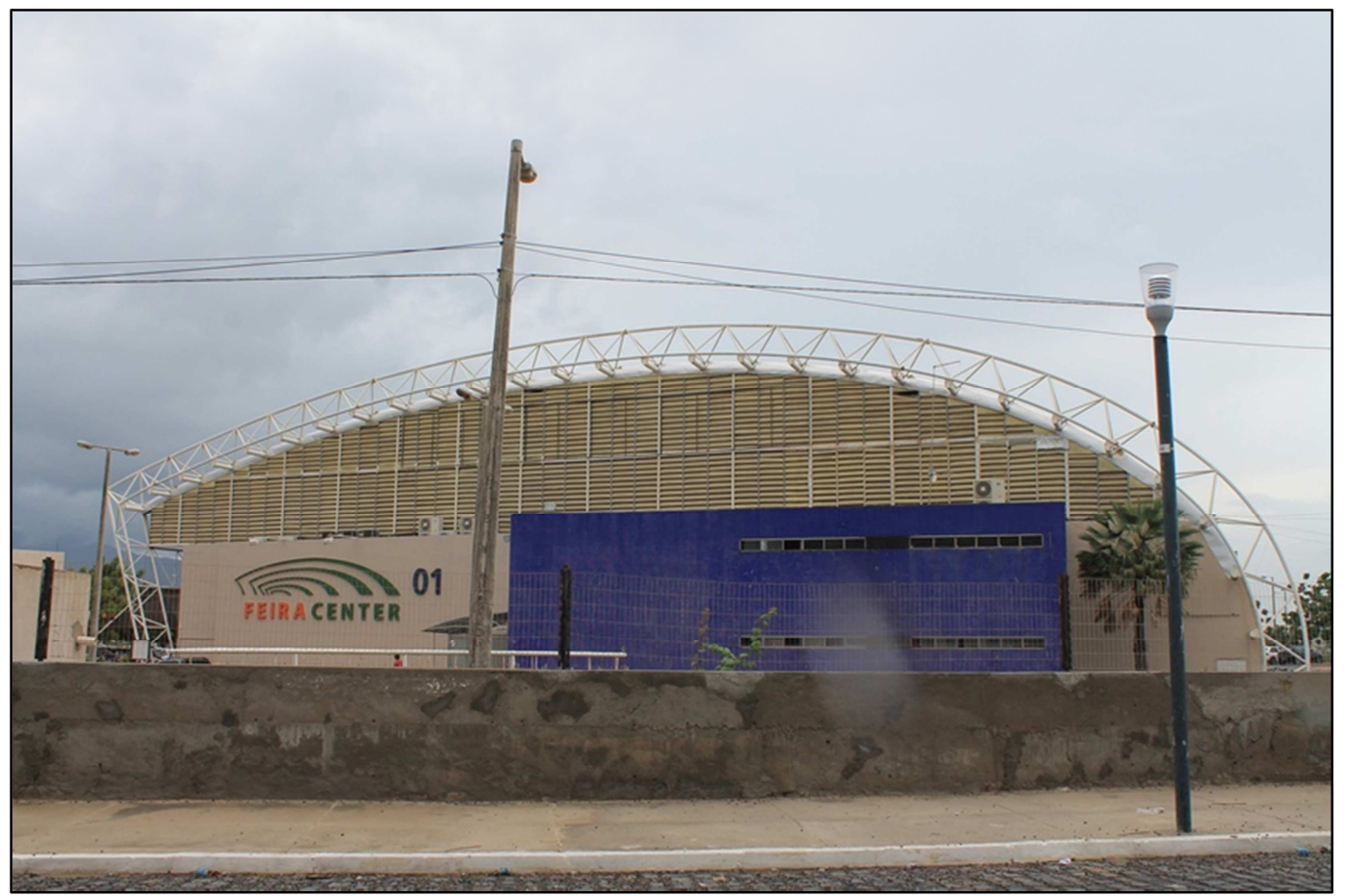

FOTO 7 - Centro de exposições FeiraCenter no Distrito Industrial de Fortaleza. Fonte: Rodolfo Finatti, trabalho de campo, 2014.

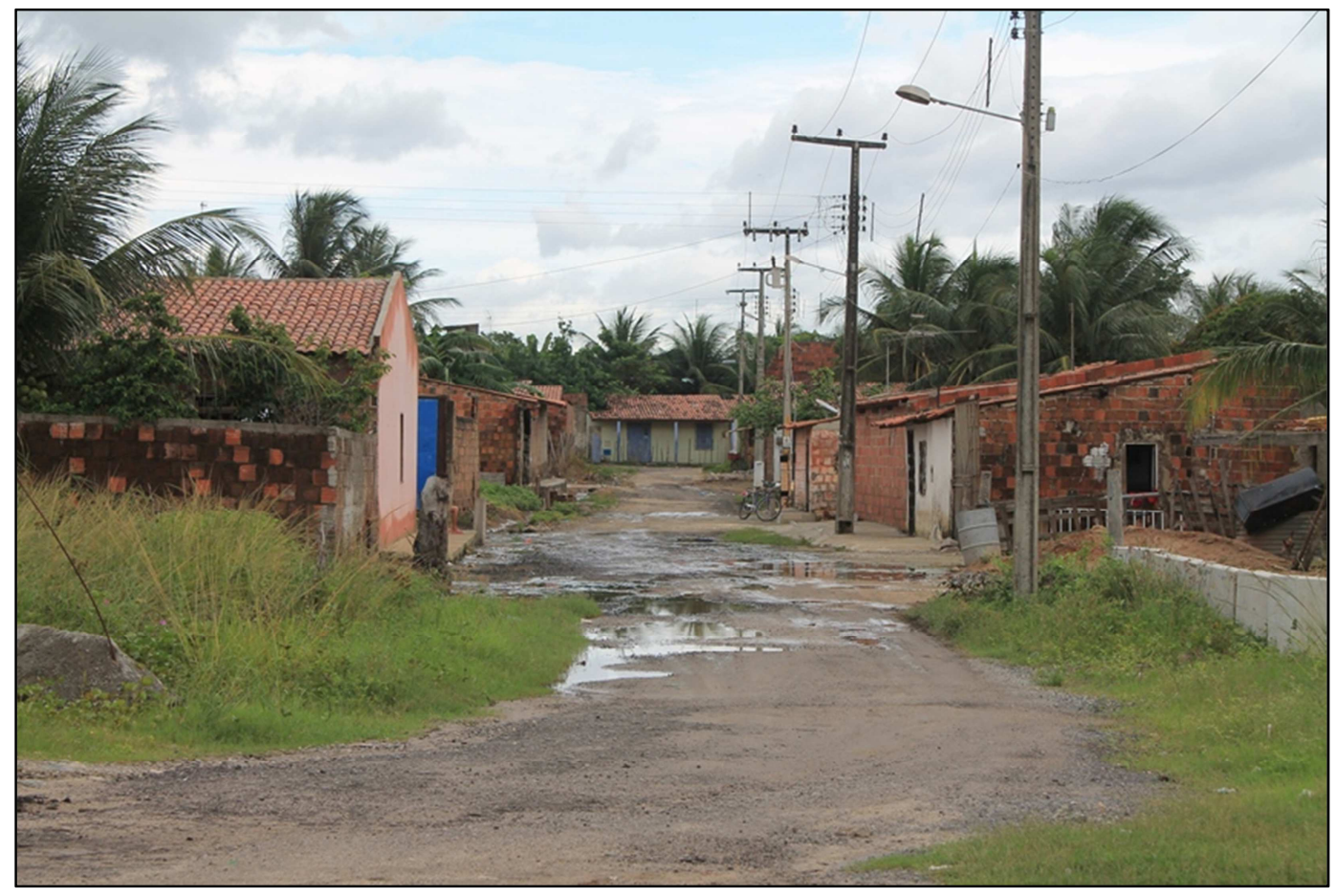

FOTO 8 - Residências localizadas no Distrito Industrial de Fortaleza e condições de urbanização (ausência de pavimentação asfáltica, áreas sujeitas ao acúmulo de água e terrenos abandonados). Fonte: Rodolfo Finatti, trabalho de campo, 2014. 
O Centro Industrial Subaé está localizado em Feira de Santana (BA), distante $115 \mathrm{~km}$ em relação à capital Salvador e privilegiado por uma posição geográfica que permite o acesso a duas importantes rodovias federais brasileiras (BR-101 e BR-116). O município de Feira de Santana possui um entroncamento rodoviário (ao qual também se conecta a BA-052 que leva à Salvador) no qual estas duas importantes rodovias federais estão mais próximas entre si.

Esta área foi originada a partir das três escalas de influência: o governo federal a partir das ações da SUDENE, o governo estadual ao qual se vincula diretamente na figura da Superintendência de Desenvolvimento Industrial e Comercial (SUDIC) e, finalmente, a partir de ações ativas da Prefeitura Municipal de Feira de Santana, por meio de um projeto de modernização industrial no final da década de 1960.

De acordo com a pesquisa de M. Freitas (2005), a história deste distrito industrial começa justamente com o Plano de Desenvolvimento Local Integrado da Prefeitura de Feira de Santana, de 1968. Este plano já detectava uma insuficiência da estrutura produtiva face à demanda do comércio local, o que influenciou o ideal de transformar Feira de Santana no $2^{\circ}$ polo industrial da Bahia. Para isso, o governo municipal desapropria uma área que seria futuramente o primeiro núcleo deste distrito industrial.

O Centro Industrial do Subaé rapidamente foi ocupado devido à sua posição logística extremamente vantajosa, ao excedente de mão-de-obra existente em Feira de Santana e, sobretudo, aos incentivos fiscais que foram destinados às empresas da área, segundo análise de N. Freitas (2009):

\begin{abstract}
Foi neste contexto que se situou a combinação favorável de fatores (incentivos fiscais, isenção de impostos, localização geográfica, entroncamento rodoviário importante, mão-de-obra disponível, desenvolvimento urbano acentuado graças à atividade comercial) e a decisão de criação do CIS: a busca da economia de custos e de padrões cada vez maiores de lucratividade, a partir da divisão do trabalho no conjunto da produção social (FREITAS, 2009, p.119).
\end{abstract}

Assim já em 1970 o distrito industrial é alavancado, quando verificadas as potencialidades de sua posição geográfica, momento em que a SUDENE passa a dar "Prioridade A" (primeira área em concessão de incentivos fiscais) em detrimento do Centro Industrial de Aratu, outro distrito industrial baiano do mesmo período. 
Em atividade de campo ${ }^{111}$ realizada em junho de 2014, pudemos constatar alguns aspectos importantes deste distrito industrial. Podemos mencionar que conta com uma estrutura de gestão própria, com sede física no próprio distrito e certa "autonomia" de decisão, que seria independente da Superintendência de Desenvolvimento Industrial e Comercial. Embora esteja vinculado à SUDIC, atualmente o distrito pode fazer o seu planejamento independentemente das decisões centralizadas que são direcionadas aos demais distritos industriais baianos.

Apesar deste quadro organizacional de maior independência face às configurações dos demais distritos, o centro apresenta infraestrutura precária, com asfaltamento precário e nenhum cuidado paisagístico. As vias de acesso são estreitas se considerarmos a intensidade dos fluxos atuais e nos foi afirmado que o distrito apresenta elevada periculosidade, principalmente no período noturno ${ }^{112}$. A estrutura de gestão é voltada, sobretudo, para a atração e direcionamento de novas indústrias, mesmo assim, podemos considerar que o Centro Industrial Subaé é o distrito de melhor organização administrativa no Estado da Bahia.

Também pudemos constatar, por meio das entrevistas, que embora seja esta uma área continua à mancha urbana, existe um processo de fiscalização constante para garantir que o uso do solo seja, na área, estritamente industrial. Qualquer tentativa de ocupação (invasão) visando instalação residencial é rapidamente afastada.

Um dos aspectos diferenciais relacionado a este distrito industrial é a forma descontínua com a qual está se expandindo. Atualmente o Centro Industrial do Subaé apresenta outros núcleos de aglomeração, além do núcleo original no Bairro do Tomba, como estratégia para sua ampliação. Essa organização territorial distorce um pouco o conceito dos distritos industrial como áreas que sejam sempre contínuas, definidas e bem delimitadas.

Há atualmente um planejamento de expansão: devido à ausência de áreas desocupadas em sua delimitação inicial, outras áreas próximas e descontínuas serão utilizadas para instalação de novas indústrias que estarão também sob a mesma administração da área principal. Pudemos conhecer uma destas áreas, cuja distância é de aproximadamente $3 \mathrm{~km}$ em relação ao núcleo no Bairro do Tomba.

\footnotetext{
${ }^{111}$ Entrevistas realizadas com a secretária P. Sobral e o gerente G. Vaccarezzo, que também nos acompanhou durante visitação às áreas do respectivo distrito, no dia 25 de junho de 2014.

${ }^{112}$ Este é um fato recorrente em muitos outros distritos industriais.
} 
Para uma ideia de ocupação deste distrito, a partir de dados utilizados nos estudos de caso sobre o Centro Industrial Subaé, podemos traçar uma perspectiva simples de evolução: Segundo Freitas (2009), no ano de 1996 o distrito industrial tinha 39 empresas instaladas (apenas no núcleo inicial, Bairro do Tomba). A partir da expansão territorial do distrito, no ano de 2009 considerava-se a existência de 120 empresas, número que aumentou para 160 empresas instaladas no ano de $2014^{113}$.

O Centro Industrial do Subaé começou a articular sua iniciativa de expansão a partir de 2012. A estrutura de gestão existente no centro, junto ao apoio direto da Secretaria de Indústria, Comércio e Mineração e sua influência foi capaz de fomentar a expansão para outros 14 municípios. Nesse escopo, o Centro Industrial do Subaé tem a expertise da administração e atração de indústrias, enquanto as prefeituras municipais tem a contrapartida da doação da área para o novo distrito e os incentivos.

Quando questionado sobre a estrutura de planejamento de um distrito industrial, o gerente do centro afirma que não existiu e não existe "planejamento das áreas industriais no Brasil". As ações são muito mais intuitivas e, por vezes, desconectadas entre as diversas esferas de poder e também o empresário industrial. Não se consegue fomentar, no Centro Industrial do Subaé, uma representatividade empresarial ou personalidades que se proponham a ajudar na gestão da área, tampouco o poder público atua no tocante à manutenção das áreas comuns e infraestruturas, dando ao distrito o aspecto deteriorado que hoje apresenta.

É relevante mencionar a visão dos analistas ${ }^{114}$ da Federação das Indústrias da Bahia a este respeito: embora seja uma variável aparentemente simples o distrito industrial deveria ser o "jardim da indústria", ou seja, o primeiro aspecto que um empresário identifica ao chegar ao distrito industrial é a organização da paisagem e o que ela lhe transmite (segurança no investimento ou falta de planejamento em uma área deteriorada?). Os representantes da FIEB afirmaram que as características deterioradas do Centro Industrial Subaé afastam investidores. Do ponto de vista do empresariado, isso é uma falha que precisa ser corrigida.

Ademais, assim como temos verificado com os outros estudos de caso, este distrito também faz parte de um processo de industrialização mais amplo que reflete um

\footnotetext{
${ }^{113}$ Dado obtido a partir de nosso trabalho de campo, informado pelo gerente do G. Vaccarezzo.

${ }^{114}$ M. E. Verhine (gerente) e C. P. Almeida (analista), da Federação das Indústrias do Estado da Bahia, em entrevista realizada no dia 27 de junho de 2014.
} 
período histórico no país que repercutiu nas ações do estado baiano e também governo municipal:

$\mathrm{O}$ processo de industrialização, tanto na Bahia, quanto em Feira de Santana naquele momento, reflete a política nacional que tem por base o ideário cepalino: tirar a América Latina do atraso econômico através da industrialização (FREITAS, 2009, p.140).

Muito embora Feira de Santana fosse, até por conta da história de sua ocupação enquanto um importante nó de circulação, voltada para o comércio (FREITAS, 2009), a industrialização foi, a partir da década de 1970, a variável escolhida pela gestão municipal para tentar alavancar modernização e desenvolvimento econômico. Nesse sentido o distrito industrial foi o instrumento escolhido para viabilizar e atrair, territorialmente, unidades industriais e de outros segmentos econômicos.

Assim como ocorre também com outros distritos industriais, não se verifica a predominância de um determinado segmento industrial. Ao mesmo tempo, há centros de distribuição e logística e empresas voltadas para serviços industriais, reforçando outros elos dos circuitos produtivos como distribuição e serviços.

Para tentar caracterizar melhor a paisagem deste distrito industrial, algumas fotos foram selecionadas, porém não tivemos condições adequadas para fazer o registro ${ }^{115}$. A Foto 9 retrata a entrada principal do Centro Industrial Subaé e a Foto 10 retrata uma das etapas de construção de um galpão logístico.

\footnotetext{
${ }^{115}$ As imagens capturadas são extremamente limitadas face à realidade deste distrito industrial. O horário já avançado no qual fizemos a visita "oficial" e guiada, devido à entrevista extensa, não permitiu que fossem capturadas fotografias adequadas.
} 


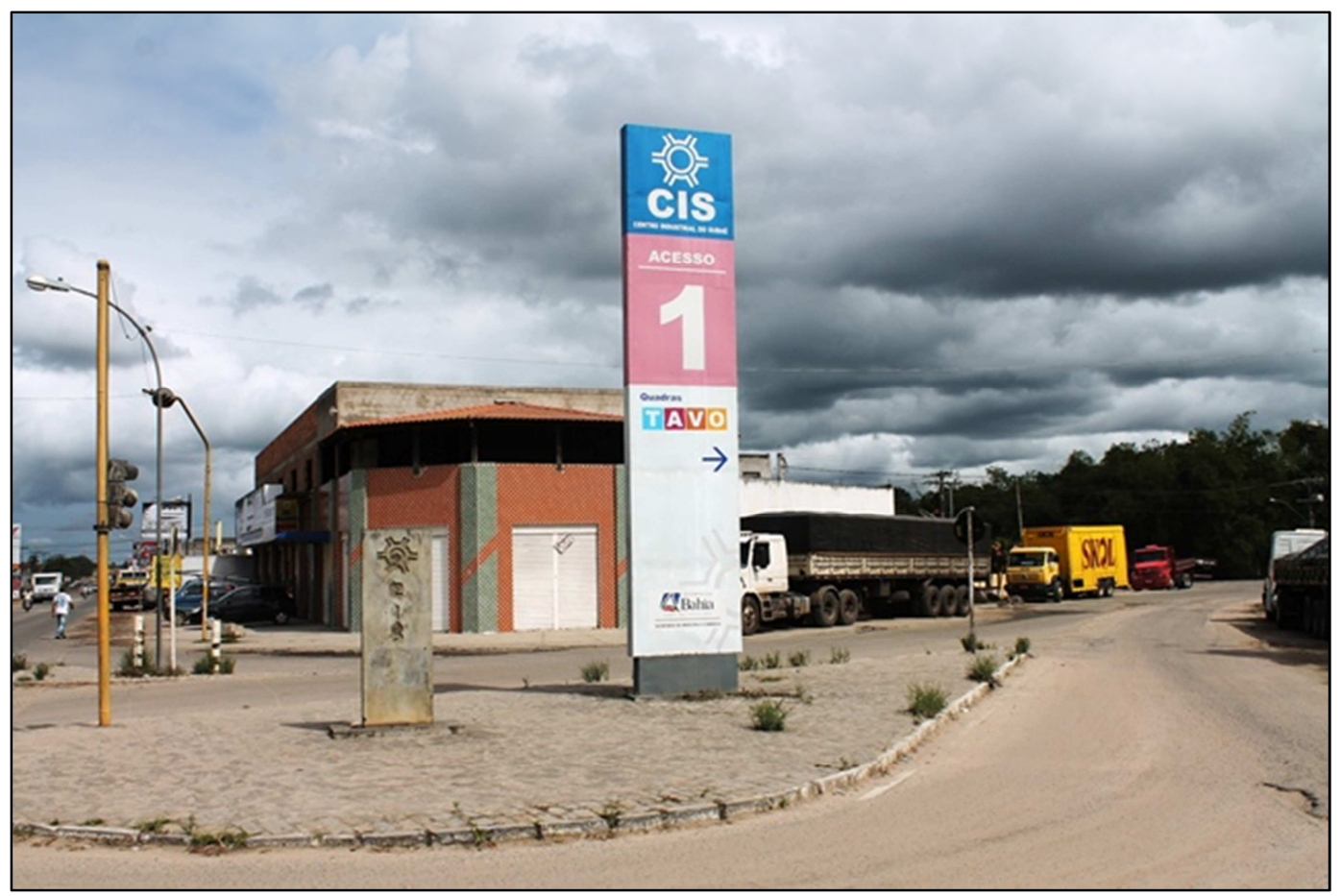

FOTO 9 - Via de acesso principal ao Centro Industrial Subaé. Fonte: Rodolfo Finatti, trabalho de campo, 2014.

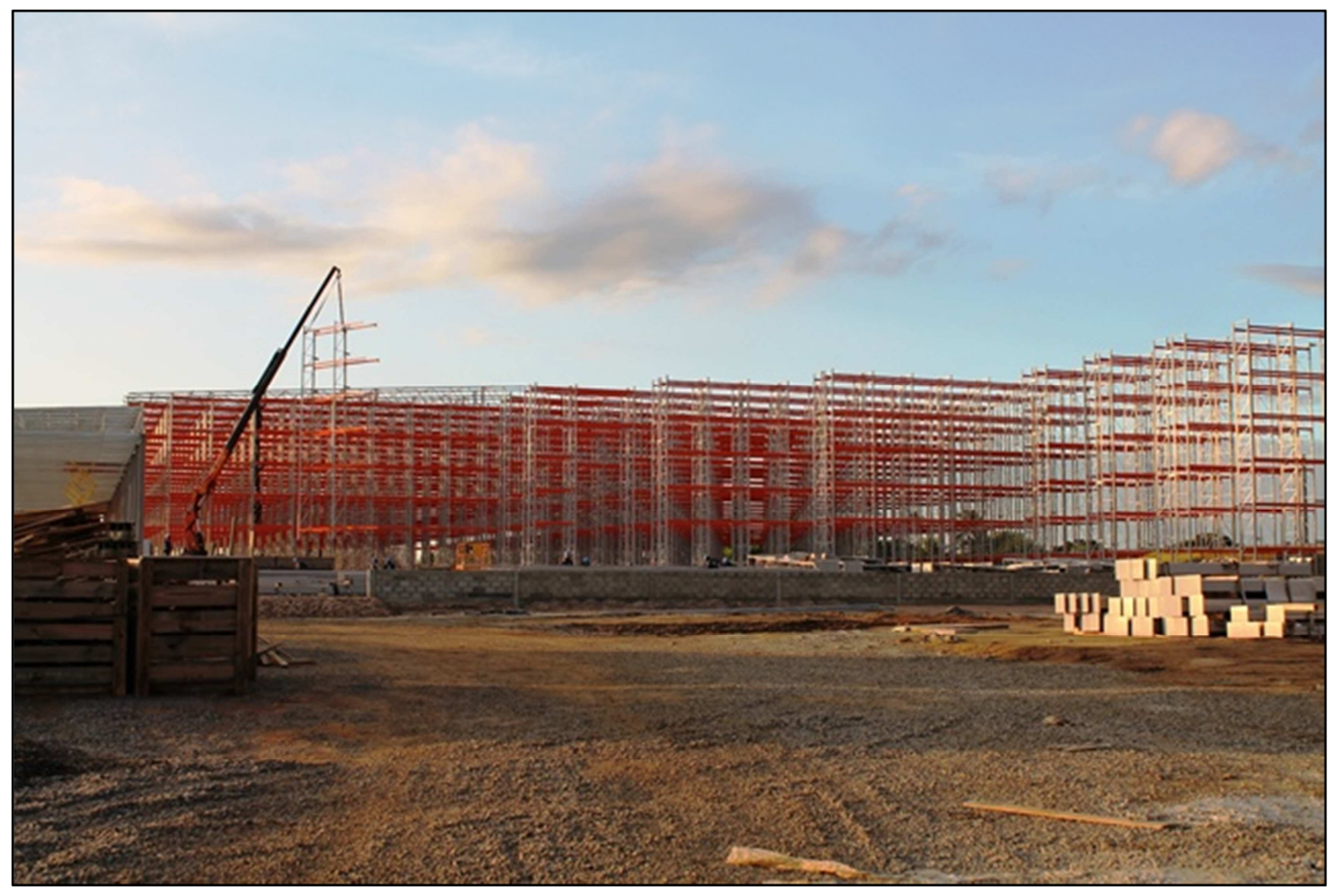

FOTO 10 - Etapa construtiva de galpão, em uma das áreas destinadas à expansão do Centro Industrial Subaé. Fonte: Rodolfo Finatti, trabalho de campo, 2014. 
Este distrito industrial está localizado no município de Queimados (RJ). Foi implantado no ano de 1976 por intermédio do Governo do Estado do Rio de Janeiro. M. Morais, que fez um estudo de caso sobre esta área, indica que a intenção foi “[...] oferecer uma opção às indústrias que procuravam alternativa aos grandes centros urbanos" (2014, p.29).

A localização do distrito industrial vai ao encontro, sobretudo, do oferecimento de fluidez territorial. Sua localização na BR-116 é também próxima à Rodovia Estadual RJ-109, que por sua vez favorece ligação com a BR-101, portanto um nó de circulação entre importantes rodovias federais brasileiras. Além disso, a posição geográfica deste distrito também permite articulação com o Porto de Itaguaí e com o arco metropolitano (distante $4 \mathrm{~km}$ ).

Essa posição geográfica permitiu com que o distrito industrial fizesse a região da baixada carioca ser reconhecida como o "novo eldorado logístico" no Rio de Janeiro ${ }^{116}$. A notícia destaca também a construção de galpões no formato de condomínio logístico, cuja existência foi possível confirmar em nosso trabalho de campo, reforçando uma tendência que também constatamos em outros distritos: a mescla de duas formas de aglomeração, por meio de investimentos imobiliários no interior de distritos industriais para atender sobretudo, à demanda logísticas das empresas.

Embora seja um distrito de 1976, só começou a consolidar-se na década de 1990. Um dos indicadores do crescimento foi a emancipação do município de Queimados (desmembrou-se de Nova Iguaçu), justamente com o pretexto de reter a arrecadação advinda das empresas existentes no Distrito Industrial, o que também denota a capacidade da aglomeração produtiva em influenciar nas normas e organização do espaço:

\footnotetext{
Essas transformações tem como vetor de progresso o distrito industrial, que criado em 1976, na então cidade de Nova Iguaçu, irá exercer um importante papel na emancipação de Queimados, esta emancipação será fortemente baseada em ideais progressistas e desenvolvimentistas, em uma premissa de que os ganhos arrecadados com o distrito industrial eram enviados para a longínqua sede de Nova Iguaçu e não revertidos em melhorias na realidade local (MORAIS, 2014, p.27).
}

\footnotetext{
${ }^{116}$ Para essa notícia, visitar: <http://queimados-rj.blogspot.com.br/2013/06/queimados-o-novo-eldorado-dalogistica.html> Acesso: abril de 2016.
} 
Nosso trabalho de campo no distrito industrial ocorreu em março de 2015, partindo da capital Rio de Janeiro (RJ) pela Rodovia Presidente Dutra. Foi possível verificar a configuração da área, que conta com infraestrutura básica para um total de 40 empresas, segundo associação das empresas deste distrito (ASDINQ, 2014), entre elas a Weber Saint-Gobain (Foto 11, ao final deste item) que fabrica insumos para construção civil. A paisagem denota organização, com asfaltamento adequado, avenida e ruas bastante amplas, iluminação pública e coleta de lixo aparentemente funcional, como ilustra fotografia da avenida central da área (Foto 12).

O estudo de M. Morais (2014) também aponta como itens de infraestrutura: subestação de energia, telefonia digital com fibra ótica, servidor de internet banda larga, fornecimento de gás e água tratada, bem como cabine de segurança da polícia militar como importante item de segurança.

Ao circular pela área notamos que há muitos lotes vagos que podem ainda ser ocupados, mesmo que se tenham planos e áreas reservadas ao redor do distrito industrial para sua futura expansão. Entre os distritos que visitamos, este é um dos poucos que está totalmente ocupado por empresas industriais, ou seja, sem a presença de áreas habitacionais (as quais, normalmente, resultam de ocupações irregulares). Outrossim, serviços industriais e galpões logísticos são encontrados, bem como pequenos vendedores autônomos.

A pesquisa de A. C. Gurgel (2015), que oferece uma análise comparativa entre os distritos industriais cariocas afirma o Distrito Industrial de Queimados como o $4^{\circ}$ no ranking do Estado do Rio de Janeiro, entre dez analisados. Além disso, é importante destacar que "[...] o distrito possui uma associação, a Associação das Empresas do Distrito Industrial de Queimados (ASDINQ), que trabalha em prol do distrito contribuindo significativamente para uma melhor pontuação" (GURGEL, 2015, p.84), evidenciando a existência de um sistema de gestão como importante fator na organização destas áreas industriais, atualmente.

Para melhor caracterizar este distrito, a Foto 11 mostra a fábrica da empresa Weber Saint-Gobain e a Foto 12 mostra a avenida central. A relação das empresas instaladas pode ser visualizada em um painel na entrada da área, como mostra a Foto 13, onde existe também um outdoor anunciando o aluguel de galpões modulares em um condomínio empresarial que coexiste com o distrito industrial (Foto 14). 


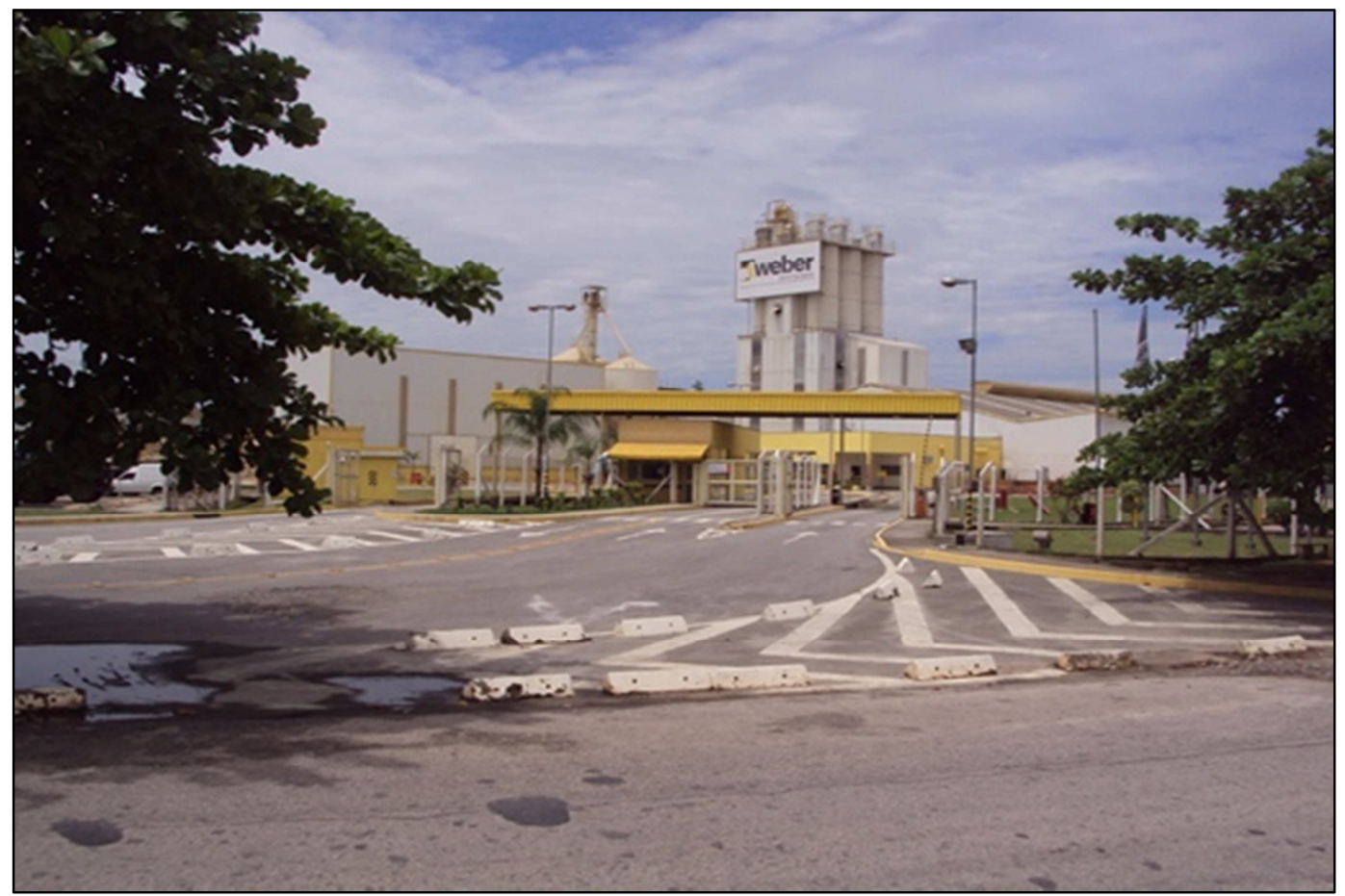

FOTO 11 - Parte da avenida central do Distrito Industrial de Queimados, onde se verifica, no segundo plano, a fábrica da empresa Weber Saint Gobain (construção civil). Fonte: Rodolfo Finatti, trabalho de campo, 2015.

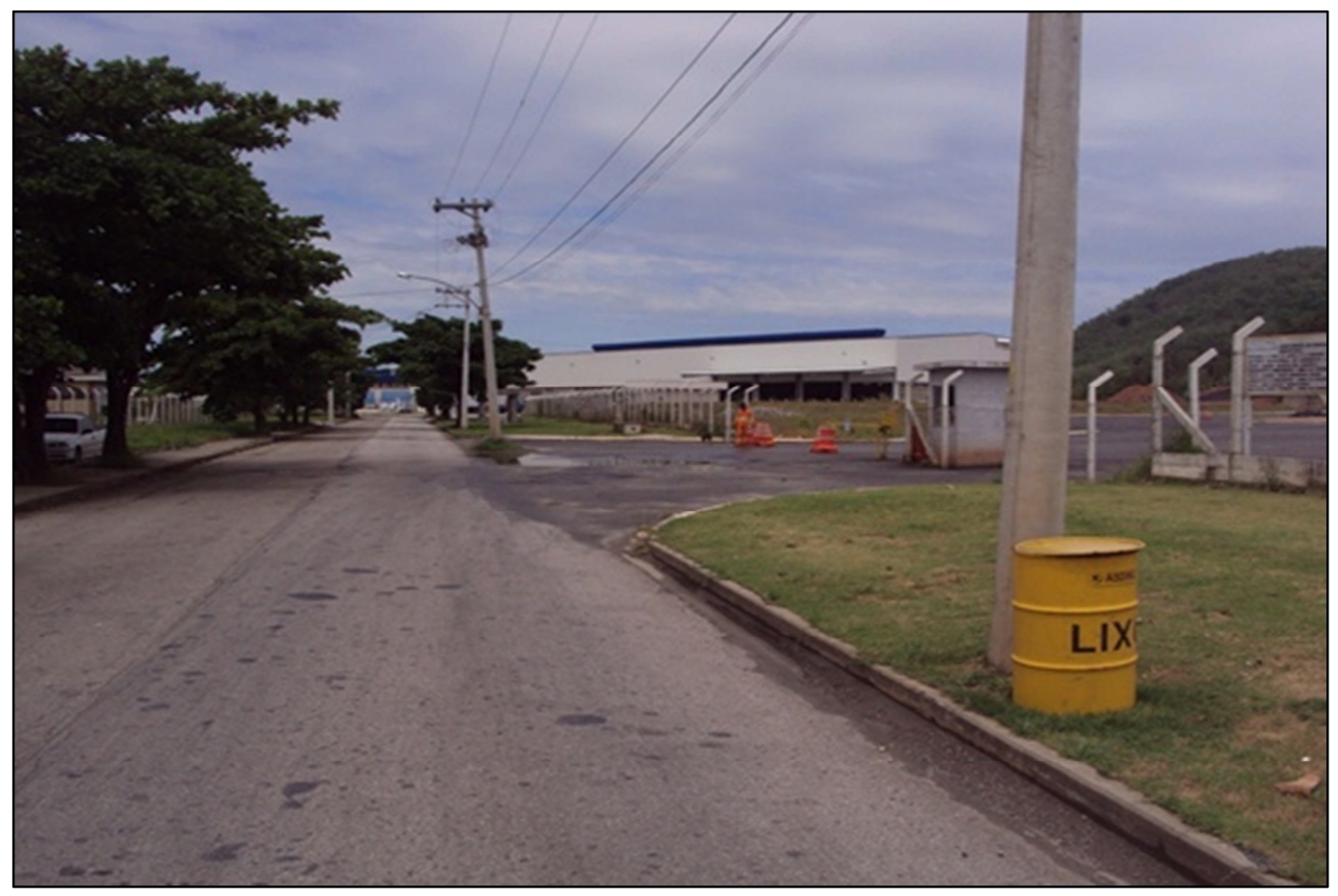

FOTO 12 - Avenida central do Distrito Industrial de Queimados, ilustrando a boa pavimentação asfáltica, existência de coleta de lixo e cuidados paisagísticos. No segundo plano, à esquerda, se verifica o condomínio de galpões modulares. Fonte: Rodolfo Finatti, trabalho de campo, 2015. 


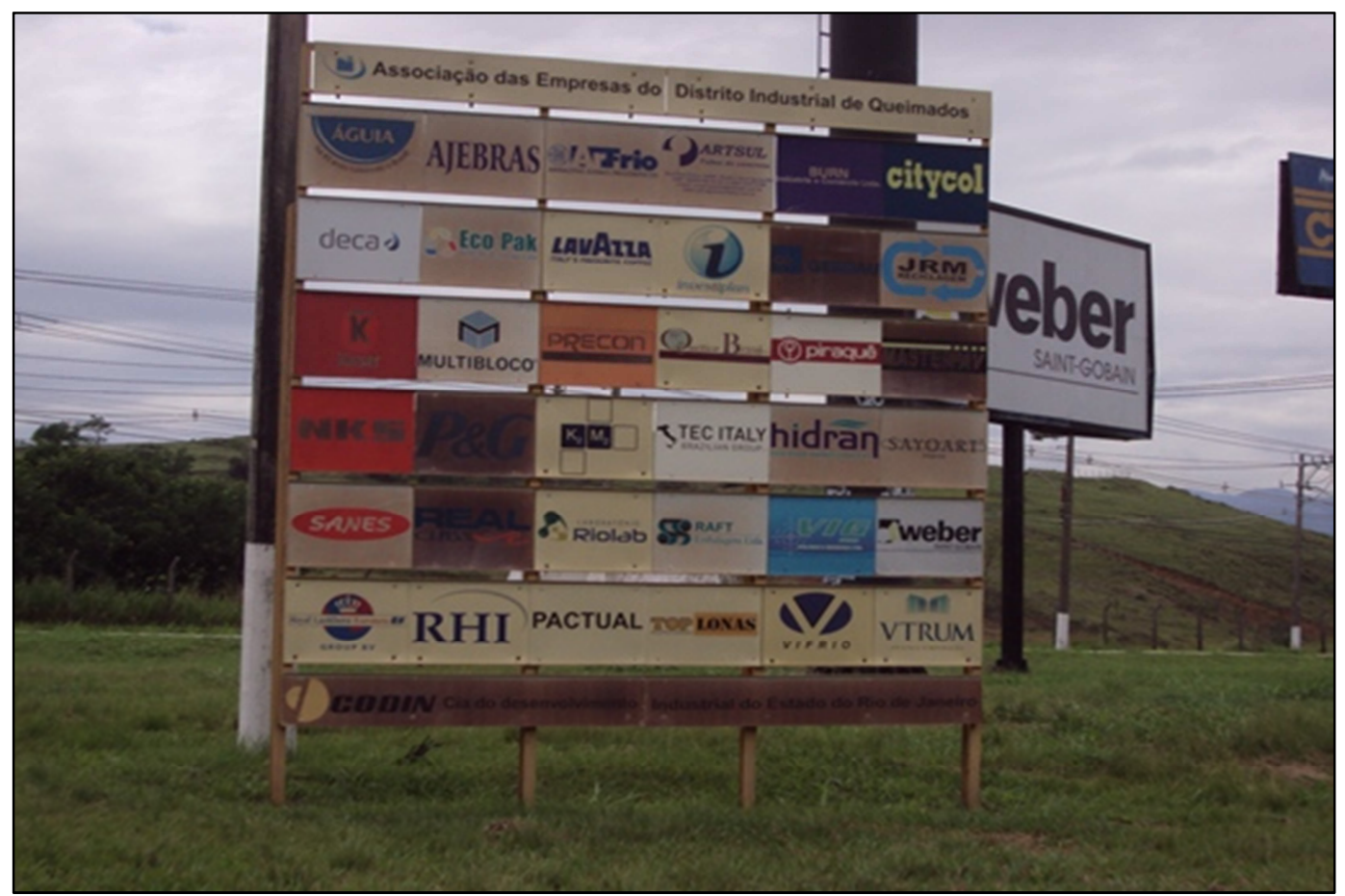

FOTO 13 - Painel das empresas instaladas no Distrito Industrial de Queimados, posicionada na rodovia de acesso à área. Fonte: Rodolfo Finatti, trabalho de campo, 2015.

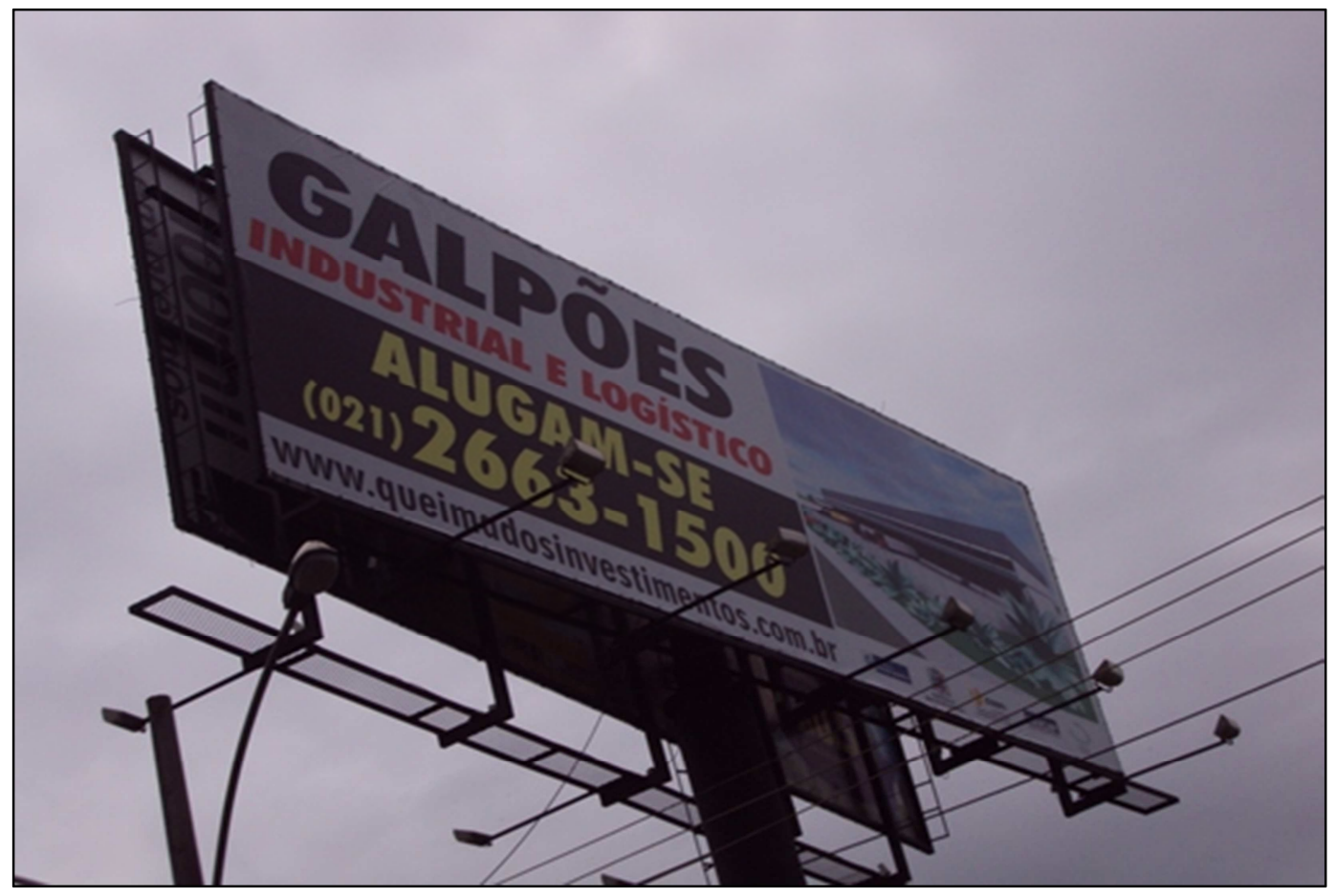

FOTO 14 - Anúncio (outdoor) de galpões disponíveis para aluguel no condomínio empresarial localizado no Distrito Industrial de Queimados. Fonte: Rodolfo Finatti, trabalho de campo, 2015. 
O Polo Industrial de Manaus pode ser considerado uma das áreas mais importantes para nossa pesquisa, pela especificidade que apresenta, no conjunto do território nacional. Datada de 1967 (quando começam os incentivos fiscais que a caracterizam enquanto zona franca) a área é, possivelmente, a maior aglomeração industrial do país (considerando o conjunto de aglomerações industriais cujo processo é planejado) tanto em extensão territorial, quanto em número de empresas instaladas.

Como processo histórico, o conjunto de incentivos fiscais expressivos voltados exclusivamente à zona franca permitiram a transferência de importantes indústrias para a Região Norte. Talvez possa essa iniciativa possa ser considerada a mais bem sucedida ação para crescimento econômico regional empreendido pelo governo federal, devido às difíceis condições de acesso e à distância de Manaus em relação ao resto do país, fatores superados apenas com a oferta agressiva de incentivos e isenções.

O modelo da Zona Franca de Manaus se expressa fisicamente por meio de um distrito industrial, com todas as características clássicas que observamos nos demais estudos de caso. O maior diferencial seja, talvez, um histórico e atuante sistema de gestão, a Superintendência da Zona Franca de Manaus (SUFRAMA), diferentemente das demais áreas nas quais verificamos dificuldades em fomentar um sistema de gestão, mesmo que simples. A SUFRAMA, todavia, já nasce instituída junto com a zona franca.

De acordo com informações desta entidade, atualmente o polo alberga cerca de 600 empresas, as quais são responsáveis pela geração de 500 mil empregos diretos e indiretos. L. Trevisan (2012), indica, em relação ao número de indústrias, a existência de 410 estabelecimentos e 98,4 mil empregos (efetivos + temporários) no ano de 2006.

Nosso trabalho de campo ao distrito, ou Polo Industrial de Manaus ${ }^{117}$, ocorreu em fevereiro de 2016, ocasião na qual percorremos as principais vias do distrito. Fomos recebidos na SUFRAMA ${ }^{118}$ e na Federação das Indústrias do Amazonas (FIEAM) ${ }^{119}$. As impressões mais imediatas da paisagem foram a grande extensão e número de empresas participantes da zona franca.

Destaque-se a extrema diversidade dos usos do solo existentes no distrito. Especificamente no polo industrial, são diferentes usos do solo formalizados, além das

\footnotetext{
${ }^{117}$ Vale lembrar que a SUFRAMA divide a zona franca em três polos: comercial, industrial e agropecuário.

118 Visita realizada no dia 26 de fevereiro de 2016, ocasião em que fomos recebidos pelo Gerente do Departamento de Desenvolvimento Regional, V. C. Lopes.

${ }^{119}$ Entrevista realizada com o vice-presidente desta instituição, Dr. S. Melo, no dia 24 de fevereiro de 2016.
} 
áreas comerciais, industriais e de serviços. Há dois bairros residenciais e um condomínio fechado, dois hotéis de médio porte, postos de gasolina, dois consulados, um supermercado, escola técnica, universidade, shopping center, um hospital e também uma igreja. As condições da infraestrutura são contraditórias dentro da mesma área: em algumas partes um ótimo estado de conservação, em outras o oposto.

Para o vice-presidente da FIEAM ${ }^{120}$, a Zona Franca de Manaus representa a sustentação econômica de Manaus e de boa parte da Amazônia. Como empresário industrial, assevera que ainda é menos oneroso a operação de uma fábrica em Manaus (em relação à região Sudeste), comparando os custos reduzidos a partir das isenções fiscais. Todavia, argumenta que enquanto as vantagens chegavam a $40 \%$ de economia no auge da zona franca, atualmente esta taxa caiu para $23 \%$. Como vice-presidente, destacou que muitas unidades industriais estão saindo da Zona Franca de Manaus e criticou o lobby (que já estende há alguns anos) para que a zona franca não tenha mais a oferta de tantos incentivos fiscais. Uma vez retirado seu principal diferencial competitivo, acredita que o modelo poderá sucumbir.

Em termos do projeto de desenvolvimento regional ao qual este distrito se vincula, consideramos que teve como resultado a modernização de um ponto específico do território nacional que cumpriu o papel, em certa medida, de contrabalancear as desigualdades regionais. Na visão de L. Trevisan:

Podemos considerar que a Zona Franca de Manaus se constitui como um importante elemento da reorganização produtiva do território brasileiro (transição da base agrário-exportadora para uma base urbano-industrial), bem como uma resposta com vistas a anular ou atenuar os efeitos negativos de uma organização produtiva pretérita na região amazônica (declínio da economia da borracha) (TREVISAN, 2012, p. 71).

Um conjunto de fotografias ajuda a caracterizar este distrito industrial. As Fotos 15 e 16 mostram as condições da avenida central do distrito e a via de acesso à mesma, em uma das entradas da área. As Fotos 17 e 18 ilustram importantes empresas presente na área, a Adukargo (logística) e a LG (eletrônicos). A Foto 19 ilustra um dos conjuntos residenciais existentes na área e, por fim, a Foto 20 mostra a entrada no distrito industrial pelo terminal portuário, em Manaus.

\footnotetext{
${ }^{120}$ Dr. S. Melo, cuja entrevista realizou-se no dia 24 de fevereiro de 2016.
} 


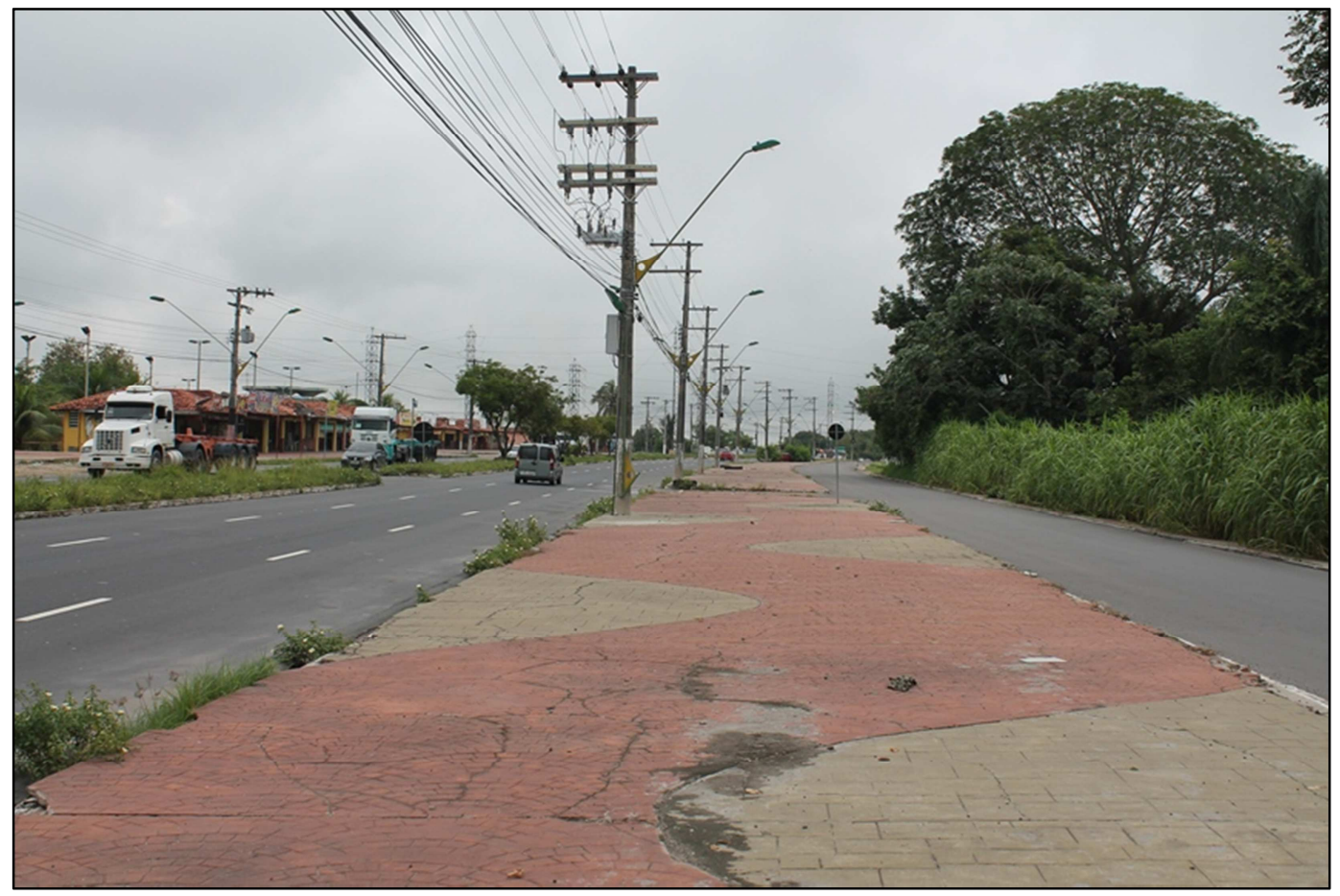

FOTO 15 - Avenida central do Polo Industrial de Manaus, na qual se verifica boas condições de asfaltamento e iluminação pública. No segundo plano, à esquerda, se verifica um conjunto de pequenos estabelecimentos comerciais (restaurantes, lanchonetes e bares). Fonte: Rodolfo Finatti, trabalho de campo, 2016.

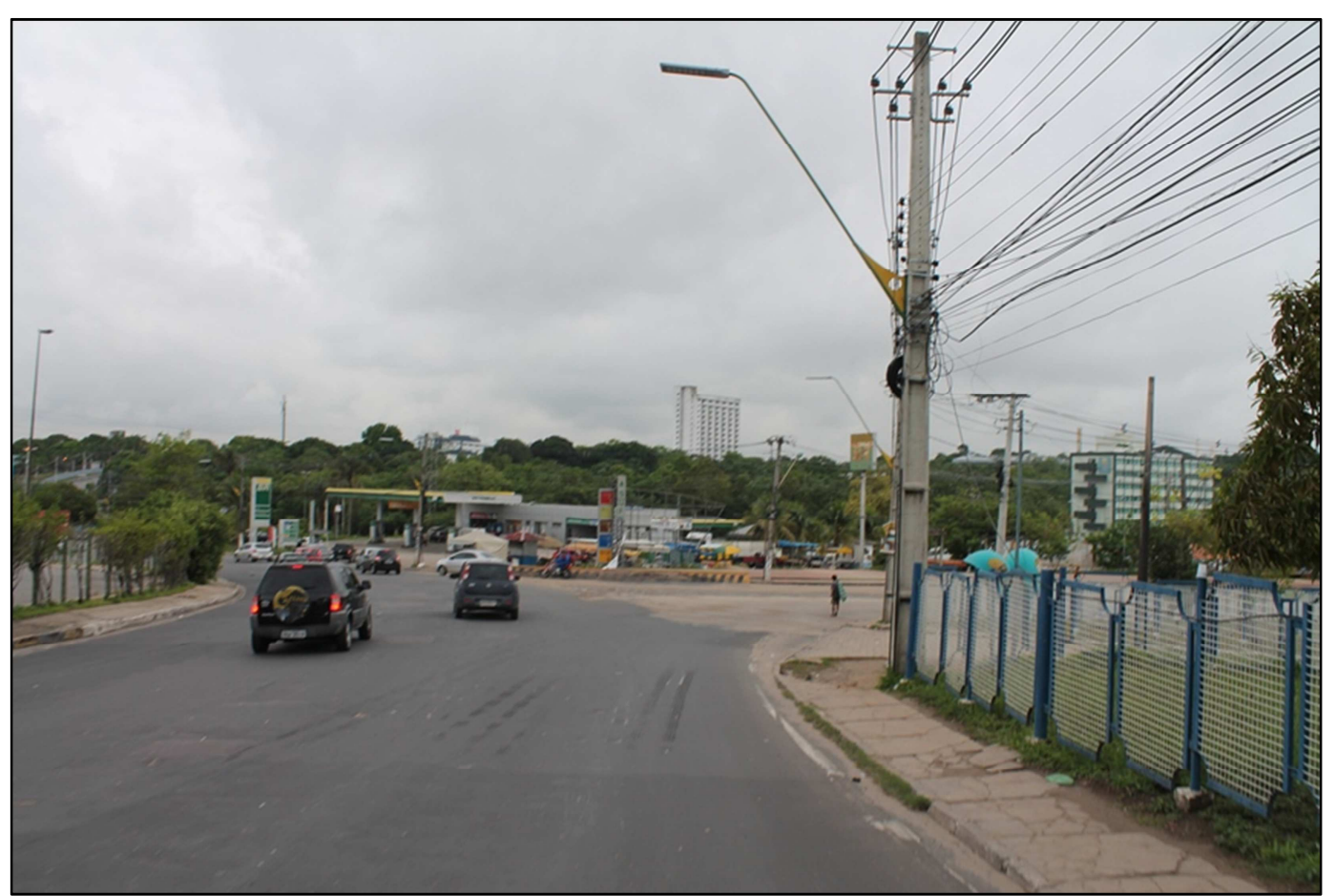

FOTO 16 - Entrada do Polo Industrial de Manaus, onde se verifica, em segundo plano, um posto de gasolina (à esquerda) e o edifício de um hotel (à direita). Fonte: Rodolfo Finatti, trabalho de campo, 2016. 


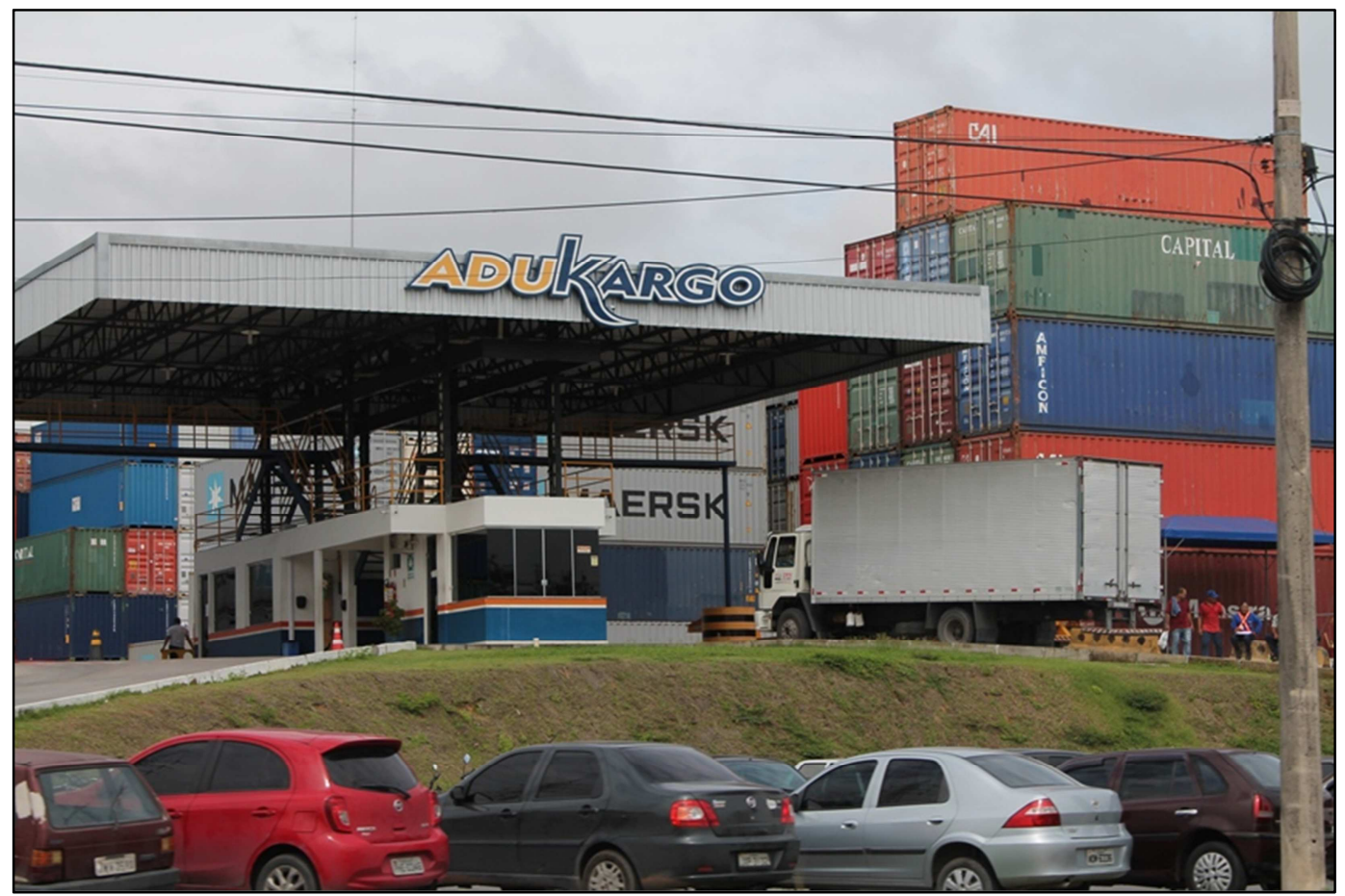

FOTO 17 - Terminal de operações da empresa Adukargo (logística) no Polo Industrial de Manaus. Fonte: Rodolfo Finatti, trabalho de campo, 2016.

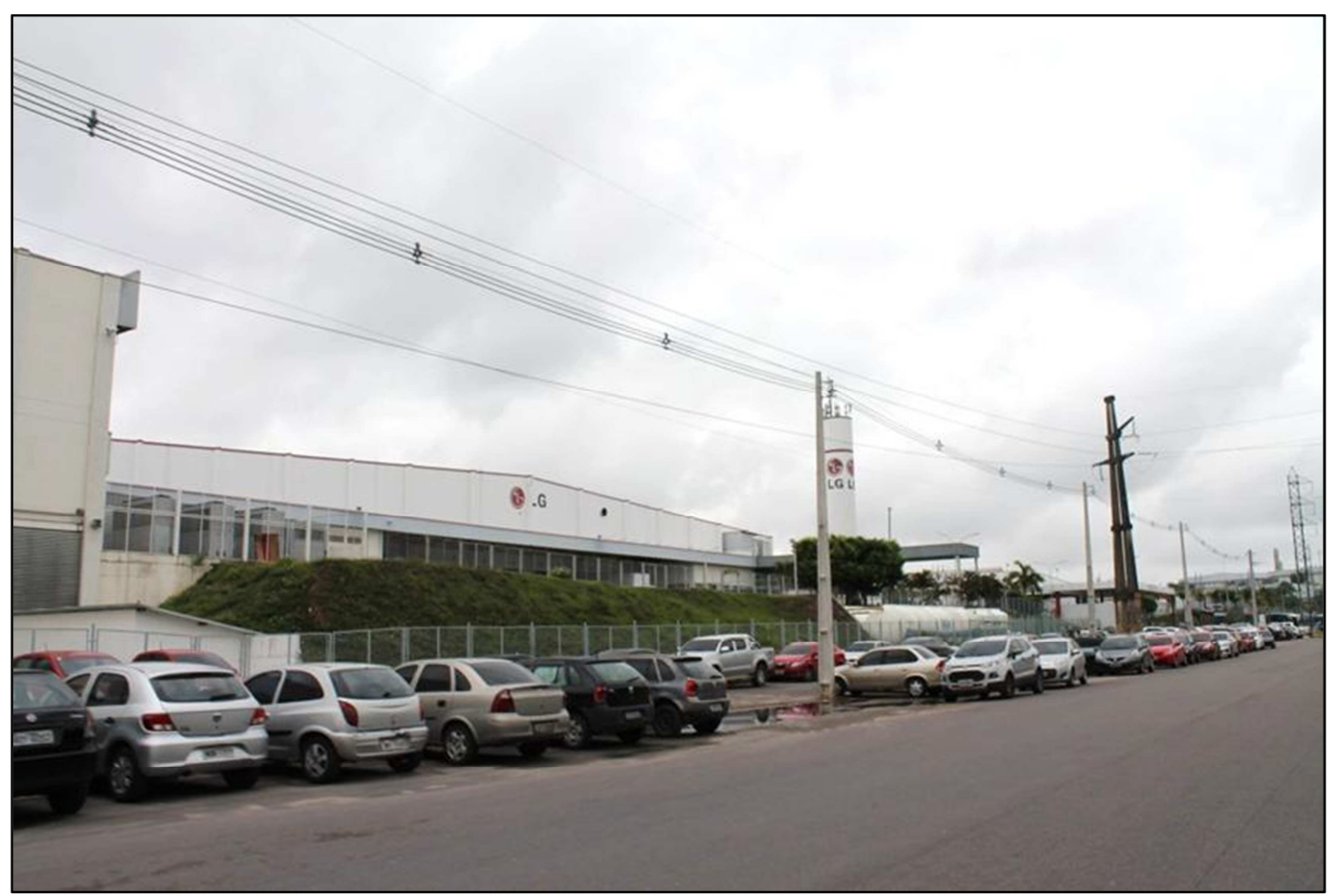

FOTO 18 - Fábrica da empresa LG (eletrônicos) no Polo Industrial de Manaus. Fonte: Rodolfo Finatti, trabalho de campo, 2016. 


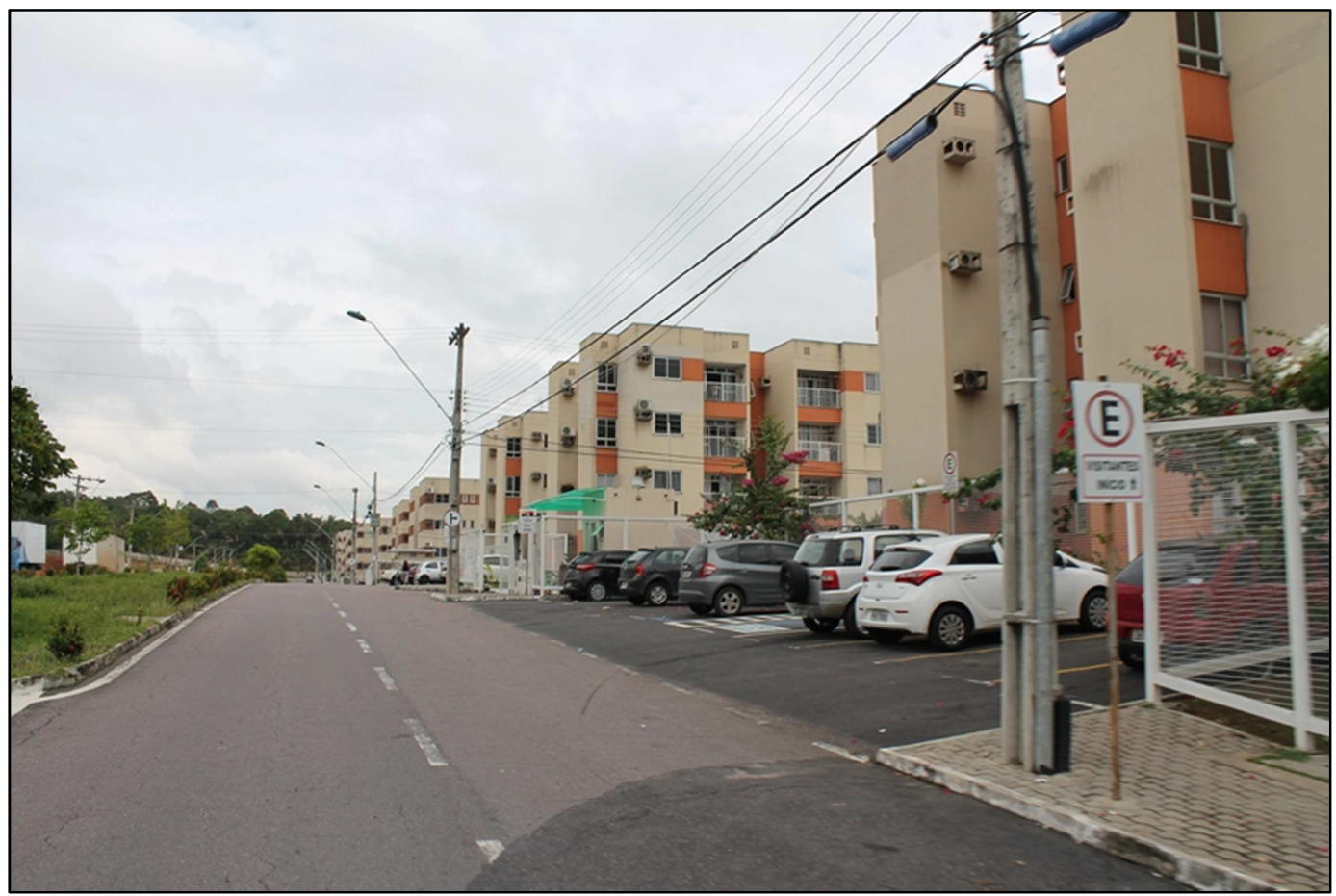

FOT0 19 - Via de acesso a edifícios de área residencial no Polo Industrial de Manaus, onde se verifica boa pavimentação asfáltica, sinalização e cuidados paisagísticos. À direita, se verifica os conjuntos de edifícios e estacionamento destinado aos moradores. Fonte: Rodolfo Finatti, trabalho de campo, 2016.

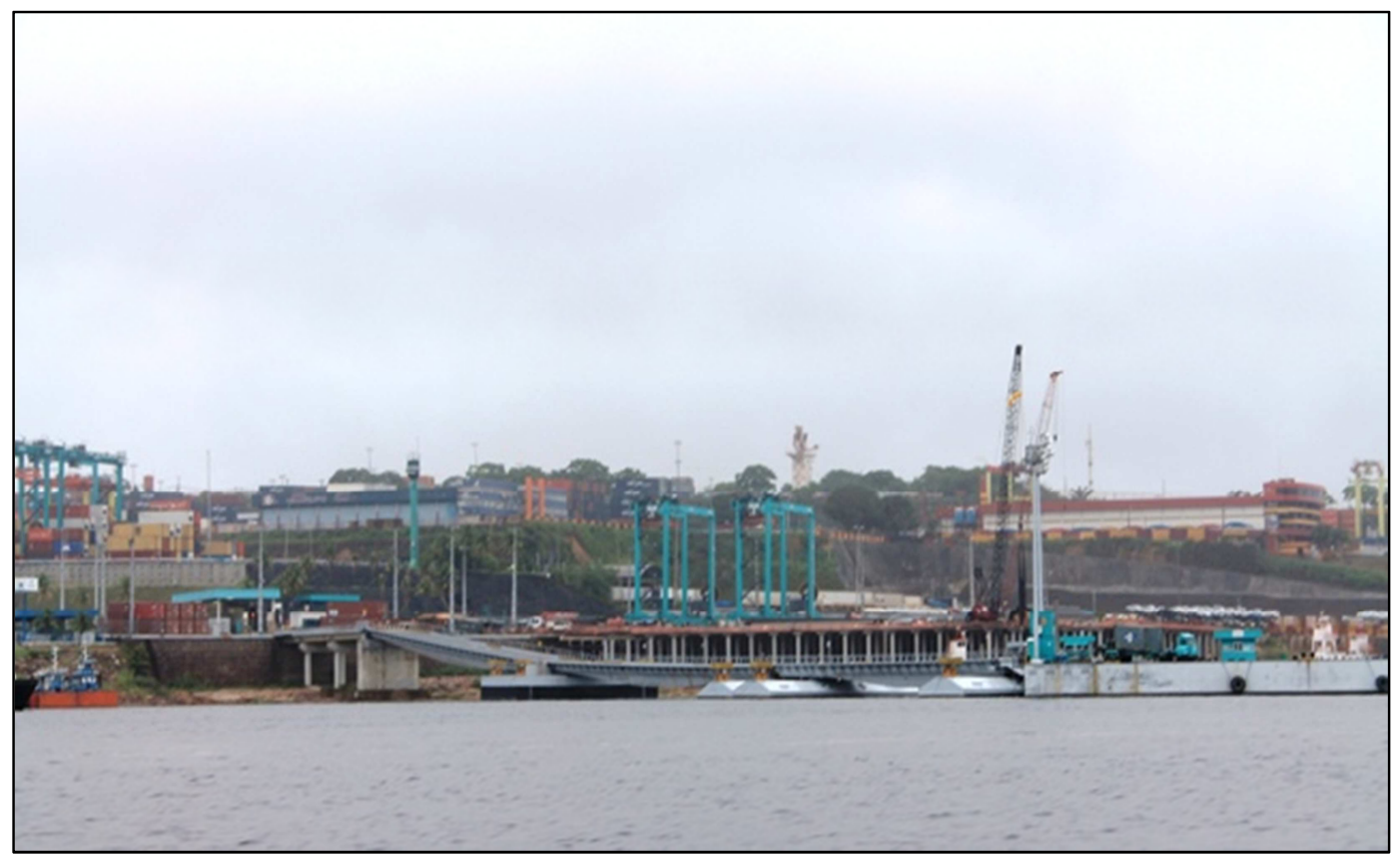

FOTO 20 - Terminal portuário do Polo Industrial de Manaus, onde se verifica, em primeiro plano, o Rio Negro e a rampa de acesso ao distrito industrial. Fonte: Rodolfo Finatti, trabalho de campo, 2016. 
A mais frequente reclamação, por parte do poder público e por parte dos representantes dos empresários industriais, é a ausência de administração dos distritos industriais. Por consequência, a infraestrutura antiga e eventualmente degradada tem dificultado a atração de empresas e compromete a permanência das antigas. Este contexto está ligado às transformações no uso do solo nos distritos industriais, que já destacamos e será nosso ponto de partida.

Segundo a opinião do Secretário de Comércio do Rio Grande do Norte ${ }^{121}$, destaca que, desde a década de 1990, as prefeituras municipais começaram a ter a ideia de que distritos industriais atrairiam empresas e gerariam empregos, porém em um processo aleatório e sem uma política de planejamento adequada.

A ingerência nos distritos industriais ${ }^{122}$ foi constatada, sobretudo, na dimensão das infraestruturas necessárias ao funcionamento, segurança e atratividade da área para outras empresas. Em termos práticos: a falta de iluminação pública e transporte coletivo faz com que seja uma área insegura; a falta de policiamento, da mesma forma, contribui com a insegurança; a deficiência da pavimentação resulta em maior desgaste dos veículos e amplia o tempo de deslocamento; a falta de paisagismo remete, simbolicamente, a um empreendimento mal administrado.

A perspectiva da ingerência foi, particularmente, comentada e aprofundada pelos analistas da Federação das Indústrias da Bahia $(\mathrm{FIEB})^{123}$. Os dois profissionais estavam, no período da entrevista, realizando um levantamento detalhado para o mapeamento e o diagnóstico da situação atual de todos os distritos industriais do Estado da Bahia. Embora o estudo ainda não estivesse concluído, foram bastante enfáticos na observação do problema central da falta de administração dos distritos industriais como um problema estrutural. Por um lado, o governo do estado não pode arcar com a administração e o provimento da infraestrutura básica, que obrigatoriamente fica ao encargo da prefeitura

\footnotetext{
${ }^{121}$ O. L. C. Júnior, em entrevista realizada no dia 21 de março de 2014.

${ }^{122}$ A partir de nossas entrevistas foi possível identificar certo padrão nas respostas que, apontando para a mesma direção, facilitam uma crítica à organização atual dos distritos industriais.

${ }^{123}$ M. E. Verhine (gerente) e C. P. Almeida (analista), nossos entrevistados, estão desenvolvendo um projeto para o mapeamento e diagnóstico atual dos distritos industriais da Bahia, conforme constatamos em entrevista realizada no dia 27 de junho de 2014.
} 
municipal ${ }^{124}$. Por outro lado, as prefeituras municipais parecem negligenciar as demandas das áreas industriais ou tampouco dispõem de verba para isso e, na terceira vertente, quando questionados sobre uma possível organização dos próprios empresários industriais para a formação de um comitê gestor, os analistas da FIEB sinalizaram ser essa uma estratégia que não funcionaria devido ao desinteresse dos próprios: uma vez que acreditam ser encargo do poder público administrar e manter estas áreas, relutam ao se envolver com a questão.

$\mathrm{Na}$ visão de um dos diretores da Federação das Indústrias do Estado do Rio Grande do Norte ${ }^{125}$, sempre existiu uma fragilidade no que diz respeito aos critérios de planejamento dos distritos industriais, no sentido de que não são analisados os critérios e necessidades das indústrias que irão operar em uma determinada localização. Sequer as indústrias de um município são consultadas no tocante aos critérios de localização ou demais serviços e infraestruturas que deverão compor a área. Queremos dar destaque para esta visão porque foram nítidas as críticas às ações dos poderes públicos municipais, não apenas no sentido da falta de administração, mas também no tocante à abertura de zonas industriais com critérios inadequados. Além disso, é importante dizer que foi ponto convergente entre nossos entrevistados ${ }^{126}$ que o interesse político partidário quanto à abertura de novas zonas industriais por parte do poder público municipal, se sobrepõem aos interesses econômicos.

Apenas para reforçar esta situação, o presidente da Companhia de Desenvolvimento do Ceará (CODECE) ${ }^{127}$ usou a ilustração de que existe uma "fila enorme de prefeitos na porta da Secretaria de Desenvolvimento Econômico", todos eles buscando apoio para os seus distritos. Por conta desta alta procura e a pressa em sua execução, as áreas acabam sendo inauguradas sem um estudo de viabilidade adequado, pois a prerrogativa é da prefeitura municipal nesta decisão. O poder público municipal, no entanto, não realiza suas ações com a maior racionalidade possível. O conselho da CODECE para os prefeitos é que os distritos sejam feitos de forma planejada, ou seja, com

\footnotetext{
${ }^{124}$ Esta informação foi confirmada pelo diretor de desenvolvimento econômico e relações internacionais da Secretaria de Indústria, Comércio e Mineração do Estado da Bahia (SICM), R. Vieira, em entrevista realizada no dia 27 de junho de 2014.

${ }^{125}$ M. Formiga, diretor da Federação das Indústrias do Rio Grande do Norte (FIERN) e ex-prefeito de Natal (RN) em duas ocasiões. Foi entrevistado no dia 25 de março de 2014.

${ }^{126}$ Essa constatação é compartilhada principalmente P. Jorge e G. Muchale, economistas da Federação das Indústrias do Estado do Ceará (FIEC), assim como A. C. Gurgel, diretor da Companhia de Desenvolvimento Industrial do Rio de Janeiro (CODIN) e Assessor de Projetos Especiais da Federação das Indústrias do Estado do Rio de Janeiro (FIRJAN).

${ }^{127}$ Entrevista realizada com o Presidente da Companhia de Desenvolvimento do Ceará (CODECE), R. C. Feijó, no dia 03 de abril de 2014.
} 
consulta anterior aos órgãos de planejamento para avaliar se área é adequada. Atualmente, o que ocorre é apenas a definição de uma área na lei de zoneamento do município, posteriormente nomeada "distrito industrial".

Em linhas gerais, com exceção do Estado da Bahia no qual não conseguimos obter uma resposta precisa sobre a atuação das prefeituras municipais, todas as demais unidades da federação reconhecem a existência deste tipo de prática. É importante afirmar que não estamos analisando os resultados positivos ou negativos dos distritos industriais municipais, apenas observando uma falha em seu planejamento, desde a ingerência das áreas existentes até a abertura de novas zonas industriais sem as preocupações e critérios adequados para isso.

Por isso, embora destaquemos que seja essa uma aglomeração industrial em cujo processo há planejamento, existe uma falha atualmente que inviabiliza alguns distritos de cumprirem os seus propósitos com eficiência. Além disso, reforçam-se situações contraditórias já que a implantação de um distrito industrial representa gasto público para, no mínimo, propor uma organização industrial ao nível municipal.

É evidente que o planejamento da área deve ser feito em função das indústrias, como requerem os empresários e seus representantes, todavia deve-se agregar uma preocupação urbanística, com a cidade e com o conjunto de relações que este espaço estabelece com a cidade.

Outra situação que deve ser destacada é a mudança no uso do território. Isso reflete o uso do território atualmente e as transformações necessárias para adaptá-lo às condições contemporâneas. O conjunto de referências bibliográficas indicou, sobretudo, uma área dedicada ao uso industrial, com poucas referências aos demais usos possíveis. Todavia, verificamos a existência de distritos industriais, em sua maioria, com múltiplos usos, regulares ou irregulares.

As transformações no uso do território foi um aspecto mencionado com ênfase e objeto de preocupação, principalmente, de nossos interlocutores no Estado de Minas Gerais, por parte da Companhia de Desenvolvimento Industrial de Minas Gerais ${ }^{128}$ e também da Federação das Indústrias do Estado de Minas Gerais ${ }^{129}$. Foi mencionado

\footnotetext{
${ }^{128}$ Entrevista realizada com D. T. Filho, diretor da Companhia de Desenvolvimento Econômico de Minas Gerais (CODEMIG), no dia 16 de março de 2015.

${ }^{129}$ Entrevista realizada com R. L. de Souza, analista da Federação das Indústrias de Minas Gerais (FIEMG) no dia 17 de março de 2015.
} 
também como um processo pelo qual passa o Distrito Industrial de Fortaleza ${ }^{130}$ e verificado, in situ, no Distrito Industrial Abreu e Lima (PE), Distrito Industrial de Campinas (SP), Cidade Industrial de Curitiba (PR) e Distrito Industrial de Cachoeirinha (RS).

Para explicar este processo é preciso lembrar que alguns dos mais antigos distritos se encontram em áreas que hoje são centrais em relação à época de sua implantação. Isso permite a valorização no preço do solo urbano e faz com que tais áreas sejam objeto de implantação de outros equipamentos urbanos. Além disso, a transição nos usos do solo pode se fazer necessária quando alguns distritos industriais, na época de sua implantação, estavam relativamente distantes dos centros urbanos, porém estes atualmente se encontram conurbados devido ao crescimento e ocupação da cidade e do próprio distrito industrial, passando a representar deseconomias de aglomeração que, por si só, motivam relocalizações.

Durante nossos trabalhos de campo verificamos, nestes distritos industriais mais antigos e consolidados, a existência de restaurantes, escolas, hospitais, supermercados, revendedoras de automóveis, centros de convenções, conjuntos habitacionais, ocupações habitacionais irregulares, universidades, igrejas, shopping centers, etc. Entre estas formas não industriais de ocupação, inclusive destaque-se a implantação de condomínios de galpões modulares ${ }^{131}$ por inversão direta de promotores imobiliários. Valeria mencionar ainda o projeto da Prefeitura Municipal de Maracanaú (CE) em transferir sua sede para o Distrito Industrial de Fortaleza.

Apesar de um cenário aparentemente estagnado por se tratar de áreas já antigas (estagnadas) no senso comum, existe dinamismo nestas áreas, tanto do ponto de vista das transformações do território, quanto de algumas iniciativas que visam o planejamento de renovações. É justamente esta dinâmica em curso que faz com que os organismos se preocupem em readequar os distritos industriais a uma nova realidade, tanto os que já estão consolidados, quanto as novas áreas em processo de implantação.

Considerando esta realidade, o planejamento do uso do solo se reflete em várias diretrizes que devem ser consideradas para a resolução de problemas atuais dos

\footnotetext{
${ }^{130}$ Dinâmica apontada durante a entrevista com F. Noronha, coordenadora executiva da Associação das Empresas dos Distritos Industriais do Estado do Ceará (AEDI), em entrevista realizada no dia 02 de abril de 2014.

${ }^{131}$ Verificamos condomínios de galpões modulares implantados, ou em implantação, na Cidade Industrial de Contagem (MG), Distrito Industrial Abreu e Lima (PE), Distrito Industrial de Queimados (RJ), Cidade Industrial de Curitiba (PR).
} 
distritos industriais, de acordo com as conclusões apresentadas no $1^{\circ}$ Workshop "Distritos Industriais em Minas Gerais" ${ }^{132}$, quais sejam:

- Conflitos com ocupações residenciais irregulares;

- Conservação e manejo de áreas verdes;

- Estabelecimento de condicionantes para novas indústrias;

- Gestão dos processos de especulação imobiliária;

- Gestão ambiental.

Neste contexto de mudanças, duas preocupações são ainda importantes: (1) que o distrito industrial deixe de ser considerado tão somente um instrumento para captação de empresas, passando a ser considerando como um elemento estruturador do espaço urbano e, assim, planejado de maneira integrada com a cidade e (2) que os dirigentes públicos tenham cuidado com a "sedução" da lógica imobiliária, que atualmente está se inserindo neste tipo de aglomeração industrial como uma possibilidade de "resolver todos os problemas de uma só vez". Na condição de empreendimento imobiliário reforçam-se algumas contradições inerentes aos espaços fechados e controlados em relação ao espaço urbano na condição de social e coletivo (FINATTI e SPOSITO, 2010).

\section{Propostas de renovação dos distritos industriais}

Pudemos identificar duas linhas de transição relacionadas aos distritos industriais brasileiros, mencionadas durante as descrições pontuais das áreas visitadas e também durante as críticas. Estas duas linhas podem ser sintetizadas como a mudança no uso do território, de industrial para um uso misto, em que devemos dar destaque para a implantação de condomínios empresariais (principalmente condomínios de galpões modulares) no interior dos mesmas, e quanto aos novos modelos de organização e gestão destas áreas, sem que alguma proposta esteja efetivamente vigente.

Cabe destacar o caso em implantação no Ceará, dos "distritos empreendedores" ou uma reedição da proposta dos "mini-distritos industriais", conforme identificamos a partir de nossa entrevista na Companhia de Desenvolvimento do Ceará (CODECE) ${ }^{133}$.

\footnotetext{
${ }^{132} \mathrm{O} 1^{\circ}$ Workshop "Distritos Industriais em Minas Gerais", do qual participamos, foi promovido pela FIEMG, CIEMG, SEBRAE-MG e Centro de Desenvolvimento e Planejamento Regional (CEDEPLAR), no dia 19 de outubro de 2015.

${ }^{133}$ Entrevista realizada com o Presidente da Companhia de Desenvolvimento do Ceará (CODECE), R. C. Feijó, no dia 03 de abril de 2014.
} 
Trata-se de uma forma mesclada de se tratar o empreendedorismo e desenvolvimento local por meio da forma clássica de distritos industriais. Esta proposta delimita uma maneira de aproveitamento das infraestruturas pertencentes ao governo do estado que estariam inoperantes. O projeto da CODECE encontra-se em fase piloto, com duas áreas destinadas ao projeto, em monitoramento. A primeira iniciativa já está em funcionamento no município de Crateús (CE), em um galpão de $1.600 \mathrm{~m}^{2}$, no qual existem sete unidades industriais.

A ideia central do projeto é a refuncionalização de infraestruturas ociosas da companhia para acolher empreendedores locais. Em geral, estas áreas são galpões ociosos que podem ser divididos para servir a pequenos empreendedores industriais. Neste escopo forma-se um mini-distrito industrial que pode ser implantado em um galpão. A definição do próprio governo cearense é a seguinte:

O programa vai fomentar distritos industriais no Interior, a partir de empreendimentos instalados em galpões pertencentes ao Estado. Os galpões, vinculados à estrutura da Companhia de Desenvolvimento do Ceará (Codece), podem ser transformados em mini-distritos, com apoio a projetos de micro e pequenas empresas (GOVERNO DO CEARÁ, 2013).

Para o presidente da CODECE, a perspectiva do projeto é justamente a possibilidade de fomentar o empreendedorismo local, fortalecendo as iniciativas de pessoas que conduziam o seu negócio em sua própria casa com poucas perspectivas de crescimento. Seu funcionamento se dá por meio do comodato oneroso, ou seja, os novos industriais não pagam pelo uso do espaço, apenas são responsáveis por uma taxa de manutenção e monitoramento.

Um segundo estudo de caso que consideramos diz respeito ao Polo Industrial Avançado de Goianinha, localizado no município de Goianinha (RN), com aproximadamente 100 hectares de extensão total. As informações sobre esse distrito industrial são decorrentes da entrevista realizada com o Secretário de Planejamento Econômico ${ }^{134}$ do município.

Segundo o secretário, a iniciativa de montar o distrito industrial partiu da vontade de mudança no perfil municipal, a partir da atração de indústrias de maior porte em relação ao perfil substancialmente comercial de Goianinha (RN). A partir da análise do projeto foi possível identificar que suas características apresentam alguns diferenciais em

\footnotetext{
${ }^{134}$ Entrevista realizada T. Thomaz, Secretário de Planejamento Econômico do município de Goianinha (RN), no dia 11 de abril de 2014.
} 
relação aos distritos industriais "tradicionais" no Brasil, daí o interesse por este estudo de caso.

O Polo Industrial Avançado de Goianinha apresenta infraestruturas diferenciais em relação ao que comumente se observa em distritos industriais, tais como: servidor de internet próprio e transmissão por fibra ótica, conexão com gasodutos, posto policial localizado na praça central e serviços terceirizados como área de convivência, hotel e área de descanso para caminhoneiros. Segundo o secretário, no momento da entrevista, seis empresas já tinham fechado o acordo para operacionalizar sua instalação.

Em nossa avaliação, muito embora estejam projetados para este espaço alguns objetos técnicos modernos, e certamente isso mostra um diferencial na atitude e no discurso da produção das áreas industriais, ainda é um "distrito industrial" conforme a denominação que adotamos para os casos brasileiros. Novamente, em nada tem a ver com a variante italiana da formulação, mas é especificamente uma zona industrial assim definida no uso do solo municipal, porém nitidamente inspirada no modelo de condomínio empresarial, conforme foi declarado por nosso interlocutor.

Os objetos técnicos que pretendem incorporar ao espaço são um exemplo da preocupação com as diretrizes contemporâneas associadas à demanda das empresas e espaços industriais. Se, por um lado, apesar do título pomposo, ele é ainda uma zona industrial promovida pelo poder público municipal, por outro lado, existe uma preocupação com a configuração contemporânea dos espaços produtivos, em convergência, evidentemente, com o paradigma flexível da produção.

O caso de Goianinha evidencia a seguinte questão: o planejamento territorial é pouco fundamentado. Os problemas ambientais atrelados à área estão ocorrendo justamente pela falta de conhecimento de que o zoneamento estava sendo feito em uma Área de Proteção Ambiental (APA), cuja gestão é estadual. A própria localização desde distrito industrial, a se considerar o município de Goianinha, na área litorânea turística do Rio Grande do Norte, parece sinalizar a crença de que o distrito industrial, por si só, se responsabiliza pela atração de indústrias e desenvolvimento econômico.

Outras iniciativas seguem uma linha um pouco mais conceitual. Ressaltamos as ações da Agência de Desenvolvimento Econômico de Pernambuco (AD-DIPER) ${ }^{135}$, no papel de instituição criada há 9 anos exclusivamente para dinamizar os investimentos econômicos no estado. Com esta agência, inicia-se em Pernambuco uma tentativa de atrair

${ }^{135}$ Entrevista realizada com J. G. do Rego, Presidente da Agência de Desenvolvimento Econômico de Pernambuco (AD-Diper), no dia 10 de julho de 2014. 
os empresários e fomentar uma espécie de planejamento participativo para a implantação das novas áreas industriais. Para isso, o Estado de Pernambuco foi administrativamente divido em doze novas regiões, seguindo os ramos predominantes em cada região, o que permitiu criar grupos focais de acordo com as características e demandas para cada uma delas.

A iniciativa posterior da AD-Diper foi justamente "quebrar o conceito de: vamos fazer um distrito industrial”, nas palavras de seu próprio presidente. Nesse sentido, sua linha de atuação se opõe à dinâmica tradicional de inaugurar uma zona industrial e tentar atrair as indústrias, percorrendo o caminho contrário (primeiro atrair e instalar as fábricas para posteriormente projetar o distrito industrial). A razão para isso é que o loteamento (previamente definido) é visto como um limitador para as instalações posteriores, até porque não sabe exatamente o tamanho que a zona industrial irá assumir, tampouco as indústrias que efetivamente irão se direcionar para a área. Nessa estratégia, o distrito pode se desenvolver paulatinamente e os problemas são tratados na medida em que se faz necessário, o que diminui gastos públicos desnecessários em áreas que posteriormente ficam ociosas.

De certa forma, esta iniciativa mescla a ideia de aglomeração, tradicionalmente por meio dos distritos industriais, aos quais se tenta evoluir e consolidar de acordo com a noção de indústria motriz, ou de indústria-âncora no caso de Pernambuco, pois as demais indústrias atraídas para área são do mesmo segmento ou complementares ao circuito produtivo do qual participa esta indústria-âncora.

Uma primeira experiência em curso se deu no município de Vitória do Santo Antão (PE), a partir da instalação da Kraft Foods e da Sadia, ambas do segmento alimentício. O distrito industrial não está definido, pois se espera atrair demais indústrias e serviços do mesmo segmento ou de segmentos complementares e, assim, dinamizar a área industrial antes de defini-la, que poderá ou não assemelhar-se a um distrito industrial clássico ou tampouco não constituir-se em uma aglomeração industrial efetivamente.

Como evidência das iniciativas atuais e relacionadas aos distritos industriais, no Estado de Pernambuco, oito dos quinze distritos industriais deste estado foram abertos na última década, a partir da atuação da agência.

Por fim, podemos mencionar as iniciativas vigentes no Estado da Bahia como forma de unir esforços para diagnosticar os problemas dos distritos industriais e encontrar uma solução da qual participem tanto os organismos públicos quanto a iniciativa privada. Partiu da Federação das Indústrias do Estado da Bahia (FIEB) a necessidade de fazer este 
diagnóstico, do qual passou a participar também a Superintendência de Estudos Econômicos e Sociais (SEI) e também a Superintendência de Desenvolvimento Industrial e Comercial (SUDIC).

A importância desta iniciativa é a tomada de consciência de que o problema não é exclusivamente de um setor ou de um agente econômico ou, em outras palavras, que pode ser resolvido em parceria e de acordo com as necessidades reais e atuais. Também precisamos ressaltar o caráter de análise para este problema, na tentativa de superar as noções de senso comum e o desconhecimento que se tem sobre a situação dos distritos industriais atualmente.

Nosso entrevistado da SUDIC $^{136}$, há mais de 30 anos envolvido com a questão dos distritos industriais neste estado, acredita que o enrijecimento da ingerência dos distritos industriais não poderia mudar sem o apoio do poder público. Outrossim, aponta que o melhor caminho é que os principais distritos tenha um centro administrativo similar ao que ocorre no Centro Industrial do Subaé, em Feira de Santana (BA).

Muito embora, no dia de nossa visita à FIEB esta iniciativa estava ainda sendo elaborada, ela mostra a intenção e capacidade de organização e articulação dos agentes responsáveis pela produção do território. Além disso, mescla poder público, empresários industriais e um centro de produção de informações (inteligência científica) no processo de renovação das áreas industriais deste estado.

Finalmente, embora já mencionado, o Programa de Revitalização e Modernização dos Distritos Industriais, por parte do governo e empresários do Estado de Minas Gerais, nos permitiu extrair estudos de casos e aplicações possíveis. Este programa está atuando com a proposição de respostas aos problemas dos distritos industriais de Minas Gerais, caso a caso. Realiza-se um diagnóstico do distrito industrial e uma equipe de especialistas (técnicos e analistas industriais, administradores públicos e acadêmicos) propõe uma série de ações que poderão ajudar na recuperação destes distritos. Vale mencionar o objetivo global deste programa:

O Plano de Ação do Distrito Industrial tem como objetivo analisar quais são os atuais desafios para o distrito e propor ações de recuperação, modernização e/ou inovação para o espaço físico e para o conjunto de indústrias nele existente, visando à ampliação da competitividade industrial (FIEMG/CODEMIG, 2015, p.4).

${ }^{136}$ A. B. Matos é técnico da SUDIC e nos concedeu entrevista no dia 01 de julho de 2014. 
Existem, portanto, diversas iniciativas atualmente em curso, elas estão espalhadas por diferentes unidades da federação (Ceará, Rio Grande do Norte, Pernambuco, Bahia e Mina Gerais) e, mesmo com características e propostas diferentes, reforçam as transições (e necessidades de soluções a problemas atuais) que os distritos industriais estão atravessando atualmente.

\subsubsection{Influência e perenidade da indústria-motriz: polos industriais}

É importante ressaltar a diferença entre o uso vulgar do termo "polo", que pode referir-se a qualquer tipo de concentração com destaque regional, para as aglomerações que estiveram efetivamente inspiradas na ideia dos polos de desenvolvimento econômico. Embora existam outras refinarias no território nacional ${ }^{137}$, inclusive atreladas a áreas industriais importantes e consolidadas, como ocorre no Polo Industrial de Manaus (AM) e na Cidade Industrial de Curitiba (PR), escolhemos para realização do trabalho de campo três polos industriais petroquímicos que, efetivamente, podemos vincular ao momento de maior ênfase do planejamento territorial brasileiro em termos do uso desta noção enquanto ferramenta para ativar o desenvolvimento econômico e também regional.

Com base neste princípio, nossos trabalhos de campo se deram em Camaçari (em junho de 2014), Triunfo (maio de 2015) e Capuava (novembro de 2015). Em todas as ocasiões, estabelecemos contato com colaboradores em posições destacadas dentro da administração dos polos, conhecedores de sua história e dinâmica de funcionamento. Também coletamos materiais e pudemos conhecer parte das áreas onde operam as petroquímicas e as demais indústrias coligadas. Apresentam dinâmicas de funcionamento bastante similar, inclusive são refinarias coordenadas pelo mesmo grupo $\left(\right.$ Braskem $\left.^{138}\right)$.

\footnotetext{
${ }^{137}$ O número de polos industriais no Brasil é sensivelmente menor que o das demais formas de aglomeração estudadas, por isso visitamos apenas três destas aglomerações industriais, conforme destacaremos nesta seção.

${ }^{138}$ Empresa brasileira constituída em 2002. É controlada pela Odebrecht, com participação expressiva da Petrobrás. O grupo controla os três maiores polos petroquímicos no Brasil (Camaçari, Mauá e Triunfo), e se destaca pela produção de biopolímeros e resina termoplásticas.
} 
O primeiro e mais importante polo industrial visitado em trabalho de campo foi o Polo Industrial de Camaçari $^{139}$, pelas seguintes razões: em primeiro lugar, sua implantação no Nordeste vem ao encontro de nosso ímpeto em compreender o planejamento das áreas industriais de acordo com os princípios do planejamento territorial do governo nacional.

Não podemos analisar, de acordo com o escopo de nossa pesquisa, se a proposta logrou sucesso em termos de desenvolvimento regional de fato, porém na condição de área estimulada diretamente pelo Estado enquanto planejador e empresário, este polo tornou-se referência para os demais polos industriais brasileiros. Dessa forma, além das práticas gerenciais e organizacionais estabelecidas em Camaçari serem replicadas nos demais polos visitados, vale também dizer que as respostas fornecidas pelos entrevistados, entre os polos industriais, foram convergentes.

No que tange às estratégias e intencionalidade acerca da implantação do polo, alguns aspectos permitem avaliar o peso dos conteúdos locais na definição da área, em detrimento da visão mais convencional que afirma as iniciativas federais como únicas definidoras de sua localização.

Além disso, como também afirma A. Oliveira (2004) em sua tese de doutorado sobre o Polo de Camaçari, esta área representa um dos mais importantes capítulos da história da indústria petroquímica no Brasil devido ao seu ineditismo e ao que representou desconcentrar a produção do Sudeste, que até então estava centralizada no Polo de Cubatão $(\mathrm{SP})$ :

Pela primeira vez, o governo escolhia a região Nordeste para instalar um complexo industrial de envergadura depois de ter incentivado a instalação de tantos outros no Sudeste, a exemplo da indústria automobilística, siderúrgica, de bens de capital e metalúrgica (OLIVEIRA, 2014, p.56).

O primeiro marco da implantação do polo, que então se chamaria Complexo Petroquímico de Camaçari, é a Refinaria Landulpho Alves já em funcionamento na década de 1950. Também influenciou os critérios decisórios a posterior implantação, em 1967, no

\footnotetext{
${ }^{139}$ As informações seguintes resultam de nossa visita à área, realizada no dia 04 de julho de 2014 , na qual fomos recebidos por E. Oliveira - jornalista e pesquisador da história do Polo Petroquímico de Camaçari.
} 
Centro Industrial de Aratu ${ }^{140}$ como um distrito industrial nascente e primeiro do estado baiano.

Apesar destes importantes fixos geográficos de natureza puramente industrial, na década de 1970 começou a se registrar estagnação econômica no Estado da Bahia, o que influenciou a busca por alternativas de dinamização e fez com que o governo do estado, com apoio do conselho administrativo da Petrobrás, buscasse apoio no Governo Federal para a implantação do polo na Bahia:

Pelas características topológicas favoráveis, optou-se pela implantação do empreendimento no município de Camaçari. Surge o Complexo Petroquímico de Camaçari - COPEC, que iniciou suas operações em 1978 (PLANO DIRETOR - POLO INDUSTRIAL DE CAMAÇARI, 2013).

Uma conjunção favorável de influências políticas sustentadas por uma posição geográfica favorável para o polo resultou na escolha de Camaçari como o município sede, ao lado de uma refinaria em plena operação e um centro industrial em desenvolvimento, além da capital Salvador que à época contava com cerca de 1,2 milhão de pessoas residentes.

Até mesmo referenciando a política de implantação do polo a partir de sua visão mais clássica, podemos assinalar a interpretação seguinte:

O argumento político falava de desconcentração da atividade econômica, de promover o desenvolvimento de regiões mais pobres do País, de fomentar o surgimento de novos grupos empresariais, etc. Os militares, que estavam no poder, aliavam a esses argumentos um outro de natureza estratégica, dizendo que a existência de um único complexo petroquímico tornava o País vulnerável em caso de um conflito internacional (OLIVEIRA, 2014, p. 60).

Entretanto, na visão do pesquisador responsável do Polo de Camaçari ${ }^{141}$, esta articulação entre a refinaria, o Centro Industrial de Aratu e o complexo petroquímico então nascente foi, na realidade, pequena. Para ele, o governo federal foi "convencido" da opção por implantar o polo no Estado da Bahia, diferentemente da tradicional mentalidade que preconizava a descentralização produtiva. Para efetivar este convencimento, justificou-se Camaçari por meio de sua situação geográfica evidente: existência de matérias-primas,

\footnotetext{
${ }^{140} \mathrm{O}$ Centro Industrial de Aratu foi uma das primeiras experiências de planejamento organizado de áreas industrial no Brasil, devido à elaboração do Plano Diretor do Centro Industrial de Aratu no ano de 1967.

${ }^{141}$ E. de Oliveira, que nos recebeu para entrevista no dia 04 de julho de 2014.
} 
energia, água, etc. os quais, embora possam ser os argumentos mais tradicionais e evidentes no ponto de vista de uma teoria de localização, mostram as articulações realizadas por governo e empresários baianos e sua interlocução com o poder público federal.

Um aspecto diferencial do polo, ao menos até sua privatização na década de 1990, foi o modelo de administração com o controle estatal com, pelo menos $51 \%$ do capital acionário das empresas, em alguns casos chegando a 90\%. O modelo de funcionamento do polo, diferentemente dos distritos industriais, era baseado em três frentes: o Estado como principal investidor e redutor de riscos, detendo o controle da maioria das empresas, seguido por investidores diretos (empresários, bancos, construção civil) e empresas estrangeiras que foram incentivadas a vir para o Brasil trazendo a tecnologia e conhecimento necessário para os processos produtivos esperados.

Foi neste modelo - modelo tripartite - que se deu a consolidação do complexo petroquímico, passando por períodos de crescimento e estagnação até a data atual. Podemos ressaltar que a petroquímica firmou-se como ramo mais importante do estado baiano já na década de 1985, quando passou a responder por mais da metade do valor agregado da indústria de transformação (PLANO DIRETOR - POLO INDUSTRIAL DE CAMAÇARI, 2013).

Na década de 1990, a dinâmica de abertura do país ao comércio internacional e o início das privatizações tiveram reflexos diretos no polo petroquímico. A privatização foi praticamente consolidada no período de 1992-1996. O ápice da reestruturação de capitais foi a venda da central de matérias-primas (Copene) em 2001, adquirida pelo consórcio Odebrecht/Mariani, fazendo nascer a Braskem S.A., empresa que pode ser considerada como o "núcleo" do polo petroquímico e responsável pela consolidação da primeira e segunda geração de produtos petroquímicos. Na visão de nosso entrevistado ${ }^{142}$, a Braskem pode ser considerada como responsável direta por maior aporte tecnológico e alçar a produção a níveis mundiais.

Em termos de infraestrutura, nossa observação in situ permitiu perceber a extensa dimensão da área, uma qualidade muito boa de asfaltamento, indicação viária, iluminação pública e paisagismo. Os lotes e indústrias estão muito bem divididos e sinalizados e trata-se de uma área industrial com uma efetiva sede administrativa e representação das empresas, por meio do Comitê de Fomento Industrial do Polo de

\footnotetext{
${ }^{142}$ E. de Oliveira, que nos recebeu para entrevista no dia 04 de julho de 2014.
} 
Camaçari (COFICPOLO). Em termos paisagísticos, em um primeiro contato, a diferença em relação aos distritos industriais, mesmo os maiores e mais bem estruturados, é bastante nítida.

Quais são as especificidades que permitem afirmar a existência de um "polo" industrial? As características identificadas em Camaçari (BA), ligadas à teoria apresentada no Capítulo 1, ajudam a responder essa questão. Trata-se, justamente, do circuito produtivo estabelecido pelas empresas componentes do polo, que compartilham insumos e serviços, cuja localização e aglomeração se consolidam pela garantia no oferecimento de matéria prima. A partir de um ponto de vista técnico, detalhamos cada um dos pontos:

- Compartilhamento de matérias-primas e insumos: uma única central produtiva - a Braskem - fornece matérias-primas e demais insumos para toda a cadeia produtiva. No polo, portanto, há uma importante garantia da oferta de matérias-primas oriundas do petróleo e demais insumos como energia elétrica ${ }^{143}$, água e vapor, de maneira centralizada e cuja distribuição é racional, otimizada e compartilhada.

Esta noção de compartilhamento é importante, pois faz com que todas as empresas do polo, do circuito petroquímico, estejam ligadas entre si por meio de uma dutovia para o transporte de água ${ }^{144}$ e vapor. Esta ligação é um importante fator que sinaliza o encadeamento das empresas, faz com que exista uma densidade forte na área e, também, motiva relações de sinergia entre elas. A densidade das indústrias e suas operações é tão significativa que a configuração espacial que hoje se verifica foi assim planejada desde a concepção do polo. A complexidade destas relações reafirma o caráter centralizado e planejado desta forma de aglomeração industrial.

- Garantia na oferta de produtos petroquímicos básicos: Mais uma vez com caráter centralizado, a Braskem recebe os derivados do petróleo da Petrobrás (Refinaria Landulpho Alves) e os transforma em produtos primários para as demais indústrias à jusante, tais como: eteno, propeno, benzeno e solventes.

O circuito petroquímico tem, em sua base, processos de transformação complexos que demandam especialização e extrema segurança em sua produção. É a

\footnotetext{
${ }^{143}$ Atualmente, a energia elétrica do polo é fornecida pela Companhia Hidrelétrica do São Francisco (CHESF) (50\%) e pela própria Braskem (50\%).

${ }^{144}$ Embora as empresas possam captar água individualmente, o papel da Braskem é também fazer o tratamento da água e prepara-la para o processo produtivo, além de produzir especificamente água clarificada, água para incêndio, entre outros tipos.
} 
garantia da oferta e qualidade dos produtos primários que se responsabilizam como o principal atrativo que mantém a coesão de um polo.

Por fim, o Polo Industrial de Camaçari apresenta-se hoje com mais de 90 empresas dos ramos químico, petroquímico, metal-mecânico, automotivo, e também pertencentes a ramos mais recentes como celulose, metalurgia do cobre, têxtil e serviços. Forma-se, no polo, um conjunto integrado "ao qual a maioria das empresas da cadeia química está relacionada através da troca de produtos e insumos transportados em dutovias e de forma colaborativa" (PLANO DIRETOR - POLO INDUSTRIAL DE CAMAÇARI, 2013, p.14).

O polo apresenta tendência evidente de crescimento. Um dos mais enfáticos indicativos é que a ampliação da produção de primeira geração da Braskem não se fez acompanhada por um correspondente crescimento da oferta da Petrobrás. Em 2013, o núcleo precisava ainda importar do exterior ou de outras refinarias brasileiras. As tendências de expansão, consideradas como oportunidades, referem-se principalmente a produção de Eteno Verde (que a Braskem já realiza no Polo de Triunfo), perspectivas de criação de novas indústrias de transformação plástica, reciclagem mecânica e também no ramo têxtil.

Do ponto de vista da organização territorial, assim como as demais áreas industriais tem apresentado como tendência, também em Camaçari foi possível encontrar formas de aglomeração mescladas. A fábrica da Ford em Camaçari foi inaugurada em 2001, assinalando a tendência à ampliação e diversificação das atividades do polo: "Ficava evidente, a partir deste momento, que o futuro do antigo Polo Petroquímico estava na incorporação de outros setores industriais" (PLANO DIRETOR - POLO INDUSTRIAL DE CAMAÇARI, 2013, p.30).

Contudo, é evidente mesmo no Plano Diretor do polo que a opção da Ford não foi motivada pela disponibilidade de produtos petroquímicos. Além de um pacote de incentivos fiscais, o fator definidor da decisão locacional da Ford foi a infraestrutura consolidada do polo, herança da presença das indústrias petroquímicas e metalúrgicas. Comprova esse fato que o modelo escolhido pela Ford foi, justamente, o consórcio modular, trazendo consigo os seus fornecedores de autopeças e componentes, bem como distribuidores dos produtos finais.

Outras indústrias de renome presentes no polo são: Proquigel, Dow Química, GDK, Jac Motors e Monsanto. A expectativa de ampliação é grande, em uma área já reservada de $240 \mathrm{mil} \mathrm{m}^{2}$. 
O trabalho de campo também permitiu a realização de alguns registros fotográficos $^{145}$ (Fotos 21 e 22). A Foto 21 retrata parcialmente a aglomeração industrial do Polo de Camaçari e a Foto 22 mostra os galpões e o pátio do condomínio industrial da Ford, instalado dentro do polo.

${ }^{145}$ Este registro ficou prejudicado em decorrência das condições temporais inadequadas e pelas próprias dimensões da área e sua situação geográfica, o que torna difícil capturar uma imagem completa do Polo de Camaçari que não seja por meio de fotografia aérea. 


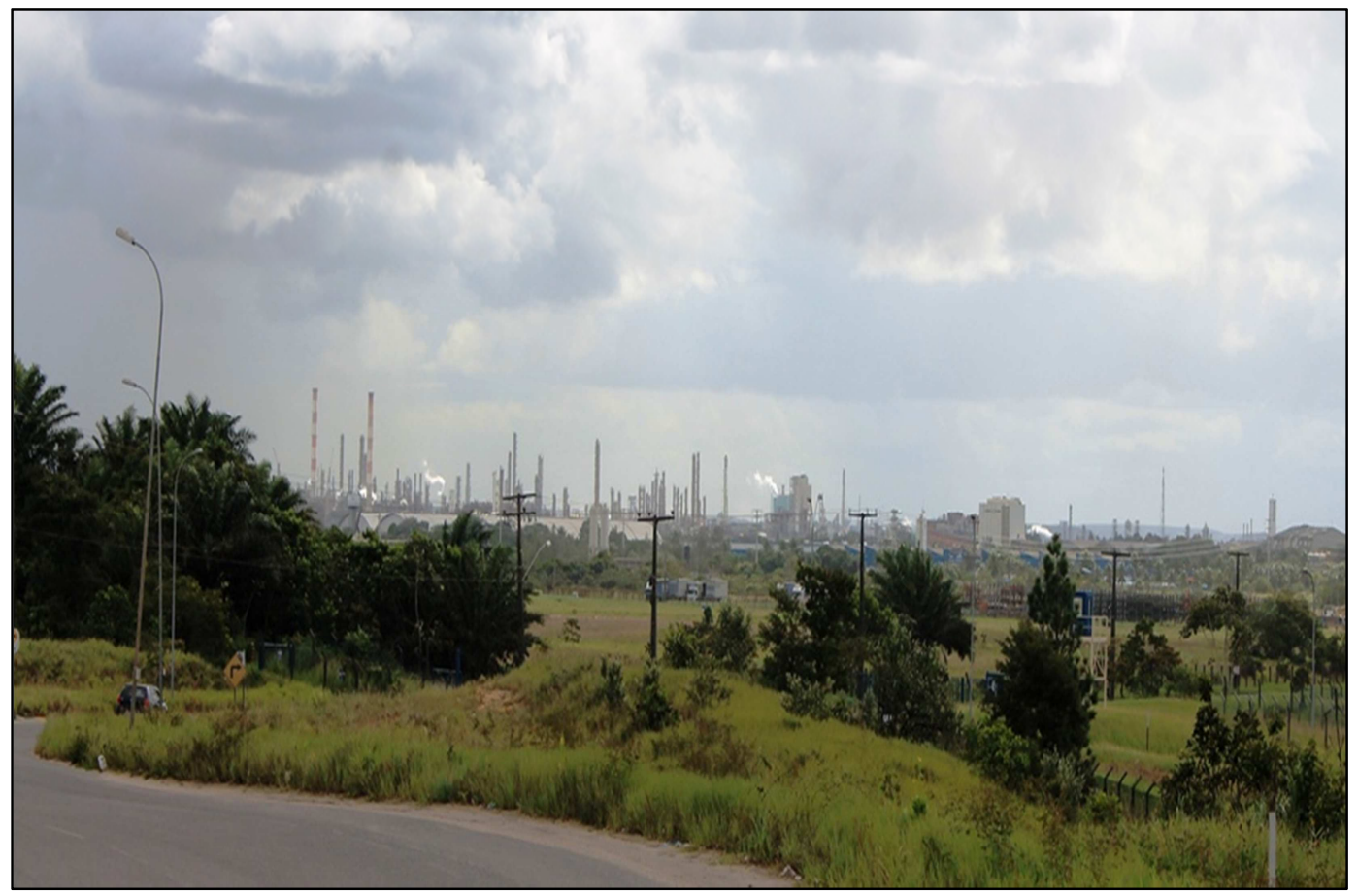

FOTO 21 - Polo Industrial de Camaçari. Em segundo plano se verifica, parcialmente, as dimensões da aglomeração industrial. Fonte: Rodolfo Finatti, trabalho de campo, 2014.

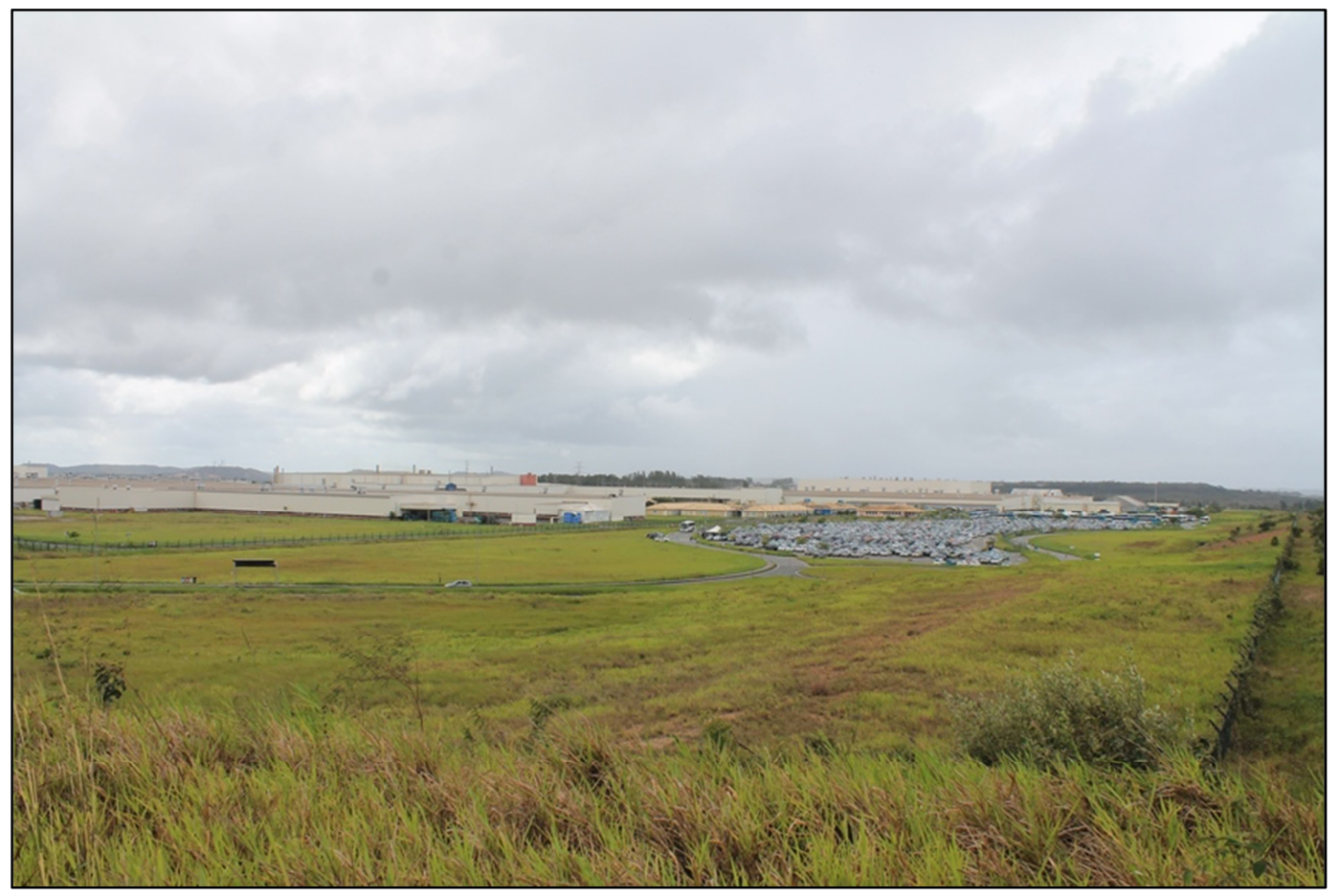

FOTO 22 - Polo Industrial de Camaçari e condomínio industrial da Ford. No primeiro plano se verifica parte da área destinada à expansão do polo e ao fundo, no segundo plano, os galpões e o pátio do condomínio industrial da Ford (montadora de automóveis). Fonte: Rodolfo Finatti, trabalho de campo, 2014. 
Para retratar os outros dois polos industriais estudados, iremos nos pautar no que apresentam como diferencial e, assim, tentar complementar a visão de polo que foi montada primordialmente a partir das constatações sobre o Polo de Camaçari (BA).

Diferentemente de Camaçari, que congrega o $1^{\circ}, 2^{\circ}$ e $3^{\circ}$ elo da geração de valor a partir do petróleo, com planejamento de expansão para o $4^{\circ}$ elo do circuito produtivo, o Polo de Triunfo ${ }^{146}$ é relativamente menor, o qual se expande até o $2^{\circ}$ elo, muito embora com planejamento de expansão utilizando um distrito industrial vizinho para este fim. Até mesmo territorialmente, o Triunfo é comparativamente menor (também por ser mais novo) em relação à Camaçari.

O Polo de Triunfo data do início da década de 1980 e, conforme apontado por nosso interlocutor na área, sua implantação enquanto um projeto federal foi uma vitória das elites politicas do Rio Grande do Sul sobre as intenções de outras unidades da federação, que também eram fortes candidatas ao recebimento deste investimento. Para tanto, apresentou-se satisfatoriamente os condicionantes: (a) proximidade da planta da Refinaria Alberto Pasqualini (REFAP), em Canoas (RS), para fornecimento direto da Nafta, (b) existência de recursos hídricos favoráveis ao fornecimento, (c) condição logística para escoamento da produção e (d) uma área de implantação distante das regiões urbanas mais densas, "para não repetir o erro de São Paulo" cuja implantação ocorreu justamente em uma área urbana já conurbada.

Estima-se a possibilidade de expansão deste polo por meio de duas vertentes; agregação de serviços industriais nas proximidades (inclusive observa-se a implantação de empreendimentos privados no modelo de condomínio logístico) e, complementarmente, a absorção do Distrito Industrial localizado em Montenegro (RS), município vizinho, para o qual se espera que seja estimulada a instalação das empresas que corresponderiam ao $3^{\circ}$ elo da geração de valor do petróleo.

Aproveitando este sentido de agregação de diversos tipos de áreas industriais às quais se aproveita sua potencialidade para diferentes funções, no Polo de Triunfo podemos verificar uma grande proximidade de aglomerações industriais, com o diferencial de funcionarem em sinergia (de acordo com os propósitos esperados para o polo). $\mathrm{O}$ sentido da "indústria motriz", além de garantir o fornecimento de insumos e fomentar uma

\footnotetext{
${ }^{146}$ As principais informações sobre o Polo Petroquímico de Triunfo resultam de entrevista realizada com o administrador S. dos Anjos, que foi nosso interlocutor nesta área, no dia 21 de maio de 2015.
} 
organização industrial necessária para sustentação operacional e normativa de um polo industrial, também funciona no sentido de congregar diferentes áreas e diferentes indústrias, estimulando uma operação conjunta entre indústrias de base, de consumo final, serviços industriais e logísticos.

No caso do Polo de Capuava ou do Grande ABC, sua sede localiza-se no município de Mauá (SP), que também é conhecido como Polo do Grande $\mathrm{ABC}^{147}$.

Este polo teve sua idealização iniciada em 1966 e efetivamente começou suas atividades no ano de 1970. Encontra-se em uma posição geográfica peculiar em relação aos demais polos do Estado de São Paulo do mesmo período, localizados em Paulínia e Cubatão. Capuava encontra-se em uma área densa, urbanizada, com muitas outras indústrias e também uma série de restrições ambientais que dificultam o planejamento e as estratégicas de ampliação, atualmente.

Estas características induziram a tendência de desconcentração entre as empresas que constituem o polo, o que faz com que o gerenciamento do Polo de Capuava (SP) tenha um desafio maior para garantir a segurança de suas operações. Esta segurança precisa abranger a segurança econômica, patrimonial e, sobretudo, a segurança nos processos de produção que possuem um risco ainda maior devido à localização em uma área densamente povoada.

$\mathrm{Na}$ visão do nosso entrevistado ${ }^{148}$, a proximidade é bastante importante para a indústria petroquímica, senão ideal. Há uma lógica operacional que induz à proximidade geográfica neste circuito produtivo, o que gera muita aderência entre as indústrias que o compõe. $\mathrm{O}$ etileno, como uma das principais matérias primas oriundas do processamento da nafta, atualmente só pode ser transportado por dutovia, pois é uma matéria-prima que precisa ser acompanhada e refrigerada. Por essa razão, todas as ligações entre a central de matérias-primas e as demais empresas são feitas por dutos. No caso do Polo de Capuava, são atendidas empresas em um arco de $25 \mathrm{~km}$.

Complementarmente, é condição ideal para um polo estabelecer sinergia entre as empresas que o compõe, e isso se expressaria, de maneira importante, no fornecimento compartilhado de vapor, nitrogênio ou ar-comprimido. Diferentemente do Polo de

\footnotetext{
${ }^{147}$ Nesta ocasião, quem nos recebeu foi o engenheiro químico e gerente Comitê de Fomento Industrial do Polo (COFIP-ABC), F. Ruiz, com quem conversamos no dia 11 de novembro de 2015. Nesta ocasião, como já ocorrera contato com outras aglomerações similares e, tendo este polo a características principal de ser territorialmente fragmentado (as indústrias que o compõe estão dispersas pela região do $\mathrm{ABC}$ e litoral paulista), o foco da entrevista se direcionou para a compreensão desta territorialidade e modelo de gestão para concatenar os agentes.

${ }^{148}$ Entrevista realizada com o gerente F. Ruiz, no dia 11 de novembro de 2015.
} 
Camaçari (BA), até por uma questão do planejamento mediante as circunstâncias da região onde este foi implantado, cada uma das "empresas satélite" (como são chamadas) precisa possuir o seu próprio sistema de fornecimento.

Os gerentes do Comitê de Fomento Industrial do Grande ABC (COFIC-ABC) atualmente tentam fomentar maior sinergia entre a central de matérias-primas e suas empresas satélite. Os polos petroquímicos possuem um Plano de Auxílio Mútuo (PAM), com participação dos bombeiros e da defesa civil. Além disso, no Grande ABC se espera fomentar o benefício de conhecimento tácito entre as empresas participantes do comitê, mesmo as distantes, por meio de uma agência que auxilia em gestão, plano de negócios e projetos temáticos.

Como pilar do planejamento estratégico do COFIC-ABC está justamente o fomento às sinergias, fazendo com que estar na cadeia signifique aprender, lidar com gestão de negócios, gestão de pessoas e segurança, evidenciando vantagens na associação ao programa e participação do polo.

Podemos observar que, no caso dos polos de implantação em localizações fora da core area da industrialização no país (situação geográfica na qual podemos vincular as perspectivas de desenvolvimento via indústria motriz), existe uma necessidade de planejamento maior em termos de insumos industriais. A ideia da indústria motriz é, além do fornecimento da matéria-prima, também uma série de vantagens que irão tornar uma localização (ou relocalização) mais atrativa. No caso dos Polos de Camaçari e Triunfo, mais modernos em relação ao do Grande $\mathrm{ABC}$, uma central de utilidades ${ }^{149}$ já nasce incorporada ao núcleo do polo. No caso das empresas satélite existentes no Grande $\mathrm{ABC}$, cada uma delas precisa de sua própria central de utilidades.

Entretanto, vemos por meio do Polo de Capuava que é possível fomentar e considerar a existência de um polo industrial mesmo sem que, necessariamente, as empresas estejam vizinhas, lado-a-lado. O Polo de Capuava (SP) é territorialmente descontínuo, muito embora as empresas estejam ligadas entre si para a transmissão de insumos e por meio de normativas de segurança.

Algumas fotos do Polo de Triunfo estão disponíveis na sequência. A Foto 23 mostra uma visão parcial da aglomeração industrial e a Foto 24 ilustra a usina da Braskem. As fotos seguintes mostra uma das entradas para a central de utilidades do polo (Foto 25) e uma das vias de circulação interna (Foto 26) que margeia uma área de preservação.

\footnotetext{
${ }^{149}$ A central de utilidades é fundamental em um polo petroquímico. Ela fornece vapor, energia elétrica, água e ar comprimido às empresas ligadas, na a produção na $2^{\mathrm{a}}, 3^{\mathrm{a}} \mathrm{e} 4^{\mathrm{a}}$ geração.
} 


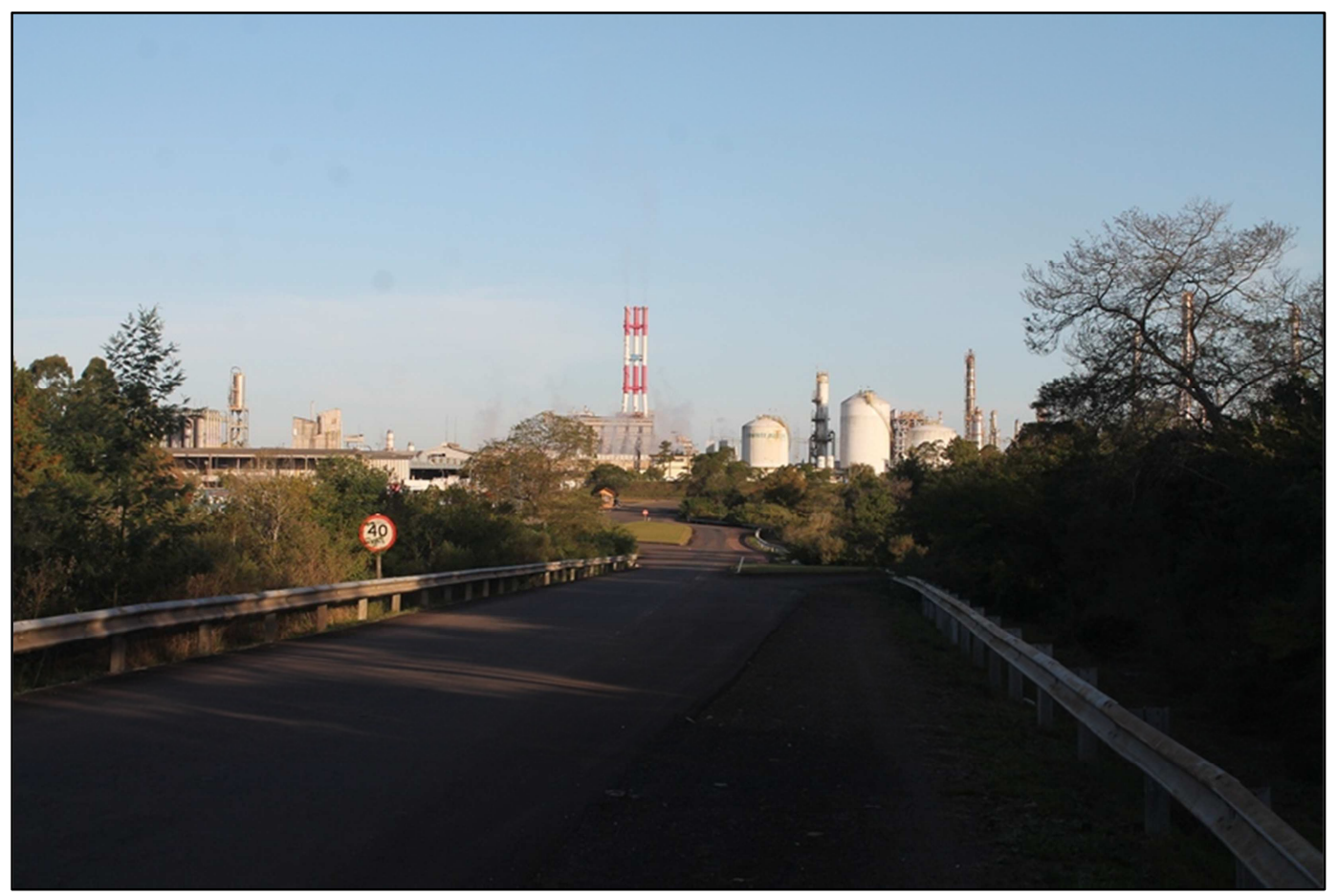

FOTO 23 - Polo Industrial de Triunfo. Em segundo plano se verifica, parcialmente, a aglomeração industrial e a refinaria. Fonte: Rodolfo Finatti, trabalho de campo, 2014.

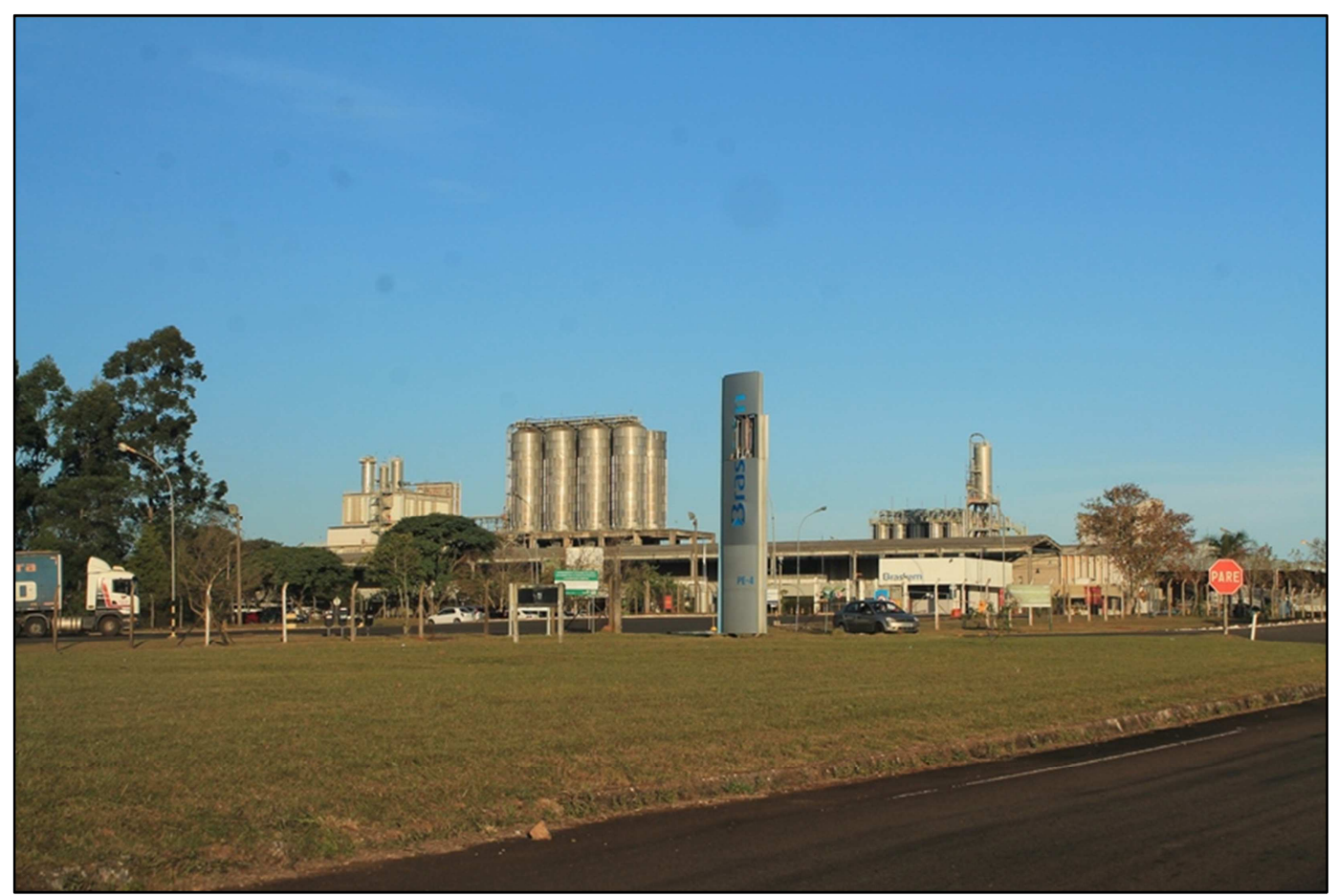

FOTO 24 - Usina da Braskem (refinaria) no Polo Industrial de Triunfo. Fonte: Rodolfo Finatti, trabalho de campo, 2014. 


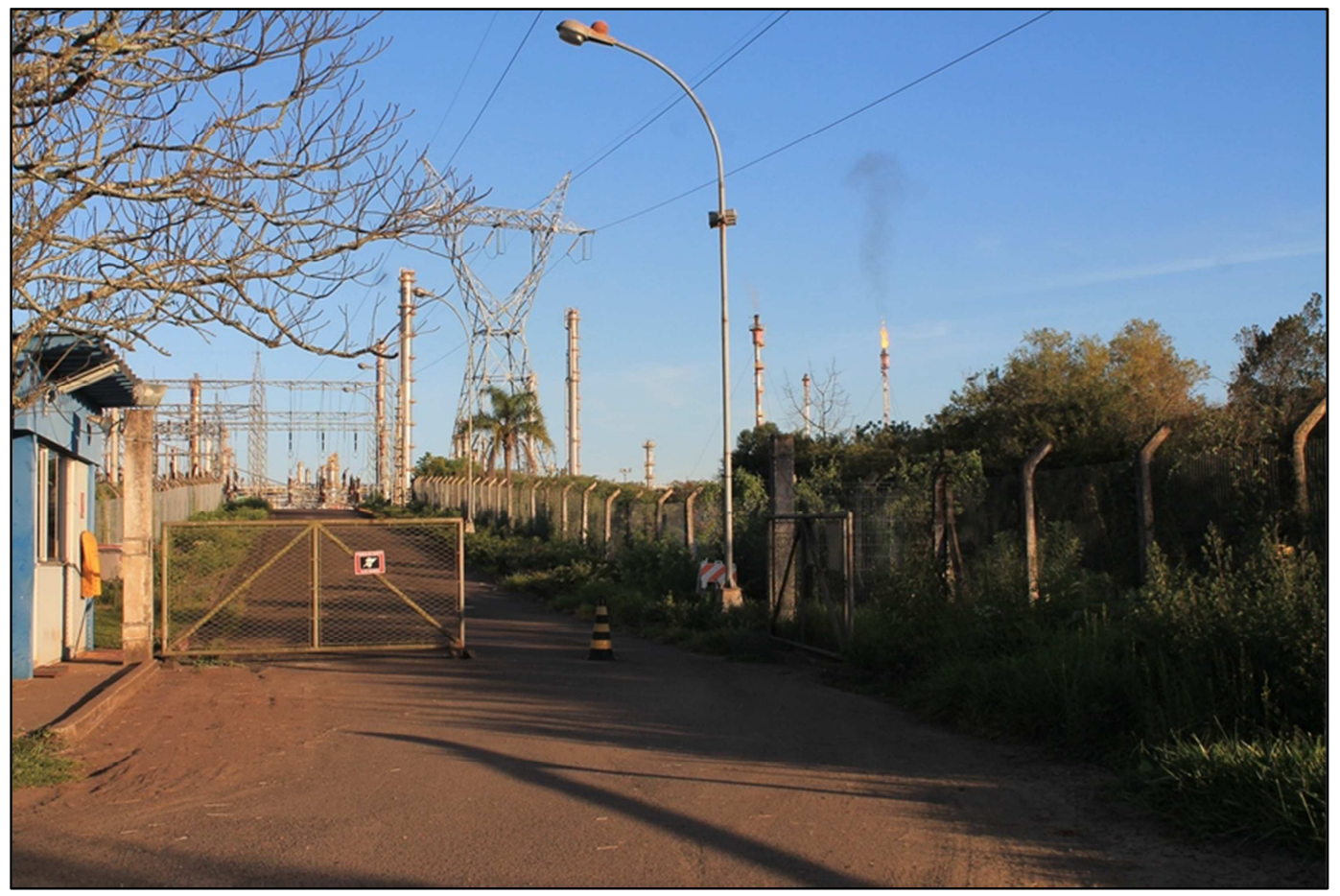

FOTO 25 - Polo Industrial de Triunfo, entrada para a refinaria. Fonte: Rodolfo Finatti, trabalho de campo, 2014.

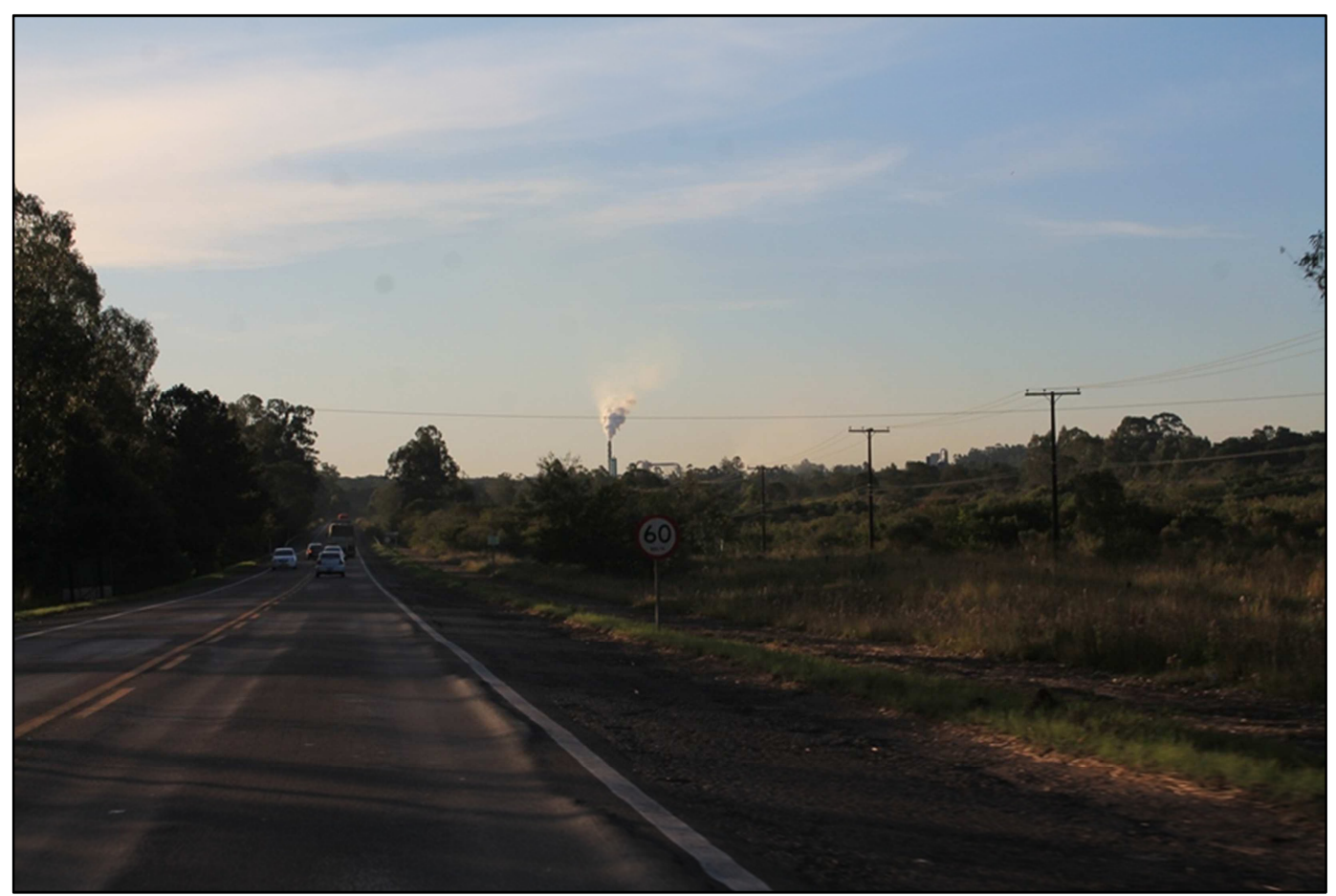

FOTO 26 - Via interna no Polo Petroquímico de Triunfo. À direita se verifica uma área reservada à expansão do polo e à esquerda da rodovia uma área de conservação ambiental. Fonte: Rodolfo Finatti, trabalho de campo, 2014. 
4.3.3. Organização territorial das pequenas indústrias: arranjos produtivos locais

Podemos afirmar que os arranjos produtivos locais ${ }^{150}$ apresentam a maior regularidade entre as que escolhemos estudar. Consideramos regularidade o fato de ter sua ocorrência em todas as unidades da federação, de assentar-se sobre um mesmo pilar conceitual (embora cada SEBRAE estadual tenha liberdade para redefinir suas linhas de atuação) e, em aspectos gerais, em cada unidade estadual apresentar um padrão de distribuição geográfica e organização territorial equivalente.

Por meio de nossas entrevistas, pudemos constatar um padrão de ocorrência relativamente bem organizado: (a) existem diferentes níveis de "maturidade" dos arranjos, (b) aqueles com maior ou menor aceitação da presença do SEBRAE (quando não, devido à rigidez e desconfiança na representatividade local ou ausência dela), (c) promoção das aglomerações que, via de regra, correspondem a atividades historicamente fundadas nas regiões, nas quais existe tradição e conhecimento e, finalmente (d) um padrão de distribuição geográfica que permite apontar a dispersão destas iniciativas pelas unidades estaduais, não restringindo-se apenas às capitais, muito embora os primeiros e mais fundamentados arranjos possam estar nas capitais.

As unidades do SEBRAE possuem certa autonomia para desenvolver seus próprios posicionamentos e conceitos e, em cada caso, liberdade para direcionar as ações práticas. É neste sentido que notamos a maior discrepância na questão conceitual, na medida em que algumas unidades consideram o arranjo produtivo local no sentido mais clássico possível, enquanto outras, buscando traçar novas estratégias de atuação, buscam aperfeiçoá-lo.

As unidades com maior preocupação com a fundamentação conceitual dos trabalhos por eles desenvolvidos são dos estados de Minas Gerais ${ }^{151}$, Rio de Janeiro ${ }^{152}$ e Bahia $^{153}$, cujos profissionais mencionados mostraram grande preocupação em atualizar o entendimento do que seria, atualmente, o arranjo produtivo local e principalmente, o que

\footnotetext{
${ }^{150}$ Para trabalhar a temática dos Arranjos Produtivos Locais, foram visitadas as unidades do Serviço Brasileiro de Apoio às Médias e Pequenas Empresas (SEBRAE) em todas as unidades da federação nas quais fizemos atividades de campo. Esta instituição é responsável por analisar os pedidos e alavancar os projetos de financiamentos e ações locais. Em alguns estados sua atuação é mais ativa (ida ao campo e iniciativa da articulação com os agentes locais) e em outros casos, como em São Paulo, o SEBRAE atua sob demanda, ou seja, é necessário que as empresas ou o representante procure o SEBRAE.

${ }^{151}$ Entrevista realizada com M. Xavier, coordenadora de implantação de arranjos produtivos locais do SEBRAE de Minas Gerais.

${ }^{152}$ Entrevista realizada com R. Regazzi, coordenador de inovação em arranjos produtivos locais do SEBRAE do Rio de Janeiro.

${ }^{153}$ Entrevista realizada com J. Chompanidis, analista da Unidade de Indústrias do SEBRAE da Bahia.
} 
pode ser feito para dinamizá-lo sobre bases que, segundo os próprios, já estariam desgastadas.

É o que aponta a analista do SEBRAE-MG quando comenta que as linhas de atuação já estão desgastadas e não surtem os mesmos efeitos que anteriormente, por se tornarem ações que já se consolidaram como treinamentos, capacitações e lideranças, ou ainda pela repetição e desgaste natural das estratégias convencionais, como eventos e feiras. A unidade do SEBRAE de Minas Gerais busca novas ações para renovar seus arranjos produtivos locais.

Os analistas de Bahia e Rio de Janeiro, por sua vez, apontam que a evolução do arranjo produtivo local está na observação da cadeia produtiva. Dizem que se deve propor, inclusive, um novo conceito que dê conta de abarcar as relações em cadeia à montante e à jusante e tentar atrelar novos agentes, de diversos setores econômicos, ao processo de desenvolvimento do arranjo produtivo local.

O caso do arranjo produtivo local de Nova Friburgo (RJ) é marcante neste aspecto. Implantado com orientação direta do SEBRAE-RJ, o qual buscou soluções para dinamizar a produção de moda íntima na localidade. A solução proposta, pensando justamente nos circuitos produtivos da moda íntima (não apenas quanto aos circuitos produtivos, mas nos processos de distribuição, consumo e serviços que podem se associar lateralmente), parece ter conseguido articulação entre os agentes de um circuito produtivo mais amplo.

Em uma localidade onde já se concentravam produtores de moda íntima, tentou-se, em primeiro lugar, articular produtores de peças de plástico e metal da região, propondo-se que se trabalhassem na produção de pequenas peças como zíperes, fechos, ganchos, botões e demais detalhes que pudessem ser utilizados. Posteriormente, tentou-se articular todos os serviços relacionados ao turismo, fomentando não apenas um arranjo produtivo, mas ao mesmo tempo um centro turístico. Dessa forma, foi agregado um circuito turístico temático atrelado à moda íntima, momento no qual restaurantes, hotéis e motéis de Nova Friburgo (RJ) assumiram esse conceito em suas propostas e decorações. O arranjo produtivo local é hoje considerado pelo SEBRAE como um arranjo inovador, seguindo a proposta de agregar segmentos ao circuito produtivo.

Por outro lado, é também possível que o arranjo se mantenha e se renove mediante um pacto da representatividade local e trabalhadores e, mesmo com pouca intervenção direta do SEBRAE enquanto agência de fomento. O caso emblemático é a da produção do jeans e moda praia no município de Toritama (PE), onde o SEBRAE e 
tampouco o Ministério do Trabalho e Emprego conseguem abrir uma linha de diálogo a atuação conjunta devido à resistência das lideranças locais. De acordo com um de nossos entrevistados $^{154}$, uma estimativa aponta o funcionamento de mais de mil unidades faccionistas em Toritama, responsáveis por diferentes etapas de confecção como o corte, lavagem e costuram do jeans. Estas unidades encontram-se bastante concentradas no município e começam a expandir-se para toda a região, denotando o crescimento desta iniciativa.

A unidade pernambucana do SEBRAE, na qual entrevistamos dois analistas ${ }^{155}$, aponta que em Toritama (PE) existe a "cultura da feira", em que a pessoa que ali reside "respira essa cultura", presente em toda a parte. É uma perspectiva na qual mesmo que a pessoa não se interesse pela produção do jeans, de alguma forma ela se envolve com a atividade. A Feira de Toritama ${ }^{156}$, também conhecida com a Feira do Jeans, reúne inúmeros expositores e tem repercussão nacional. Uma das marcas nascentes em Toritama, a Rota do Mar, é também exportadora.

A repercussão da estrutura produtiva de Toritama faz com que o espaço rural comece a ser impactada pela produção industrial, por meio de pequenos distritos que realizam também processos de produção dos vestuários. Da mesma forma, os municípios de Caruaru (PE) e Santa Rita do Capibaripe (PE), nas imediações, já se consolidaram como parte deste "polo" (expressão empregada pela liderança local) e, segundo indicações do SEBRAE pernambucano, cujo raio de influência pode chegar a 300 quilômetros a partir do município sede.

No caso dos arranjos produtivos locais, a densidade física é, evidentemente, fraca se comparada às demais formas estudadas. $\mathrm{O}$ arranjo pode ser composto por inúmeras pequenas ou médias fábricas que, não necessariamente, estarão lado a lado. Um arranjo produtivo local é municipal ou, na maioria das vezes, regional com uma sede reconhecida. Entretanto, pelos exemplos verificados, devemos salientar que a densidade de relações (lideranças, relações de contratação, compartilhamentos e trocas) é muito mais forte e duradoura do que nas demais formas de aglomeração, já que assentada em uma história, um "DNA local" que, em um determinado momento, impulsionou e definiu a atividade do arranjo.

\footnotetext{
${ }^{154}$ Entrevista com o Diretor de Pesquisas Sociais da Fundação Joaquim Nabuco, L. H. Campos, realizada em Recife (PE) no dia 09 de julho de 2014.

${ }^{155}$ Entrevistas realizadas com os analistas A. C. Dias e A. Rodrigues, do SEBRAE-PE, no dia 08 de julho de 2014.

${ }^{156}$ Disponível em: 〈http://toritama-jeans.com/feira-de-roupas〉. Acesso: maio de 2015.
} 
Finalmente, para apenas fazer outro paralelo importante com as demais formas de aglomeração, um aspecto de extrema importância destacado pelo SEBRAE foi a questão da estruturação de uma liderança local. É importante lembrar que o Estado não é a liderança destas formas de aglomeração, mas apenas uma linha de apoio e capacitação. Nesse sentido, o trabalho começa sempre com a tentativa de localizar e articular, quando existente, a liderança do futuro arranjo. Quando não há, é preciso fomentá-la. Este foi apontado como um dos principais problemas e dificuldades para se iniciar ou consolidar o crescimento em um arranjo produtivo local.

Por fim, resta apontar a proximidade entre o arranjo produtivo local e a conceituação italiana de distrito industrial. Os distritos à italiana seriam aqueles justamente apoiados em uma história local que sustenta um forte senso de comunidade e compromisso entre as empresas participantes. Seriam estes alguns aspectos em comum entre os dois conceitos, fato que faz os pesquisadores de arranjos produtivos locais se inspirarem nos distritos industriais marshallianos ou italianos.

\subsubsection{Quando o imobiliário define a localização: condomínios empresariais}

Os condomínios empresariais se confirmam como tendência na produção territorial de áreas industriais capazes de atrair e aglomerar indústrias e prestadores de serviço, porém com o diferencial de terem sua origem vinculada diretamente à iniciativa privada, que desempenha a escolha locacional, planejamento da estruturação do empreendimento, negociação da área e sua posterior administração.

Podemos identificar três leituras que podem confirmar a existência de condomínios empresariais como formas de aglomeração que apresentam importância e certa dispersão por todas as regiões do território nacional. Estas três leituras são: (a) o número de empreendimentos implantados em curto período de tempo e sua distribuição geográfica contemplando todas as regiões do país, (b) a maneira como o conceito do condomínio empresarial tem sido incorporado / copiado no planejamento de outras formas aglomerativas e (c) a combinação de condomínios empresariais às formas de aglomeração já existentes, principalmente distritos industriais.

A primeira constatação importante é sua distribuição por todas as regiões do território nacional, porém marcadamente na Região Concentrada como expressão das iniciativas privadas cuja intencionalidade é, tão somente, a obtenção da renda da terra. 
Quando estas iniciativas se dirigem para outras regiões do país, se obriga a escolher os pontos luminosos, de maior dinamismo econômico, garantia de circulação e clientes. Dessa forma, os condomínios empresariais não se vinculam ao qualquer projeto ou política industrial, federal ou estadual. É um interesse particular.

A dispersão na Região Concentrada aumentou nos últimos anos, a despeito dos condomínios pioneiros que se concentraram nas sedes e suas áreas metropolitanas (FINATTI, 2011). Atualmente, seguindo os principais eixos de circulação rodoviários, estas formas aglomerativas existem também no interior do Estado de São Paulo e de outros estados.

Na Região Nordeste, por outro lado, a segunda com maior número deste tipo de empreendimentos, nota-se uma distribuição que respeita justamente as capitais das unidades da federação ou, como verificamos em campo ${ }^{157}$, algumas áreas em que existe a promessa de grande dinamismo econômico e industrial futuro, como o caso do Complexo Portuário do Pecém (CE) e do Porto de Suape (PE). No trajeto para o Pecém e também nas imediações do Porto de Suape pudemos encontrar condomínios empresariais, principalmente do tipo Condomínio de Galpões Modulares, sempre seguindo um padrão de localização que respeita certa proximidade com importantes centros urbanos e alta fluidez territorial, ou seja, proximidade de até $2 \mathrm{~km}$ em relação ao eixo rodoviário ${ }^{158}$.

Para falar da Região Centro-Oeste, a lógica é similar à da Região Nordeste, porém com sensivelmente menos ocorrências, acompanhando a expansão geográfica paulatina dos processos que historicamente atingem o Centro-Oeste brasileiro. No caso dos empreendimentos privados, também se manifestam nas capitais estaduais e Brasília. Na Região Amazônica, as principais ocorrências estão em Manaus, em respeito ao hiato industrial ali existente, o que pode ser bem aproveitado por Condomínios de Galpões Modulares.

Além da já implantação de condomínios empresariais junto a outras aglomerações como os distritos industriais, podemos destacar que existe uma influência conceitual do modelo desenvolvido pelos agentes imobiliários. Portanto, o "modelo condominial" tem sido incorporado / copiado no planejamento de novas formas

\footnotetext{
${ }^{157}$ No dia 02 de abril de 2014, percorremos boa parte do Quarto Anel Viário de Fortaleza, bem como a Rodovia Estadual CE-085, que liga Fortaleza (CE) a Caucaia (CE) e a Complexo Portuário do Pecém, onde existem novos condomínios empresariais em implantação. No dia 13 de julho de 2014 percorremos os dois sentidos da Rodovia BR-101 que liga Recife (PE) a Porto de Galinhas (PE), com o objetivo de analisar as obras em curso que estão fortemente associadas ao Porto de Suape.

${ }^{158}$ Este padrão de localização, que poderíamos qualificar como de alta fluidez territorial para os condomínios empresariais, está explicado em nossa dissertação de mestrado. $C f$. Finatti (2011).
} 
aglomerativas, mesmo que associada ao poder público. O exemplo mais significativo foi encontrado junto ao Secretário de Planejamento Econômico do Município de Goianinha $(\mathrm{RN})^{159}$, o qual nos afirmou que a inspiração para o seu distrito industrial fora, justamente, os condomínios empresariais que ele visitou no Estado de São Paulo.

No mesmo sentido, nos foi apontado por nossos interlocutores das federações de indústrias da Bahia ${ }^{160}$ e de Minas Gerais ${ }^{161}$ que o "modelo" que procuram, junto aos empresários industriais e junto ao poder público, é justamente aquele que se verifica hoje nos condomínios empresariais. A preocupação com a segurança e as vantagens advindas do compartilhamento de serviços são os principais atrativos neste caso.

Cabe destacar também uma dinâmica que identificamos no Estado do Ceará, que também pode ser apontada como uma novidade que mostra a influência da lógica imobiliária. Uma iniciativa pontual nos chamou atenção, apesar de seu status ainda em projeto: trata-se de um condomínio empresarial que está sendo capitaneado pelo Sindicato das Indústrias Químicas, Farmacêuticas e da Destilação e Refinação de Petróleo do Estado do Ceará, na figura de seu presidente ${ }^{162}$.

A razão deste condomínio empresarial decorre do novo plano diretor que será implantado no município de Fortaleza (CE), o qual influirá na localização de empresas com processos produtivos que gerem algum tipo de resíduos tóxicos, obrigando-as a deslocarem-se para outras áreas. Como esse fato afetará todas as indústrias químicas do aglomerado metropolitano, estas resolveram promover, em conjunto, uma área com infraestrutura adequada para sua relocalização, e o modelo escolhido foi justamente o do condomínio empresarial.

Os dirigentes do sindicato visitaram o condomínio empresarial da Bayern, em Dortmund (Alemanha), e almejaram exportar o modelo para o Brasil. Segundo o presidente do sindicato, um condomínio empresarial "é o que existe de mais moderno em termos de infraestrutura e facilidades para a operação de uma indústria”.

Embora o projeto deste condomínio resulte de uma demanda real e não de ações voltadas para o mercado imobiliário, as motivações para sua implantação são muito similares; a escolha de uma localização adequada, divisão de gastos e garantia de segurança em uma área vigiada. Ao questionarmos o entrevistado sobre a possibilidade de relocalização das indústrias em outros condomínios empresariais que já existem na Região

\footnotetext{
${ }^{159}$ Entrevista realizada com T. Thomaz, no dia 11 de abril de 2014.

${ }^{160}$ M. E. Verhine (gerente) e C. P. Almeida (analista), em entrevista no dia 27 de junho de 2014.

${ }^{161}$ R. L. de Souza (analista), em entrevista no dia 17 de março de 2015.

${ }^{162}$ Entrevista com M. F. Soares, Presidente do SindQuímica, no dia 31 de março de 2014.
} 
Metropolitana de Fortaleza, constatamos uma questão específica: para a indústria química, os galpões precisam de detalhes específicos e adaptados à realidade da indústria química, como piso mais resistente, isolamento térmico e acústico, revestimento e infraestrutura.

Esta iniciativa do SindQuímica revela que ao falar em espaços privados, podemos estar diante não apenas da produção destes espaços pelo investidor privado e imobiliário, mas também pela cópia de seu modelo por outros agentes, ora privados, ora públicos e, neste caso, em parceria, sem que exista necessariamente a intencionalidade imobiliária (obtenção da renda do solo por venda ou aluguel de lotes ou galpões). A dinâmica das áreas industriais privadas atualmente perpassa também por estas nuances.

Os condomínios empresariais, embora não sejam formas puramente industriais e, em algumas vezes a indústria pode mesmo não ser o uso do território predominante, evidenciam o contraponto junto às iniciativas do poder público. Enquanto distritos e polos industriais, em um determinado momento histórico de nossa formação social podem ser apontados como ferramentas para o desenvolvimento (idealmente) e, algumas vezes, por esta razão, foram levados e implantados em regiões que, do ponto de vista de dinamismo econômico poderiam ser consideradas mais "opacas", a iniciativa privada mostra o oposto.

Se os arranjos produtivos locais, como objetos de financiamento da esfera federal visando o desenvolvimento local, mesmo que idealmente (não iremos questionar o seu real funcionamento e sucesso), enquanto programas, conseguem chegar até o interior dos estados, os condomínios empresariais irão limitar-se às capitais, regiões metropolitanas e áreas mais afastadas quando existe a promessa de crescimento econômico.

Isso mostra o contraponto entre as ações do Estado e a seletividade dos promotores imobiliários.

a) Techno Park Campinas (SP)

O Techno Park Campinas é um dos condomínios empresariais pioneiros no Estado de São Paulo e no Brasil, cuja implantação iniciou-se em 1998. É uma incorporação do grupo DPaschoal (autopeças e construção civil), sediado em Campinas, que já reunia alguma experiência com empreendimentos imobiliários de caráter residencial.

Este empreendimento goza de alta fluidez territorial, uma vez que se localiza no entroncamento das importantes rodovias estaduais Anhanguera (SP-330), Bandeirantes 
(SP-348) e Dom Pedro I (SP-65), garantindo rápido acesso e ligação com a capital São Paulo, Aeroporto de Viracopos e Universidade Estadual de Campinas (UNICAMP). Além disso, confirmando as demais características de um condomínio empresarial, a filosofia do Techno Park assentou-se nos eixos: "localização, compartilhamento de serviços e ambiente de desenvolvimento" destacando as características que seus idealizadores consideraram como diferenciais competitivos. O Plano de Ciência e Tecnologia do Techno Park Campinas informa o seguinte:

O Techno Park é propiciado pelo compartilhamento de conhecimento e serviços, adotado como corolário ao desenvolvimento técnico e profissional a partir da interação social decorrente da convivência em ambiente que oferece segurança e bem-estar aos recursos humanos de elevada qualificação, e, por retirar parte significativa da carga de responsabilidade das empresas no que diz respeito às atividades de gestão de serviços indiretos como segurança, manutenção de áreas comuns, de redes comuns de telecomunicações e outras facilidades (TECHNO PARK CAMPINAS, 2015, p.28).

Durante nosso trabalho de campo a este empreendimento, fomos recebidos pelo gestor ${ }^{163}$ da Associação dos Proprietários do Techno Park Campinas (ASSOCITECH), que destacou aspectos sobre a composição de empresas existentes no empreendimento e as funcionalidades consideradas estratégicas para as empresas. Além disso, mencionou aspectos do planejamento realizado para obter o credenciamento deste condomínio empresarial enquanto um parque tecnológico do âmbito do Sistema Paulista de Parques Tecnológicos (SPTEC).

Na condição de um condomínio empresarial misto, o Techno Park possui lotes, galpões e escritórios. Estes dois últimos podem ser alugados. Atualmente, $55 \%$ das empresas existentes no condomínio são indústrias, e as demais se dividem entre empresas de tecnologia da informação, agroalimentar e serviços comuns. Entre elas, existe um agrupamento de empresas de biotecnologia, relativas ao segmento de pesquisa e produção de equipamentos médicos.

As empresas de tecnologia da informação e biotecnologia sustentam o empreendimento na condição de um espaço em que pode acontecer inovação. São elas, em sua maioria, empresas oriundas da UNICAMP e que contam, em seus quadros

\footnotetext{
${ }^{163}$ Entrevista realizada com J. L. Guazzelli, diretor do Techno Park Campinas e da ASSOCITECH, no dia 28 de julho de 2016.
} 
profissionais, com doutores e professores universitários, mantendo assim vínculos entre o condomínio empresarial e a universidade.

Segundo planejamento do Techno Park, seus diferenciais podem ser considerados os seguintes: infraestrutura urbanística e ambiental ${ }^{164}$ (A Fotos 27 e 29, ao final deste item, ilustram a qualidade da infraestrutura urbanística em uma via de circulação interna do condomínio) e também localização, fluidez territorial, segurança, ambiente de desenvolvimento.

Uma das premissas do condomínio empresarial é o compartilhamento de serviços, que pode ser traduzido como redução de gastos. Este é um importante diferencial dos empreendimentos imobiliários e por isso vale a pena o seu detalhamento. Para uma melhor definição do que são os serviços compartilhados oferecidos pelo condomínio empresarial, podemos considerar, a título de custos condominiais: (1) custos indiretos de administração, (2) telecomunicações (backbone ${ }^{165}$ ), (3) limpeza e jardinagem, (4) transporte de funcionários, (5) água e esgoto (uso comum), (6) manutenção de prédios comuns, (7) rede de energia elétrica, (8) remoção e destinação de resíduos, (9) manutenção de vias, (10) segurança patrimonial, (11) gerência de manutenção e (12) imprevistos.

O Techno Park Campinas também conta com um centro de convenções (Foto 28) e um hotel - Hotel Dan Inn - terceirizado, no interior do condomínio (verificar Foto 30, ao final deste item).

Entre este conjunto fatores, a segurança patrimonial corresponderia de 30 a 40\% dos custos para uma empresa neste condomínio, denotando sua importância relativa. Por outro lado, devemos destacar, conforme ilustra o Gráfico 3, que a operacionalização dentro do condomínio empresarial pode significar uma redução destes custos na ordem de $50 \%$ ou mais.

\footnotetext{
${ }^{164}$ Incluindo-se na infraestrutura ambiental a obtenção de licenciamento ambiental, embasado em relatório ambiental aprovado pela Secretaria Estadual do Meio Ambiente (SMA). Dessa forma, os possíveis impactos são considerados identificados e mitigados. A implantação de uma nova unidade que exija licenciamento específico terá respeitado o referido relatório ambiental para obtenção do Alvará de Uso e Instalação Municipal.

165 O termo backbone ("espinha dorsal") refere-se ao caminho principal por onde circulam as informações enviadas e recebidas por aparelhos de telecomunicação. O backbone seleciona as melhores vias de circulação da informação e impede que sejam sobrecarregadas. Seria a inteligência do sistema de transmissão de dados. O fato do condomínio empresarial possuir um sistema de backbone (em parceria com a empresa Telefônica) significa dizer que possui privilégios quando à rapidez e eficiência na transmissão de informações, principalmente porque esta tecnologia impede a interrupção do serviço. Esse fato é essencial, por exemplo, para empresas de telecomunicação, call centers e outros tipos de serviços que precisam funcionar 24h. Esta é uma condição que mostra a inserção do condomínio empresarial como parte do meio técnico-científicoinformacional, permitindo rápida (e garantida) circulação de informações.
} 


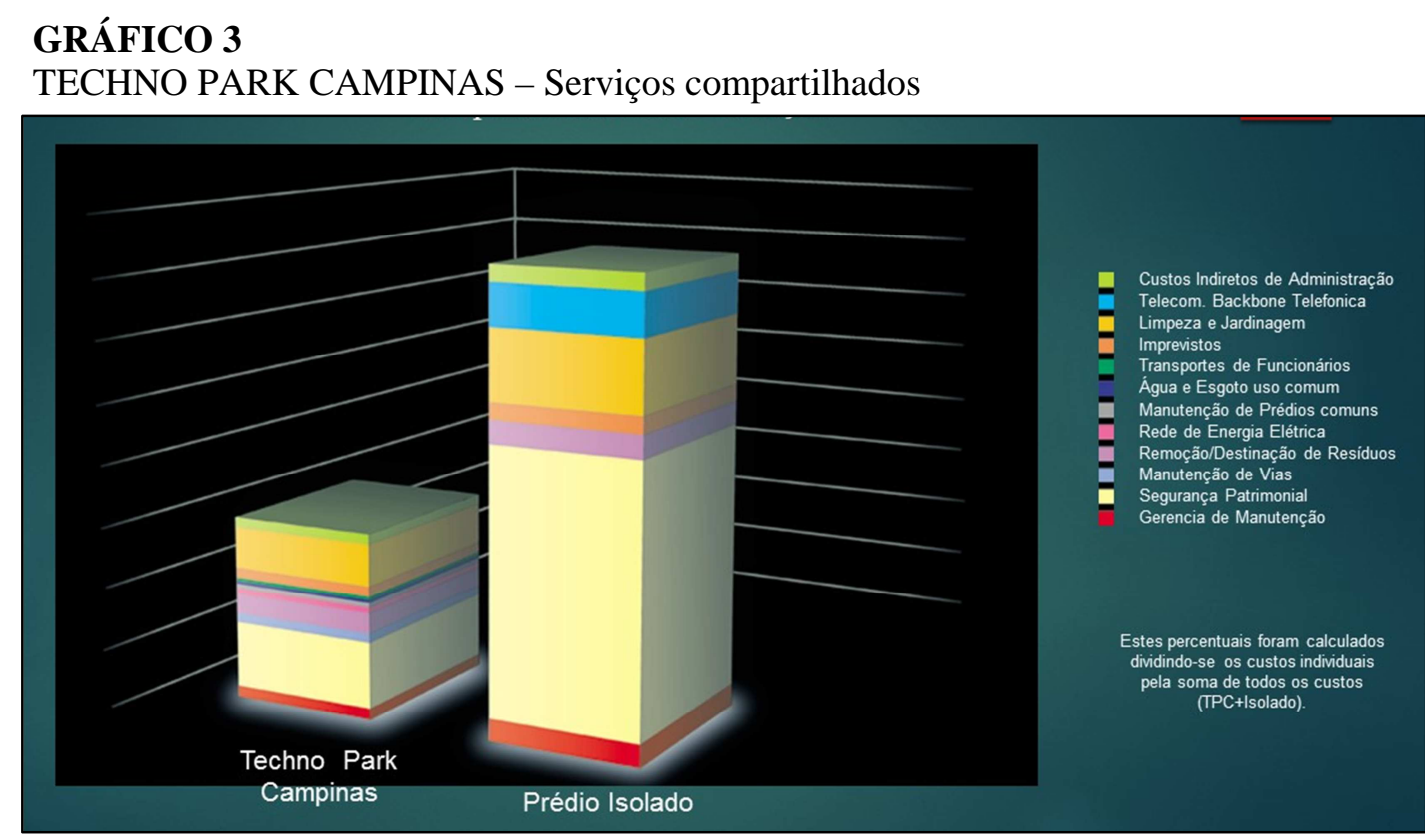

Fonte: Techno Park Campinas (2015).

Finalmente, vale mencionar que após formalizar acordos de cooperação entre sua associação de empresas (ASSOCITECH) e demais centros de pesquisa principalmente Inova Unicamp e Instituto Agropolis (França) - o Techno Park obtêm o status e as vantagens fiscais para se credenciar como um parque tecnológico.

Estas vantagens expressam a linha de atuação do Governo do Estado de São Paulo ao criar o Sistema Paulista de Parques Tecnológicos (órgão colegiado que analisa e aufere o credenciamento de uma área industrial como um parque tecnológico, bem como monitora as ações necessárias para a manutenção do credenciamento), sobretudo por meio da Lei Paulista de Inovação que, a partir do credenciamento definitivo, todas as empresas do condomínio, mesmo aquelas que já estavam instaladas, podem usufruir.

O caso do Techno Park Campinas é emblemático por ter sido a primeira área privada a ingressar no SPTEC, o que sinaliza a associação entre as aglomerações industriais e a lógica imobiliária. O município de Campinas, onde se encontra, possui outros três parques tecnológicos, todos eles de natureza pública: Parque Científico e Tecnológico da Universidade Estadual de Campinas; Parque Tecnológico CTI-Tec, do Centro de Tecnologia da Informação Renato Archer (unidade de pesquisa do Ministério da Ciência, Tecnologia e Inovação) e Parque Tecnológico CPqD.

Algumas fotografias podem ajudar a caracterização deste espaço. Destacamos as condições urbanísticas do espaço interno (Fotos 27, 28 e 29), entre elas a existência de um centro de convenções, e também a possibilidade de serviços terceirizados, como hotel (Foto 30). 


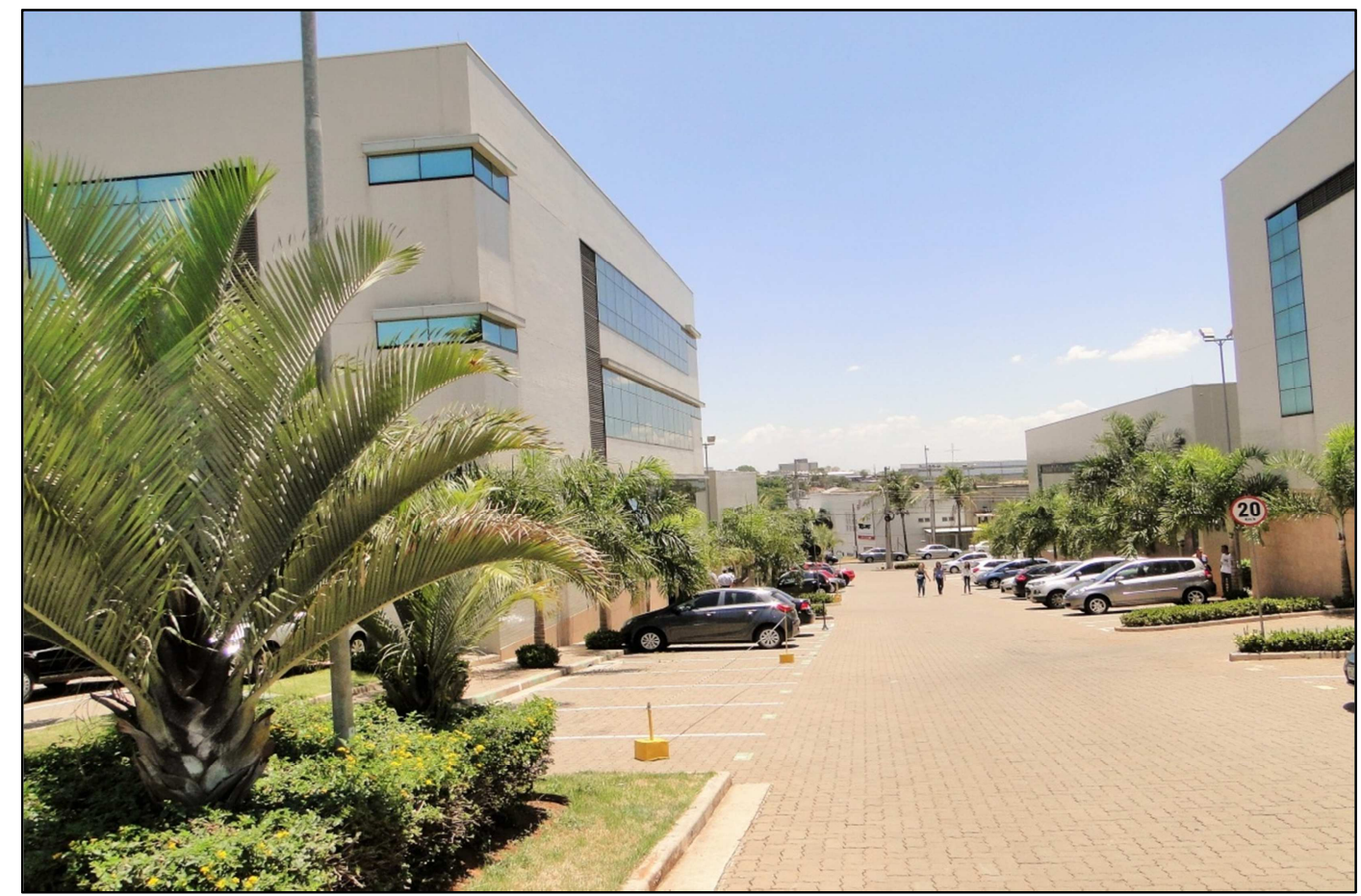

FOTO 27 - Techno Park Campinas, via de circulação interna. Na parte esquerda da imagem, em segundo plano, prédio da empresa Transitions (fabricante de lentes fotossensíveis). Fonte: Techno Park Campinas (2015).

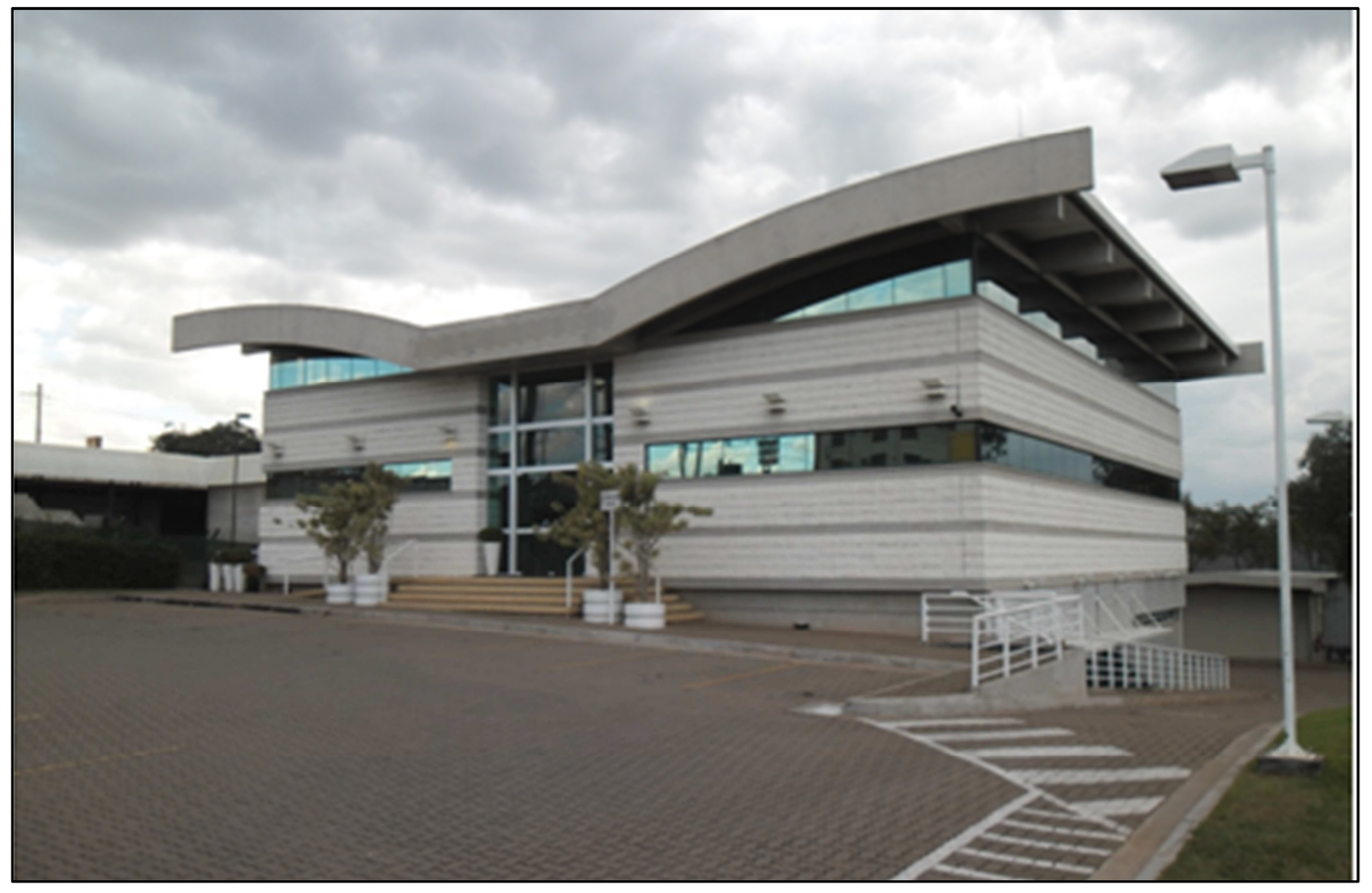

FOTO 28 - Centro de convenções do Techno Park Campinas. Fonte: Techno Park Campinas (2015). 


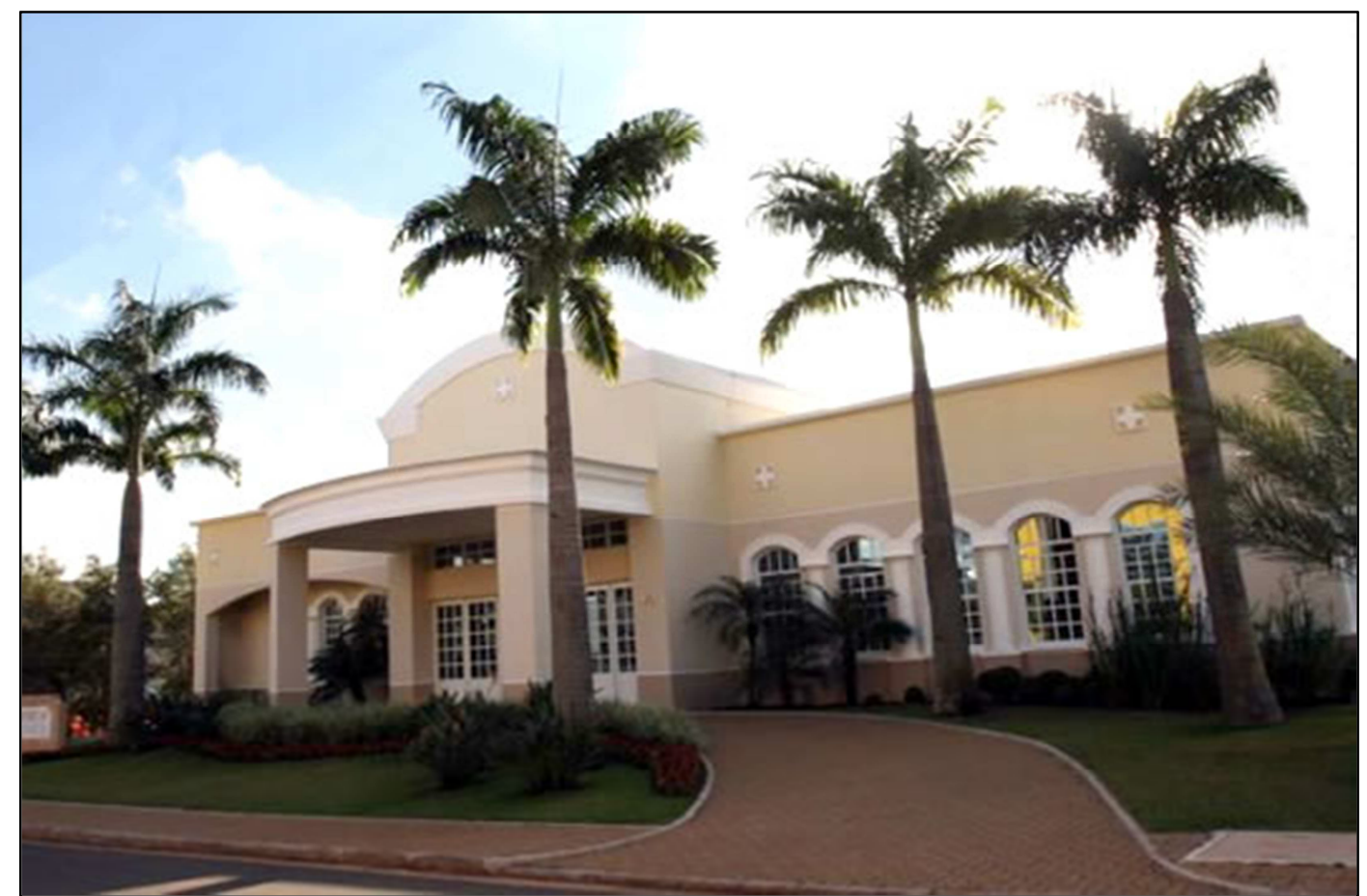

FOTO 29 - Fachada da Intertech Worldwide no Techno Park Campinas (empresa produtora de equipamentos para logística e usinagem). Fonte: Techno Park Campinas (2015).

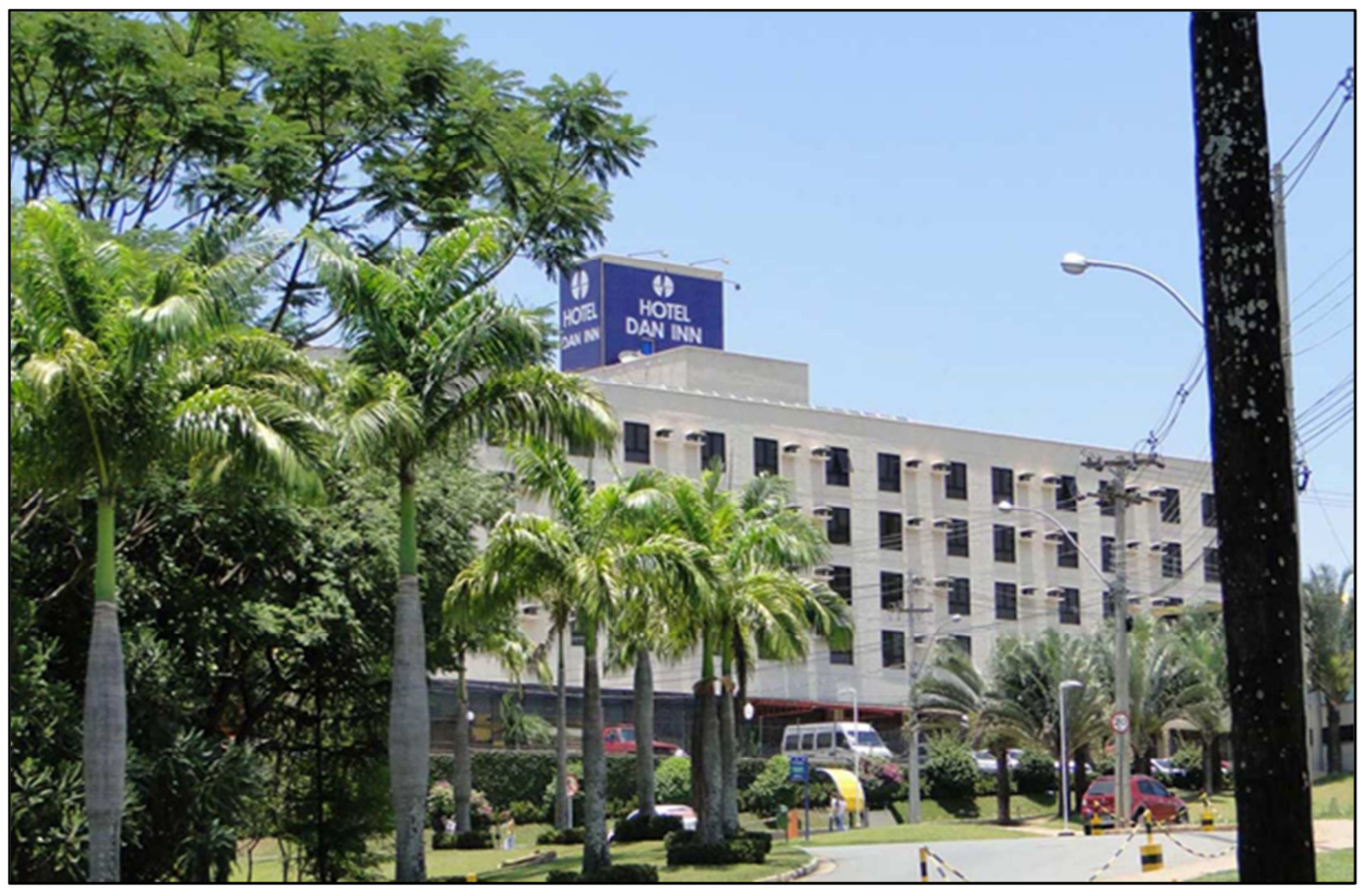

FOTO 30 - Hotel Dan Inn no Techno Park Campinas. Fonte: Techno Park Campinas (2015). 


\subsubsection{O território especializado: Parque Tecnológico de São José dos Campos}

O primeiro aspecto importante a ser ressaltado, a partir da entrevista com um dos gestores do Parque Tecnológico de São José dos Campos ${ }^{166}$ diz respeito às estratégias empregadas para a implantação do parque. O que sustentou os primeiros anos do parque, sobretudo em termos de viabilidade econômica foi a participação direta da prefeitura municipal. Isso difere dos outros modelos tradicionais que existem no Brasil, nos quais é a universidade e o governo do estado é que ancoram e dão este suporte financeiro à implantação da área.

Essa situação explica, de certa maneira, a existência de um parque tecnológico num município onde, no momento de sua implantação, não existia uma grande universidade $^{167}$, muito embora existissem instituições de pesquisa, tais como o Centro Técnico Aeroespacial e Instituto Tecnológico da Aeronáutica (CTA/ITA) e a Empresa Brasileira de Aeronáutica (EMBRAER). Estas instituições, inclusive, tem laboratórios instalados no parque, atualmente. A fundação do Parque Tecnológico de São José dos Campos é de 2007, com a aprovação de um planejamento estratégico em uma visão de sete anos (2008-2015) de acordo com H. A. Forjáz et al. (2013).

Todavia, o potencial de fomento de relacionamento entre agentes no caso de um Parque Tecnológico mostrou-se grande a partir da consolidação do empreendimento em São José dos Campos. As instituições formalmente localizadas em São José dos Campos hoje apresentam laboratórios no parque. Todavia, há uma equipe que trabalha justamente para fomentar estes relacionamentos. A entrevista com um dos gestores do parque $^{168}$ permitiu identificar que existem, hoje, 300 parcerias firmadas (sendo 70\% delas localizadas no próprio Estado de São Paulo). Entre as parcerias, Universidade de São Paulo (USP) e Universidade Estadual Paulista (UNESP) mantem relacionamento com o parque tecnológico. Outras instituições optam por instalar-se fisicamente, casos do SENAI e da Faculdade de Tecnologia do Estado de São Paulo (FATEC), bem como da UNESP, já

\footnotetext{
${ }^{166}$ Como exemplo de um território especializado para o uso produtivo, visitamos o Parque Tecnológico de São José dos Campos. Nossa entrevista foi realizada com L. F. Carvalho (Gestor de empresas e instituições) no dia 02 de setembro de 2016.

${ }^{167}$ No Estado de São Paulo entendemos que tem esse papel as seguintes universidades públicas: Universidade Estadual de São Paulo (USP), Universidade Estadual de Campinas (UNICAMP) e Universidade Estadual Paulista (UNESP).

${ }^{168}$ L. F. Carvalho, gestor de empresas e instituições no Parque Tecnológico de São José dos Campos, em entrevista realizada no dia 02 de setembro de 2016.
} 
mencionada, que abriu um campus no parque tecnológico, no qual funciona o curso de Engenharia Ambiental.

Nesse sentido, foi possível verificar o significado prático da sinergia que pode ser fomentada no parque tecnológico. Ela tem muitas escalas de ligação: no interior do próprio Parque Tecnológico por meio de parcerias entre as empresas participantes, que optam por realizar pesquisas de interesse comum. A etapa de pesquisa e desenvolvimento é pré-competitiva e por isso não fere possíveis estratégias comerciais das empresas. Nosso interlocutor afirmou: "O parque é um ambiente de parcerias". Outra escala de ligação entre os agentes é a regional, na qual ocorre a maioria dos relacionamentos do parque, dela participam universidades e empresas envolvidas com pesquisa, desenvolvimento e inovação.

Uma terceira e importante escala, que também remete ao interior do parque tecnológico diz respeito à vivência dos alunos junto às empresas, pesquisadores e laboratórios. Esse contexto cria um ambiente de estudos e de relacionamento no qual os alunos podem ter contato direto com seu objeto de estudo (evidentemente, se a empresa influenciar as pesquisas universitárias apenas a sua demanda particular), bem como laboratórios, ensaios técnicos e também com os pesquisadores. Além de uma vivência cultural, muitas vezes isso acaba também direcionando os alunos ao envolvimento com atividades de pesquisa, mesmo que em outras empresas nas quais irão se desenvolver profissionalmente, sem ser estas as empresas do parque.

Pelas razões acima explicitadas, podemos argumentar sobre uma das principais caraterísticas do parque tecnológico enquanto uma aglomeração produtiva, ou seja, sua capacidade para fomentar relacionamentos e propiciar ações sinérgicas entre as empresas.

O mesmo caso pode ser afirmado para o caso do Techno Park Campinas, muito embora seja este um parque tecnológico muito mais recente, como mostramos no item anterior. As parcerias em andamento no Techno Park Campinas envolvem instituições locais e internacionais (em andamento, mencione-se a parceria com a Inova Unicamp, FIniciativas e CVT Valorization SUD) e visam subsidiar as empresas no tocante à aproximação empresa-universidade e também facilitar a obtenção de financiamento para a pesquisa.

Em especial, mencione-se a participação do Techno Park Campinas no Programa Agropolis Campinas ${ }^{169}$, de natureza internacional e que congrega as seguintes

\footnotetext{
${ }^{169}$ De acordo com o Projeto de Ciência, Tecnologia e Inovação do Techno Park Campinas (2015).
} 
instituições: Agropolis Internacional ${ }^{170}$, UNICAMP, Secretaria Estadual de Agricultura e Abastecimento, Prefeitura Municipal de Campinas e Techno Park Campinas, com o seguinte objetivo: “[...] estabelecer o intercâmbio entre as incubadoras instaladas nas duas regiões, objetivando estimular o surgimento de startups" (TECHNO PARK CAMPINAS, 2015, p.73).

Ambas as aglomerações, embora tenham um sistema de gestão próprio das áreas, apresentam núcleos de gestão para a ciência e tecnologia. O Parque Tecnológico de São José dos Campos possui seu núcleo de "Empresas e Instituições" e o Techno Park Campinas, junto à Associação dos Empresários do Techno Park (ASSOCITECH), possui o seu Comitê de Ciência e Tecnologia. Na visão do gestor do parque de São José dos Campos $^{171}$, um parque tecnológico tem o papel de ser "meio de campo" entre universidade e empresa, fomentando relacionamentos, parcerias e financiamento. Ambas as instituições também realizam palestras e workshops sobre temas pertinentes.

$\mathrm{Na}$ condição de aglomeração produtiva, nos perguntamos, para os parques tecnológicos, quanto à presença de atividades de transformação. No caso do Techno Park Campinas, mais simples, o percentual é $65 \%$ de unidades industriais, muito embora não seja esse um parque tecnológico genuíno ${ }^{172}$. O Parque Tecnológico de São José dos Campos, de acordo com nossa entrevista, tem a maioria de seus processos produtivos vinculados ao desenvolvimento de softwares. Existem ainda algumas atividades de transformação, porém unicamente vinculadas ao desenvolvimento de protótipos. Entre estas atividades, destacam-se os segmentos de estruturas leves, hardware aeronáutico, equipamentos médicos e saneamento ambiental.

Atualmente, é preocupação do Parque Tecnológico de São José dos Campos que os processos que necessitem de produção em escala (resultado esperado da inovação tecnológica) tenham um local adequado para a produção. Por esta razão, uma iniciativa atual tenta articular o parque tecnológico a um distrito industrial (vinculado ao parque, inclusive no mesmo terreno) no qual as empresas tenham subsídios para implantar seus processos fabris em escala. Atualmente, existe apenas um comitê que auxilia este tipo de

\footnotetext{
${ }^{170}$ Instituto de pesquisa científica sediado em Montpellier (França), com ênfase no segmento agroalimentar e desenvolvimento sustentável. Mais informações disponíveis em: 〈http://www.agropolis.fr〉 Acesso: setembro de 2016.

${ }^{171}$ L. F. Carvalho, gestor de empresas e instituições no Parque Tecnológico de São José dos Campos, em entrevista realizada no dia 02 de setembro de 2016.

${ }^{172}$ Como já destacamos, a origem e principal nicho deste empreendimento é o imobiliário. Entretanto, a observação é válida, pois verificamos também uma tendência de que outros empreendimentos privados também participem do processo de obtenção de credenciamento (provisório e depois permanente) junto ao Sistema Paulista de Parques Tecnológicos.
} 
indústria nascente a encontrar um local apropriado para a produção fabril, no momento em que a empresa precisa se "desprender" do parque tecnológico, sobretudo as empresas que se encontram incubadas (o tempo médio de permanência de uma empresa em incubadora é de cinco anos, e no Parque Tecnológico de São José dos Campos o tempo máximo permitido é de sete anos).

Dessa forma, podemos nitidamente encaixar o parque no circuito da produção como uma etapa (pré-comercial) de pesquisa, desenvolvimento e inovação, cujos resultados e produtos tendem a fazer parte do circuito produtivo em etapas de produção em escala e standartizada, após o desenvolvimento tecnológico (produtos e processos produtivos). Na condição de aglomeração produtiva existem processos de transformação que ocorrem no parque, apesar de não serem processos em escala. Na condição de etapa de um circuito produtivo maior o parque insere-se como uma aglomeração especializada para o desenvolvimento tecnológico.

Algumas fotografias do Parque Tecnológico de São José dos Campos estão disponibilizadas na sequência: o portal de entrada do parque, bem como parte de sua sede administrativa (Foto 31) e uma das vias internas, na qual se pode verificar algumas infraestruturas que albergam os laboratórios (Foto 32). 


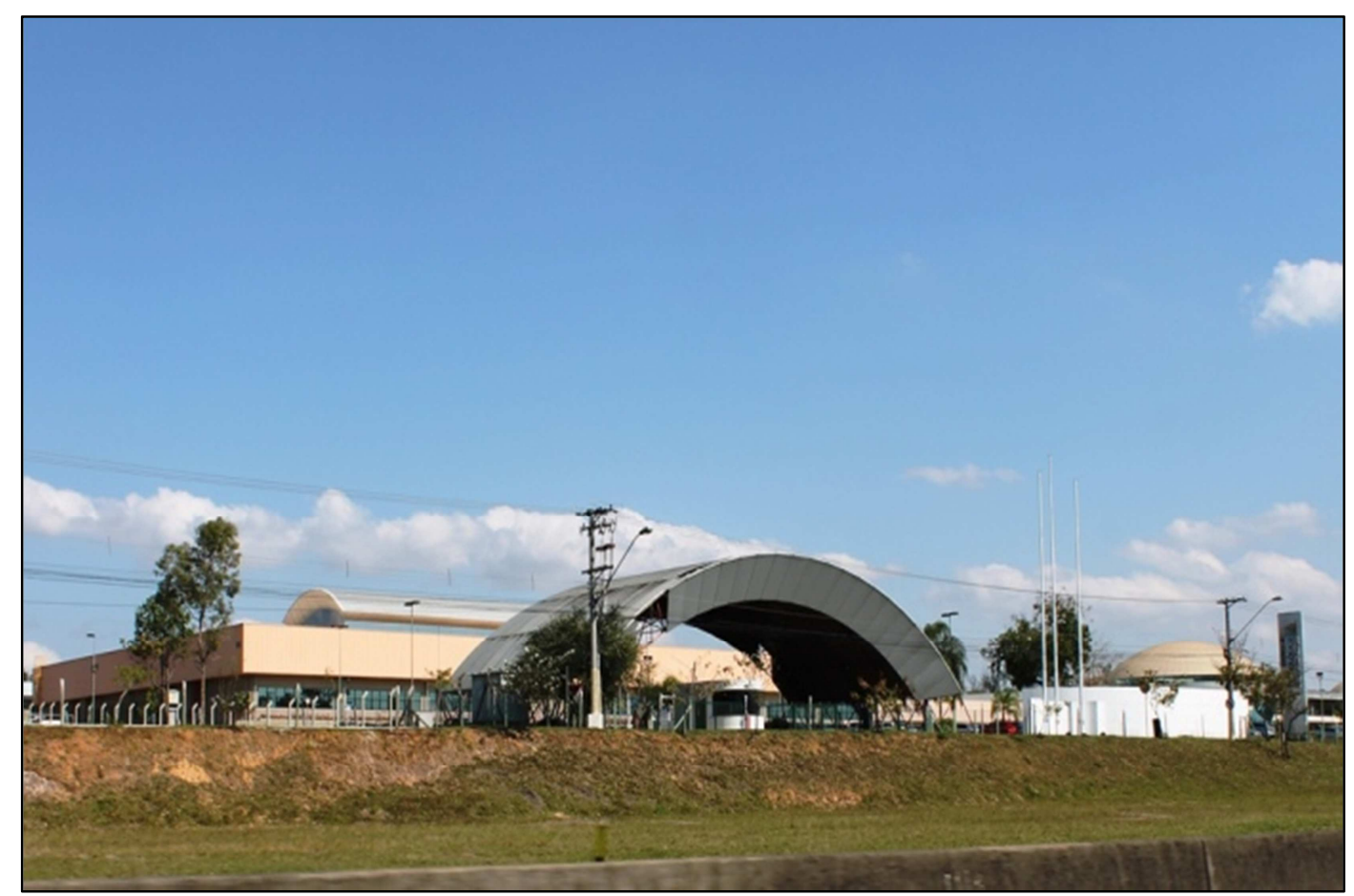

FOTO 31 - Parque Tecnológico de São José dos Campos, portaria do empreendimento. Em segundo plano se verifica parte da sede administrativa do parque. Fonte: Rodolfo Finatti, trabalho de campo, 2016.

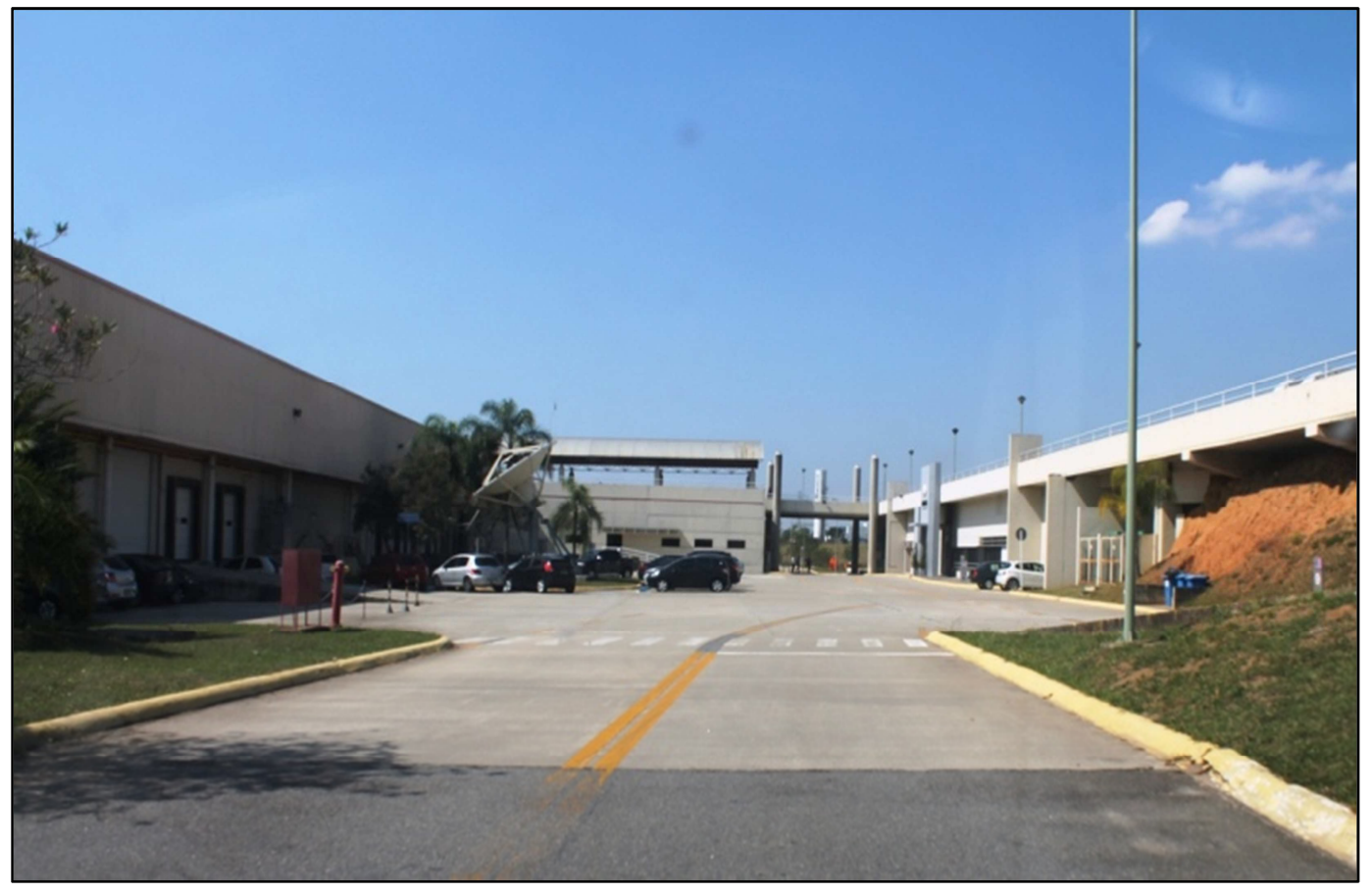

FOTO 32 - Via interna do Parque Tecnológico de São José dos Campos. Verificamse, à direita e à esquerda desta via, algumas infraestruturas nas quais funcionam laboratórios. Fonte: Rodolfo Finatti, trabalho de campo, 2016. 


\section{CONSIDERAÇÕES FINAIS}

As aglomerações industriais expressam a geografia econômica na condição de um traço marcante de sua distribuição e concentração no território, bem como na condição de uma forma geográfica capaz, uma vez implantada, de motivar outros processos econômicos e sociais, como as decisões de localização de outros investimentos e infraestruturas. Podemos apontar uma carência de estudos com caráter mais abrangente (não apenas estudos de casos) que permitam melhor sistematizar o conhecimento sobre as aglomerações industriais e produtivas, atualizar suas características e articular este fenômeno com relação ao conjunto do território.

É indispensável dizer que as aglomerações industriais são áreas articuladas a muitos processos: industriais, logísticos, comerciais, residenciais, ambientais, de serviços, de lazer, etc. Sua localização pode se dar em áreas economicamente dinâmicas, fazendo com que tenham uma taxa de ocupação expressiva ou, por outro lado, podem ser aglomerações industriais desocupadas. Em outra perspectiva, podem ser pontos isolados com dinamismo produtivo em regiões cuja economia não acompanha o mesmo dinamismo. Elas podem ser muito bem delimitadas e acessíveis ou podem ser área cujo acesso é securitizado e controlado. Podem ser também fragmentadas, descontínuas e organizadas em rede. Muitas vezes se conectam apenas localmente, porém outras vezes ativam escalas comerciais e informacionais em outros pontos do mundo. Todas estas situações foram verificadas no decorrer de nossa pesquisa.

Para os referenciais teóricos acadêmicos ou mesmo na perspectiva da instrumentalização da gestão pública, almejamos registrar alguns caminhos de interpretação e noções que permitam posteriores análises e comparações sobre este fenômeno. Uma vez que tentamos percorrer esta trajetória, identificamos como a formação espacial brasileira determinou e determina investimentos (públicos ou privados) que resultam nas formas de aglomeração industrial. Com isso, ao mesmo tempo, se reforça a diferenciação existente no território nacional: dinamismo econômico na Região Concentrada estimulando a maioria dos investimentos e inovações versus investimentos pontuais em pequenas manchas de dinamismo nas regiões Norte, Nordeste e Centro-Oeste. 
Essa concentração (polarização) manifesta-se ao mesmo tempo na distribuição das aglomerações industriais e suas características.

A distribuição geográfica da indústria se associa à estrutura econômica do território nacional, conforme evidenciado no mapa que se intitula Indústria de transformação e sua tendência à concentração geográfica (Mapa 2). Trata-se de uma distribuição muito concentrada no Sudeste e Sul, com manifestações densas (porém pontuais) no Nordeste. Nota-se também uma ampliação da mancha industrial para o Estado de Goiás, partindo de Minas Gerais e São Paulo, evidenciando uma possível expansão do polígono industrial.

Outro aspecto territorial importante que as aglomerações industriais permitem elucidar diz respeito às dinâmicas pertinentes a cada uma, e destas com relação às características da região nas quais estão inseridas, caracterizando a própria formação espacial brasileira. A análise dos mapas 4 a 8 (distribuição das aglomerações industriais, por tipo) referentes aos estados de São Paulo, Rio de Janeiro, Minas Gerais, Bahia e Amazonas, mostra diferentes tipos de complementaridade entre a "capital" de uma unidade estadual e o seu chamado "interior", permitindo um debate sobre o que muitas vezes é entendido de forma linear e mecânica em todo o território: se encontra mais desenvolvimento nas capitais e menos desenvolvimento no interior dos estados.

As aglomerações industriais permitem observar diferentes dinâmicas no interior dos estados brasileiros. Fica evidente a grande diferença entre o interior (lugares mais afastados da capital) de São Paulo ou de Minas Gerais, com muitos e bem distribuídos fixos, em relação à Bahia, Amazonas, ou mesmo Rio de Janeiro, em que há menor número de fixos e concentrados em poucos pontos do território, cada um por razões específicas, que podem estar relacionadas tanto às políticas industriais, à produtividade espacial ou ao meio natural predominante em cada unidade estadual. Portanto, o que é a "capital" e comparativamente o que é o "interior" requer que sejam consideradas as particularidades.

Em relação à ação do poder público, dimensão à qual demos destaque na tese, devemos mencionar que o mais tradicional instrumento de tentativa de atração de indústrias é ainda o distrito industrial. No Nordeste, especialmente, esta forma aglomerativa é objeto de iniciativas atuais, sendo algumas delas inovadoras em relação aos primeiros distritos brasileiros (principalmente no que tange à busca por novos modelos $\mathrm{e}$ parcerias para novos distritos industriais, por parte das secretarias de planejamento estaduais). No Sudeste, especificamente no Estado de Minas Gerais, podemos mencionar 
uma ação expressiva em curso - por parte do governo do estado, SEBRAE e sindicato patronal da indústria - que visa justamente a renovação e modernização de todos os 48 distritos industriais mineiros. Em outras palavras, novos projetos envolvendo distritos industriais são desenvolvidos, o que mostra a ação do poder público e uma tendência de adaptação desta aglomeração, sejam eles novos distritos ou não.

O Estado é também responsável por potencializar áreas que já tem algum dinamismo industrial, dentro ou fora das principais manchas econômicas, e isso é evidenciado pelas ações envolvendo os arranjos produtivos locais. Há várias iniciativas de fomento a estas aglomerações existentes e atuantes em todas as unidades estaduais visitadas em campo. Apesar das dificuldades específicas para que cada estado possa alavancar estas iniciativas - e isso diz respeito à formação espacial - em linhas gerais verificamos a existência de uma abordagem voltada às micros e pequenas empresas, inclusive no interior dos respectivos estados. Esse é um aspecto que mostra uma das maneiras como o Estado está presente nestas áreas mais afastadas. $\mathrm{O}$ arranjo produtivo local, no papel de aglomeração industrial, evidencia a importância da concentração e da proximidade entre as empresas, e mostra que elas podem ter alguma representatividade econômica, mesmo que afastadas das manchas e das áreas metropolitanas.

No que tange à linha de atuação direta do incorporador imobiliário, responsável principalmente pelos condomínios empresariais e das demais empresas que, em parte, são incentivadoras dos parques tecnológicos (os parques tendem a seguir o modelo triple helix, o qual define o modelo de participação conjugado entre poder público, universidade e empresas), identificamos com mais clareza a diferenciação regional brasileira e a seletividade espacial. A grande concentração $(80 \%)$ destes investimentos está na Região Concentrada, sobretudo no Estado de São Paulo, e nas áreas metropolitanas, o que denota a preferência do incorporador imobiliário.

Se compararmos a distribuição destas diferentes formas de aglomeração, fica evidente a concentração econômica e a localização predominante dos novos investimentos no território nacional. Quanto a isso podemos apontar:

(a) Aprofunda-se uma divisão territorial do trabalho já consolidada: as aglomerações predominam nas áreas em que já existe o maior conteúdo técnico, de pesquisa, de inovação e de produção e circulação de informações, reforçando diferenciações regionais. 
(b) Localização seletiva (ou restritiva) dos investimentos: há maior produtividade em algumas parcelas do território nacional e isso se reflete na seletividade espacial dos investimentos, o que mostra que as decisões de localização da indústria respeitam fatores locacionais determinados. Em outras palavras, a dispersão dos investimentos é delimitada pela configuração territorial.

Em contrapartida, podemos afirmar que existe diversificação da natureza do investimento. Em relação a todos os tipos de aglomeração que estudamos mais detalhadamente (distritos industriais, polos industriais, arranjos produtivos locais, condomínios empresariais e parques tecnológicos) pudemos identificar algum nível de dispersão no conjunto do território, considerando apenas as iniciativas recentes. Ou seja, a seletividade espacial dos investimentos econômicos, embora permaneça concentrada pela lógica dos fatores locacionais, apresenta uma tênue diversificação (todos os tipos de investimentos ocorrem em todas as regiões do país).

A importância desta diversificação radica no fato de que é melhor distribuir o investimento, pois se torna possível acompanhar as mudanças da estrutura produtiva. Uma vez que é frequente das aglomerações industriais transformar-se/adaptar-se às características do período atual, aumentam-se as chances de reverter a lógica da diferenciação regional. Se outrora as aglomerações industriais eram uma área dedicada exclusivamente ao chão de fábrica, atualmente são áreas diversificadas e até especializadas, podem ser voltadas a unidades produtivas menores e também a um leque de serviços industriais que a elas se coadunam. Podemos afirmar que, cada vez mais, fazem parte das aglomerações industriais a gestão, pesquisa e desenvolvimento, prestadores de serviços, operadores logísticos e outras funções terceirizadas de alimentação, segurança ou lazer.

É importante lembrar que consideramos as aglomerações industriais não apenas como um resultado. Assim como quaisquer outras formas geográficas, são expressão de uma intencionalidade (preparar o território para o uso produtivo), cuja localização resulta de critérios (os quais devem considerar uma configuração territorial prévia ou configuração territorial de base) e que, por sua vez, cumprindo seu papel, são capazes de definir e redefinir localizações de outros fixos e estimular fluxos de pessoas, produtos e informações. Ou seja, passam a integrar e potencialmente ser pontos ativos de circuitos produtivos em diversas escalas.

A aglomeração industrial é uma importante expressão geográfica da industrialização, devido à concentração (no sentido expressivamente geográfico) e à 
capacidade desta concentração em orientar processos econômicos e sociais, tanto na direção de um possível crescimento econômico quanto na ampliação de desigualdades ou outros déficits sociais e ambientais.

Vale ressaltar algumas análises pormenorizadas, sobretudo quanto à ação dos incorporadores imobiliários. Em linhas gerais, as características das formas de aglomeração permitem afirmar que são os investimentos particulares que mais rapidamente acompanham as tendências e transformações da indústria (restruturação produtiva) e são também aqueles que, com mais eficiência, produzem os objetos geográficos e funcionalidades pertinentes ao período contemporâneo, portanto compondo parte importante do meio técnico-científico-informacional.

O estudo atual das aglomerações industriais deve considerar, sem dúvida, o papel desempenhado pelo investimento privado, não apenas pela força do mercado, mas efetivamente como um agente planejador e produtor do território. $\mathrm{O}$ número de condomínios empresariais apresenta crescimento e dispersão pelo território, o que permite uma reflexão: quais são os critérios de localização dos incorporadores imobiliários? Evidentemente, diferente do Estado, seu objetivo é a mercantilização do solo urbano, disso resultando impactos na urbanização e na economia regional.

A atuação destes agentes econômicos permite também dialogar com a ideia de um período da formação social que seria a da "privatização" da gestão do território, uma vez que a decisão de investimento é do agente privado e, portanto, a posterior atração de empresas fica condicionada por este agente, o que difere muito do papel do Estado (desenvolvimentista) que, como contraponto, era investidor direto nas áreas consideradas menos dinâmicas. Uma face da privatização da gestão do território são os hibridismos identificados pela pesquisa. Entre eles, o mais emblemático é o poder público, na figura da prefeitura municipal, chamando ao investidor imobiliário para parcerias que resultam em um tipo de "distritos-condomínios".

Entretanto, assim como aconteceu com os edifícios corporativos voltados ao segmento de escritórios, a literatura especializada no tema já apontou uma redução esperada nestes investimentos para os próximos anos, sob o risco de uma alta taxa de vacância nos empreendimentos já existentes, portanto as análises referentes aos condomínios empresariais devem seguir cautelosas.

Com base nesta perspectiva, podemos questionar se não seriam os condomínios empresariais os indicativos para um processo de desindustrialização em curso. Uma esperada taxa de vacância nos empreendimentos poderia ser a indicação de um 
arrefecimento da economia e do investimento industrial. Além disso, podemos reforçar que parte dos condomínios empresariais, embora tenham indústrias instaladas, albergam outros segmentos econômicos (armazenagem e logística, serviços industriais e escritórios, entre os principais).

Em um ponto de vista conceitual, devemos destacar que o estudo das aglomerações industriais não pode limitar-se ao que se considera estritamente industrial. Embora os tipos clássicos (distritos industriais, polos industriais) definem-se, a priori, como aglomerações industriais, não o são de fato. Trata-se de áreas que estão passando por expressiva transformação, desde a tendência à regularização de áreas residenciais já antigas nos distritos, até a presença conjunta de outros segmentos econômicos.

Além disso, mostra-se a tendência de que as formas de aglomeração mais recentes acompanhem as caraterísticas atuais da indústria. Neste sentido, são unidades menores, modulares e flexíveis, o que tende a dinamizar ainda mais a noção de circuito produtivo, pois quanto mais "modularizada", mais vantajosa é a proximidade com fornecedores (e diminui-se a necessidade de logística de transportes). Neste raciocínio, verifica-se uma das vantagens locacionais dos condomínios de galpões modulares e como eles se coadunam com as características do período contemporâneo.

Essa síntese de ideias sobre as aglomerações industriais - como definidas a rigor - precisa, ainda, ser estudada e atualizada. O que se verifica hoje, considerando: (1) as transformações pelas quais estão passando as áreas tradicionais, (2) as características próprias da organização industrial atual, (3) a configuração das aglomerações de natureza imobiliária e (4) as características da configuração territorial e do meio técnico-científicoinformacional, é a existência de aglomerações industriais que podem ou não ter algum segmento econômico predominante. São aglomerações industriais que devem ser analisadas pela localização e papel que desempenham nos circuitos produtivos.

Portanto, nossa sugestão para aprimorar a análise das aglomerações industriais/produtivas é que sejam analisadas a partir da divisão territorial do trabalho (territórios especializados e seu uso corporativo) e a partir do circuito produtivo (quais ramos da produção e quais fases dos circuitos produtivos predominam nas aglomerações, pois um mesmo tipo de aglomeração pode ser direcionado para diferentes ramos, bem como para diferentes etapas de um mesmo circuito). Esse seria outro caminho viável, complementar, para classificar e analisar os tipos de aglomeração industrial.

Por fim, as aglomerações industriais ou produtivas mostram a importância da proximidade. Cada qual por meio de uma determinação específica, a proximidade 
geográfica é relevante para a atividade produtiva e isso pode ser apresentado por meio da análise das diferentes formas de aglomeração.

No caso dos distritos industriais são as externalidades comparativas que priorizam a área, como os conjuntos de fortes incentivos fiscais que se responsabilizaram por povoar os principais distritos brasileiros. Para os polos industriais fala-se dos efeitos indutores em cadeia, formando um tipo de complexo, porém a própria indústria química tem também uma necessidade inerente de proximidade devido às características da produção, circulação de insumos e análises de risco/medidas de segurança necessárias. Os arranjos produtivos locais apresentam uma localização e proximidade históricas, bem como são também a forma que apresenta mais forte relação como o meio em que se insere. Os condomínios empresariais, também como um tipo de vantagem comparativa, apresentam e publicizam a divisão de gastos entre as empresas coproprietárias da área como aspecto que viabiliza estes empreendimentos financeiramente e cumpre o papel da atração e (posteriormente) de inércia das empresas, garantindo a manutenção de sua localização.

Os parques tecnológicos apoiam-se na proximidade entre os agentes e tem como princípio o contato face-a-face como estratégia para aumentar o nível de interações entre pesquisadores e suas preocupações, um dos aspectos mais abordados da literatura a este respeito. A proximidade já é pressuposto do parque tecnológico.

Com base na tendência de que as empresas respeitem as especificidades locacionais de seu ramo, há aglomerações produtivas especializadas que contemplam estas especificidades: pesquisa e desenvolvimento (pré-comercial), gerenciamento das atividades (organizacional), produção propriamente dita (processos de transformação, especializados ou escalares), armazenamento e transporte (circulação).

As aglomerações, nesse sentido, são expressão da divisão territorial do trabalho e mostram a seletividade especial (neste caso, seletiva ou específica para cada segmento ou atividade). Para cada etapa, um conjunto de fatores importantes se faz presente. As formas de aglomeração, como se organizam, se localizam e sua indução nas decisões locacionais das empresas, mostram que há maior rigor na decisão locacional, opostamente à ideia de que haveria atualmente maior liberdade.

Em síntese, as aglomerações industriais são uma das formas geográficas que explicam a formação espacial e a estruturação do território brasileiro, permitem analisar os papéis complementares do Estado e do mercado, induzem a divisão territorial do trabalho e 
sua especialização em alguns pontos, bem como evidenciam a importância da proximidade para a atividade produtiva. 


\section{REFERÊNCIAS}

ANDRADE, M. C. de. Espaço, polarização e desenvolvimento (a teoria dos polos de desenvolvimento e a realidade nordestina). São Paulo: Brasiliense, 1970.

ARROYO, M. M. La división territorial del trabajo: un processo y uma categoria para interpretar el mundo. In: Anais da $4^{\mathrm{a}}$ Conferencia Internacional de Geografía Crítica. Ciudad Del Mexico, 2005.

ARROYO, M. A economia invisível dos pequenos. Le Monde Diplomatique Brasil, 2008. pp.3021. Disponível em: <http://www.diplomatique.org.br/artigo.php?id=283>. Acesso: outubro de 2016.

ASSOCIAÇÃO DAS EMPRESAS DO DISTRITO INDUSTRIAL DE QUEIMADOS (ASDINQ). Endereço do sítio virtual da associação. Disponível em: <http://asdinq.org.br〉. Acesso: novembro de 2015.

ASSOCIAÇÃO NACIONAL DE ENTIDADES PROMOTORAS DE EMPREENDIMENTOS INOVADORES (ANPROTEC). Endereço do sítio virtual da associação. Disponível em: <http://anprotec.org.br/site/>. Acesso: abril de 2016.

AUDY, J. L. N.; MOSCHETTA, R.A.; FRANCO, P.R.G. Modelo de atração de empresas focado na pesquisa e na pós-graduação: o caso do Tecnopuc. In: HAUSER, G. e ZEN, A.C. (Org.). Tecnopole: o desafio da sinergia. Porto Alegre: Nova Prova, 2005. pp.183-200.

BALDONI, L. A estratégia empreendedora da Unicamp para a consolidação do Parque Científico e Tecnológico, 2015. Dissertação (Mestrado) - Instituto de Geociências, Universidade Estadual de Campinas, Campinas.

BARAT, J. A evolução dos transportes no Brasil. Rio de Janeiro: IBGE/IPEA, 1978.

BARBOSA, C. A. A FIESP E O ESTADO NACIONAL: De escudeiros e opositores (Uma breve história do empresariado industrial paulista e a crise do regime autoritário), 2008. Dissertação (Mestrado) - Faculdade de Filosofia, Letras e Ciências Humanas, Universidade de São Paulo, São Paulo.

BARROS, J. B. A experiência regional de planejamento. In: LAFER, B. M. (org.). Planejamento no Brasil. São Paulo: Editora Perspectiva, 1970. pp.111-138.

BECATINI, G. O distrito marshalliano. In: BENKO, G. e LIPIETZ, A. As regiões ganhadoras. Distritos e redes: os novos paradigmas da geografia econômica. Oeiras: Celta, 1994. pp.1932.

BENKO, G. Economia, espaço e globalização na aurora do século XXI. São Paulo: Hucitec, 1996. 
BETIM, L. M., RESENDE, L. M., AGNER, T. von. Aglomeração de empresas: uma avaliação dos modelos teóricos. In: Anais ADM2009 - Gestão Estratégica em Tempos de Mudanças. Ponta Grossa: UTFPR, 2009.

BITTENCOURT, J. T. Inovação e cooperação em arranjos produtivos locais, 2011. Tese (Doutorado) - Setor de Ciências da Terra, Programa de Pós-Graduação em Geografia Humana, Universidade Federal do Paraná, Curitiba.

BOUDEVILLE, J.-R. Os espaços econômicos. São Paulo: Difusão Europeia do Livro, 1973.

BRANDÃO, A. C. Território e desenvolvimento: as múltiplas escalas entre o local e o global. Campinas: Editora da Unicamp, 2007.

BRASIL. Programa de Metas do Presidente Juscelino Kubitschek. Estado do plano de desenvolvimento econômico em 30 de junho de 1958. Rio de Janeiro: Presidência da República, Serviço de Documentação, 1958.

BRASIL. Presidência. I Plano Nacional de Desenvolvimento 1971-1974. Rio de Janeiro: IBGE, 1971.

BRASIL. Presidência. II Plano Nacional de Desenvolvimento 1975-1979. Rio de Janeiro: IBGE, 1974.

BRASIL. Plano plurianual 2000-2003. Brasília: República Federativa do Brasil, 2000. Disponível em: <www.ifhc.com.br>. Acesso: julho de 2013.

BRASIL. Plano Brasil - Participação e Inclusão. Brasília: República Federativa do Brasil, 2004. Disponível em: <www.planobrasil.gov.br:. Acesso: julho de 2013.

BRASIL. Plano Plurianual 2008-2011 - Mensagem presidencial. Brasília: Ministério do Planejamento, Orçamento e Gestão, 2007.

BREDO, W. Industrial States: tool for industrialization. Glencoe: The Free Press, 1960.

BRUNA, G. C. Conceito de Distrito Industrial: notas de aula. São Paulo: FAUUSP, 1974.

CAMILLO, O. F. de., Distrito Industrial de Piracicaba. 1974. Trabalho de Graduação Individual (bacharelado) - Faculdade de Arquitetura e Urbanismo, Universidade de São Paulo, São Paulo.

CARDOSO, F. H. Nova Política Industrial: desenvolvimento e competitividade. Brasília: Presidência da República, 1998. Disponível em: 〈http://www.ifhc.com.br〉. Acesso: julho de 2013.

CARDOSO JUNIOR, O. L. O CIA - Centro Industrial Avançado: um novo espaço?, 2005. Dissertação (mestrado) - Centro de Ciências Humanas, Letras e Artes, Universidade Federal do Rio Grande do Norte, Natal.

CARVALHO, K. B. Territórios produtivos: estudo geográfico do I distrito industrial do Ceará, 2009. Dissertação (mestrado) - Centro de Ciência e Tecnologia, Universidade Estadual do Ceará, Fortaleza.

CANO, W. Desequilíbrios regionais e concentração industrial no Brasil 1930-1970. São Paulo: Global, 1985 [1998]. 
CANO, W. A desindustrialização no Brasil. Texto para discussão, Instituto de Economia da Universidade Estadual de Campinas IE/Unicamp, n²00, janeiro de 2012.

CASSIOLATO, J. E.; LASTRES, H. O foco em arranjos produtivos e inovativos locais de micro e pequenas empresas. In: CASSIOLATO, J. E.; LASTRES, H.; MACIEL, M. L. (Comp.). Systems of innovation and development: Evidence from Brazil. Cheltenham, RU: Edward Elgar, 2003.

CASTELLS, M. A sociedade em rede. São Paulo: Paz e Terra, 1999.

COURVET, C. e PECQUEUR, B. Os sistemas industriais locais em França. In: BENKO, G. e LIPIETZ, A. As regiões ganhadoras. Distritos e redes: os novos paradigmas da geografia econômica. Oeiras: Celta, 1994. pp.49-62.

CHARDONNET, J. Os grandes tipos de complexos industriais. Boletim Geográfico, Instituto Brasileiro de Geografia e Estatística, nº 185, março-abril de 1965. pp.218-223.

COMISSÃO INTERESTADUAL DA BACIA PARANÁ-URUGUAI. Projeto de um distrito industrial - Presidente Prudente. São Paulo: FAUUSP, 1966.

COSTA, W. M. da. O Estado e as políticas territoriais no Brasil. São Paulo: Contexto, 2011 [1988].

COSTA, H. A., SAWYER, D. R., NASCIMENTO, E. P. do. Monitoramento de APL de turismo no Brasil: o (não) lugar das dimensões da sustentabilidade. Revista Brasileira de Pesquisa em Turismo, vol. 3, $\mathrm{n}^{\mathrm{o}}$ 3, dezembro de 2009. pp.57-79.

CORREA, R. L. Interações espaciais. In: CASTRO, I., GOMES, P. C. C., CORREAA, R. L. (orgs.). Explorações geográficas: percursos no fim do século. Rio de Janeiro, Bertrand Brasil, 1997. pp.279-318.

CORREA, R. L. Trajetórias geográficas. Rio de Janeiro: Bertrand Brasil, 1997b.

DINIZ, C. C. Estado e capital estrangeiro na industrialização mineira. Belo Horizonte: Imprensa da UFMG, 1981.

DINIZ, C. C. Desenvolvimento poligonal no Brasil: nem desconcentração, nem contínua polarização. Nova Economia, Belo Horizonte, v.3, nº1, setembro de 1993. pp.35-64.

DINIZ, C. C. Impactos territoriais da reestruturação produtiva. In: RIBEIRO, L. C. de Q. (org.). $O$ futuro das metrópoles: desigualdades e governabilidade. Rio de Janeiro, Revan: Fase, 2000. pp.21-61.

DINIZ, C. C. e CROCCO, M. A. Reestruturação econômica e impacto regional: o novo mapa da

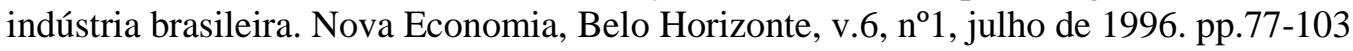

DUARTE, F. W. A Dinâmica da indústria de transformação do Rio Grande do Norte nos anos 90: o PROADI como indutor do processo de desenvolvimento industrial do Estado, 2000. Dissertação (mestrado) - Centro de Ciências Humanas, Letras e Artes, Universidade Federal do Rio Grande do Norte, Natal.

ESTALL, R. C. e BUCHANAN, R. O. Atividade industrial e geografia econômica. Rio de Janeiro: Zahar, 1976. 
ETZKOWITZ, H. e LEYDESDORFF, L. The dynamics of innovation: from National Systems and 'Mode 2' to a Triple Helix of university-industry-government relations. In: Research Policy, 29, 2000, pp. 109-123.

FEDERAÇÃO DAS INDÚSTRIAS DO ESTADO DE MINAS GERAIS (FIEMG) / COMPANHIA DE DESENVOLVIMENTO ECONÔMICO DE MINAS GERAIS (CODEMIG). Projeto de revitalização e modernização dos distritos industriais (Contagem: plano de ação - distrito industrial). Belo Horizonte: FIEMG/CODEMIG, 2015.

FELIPE, J. L. A. História da industrialização do Rio Grande do Norte. Natal: Federação das Indústrias do Rio Grande do Norte, 2010.

FERNANDES, J. C. Condomínios Logísticos: Porque os números de vacância continuam elevados? Galpão Aluguel e Venda, 2016. Disponível em: <http://galpaoaluguelevenda.com.br/2016/09/08/galpoes-logisticos/>. Acesso: outubro de 2016.

FINATTI, R. Condomínios empresariais nas áreas metropolitanas do Estado de São Paulo: produção imobiliária e localização da indústria, 2011. Dissertação (Mestrado) - Faculdade de Filosofia, Letras e Ciências Humanas, Universidade de São Paulo, São Paulo.

FINATTI, R. e SPOSITO, M. E. B. Produção do espaço urbano e fluidez territorial - análise das escolhas locacionais associadas ao Condomínio Empresarial Techno Park Campinas. Revista Brasileira de Estudos Urbanos e Regionais, Associação Nacional de Pós-graduação e Pesquisa em Planejamento Urbano e Regional - ANPUR. v.12, n.2, 2010. p.75-86.

FISCHER, A. Indústria, ordenamento do território e transportes. A contribuição de André Fischer. São Paulo: Expressão Popular, 2008.

FISCHER, A. Os efeitos geográficos das novas tecnologias. Abordagem geral. In: FIRKOWSKI, O. L. C. de F. e SPOSITO, E. S. (orgs.). Indústria, ordenamento do território e transportes. A contribuição de André Fischer. São Paulo: Expressão Popular, 2008. pp.23-52.

FIRKOWSKI, O. L. C. de F. A nova territorialidade da indústria e o aglomerado metropolitano de Curitiba, 2001. Tese (Doutorado) - Faculdade de Filosofia, Letras e Ciências Humanas, Universidade de São Paulo, São Paulo.

FIX, M. São Paulo cidade global: fundamentos financeiros de uma miragem. São Paulo: Boitempo-ANPUR, 2007.

FORJÁZ, H. A., CAVAli, S. G., SOUZA, L. F. C. de, ALBERTI JUNIOR, E. Parques Tecnológicos e incubadoras modelando novas cidades - O case de São José dos Campos. In: Anais do XXIII Seminário Nacional de Parques Tecnológicos e Incubadoras de Empresas. Recife, ANPROTEC, 2013.

FREITAS, N. B. Modernização industrial em Feira de Santana: uma análise da implantação do Centro Industrial do Subaé-CIS. In: Sitientibus, n.41, jul. 2009. pp.139-160.

FUINI, L. L. Os arranjos produtivos locais (APLs): uma breve explanação sobre o tema. GeoTextos, vol.9, n. 2, dez. 2013. pp.57-83.

FUINI, L. L. Os arranjos produtivos locais na região de Ourinhos - SP - Brasil: Dinâmica socioprodutiva e desenvolvimento territorial. Revista de Desenvolvimento Regional, Santa Cruz, vol. 19, nº 1 jan-abr. 2014. pp.236-257. 
FURTADO, C. Formação econômica do Brasil. São Paulo: Companhia Editora Nacional, 2003 [1958].

GALVÃO, A. C. F. e BRANDÃO, C. A. Fundamentos, motivações e limitações da proposta dos "Eixos Nacionais de Integração e Desenvolvimento". In: GONÇALVES, M.F., BRANDÃO, C.A. e GALVÃO, A.C.F. (orgs.). Regiões e cidades, cidades nas regiões: o desafio urbanoregional. São Paulo: Editora UNESP: ANPUR, 2003.

GEORGE, P. Geografia econômica. Rio de Janeiro/Lisboa: Fundo de Cultura, 1967 [1958].

GÓIS SOBRINHO, E. M. Aglomerações industriais relevantes no Brasil - Parte I. In: Boletim de Informações FIPE, Temas de Economia Aplicada, mai. 2014, pp.32-39.

GÓIS SOBRINHO, E. M. Aglomerações industriais relevantes no Brasil - Parte II. In: Boletim de Informações FIPE, Temas de Economia Aplicada, jun. 2014, pp.12-19.

GÓIS SOBRINHO, E. M. Aglomerações industriais relevantes no Brasil - Parte III. In: Boletim de Informações FIPE, Temas de Economia Aplicada, jul. 2014, pp.35-44.

GOMES, R. B. Metropolização do consumo: as transformações do comércio varejista em Maracanaú, 2015. Dissertação (mestrado) - Centro de Ciência e Tecnologia, Universidade Estadual do Ceará, Fortaleza.

GURGEL, A. C. Desenvolvimento industrial em espaços organizados: uma análise dos fatores de competitividade nos distritos industriais do Estado do Rio de Janeiro, 2015. Dissertação (mestrado) - Escola Brasileira de Administração Pública e de Empresas, Fundação Getúlio Vargas, Rio de Janeiro.

GOVERNO DO ESTADO DE SÃO PAULO. Identificação e caracterização de agrupamentos industriais como subsídio à política de desenvolvimento regional. São Paulo: Coordenadoria de Ação Regional, 1981.

GREMAUD, A. P. e PIRES, J. M. "Metas e bases" e I Plano Nacional de Desenvolvimento - I PND (1970-1974). In: KON, A. (org.). Planejamento no Brasil II. São Paulo: Editora Perspectiva, 1999. pp.41-66.

GRIZENDI, E. Alguns aspectos relacionados ao Parque Tecnológico de Campinas. Revista Inovação. São Paulo, v.3, n.2, p. 40-41, mar-abr. 2007.

IANNI. O. Estado e Planejamento Econômico no Brasil. Rio de Janeiro: Civilização Brasileira, 1991.

INSTITUTO BRASILEIRO DE ECONOMIA (IBRE). A Desindustrialização Brasileira em Debate. Carta do IBRE, Agosto de 2010. Disponível em: $<$ http://www.fgv.br/mailing/ibre/carta/agosto.2010/CIBRE agosto 2010.pdf >. Acesso: agosto de 2015.

INSTITUTO DE ESTUDOS PARA O DESENVOLVIMENTO INDUSTRIAL (IEDI). Indústria $e$ economia brasileira na atualidade. Carta IEDI nº499, Dezembro de 2012. Disponível em: $\langle$ http://iedi.org.br/cartas/carta_iedi_n_499_industria_e_economia_brasileira_na_atualidade.ht ml>. Acesso: agosto de 2015.

KALIFE, M. P. F. L. Relações interfirmas dentro do conceito de condomínio industrial: estudo de uma cadeia produtiva da Daimler Chrysler do Brasil, 2002. (Dissertação de mestrado) Escola de Engenharia, Universidade Federal de Minas Gerais, Belo Horizonte, 2002. 
KON, A. Introdução: a experiência brasileira de planejamento público federal. In: KON, A. (org.). Planejamento no Brasil II. São Paulo: Editora Perspectiva, 1999. pp.15-39.

LAFER, C. O planejamento no Brasil - Observações sôbre o Plano de Metas (1956-1961). In: LAFER, B. M. (org.). Planejamento no Brasil. São Paulo: Editora Perspectiva, 1970. pp.33-50.

LALKALE, R. e BISHOP, J. L. Parques tecnológicos e incubadoras de empresas: o potencial de sinergia. In: GUEDES, M. e FORMICA, P. A economia dos parques tecnológicos. Rio de Janeiro: ANPROTEC, 1997.

LAMOSO, L. P. Indústria, desindustrialização e território. Boletim Campineiro de Geografia. Campinas: Associação dos Geógrafos Brasileiros, v.3, nº3, 2013. pp.408-429.

LENCIONI, S. Reestruturação urbano-industrial no Estado de São Paulo: a região da metrópole desconcentrada. Espaço \& Debates. São Paulo: NERU, n. 38, 1994, p.54-61.

LENCIONI, S. Cisão territorial da indústria e integração regional do Estado de São Paulo. In: GONÇALVES, M. F., BRANDÃO, C. A., GALVÃO, A. C. (orgs.). Regiões e cidades, cidades nas regiões: o desafio urbano-regional. São Paulo: UNESP/ANPUR, 2003, p.465-475.

LENCIONI, S. Condomínios industriais: um novo nicho dos negócios imobiliários. In: PEREIRA, P. C. X. (org.). Negócios imobiliários e transformações sócio-territoriais em cidades da América Latina. São Paulo: FAUUSP, 2011. pp.185-197.

LEMOS, M. B., MORO, S., DOMINGUES, E. P., RUIZ, R. M. A organização territorial da indústria no Brasil. In: De Negri, J. A., SALERMO, M. (orgs.). Inovação, padrões tecnológicos e desempenho das firmas industriais brasileiras. Brasília: IPEA, 2005. pp.325-363.

LIMA, L. C. Novo espaço da produção: os tecnopólos, 1994. Tese (doutorado) - Faculdade de Filosofia, Letras e Ciências Humanas, Universidade de São Paulo, São Paulo.

LIPIETZ, A. O capital e seu espaço. São Paulo: Nobel, 1988.

MACHADO, S. A., CARVALHO, M. M. de, PIZYSIEZNIG FILHO, J. Condomínios industriais e de serviços - Uma alternativa para redução de custos e focalização das empresas. In: Anais do 17º Encontro Nacional de Engenharia de Produção, Porto Alegre: UFRGS/PPGEP, 1997.

MAMIGONIAN, A. Teorias sobre a industrialização brasileira. Cadernos Geográficos, Florianópolis, CHF/UFSC, $\mathrm{n}^{\mathrm{o}}$ 2, maio de 2000. pp.93-128.

MAMIGONIAN, A. Notas sobre o processo da industrialização no Brasil. Boletim do Departamento de Geografia, FFCL de Presidente Prudente, 1969.

MANZAGOL, C. Lógica do espaço industrial. São Paulo: DIFEL, 1997.

MARKUSEN, A. Áreas de atração de investimentos em um espaço econômico cambiante: uma tipologia de distritos industriais. Nova Economia, Belo Horizonte, vol 5, $\mathrm{n}^{\mathrm{o}} 2$, dezembro de 1995. pp.9-44.

MARSHALL, A. Principles of economics. London: Macmillan and Co., 1890. Disponível em: $<$ http://oll.libertyfund.org/titles/marshall-principles-of-economics-8th-ed> Acesso: junho de 2016. 
MARTINS, J. G. F. Proposta de método para classificação do porte das empresas, 2014. Dissertação (Mestrado) - Programa de Pós Graduação em Administração, Universidade Potiguar, Natal.

MEDEIROS, J.A. Estruturas e espaços voltados à inovação e parceria: Papel dos polos e parques tecnológicos. In: PALADINO, G. G.; MEDEIROS, L. A. (orgs.). Parques tecnológicos e meio urbano: artigos e debates. Brasília: ANPROTEC/SEBRAE, 1997.

MELO, R. de C. N. Parques tecnológicos do estado de São Paulo: incentivo ao desenvolvimento da inovação, 2014. Tese (doutorado) - Faculdade de Filosofia, Letras e Ciências Humanas, Universidade de São Paulo, São Paulo.

MENDES, A. A. Quando o espaço determina a indústria: o exemplo do Condomínio Empresarial Atibaia, 2007. Tese (livre-docência) - Instituto de Geociências, Universidade Estadual Paulista, Rio Claro.

MÉNDEZ, R. Geografia económica: la lógica espacial del capitalismo global. Barcelona: Ariel, 1997.

MERGULHÃO-BARROS, A. Formação e desenvolvimento do parque industrial paulista segundo as informações censitárias e as pesquisas industriais anuais, 2011. Tese (doutorado) Faculdade de Filosofia, Letras e Ciências Humanas, Universidade de São Paulo, São Paulo.

MERGULHÃO-BARROS, A. Serviços industriais no Estado de São Paulo e suas relações interempresariais. GEOUSP - Espaço e Tempo, vol.19, nº 1, 2015. pp.44-59.

MITRA, J. Relacionamento entre os investidores e parques tecnológicos - recuperação econômica de um ambiente inovativo. In: GUEDES, M. e FORMICA, P. A economia dos parques tecnológicos. Rio de Janeiro: ANPROTEC, 1997.

MORAIS, M. L. de. A baixada fluminense respira os ares do progresso: um estudo do Distrito Industrial de Queimados. 2014. Monografia (licenciatura) - Departamento de Geociências, Universidade Estadual Rural do Rio de Janeiro, Seropédica.

MOREIRA, R. Ascenção e crise de um paradigma disciplinar (O espaço do complexo CSN-Volta Redonda). Caderno Prudentino de Geografia, n 18, Dossiê Geografia e Globalização. 1996. pp.40-64.

MOREIRA, R. Formação espacial brasileira: uma contribuição crítica à geografia do Brasil. Rio de Janeiro: Consequência, 2012.

NOGUEIRA, B. C. Áreas industriais: conceitos básicos, tipologia e roteiro de planejamento. São Paulo: FAUUSP, 1991.

OBSERVATÓRIO BRASILEIRO DE ARRANJOS PRODUTIVOS LOCAIS (OBAPL). Endereço do sítio virtual da associação. Disponível em: 〈http://portalapl.ibict.br/〉. Acesso: março de 2016.

OLIVEIRA, A. de. Território e mercado de trabalho: discursos \& teorias. São Paulo: UNESP, 2006.

ORGANIZAÇÃO DAS NAÇÕES UNIDAS (ONU). Seminário de Madras (Resumo). [1962] In: Textos sobre planejamento de áreas industriais. São Paulo: FAUUSP, 1966. pp.66-79 
ORGANIZAÇÃO DAS NAÇÕES UNIDAS (ONU). Trade and development report. New York and Geneva: United Nations Conference on Trade and Development, 2016.

PACHECO, C. A. Novos padrões de localização industrial? Tendências recentes dos indicadores da produção e do investimento industrial. Textos para Discussão no 633. Brasília: IPEA, 1999.

PEREIRA, E. A. A. A empresa e o lugar na globalização: a "responsabilidade social empresarial" no território brasileiro, 2007. Dissertação (Mestrado) - Faculdade de Filosofia, Letras e Ciências Humanas, Universidade de São Paulo, São Paulo.

PEREIRA JUNIOR, E. A. e SPOSITO, E. S. Economia política do território e estratégias de investimentos - A geografia da subvenção industrial no Ceará como exemplo. GEOUSP Espaço e Tempo, nº 35, 2013. pp.3-18.

PERROUX, F. O conceito de pólo de crescimento. [1970] In: FAISOL, S. Urbanização e regionalização, relações com o desenvolvimento econômico. Rio de Janeiro: IBGE, 1975. pp.97-110.

PIQUET, R. Indústria e território no Brasil contemporâneo. Rio de Janeiro: Garamond, 2007.

PORTER, M. E. Competição: estratégias competitivas essenciais. Rio de Janeiro: Campus, 1999.

RATTNER, H. Política industrial: um projeto social. São Paulo: Brasiliense, 1988.

RELAÇÃO ANUAL DE INFORMAÇÕES SOCIAIS (RAIS) 1985, 1995, 2005, 2010 e 2013. Ministério do Trabalho e Emprego (MTE) - Programa de disseminação de estatísticas do trabalho (PDET). Endereço do sítio virtual do programa. Disponível em: <http://www.mte.gov.br/pdet/index.asp>. Acesso: outubro de 2014 (Decreto $\mathrm{n}^{\mathrm{o}}$ 76.900/75).

REVISTA BUILDINGS. O panorama do mercado de condomínios de galpões. BUILDINGS, 2016. Disponível em: <http://www.buildings.com.br/noticias/o-panorama-do-mercado-decondominios-de-galpoes/>. Acesso: outubro de 2016.

ROXO, L. A. T., SANTAROSSA, E. T., BERTOTTI, G. Aglomerados produtivos e concentração: uma análise teórico-conceitual. In: Anais do $\mathrm{V}$ Encontro de Economia Catarinense, Florianópolis: UNESC, 2011.

SABOIA, J. L. Desconcentração industrial no Brasil nos anos 90: um enfoque regional. Pesquisa e Planejamento Econômico, vol. 30, nº1, 2000a. pp.69-116.

SABOIA, J. Aglomerações industriais especializadas no Brasil. Nota técnica $n^{\circ} 32 / 00$ (Versão preliminar). Rio de Janeiro: Instituto de Economia da UFRJ, $2000 \mathrm{~b}$.

SANTOS, G. A. G. dos; DINIZ, E. J.; BARBOSA, E. K. Aglomerações, Arranjos Produtivos Locais e Vantagens Competitivas Locacionais. Revista do BNDES, v.11, n. 22, 2004. pp.151179 .

SANTOS, M. Espaço e método. São Paulo: Nobel, 1985.

SANTOS, M. Metamorfoses do espaço habitado. São Paulo: Hucitec, 1988.

SANTOS, M. Economia espacial. São Paulo: Edusp, 2003 [1979]. 
SANTOS, M. A Natureza do Espaço: técnica e tempo, razão e emoção. São Paulo: Edusp, 2004 [1996].

SANTOS, M. O espaço dividido: os dois circuitos da economia urbana dos países subdesenvolvidos. São Paulo: Edusp, 2006 [1979].

SANTOS, M. Da totalidade ao lugar. São Paulo: Edusp, 2012 [1979].

SANTOS, M. e SILVEIRA, M. A. O Brasil: território e sociedade no início do século XXI. São Paulo: Record, 2001.

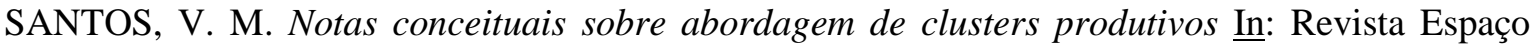
Acadêmico, 2003, Ano III, no 27.

SASSEN, S. El reposicionamento de las ciudades y regiones urbanas en una economía global: ampliando las opciones de políticas e governanza. In: EURE, 2007, v.33, nº 100. pp 9-34.

SELINGARDI-SAMPAIO, S. Indústria e território em São Paulo: a estruturação do multicomplexo territorial industrial paulista. Campinas: Alínea, 2009.

SILVA, J. A. e LOURENÇO, A. L. C. de. Revisitando o conceito de desindustrialização. In: Anais do X Encontro de Economia Baiana "Planejamento e Estratégias de Desenvolvimento". Salvador: UFBA, 2014. pp.533-548.

SILVA, R. B. Polo e Parque de Alta Tecnologia de Campinas: uma análise da política pública. Campinas: Editora RG, 2010.

SOARES, P. R. R. A cidade-região de Porto Alegre: análise da desconcentração metropolitana no Rio Grande do Sul. In: Anais do Seminário Nacional de Governança e Desenvolvimento Metropolitano. Natal: UFRN, 2010.

SOLLEIRO, J. L. Gestión de la vinculation universidad-sector productivo. In: MARTÍNEZ, E. Estrategicas, planificacion y gestion de ciência y tecnologia. Caracas: Editorial Nueva Sociedad, 1993. pp.403-429.

SOUZA, E. B. C. de. O território e a região: análise das políticas públicas. In: SAQUET, M. A. e SPOSITO, E. S. (orgs.). Território e territorialidades: teorias, processos e conflitos. residente Prudente: Expressão Popular, 2009. pp.341-365

SPOSITO, E. A produção do território, o paradigma dos eixos e a localização de atividades industriais. In: PEREIRA, P. C. X. (org.). Negócios imobiliários e transformações sócioterritoriais em cidades da América Latina. São Paulo: FAUUSP, 2011. pp.245-258.

SPOSITO, E. Rede urbana e eixos de desenvolvimento: dinâmica territorial e localização da indústria e do emprego no estado de São Paulo. In: Sposito, E. (org.). O novo mapa da indústria no início do Século XXI. Diferentes paradigmas para a leitura das dinâmicas territoriais do estado de São Paulo. São Paulo: Editora da Unesp-Digital, 2015. pp.369-404.

STEDA, M. M. V. Tecnologias da informação e território: políticas para o setor de software no Brasil, 2015. Dissertação (mestrado) - Instituto de Geociências, Universidade Estadual de Campinas, Campinas.

SUAREZ, M. A. A evolução da indústria petroquímica brasileira e o modelo tripartite de empresa. Revista de Economia Política, Vol.3, nº 3, Julho-Setembro de 1983. pp.89-102. 
SUZIGAN, W. Sistemas Locais de Produção: mapeamento, tipologia e sugestões de políticas. ANPEC, 2003.

TAKAMI, S. T. Distritos industriais como condições gerais para a reprodução do capital em Piracicaba (SP), 2013. Dissertação (Mestrado) - Instituto de Geociências e Ciências Exatas, Universidade Estadual Paulista "Júlio de Mesquita Filho", Rio Claro.

TAVARES, H. M. Estratégias de desenvolvimento regional. Da grande indústria ao arranjo produtivo local? Revista Brasileira de Gestão e Desenvolvimento Regional. Taubaté, vol. 7, $\mathrm{n}^{\mathrm{o}}$ 1 , janeiro de 2011. pp.50-68.

TECHNO PARK CAMPINAS. Plano de ciência, tecnologia e inovação do Techno Park Campinas. Campinas: ASSOCITECH, 2015.

TREVISAN, L. Os usos do território brasileiro e o imperativo da logística : uma análise a partir da Zona Franca de Manaus, 2012. Tese (doutorado) - Instituto de Geociências, Universidade Estadual de Campinas, Campinas.

TRIPLE HELIX Research Group. Página de grupo de pesquisa. Disponível em: <http://www.triple-helix.uff.br/sobre.html〉. Acesso: fevereiro de 2016.

VILLARES, H. D. Urbanismo e industria em São Paulo. São Paulo: Revista dos Tribunais, 1946.

WILTGEN, R. da S. Notas sobre polarização e desigualdades regionais. Ensaios FEE. Porto Alegre, vol. 12, $\mathrm{n}^{\mathrm{o}} 2$ 2, 1991. pp.532-539.

WIRED MAGAZINE. Revista eletrônica estadunidense sobre tecnologia com versão on-line. Disponível em: <http://www.wired.com>. Acesso: março de 2007. 


\section{ANEXO I}

Detalhamento da atividade de campo, por unidade da federação (ordem cronológica)

\section{Rio Grande do Norte}

As atividades de campo no Rio Grande do Norte foram realizadas junto ao estágio de pesquisa na Universidade Federal do Rio Grande do Norte (UFRN), com supervisão do Prof. Dr. Aldo Dantas. Este estado foi escolhido para aplicação do trabalho de campo piloto. A primeira atividade de campo ocorreu no dia 14/03/2014 e a última no dia 11/04/2014, mescladas ao período de permanência na UFRN no qual também assistimos aulas, participamos de debates com demais integrantes do grupo de estudos e também ministramos dois cursos. Ao total foram somadas 06h59 de áudio gravados durante as entrevistas, quais sejam:

- 14/03/2014 - Entrevista com o Sr. José Lacerda A. Felipe, secretárioadjunto de planejamento na Secretaria de Planejamento e Finanças (SEPLAN) do Rio Grande do Norte.

- 19/03/2014 - Entrevista com o Sr. Roberto J. Serquiz, empresário produtor de água mineral e $1^{\circ}$ tesoureiro da Federação das Indústrias do Rio Grande do Norte (FIERN).

- 21/03/2014 - Entrevista com o Sr. Otomar L. Cardoso Júnior, coordenador de desenvolvimento comercial na Secretaria Estadual de Desenvolvimento Econômico (SEDEC) do Rio Grande do Norte.

- 25/03/2014 - Entrevista com o Sr. Marcos César Formiga, Diretor da Federação das Indústrias do Rio Grande do Norte (FIERN), fazendo-se acompanhar também por Mário Sérgio Viveiros, assessor para assuntos econômicos da FIERN.

- 27/03/2014 (A) - Deslocamento Natal-São José do Seridó: O Seridó é uma região do Rio Grande do Norte com significativa aglomeração de fábricas que funcionam no sistema de facções e perspectiva de transformar essa aglomeração em Arranjo Produtivo Local. Foi realizada entrevista com a empresária Anny Fabíola e visita a seis fábricas da região. Para o deslocamento de retorno de São José do Seridó à Natal foi utilizada a Rodovia BR-304, o principal eixo de deslocamento do Estado do Rio Grande do Norte que liga os dois principais centros urbanos (Natal e Mossoró) para realização de um campo de reconhecimento no qual foi confirmada e coletada por GPS a localização do Centro Industrial Avançado (CIA), que abordaremos nesta pesquisa. 
- 27/03/2014 (B) - Entrevista com a empresária Anny Fabíola, proprietária faccionista no município de São José do Seridó (RN), na região potiguar conhecida como Seridó, onde ela é proprietária e administradora de seis facções têxteis.

- 28/03/2014 (A) - Entrevista com o Sr. Pedro Antônio, empresário faccionista no município de Vera Cruz (Região Metropolitana de Natal), onde ele é proprietário e administrador de uma fábrica no sistema de facção.

- 28/03/2014 (B) - Trabalho de campo de reconhecimento ao Centro Industrial Avançado (CIA), um dos distritos industriais do Rio Grande do Norte localizado no município de Macaíba (Região Metropolitana de Natal), onde foi percorrida a extensão dessa aglomeração, feito levantamento das empresas presentes e das infraestruturas desta área, bem como realização de registros fotográficos.

- 11/04/2014 (A) - Entrevista com o Sr. Téo Thomaz, secretário de desenvolvimento econômico na Prefeitura Municipal de Goianinha $(\mathrm{RN})$.

- 11/04/2014 (B) - Trabalho de campo de reconhecimento ao Distrito Industrial de Natal, o principal distrito industrial do Rio Grande do Norte, localizado entre os municípios de Natal e Extremoz (ambos na Região Metropolitana de Natal). Na ocasião foi percorrida a extensão dessa aglomeração, feito levantamento das empresas presentes e das infraestruturas, bem como realização de registros fotográficos.

A atividade de campo realizada neste estado, como experiência piloto, foi bastante positiva. As entrevistas foram satisfatórias no tocante à investigação a que nos propomos, bem como a escolha dos agentes entrevistados foi adequada. Além disso, destacamos também a possibilidade de iniciar a atividade de campo da pesquisa a partir de um cenário não tão complexo no conjunto do país, se pensado em termos industriais. Essa possibilidade permitiu ajustes no questionário e a construção de um discurso mais aprimorado, e ao mesmo tempo mais objetivo, para lidar com os agentes.

\section{Ceará}

As atividades de campo no Estado do Ceará se desenvolveram concentradamente, na semana de 31/03/2014 a 04/04/2014, contemplando entrevista com agentes locais (secretarias, associações e empresários industriais) totalizando 5h09min 
registrados de áudio e também visita às aglomerações industriais, com destaque para o Distrito Industrial de Fortaleza, o maior distrito industrial do Ceará com 174 indústrias instaladas. As atividades de campo realizadas no Ceará foram as seguintes:

- 31/03/2014 - Entrevista com o Sr. Guilherme Alves Muchale, economista do Instituto de Desenvolvimento Industrial (INDI), departamento da Federação das Indústrias do Estado do Ceará (FIEC).

- 31/03/2014 - Entrevista com o Sr. Marcos Antônia F. Soares, empresário do circuito químico e presidente do Sindicato das Indústrias Químicas do Estado do Ceará (SindQuímica), que está no comando do desenvolvimento de um condomínio empresarial exclusivo para indústrias químicas existentes na Região Metropolitana de Fortaleza.

- 02/04/2014 (A) - Trabalho de campo de reconhecimento às formas de aglomeração industrial existentes no Anel Viário de Fortaleza, que notadamente é onde existe a maior ocorrência de formas aglomerativas industriais. Visitamos o Distrito Industrial de Fortaleza 2000 (DIF2000) no município de Maracanaú (CE) e confirmamos a existência de dois condomínios empresariais previamente mapeados pela Internet, os quais tiveram suas localizações confirmadas e coletadas por GPS: tratase do condomínio de galpões modulares LOG Fortaleza, em Maracanaú (CE) e do condomínio de galpões modulares Cidade do Atacado instalado no município de Caucaia (CE).

- 02/04/2014 (B) - Entrevista com Fernanda Noronha, coordenadora executiva da Associação das Empresas dos Distritos Industriais do Estado do Ceará (AEDI).

- 02/04/2014 (C) - Trabalho de Campo de reconhecimento ao Distrito Industrial de Fortaleza (DIF), o principal distrito industrial do Ceará localizado no município de Maracanaú (Região Metropolitana de Fortaleza). Na ocasião foi percorrida a extensão dessa aglomeração, feito levantamento das empresas presentes, das infraestruturas do distrito industrial e também das demais formas de ocupação existentes, tais como associação, escola, supermercado, posto de atendimento ao trabalhador, etc., bem como foram feitos registros fotográficos (usados no Relatório de Desenvolvimento).

- 03/04/2014 (A) - Entrevista com o Sr. Roberto Capelo Feijó, presidente da Companhia de Desenvolvimento do Ceará (CODECE), companhia que cuida diretamente das áreas e infraestruturas de propriedade do Estado do Ceará. Além disso, é o idealizador do Programa Distrito Empreendedor, uma iniciativa da CODECE que diretamente se associa a formas de aglomeração produtiva.

- 03/04/2014 (B) - Entrevista com o Sr. Pedro Jorge Roberto Vianna, Coordenador da Unidade de Economia e Estatística (UEE) da 
Federação das Indústrias do Estado do Ceará (FIEC), com vasta experiência na implantação de Arranjos Produtivos Locais, nos estados do Maranhão e Ceará.

- 04/04/2014 - Palestra realizada na Universidade Estadual do Ceará (UECE), em aceite ao convite dos professores Edilson Alves Pereira Júnior e Denise Cristina Bomtempo. Foi feita uma abordagem principalmente da dissertação de mestrado, intitulada: "Condomínios empresariais: produção imobiliária e localização da indústria”, porém já com uma roupagem preocupada com as questões do doutorado e expandindo a interpretação das áreas de aglomeração industrial estudadas no mestrado para o Estado do Ceará (na dissertação de mestrado a área de estudo foram as regiões metropolitanas do Estado de São Paulo).

As entrevistas foram satisfatórias no tocante à investigação proposta e a escolha dos agentes entrevistados mostrou-se acertada. O Ceará pode ser considerado um dos mais importantes estados do Nordeste no tocante à representatividade industrial. É importante destacarmos ainda a oportunidade de dar uma palestra para alunos de graduação e pós-graduação em Geografia na Universidade Estadual do Ceará, por meio de convite realizado pelo Prof. Dr. Edilson Alves Pereira Júnior e que, para nós, foi uma ocasião de divulgação de nossa pesquisa atual, na qual pudemos além de sistematizar e apresentar o conhecimento até então adquirido, também receber questionamentos e sugestões dos alunos e professores desta respectiva universidade.

\section{Bahia}

As atividades de campo no Estado da Bahia foram realizadas durante 25/06/2014 e 04/07/2014, contemplando a realização de entrevistas com agentes locais (secretarias, associações e representantes de empresários industriais) em um total de 09h22m de áudio registrado e visitas de campo às principais áreas industriais próximas à Salvador.

- 25/06/2014 - Fomos recebidos por Priscilla Sobral e Guilherme Vacarezzo no Centro Industrial do Subaé, que pode ser considerado o distrito industrial mais bem estruturado do Estado de Bahia. Priscilla Sobra é coordenadora de investimentos e Guilherme Vacarezzo é o diretor responsável pelo distrito. Além da realização de entrevista com estes dois agentes também pudemos conhecerr a área do distrito e, 
acompanhados por Vacarezzo, fizemos visitação a uma das indústrias que está em fase de implantação.

- 26/06/2014 - Entrevistas com Fábio Brito e Lucas Figueiredo, ambos analistas na Superintendência de Estudos Econômicos e Sociais (SEI), que nos permitiu compreender a situação atual dos distritos industriais baiano. A SEI está participando do diagnóstico econômico destas áreas, em parceria com a Secretaria de Indústria, Comércio e Mineração e Federação das Indústrias do Estado da Bahia, sendo assim uma fonte privilegiada de informações para nossa pesquisa.

- 27/06/2014 (A) - Entrevista com Ricardo Vieira, diretor de desenvolvimento econômico e relações internacionais da Secretaria de Indústria, Comércio e Mineração do Estado de Bahia (SICM), que nos relatou quais são as perspectivas atuais de atuação da secretaria, principalmente no tocante à atração de novas indústrias e, nesse âmbito, quais são as principais demandas e a linha de atuação assumida para atendê-las, principalmente de cunho territorial.

- 27/06/2014 (B) - Entrevista realizada na Federação das Indústrias do Estado da Bahia (FIEB) com Marcus Emerson Verhine, Gerente de Estudos Técnicos, e Carlos Danilo Peres Almeida, analista, ambos responsáveis pelos estudos técnicos de análise das áreas industriais. Por meio dessa entrevista pudemos compreender a opinião e o posicionamento assumido pelos empresários industriais baianos para o tratamento do planejamento territorial da indústria.

- 30/06/2014 - Entrevista com Julio Chompanidis, analista da Unidade de Indústria do SEBRAE-BA, com quem pudemos dialogar sobre a organização atual dos Arranjos Produtivos Locais em funcionamento na Bahia, os principais ramos econômicos representados por esses arranjos e qual o papel desempenhado pelo SEBRAE em auxílio à organização, governança e veiculação da produção.

- 01/07/2014 - Entrevista realizada com Alcebíades Barbosa Matos, técnico da Superintendência de Desenvolvimento Industrial e Comercial (SUDIC) da Bahia, órgão responsável pela manutenção das áreas industriais pertencentes ao governo estadual da Bahia, bem como pela abertura e fechamento destas áreas.

- 04/08/2014 - Entrevista com Érico Oliveira, jornalista responsável pela equipe de ouvidoria e atendimento público sobre os assuntos relativos ao Polo Petroquímico de Camaçari na figura da associação das empresas inseridas no polo, denominada CoficPolo. Além de nos apresentar uma visão geral do polo petroquímico, também abordou a história de implantação desta área industrial e, atualmente, quais são as perspectivas de expansão vigentes.

- 04/08/2014 - Realizado trabalho de campo em algumas áreas principais do Polo Petroquímico de Camaçari. 
O trabalho de campo realizado na Bahia foi importante como nosso primeiro contato com áreas mais bem organizadas em seu aspecto administrativo, tanto pela administração pública quando a partir de iniciativas internas. Foi importante conhecer, pela primeira vez, um estado cuja industrialização já tem mais tempo e repercussão mundial (vide a estruturação do Polo Petroquímico de Camaçari) bem como o primeiro estado até então que manteve sua unidade administrativa para as áreas industriais, e ainda centraliza as decisões quanto aos distritos industriais, caso da Superintendência de Desenvolvimento Industrial e Comercial (SUDIC). Portanto, a Bahia ampliou nossa visão e passou a ser referencial para as investigações posteriores.

\section{Pernambuco}

As atividades de campo no Estado de Pernambuco foram realizadas durante a semana de 08/07/2014 a 13/07/2014, totalizando $05 \mathrm{~h} 33 \mathrm{~m}$ de áudio registrado e visitas in situ a algumas áreas industriais próximas à capital Recife e também no interior desta unidade da federação, principalmente para conhecer o sistema faccionista e um novo modelo de distrito industrial proposto pelo governo pernambucano.

- 08/07/2014 (A) - Entrevista com a diretora Ana Clara Dias do SEBRAE-PE, responsável pelo apoio aos Arranjos Produtivos Locais no Estado de Pernambuco, sobretudo os que estão relacionados ao ramo de confecções.

- 08/07/2014 (B) - Entrevista realizada com o analista do SEBRAE-PE, Alexandre Rodrigues, que possui vasta experiência no tratamento da questão dos Arranjos Produtivos Locais, tendo nos informado acerca da dinâmica - histórica e atual - dos APL no Estado de Pernambuco, com ênfase para os de natureza industrial, bem como os principais problemas que hoje enfrentam.

- 09/07/2014 - Entrevista com Luiz Henrique Campos, diretor de pesquisas sociais pela Fundação Joaquim Nabuco, por meio da qual pudemos obter importantes informações, em uma visão geral, sobre a dinâmica econômica atual de Pernambuco, quais são os principais agentes atuando no território, sua natureza e as áreas que estão sendo focadas por essa atuação.

- 10/07/2014 - Realização de entrevista com o diretor econômico Jenner Guimarães do Rego, da Agência de Desenvolvimento Econômico de 
Pernambuco (AD-Diper), uma instituição de economia mista criada há oito anos para centralizar a administração das áreas industriais no Estado de Pernambuco, também responsável pela dinamização das áreas industriais existentes e consolidadas, criação de novas áreas e atração de empresas industriais para Pernambuco. Por meio desta entrevista pudemos obter o panorama mais completo possível da situação atual das áreas industriais e do planejamento do governo de Pernambuco para sua dinamização.

- 11/07/2014 - No dia 11 de julho, em trabalho de campo na Superintendência para o Desenvolvimento do Nordeste (SUDENE), entrevistamos o Dr. Martinho, atualmente responsável pela coordenação de incentivos fiscais da instituição. Nossa entrevista, no entanto, teve o foco voltado para a atuação da Sudene em seu primeiro Programa de Distritos Industriais na década de 1960, do qual nosso entrevista participou ativamente. Dessa forma, pudemos entender um pouco mais sobre a atuação histórica e atual dessa importante instituição no fomento à dinamização econômico no Nordeste do Brasil.

- 12/07/2014 - Trabalho de campo nos municípios: 1) Abreu e Lima, para visita ao Distrito Industrial de Abreu e Lima, de implantação na década de 1970 e uma área industrial já consolidada em Pernambuco; 2) Goiana, atualmente onde está em implantação uma grande fábrica de montagem da Fiat e também um polo químico da Petrobrás, sendo uma das áreas de maior dinamização em PE e 3) Toritama e Caruaru, na condição de mais importantes polos de confecções existentes em Pernambucos, os quais funcionam no sistema de facções e, atualmente, são foco também de programas para consolidação de arranjos produtivos locais.

- 13/07/2014 - Trabalho de campo nos municípios: 1) Vitória de Santo Antão, com objetivo de conhecer um dos distritos industriais de implantação recente de acordo com as estratégias da AD-Diper; 2) Jaboatão dos Guararapes, para conhecer um condomínio empresarial promovido pelo governo do Estado de Pernambuco. Por fim, neste mesmo dia percorremos, nos dois sentidos da rodovia que liga Recife à Porto de Galinhas, todo o trecho que está diretamente ligado às obras do Porto de Suape, podendo averiguar muitas áreas sendo edificadas, algumas unidades industriais em funcionamento e muitos condomínios empresariais, sobretudo de galpões modulares, alguns dos quais já em funcionamento.

O Estado de Pernambuco possui iniciativas expressivas de industrialização mais recentes, sobretudo nos últimos oito anos a partir de iniciativas do ex-governador Eduardo Campos. O estado pode ser considerado uma área em transição, que buscava politicamente criar um cenário favorável para a industrialização, apoiado justamente na ideia de "preparar o território" para este fim. Apoiando-se na ideia de regionalização e de 
vocações locais, a indústria passou a ser estimulada regionalmente e setorialmente. Novos distritos industriais com aporte do governo estadual foram criados, além do apoio muito expressivo à construção das infraestruturas do Porto de Suape e arredores, uma das áreas que, no Brasil, apresenta mais rápido ritmo de crescimento industrial e logístico.

\section{Rio de Janeiro}

As atividades de campo no Estado do Rio de Janeiro foram realizadas durante a semana de 09/03/2015 a 13/03/2015, com entrevistas e participação em evento relacionado aos Arranjos Produtivos Locais. No RJ totalizamos 03h55m de registro de áudio e também visita ao Distrito Industrial de Queimados.

- 09/03/2015 - Entrevista com o analista Renato Regazzi do SEBRAERJ, responsável pela coordenação de inovação de Arranjos Produtivos Locais em seu respectivo estado.

- 10/03/2015 - Entrevista realizada com o diretor Alexandre Castanhola Gurgel, na condição de ex-diretor da Companhia de Desenvolvimento Industrial (CODIN) do Rio de Janeiro e atualmente Assessor de Projetos Especiais e de Relações com o Mercado da Federação das Indústrias do Estado do Rio de Janeiro (FIRJAN).

- 11/03/2015 - Acompanhamento do Seminário de apresentação do livro "Diálogos Empresariais", que contou com analistas do SEBRAE-RJ, FIRJAN, Secretaria de Desenvolvimento e outras autoridades do Estado do Rio de Janeiro. Realizado no Fórum de Desenvolvimento do Rio de Janeiro, o seminário debateu sobre a situação do micro, pequeno e médio empresário fluminense.

- 12/03/2015 - Foi realizada entrevista com André Tostes, analista da Companhia de Desenvolvimento Industrial do Rio de Janeiro (CODIN), o qual trabalha diretamente com a análise e o planejamento de novos investimentos em Distritos Industriais no Estado do Rio de Janeiro.

- 13/03/2015 - Trabalho de campo no Distrito Industrial de Queimados, no município de Queimados (RJ) que fora indicado por Alexandre Gurgel (FIRJAN) como um dos mais bem estruturados do Estado do Rio de Janeiro e de mais fácil acesso para a nossa visitação e realização de inventário do local. 
O Rio de Janeiro iniciou nossa etapa de trabalhos de campo na Região Concentrada do país. A partir deste estado pudemos começar a desenhar um quadro de referências mais adequado em relação à densidade industrial do território, às iniciativas das instituições responsáveis, funcionário que, também não condição de estudantes/pesquisadores, se preocupam com seu objeto de trabalho também do ponto de vista conceitual e, por isso, são propulsores de novas iniciativas.

\section{Minas Gerais}

As atividades de campo no Estado de Minas Gerais foram realizadas durante a semana de 16/03/2015 a 20/03/2015, com registro de 04h22m de áudio e visita à Cidade Industrial de Contagem, que pode ser considerado o distrito industrial mais antigo do país.

- 16/03/2015 - Entrevista com o diretor de investimentos industriais da Companhia de Desenvolvimento Industrial de Minas Gerais (CODEMIG), Dante Teixeira Filho, que possui um conhecimento sólido em decisões locacionais e direcionamento de investimentos para os Distritos Industriais do Estado de Minas Gerais.

- 17/03/2015 - Entrevista com Raquel Lopes de Souza, analista da Federação das Indústrias do Estado de Minas Gerais (FIEMG), na condição de representante do empresariado industrial nos temas de políticas industriais e dinâmicas de competitividade industrial em seu respectivo estado.

- 19/03/2015 - Trabalho de campo no Distrito Industrial de Contagem, no município de Contagem (MG) que tem a importância de ser um dos primeiros Distritos Industriais do Brasil, inaugurado já na década de 1940 como objeto do planejamento estadual e que atualmente passa por expressivas transformações.

- 20/03/2015 - Entrevista realizada com a analista do SEBRAE-MG Marise Xavier, profissional que possui vasta experiência de implantação e coordenação de Arranjos Produtivos Locais em seu respectivo estado.

- 19/10/2015 - Apresentamos, junto aos técnicos da Federação das Indústrias de Minas Gerais (FIEMG) e respectivos empresários industriais, palestra de abertura intitulada "Panorama dos Distritos Industriais no Brasil" como parte do $1^{\circ}$ Workshop do Programa de Revitalização e Modernização dos Distritos Industriais de Minas 
Gerais, promovido pela FIEMG, CIEMG, SEBRAE-MG e Centro de Desenvolvimento e Planejamento Regional (CEDEPLAR).

Similar ao Rio de Janeiro, o Estado de Minas Gerais fornece uma perspectiva mais realista da industrialização na Região Concentrada do Brasil, porém em uma unidade da federação territorialmente muito mais ampla, onde se encontra uma diversidade de iniciativas - tanto estaduais quanto municipais - com respeito a distritos ou arranjos produtivos locais bastante diversificados. Os órgãos públicos e também a representação dos empresários, em Minas Gerais, preocupa-se com a renovação das áreas industriais deste estado e já alçou algumas iniciativas que poderão renovar/modernizar um conjunto de onze distritos industriais neste estado.

\section{Rio Grande do Sul}

As atividades de campo no Rio Grande do Sul foram realizadas entre 19/05/2015 e 22/05/2015, cujo registro de áudio totalizou 04h45m, e uma importante visita ao Polo Petroquímico de Triunfo.

- 19/05/2015 - Entrevista com a Enga Marta Vieira da Secretaria de Desenvolvimento Econômico, Ciência e Tecnologia do Rio Grande do Sul (SDECT-RS), a respeito da organização e fomento dos distritos industriais no respectivo estado.

- 20/05/2015 - Entrevista com a equipe responsável por análises de industrialização da Fundação de Economia e Estatística, chefiada pelo economista André Coltri. Na ocasião, abordamos aspectos dos distritos industriais, arranjos produtivos locais e também condomínios empresariais no Rio Grande do Sul.

- 21/05/2015 (A) - Entrevista com Sidnei dos Anjos, administrador responsável pelo atendimento ao público no Polo Petroquímico de Triunfo, em nome da associação das empresas credenciadas (COFIC$\mathrm{RS}$ ), que nos apresentou uma visão histórica e geográfica do respectivo polo, bem como as perspectivas de organização e expansão.

- 21/05/2015 (B) - Trabalho de campo de reconhecimentos às áreas do Polo Petroquímico de Triunfo, percorrendo as principais vias de acesso e realizando alguns registros fotográficos das principais indústrias do polo. 
- 22/05/2015 (A) - Entrevista com Alexandro Oto Hanefeld, analista técnico do Conselho de Inovação e Tecnologia da Federação das Indústrias do Estado do Rio Grande do Sul (FIERGS) com o qual aprofundamos a visão da industrialização no respectivo estado a partir da visão do empresariado industrial.

- 22/05/2015 (B) - Trabalho de campo no Distrito Industrial de Cachoeirinha, nas imediações de Porto Alegre, que nos foi indicado pela analista da FIERGS como o distrito de maior crescimento no Rio Grande do Sul atualmente. Verificamos o perfil da infraestrutura da área e indústrias em instalação. Foi realizado registro fotográfico da área em questão.

O Rio Grande do Sul, cronologicamente, foi uma unidade da federação que nos ajudou a reforçar a visão de organização territorial presente na Região Concentrada, a partir de uma densidade industrial maior e, assim, exigente de instituições de caráter técnico e analítico para tratar as questões adequadamente. Outrossim, pela segunda vez estudamos um polo petroquímico, fundamental para melhorar nosso conceito deste tipo de área.

Amazonas

As atividades de campo no Estado de Amazonas foram realizadas entre 23/02/2016 e 26/02/2016, cujo registro de áudio totalizou 04h52m. Nesta oportunidade, fizemos importante visita ao Distrito Industrial (Zona Franca de Manaus), que pode ser considerado o maior do país. Neste, participamos como ouvintes, da reunião do conselho administrativo, que na ocasião (26/02/2016) comemorava os 49 anos da zona franca, em audiência aberta.

- 23/02/2016 - Entrevista com o gerente Vicente de Paulo Schettini, do SEBRA-AM, responsável pela implantação dos arranjos produtivos locais no estado, e que nos deu uma panorama sobre a situação atual dos mesmos.

- 24/02/2016 (A) - Entrevista com o vice-presidente da Federação das Indústrias do Estado de Amazonas, Dr. Sérgio Melo, que nos forneceu a perspectiva do empresário industrial acerca da operação industrial em seu estado e também da Zona Franca de Manaus. 
- 24/02/2016 (B) - Entrevista com Victor César Picanço Lopes, gerente do departamento de desenvolvimento regional da Superintendência da Zona Franca de Manaus (SUFRAMA), que contribui com informações históricas e atuais sobre o distrito industrial.

- 25/02/2016 (A) - Entrevista com José Sandro da Mota Ribeiro, diretor do Departamento de Diversidade Econômica, com quem conversamos sobre o distrito industrial de Manaus e as tendências recentes dos arranjos produtivos locais no estado.

- 25/02/2016 (B) - Entrevista com Edmar Lopes Magalhães, assessor técnico do Departamento de Diversidade Econômica, com quem pudemos aprofundar o entendimento das características dos arranjos produtivos locais do Estado de Amazonas.

- 26/02/2016 - Trabalho de campo de reconhecimento à área do distrito industrial (Zona Franca de Manaus), percorrendo boa parte das avenidas nas quais há ocupação industrial, bem como conhecendo as partes comerciais e bairros residenciais deste distrito industrial. Realizamos registro fotográfico da área.

O Amazonas foi uma visita fundamental para estabelecer um contato direto com aquela que pode ser considerada a mais extensa (e numérica) aglomeração industrial do país, bem como compreender melhor a realidade do Norte do país e os mecanismos que, diferencialmente, devido à própria geografia da floresta ou à cultura local, impõem um comportamento peculiar quanto ao desenvolvimento das aglomerações industriais.

\section{São Paulo}

O Estado de São Paulo, em decorrência das dificuldades de agendamento das entrevistas, ocorreu no decorrer do segundo semestre de 2015 e primeiros meses de 2016. Foram registradas $9 \mathrm{~h} 51 \mathrm{~m}$ de áudio neste estado e também podemos mencionar que foi o que teve o maior número de visitas in situ a formas de aglomeração específicas, além da importante entrevista no Polo Petroquímico de Capuava. Para o Estado de São Paulo utilizamos também a metodologia de realizar enquetes, por via telefônica, para obter dados básicos junto a incorporadores imobiliários. Como especificidade deste estado, também fizemos trabalho de campo em seu Parque Tecnológico pioneiro, no município de São José dos Campos. 
- 08/10/2015 - Entrevista realizada com a administradora Lucia Regina, responsável técnica pela Associação das Empresas do Distrito Industrial de Campinas (AEDIC), que transmitiu uma noção ampla do funcionamento e demandas de uma associação distrital, bem como contribui com nossa necessidade de caracterizar e entender o distrito industrial, tomando como caso o Distrito Industrial de Campinas.

- 27/10/2015 - Acompanhamento do Seminário "Parques Tecnológicos: Inovação acelerando o desenvolvimento", realizado em conjunto pela Agência Paulista de Promoção de Investimento e Competitividade (INVESTE-SP) e Secretaria de Desenvolvimento Econômico, Ciência, Tecnologia e Inovação, por meio do qual pudemos desenvolver nossa apreensão dos Parques Tecnológicos na condição de aglomerações produtivas no Estado de São Paulo.

- 11/11/2015 - Entrevista realizada no Polo Petroquímico de Mauá, com o Gerente Francisco Ruiz, respondendo pelo Comitê de Fomento Industrial do Polo do Grande ABC (COFIP-ABC), que nos apresentou o conceito de territorialização do polo, bem como as perspectivas administrativas e estratégias de ampliação vigentes sob sua gestão.

- 26/11/2015 - Entrevista realizada com Eduardo da Costa Sene Neto, analista de negócios do SEBRAE, Unidade Campinas, com quem pudemos abordar a questão dos arranjos produtivos locais no Estado de São Paulo, sobretudo na Região Metropolitana de Campinas.

- 14/12/2015 - Entrevista realizada com Vagner Bessa, gerente de indicadores econômicos da Fundação SEADE, a respeito do uso de variáveis indicadoras de concentração econômica e industrial no território paulista.

- 15/01/2016 - Entrevista na Prefeitura Municipal de Itupeva, com o Secretário de Indústria e Comércio e Desenvolvimento Econômico, Luiz Carlos Pires de Campos, com quem tivemos a oportunidade de analisar a perspectiva de um governo municipal com o distrito industrial em estágio de implantação, evidenciando intencionalidade, organização, agentes envolvidos e perspectivas esperadas para o futuro da área.

- 03/03/2016 - Entrevista realizada no SEBRAE, Unidade São Paulo, com a coordenadora Ilsiane Peloso que esteve à frente da implantação de Arranjos Produtivos Locais no Estado de São Paulo desde 2010, com quem pudemos conversar sobre as diferentes características dos empresários paulistas (interior/capital) e as características fundamentais do planejamento para os APL em São Paulo.

- 07/04/2016 - Entrevista realizada na Federação das Indústrias do Estado de São Paulo com Paulo Sergio Pereira da Rocha, especialista em competitividade e tecnologia, com quem pudemos dialogar sobre a 
visão da instituição quanto aos arranjos produtivos locais e distritos industriais.

- 28/07/2016 - Entrevista realizada com o diretor do Techno Park Campinas e da Associação das Empresas do Techno Park Campinas, José Luiz Guazzelli, a fim de melhor determinar como se deu o processo de credenciamento do condomínio empresarial Techno Park Campinas junto ao Sistema Paulista de Parques Tecnológicos, bem como melhor compreender a natureza e proporção dos segmentos econômicos que operam em um condomínio empresarial.

- 15/08/2016 a 19/08/2016 - Nesta semana estivemos empenhados em realizar enquete telefônica com as principais incorporadoras imobiliárias, construtoras e também administradoras de condomínios de galpões localizadas no Estado de São Paulo (mas que tem empreendimentos em todo o Brasil). Entre as empresas entrevistadas, com sucesso na obtenção de dados, estão: LogCP, Retha Imóveis e Serviços, Sanca Galpões, Fulwood, DVR Incorporações e Brazilian Business Parks. Embora tenhamos solicitado dados básicos e não identificados, muitos outros contatos não tiveram sucesso.

- 02/09/2016 - Entrevista no Parque Tecnológico de São José dos Campos, com o gestor de empresas e instituições Luiz Fernando Carvalho visando compreender a formação do parque tecnológico pioneiro no Estado de São Paulo e atualmente um dos mais importantes do Brasil. Também abordarmos sistema de gestão da área e os mecanismos de interação governo-universidade-empresa (Modelo Triple Helix) e transferência de conhecimento para os processos industriais, junto ao nosso entrevistado. Seguiu-se a visitação in situ às áreas comuns do parque.

- 02/09/2016 - Entrevista realizada junto à Associação dos Empresários do Chácaras Reunidas (ASSECRE), principal aglomeração considerada como o distrito industrial de São José dos Campos, visando compreender as composição desta aglomeração e também a diversidade no uso e ocupação do solo, bem como o funcionamento da associação, temas que administra e representação face ao poder público.

A importância inegável do Estado de São Paulo, devido à densidade industrial de seu território, complexidade e níveis de organização requisitados, foi apenas reforçada a partir das entrevistas e trabalhos de campo realizados. Embora seja o core industrial da Região Concentrada, a partir do trabalho de campo descobrimos que há dinâmicas diferentes em relação ao resto do país, bem como necessariamente lidar com a maior complexidade das aglomerações industriais do ponto de vista de sua quantidade e complexidade (diferenciações entre as áreas). 


\section{Paraná}

No estado paranaense, assim como em São Paulo, enfrentamos algumas dificuldades de agendamento das entrevistas, o que obrigatoriamente reduziu o número de entrevistados. O trabalho de campo no Paraná realizou-se no primeiro semestre de 2016, entre os dias 27/05/2016 e 30/05/2016. Nesta atividade de campo, registramos 2h26m de áudio e também visitamos o distrito industrial pioneiro neste estado, chamado Cidade Industrial de Curitiba e uma parcela do Distrito Industrial de Araucária (contiguo a Cidade Industrial de Curitiba).

- 28/04/2016 - Entrevista realizada com João Percy Hohmann, coordenador de promoção industrial e comercial da Secretaria de Planejamento e Noé Vieira dos Santos, assessor técnico da Secretaria de Planejamento do Estado do Paraná, com os quais pudemos dialogar sobre a configuração básica dos distritos industriais paranaenses e as tendências de promoção recentes, bem como tivemos uma ótima abordagem sobre arranjos produtivos locais paranaenses, dos quais Noé Vieira dos Santos foi coordenador responsável por muitos anos.

- 29/04/2016 - Entrevista realizada com Marcelo Antonio Percicotti da Silva, Gerente de Fomento e Desenvolvimento da Federação das Indústrias do Estado do Paraná (FIEP), com quem pudemos conversar sobre as iniciativas da Federação para implantação de distritos industriais junto com as prefeituras municipais, bem como os estudos recentes da gerência de fomento e desenvolvimento com objetivo de mapear as cadeias produtivas do Paraná para que as futuras áreas industriais sejam focadas nesta abordagem.

- 30/04/2016 - Trabalho de campo de reconhecimento às áreas principais áreas que fazem parte da Cidade Industrial de Curitiba, aglomeração industrial pioneira neste estado, ocasião em que percorremos boa parte da via marginal à BR-116, na qual as indústrias historicamente se instalaram (respeitando o perfil alongado da rodovia e suas vias de acesso), áreas nas quais hoje coexistem muitos pequenos comércios e bairros residenciais, até chegar ao Distrito Industrial de Araucária, de implantação mais recente e territorial contíguo à área da cidade industrial.

O Paraná é um dos mais importantes estados na Região Concentrada e também apresenta importância se comparado ao conjunto do território nacional. Com a especificidade de uma industrialização concentrada (o interior do estado é predominantemente agropastoril) pudemos observar os traços da organização territorial em 
uma situação na qual a indústria apresenta uma taxa de concentração expressiva, porém é também expressiva em números face ao contexto nacional. Situação essa que se expressa na existência de distritos industriais bastante próximos e nas iniciativas oriundas da FIEP em fomentar a criação de outros distritos no interior do estado. 